FRANCISCO LAURIDSEN RIBEIRO

ESBOÇAMENTOS DE CORPOSSOM

A ESCRITA DO CORPO NA VÍSCERA DO SOM

[SÃO PAULO, 2019] 



\section{[resumo]}

\section{Esboçamentos de corpossom: a escrita do corpo na víscera do som.}

Neste trabalho se busca pensar a individuação conjunta do corpo e do som, através da improvisação e segmentos de roteiros performáticos. Assim, colhemos traços metodológicos da atuação teatral para pensar as relações entre produção de corpo, som e vocalização. Para fazer jus a essa lógica, cada segmento da tese se debruçou em uma prática produtiva de corpo: caminhada, desenho e conversação. Guiei-me, para esse campo operativo, na noção de transdução, conforme trabalhada por Gilbert Simondon.

É escritura, portanto, experimental, que compromete o tecido argumentativo de uma tese com procedimentos oriundos de outros ambientes, mais instáveis, como a precariedade do caderno. Referência vitalista nesse caso é o Artaud tardio (1943-1948). Focalizamos, em sobreposição, as práticas dos núcleos de corpossom, coletivos de dimensões artístico-pedagógicas que se envolveram no trabalho acima descrito.

Palavras-chave: performance; performance vocal; cadernos; transdução; Simondon, Gilbert (1924-1989).

Adendo: diários de Vaslav Nijinsky (1889-1950); sonhos de Franz Kafka (1883-1924); 0 homem-árvore, carta de Antonin Artaud (1947); cadernos de Antonin Artaud (18961948). 


\section{[abstract]}

\section{Draftlinings of corpossom [bodysound]: the writing of the body in the viscera of sound.}

In this work we seek to think about the combined individuation of body and sound, through improvisation and segments of performance routines. Thus, we collect methodological traits of theatrical performance to think about relations between body generation, sound and vocalization. To make justice to this logic, each segment of the thesis has looked over on a generative body practice: walking, drawing and conversation. I guided myself, for this operative field, by the notion of transduction, as worked by Gilbert Simondon. It is scripture, therefore, experimental, which compromises the argumentative fabric of a thesis with procedures from other, more unstable environments, such as the precariousness of the notebook. Vitalist reference in this case is the last Artaud (1943-1948). We focused, in overlapping, the practices of the nuclei of corpossom [bodysound], collective of artistic-pedagogical dimensions that were involved in the work described above.

Keywords: performance; vocal performance; notebooks; transduction; Simondon, Gilbert (1924-1989).

Addendum: diaries of Vaslav Nijinsky (1889-1950); dreams of Franz Kafka (1883-1924); the man-tree, letter by Antonin Artaud (1947); notebooks of Antonin Artaud (18961948). 


\section{[abrégé]}

\section{Esquisse-étoffe du corpossom [corps-son]:}

l'écriture du corps dans les viscères du son.

Dans ce travail, nous cherchons à penser à l'individuation conjointe du corps et du son, à travers l'improvisation et des segments des scripts performants. Ainsi, nous collectons des traits méthodologiques de la performance théâtrale pour penser aux relations entre production corporelle, son et vocalisation. Pour faire justice à cette logique, chaque segment de la thèse s'est penché sur une pratique corporelle productive: la marche, le dessin et la conversation. J'ai été guidé, pour ce champ opératoire, par la notion de transduction, telle que travaillée par Gilbert Simondon. II s'agit donc d'une écriture expérimentale qui compromet le tissu argumentatif d'une thèse avec des processus issus d'environnements plus instables, comme la précarité du cahier. La référence vitaliste dans cette affaire c'est Artaud final (1943-1948). Nous avons focalisé, en chevauchant, les pratiques des noyaux du corpossom [corps-son], collectifs aux dimensions artistiques et pédagogiques, impliqués dans le travail décrit ci-dessus.

Mot-clés: performance; performance vocale; cahiers; transduction; Simondon, Gilbert (1924-1989).

Addenda: jornaux de Vaslav Nijinsky (1889-1950); rêves de Franz Kafka (1883-1924); I'homme-arbre, lettre d'Antonin Artaud (1947); cahiers d'Antonin Artaud (1896-1948). 



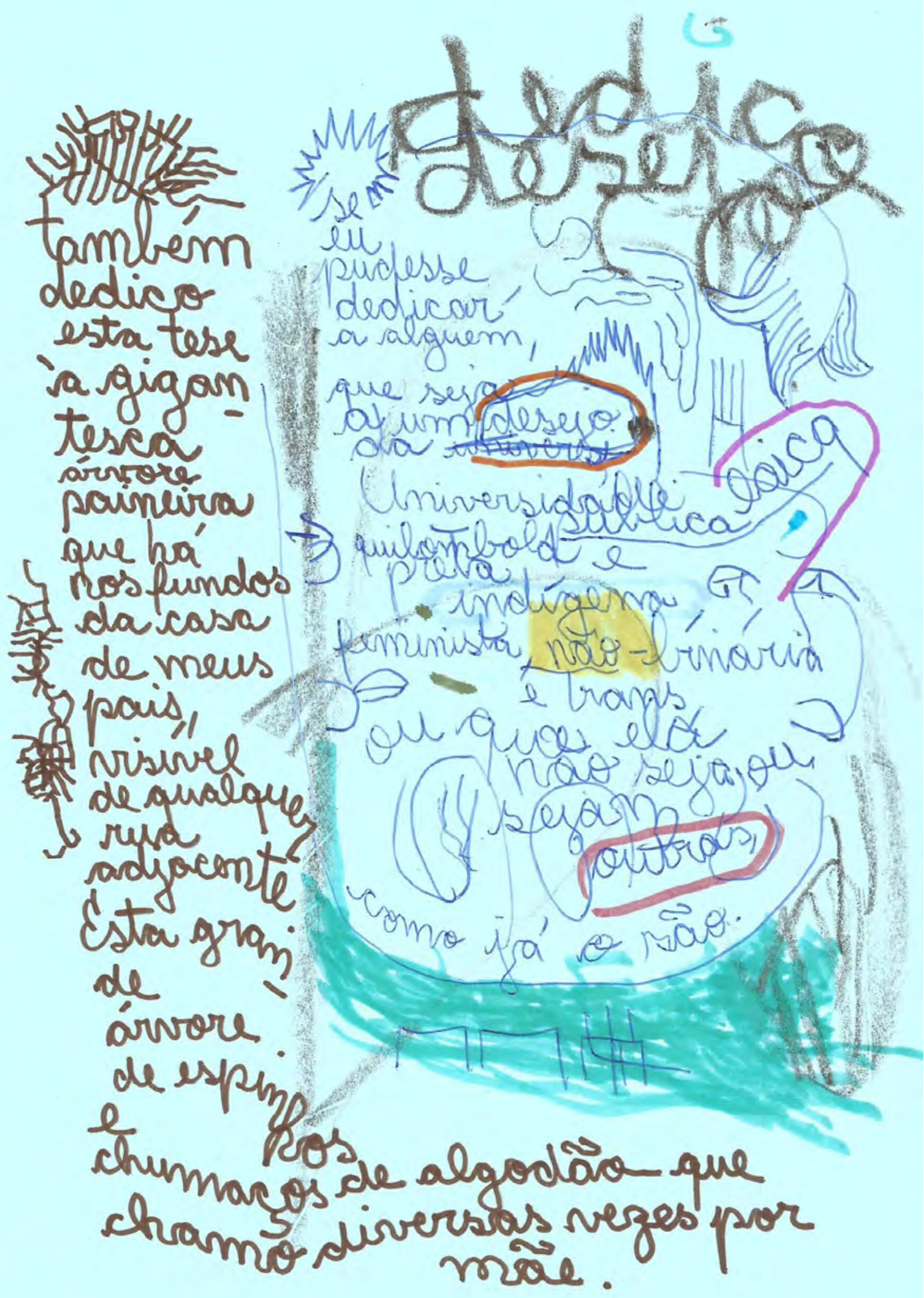


[agradecimentos] Adriana Grechi, Adriana Oliveira, Adriana Siqueira, Aida Lamas, Alberto Tembo, Alice Vignloli Reis, Aline Alves, Aline Guarato, Ametonyo Silva, Amnéris Maroni, Ana Beatriz Nestlehner, Ana Bonetti, Ana Carolina Savani, Ana Kiffer, Ana Marincek, Ana Paula Fiorotto, Andressa M ello, Ancestres, Anna Júlia Santos, Antonio Januzelli, Antonio Salvador, aos que vieram antes de nós, Auber Bertinelli, Beatriz Id, Bia Bouissou, bisavó Alpha, bisavó Ana, bisavó Felicia, bisavô Giacomo, bisavô Ubirajara, Bruna Carvalho Almeida, Bruna Zullo, Bruno Caetano, Bruno Moreno, Caboclo Sete Folhas Secas, Camila Chang, Camila Jabur, Camila Valones, Carla Ferro, Carolina Rosa, Carolina M andell, Carolina Vélasquez, Catarina São M artinho, Cecilia Gobeth, Christiana Cavalcanti, Christine Greiner, Clarissa Reche, Claudia Ortega, Cléia Plácido, Companhia Teatro Balagan, Dalila Camargo Martins, Dani Boni, Daniel Córdova, Débora Oliveira, Deborah Penafiel, Deuses, Di [Diego], Dinah Feldman, Dulce Coppedê, Edith Derdyk, Edith Lauridsen Ribeiro, Elvira Cardeal, Emilie, Fátima Saraceni, Felipe Stocco, Ester Bortoletto, Fabio Cintra, Felipe Martins, Felipe Merker Castellani, Fernanda Aoki Navarro, Fernando (xerox da ECA), Flora Holderbaum, Gabriela Itocazo, Gabriela M afud, Gabriela Segato, Georgina Magdalena, Gisele Calazans, Giulia Castro, Giulia Esteves, Giulia M artini, grupos de astrologia da escuta, Gisele Petty, Helder Fouto, Helena Bastos, Helena Obersteiner, Henrique Chiurciu, Ierê Papá, Indrani Taccari, Isabel Tica Lemos, Isabela Rossi, Isadora Ferraz, Ivola Demange, Ivy Souza, Janaína Navarro, Jane Helena, Javi Sanhuez, Jennifer Bastos, Joana Ferraz, Jorginho, José de M attos Neto, José M oraes Neto, José Vieira, Júlia Burnier, Julia Fávero, Juliana Jardim, Julia Pignalosa, Juliana Martins, Juliana Molla, Juliana Piesco, Julio Groppa Aquino, Kall Andrade, Karina Pinheiro, Laís Reis, Laís Taufic, Laris Gabrianne, Larissa Finnochiaro, Laura Saad, Leonardo Cardoso, Lilian Campesato, Lilith Prexeva, Lina Prosa, Lívia Seixas, Liz Nátali Sória, Luana Gouveia, Lucas Abe, Lucas Gabriel Wickaus, Lucía Jasmin, Luciana Bortoletto, Luciana Hoppe, Luciane Ramos Silva, Luiz Pimentel, Luiza Rolla, Ma Bodhigita, Magô (M aria Glória), M aike Rinne, Madhu, M aíra do Nascimento, M aíra Vaz Valente, Manoela Rangel, M arcela Lucatelli, M aria Esmeralda Forte, Maria Thais Lima Santos, Mariana Carvalho, Mariana Carvalho Carminati, Mariana Farinas, Mariana Louver, Marília Persoli, Marina Matheus, Marina Merlino, Marô Zamaro, Maurício Perussi, M aurizia, M avutsinim Santana, M ayxue Ospina Posse, Michele M attos, Miguel Prata, Milson Santos, M irella Façanha, M ônica Caldeira, Monica Huanca M aldonado, Muriel Combes, Multiofício, Nair Sasaki, Natalia Campanella, Natália Reis, Nathalia Nolli Sasso, núcleos de corpossom, Orin, Palomaris M athias, Patrícia Alcalá, Paula Cassimiro, Paulo Renato Panzeri, Pedro Lauridsen Ribeiro, Pedro Penuela, Piera M archesani, Piera Peres Portasio, Priscila Regina Jorge, Raquel Bortoletto, Raquel Morales, Renata Asato, Ricardo (xerox da ECA), Rita M aria, Roberto Ribeiro, Rodrigo Batista, Rodrigo Fabbro, Rogério Costa, Rubens Saraceni, Sasha Bezrodnova, Sérgio de Carvalho, Silvana del Bosque, Sílvia Fernandes Telesi, Silvio Ferraz, Sofia M aruci, Sofia Tsirakis, Stelio M arras, Stenio Biazon, Stylianos Tsirakis, Tais Ramirez, Talita Alcalá Vinagre, Tarina Quelho, Tarsila Doná, Tatiana Abitante, Thais di M arco, Thais Leão, Thais Sodré, tia Edith, Tiago Luz, Toumani Koyuaté, Tumbao Velasquez y Castro, Vi [Vicente], Viviane Nicoletti, vó Lourdes, vó Vilma, Wang Te Cheng, Yasuyuki Sasaki, Yukari Tome, Zebba dal Farra. Às pesso as e existências que escreveram todas essas linhas e a todas as gentes que esqueci. 
[SUM ÁRIO]

[nome da parte] - $\mathrm{N}^{\circ}$ da página

[INTRODUÇÃO] [PERAM BULAR COM PALAVRAS-TALSMÃ] - 4

[PEQUENA SÍNTESE] - 14

[ANOTAÇÕES DE LOCAUZAÇÃO] - 15

[UM: perambulações com corpossom] - 21

[BLOCO UM : o que pode ser um corpossom?] [9 partes] - 23

[CORPO, DETRITO, TEIA, CAMINHADA]

[CORPO-DIFERENÇA, ALTER-ORGANISM O] - 24

[O DOBRAR E A CONSTRUÇÃO DE UM CAM PO RECEPTIVO-ATIVO] - 30

[ANOTAÇÃO COM PEDAGOGIA, PERFORMANCE E SONOPLASTIA] - 33

[JANÔ E AS LINHAS VITAIS] - 34

[ANTERIORIDADE DO ESPAÇO: PELO MENOS DOIS CASOS] - 42

[DESCONHECIDO, CUPINZEIRO, GÊNESE ESCALAR]

[SOLTAR PODE SER SALTAR]

[NOÇÃO COMUM DO CORPO-OPACIDADE] - 46

[ONTOGÊNESE DO CONTATO: POR UM PIANISMO DE BORDA (UM)] - 50

[ONTOGÊNESE DO CONTATO: POR UM PIANISMO DE BORDA (DOIS)] - 54

[QUASE-NADA] - 59

[BLOCO DOIS: caminhada-catástrofe.

Primeiras imagens de víscera] [17 partes] - 66

[CAM INHADA DA CAVERNA COMO VÍSCERA]

[POTÊNCIA GERM INANTE DA PERAM BULAÇÃO NA CAVERNA] - 72

[PENSAR INSTÁVEL COM A CAMINHADA DE JEAN-JACQUES ROUSSEAU

(UM)] - 81

[TOLOS] - 84 
[REFOCAUZAÇÃO DA PRÁTICA, CONTRA-METODOLOGIA, PERAM BULAÇÃO] - 89

[PASSEIO SIM ONDONIANO] - 92

[PENSAR INSTÁVEL COM A CAMINHADA DE JEAN-JACQUES ROUSSEAU (DOIS)] - 96

[O PASSEIO DO ALTER-ORGÂNICO COM ALTER-PARENTESCO] - 106

[UMA PRÁTICA ATERRISA DO MEU LADO:

PRÁTICAS INVOLUNTÁRIAS E DISTRAÍDAS] - 109

[CORRER OU ESPERAR SÃO TAM BÉM CAM INHADAS:

ALGUMA ATIVAÇÃO POĹTICA] - 115

[UUTH] - 121

[MUTAÇÃO: CORPOSSOM E BUTÔ] - 124

[VÍSCERA COMO EMERGÊNCIA E NÃO-LOCALIZAÇÃO DA FONTE;

EU CAMINHO PELA VÍSCERA] - 132

[O VENTO NOTURNO COMO VÍSCERA: ANOTAÇÕES] - 142

[CAM INHADAS] - 146

[M ARGEAR A CATÁSTROFE]

[BUTÔ DE UNO E A FILOSOFIA ANTIEDIPIANA DE NIJINSKY] - 150

[CONFIGURAÇÕES DE DESUZE AO FIM] - 160

[RESTOS] - 162

[DOIS: instintos de germinação e cadernos - monstro que coleta] - 167

[PRIM EIRA COLETA: germinação e mito Armonia] - 169

[SEGUNDA COLETA: caderno] - 275

[ANTECEDENTES DO CADERNO]

[TRANSCRIÇÕES DE FRAGM ENTOS DE VICENTE CECIM

COM FRAGMENTOS DE FALAS, APARIÇÕES E DETRITOS] - 295

[CALDEIRAS: fragmentos] [PREPARAÇÃO PARA CADERNOS KAFKAS] - 310 
[FRAGMENTOS DE CADERNOS KAFKIANOS] - 324

[TRÊS: do homem-árvore ao umanimusgo] - 403

ANTECEDENTES DE ESBOÇAM ENTOS - 406

[[[FOTOS - IM PROVISAÇÕES NA CASA DAS CALDEIRAS]]] - 409

[[[LOCALIZAÇÃO PRECÁRIA]]] [[[PEDAÇOS DE M APA]]]

[[[ZONAS DE HABITAÇÃO, NICHOS SONOROS]]] - 417

ESBOÇAM ENTOS PARA LUGARES - 429

[[[MEDITAÇÃO OU DANÇA DO DRAGÃO]]] - 433

[[[O CHÃO COMO MUNDIFICAÇÃO: A SITUAÇÃO]]] - 437

[[[A NECESSÁRIA FICCIONALIZAÇÃO DO CORPO]]] - 438

[[[APENAS UMA CONVERSA]]] - 439

[[[FOTOS DE JÚLA FÁVERO - PARQUE DA ÁGUA BRANCA]]] - 443

[[[DOS NOMES, MAISUMA VEZ]]] - 445

[[[DEZ DIAS DE ÁRVORE]]] [[[EM ANEXO]]] - 445

[[[POSSÍVEL PROPOSIÇÃO E ESTRUTURA PARA UMANIMUSGO]]] - 446

[texto de Artaud: 0 Homem-Árvore] - 447

[[[COLAGEM DE BULAS]]] - 456 
[ESTRUTURA DO UM ANIMUSGO] - 456
A. Três modos de habitação arbórea:
como se construir uma 'dança da árvore' - 456
B. Giros que sabem de si (e decidem por si) - 458
C. Pseudo-taichi-árvore - 458

\section{[[[INVENTÁRIO DE PRÁTICAS]]] [[[DESCRIÇÃO DE ALGUMAS PRÁTICAS]]] - 462}

1. Formas de estabilidade viva e trabalhos específicos de chão (modos de se habitar 0 chão) - 462

2. Formas oscilatórias/pendulares: pêndulos e ondas como movimentos auto-sustentados - 464

3. Formas de contato - 466

4. Formas de emissão - 474

5. Uma sequência pedagógica sensibilizadora para a proliferação de esferas [enquanto movimento, não enquanto forma] - 477

6. Uma pequena condução para espirais - 477

7. Dinâmicas de movimentação a partir do vegetal, [como uma 'eletricidade gentil'] - 478

8. A preguiça - 478

9. Anotar as sensibilizações acontecidas em estados meditativos - 478

LUGARES - 479

[[ICADEIA DE NOTAS E CONVERSAS

SOBRE O PROCESSO DE 'CORDARIA' E CORPOCORDA]]] - 484

[PEQUENOS APONTAM ENTOS CONCLUSIVOS] - 501

[REFÊNCIAS BIBLIOGRÁFICAS] - 509 


$$
\begin{aligned}
& \text { [[[DISCOGRAFIA GERMINAL]]] - } 521 \\
& \text { [[[ALGUNS DOS SITES CONSULTADOS]]] - } 521 \\
& \text { [[[OUTROS]]] - } 522
\end{aligned}
$$

[2 ANEXOS] - 523

[ANEXO UM: $O$ QUE PODE SER UMA VÍSCERA?]

[RASTRO DE CAMINHAR PERGUNTANDO] - 524

[ANEXO DOIS. DEZ DIAS DE ÁRVORE] - 541 


\section{[SÉRIE DE DESENHOS DA PRIM EIRA COLETA (SEGUNDO CAPÍTULO)]}

\section{ÁRVORES PLAUSÍVEIS E LILITHS}

1. [árvore plausível]

2. [árvore plausível]

3. [árvore plausível]

4. [árvore plausível (árvore de fogo)]

5. [idem - verso]

6. [árvore plausível]

7. [árvore-axolote]

8. [árvore plausível - Melíade (árvore freixo) - Armonia - Mãe das amazonas]

9. [ناith 2 - Lilith como Gaia? como Lilith?]

10. [Lilith - árvore plausível]

11. [Lilith 6: a indestrutível árvore de Lilith (árvore plausível)]

12. [Lilith, oito: encontra sua irmã Pandora no fundo do mar. Juntas elas vão inventar a respiração, já que a respiração ainda não existe]

13. [Lilith nove, a lilith dos bichos. 'lilith-bicho, lilith-bichos, lilith-jamais-origemúnica, o-céu-de-lilith-está-sempre-do-outro-lado-da-terra, (...)']

14. [Lilith treze, esta é a Lilith das cinzas e dos insetos]

15. [L. catorze. do sangue que é pássaro (Árvore plausível)]

16. [Lilith vinte e um: Lilith dos entulhos (árvore plausível)]

17. [Lilith quinze. 0 grão do corpo como um milharal inundado]

18. [Lilith como uma quase-voz tecelã, A ESTRELA XVII do Tarô]

19. [anotação vitalista]

20. [Árvore plausível: Lilith 18, dos galhos que caem no mar. A partir da imagem que me contou a Talita Alcalá Vinagre]

21. [Lilith dezenove: a Lilith do trauma, do sol com casca e seu passo insólito]

22. [Árvore plausível. Lilith vinte, como uma gigantesca árvore de facas. Inspirado em imagem que ilustrava a carta do arcano menor 'dez de espadas' do Tarô. Alguém mais viu uma Curupira escondida?]

23. [L. 23. Lilith das escavações em busca dos gatos indesejados] 
24. [idem - verso]

25. [um papel que dorme - boa noite]

26. [Lilith 27A. do fingerprint]

27. [Lilith 27B. 0 avesso de um céu estrelado]

28. [Lilith 28. 0 parto da suavidade (um parto)]

29. [Lilith 29. Vida inseparada. Feita a partir das microfotografias publicadase autorizadas de uma amostra de fluxo da colega C.R.]

30. [idem - verso]

31. [Lilith 26. A silenciosa máscara]

32. [Lilith 30 (1). Lilith acompanha passo a passo um luto. Árvore plausível]

33. [Lilith 31 dos rastros]

34. [L. 32. A Lilith-multidão. Esboço]

35. [idem - verso]

36. [Ressonância de Lilith]

37. [Estudo 1 - Lilith]

38. [Lilith 4 como o rosto da terra]

39. [Lilith 3]

40. [Lilith sete. encontra Hécate senhora dos caminhos e dos caminhos cruzados]

41. [Lilith 34 (esboçamento 24). Lilith das pétalas: aquela que nos guarda]

42. [Lilith 18, dos galhos que caem no mar - esboço]

43. [Lilith 30 (2). Das fendas]

44. [Lilith 30 (3). Enquanto eu choro outras coisas acontecem]

45. [Lilith 5 - como uma deusa desconhecida]

46. [Lilith doze: a árvore indestrutível de Lilith antes do amanhecer (detalhe)] 
[OBSERVAÇÕES]

[1. TODAS AS FOTOS DE REGISTRO DE ACCÕES DOS NÚCLEOS DE CORPOSSOM TIVERAM AUTORIZAÇÃO VERBAL DE TODOS OS ARTISTAS ENVOLVIDOS (PERFORMANTES, ARTISTAS PLÁSTICOS E RESPONSÁVEIS PELOS REGISTROS)]

[2. DESENHOS FEITOS A PARTIR DE MATÉRIAS DE OUTRAS PESSOAS TIVERAM TAM BÉM CONCESSÃO DE EXPOSIÇÃO NESTA TESE]

[3. AS DIMENSÕES DOS DESENHOS NÃO SÃO INFORM ADAS, POR DUAS RAZÕES: UM, A DE QUE ELES ESTÃO DISPOSTOS NA ESCALA MAIS PRÓXIM A POSSÍVEL DAQUELA DOS ORIGINAIS; DOIS, A DE QUE, NOS CASOS EM QUE HÁ UMA DISPARIDADE DE ESCALA, ESTA É APREENSÍVEL A PARTIR DOS OUTROS DESENHOS] 


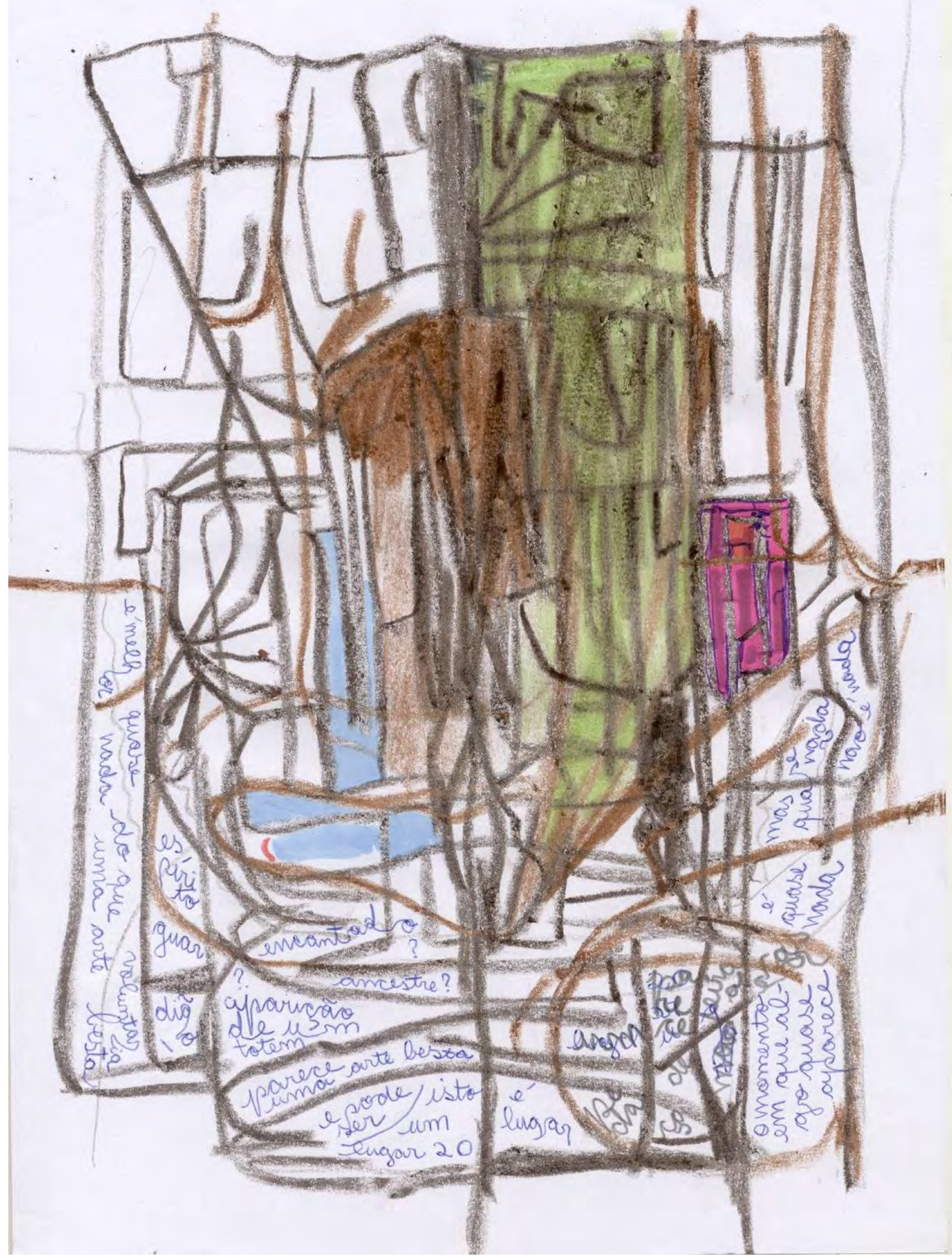




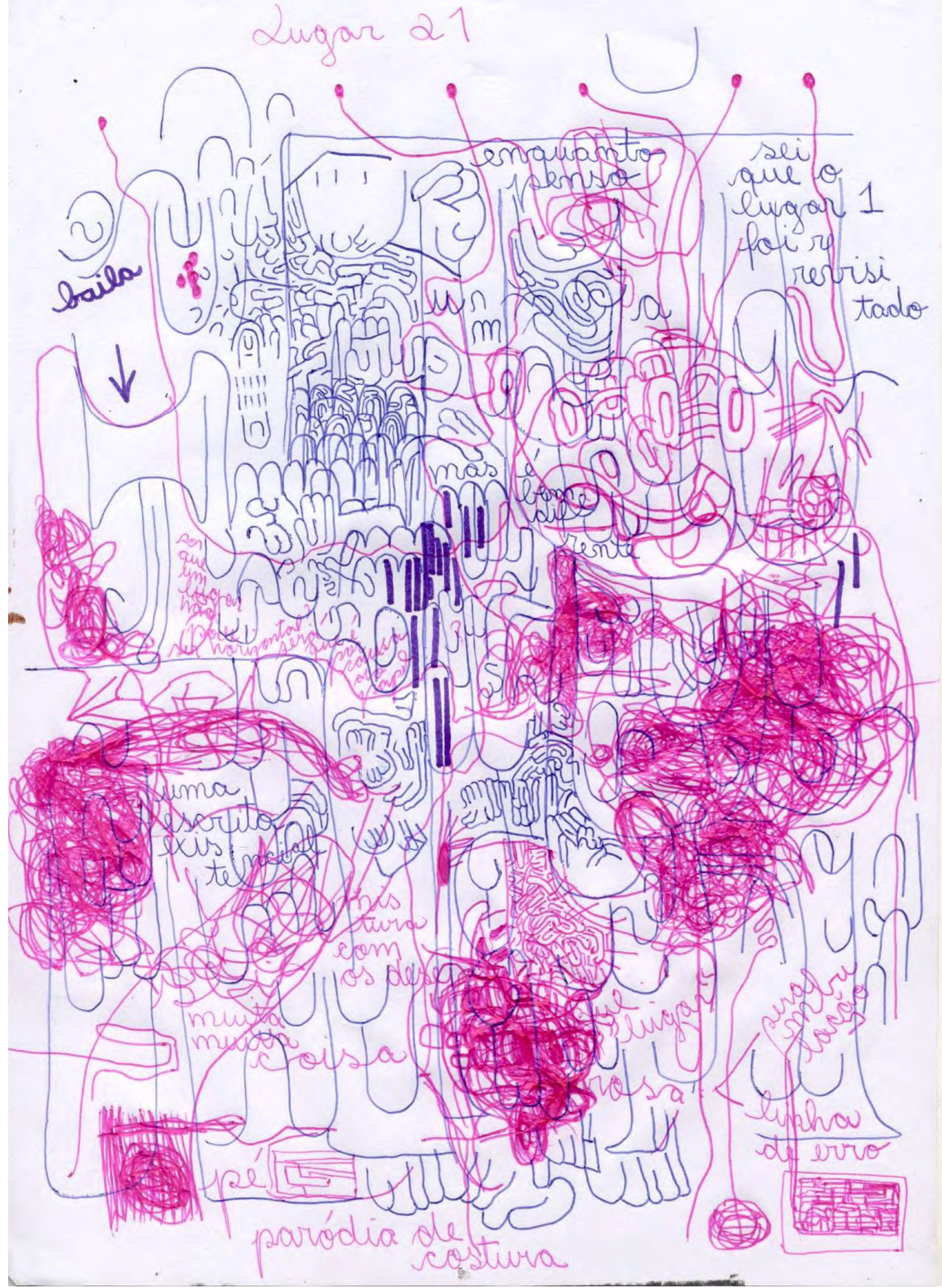




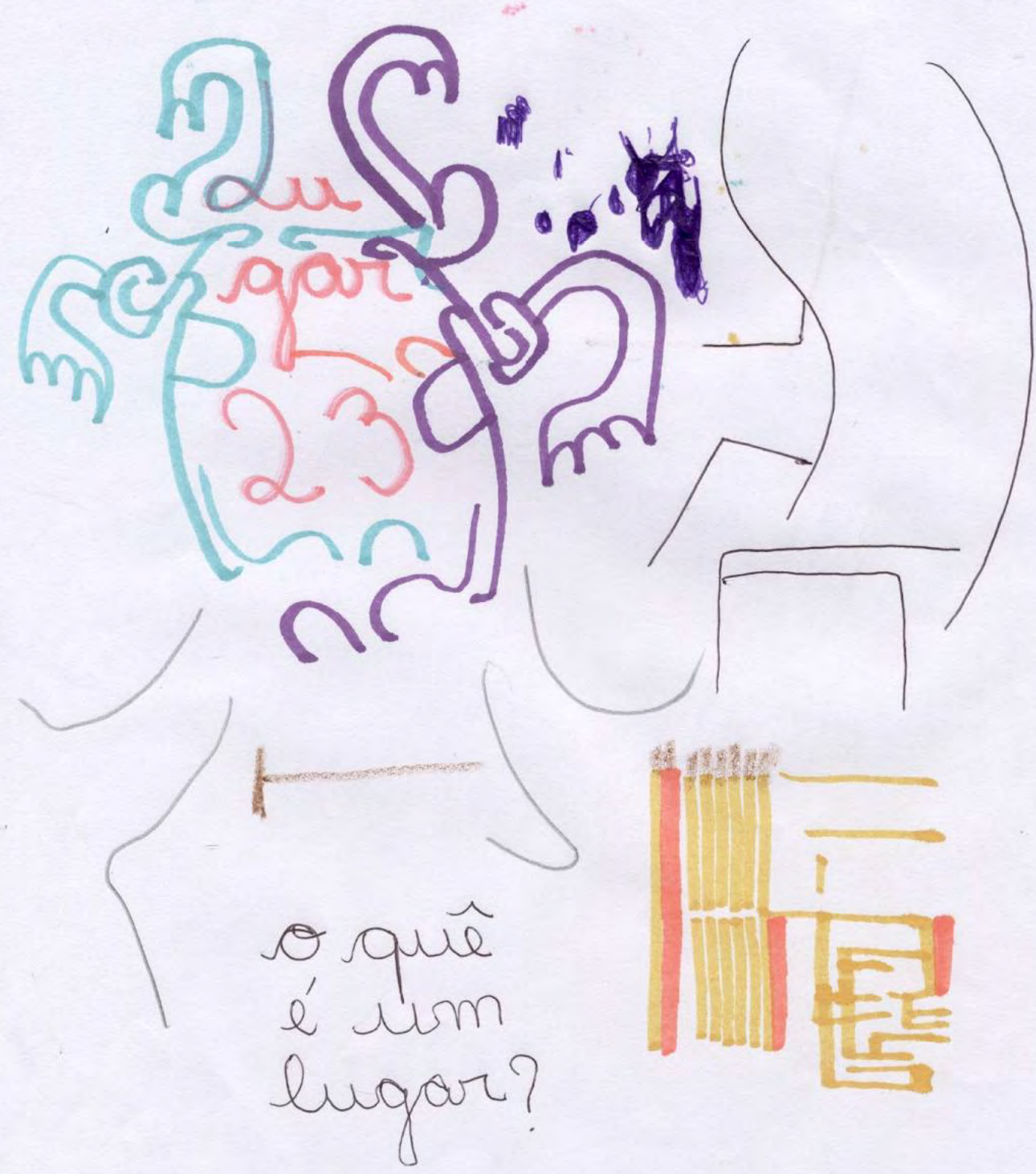




\section{[INTRODUÇÃO]}

\section{[PERAM BULAR COM PALAVRAS-TALISMÃ]}

Pode parecer extravagante, mas esta introdução é um aceno de um outro lugar, e uma espécie de bula existencial.

Pode parecer excessivo, mas este livro que você tem em mãos é um livro sobre um quase-nada. Um pedaço de corpo. Pedaços de caderno.

Existem algumas palavras-talismã que nos convocam para caminhar junto delas. Isso é um fato da vida. Ao menos da minha vida.

Pode ser que nem saibamos como, muito menos o como delas chegarem.

Algumas dessas palavras-talismã não têm sentido nenhum, mas isso não impede que elas estejam lá conosco. Ainda que tenhamos aptidão mínima em coletar interpretações ou ainda que essas palavras possam arcar ser suporte de uma suposta educação, isso tudo é, em maior ou menor grau, sem dúvida irrelevante.

Quando eu me sentia muito perseguido, na minha adolescência, aparecia um prefixo 'sabe' em tudo o que eu pensava: sabediz, sabedeus, sabedeia.

A primeira coisa, então, é reconhecer a completa autonomia das palavras não só como coisas, como o diria Fernand Deligny, mas como sujeitos. Palavras-talismã: portadoras de completa autonomia e providas da suficiente saturação, massa crítica, enfim, de potência para nos arrastar, às vezes por longuíssimos períodos de vida.

Uma palavra pode nos arrastar por muito tempo. 
A que se deveria essa saturação: não sei. Às vezes é apenas algo que empurra o corpo. Às vezes é uma dura pontada que se espalha pelo espaço e que faz questionarmos tudo.

Ontem eu tive insônia, e uma das coisas que meu corpo fez foi oferecer, distante de mim, o meu próprio coração. Apareceu-me assim. Ele estava lá, diante de mim, como um recipiente mineral que brilhava uma luz alaranjada. A imagem me aconchegou um pouco.

Logo antes, nessa mesma noite, aconteceu algo que há anos não acontecia: dormi sobre meus braços, e eles pareciam estar sem atividade. Eles dormiram. Minha mãe uma vez me disse que isso acontece quando estamos, em resumo, tensos e também fracos. Meus braços. Pareciam bexigas cheias de lodo, toalhas pesadas, ou cobras que dormiam. Não pensei isso no momento, mas hoje, durante o dia, lembrei de uma história que meu querido professor de taichi chuan (ou taijiquan) contou. A história foi contada como real. Sobre um mestre que, quando era estudante, não conseguia compreender o treino de taichi, até que numa noite ele sonhou que ele estava com 0 braço quebrado, que não tinha, portanto, nenhuma força no braço. E então ele entendeu o treino de taiji, se diz. Para mim, essa é uma história bastante forte sobre algum sentido de um corpo. 0 corpo precisou lhe dizer algo.

Nós somos muito pequenos diante do nosso próprio corpo.

Existem palavras-talismã autônomas certamente. Talvez corpossom ela mesma seja uma delas. Foi uma palavra que usei uma vez em 2008, acho, para me defender de uma outra, corpomídia, palavra da qual não gosto. Acabou que o 'inimigo' se afastou sozinho, aparentemente indiferente, interessado em outras coisas. E o Corpossom ficou germinando diversas práticas. E hoje estou aqui.

No teatro e seu duplo, Antonin Artaud se referiu uma vez à necessidade de ver as palavras como encantatórias. Ou o encantamento como palavra, na via do sangue, da carne, do rigor da crueldade, dos hieróglifos vivos. Quando digo que as palavras não 
são só coisas, mas também talismãs, sujeitos, pessoas, comunidades, digo também que às vezes penso nessa parte da gramática artaudiana que se manteve, pareceu-me, ao menos no seu tom, por grande parte de sua vida. ${ }^{1}$

Eu disse 'e o Corpossom ficou germinando diversas práticas'. Neste caso, uso o gerúndio sem qualquer vergonha. Pois a noção de processo é tão vital quanto o próprio vitalismo. E aqui se pretende, com alguma sorte, anotações vitalistas. Se servirem ao estudo do som, tanto melhor.

Existem também palavras-pela-metade, muito distintas das meias-palavras, estas que se afogaram para sempre em algo muito vivo. São detritos valiosos as 'Palavraspelametade'. Isso é um modo de dizer, pois pode ser que sejam pedaços maiores que a metade, ou ainda quase ínfimos, como é o caso de um prego solto no assoalho em um trem. Ou ainda uma formiga dialogando com a poeira oriunda de uma casa de pessoa. Tudo isso para dizer que uma palavrapelametade poderá compor um talismã.

\section{Como assim?}

A palavra-pela-metade não tem a mesma imantação e exigência da palavra-talismã. A palavra-pela-metade vem como um processo que germina, é um cochicho. A palavratalismã também germina, mas vem como algo bizarro, sólido, fortemente atado na vida: é intransponível.

Um pouco mais.

\footnotetext{
${ }^{1} 0$ Artaud de 0 teatro e seu duplo se esforça para pensar uma cultura. Esse Artaud, que já não é o 'primeiro Artaud', talvez seja a culminação deste, colapsa de 1936 a 1937, penso eu, quando Artaud conheceu etnias tradicionais do terreno mexicano e passou, penso eu, a questionar a prevalência de um olhar europeu sobre o mundo. E depois quando, de uma briga que sucedeu em Dublin, na Irlanda, em 37, ele é preso e vive em hospitais psiquiátricos durante cerca de nove anos, em um período histórico muito singular, de experimentos de contenção e correção no contexto do nazi fascismo. Ana Kiffer relata fragmentos desse processo através das cartas e cadernos de Artaud (KIFFER, 2016 e 2017).
} 
Gostaria de dizer que eu tive de abraçar profundamente minha ignorância acerca de algumas palavras-talismã. E que talvez esta tese seja um percurso sobre ignorâncias profundas.

Há ainda outras ações da parte das palavras-talismã.

Há livros que aparentemente falam sobre a ignorância, livros que caberiam ler neste contexto. E o tempo das trilhas e daquilo que nomeamos 'escolhas' os excluiu do percurso, mesmo porque o que veio acontecer foi a apreensão de que eu não os devia ler. Não o consegui. E é assim, de modo um pouco amargo, que efetivamente ocorre: essas palavras-talismã afugentam veementes alguns objetos das proximidades e do cotidiano, como a fantasmas indesejáveis. Os objetos educativos, que poderiam detalhar e aproximar. EXPLICAR. Eu juro que não é desdém. É uma exigência concreta do talismã vivo.

Sei que o meu juramento ('não é desdém') não surgirá efeito. Os artistas politizados apenas na superfície da vida, ou apenas retos e morais (mais sinceros), eles mesmos é possível que me odiarão pelo meu aparente desdém. 0 projeto deles é o poder, ainda que um poder ilusório oriundo do território único e fortificado da servidão. Sou presa fácil para eles. Com os intelectuais-artistas, os ecléticos do paladar e os latifundiários da desconstrução, é ainda pior, e paro por aqui.

Para as 'afinidades de estilo' é igual, as palavras-talismãs são implacáveis. Ao redigir estas linhas, lembro-me da estética de Valère Novarina (nascido em 1947), o dramaturgo, diretor, performer e artista plástico. Bastante se diz e se formula sobre sua afinidade com Artaud (morto no início de 1948). Seria perfeito retomar Novarina neste ponto, um autor no qual já havia me debruçado outra vez. No entanto, foi-me impossível. Ele está ali. Eu, aqui. As palavras-talismã impuseram sua ignorância ao me exigirem a exclusividade de sua experiência comigo, como se algo de extremamente pessoal se processasse e se abrisse para as páginas. Algo que Novarina não pode, por alguma razão, neste caso, tocar. 
Desse modo, quero supor poética e subversivamente, à maneira de Gilbert Simondon em sua filosofia da individuação, que uma palavra-talismã me convoca a uma individuação conjunta com ela. Uma individuação é sempre heterogênea e conjunta. Essa palavra que veio, veio para ter uma nova individuação, da ordem do conjunto. Ou seja: eu também me valerei dela para operar uma nova individuação - desconhecida. De que modo? Ainda não sei. É uma espécie de aliança que persistirá o tempo de um nascimento. Isto é muito importante.

Uma dessas palavras é 'música'. Eis o enigmático: não é garantido que a palavra nasça ela mesma: ela pode, de outro modo, parir muitas coisas, mas não nascer ela mesma. Isto também é muito importante.

Autonomia dos talismãs, ignorância, desconhecido.

Meu irmão, quando trabalhava em sua tese em casa, há vários anos, perambulava muito, como se o caminhar fosse um turbilhão que magnetizasse os pedaços de pensamento. Comigo talvez seja assim também. Um pouco.

Nijinsky tinha uma coleção de talismãs escritos em seus diários ou cadernos, e uma noção bastante precisa de seu uso, vinda da necessidade. Esses pedaços singulares de vida atados à vida.

Da palavra-talismã era um pouco isso, no momento.

De outro lado, há ainda o perambular. E também a víscera.

A víscera, estamos caminhando por ela. Um túnel, um cupinzeiro. 0 vento da noite. Estamos caminhando por ela. A víscera pode ser esse fora dobrado em si. Assim, bastará por ora que eu fale do perambular. 
Amnéris Maroni me indicou a obra tardia de Rousseau 'devaneios de um caminhante solitário'. Esse livrinho estranhíssimo disparou movimentos em mim que eu poderia chamar de 'proto-anárquicos', movimentos ressoantes em partes desta tese. $\mathrm{E}$, quando me refiro aos devaneios Rousseaunianos como coletores de elementos protoanárquicos, trata-se de uma apropriação. Estou certamente falando mais de mim do que dele. É como se o livro disparasse algo em mim, e isso ainda dependesse do livro. Então ele ainda está lá para que eu pense movimentos proto-anárquicos.

Nijinsky e Rousseau disparam movimentos no primeiro capítulo, que foi o capítulo mais difícil de escrever. Vários fluxos contraditórios. A presença de Nijinky e Rousseau aparenta ser definida, central, compor um eixo, mas na realidade há diversos outros fluxos atravessando o caminho, por vezes até mais importantes. Gilbert Simondon certamente. Kuniichi Uno. Anti-Édipos. Artaud. Situações da vida e da criação. Os Butocas que atravessam a página dançando catástrofes. Falarei dos capítulos em breve.

Os Butocas, aqueles que dançam Butô, me lembram que a alavanca desta escritura é a prática de um corpo desconhecido. E é aí que está a dificuldade do primeiro capítulo: lembrar-me de que eu estava em perambulação, lembrar-me de que esta já era a víscera.

A tese inteira remete ao recurso e à estética do aforisma e do fragmento (Heráclito, Salústio, Nietzsche, Césaire, Deligny etc). 0 auxílio que Silvio Ferraz me concedeu, com seu próprio trabalho com aforismas, é inestimável. Foi a maneira executável de se constelar e ressoar as experiências tão distantes e heterogêneas entre si que compõem este trabalho.

0 auxílio que Helena Bastos me concedeu na banca de qualificação, ao me assegurar que era preciso confiar na poesia inerente à própria matéria de pesquisa, também é 
inestimável. Heráclito é infinitamente mais exato do que o positivismo que quer nos devorar.

A tese é estruturada como uma fenda, cujo recheio cai para os lados, transborda. E a fenda ficará aberta enquanto algo se passar ali.

E algo de fundamental que preciso dizer desde agora, e sempre que eu puder:

\section{CADA CAPÍTULO É UMA PRÁTICA QUE O ARTICULA E ENGENDRA.}

0 primeiro capítulo (perambulações com corpossom) foi integralmente escrito após março de 2017, que coincide com a banca de qualificação. Ele é o capítulo mais dissertativo e ensaístico, talvez o mais difícil. Não sei ainda qualifica-lo a contento, por ora me parece um cultivo feroz, uma vegetação cerrada, talvez um pouco hostil, de narrativas, leituras, ideias violentas. Como o próprio nome diz, a dinâmica do capítulo se volta para a perambulação.

O segundo capítulo (instintos de germinação e caderno - monstro que coleta) é um conjunto de relações com o desenho (árvores plausíveis, Liliths e caligrafias experimentais) que são aprendidas com o próprio desenho. Sua prática, portanto, é uma tipologia de germinações ${ }^{2}$ cujo modelo é o desenho guiado por alguns instintos. Este capítulo se inicia com um aprofundamento da noção de transdução no universo filosófico de Gilbert Simondon.

Desenhos: captados desde a formação de séries independentes e paralelas entre corpos-desenho e escrita-corpo, até os pedaços dos cadernos nos quais exercitei a transcrição experimental de alguns dos sonhos de Franz Kafka. Neste último procedimento, o desenho guia a aprendizagem: pela corporificação, pelas inscrições, pelos caminhos e imagens. Há, nas relações de desenho do segundo capítulo, emergência de 'esboçamentos' - corpos com autonomia que aparecem, dizem ou não dizem algo, ali ficam ou se vão. Os esboçamentos são divergentes dos esboços, pois não querem ser obra nem nada acabado. Também não estão submetidos a uma

\footnotetext{
${ }^{2}$ Com referência ao ensaio de Eduardo Subirats a flor e o cristal [1988 (1986)], sobre o pensamento germinativo de Paul Klee.
} 
partitura musical, a uma estrutura paralela, e talvez por isso não sejam rascunhos tampouco. Apenas contemplam e são a opacidade de um corpo. Não são úteis... são a massa que acompanha.

Através das relações de desenho, o segundo capítulo traz o reverso e o verso de um solo perfurado por túneis; alguns acabam dentro de árvores. Me explicarei. Ali, no campo de disparação do segundo capítulo, há restos do projeto inicial de doutoramento de que abdiquei e, com ele, o projeto de música, de corpo e de intelectualidade que eu não sabia então portar comigo. Aquele disparamento fala mais daquilo que não é. Contrariamente aos caminhos que ali se apontam, e o capítulo seguinte. $\mathbf{0}$ terceiro (do homem-árvore ao umanimusgo). Aqui a prática é mais a de matrizes descritivas do estar. Então seriam conversas mais ou menos loucas. Algo também de diário de bordo (no sentido de ver, ouvir, sentir, falar e habitar a partir de um limiar - o bordo). Lá estão as falas práticas que responderam a uma catástrofe de dentro dela, com estratégias de habitações ambíguas e incoerentes, recuadas e dissidentes: os exercícios. Ali se encontram rastros erráticos de um conjunto de açõesensaio e performances: os exercícios que fiz comigo mesmo e outras pessoas.

Fazer uma ação-ensaio, bem como uma performance, é habitar um local durante um tempo. Acampar, situar-se, sitiar. As categorias se borram em alguns momentos. Aqui, algumas alianças momentâneas.

Algumas das trilhas do terceiro capítulo se situam no preparo de uma ação que se baseou no texto de Antonin Artaud o homem-árvore, carta a Pierre Loeb, de 23 de abril de 1947. A ação se chama umanimusgo.

0 trabalho inclui ainda uma pequena 'glândula-caderno' que contém impressão cuidadosa de alguns dos desenhos e textos. Esse pedaço de corpo foi pensado e montado em conjunto com Isadora Ferraz e executado por ela (Atelier feito em casa). 
Quem guia a tese são os desenhos e as palavras-talismã, expressão que são de uma desistência de um certo discurso acadêmico. Em realidade da total impossibilidade deste, em um percurso inevitável com o quase-nada, que em verdade é muito. Quasenada de um abraçar a ignorância a respeito do som, do corpo, da voz.

Os desenhos também são talismãs. Existe uma reviravolta que quero fazer aqui que é a seguinte: chamá-los de inscrição-desenho-escrita. Eles não são desenhos apenas, são pedaços de corpo. E não apenas também isso: são sujeito da tese. Em definitivo.

Será surpreendente demais repropor que escrever é pedaço de corpo e é vivo, posto ainda que é gesto vindo de um percurso que é desenho e é corpo em mutação? Se sim, realmente estaremos em gravíssima situação. As agências de fomento à pesquisa, que só pensam em termos de excelência e produtividade, parecem distraída e oportunamente se surpreenderem e ignorar esse descompasso entre uma pergunta e um constrangimento. E é desconcertante que um pensamento de universidade pública tenha tão apaixonadamente, ainda que sub-repticiamente, incorporado vozes tão predatórias de mercado. Pagaremos caro com tal concessão.

Por isso tudo e por razões íntimas, as principais razões que magnetizam uma pesquisa de vida, eu tinha o intento de desenhar integralmente a tese. Pelo prazo, isso só aconteceu parcialmente.

É algo assim com o desenho. Às vezes se trata de uma escultura com o lápis. Às vezes trata-se de furar uma película para que algo vaze ou brote. Às vezes basta um tracejar para ser rapidamente capturado por algo que já está ativo como um turbilhão.

O segundo capítulo se haverá um pouco com isso. $\mathbf{O}$ desenho é o sujeito da tese. Ele dá testemunho de uma produção de corpo que a performance também capta. 0 desenho é uma das maneiras de se tornar aluno do próprio corpo.

Isso é tão importante, que às vezes me esqueço disso. Então cabe o lembrete. 
Outros lembrete: não tenho intenção de disputar teoria da música ou teoria do som. 0 objetivo desta pequena massa impressa e, bem ou mal costurada, é dar testemunho de um pedaço de corpo. Um corpo que acontece em torno de palavras-talismã, escavações, brotamentos e sobreposições. Talvez assim eu possa deixar vibrar, através da assunção das minhas ficções que buscam contato, as ficções não assumidas do campo de estudo já identificado.

Indagar as próprias palavras. É um gesto simples porém difícil, pois pressupõe uma espécie de força e uma espera. Dali podem vir palavras-talismã. Falarei mais sobre isso.

Um ainda outro lembrete é algo, para mim, agora, muito evidente: a relação com os autores e autoras é extremamente heterogênea, não haveria como ser diferente. $\mathrm{E}$ para fazer valer o registro afetivo deste trabalho, que é sua matéria, há um bolsão de vida que acolheu um comentário de boteco e uma leitura profunda de texto, uma pedra e um sonho. Há escritos inteiros que geram em nós um profundo senso de vínculo e intimidade. Os livros Hijikata Tatsumi: pensar um corpo esgotado (trad. 2018) e gênese de um corpo desconhecido (2012) de Uno Kuniichi são exemplos. E às vezes, do contrário, tudo o que precisamos é de uma frase. Ela é o que furou o marasmo. Nada mais. Todo o resto redunda e passa.

Essas diferentes atitudes se refletem também nas diferentes maneiras com as quais endereço as referências. Desde o proceder formal até 0 informal, o detalhamento obsessivo ao quase-anonimato que constitui, neste contexto, uma potência. Possivelmente fracassei nesse intento. No último caso, é como se houvesse uma indeterminação de vozes, e é a ela que me dirijo. 
[PEQUENA SÍNTESE]

Palavras-talismã. Palavras-pela-metade. Abraço da ignorância.

Corpo, voz, som: individuação conjunta. Não há como saber. Tempo de nascimento da individuação, mas às vezes a palavra está lá sem nascer.

Caminhar na víscera. Inscrição-desenho-escrita. Produção de um corpo. Aprender com o desenho. Desenho é sujeito.

Indagar as palavras. Espera.

Primeiro capítulo. Prática: PERAM BULAÇÃo. Texto um pouco mais corrente.

Segundo capítulo. Prática: GERMINAÇÃO (desenho). Conjuntos principais: séries paralelas de textos e desenhos, uma série não quer explicar a outra.

Aprender com o desenho.

Os cadernos de desenho são os guias da aprendizagem do desenho-corpo. Depois, o campo problemático e produtivo do caderno.

Terceiro capítulo. Prática: CONVERSA DE BORDO (conversa mesmo). Reunião de conversas e exercícios; muitos desenhos; anotações de performance...

(Anexos: sínteses em paralelo; fluxos de fala) 


\section{[ANOTAÇÕES DE LOCAUZAÇÃO] \\ [que eu mesmo, se estivesse lendo, gostaria de saber]}

\section{[1. 0 que é isto?]}

Este trabalho é uma espécie difusa de aprofundamento da pesquisa Corpossom, desenvolvida de modo compacto no período do mestrado (2009-2011) e no projeto que o núcleo laboratório corpossom, o primeiro núcleo da pesquisa, realizou em 2013. No período que seguiu, ou seja, de 2014 em diante, houve um acúmulo de experiências pedagógicas com coletivos diversos. Simultaneamente a isso, deu-se também uma intensificação da necessidade de performar sozinho, como se esse fosse (e é) um modo especial de assimilação e atualização dos processos anteriores.

\section{[2. 0 que é voz neste estudo?]}

No que se entende por trabalho de voz, há elementos dessa pesquisa que reconheço desde 2007, enquanto vocalidades interessadas em operadores-objetos específicos. Exemplos são a tentativa de fazer valer o mote de uma não-técnica, bem como procedimentos de 'composição' de uma vocalidade desconhecida (ou seja, uma modalidade de improviso corpo-vocal-verbal). Meu interesse em 2007 por manifestações vocais incomuns e pela performance vocal de artistas, em geral, da contracultura, culminou nos desejos de ações nesse sentido. Reconheço que essa modalidade de improviso ao longo dos anos foi se tornando mais ambiente-específica do que encerrada no corpo próprio do performer. Alguns desses desejos e ações valeram nomear a posteriori, como os 'gatilhos sonoros' intensidade, densidade, duração, velocidade, ataque' 3 .

\section{[3. 0 que é corpo neste estudo?]}

\footnotetext{
${ }^{3}$ Essa nomenclatura é objeto de investigação e descrição na dissertação de mestrado preparação do corpossom: atuação e voz concreta (2011).
} 
No que se entende comumente como trabalho de corpo e expressão corporal, há práticas e técnicas que reconheço desde 2005, e eventos do corpo desde muito antes. Já que o conceito de corpo, nesta tese, inclui o desconhecido e o traço vivo do desenho e da caminhada errante, bem como outras zonas de suscitação, limito-me a dizer que a própria palavra corpossom tenta enovelar e reunir um conjunto dessas práticas. Práticas de corpo, de produção de corpo, de gênese de corpo, cujo fundamento também ainda não nasceu para ele.

\section{[4. Como se pode pensar o corpossom?]}

O corpossom é um som desconhecido que o corpo pode deixar registrar, na medida em que entra em devir de um modo particular. Essa é uma das definições possíveis.

Existe uma esquiva conceitual deliberada. Essa esquiva se propõe a pensar o binômio corpo-voz, ou o binômio corpo-som, binômio que privilegio, mas é esquiva pois tem dificuldade de pensar o trinômio corpo-voz-som, possivelmente a partir do problema de se pensar o binômio voz-som. Por quê? Justamente por ser o binômio que exclui tudo aquilo que está em jogo: a experiência de um corpo desconhecido. Não podemos perder de vista a corporificação. 0 que quero dizer é que um som desconhecido é contato com um corpo desconhecido, sendo a noção de voz sentida como passagem entre eles. Assim, enquanto eu treino o corpo, eu mobilizo um pensamento vocal em aberto. Desse modo, escolho o binômio corpo-som, pois intuo, pela prática, que 'voz' seja a própria víscera: emergência de origem não-localizável do campo afetivo que instaura devires, mobiliza potenciais, faz saltarem coisas, e vem dizer de um corpo que é avesso do som. A exclusão do termo 'voz' do trinômio é uma consequência desses pensamentos. Eu também treino um pouco a voz, mas eu não posso pensar muito em termos de voz. Eu treino o corpo e penso em termos de corpo, ainda que ele não seja exatamente o corpo da pessoa-eu, mas é ele pois quem vai suportar esses devires, 0 que poderá ser igual a um sucumbimento. Ele também é o próprio elo cotidiano das

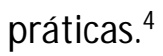

${ }^{4} 0$ que também quero dizer com esse labiríntico parágrafo é que os complexos corpo-voz-som, desenho-caminhada-performance etc são gerados em paralelo, via transdução, ontogênese, 
Nessa definição penso que se pode captar uma preocupação com um pensamento vivo do corpo. Também acredito poder deixar ver a suspeita de que o suposto objeto 'som', pode ser deixado de lado, ou tido como enigma ou indagação, ainda que se trate, em parte, de som. Prefiro a hipótese da indagação viva. Indagar através da corporificação de algumas tarefas, através de traços metodológicos das artes da cena, através de práticas meditativas e energéticas, através de enunciados vitais da voz e da verbalização. Indagar o que seja o corpo, o som, e a voz. É preciso perambular muito para deparar com uma experiência de indagar palavras. A indagação é poética e também concreta. Contudo, o paradoxal e essencial é que essa prática de indagação seja aquela sem resposta, pois o que está em jogo não é propriamente uma resposta, mas uma produção de corpo. Não se pode contentar apenas com a resposta. Nos ensaios que conduzo, tenho usado uma frase que vem mais ou menos assim: 0 importante não é o quê, talvez seja o como, e talvez nem isso: é mais aquilo que é produzido enquanto eu faço algo, enquanto eu me engajo. ${ }^{5}$

\section{[5. Quais são os coletivos de corpossom?]}

Eu chamo de núcleos de Corpossom as diferentes frentes de trabalho que 'evoluem', por assim dizer, de modo mais ou menos independente. Laboratório corpossom, aquele primeiro (2011-2013, principalmente). Agrupamento corpossom, aquele que nomeei com as pessoas que trabalharam comigo durante o período do doutoramento

individuação conjunta. Nenhum termo pode ser pensado por si mesmo, isoladamente. A escolha de corpo e som, portanto, é estratégica. Discutir pelo recorte da voz tem uma complexidade à parte, que me pareceu limitante em algum momento. Penso hoje que isso talvez tenha a ver com a noção moderna de indivíduo, e depois de suj eito, principalmente um sujeito freudiano da falta do seio. Vemos associarse a esse quadro uma ideia abstrata e geral de voz que não dei conta de manejar. As consequências dessa noção de voz na matriz subjetiva freudiana ainda não sei se foram devidamente medidas. Talvez voz seja apenas aquilo que é a ressonância do vivente. Ou ainda a definição de Simondon para a angústia pudesse nos servir: 'angústia é pura ressonância do ser nele mesmo'. Será voz ressonância do fora dobrado na carne?

${ }^{5} \mathrm{Na}$ aula de metodologia de pesquisa em música, em meio a pesquisadores músicos, chegou-se à conclusão de que eu fazia uma pesquisa entre filosofia e teatro, e isso se deu com um certo constrangimento. A divisão também pressupõe que estejamos certos do que seja música. 
(2015 até agora). As pessoas que integram esses coletivos e as pessoas que ajudam no registro audiovisual - e as que dão ou trocam outros tipos de ajuda - serão nomeadas ao longo do texto.

Sempre trabalho bastante sozinho em paralelo com os grupos. Quando digo 'trabalho' falo das práticas mais ou menos diretamente relacionadas a um campo mais ou menos definido de corpossom. As performances que realizo sozinho com este nome (corpossom) tomaram maior densidade a partir de 2014, quando percebi que seria necessário uma intensificação ainda maior dos procedimentos que eu aplicava comigo mesmo. 0 trabalho solo também é coletivo. Assim, esse núcleo não tem um nome específico, ainda que eu use em alguns momentos um nome de que gosto para minhas ações: agência de cisma. Então, para esta tese, principalmente no terceiro capítulo, me vali do nome corpossom em cisma quando da referência aos solos.

\section{[6. Quais as dimensões estético-pedagógica das ações de corpossom?]}

O corpossom penso que possa ser lido pela pedagogia - razoavelmente heterogênea e nômade, atenta às potencialidades do imprevisto, do aberto e do inacabado. A pesquisa tem alguns parentescos e alianças artísticas nesse sentido.

As características do trabalho também podem ser tateadas, creio eu, no tipo de repercussão que as ações rastreiam e buscam, que passa pelo radicalmente singular, e passa por uma relação de voz e som, a grosso modo, 'involuntária', no sentido de que não é a pessoa que faz, mas o corpo. Isso é um modo de dizer. E isso, penso, é uma sofisticada variação da ação.

Acho que os traços pedagógico-criativos próprios também vêm do fato de que há uma relação da pesquisa estética com um pequeno grupo de práticas de meditação (que também são, em paralelo, estéticas pedagógicas), e acho que há um interesse nessa relação. Em resumo, acho que foi cumprido nesse período mais recente um certo caminho tateante de se compreender uma certa conversão estética de um lugar inominável. 


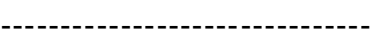




\section{[UM]}

\section{[perambulações com}

\section{corpossom]}

[BLOCO UM: o que pode ser um corpossom?]

[BLOCO DOIS: caminhada-catástrofe: primeiras imagens de víscera] 


\section{[BLOCO UM]}

\section{[o que pode ser um corpossom?]}

Este texto foi escrito após a maior parte da elaboração do BLOCO DOIS deste capítulo (caminhada-catástrofe: primeiras imagens de víscera). Pois era preciso chegar a um 'nada', um campo de desconstituição de tal ordem que não se pudesse falar mais nada senão da retomada de um conjunto de situações que este trabalho envolve. 


\section{[CORPO, DETRITO, TEIA, CAMINHADA] \\ [CORPO-DIFERENÇA, ALTER-ORGANISM O]}

\section{1.}

\section{Quais são as situações?}

Situação. M eu corpo se move em um espaço. Faço variações de movimento. Não é tanto preciso especificar quais variações. Vamos dizer didaticamente que eu faço o movimento, mas não é exatamente isso. Canso, tento outra coisa. Surgem diferentes movimentos. Canso, tento diferentes estratégias de movimento. Concentrome em outra coisa ou tento espaços de atenção onde eu possa deslizar entre as variações ou escavar algo que eu poderia chamar de estratégia. Por exemplo, concentro-me nos pés, ou no movimento que é minha respiração, ou na textura de algum material. Deixo o movimento aparecer. Assim, do contato com algumas estratégias, combino e fricciono diferentes movimentos, tentando rastrear outros, deixando moverem-se outros; polarizo estados, paulatinamente me agito, solto gemidos e grunhidos. Um longo gemido se converte lentamente em uma monodia. A partir da monodia, um outro corpo, bizarro, mas estranhamente ordenado, toma lugar. É importante dizer que, neste trabalho, a voz não é uma técnica no sentido positivo, nem apenas no negativo, mas no sentido enigmático: a voz é em aberto. É a produção e vocalização de sensações que está em jogo. Nada mais terrível do que ter por respondido a questão de se ter um corpo, nada mais terrível do que se dar por respondido o que seja a voz, o som, do que dar por respondido o que seja, portanto, 0 pensar, o humano... (segue o improviso)

\section{2.}

0 trecho logo acima é uma descrição de uma sessão de improvisação. Uma situação de ensaio ou performance onde é o meu corpo que atua. 0 corpo neste contexto é e tem um modo composto (1), móvel (2) e multiescalar (3) de produção. 0 que quero dizer 
com isso? Que o corpo seja uma reunião ou ainda associação de diferentes coisas (1). Que o corpo faça e refaça, pelo próprio fato de existir, seus próprios diagramas (o que inclui os diagramas rítmicos: esqueletos de deslize, suspensão de acúmulo, escavação...) (2). Que o corpo tenha produção de escalas de relação e movimento (3), como o sugere, por exemplo, José Gil na introdução de seu movimento total e toda a sua série de escritos sobre a metafenomenologia e o inconsciente do corpo.

Prossigo na minha invenção de palavras. Um corpo é aqui compreendido como um coletivo multiescalar ${ }^{6}$, multiespecífico e alter-orgânico (sobreposição entre orgânico e inorgânico que configura órgãos que a medicina e a ciência modernas não medem). Ou seja, posso querer dizer muitas e muitas coisas quando digo 'meu corpo', e proponho escrever aqui sobre corpo por ora nas chaves acima mencionadas.

\section{3.}

É bastante constrangedor falar assim, taxativamente, sobre o corpo. M as é importante ressaltar uma tipologia momentânea dos magnetismos que me guiam pelos espaços próprios a este trabalho. 0 espaço perfurado (não necessariamente aberto), o espaço heterogêneo e ambíguo, o espaço de detrito, o espaço de musgos e entre-limites são algumas categorias ou imagens de base para a captação de uma dinâmica espacial própria. Traduzo-me: corresponde, a tipologia acima, por exemplo, a um pequeno espaço entre salas, um gramado; um espaço em reforma ou os canteiros que reúnam seus montes de detritos; um galpão abandonado. Uma garagem usada para outro fim qualquer, o lado de fora da cerca de uma casa, um canteiro ao lado das estradas etc. Esta topologia é o que me permite ler a heterogeneidade nos raros momentos em que adentro um espaço de estúdio ou de um edifício teatral, por exemplo. Nesse sentido a prática do devir pela caminhada me aguça a sensibilidade para captar 'lugares': um conjunto de diferentes coisas que configuram uma espécie de membrana de potenciais ou uma forma de tempo esquisita, particular.

\footnotetext{
${ }^{6}$ Aqui inspirado por Gabriel Tarde, Gilbert Simondon, Donna Haraway e outros e outras.
} 


\section{4.}

A ação de corpossom é sempre vivida em meio a detritos para sempre desconstituídos, desfeitos, de que 0 objeto inicial está para sempre perdido ${ }^{7}$. Um paralelo com 0 desobjeto ${ }^{8}$ de Manuel de Barros, com exceção do fato de que um pente pela metade ainda viria de um pente. Se bem que o menino no poema diga: 'não se poderia mais dizer se aquela coisa fora um pente ou um leque.'

Um detrito, neste contexto, também não se pretende elemento da dramaturgia da ruína ${ }^{9}$. Elemento também barriano, mas em verdade helenístico e depois romântico. 0 detrito é apenas o pedaço de algo cujo tema é a fratura e cujo objeto inicial é uma virtualidade infinita ou vazia. Ele não se pretende mais. Não se pretende futuro. Ao contrário desta ruína barriana que o monge da anedota descreve.

\section{[...] Continuou: digamos que a palavra AMOR. A palavra amor está quase vazia. Não tem gente dentro dela. Queria construir uma ruína para a palavra amor. Talvez ela renascesse das ruínas, como o lírio pode nascer de um monturo". E o monge se calou descabelado.}

Das ruínas nasceriam então lírios. E do calar-descabelar do monge nasceu 0 detrito.

Vejo, de outro lado, um eco de Fernand Deligny no detrito: 'Que o ser sem querer seja também sem desejo - essa é uma questão que eu deixo ao cuidado de outros. / No entanto, ser sem querer não implica que o ser seja inerte. ${ }^{10}$ Saturação de potenciais. Talvez mais um Agroval11 barriano do que sua ruína. Certamente, a pressão que chamamos 'futuro' pode não ser algo: é mais uma orquestra involuntária de tropeços, em correspondência com o estapafúrdio comércio de limbo de inqualificáveis caminhos ínfimos deste poema barriano.

\footnotetext{
${ }^{7}$ Neste sentido, a noção de 'esboçamento' emerge como um verso ou modalidade de detrito. 0 esboçamento é o modo de desenho (ou produção de corpo: corporificação) pelo qual um detrito pode ser construído: uma associação de linhas vitais autônomas que geram uma espécie de corpo ou uma espécie de lugar.

${ }^{8}$ Desobjeto, poema de memórias inventadas - a infância (2003).

${ }^{9}$ Ruína, poema de ensaios fotográficos(2000).

${ }^{10}$ Fernand Deligny, L'arachneén (o aracniano) (1981 ou 1982). P. 47. Aforismo 23.

${ }^{11}$ Agroval, poema de livro de pré-coisas (1985).
} 
5.

Em suma: em ação rapidamente venho verificar que meu corpo é uma reunião de muitas diferentes coisas. A heterogeneidade radical e simbiose compositora da membrana que chamamos 'meu corpo' está imersa e também imerge 0 ambiente como heterogeneidade radical. Há membranas, mas os pedaços de corpo, que é e não é 'eu', produzem linhas e feixes de continuidade.

\section{6.}

Posso vir a verificar também que meu corpo é um nó de diversas linhas que já se cruzavam $^{12}$. A noção de emaranhamento do antropólogo-biólogo Timothy Ingold pode ser praticada. 'Every plant, too, is a living tissue of lines. And so, indeed, am I. [...] The world, for me, is not an assemblage of heterogeneous bits and pieces but a tangle of threads and pathways. Let us call it a meshwork, so as to distinguish it from your network.'13 (Ingold, 2008, p. 212). Entre a malha emaranhada do antropólogo Ingold (1948-), as linhas errantes do poeta e etólogo Fernand Deligny (1913-1996) e o denso emaranhado que vibra e se transforma, do sonho do compositor György Ligeti (19232006) quando criança, há muita coisa. ${ }^{14}$

In my early childhood I once dreamt that I could not make my way to my little bed (which had bars and for me signified a haven) because the whole room was filled with a finely spun but dense and extremely tangled web, similar to the secretions with which silkworms fill their entire breeding box as they pupate. Besides myself, other living creatures and objects were caught in this immense web: moths and beetles of all sorts, which were trying to get to the weakly flickering candle in the room; and enormous

\footnotetext{
${ }^{12}$ A noção de 'anterioridade do espaço' se baseia, em parte, nessa apreensão prática.

${ }^{13}$ [Cada planta, também, é um tecido vivo de linhas. E também, por certo, eu sou. [...] 0 mundo, para mim, não é uma montagem de pedaços heterogêneos, mas um emaranhado de fios e caminhos. Chamemos ela de malha, então para dintingui-la da sua rede.] (tradução por minha responsabilidade) ${ }^{14} \mathrm{O}$ relato de Ligeti é impressionante e merece ser incluído na íntegra. É o início de states, events, transformations (LIGETI; BERNARD, 1991. In: WINTER, 1993), ensaio publicado trinta anos antes e revisado algumas vezes ao longo das décadas.
} 
damp, dirty pillows, whose rotten stuffing was bulging out through rips in the covers. Every movement of an immobilized insect caused the entire web to start shaking so that the big, heavy pillows swung back and forth; this, in turn, made everything rock even more. Sometimes the reciprocal movements became so violent that the web tore in places and a few beetles were unexpectedly liberated, only to be ensnared soon thereafter, with a choked buzz, in the rocking mesh once again. These periodic, suddenly occurring events gradually altered the internal structure of the web, which became ever more tangled. In places impenetrable knots formed; in others, caverns opened up where shreds of the original web were floating about like gossamer. These transformations were irreversible; no earlier state could ever recur. There was something inexpressibly sad about this process: the hopelessness of elapsing time and of the irretrievable past. ${ }^{15}$ (Idem, 1991, p. 164)

Ligeti afirma em seguida que esse sonho tem uma presença perene e viva na sua atividade de compositor em vários sentidos. No meu caso, é uma imagem de improviso, de performance, de caminhada.

\section{7.}

E o que é, finalmente, que é feito? Sim, uma espécie de caminhada. Uma caminhada física e também qualitativa e também multiescalar, em torno de diversas

${ }^{15}$ [Na minha primeira infância eu uma vez sonhei que eu não conseguiria chegar na minha pequena cama (que tinha barras e para mim significava um refúgio) porque o quarto inteiro estava cheio de uma teia fina, mas extremamente emaranhada, semelhante às secreções com os quais os bichos-da-seda preenchem toda a sua crisálida enquanto eles pupam [metamorfoseiam]. Além de mim, outras criaturas vivas e objetos foram apanhados nesta imensa teia: mariposas e besouros de toda sorte, que tentavam chegar à vela que tremeluzia fracamente na sala; e enormes travesseiros úmidos e sujos, cujo recheio apodrecido brotava através de rasgos nas capas. Cada movimento de um inseto imobilizado fazia com que toda a teia começasse a tremer, de modo que as almofadas grandes e pesadas oscilassem para a frente e para trás; isso, por sua vez, fez tudo balançar ainda mais. Às vezes os movimentos recíprocos tornavam-se tão violentos que a teia se rasgou em alguns lugares e alguns besouros foram inesperadamente liberados, apenas para serem capturados logo depois, com um zumbido abafado, na malha balançante mais uma vez. Esses eventos periódicos e repentinos alteraram gradualmente a estrutura interna da teia, que se tornou cada vez mais emaranhada. Em alguns lugares, nós impenetráveis se formaram; em outros, cavernas se abriram onde fragmentos da teia original flutuavam como se fossem de gaze. Essas transformações eram irreversíveis; nenhum estado anterior poderia se repetir. Havia algo inexprimivelmente triste em relação a esse processo: a desesperança do tempo decorrido e do passado irrecuperável.] 
configurações de danças, modos de escuta e vocalização, que também são caminhadas. Então, o corpossom pode ser uma caminhada de caminhadas que pode cantar e dobrar a noção de canto improvisado sobre si e seus componentes, produzindo uma caminhada-canto, uma respiração-caminhada, um corpo-caminhada que é canto de algo... uma caminhada que é também rastro de desenho e de vozes ecoadas e recomposta de outros. 


\section{[O DOBRAR E A CONSTRUÇÃO DE UM CAM PO RECEPTIVO-ATIVO]}

\section{8.}

A caminhada é uma prática de devir, uma prática de metamorfose, uma prática da mutação. No corpossom, a caminhada está dobrada sobre si, bem como os pulmões, os intestinos e o cérebro estão dobrados sobre si. Bem como o coração está torcido e envelopado sobre si. Bem como as peles são membranas que se dobram, se envelopam e se costuram com caminhos envolvidos e caminhos comunicantes. Bem como a crisálida secreta seu próprio envelope de tempo e de metamorfose.

9.

E assim, trata-se de um improviso de lugar, trata-se de acompanhar um ser-corpo em si, em primeiro lugar (o que já é bastante coisa), e como avesso do som, em segundo lugar, já que não existe som a priori, o som é uma relação de coisas.

Lembrei da frase de uma aula de Claudio Ulpiano, falando dos estóicos: 'a essência de um corpo é a multiplicidade de potências ${ }^{\prime 16}$.

\section{0.}

Então o que eu faço, essencialmente, é produzir e vocalizar sensações, e escavar em meu corpo lugares para que essa atividade ambígua seja uma mutação. Nisso me apoio, dentre outras coisas, em uma sentença, apenas um ou dois pedaços de frase, ditas pelo improvisador Phil Minton: 'cantar sem técnica'. Pois, segundo ele, a técnica da voz na Europa (não apenas lá) está impregnada pela cristandade, 'e a cristandade fez muito mal pra voz'17. Na série de vídeos 'John's house' $(2008)^{18}$, por exemplo, 0

\footnotetext{
16 Aula de 05/04/1999 de Claudio Ulpiano: acontecimento e campo de poder. Consultado em https://acervoclaudioul piano.com/2017/09/16/aula-de-05041989-acontecimento-e-campo-do-poder-2/ ${ }^{17}$ No vídeo the feral voice. Phil M inton's Feral Choir in Cologne. Disponível até a data desta escrita no site www.youtube.com
} 
som vocalizado por Phil é um personagem autônomo traçado por um campo afetivo. 0 campo se dá com relação a tantas coisas, tantas linhas e membranas comunicantes, tantas passagens e tantos encontros singulares, que nem Phil, nem 0 ambiente e nem nós sairemos ilesos. E é antes o contrário: essa habitação e esse contato momentâneo 'geram' os termos de uma relação. É uma técnica radicalmente relacional e processual e, portanto, do contato, ativa, criativa, diferenciante ${ }^{19}$ e transdutiva ${ }^{20}$.

\section{1.}

Daí que eu volto àquela questão da caminhada de corpossom: das linhas que já estavam lá. É muito difícil para os musicistas ou os atuadores conceberem uma ação que você executa, mas que já estava lá. 'M as como assim: o som é um objeto ou uma relação que você faz.' Não penso que seja assim. Podemos falar em termos de atualização de potenciais, mas não sei se essa noção abrange o que tento dizer. É como se o som já estivesse dobrado, ou ainda não seria isso. É talvez assim: você não vê o surgimento do som. Existe um tipo de invisibilidade do som que na verdade é uma opacidade. Daí que eu relaciono a anterioridade do espaço a uma opacidade do invisível, e um som como tecido por ambas.

\footnotetext{
${ }^{18} \mathrm{Em}$ parceria com a artista plástica Patricia Osses. Phil improvisa em diferentes lugares da casa onde morava o dramaturgo John Osborne. Eu digo justamente 'lugares' que não poderiam a rigor ser chamados por cômodos: sob a escada, uma janela do porão...

${ }^{19}$ A partir da leitura de Eduardo Vargas para a microssociologia de Gabriel Tarde.

${ }^{20}$ Termo muito empregado por Simondon ao designar a operação especial através da qual uma estrutura é transmitida a outra estrutura de um campo próximo, em contato. É uma ontogênese (não apenas uma noção abstrata de ontologia ou cultura, tão próprias do positivismo), ontogênese viva do contato, do processo, da experimentação parcial, da formalização parcial e do relacionar-se. A filósofa Muriel Combes faz uma apresentação didática dos principais conceitos Simondonianos no livro Gilbert Simondon: individu et collectivité (1999). O filósofo Pascal Chabot também apresenta o conceito conforme utilizado por Simondon no necessário filme Simondon du desért (2013, direção de François Lagarde e Pascal Chabot). Esses dois materiais foram a minha porta de entrada para o universo da escrita de Gilbert Simondon, porta esta que eu chamo por minha primeira onda na direção de Simondon.
} 
12.

Parece-me evidente que o que chamamos som vem atualizar ou ainda realizar virtualidades ${ }^{21}$ e produzir corpo. E eu reconheço um corpo devidamente treinado ou 'destreinado' na medida em que desenvolveu uma especial sensibilidade produtiva para os potenciais do ambiente. M as estou a chamar a atenção para a processualidade radical da possibilidade de realização desse modelo: o que é que me dá a irrecusável sensação do que o som 'já estava lá?'

13.

A minha resposta poderia ser: pois é preciso criar ou tocar-e-ser-tocado em um campo receptivo-ativo que vai captar rumores antes mesmo de você deparar com o lugar da performance. $\mathbf{O}$ contorno da criação e da obra (se se quiser) é a própria construção de um campo receptivo-ativo. 0 sujeito da criação é uma espécie de monstro, de Godzilla formado por inumeráveis componentes distribuidores de potenciais, dos quais o performer é apenas mais um elemento. Trata-se de uma escuta difusa que escava o rumor do contato. Não se trata de obter fórmulas e aplicá-las. Em termos parcialmente simondonianos, seria algo de experimentar a ontogênese do som, por tudo aquilo o que ele não é ou não parece ser. A sensibilidade para o rumor 'abre' um canal paralelo para os ditos 'sons' atuais, que não são a base.

Seguem algumas reflexões pedagógicas.

${ }^{21}$ Os pares atual-virtual e real-abstrato são trabalhados pela filosofia deleuziana. Utilizo eles conforme aparecem no livro de Peter Pál Pelbart o tempo não reconciliado: imagens do tempo em Deleuze (1998). 


\section{[ANOTAÇÃO COM PEDAGOGIA, PERFORMANCE E SONOPLASTIA]}

14.

Situação. A sala de ensaio ou lugar de ensaio: uma membrana maior, transitória, onde cada um nina a si mesmo como a uma criança, em seu próprio nicho ou placenta móvel. Aqui, no lugar de ensaio, há uma conjunção entre performance, pedagogia e sonoplastia. 0 encontro, por fugaz que seja, ou mesmo o rumor dele, é o emaranhado de inumeráveis linhas. Quando conduzo um ensaio, além da condução ser naturalmente uma exigência física, percebo que meu corpo coleta informações sobre sonoplastia ou dramaturgia sonora. Há uma linha aparentemente tênue que comunica, em termos conceituais, atuação e dramaturgia sonora ${ }^{22}$. Contudo, a comunicação, para muito além ou aquém da dimensão conceitual, é profusa e permanente. Um corpo de atuador-pedagogo que exerce seu trabalho livre num encontro laboratorial coletivo (ainda que seja solitário será coletivo) se aproxima dessa zona instável de intensa comunicação.

\section{5.}

Como o conjunto de práticas de corpossom tenta levar em conta o som sem privilegiálo, ainda que se trate de práticas de som, prefiro formular que corpossom seja algo do som como relação e não como objeto. Ou ainda, em termos simondonianos, um corpossom pode ser a individuação (ontogênese) conjunta do corpo e do $50 \mathrm{~m}^{23}$ Ainda que os eventuais sentidos de 'som' e 'corpo' estejam calados (não patentes como tais), eles se individuam localmente nesse coletivo. E não necessariamente se individuam como uma disciplina. 0 essencialismo e o idealismo são desincorporantes, eles roubam os corpos.

\footnotetext{
22 Trabalho com sonoplastia e dramaturgia sonora desde 2005.

${ }^{23}$ Conforme eu disse da relação entre uma pessoa e uma palavra-talismã, na introdução desta tese.
} 


\section{[JANÔ E LNHAS VITAIS]}

16.

0 professor Januzelli ${ }^{24}$ disse algumas vezes, ao expressar sua resistência ao uso apriorístico de trilha sonora nos trabalhos que dirigia, que ‘a música é 0 ator’25. Não sei se essa é uma afirmação apenas essencialista. Creio que essa afirmação corresponde a uma tentativa dar conta de um campo de saber-fazer anti-disciplinar ou alterdisciplinar e recursivo que re-inventa seus próprios termos, como gênese de um ambiente de trabalho. Falarei um pouco mais sobre isso para rastrear uma raiz metodológica ou contra-metodológica do ambiente de trabalho do corpossom.

\section{7.}

Janô já se referiu à metamorfose do performer, posta em paralelo à possibilidade de escritura-leitura de um senso de música, como 'a grande dança do logos', termo que ele empregou algumas vezes, ocultando a fonte. Essa é outra expressão, ainda que misteriosa, de caráter aparentemente essencialista. 0 que é a dança do logos? Sem dúvida que a junção de singulares gerais expressa uma universalidade. Não penso, contudo, que seja uma tentativa de aplicar um conhecimento ou noções musicais formais e estritas na proposição de laboratórios, na dramaturgização ou na encenação.

${ }^{24}$ (1940-) Diretor, pesquisador, professor, ator. Orientador durante o meu mestrado (2009-2011) e diretor do trabalho subsequente laboratório corpossom na foz das cavernas (2013). Legou dois trabalhos escritos de maior escala: 0 ofício do ator e o estágio das transparências (1992), sua tese de doutoramento, e a aprendizagem do ator (2003), além de publicações esparsas. Contudo, sua principal contribuição, penso, são as mais de quatro décadas dedicadas ao ensino e a pesquisa da atuação, pautada em grande parte na exploração do corpo e na dramaturgização de improvisos, que podiam resultar em estudos cênicos ou espetáculos.

${ }^{25}$ As reflexões a seguir são de inteira responsabilidade minha. Há fontes orais e escritas para adensar a multiplicidade de perspectivas so bre o campo de pesquisa que será pensado. A simbiose entre música e práticas da cena é praticamente infinita. Em fala do professor Jacó Guinsburg em aula (2009), que transcrevo livremente, a relação do teatro com a música é, salvo engano, a principal fonte de impulsos para a renovação da cena. Deixo registrados aqui dois exemplos acadêmicos de compilação de casos, especificamente da relação de campos musicais com a 'linguagem' do teatro. Exemplos de compilação dos quais penso que ainda não se extraíram todas as consequências práticas: a tese de Fabio Cintra (2006) e a dissertação de Jussara Fernandino (2008). 
18.

Janô. Talvez se tratasse da tentativa de pensar um sentido germinal com as palavras, um sentido de algo que misteriosamente se organizasse com o próprio contato entre corpos. Ao passo em que se alude a um corpo misterioso, mas nomeável, que a dramaturgia, como campo procedimental, tenta coletar e depois retracejar continuamente. 0 corpo do 'teatro dos desejos'26 tem algo de tão radicalmente singular e explosivo, que coloca em questão o ser-corpo dado de antemão. Vislumbrase um corpo desconhecido que vai construir uma explosão, um furo, uma metamorfose: algo que só pode ser tateado com palavras estrangeiras e impregnadas da situação de um mistério vivo. A palavra 'música' pode virtualmente suportar essa imantação, com todo o perigo do idealismo e do essencialismo, ainda e contanto que palavra 'música' aqui tenha a valência daquilo que é desconhecido e estrangeiro. ${ }^{27}$

19.

Com isso não quero dar a entender que o professor Januzelli não seja um conhecedor formal de música. Quero apenas com isso dizer que podemos usar outras palavras para o que se passa. Reproduzir um essencialismo na música ou na cena impunemente é diferente de tentar reconhecer e tentar coletar ou tentar atingir movimentos misteriosos da vida que aparecem em cena. E o vocabulário se apresenta para nós, nessa perspectiva, como uma redescoberta e um desafio. ${ }^{28}$

\footnotetext{
${ }^{26}$ Constantemente referido pelo próprio Janô como um eixo de sua metodologia.

${ }^{27}$ Há outras peculiaridades do vocabulário de Janô, como o uso quase constante e quase compulsivo, no tocante aos comentários de seu método de trabalho, da palavra ator e homem. 'Ator é função do homem'. Na minha visão, isso corresponde em parte a uma produção epocal de vocabulário, entretanto duradoura, que traça humano como homem, o que vemos constante em muitos autores. Um exemplo disso é o uso que o próprio Antonin Artaud faz de homem. Tento problematizar este ponto na performance umanimusgo. Ver o capítulo três desta tese: 'do homem árvore ao umanimusgo'.

${ }^{28}$ Cito de memória uma fala da dramaturga feminista e anticapitalista Lina Prosa, durante uma oficina com ela na qual eu estive em 2017, o EmpalavradaS: 'é preciso cultivar mais mistério e menos conhecimento'.
} 


\section{0.}

Posto tudo isso, na medida em que as pessoas se valem do vocabulário do Janô visando 'uma escola' formalizada que pode ser reproduzida, isso pode vir a resvalar em problemas éticos. De outro lado, não se pode dizer que Januzelli não tenha desenvolvido uma metodologia da criação cênica, e é isso o que penso estar em jogo. É uma metodologia que envolve a legitimidade e a valência de palavras muito vivas: laboratório e aprendizagem. Nessas duas palavras se pode reconhecer uma herança de importantes pedagogos da cena, como Jerzy Grotowski (1933-1999) e Joseph Chaikin (1935-2003) entre outros e outras, de um lado, e o olhar para a cena e a literatura latino-americanas, de outro.

\section{1.}

Digo 'método' por conveniência, e é bem mais visceral do que isso: é mais uma gramática existencial vinculada a um campo de trabalho livre e ético. Mas ocorreu para mim que 'método' parece ser a entrada no objeto a ser compreendido e relacionado, mas ao cabo de um processo vem a ser a própria construção do objeto e da relação de 'objetalidade' deste. Eu construo um objeto. Daí que o emprego de 'traços metodológicos' parece se adequar ao caso, como aquilo que me permite construir uma relação de objeto de experiência. Pesquisa em atuação: numa instância oficial, 'construção de objetos de experiência'.

\section{2.}

Suponhamos uma correspondência de objeto e objetivo, de um lado, e natureza e cultura, de outro. 0 'objeto' enquanto modo controlado de dizer 'um outro'. É o outro que se 'tolera'. E suponhamos a existência de um dado projeto (lembremo-nos da retirada que Deligny faz da dimensão do projeto) como prospecção dos vínculos entre esses dois pares de entidades 'purificadas' (com Bruno Latour) sobre as 'mutilações digestivas' (com Artaud). A conclusão desse raciocínio é simplesmente um disparate. Poderia ser: 'De que modo eu posso extrair a reafirmação da cultura hegemônica 
('objetivo') a partir de uma mentira sobre alteridade ('objeto')'. 0 que dizer? Qual 0 tamanho da aberração em que estamos metidos? ${ }^{29}$

\section{3.}

Duas conversas com Janô mais recentes me deixaram saber mais dessas palavras que usamos que são apenas traduções vitalistas, e isso é muito. Falarei delas. Palavras como traduções de algo parcial comprometido com um campo afetivo da cena e do trabalho do atuante onde as saturações da vida se podem redistribuir, onde figuras mágicas podem fazer passagem e deixar senhas vivas. Ou 'hieróglifos vivos', como, escreveu Artaud. Aqui a noção de metodologia faz algum sentido mínimo, de acordo com uma vida que pesquisa a si mesma, uma vida que se dobra sobre si, torce em si em contato afetivo (e não é apenas mediada por um conceito) com sua própria realização. A vida tem seu próprio método vital, válido para uma vida. Contudo, essa vida é um bem coletivo, emaranhada de muitas coisas. Assim, refiro-me aqui não só ao trabalho físico 'de estúdio', de ensaio, mas ao grupo de laboratórios que se dedicam a estudar, inventariar e conhecer as diversas linhas que se cruzam na existência de uma pessoa. Árvores genealógicas ${ }^{30}$ de diversos tipos de parentesco; listas guiadas por uma pergunta; mapas-mundi; listas de eventualidades ou relações... A recomposição continuada dos laboratórios e das aprendizagens também confere sentido local e mínimo de método, de acordo com princípios gerais de expressão e pensamento que são reconhecidos e retracejados, renomeados, no contato. Para serem apreendidos, esses princípios devem ser reinventados de acordo com um tracejar vitalista. A empresa é imensa e inescapável. Resta saber se o nome 'método' se aplica. Algumas

\footnotetext{
${ }^{29}$ Uma antropologia de borda ou contra-antropologia poderia nos ajudar a reconhecer que todo objeto é antes um sujeito. Isso é arriscado demais para instituições comprometidas com uma herança colonial, proto-colonialista (patriarcado). E numa correspondência ainda mais ampla, uma herança antropocênica.

${ }^{30}$ Este laboratório em específico parece ser, ao menos parcialmente, no caso de Janô, um campo comum com o professor Clóvis Garcia (a partir de narrativas de um ex-aluno de ambos). Januzelli reverencia Garcia no início de sua tese. Hoje se tem noção de que a auto-arqueologia - ou algo do gênero - seja uma prática difundida na pesquisa em atuação, para rastrear as linhas vitais que se emaranham na sua própria.

Inventariar de onde eu vim. Ainda no caso de Janô, esse grupo de laboratórios embrenha-se também com o laboratório do contar-se.
} 
vezes Janô disse que existem os exercícios, e de outro lado é preciso que 'eu invente exercícios partindo do acontecimento'. 'Quais são os exercícios?'

\section{4.}

Uma pista foi de uma conversa onde, em dado momento, quando me queixei (mais uma vez) da necessidade de se adequar a um estilo acadêmico, ele emendou: 'mas nós somos de uma outra academia'. A frase é de se deixar em situação de alerta, pois vem lembrar que a pesquisa é a própria matéria da vida. Vem lembrar que a noção de arte 'epocaliza' e distribui as disciplinas artísticas, não nos livrando contudo de uma tarefa mais insólita e necessária a cada dia: reconhecer que as coisas têm sua língua, externa ao mundo humano. Ainda que sejam participantes e constituintes do mundo humano. Aliás, justamente por conta isso: é nas coisas que nos ancoramos. Assim, é preciso problematizar a pesquisa e a noção de ciência e as especialidades artísticas têm especial sensibilidade às regiões problemáticas da mutilação que gera a especialidade das disciplinas. Com isso não quero dizer que não exista uma particularidade dos fazeres. Mas é uma divisão infinitamente diversa. 
25.

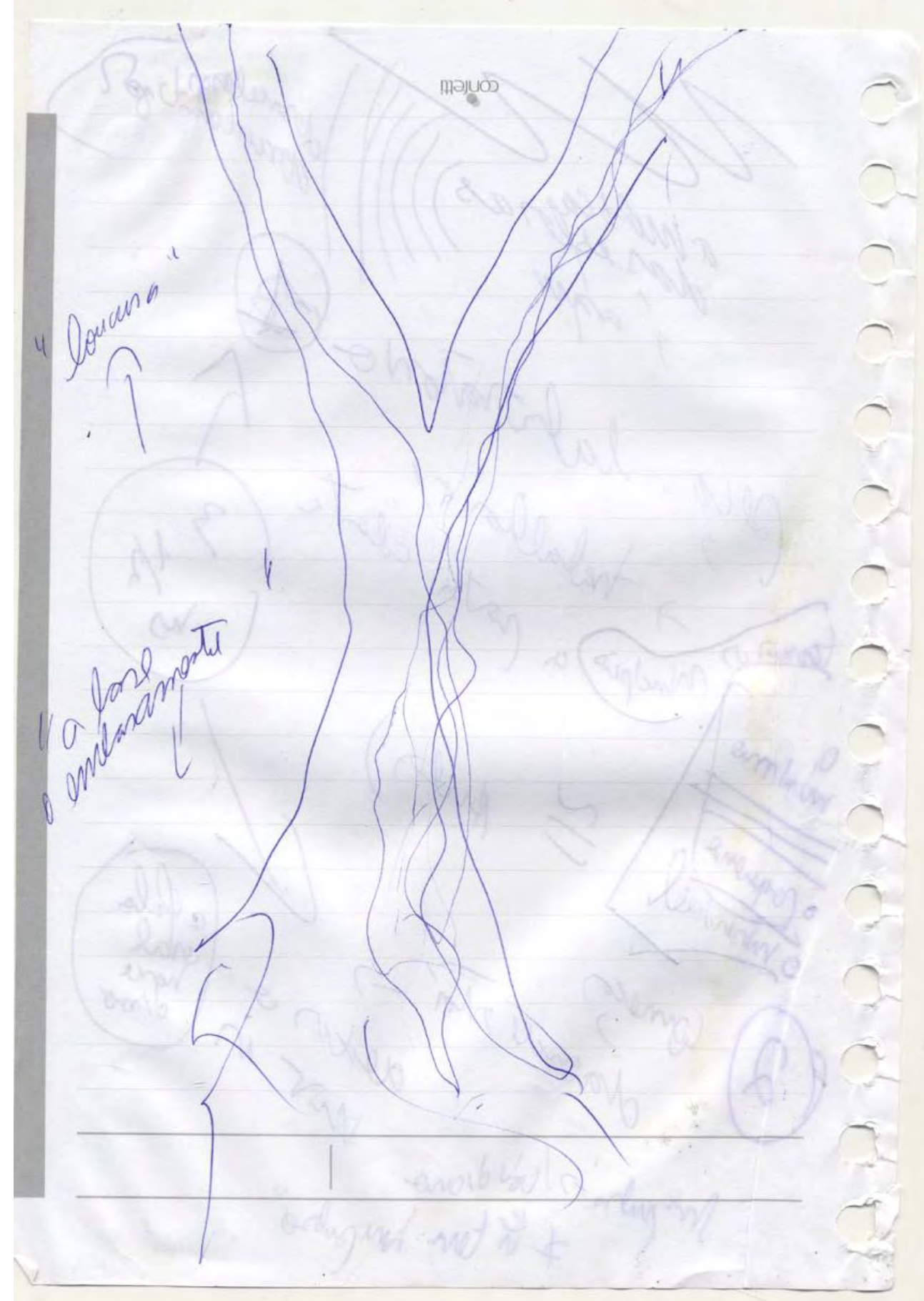

Figura 1. A árvore que Janô desenhou no meu caderno nesse dia. As anotações 'loucura' e 'a base' / 'embasamento' são minhas a partir dos comentários dele. 


\section{6.}

A outra conversa foi talvez nosso último encontro prático, agora em 2018. Conversávamos, em dado momento, sobre como alguns alunos antigos se fixaram no vocabulário que ele usava, e não atentaram para a experiência viva que torna urgente o retraçar do próprio vocabulário.

27.

Se eu utilizei muitas vezes, ao comentar o trabalho do Janô, a palavra 'vida', quase simulando o uso compulsivo que Nijinsky faz dela, é porque também nisso consiste um retracejado. ${ }^{31}$ Começo a me indagar se não alerto o leitor para as inevitáveis redundâncias.

\section{8.}

Eu relaciono o pensamento de anterioridade do espaço que descrevi acima com um laboratório que o professor Januzelli trabalhava e, se preferirmos, o primeiro dos estágios da improvisação: o laboratório da chegada. 'Como eu venho vindo até aqui?' Nesse trabalho, nós nos indagávamos sobre aquilo que aconteceu antes e dava condições para que algo em seguida pudesse acontecer. Até o ponto em que fosse possível conceber a chegada em tempo e espaço combinados, com condições para

\footnotetext{
${ }^{31}$ Pode parecer ao leitor distraído um ataque a Janô, mas na verdade trata-se de uma ampla e franca defesa, pois já testemunhei professores e profissionais acusando-o de não sistematizar o conhecimento que reuniu ao longo dos anos, publicando-o e difundindo-o em maior escala. Alguns alunos antigos também vêm expressar, vez ou outra, a estranha pretensão de 'suceder ao mestre'. 0 problema da 'sucessão de escola' é complexo e problemático, começando-se por que esse ensejo tenha como pressuposto a existência formal de uma escola consolidada a ser transmitida como bloco. Não digo que seja um pressuposto, mas que esse limiar é problemático. 0 que quero dizer? É simples: que o senso de pertencimento (em verdade basta a intensa vontade de pertencimento) a uma escola pode ser máquina de fabricar Pais Fundadores, pioneiros e originários. E eu estou aqui em defesa de Janô como um pesquisador errante e nômade em suas estratégias.

De qualquer forma, não é o caso de uma escola consolidada em sentido estrito. Contudo, há ainda de se fazer um mapeamento da escala da reverberação que sua atuação pedagógica continuada de décadas teve e tem. Resta dizer que, ao passo em que Januzelli é visto como um acadêmico incomum, tanto melhor. É na sua excepcionalidade de pesquisador vitalista e em seus conflitos com o mundo acadêmico que poderíamos verificar o vigor de seus pensamentos da criação e traços metodológicos.
} 
uma criação conjunta. Essa recapitulação recuava até onde fosse possível. 0 laboratório da chegada era muito conduzido também em função dos atrasos: 'chegar antes para não chegar depois'. Como eu atrasava muito nos ensaios, esse laboratório me foi explicado algumas vezes. 


\section{[ANTERIORIDADE DO ESPAÇO: PELO MENOS DOIS CASOS]}

\section{9.}

Entretanto, minha percepção de uma opacidade do invisível aliada a uma anterioridade do espaço teve dois processos muito definitivos. 0 primeiro, ao propor para pequenos grupos, ao longo do tempo, o laboratório da nota ${ }^{32}$. Ele é uma proposta de campo de trabalho.

Situação. Consistia em vocalizar junto, concebendo o espaço que vibra como campo do comum. Digo 'espaço' de um modo simplista. É a dimensão da construção do comum: pode ser o espaço onde todos habitam, pode ser 0 ar que comunica os corpos, pode ser a própria massa sonora do ambiente. 0 que chamamos 'espaço' vem com suas configurações, pressões e gêneses heterogêneas (de ordem elástica, oscilatória ou vibrátil, e outras que se queira).

\section{0.}

A nota: deveríamos negociar a gênese desse campo comum a partir da emissão de um som preferencialmente vocálico e longo. Apenas preferencialmente. Assim, deveríamos compor uma 'cama' para utilizar de diversas maneiras - 'de diversas maneiras'... essas variações foram objeto posterior de sessões de improviso, roteirização e de performance. Uma das variantes desse laboratório é uma modalidade de emissão que chamei 'do inaudível ao audível' e vice-versa. Nele, deveríamos encontrar uma maneira de vocalizar 'para nós mesmos', de forma inaudível para 0 ambiente ${ }^{33}$, e modular essa emissão, através da intenção ou da sensação, e não do resultado. Tentaríamos amplificar o som resultante até ocupar amplamente o espaço compartilhado de modo mais ou menos negociado. 0 inverso também foi proposto: 'engolir o som, fazer ele se abrigar entre as fibras do corpo'. 0 espetáculo laboratório corpossom na foz das cavernas (2013) começava com essa variação do laboratório da

\footnotetext{
32 Este laboratório parte daquilo exposto no desafio 'voz harmônica' na dissertação de mestrado (RIBEIRO, 2011, p. 82).

${ }^{33}$ Como saber que um outro não o escuta? Me faz pensar em micro-feedbacks que o corpo emite, que permite que saibamos estarmos razoavelmente 'camuflados' nos sons do espaço.
} 
nota. Da ação participávamos eu, Felipe Stocco e M iguel Prata. 0 que ocorria era que o som era 'engolido' por sonoridades extremamente delicadas do ambiente que não havíamos percebido antes - o som do circulador de ar, o som da corrente elétrica ao passar pelo refletor de luz, algum espectro de harmônicos que circulava no próprio ambiente etc. Isso me mostrou o quanto era possível elaborar vocalizações ou estratégias corpo-vocais 'em estado de vocalização' que tirassem partido de ressonâncias, vetores, enunciados e circulações 'involuntárias'. Que tirasse partido de um jogo entre os agentes multi-específicos não levados em conta de partida. ${ }^{34}$ Uma vida 'pequena' do próprio ambiente.

\section{1.}

O segundo processo foi ao estudar a linguagem da narrativa com a professora Maria Thais ${ }^{35}$, que estuda profundamente 0 assunto. Em 2015 ela trouxe como conferencista para o departamento de artes cênicas o dramaturgo Luis Alberto de Abreu. Ele falou sobre aquilo que apreendeu da prática pedagógica e dramatúrgica de muitos anos e de seu grupo de estudos sobre o gênero narrativo, que em muito se diferencia do drama. Uma de suas sugestões foi que a narrativa seja um modo predominantemente imagético e espacial, ao contrário do modo clássico de se entender o drama que é aquele de acordo com um 'encadeamento de ações', ou seja, drama como conflito de ações no tempo sequencial. Abreu dizia, ao recapitular, que a narrativa se caracterizaria por três elementos. 0 caráter imagético, o tom inaugural e a síntese.

\footnotetext{
${ }^{34}$ Esta apreensão ajudou a fundamentar diversas ações, tanto ações já experimentadas quanto aquelas em preparação e elocubração. Também tive, depois dessa ocasião em 2013, algumas oportunidades de testar esse laboratório com diferentes grupos. Para além disso, creio que a proposta do laboratório da nota desdobrou da prática de dramaturgia sonora, prática da sonoplastia.

${ }^{35}$ Encenadora-pedagoga. Participei como aluno ouvinte de disciplinas práticas de atuação dentro da graduação com Maria Thais nos anos de 2007, 2015 e 2016, em ambos os semestres. Em 2009 (1 ${ }^{\circ}$ semestre) e 2015 ( $2^{\circ}$ semestre) participei de cursos da pós-graduação. Em 2017 participei de duas oficinas na casa Balagan, (ateliê encantarias e EmpalavradaS), então sede da Companhia Teatro Balagan, companhia em que Maria Thais foi e ainda é propositora de diversas ações. A sede era no bairro da Barra Funda e encerrou as atividades no início de 2018. No ano de 2015, o curso na universidade se propunha estudar matrizes narrativas no teatro, juntando a este estudo prático materiais físicos diversos e o livro Pedro Páramo de Juan Rulfo. A pesquisa desse ano resultou no espetáculo aos que vieram antes de nós, que estreou na SP Escola de Teatro em janeiro de 2016 e integrou a programação de dois festivais de teatro fora do Estado de São Paulo. A contribuição e parceria de Thais são fundamentais para a realização desta tese e para algo que possa consistir em 'minha concepção de atuação'.
} 


\section{2.}

Do contato com Thais e Abreu, e algumas outras e outros em menor grau, se foi confirmando uma impressão de que eu já tinha rumores: outras temporalidades são possíveis em teatro. Comecei a pensar de modo mais explícito a minha própria prática como um espaço, como uma plasticidade espacializante e em mutação da qual se sabe muito pouco, e se sabe quase nada quando adentramos nesse espaço. E não só uma ação do performer como uma linha causal, escorado em lugares-comuns como 'o ator precisa saber o que está fazendo' etc. Algo da ordem de um projeto controlado que simula o tempo. 0 tempo é o próprio curso da vida.

\section{3.}

Pensei também algo que hoje traduzo assim, como uma desrazão: que entre os grandes grupos genéricos que nos ensinam - lírico, dramático e épico ${ }^{36}$ - poderia haver um grande gênero escondido - uma espécie de plástica ${ }^{37}$ ou drástica (por um prolongamento da lógica crua da crueldade artaudiana). Esse gênero sem nome ligaria intima e secretamente o lírico e o épico, pelo caráter energético-imagético, por uma gramática da existência que está alheia às aventuras dos heróis, e deixando ver que as coisas podem falar por si. Se bem que, quando Kuniichi Uno fala dos diários de Nijinsky e diz 'talvez não se trate nem mesmo de poesia', talvez anuncie, pela negativa, algo deste lugar. Se bem que, quando Carlos Drummond de Andrade escreve procura da poesia $^{38}$ e quando descreve as dificuldades e a aparente indiferença da poesia, ele

\footnotetext{
${ }^{36}$ Há hipóteses de que o gênero do drama é uma resultante histórica e experimental entre o lírico e 0 épico que acabou por se cristalizar em alguns eixos de linguagem. Isso me fez esquecer muitas vezes de outros vínculos possíveis e talvez paradoxais entre épica e lírica. E isso sem mencionar os gêneros derivados da comédia, da sátira, da imprecação, da festa e do luto apreendidos para além da função crítica ou descritiva, e sem mencionar os refluxos de linguagem cênica advindos de outros campos, como a técnica, a música, as artes plásticas. Em síntese, cabe que 'a simbiose entre gêneros e procedimentos', nas palavras do professor Jacó Guinsburg (2001), vem informar fragmentos de compreensão desse campo radicalmente heterogêneo e de difícil definição que é teatro. Os gêneros festivos e satíricos, por razões óbvias, foram especialmente mutilados no largo processo de consolidação de uma 'ontologia cristã'. Outros sincretismos precisam ser reconhecidos.

${ }^{37}$ Nos ecos de Herder e sua plástica, e também na afirmação Deleuziana de Francis Bacon: lógica da sensação (1981) de que haveria pintura em toda arte. Eu acho que há escultura em toda arte.

${ }^{38}$ Do livro a rosa do povo (1945).
} 
talvez nos esteja a dizer que a poesia é uma espécie bizarra de platô de onde se olha algo deste lugar. Os dois exemplos me levam a reconhecer, de qualquer maneira e no mínimo, o total desdém da vida acadêmica geral (não apenas universitária) pela poesia. A vida acadêmica adora o formalismo da epicidade mas repudia o protoanarquismo da poesia, da plástica ou da drástica, da qual tanto a épica quanto a dramática tanto imprescindem. A Drástica é o agroval dos 'grandes gêneros'. Uma escrita pautada na anterioridade do espaço e na opacidade do invisível.

\section{4.}

Linhas tão bizarras me fazem lembrar mais uma vez daquelas linhas do aracniano: '0 mistério está, portanto, no próprio projeto. / É o projeto que é mistério.' (ibidem, p. 54)

\section{5.}

E então me baseio em uma única frase também, apenas, da percussionista Evelyn Glennie, quando diz que é preciso ir 'abaixo' da superfície 'do som'39. Ela ficou famosa por suas qualidades de percussionista-concertista e por redimensionar a noção de escuta. Em um processo de surdez quase total vivida ao final da infância, Glennie faz uma aliança com seu primeiro professor de percussão, Ron Forbes - segundo ela, um músico 'peripatético' - para reaprender a tocar e escutar através de sensações, imagens e situações. Como base disso tudo, aprendeu a tocar e escutar pelo corpo: pelas ressonâncias, lugares, caminhos: relações e sensações do corpo. De um outro corpo. Não me satisfaço aqui em discutir uma incorporação de skill. Discutir talvez uma realização de potenciais (e não atualização).

\footnotetext{
${ }^{39}$ No documentário touch the sound: a sound journey with Evelyn Glennie (2004, direção de Thomas Riedelsheimer); no depoimento mais específico sobre o professor em https://www.tes.com/news/mybest-teacher-evelyn-glennie ; há ainda um vídeo de ambos juntos, muitos anos mais tarde, no vídeo Polar music prize laureate Dame Evelyn Glennie meets her first percussion teacher Ron Forbes, disponível no site www.youtube.com .
} 


\section{[DESCONHECIDO, CUPINZEIRO, GÊNESE ESCALAR] \\ [SOLTAR PODE SER SALTAR] \\ [NOÇÃO COMUM COMO CORPO-OPACIDADE]}

\section{6.}

A questão é: eu preciso inventar um modo de desconhecer o som, para que um feixe de forças possa tomar o meu corpo. É essa a questão desde o início. E então retorno à questão: o quê é que faço? 0 que pode ser um corpossom?

\section{7.}

Tento fazer composição dramática ${ }^{40}$ (junção ${ }^{41}$ parcial e agonística de uma multidão de fluxos contraditórios) de quaisquer coisas ou relações compatíveis com o campo de sensações de determinado espaço. Sensações produzidas e coletadas pelo corpo, pela corporificação que sempre esteve lá. Quando digo 'quaisquer coisas ou relações', isso pressupõe também uma inscrição e estratificação que aconteceu ao longo da vida: escolarização, treinamentos, repertórios, doenças, violências. Ou ainda coisas que apenas vi e ouvi, coisas de que meu corpo se lembraria, ativando um pedaço de rede. Essas estratificações imensamente variadas às vezes erodem e são sugadas, se recompondo em insólitos agrupamentos. Daí às vezes eu afirmar para outras pessoas que o corpossom pode incluir uma espécie de arqueologia ${ }^{42}$. M as o espaço visado é

\footnotetext{
${ }^{40} \mathrm{Com}$ 'drama' não me refiro à literatura dramática, mas às linhas vitais e conflituosas que formam a vida como ela se apresenta e se sustenta. Foi nessa dimensão que o termo 'dramático' me foi apresentado pelo professor Antonio Januzelli durante o período em que trabalhamos (2009-2013).

${ }^{41}$ A noção de junção de fluxos contraditórios é uma concepção ióguica. 0 que fiz aqui foi apenas multiplicar os fluxos, posto que no yoga são apenas dois dominantes: o ha e o tha; a ingala e pingala; surya (sol) e chandra (lua). Especificamente neste sentido o yoga, como tradição composicionista, se mostra como um processo de alquimia, paralelamente, guardadas inúmeras diferenças, à noção de taiji.

0 taiji e 0 ioga fazem parte da minha formação: treino taiji quan desde setembro de 2004, e pratico ioga desde 2001; em 2012 me tornei formalmente habilitado a dar aulas de hatha ioga (pelo IEPY: Instituto de Ensino e Pesquisas em Yoga). Sabemos que a habilitação é apenas formal, pois é uma ocupação cujo aprimoramento é extremamente lento. Por fim, essas duas artes corporais tecem continuamente meu corpo.

42 O paralelo com o que diz Meredith Monk acerca da voz como arqueologia já foi apontado na dissertação de mestrado preparação do corpossom: atuação e voz concreta (RIBEIRO, 2011, p. 74).
} 
outro, é o espaço mutante do devir. A arqueologia no contexto do corpossom não são os estratos mas, se o for, o interesse será em como eles reaparecem recombinados.

\section{8.}

Esse campo é plástico e também fantasmático. Emergem formas dinâmicas disparadas pelo campo afetivo. Ativar o campo afetivo é o primeiro objetivo da ação, de início totalmente desamparada, contendo linhas desamparadas. Aos poucos os trajetos fazem sentido. O que chamo 'treinamento' é a escavação de uma espécie de cupinzeiro no corpo, pois muitas vezes trata-se mesmo disso: de comer a terra e cavar buracos para passar algo que compõe 'comigo'. Um 'comigo' que não coincide com o eu. A escavação já é esse algo.

\section{9.}

Eu então me movo conforme configurações específicas de danças (mapas vivos de movimento), me (ou 'me') chocando ${ }^{43}$ com dimensões afetivas, sensações, objetos, que me devolvem algo. Mais importante que isso: algo se vai configurar na medida em que algumas figuras 'saltarem'. Figuras que têm seu tempo e sua temporalidade, mais ou menos linear, mais ou menos circular, ou ainda completamente verticais, não como um anjo, mas como um abismo. Pois a qualidade do anjo, além da fulguração, é o abismo.

\section{0.}

Acho que esse salto de uma figura vem explicitar a noção de multiescalar que foi aqui empregada, contrária àquela de algo previamente fixado. E aqui comento de quando descreve Deleuze sobre a primeira das três "Éticas" de Spinoza como uma dinâmica

\footnotetext{
${ }^{43}$ Aqui se cumpre a influência da visão de 'matéria' oferecida por Bergson em matière et memoire (1896), adicionando-se sua referência e uso por Deleuze. Também me lembro das proposições iniciais de Simondon em imagination et invention (1965-1966) (2008). Os três autores franceses, dentre outros, foram referidos e trabalhados por Silvio Ferraz no curso de pós-graduação a noção de imagem de composição (2018). Também aqui se cumpre, no meu ver, uma variação da harmonia Heraclitiana do combate.
} 
escalar (no contexto de uma correspondência ótica). A escala no contexto da ação no corpossom não é um caso apenas da graduação ínfima de mais potência ou menos potência de agir, força de existir e afetividade, mas talvez antes dizendo respeito à ativação de um espaço. Ele cria suas próprias escalas e territórios. 0 salto da figura é a gênese de uma nova 'escala' de campos, o salto óptico que deleuze rastreia no livro $\mathrm{V}$ da Ética de Spinoza ${ }^{44}$ (a terceira Ética). Com a ênfase que ora dou de que trata-se de uma ontogênese. No segundo capítulo a gênese escalar encontra sua operacionalidade no noção de transdução.

E não é por propriamente saltar da primeira à terceira Ética que ignoro a importância das noções comuns (a segunda Ética). O jogo vetorial é perpetuamente retraçado e uma gramática existencial toma corpo em novelos de densidade atados e aderentes em inumeráveis pontos: brinco com o Sonho de Ligeti criança. A minha segunda Ética é um terreno de opacidades e perfurações.

\section{1.}

Situação. No improviso, eu me engajo em algo, eu percebo que estou engajado, eu me desprendo de engajamentos automáticos. Daí que a atenção é plástica e também opera uma mudança escalar. Nesse contexto, esse 'soltar' do automatismo de uma ação é muito importante. Isso significa, na maior parte das vezes, não-cantar, nãosonorizar, não-mover. É possível não mover? Como diz José Gil, isso depende da escala. Eu coloco o hífen de não-algo por pelo menos dois motivos, porque essa retirada, esse não, é uma ação e, portanto, um movimento, e porque talvez fosse possível imaginar um antiverbo, algo que é precisamente um 'soltar literal'. 0 soltar/largar literal que pode ser um antiverbo é crucial no câmbio de escala de uma atividade. É uma das possibilidades de mudança de escala ou produção de escala. Por exemplo: é bem diferente cantar intencionando a temporalidade de uma inflexão

\footnotetext{
${ }^{44}$ Essa visão heterogênea da Ética de Spinoza nos textos Espinosa e nós (original em francês em Spinoza - Philosophie pratique, 1978, 1981) e Espinosa e as três "Éticas" (original em francês de 1993, em critique et clinique). Este último texto mais evidentemente portador da correspondência ótica, já que Spinoza tinha como ofício o de polidor de lentes. 0 primeiro dos dois textos traz um campo de correspondências totalmente diverso, nas relações da etologia e da música. Sempre que possível utilizarei Spinoza desta forma, sem o 'E' e com ' $z$ ' ao final. De resto é a opção contida nas publicações disponíveis.
} 
melódica, do que deixar esse foco deslizar para os dedos dos pés, caso seu pé o queira. Deixar cair. Literalmente. Às vezes é o dedo do pé que ativa o espaço. Ainda que a inflexão melódica permaneça como rumor que acompanha, como envelope paralelo de vetores ou fluxo de fundo... componentes ou personagens sinalizados, difusos. E às vezes o caso é deixar que uma focalização seja sugada para o nada, enquanto deixamos um pouco o corpo pensar! 


\section{[ONTOGÊNESE DO CONTATO: POR UM PIANISMO DE BORDA (UM)]}

42.

Ainda assim parecerá que eu não disse daquilo que faço.

Uma outra noção importante do corpossom é, no caso da voz aparecer como tal, ela é apenas uma espécie de antena para a escuta. Existem essas inversões e permutações. Falar ou cantar para escutar é uma delas. Tocar para ver etc. Tanto a voz quanto o som são peças pertencentes a uma imensa série, onde se situam tão desimportantes quanto possível.

43.

Por um pianismo de borda.

44.

Situação. Posso dizer de uma maneira direta? 0 instrumento musical é aquilo que me permitiu compreender que tocar é ser tocado, e isso é o contato e consequente brotamento de um corpo-diferença. Não sei se se trataria de assuntar o quiasma, um cruzamento ou re-embaralhamento da orientação e do fluxo entre sujeito e objeto, tornando-me um objeto do piano. Isso é verdade e é importante, mas não é apenas isso. A situação é mais ambígua, flutuante e instável. Ressoa em mim como diz Pelbart [2016 (2013)], ao comentar um processo de individuação: ele expressa um estágio 'indecidível'45. A ontogênese do contato com 0 instrumento permite também compreender um 'modo de existência de objeto técnico' enquanto invenção, posto que a noção de invenção vem acoplada à noção de compatibilidade ${ }^{46}$, e esta, à de ontogênese.

\footnotetext{
${ }^{45}$ Em a catástrofe da liberação, ensaio do livro o avesso do nihilismo.

${ }^{46}$ A noção de compatibilidade é explorada por Simondon na sua note complémentaire sur les conséquences de la notion d'inviduation, originalmente redigida como uma extensão à conclusão de sua tese (1958), mas publicada em 1989 (quando da publicação em livro da segunda parte da tese) e 2005 (da publicação integral da tese). Utilizei a edição argentina (2013). 0 problema da alienação da máquina
} 


\section{5.}

Nos permitiremos compreender e/ou participar de uma tentativa de não-alienação das máquinas? Uma concepção não-alienada e não-alienante das máquinas? 0 que se passa é que, no processo na lida com instrumentos musicais, ou com o piano, que foi o instrumento musical que mais explorei, eu instintivamente valorizava lugares do contato onde meu corpo 'saía do controle' e produzia algo diferente. Daí comecei a me interessar no instrumento como acoplamento, simbiose, encaixe, geologia, como topografias vivas etc, de modo a rastrear, com o corpo (como se uma antena fosse), disparações de zonas temporárias de turbulência e mutação.

\section{6.}

Acho que a particularidade deste pensar é, em parte, o fato de que não se trata de um projeto de composição, mas um corpo bizarro extremamente heterogêneo em funcionamento. Um elemento longínquo pode ser mobilizado e convocar a individuação do improviso. E isso leva ao especial lugar que a afetividade tem no improviso, ao processar privilegiadamente, em situação de nomadismo de escuta, configurações limítrofes, insustentáveis, ou configurações ínfimas. É a propiciação do disparate. É um modelo de individuação conjunta, havendo expostas suas zonas agonísticas de criação.

\section{7.}

Uma parte considerável da minha formação foi como instrumentista. Em 1996 decidi estudar 'a fundo' o instrumento: piano. Em 1999 ingressei em arquitetura e em 2000 ingressei na música, para ser um instrumentista. Fiz meu recital de formatura no dia 3

pelo homem, e não o contrário, é abordado na conclusão de du mode d'existence des objets techniques (1958; utilizo a tradução argentina de 2007 - Prometeo Libros). 
de julho de 2006. Durante a graduação, porém, meu corpo e minha afetividade deram sinais claros de colapso. Com o tempo, me foi dado perceber que o que me interessava não era exatamente executar de modo apenas interessante e estilisticamente correto um repertório como ele 'é', mas me interessava saber que algo se passava com meu corpo. Eu conseguiria executar uma peça somente se eu conseguisse assimilar e subverter sua lógica disciplinar para transformá-la em algo do que eu poderia nomear, através de uma 'lógica de crueldade'47, uma fórmula de continuidade, fórmula de tempo ${ }^{48}$, fórmula de corpo. Encadeando e transformando recursos e operações mecânicas do próprio estudo formal, convertendo-Ihes em outras peças ou pedaços de peças, mas sem recorrer necessariamente ao comentário, à citação, ou à paródia. Podemos colher fartos exemplos da paródia em música, um campo de estudos à parte. A questão, na época da graduação, era saber se a estrutura da peça e sua tradição de estilo, nos fragmentos que me chegaram, suportariam tal inversão. Ou se haveria tempo hábil para percorrer todo o percurso. 0 processo da lógica da crueldade poderia refluir lentamente para a peça, por pedaços, e então eu conseguia virtualmente tocá-la em recital enquanto 'repertório'. Afinal, o que é 'o repertório? Para mim, são esses pedaços de corpo que ressoam dentro da peça desfeita e refeita.

\footnotetext{
${ }^{47}$ Aqui me inspiro na proliferação de lógicas no livro de José Gil ritmo e caos (2018) - lógica do delírio, lógica da envolvência; lógica do discurso populista - que por sua vez penso se inspirarem nas duas lógicas deleuzianas: logique du sens (1969) e Francis Bacon - logique de la sensation (1981). 0 que vou desenvolver como lógica da crueldade está associado também com uma proposição de leitura para 0 uso que Artaud faz da palavra crueldade, que designaria um modo específico de rigor. Para explicitar esse modo, me valho do que Kuniichi Uno (2018) designa como sobriedade na pesquisa de Tatsumi Hijikata, contrariamente ao senso-comum que dita que a estética hijikatiana é centrada na vanguarda espetacular explosiva e frontalmente contestatória. Uno trabalha a noção de sobriedade como eixo de sua gramática existencial e artística, e assim de seu pensamento subversivo e contestatório. Então, quando expresso 'lógica da crueldade', digo de um modo de pensamento do corpo atento ao vital e às escavações e costuras para se acompanhar o vital. Operações estas que são criativas mas também destrutivas, o perações que necessitam, portanto, da sobriedade para a compreensão de compromissos paradoxais. Talvez a lógica da crueldade seja a própria construção da so briedade.

${ }^{48}$ A perspectiva das fórmulas temporais, bem como a forma aforística e o paralelismo com o desenho foram trabalhados por Ferraz em o livro das sonoridades (2006) e notas do caderno amarelo: a paixão do rascunho (2008).
} 


\section{8.}

A emergência da pesquisa em corpossom, ao longo de aproximadamente uma década: é como se meu próprio corpo a tivesse exigido, a partir, dentre outras coisas, dessa experiência devastadora e obsessiva do pianismo de borda. 'Pianismo de borda' é uma palavra-talismã. No período posterior à graduação, de início, lembro-me hoje de ficar cerca de dois anos sem tocar. Depois desse primeiro período pós-bacharel, passei a fazer algumas sessões improvisação ao piano com intervalos esparsos. Era preciso detectar os compromissos paradoxais que ali trabalhavam.

\section{9.}

Os improvisos operaram em si e deram franco testemunho dessa longa e larga mutação de estratégia do próprio corpo em simbiose com o instrumento. Algumas peças, ou 'pedaços' delas, estraçalhados ou deformados, suportaram e convivem comigo até hoje, como pessoas do meu círculo de amizades, como personagens da minha vida, com quem eu consigo vez ou outra encontro, converso, penso junto questões. Às vezes as peças ou pedaços 'fazem visita'. E às vezes é exatamente isso: um pedaço de corpo. Um detrito que se desenvolve à sua maneira.

Terrenos baldios, detritos, companhias.

\section{0.}

Individuação conjunta. 


\section{[ONTOGÊNESE DO CONTATO: POR UM PIANISMO DE BORDA (DOIS)]}

\section{1.}

Eu cruzava os limites disciplinares, mas também os afetivos, de auto-cuidado mínimo, quando tentava me adequar ao 'correto', especialmente em situações e épocas de avaliação formal e informal das turmas de piano durante a graduação. Ou ainda em apresentações nos raros festivas de que participei. Lembro-me de coisas estranhas. Dentre elas, momentos de ataques violentos de coceira enquanto estudava, inclusive um ataque de coceira durante um teste; lembro-me de, às vezes, salivar sem parar enquanto tocava, de ter de cuspir no chão repetidas vezes. Quando tomei para mim o trabalho dos detritos pianísticos, esse foi um modo de 'canalizar', digamos assim, parte desse excedente, deste excesso de corpo, que não poderia ser domesticado. Foi preciso tomar o corpo.

Lembro muito também daqueles ataques neuróticos de raiva ao repetir o erro no estudo de uma peça, que é quando 'martelamos' o instrumento, e daí repentinamente animar-me com o resultado, durante minha própria reação raivosa. UM LABORATÓRIO AFETIVO. Os músicos terão de me perdoar, pois eles nunca salivaram, nunca comicharam, nunca tiveram raiva ao estudar. E estes são só alguns exemplos. Talvez os mais acessíveis e os mais emblemáticos.

\section{2.}

Isto que narro, seria isto uma 'histeria da música'49, como o supôs Deleuze? Penso eu: seria essa histeria uma espécie bizarra de teatralidade borrada porém, à sua maneira, visceral, aquela que têm de se haver continuamente com as trilhas que levam à catástrofe? Ou ainda, corpo catastrófico no sentido do próprio corpo repleto de fendas, uma teatralidade adjunta (em outras palavras, associada) do próprio engajamento no desastre, que poderia abrigar desastrosamente, mas ainda assim

${ }^{49}$ Essa questão atravessa Francis Bacon - logique de la sensation (1981). 
abrigar uma catástrofe? Teatralidade esta que, para tal abrigo, rastejaria nas fendas, na poeira, e com a força da própria escritura-escultura-a-golpes? Seria preciso complementar que a escritura, essa noção vaga de inscrição, é uma ação do corpo e um modo de associação por perfurações. E assim opera a lembrança concreta de um ser-desenho. Abrigar desastres pianísticos, rastejar no piano, golpear-se com piano.

Quero buscar aliança com Deleuze quando ele dá a entender que o esquizo e o histérico que ele se força a pensar não são o esquizo e o histérico da medicina, ainda que se trate de uma clínica. ${ }^{50}$

\section{3.}

O pior era a 'fantasia do correto': o contrário de uma lógica de crueldade que processa os mecanismos em função de uma atividade sensível. Não à toa que o título do meu trabalho de formatura, em 2006, foi a experiência do movimento sensível. Eu sempre quis sair do correto e pular para um lugar impossível-imanente: o lugar da sobriedade vitalista, dos compromissos paradoxais. A fantasia do correto foi meu algoz durante grande parte da graduação e mesmo depois.

\section{4.}

Tudo isso me lembra de que meu corpo já enlouqueceu muitas vezes, ainda que algo de mim estivesse salvaguardardado. Não sei se era 'algo de mim'. Mas algo que já passava em mim, como um circuito muito vivo ou um ambiente meta-estável [cf. SIM ONDON, 2015 (1958); DELEUZE, 1966]. Ambiente duvidoso em vias de saturação a longuíssimo prazo, configurando travessia por um outro corpo chamado 'instituição musical' ou meramente 'pianística'.

0 pianismo de borda que penso agora me força a comentar alguns dos campos laboratoriais do corpossom como tocar e ser tocado. Hoje penso que não há como tocar sem ser tocado. 0 que é que toca e é tocado? 0 que se passa? Resta saber como acompanhar essa lógica e construir um cupinzeiro em si, pensar com a cabeça desconhecida dos mediadores de Latour (1991).

\footnotetext{
${ }^{50}$ Deleuze, Idem.
} 
É uma ontogênese do contato.

\section{5.}

O processo acima descrito aos poucos traçou linhas de composição de um estilo de intervenção pianística que, na época do mestrado eu chamava, conforme disse, de 'fórmulas de continuidade' e hoje chamo timidamente às vezes de 'fórmulas topográficas'. São conjuntos de adaptações, compatibilidades e simbioses do corpo com 0 instrumento muito inspiradas nas sessões de improvisação de Cecil Taylor (1929-2018) principalmente as dos anos 1970 e 80.51 Também, mais recentemente e em menor grau, interessei-me pelos vídeos do pianista Pat Thomas (1960-) e pelas estratégias de temporalidade no corpo de Keith Jarrett (1945-). Ainda que o 'idioma sonoro' de Jarrett seja infinitamente mais acabado e encerrado. E é por isso que é preciso vê-lo, e não apenas ouvi-lo. Algo se passa entre o corpo e o som de Jarrett que é matéria de interesse. Dos três pianistas, o idioma de Taylor me é o mais próximo, à exceção talvez do que direi a seguir.

\section{6.}

Minhas pequenas fórmulas topográficas ou meus 'pedaços de corpo' tinham como terreno uma temporalidade imprevista. Quase sempre pequenas ações, condensações de notas, pressões inscritas em economia pontual, em amplitudes localizadas e concentradas. São, por assim dizer, 'destinadas ao fracasso', um pouco à maneira do detrito. Esse é o modo preferencial de ação. Curto e condensado, desdobrando-se numa economia géstica pontual.

\section{7.}

Se perdurasse a sessão, ficariam mais evidentes os gestos e dimensões reiteradas e 'escavadas' um pouco ressonantes à estética Scelsiana, só que com uma economia

${ }^{51}$ No site www.youtube. com há diversas dessas gravações na íntegra. Recomendo os álbuns de 1973, 1974 e a gravação televisionada de 1984. 
ainda compacta. Ou tomaria lugar outra estratégia: gestos e dimensões recusados por saltos e depois relacionados e sincretizados.

Se aquela escavação de lugares ou este perpétuo movimento de evasão e localização perdurassem, poderiam trazer um novo estágio: uma modulação da inscrição do que se chama 'nota', ou mesmo do que se chama 'tocar'. Então, o movimento geral do pianismo de borda é aquele que indaga o tocar e o operador 'nota'.

E na medida em que a intervenção perdurasse, mas claro ficaria o lugar que Taylor ocupa, o que é aquilo no qual ele me ajuda, o seu lugar de 'personagem' no meu pianismo.

58.

Acaba que essas fórmulas têm uma relação íntima com o que eu descrevo como a lógica do detrito, pois alguns lugares e inscrições se compuseram no invisível e na opacidade do corpo, perdendo as origens. Traduzo: por ser um conjunto tão disperso e heterogêneo, simultaneamente intenso e extenso, vivido por muitos anos, misto de abandono e obsessão, minhas estratégias e meu pianismo de borda se tornaram não uma obra, mas um modo de pensar. E um modo de abominar a obra, ainda que esta se produza. E nesse sentido é importante descrevê-lo como um germe e desdobramento político, e ainda um 'meio associado' para o conjunto de práticas de corpossom.

$\mathrm{Na}$ errância de um 'lugar de onde se ouvir', e ao mesmo tempo na circulação de gestos em torno do corpo que toca e é tocado, compreendi que o que eu busco não é tocar, é ser tocado e fabricado por esse toque que vem. Às vezes, ser perfurado.

\section{9.}

Dessa noção surge, acredito eu, a proposição de um 'canto que escuta' e aquela de deixar o corpo fazer as coisas: deixar o corpo respirar, deixar o corpo dormir. A caminhada compreende a construção desse campo receptivo. 
60.

Um pianismo de borda é uma máquina de tocar e ser tocado. 


\section{[QUASE-NADA]}

61.

O tema do tocar/ser tocado, se o indagarmos como modernos, colonizadores e brutalizados que somos ${ }^{52}$, pode ser o próprio tema e a própria desgraça da cisão entre cultura e natureza. Não é apenas um problema de percepção concebido conforme a atualidade acadêmica. Neste contexto perfurado e desgraçado pode emergir uma figura de som. Se vista autonomamente, como personagem que habita e ativa uma máquina.

Como personagem insólito.

O Som pode ser personagem insólita.

62.

Faço correspondências, também insólitas, com a conferência do antropólogo Mauro de Almeida ${ }^{53}$, ao lançar a hipótese da figura Caipora como 'conflito ontológico'. Ou seja, a hipótese de algo ativo que seja não da ordem de uma criatura própria a um domínio, mas um ser que é efeito de uma relação entre mundos.

Uma figura, um personagem Som, se concebível, o proponho como expressão de um conflito e uma passagem ínfima entre mundos. Sim, é uma proposta séria. Uma fantasmagoria voluntária.

0 que quero com isto dizer, entre outras coisas, é que a ontogênsese do contato é uma tarefa de extremo risco, porém inevitável.

\section{3.}

A máquina de tocar e ser tocado é um traço metodológico, ou contra-metodológico, do corpossom. Comprometimento paradoxal, expressão da ontogênese do contato.

\footnotetext{
52 Para falar com Aimé Césaire em discours sur le colonialisme (1950).

${ }^{53}$ ALM EIDA, Mauro W. Barbosa de. Caipora e outros conflitos ontológicos $(2007,2013)$.
} 


\section{4.}

Mais uma vez. Não tem a ver apenas com uma inversão, um quiasma, uma zona de indeterminação e de ambiguidade. É preciso ir mais longe. É preciso assumir que não se sabe o que é tocar, o que é ser tocado. Sabe-se quase nada, ou até mesmo nada, sobre essas coisas. Aqui retorna a indagação que não quer resposta. Uma indagaçãodetrito, que tem muito pouco a tratar com respostas.

\section{5.}

Se o pianismo de borda, enquanto ontogênese do contato, não puder constituir um furo contra-antropológico, nos fecharemos apenas nas ilusões de valor de uma cultura hegemônica e predatória. 0 que quero dizer com isso? É simples (ainda que difícil de efetuar): é não dar como feitos, dados, o sujeito que toca. 0 tocar, o pianismo, não se restringe aos viventes humano-específicos; eu tenho de desconhecer e habitar 0 desconhecido. A espera, a espreita e a perambulação passam a ser um apontamento recorrente. E basta de dizer que tocamos o instrumento, apenas!

Aqui é deflagrada uma caminhada desconstituinte.

É uma dimensão onde as inscrições recebidas na 'formação', as inscrições da educação musical, por exemplo, como fendas, como feridas, podem ser indagadas. A educação sempre se inscreve no corpo.

O pianismo de borda, bem como as ações de corpossom, são regiões onde uma educação predatória pode se voltar contra si mesma, portanto, indagando-se, mobilizando forças. Uma prática de indagação sobre as forças que se inscrevem e que circulam no próprio treinamento e na própria ideia de treinamento. Não é um treinamento utilitarista, 'para alguma coisa'. Daí, acho, o impacto que as falas e as ações do improvisador Phil M inton me causam. Daí, acho, a hipnose que me causam os percursos catastróficos de Cecil Taylor.

Algo é produzido em um não saber que suscita que o treinamento e a educação, em suas marcas, mostrem miseráveis pedaços de corpo em re-composição. É, em palavras aparentadas às de Ana Kiffer (2018, ps. 97-99), lodaçal da permanência do não-entendimento que gera outras modalidades de compreensão. 
O que pode estar em jogo não é nem cura, nem obra, nem projeto. É um movimento esquivante e oscilante que produz corpo. 0 que está em jogo é apenas 0 próprio detrito e a opacidade. É claro, muito se precisa cantar para quase não-cantar. Muito se precisa representar para habitar um detrito.

Mas não haveria nenhuma voz a se espelhar? Nenhum objeto de experiência sonoro e vocal em que possamos rastrear um corpossom? De fato, sim. Reconheço a estranheza do detrito nos canti de capricorni (1969, 1981-2), de Giacinto Scelsi (19051988), escritos em parceria com Hirayama Michiko (1923-2018). Reconheço alguns traços de dramaturgia catastrófica de corpossom nas lúcidas e alucinadas progressões da plague mass, performance de Diamanda Galás (1955-) registrada em outubro (12 e 13) de 1990 e lançada em álbum em 10 de abril de $1991^{54}$.

Mas principalmente reconheço como objeto miserável de uma sóbria investigação, com potência para revirar o sentido de corpo, o disco lost rivers (199192), da performer da etnia Tuvanu, Saimkho Namtchylak. Nos outros discos que escutei da performer, ela pareceu trabalhar habitualmente em composição com eletrônicos, flertando com o gênero mercadológico world music. Mas este disco em especial tem apenas vozes solitárias, redobrando-se, fazendo percursos de metamorfose. Cada faixa não é só uma proposta dramatúrgica, mas uma técnica vitalista em si55. A última produção de Saimkho que consegui encontrar é de 2015. Chama-se like a bird or spirit, not a face. ${ }^{56}$ Aqui ela pareceu apostar mais uma vez em uma tônica experimental, ainda que haja uma moderação no risco propriamente sonoro. Há registro em vídeo de uma ação relativa a álbum, onde Saimkho está com o rosto encoberto... ${ }^{57}$ 'not a face'.

Passar a simular uma visceralidade, com fins de adequação mercadológica, é sempre um risco, e as quatro experiências acima citadas enfrentam esse risco. ${ }^{58}$

\footnotetext{
${ }^{54} \mathrm{~A}$ missa da praga ou da peste é uma peça de protesto contra o moralismo e os estigmas sociais em torno da do ença de 'imuno-deficiência adiquirida' chamada AIDS.

${ }^{55}$ Há algumas faixas disponíveis na página www.youtube.com .

${ }^{56}$ Pode-se escutar o álbum inteiro like a bird na mesma página: https://www.youtube.com/watch?v=9griSyHkWgY\&list=0LAK5uy k6l6310XthcLXtB7 qJfR7jM XLOM qq7 0 Q .

${ }^{57}$ Verificamos em https:// www.youtube. com/watch?v=BR2mZLW nGCk.

${ }^{58}$ No caso de Hirayama e Namtchylak, principalmente, mas também no caso de Galás, trata-se de uma investigação experimental de borda, partindo-se do interior de técnicas tradicionais, e esse fato, no meu ver, corrobora com o questionamento prático do próprio conceito de técnica e de treinamento. 0 problema de uma tradição-experimentação enquanto prática é recorrente para mim. Tentei tocar esse
} 


\section{6.}

0 detrito se amplifica na ontogênese que é contato, e aí esse corpo vive sua vida.

Não sei se há relações do detrito, conforme o percorri, com o ritornelo. As fórmulas pianísticas parecem detritos compactos em contato com o ritornelo. Como diz Silvio Ferraz no livro das sonoridades (2006), a partir de Gilles Deleuze: ritornelo é o próprio assunto da música. E isto não é algo simples. Um palalelismo parece ocorrer com os roteiros móveis de corpossom, ainda que estes pareçam mais difusos. Mas sempre será um paralelismo não simétrico, uma vez que visamos a singularidade.

\section{7.}

Modelo-vivo.

Há algo próximo em uma sequência de poses de um modelo que posa nu e tem suas fórmulas de sobrevivência. São ajustes, às vezes dramáticos. Captados nas crepitações, reticulações e dobraduras do corpo. É claro, deve-se buscar o menor esforço.

Eu digo tudo isso pois trabalhei como modelo-vivo de 2008 a 2015, e esses estados corporais de difusão, crepitação e retracejamento de estruturas de habitação me são bem familiares. Como habitar um corpo sendo corpo? Habitar não significa estar contido em algo, talvez tenha a ver com retracejar os limites, tensionar presenças.

problema no meu mestrado (2011), quando abordei o trabalho do improvisador tradicional basco e também 'contemporâneo-experimental' Beñat Achiary, atuante, portanto, nos 'entres' dos ramos do free jazz e world music. A oposição entre tradição e experimentação talvez seja muito tipicamente ocidental; essa aparente oposição traz para a fala vestígios de uma museologia quando abordamos materiais das tradições enraizadas que dependem de uma extrema experimentação. É preciso sempre testar a tradição, não como imperativo da novidade, mas como consistência e criatividade da própria cultura viva. Tentei falar sobre isso no mestrado. 
68.

0 corpossom parece uma corporificação oscilante entre os galopes e os ritornelos ${ }^{59}$, que são os modos de saída de um território (modos de criação de outros possíveis territórios?). Pascale Criton descreve como Deleuze pensou o galope a partir do ritornelo, o galope como ainda outra coisa.

A corporificação do som desconhecido parece contar sobre a tentativa de se ser um radar para temporalidades aberrantes. Gravitações múltiplas no cristal de tempoespaço, gravitações múltiplas com ritornelo e galopada. Gravitações múltiplas nãopertencentes nem à música, nem ao teatro, nem à filosofia ou à antropologia, se forem entendidos como domínios purificados, com seus objetos fixados.

Corporificação assimétrica em função da distribuição de saturações. Assimetria para o desconhecido.

69.

O quase-nada que dá saltos.

70.

Lembro-me agora que a primeira narrativa de corpo que trouxe a Janô foi de um corpo que ao tocar babava. De que modo isso passou a me interessar?

[FINAL DO BLOCO UM]

${ }^{59}$ Essas duas noções pertencem ao texto de Palcale Criton: a propósito de um curso do dia 20 de março de 1984 / o ritornelo e o galope [2000 (em francês, 1998)]. 


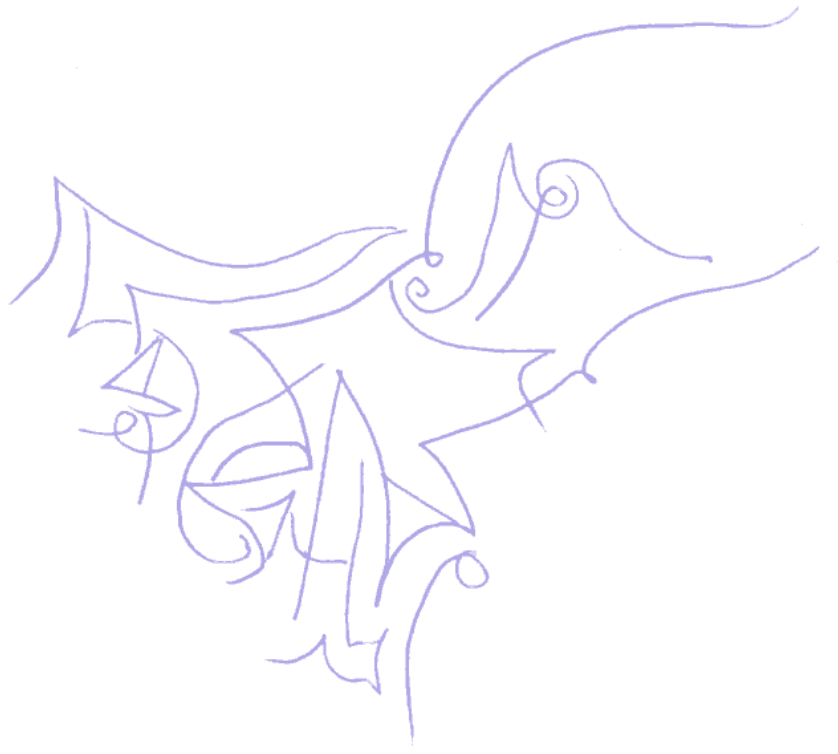




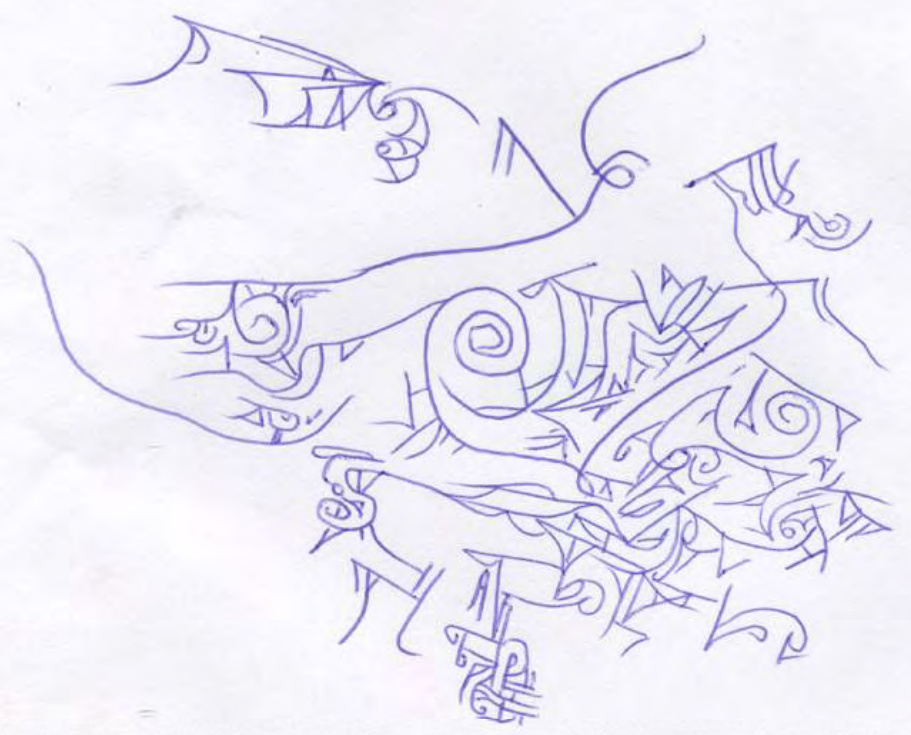




\section{[BLOCO DOIS]}

\section{[caminhada-catástrofe: primeiras imagens de víscera]}

[...] Só a despedida é verdadeira, só agora inicia o longo desprendimento de si. Antes que a vagarosa criança volte a experimentar, um a um, os seus rubores; uma a uma, imperiosamente, as suas hesitações.

[AGAM BEM, 2007 (2005), p. 19]

IV

E nós: espectadores, sempre, em tudo, diante de tudo e jamais para fora! Cheios de algo, pomos ordem. Desfaz-se. Pomos ordem de novo e desfazêmo-nos.

[Rainer Maria Rilke, Oitava Elegia de Duíno (tradução de Vicente A. de Arruda Sampaio)]

Só um avesso de poesia pode sustentar a catástrofe.

Não sei exatamente o que essa frase quer dizer. Talvez que não possamos ter a pretensão de poesia, ou ainda de que não haja outro modo de ser senão pela poesia, pois ela é o modo se ser que contempla seu avesso, sua 'drástica'.

Já havemos o detrito e a máquina de tocar e ser tocado. Nesta, formas de vida de uma ontogênese do contato (não uma ontologia já instituída).

E este bloco visa um paradoxo: a constituição de um procedimento de desconstituição. Assim, a pergunta 'o que pode ser um corpossom?' que associa elementos simultâneos de uma individuação, pode fabricar outras formulações descentradas de um objeto único, levando-se em conta o acionamento de uma máquina desconstituidora do som. Pressupondo-se que o termo máquina ele mesmo funcione. Funcionará, acredito, se houver a perspectiva de um campo afetivo que já é uma produção de máquina. Sempre que possível farei um desvio da máquina em direção à ontogênese (individuação conjunta). 
$\mathrm{Na}$ introdução já disse um pouco do que seria, mas restou dizer um pouco do como.

O próprio objeto da caminhada é múltiplo. Entre depoimentos e referências variadas, tentei fazer um percurso com os devaneios de Rousseau, um texto inacabado e bizarro, e com os diários de Vaslav Nijinsky e como estes se prolongam em um ensaio de Kuniichi Uno sobre os mesmos diários.

Ainda tento compor esse percurso com o pensamento da ontogênese de Gilbert Simondon e variações da catástrofe conforme constam em outro ensaio de Uno. Também vêm me socorrer em meu desvario outros e outras, como os gestos erráticos dos performers de Butô. Acaba que há figuras aparentes e figuras escondidas que saltam, galopam. Pode ser que, no fim das contas, isto seja um ensaio-caminhada entre Simondon, um filósofo da ontogênse, e Hijikata, apontado habitualmente como criador do butô.

No que uma caminhada-catástrofe pode nos ajudar a compreender um corpossom? Parece-me que esse ponto tenha algo a ver com uma contra-disciplina musical, ao tentarmos o som pelo avesso. Nenhuma fórmula serve. E tentei também formas de experimentação escrita que, sem prejuízo grave ou definitivo, acredito, à condução da textura do texto, buscassem ressoar a desconstituição. De certo modo algum prejuízo é desejado. Espero então, apenas, que que me leia não veja o seu tempo irremediavelmente perdido.

Há autênticos filósofos sem filosofia, músicos sem música. Aqui não me refiro apenas à inconsciência de uma prática, ao que se diz de 'atuação' do inconsciente. Refiro-me a um espaço de dilatação do processo da vida ainda mais abrangente, ao qual, por acidente, às vezes posso e é preciso, aliás, estar em aderência. Essa dilatação excessiva às vezes parece efetuar uma 'não-criatividade', um aniquilamento que se arrasta. E é aqui que nos fareja a desconstituição e a noção de caminhada-catástrofe.

Mas a pauta do inconsciente merece ser abordada por um instante aqui nesta breve introdução do segundo bloco.

Podemos atuar sem nos sabermos atuadores? Certamente. A centralidade da consciência é no mínimo problemática nas questões de arte e também nos processos afetivos pessoais. Esta é, aliás, uma contribuição dos fazeres artísticos para qualquer 
atividade: operar sensivelmente com vontades assimétricas ao sujeito. E, com Simondon, sabemos que o sujeito é assimetria na direção da vida disparada, contraditória ao indivíduo: uma defasagem. Isto é assunto que será ora abordado mais adiante.

A cultura moderna, penso, está mais ou menos familiar com a formulação de 'inconsciente', como a leem e repropõem incansavelmente, de diferentes maneiras, as escolas psicológicas. A polarização entre consciente e inconsciente é uma paradigma binário razoavelmente aceito, modelo teórico-prático de termos que, por assim dizer, se definem por mútua defesa, ainda que essa divisão não tenha o menor grau de operacionalidade criativa. 0 que quero dizer é que são termos congelados. 0 campo dos processos da afetividade, nesses termos binários, acabou por se tornar em grande medida apenas um problema de escola, de diagnose e de adequação dos sentidos nascentes da vida a uma sociedade individuada, moralista.

Há autores também que valorizam a sensibilidade subconsciente, mais operativa, relacional, processual, traços esses sediados, ainda que dificilmente localizáveis, em um entre, um campo intermediário nascente. Esses traços que contemplam a multiplicidade de uma vida. ${ }^{60}$

Estou aqui mais próximo, talvez, da noção Simondoniana ${ }^{61}$ de 'pré-individual', do que da noção de inconsciente. Essa noção simondoniana tem um parentesco declarado com o 'apeiron' conforme posto por Anaximandro ${ }^{62}$, filósofo pré-socrático. É importantíssimo que as condições que Simondon desenha para a individuação, ou seja, a saturação e criatividade pré-individual, sejam o sistema meta-estável. Deleuze também sublinha este ponto em sua resenha de 1966 publicada no ilha deserta e outros textos. Meta-estável: nem estável, nem instável. Essa formulação em si já é a

\footnotetext{
${ }^{60}$ Para rastrear estes autores do subconsciente, indico as valiosas ferramentas que Amnéris Maroni nos oferece com os livros Jung, o poeta da alma (1998), e Eros na passagem (2007). As leituras que Maroni me indicou do próprio Jung foram de grande peso na percepção de um subconsciente. Um exemplo é o eu e o inconsciente (CW VII/2). Aqui, a personalidade ela mesma é dita como resultado de um jogo de forças entre consciência e inconsciência e entre indivíduo e coletividade.

${ }^{61}$ Simondon propõe uma filosofia da individuação [ontogênese], tendo como pressuposto a recusa do hilemorfismo (modelo de forma sobre a matéria, largamente aplicado por Aristóteles), com suas variantes, e do atomismo (a identificação e representação de unidades últimas da vida).

${ }^{62}$ Alguns dos filósofos pré-socráticos propõem de diferentes maneiras o ápeiron. Emilia Marty se debruça na correspondência da noção pré-individual com o ápeiron em seu texto Simondon, un espace à venir (2004). Artigo disponível em

http://www.multitudes.net/Simondon-un-espace-a-venir/ .
} 
proposição de um campo intermediário. Isto tem consequências para a definição apenas recíproca, binária, entre consciente e inconsciente, definição esta, como eu disse, aparentemente assimilada pelo psicologismo moderno.

Concordo ainda quando se diz que o pré-individual, campo excessivo de saturações presente em ambiente meta-estável, corresponda à 'substância' Spinozeana. Caso precisemos de um exemplo, há a frase, para mim, emblemática, de David Scott: 'Simondon é fundamentalmente spinozeano' (2014, p. 80). Também é uma correspondência recorrentemente levantada no grupo de estudos sobre Simondon do qual participo, coordenado por Amnéris Maroni e Camila Jabur.

Substância. Esta infinitamente infinita, de infinitos atributos que se expressam em modos de existência contidos nas essências (potências) dos atributos. Então, da mesma forma que o pré-individual só pode produzir individuação, e o processo de individuação só pode se dar pela carga que pré-individual que porta, com a substância é parecido: ela só pode ser conhecida através dos modos existentes, que por sua vez só podem expressar sua causa: a substância. A substância é a única coisa que é a causa de si mesma.

Essa foi uma correspondência, para mim, evidente, ao ler textos introdutórios e didáticos sobre esses dois pensadores ${ }^{63}$, apartados por três séculos um do outro, mas estranhamente similares na sua gênese. Poderão haver muitas outras correspondências.

A noção de pré-individual, ao meu ver, corporifica, desmistifica e des-imanta (desfantasmagoriza) a dimensão representacional transcendente do inconsciente. Preciso me explicitar: o pré-individual não é apenas humano-específico, e essa nãoespecificidade constitui um detalhe aparentemente mínimo mas de extrema

\footnotetext{
${ }^{63}$ Sobre Spinoza, segui recomendações das filósofas Camila Jabur e Carla Ferro. Então li Espinosa: uma filosofia da liberdade, de Marilena Chaui (1995), que me foi extremamente útil como introdução. Em seguida Espinosa: filosofia prática (DELEUZE, 2002 - em francês Spinoza - philosophie pratique, 1981), livro cuja leitura, além de extremamente proveitosa, dá testemunho das várias fases da escrita de Deleuze sobre 0 assunto. Em seguida, parti para a leitura dos livros da Ética, leitura que está em processo.

Sobre Simondon, já me referi ao livro de 1999 de Muriel Combes (Simondon - individu et collectivité: pour une philosophie du transindividuel), além do filme Simondon du désert (Chabot; Lagarde, 2013). Houveram ainda outras 'ondas na direção de Simondon', que comentarei mais detalhadamente ao longo desta escritura.
} 
importância política. E por que a noção simondoniana de invenção, por sua vez, seria especificamente humana? ${ }^{64}$

O inconsciente coletivo de Jung já era não-humano-específico. E Jung, herdeiro do romantismo constituído na Europa do XIX e herdeiro das tentativas de formalização típicas a uma historicidade de tom cientificista e antropocêntrica, muitas vezes nos ofereceu nomes que não encontram operacionalidade no campo criativo. ${ }^{65}$

O que quero dizer com 'operacionalidade no campo criativo'? O psicanalista e ensaísta Adam Phillips nos ajuda em seu impactante prefácio à coletânea de textos de um outro psi contemporâneo, Christopher Bollas, em Christopher Bollas reader (2011). Campo criativo: talvez uma criatividade revolucionária, marca dos primórdios da psicanálise, a qual passou a mobilizar rapidamente, em contra-fluxo, suas formas de contenção teórica e prática. São palavras de Phillips.

Operacionalidade não é mediação, é o rumor incômodo de um entre, ativação de um campo dramático de ressonâncias e repercussão característico da operatividade que é ela mesma um ser-entre.

A máquina desejante anti-edipiana de Gilles Deleuze e Félix Guattari tem um parentesco Spinozeano e Simondoniano ${ }^{66}$ evidente ao principalmente atacar a servidão à representação da vida, servidão à representação, por exemplo, do insconsciente. Como diria Simondon no desfecho da introdução de sua tese, não

\footnotetext{
${ }^{64}$ Faço referência à recente 'moda' simondoniana no Brasil, onde percebo que algumas tendências positivistas e antropocêntricas tentam 'trazer de volta', 'salvar' o pensamento simondoniano da 'mistificação'. Na europa também ocorre essa tentativa de esquadrinhamento e disciplinarização do pensamento da ontogênse de Gilbert Simondon nas diferentes disciplinas acadêmicas: antropologia da técnica, psicologia, filosofia, educação... qual será o Simondon 'autêntico'? Claramente, nenhum. Numa pesquisa futura, gostaria de mapear as tendências políticas e antropológicas das releituras de Simondon, havendo como ponto de partida experiencial algumas operações artísticas entendidas na chave de etnografias experimentais.

${ }^{65}$ Quem me alertou a isso foi a própria Amnéris, cientista social estudiosa de Jung há mais de trinta anos, ao me chamar a atenção a termos da vulgata mistificadora junguiana, como: sombra, anima, animus, etc. Se compreendi bem a leitura de Amnéris, Jung tentava contemplar em sua prática um assento afetivo-imagético daquilo que existe ativamente. 0 pensamento vivo de Amnéris sobre Jung merece ser visitado como alguém que perfurou esse ambiente de mistificação em torno do autor, havendo-Ihe re-individuado, individuando em si seu pensamento, individuando-se com ele. Jung tornase assim um talismã vivo.

${ }^{66}$ Inclusive M uriel Combes pontua (1999) que Simondon é muito mais utilizado do que citado na obra de Deleuze-Guattari capitalisme et schizophrénie [volume um: o L'Anti--Edipe (1972), e volume dois: mille plateaux (1980)].

É muito interessante verificar que é do período de escritura de mil platôs a orientação por Deleuze do doutorando Uno Kuniichi na université Paris 8 Vincennes (Vincennes-Saint-Denis a partir de 1980).
} 
podemos conhecer a individuação [ontogênese], podemos apenas individuar 0 conhecimento. Eu digo: abrigar muito-precariamente sua individuação. Assim, o conhecimento não é uma forma de mediação, é uma individuação em si.

Esse campo dilatado, estranho, próprio do contato improvável com o préindividual, é o que tento formular com a caminhada-catástrofe. Daí também a escolha dos autores e das autoras: habitam uma zona demasiado estranha, onde a potência se mistura à imensa impotência.

Talvez a operatividade, no caso de um corpossom, possa ser traduzida precariamente por uma espécie de clínica artística, ou seja, uma clínica alter-orgânica. Esta operatividade expressa por vezes a necessidade de se levantar contra a diagnóstica, de se anunciar uma diagnóstica inversa, que depõe de forma constrangedora diante de uma clínica constituída.

Uma última nota: não tive condições nem o intento de realizar um texto com foco na compilação exaustiva de imagens de víscera na cultura. Isso não quer dizer que uma louca compilação não esteja presente... Nem consegui estudar uma teorização ampla especificamente sobre dimensões viscerais, como seria o caso do informe de Georges Bataille. Ocupei-me mais em deixar registrar operadores viscerais da minha própria experiência, que convocava leituras: a caverna, o vento noturno, a escavação do caminho, a voz da escrita revirada... 


\section{[CAM INHADA DA CAVERNA COMO VÍSCERA] [POTÊNCIA GERM INANTE DA PERAM BULAÇÃO NA CAVERNA]}

\section{1.}

Ter de escrever sobre o que tenho feito me forçou a esticar um mapa e descobrir uma periodização razoavelmente nítida nas práticas/ações. Os relatos deste bloco e 0 anterior oscilam entre o perío do que vai de 2005 a meados de 2007, e outro período, mais ou menos entre 2008 a 2013, além de citarem fatos posteriores e anteriores.

O percurso de pesquisa (2009-2011) que resultou na minha dissertação de mestrado preparação do corpossom: atuação e voz concreta teve alguns prolongamentos. Um desdobramento importante, creio eu, foi aquele através de um projeto aprovado pela Secretaria de Cultura do Governo do Estado de São Paulo, através do edital ProAC 'primeiras obras' para um dado período entre 2012 e 2013. 0 nome do projeto era Laboratório Corpossom: um estudo das cavernas com Édipo em Colono. Ao final do período do mestrado (a defesa foi em 8 de novembro de 2011), havíamos formado um agrupamento relativamente consistente e coerente. Sua consistência e coerência se teceram evidentemente em processo.

\section{2.}

Este processo de encontro (durante até hoje) com o primeiro núcleo de corpossom, mira constantemente, portanto, o período 2011-2013, e experiências aí geradas.

Uma vez que o núcleo em questão se constituiu logo após a banca de qualificação do mestrado, havia elementos anteriores que foram partilhados. A nossa atividade comum também portava e revolvia fragmentos de processos paralelos de nós todos.

É natural admitir um regime constante (porém irregular e heterogêneo) de suscitação de elementos públicos e íntimos vindos do contato, elementos surgidos entre pessoas em ambiente prático de pesquisa. Bem como admitir as diagonais do tecido social que nos cortam, dilatam, comprimem. Em resumo: nunca deixamos de improvisar, habitar, circular, em nossas múltiplas individuações. Habitar-circular me faz 
pensar no sistema meta-estável. A questão às vezes talvez seja de que modo habito ou: o que se passa na habitação, por exemplo, e nos modos de descrição que também são caminhadas... há muito mais devir do que parece. Um espaço partilhado é uma vertigem.

\section{3.}

Quando digo 'essas pessoas', 'o núcleo em questão'... falo especificamente do laboratório corpossom. Refiro-me, então, ao núcleo formado por Antonio Januzelli (Janô - orientador do mestrado e do projeto subsequente), Felipe Stocco, por mim e Miguel Prata. Na mostra de experimentos do TUSP, na Maria Antônia, em 11 de abril de 2012, apresentamos uma vez uma variação do roteiro posto em cena no dia da defesa, 8 de novembro de 2011. E nos meses seguintes de 2012 nos ocupamos de elaborar o projeto do nosso estudo nas cavernas. Conseguimos o prêmio ProAC (2012), e adentramos 0 ano de 2013 com uma perspectiva de aprofundamento do nosso estudo prático, ainda que por alguns poucos meses. Nosso prazo de projeto, incluindo a prestação de contas, abrangeria até o início do segundo semestre de 2013.

\section{4.}

No projeto realizado via ProAC (Projeto de Ação Cultural), tentamos aperfeiçoar nossa rotina de improvisos e nosso processo de dramaturgização dos rastros e acontecimentos do fazer. Encerramos com o experimento laboratório corpossom na foz das cavernas com uma pré-estreia ${ }^{67}$ na cidade de Araras e breve temporada ${ }^{68}$ na sede da Companhia do Feijão, na cidade de São Paulo. No experimento minimamente formalizado, trazíamos textos de Hesíodo, Sófocles, Carlos Nejar e uma breve narrativa acerca do desaparecimento de Édipo em uma caverna em Colono. 0 desaparecimento de Édipo era um evento axial da narrativa para o que chamávamos, no caso, 'espetáculo-laboratório'. Além disso, o cerne experiencial do espetáculo-laboratório se alojava não apenas na pesquisa vivida em mestrado, mas também em duas viagens

\footnotetext{
6726 e 27 de junho de 2013.

${ }^{68} 11,12,13,14,18,19,20,21$ e 22 de julho de 2013.
} 
para a 0 Vale do Ribeira, para a região do $\operatorname{PETAR}^{69}$, viagens contempladas pelo cronograma do projeto. Lá, numa região de cavernas $^{70}$, realizamos vocalizações, improvisações e nosso pequeno roteiro de 'gatilhos sonoros'71 (Ribeiro, 2011).

5.

Adentramos o vale através do município de Iporanga, cidade onde tivemos uma rede de apoio e orientação a partir de amizades próximas. Destas, a pessoa que nos acompanhou em parte da estada foi Beatriz Nestlehner. Nossa rede de suporte nos apresentou o guia cujo modo de ação mais se adequava à nossa proposta: Leonardo Cardoso, com quem as pessoas do núcleo de pesquisa acabaram por tecer vínculo. É importante reconhecer essa rede que se configurou.

Por fim, encerrávamos em agosto daquele ano um ciclo de pesquisa. 0 grupo se dispersou e, se não me falha a memória, foi apenas em 2016 que voltamos a falar sobre experimentos. Continuávamos a ver Janô nesse silêncio, mas individualmente, ao menos eu e Felipe, e por necessidades pessoais.

6.

Este é um dos feixes, um dos estratos, uma das inserções por onde simulo um reinício da minha caminhada nesta escritura-caminhada-corpo que é a escrita do corpo na víscera do som, por pelo menos duas razões. [1] Creio que aquele experimento cavernoso foi germinal para a escritura do projeto de doutoramento, que já estava em

\footnotetext{
${ }^{69}$ Parque Estadual Turístico do Alto Ribeira.

${ }^{70} \mathrm{~A}$ primeira viagem e a primeira visita às duas cavernas que escolhemos foi no dia 29 de maio, com caráter um pouco mais aberto. A segunda viagem, contendo a segunda e terceira visitas foi exatamente entre as duas semanas da temporada em São Paulo: 16 e 17 de julho. Cada uma das três visitas às cavernas escolhidas tinha um diferente tom de exploração, respectivamente: ensaio (1), registro (2) e performance registrada com público (3). A escolha das cavernas se deu antecipadamente em consulta e negociação com nossa mediadora, nosso guia e os agentes da Fundação Florestal.

${ }^{71}$ [...] No tocante exclusivo à contrapartida no PETAR (Parque Estadual Turístico do Alto Ribeira), adaptamos progressivamente parte do roteiro para realizar as apresentações nas cavernas Santana e Morro Preto, observando as condições, primeiro, do nosso acordo com a Fundação Florestal que administra o parque onde se situam as cavernas, e segundo, das respostas físico-acústicas de cada ambiente escolhido, configurando aos poucos um plano básico de ação no local, que incluísse, portanto, o elemento de 'ética acústica' constante no projeto, bem como a proposta de lidar com o tema da caverna em intersecção com o mito edipiano encerrado em Édipo em Colono. [trecho do relatório final (agosto de 2009) - redação coletiva]
} 
tímido desenvolvimento e me acompanhou por todo o período do foz das cavernas e também durante 0 ano de 2014. [2] Também porque a caverna articula um gesto de retomada de um ponto de vista sobre corpo e som que a escolha inicial de objeto de estudo para o doutoramento ocultou.

\section{7.}

A naquele ano subsequente (2014) um outro feixe, penso eu, se abriu. Ele tem seus componentes germinantes. 0 segundo feixe será abordado no segundo capítulo através da noção um tanto esquisita de germinação. Dado que seja, a germinação, principalmente uma prática, bem como a caminhada - a perambulação - ou a conversa o são. Eu preciso retomar sempre esse ponto pertinente à prática.

\section{8.}

A germinação é uma continuação ou uma dobra da caminhada; a caminhada no corrente capítulo se dirige para a divergência da redenção que é a catástrofe. Assim proponho pensar, e a partir dos detritos e ambiente catastrófico a germinação vem. Ela já tinha começado. Entretanto cabe pontuar que, precisamente na escritura do projeto aprovado para o doutoramento (ingresso em 2015), ocorreu uma bifurcação que só percebemos, eu e meu orientador do doutoramento, quando mais da metade do processo. Essa bifurcação foi ocultada pela escolha de objeto inicial da pesquisa.

E esta é a segunda razão [2]. Uma aparente bifurcação de tema, quando o que havia era um erro de ênfase. Posso me explicar melhor.

Alimentei-me de fragmentos fabulares míticos concretos para meu tecido de projeto, acreditando haver ali um modelo de dramaturgia misteriosa para o som. E tratei os fragmentos de estatuto fabular havendo como eixo as variações da deidade ou força Armonia ${ }^{72}$, apontando privilegiadamente a variação Heraclitiana. De modo

\footnotetext{
72 Uso o nome Armonia, sem ' $h$ ', para tentar diferenciar de uma leitura já dada da entidade moral Harmonia, bem característica da mo derna-contemporaneidade, e para aproximar da deidade grega, que dispensa 0 ' $h$ '.
} 
que 'Armonia como combate' tornar-se-ia um instrumento de leitura para os demais fragmentos em estatuto fabular.

E a prática miserável e direta do corpossom, uma espécie de espaço de deriva e perambulação ele mesmo, que constitui o próprio modo de escuta dessa possível dramaturgia mítico-política, prosseguia ao fundo, dormente. Essa aparente bifurcação de tematização é crucial para a compreensão do que parece ser, ao longo desse percurso tumultuado dos quatro anos de doutorado vividos com dinheiro público, um aparente duplo objeto. Seriam eles: o mito arcaico de armonia (projeto inicial do doutorado) e a extensão de uma prática de corpossom para que a escritura, corpo de errância, acontecesse e fosse um pedaço de corpo (o que se intenta ser esta tese). Do mito arcaico de Armonia para a escrita do corpo na víscera do som, há uma processualidade múltipla que ora abordamos. São duas entradas para a mesma problemática, uma entrada a partir de um ponto de vista estritamente cultural (mito Armonia), e outra operativa (esboçamentos de corpossom), que é a chave principal que não pode ser ignorada, pois serve como uma produção fabular de corpo.

9.

Em resumo: esboçamentos de corpossom são caminhadas sem utilidade, mas que tendem a se aproximar de uma espécie de 'instinto de germinação'. Este corresponde, no limite, à fabulação da Armonia experimental do combate e da dissidência e daquelas Armonias que dela emergem.

10.

Então, dois problemas: a ressonância da própria caverna e sua convivência do germe de estudo, e o aparente duplo objeto que encaminharemos de modo miserável remetendo da fábulas 'prontas' à própria miserabilidade das práticas. Dos detritos. 


\section{1.}

Creio que ainda estou lá cantando nas cavernas. Retomarei em breve essas duas viagens às cavernas do PETAR para narrar fatos singulares.

12.

Lembro de conversas daquele período da foz das cavernas, como uma compreensão do devir-caverna. 'O corpo é uma caverna', 'a voz é uma caverna', eram frases correntes no grupo. A relação com a víscera, a invisceração, é evidente. Contudo, é uma víscera da Terra, ou apenas de sua crosta, como quando reparamos com detalhe em uma casca de ferida que se desprende da pele. Olhamos o espaço da crosta, 0 espaço deixado pela crosta, e verificamos pequenos mundos.

Não, não é a mesma coisa. Foi só a tentativa de pensar a imensidão da terra em pequenas relações de produção de corpo.

\section{3.}

Então é uma víscera que é o fora, para dialogar com Maurice Blanchot da conversa infinita, e o Deleuze no livro Foucault, Deleuze evocante de Blanchot no capítulo sobre subjetivação ${ }^{73}$.

E então se trataria de eviscerar, tratar-se-ia de algo que se espreme, brota e invade 0 ambiente que já habitava a víscera.

Outra formulação insólita, inviscerar-eviscerar: algo que, ao invadir um ambiente, se redobraria sobre si, comendo o lugar. Dimensões viscerais e redobradas de uma troca local.

Fluxos e estratos que se dobram em linhas quebradas, espaços nascentes, flutuação e circulação. A simultaneidade entre membrana vivente e diagrama do ambiente...

${ }^{73}$ Falo do capítulo as dobras ou o lado de dentro do pensamento (subjetivação) (2008, p.101). 


\section{4.}

E se evocássemos uma imagem alternativa para a víscera do fora na língua do camaleão, espaço vertiginoso do fora dobrado, e da ingestão desdobrada? Ou na figura do inseto, que tem um exo-esqueleto? Serão estas ponderações por demais antropocêntricas? ${ }^{74}$

15.

A víscera não é a representação da víscera.

\section{6.}

A víscera se passa em uma gênese de movimento em vias, por assim dizer, que vão ao largo, que estão descentradas da representação da víscera, e contudo podem permear essa representação. De outro modo, poderíamos até lançar uma pergunta hipotética: o que alguém busca, o que se passa ao representar a víscera? Certamente muitas coisas se podem passar, mas me interessou uma modalidade de passagem que vai ao largo, que tenta evitar escatologias finalistas ou de um saber médico. Procurei ter estas precauções.

17.

Vislumbro uma víscera como um forro daquilo que chamamos som, mais uma vez falando com o Foucault de Deleuze, quando este vai pensar a subjetivação e a cultura de si. Mas é um forro que, conforme penso, poderia ser dita como diz Artaud em seu homem-árvore (1947), 'uma vontade única e bastante impossível de ser encontrada'.

\footnotetext{
${ }^{74}$ Lembro-me de que, quando meu orientador propôs que estudasse a víscera em Leonardo da Vinci, rapidamente me atacou a intuição conta de que haveria, neste pensador, uma víscera do fora: os esboços de maquinaria. Mesmo por que, nos desenhos, descrições e comentários 'viscerais' de cadáveres e bichos que encontrei em da Vinci, à exceção daquele famoso desenho do corpo de um bebê na placenta e talvez à exceção da asa do pássaro, havia só descrições de corpos mortos. Esse tríptico <<adáveres, placenta-pássaro, maquinaria» poderia ser mote de um ensaio posterior. Quando digo 'talvez', não quero dizer que, na asa de um pássaro, da Vinci não buscasse uma maquinaria viva. 0 problema é mais largo e inclui o próprio procedimento de descrição.
} 
Não compreendo bem aqui o alcance da fórmula 'vontade única'. Mas ela é bastante impossível de ser encontrada. Então posso supor que a 'vontade única' é algo diferente da 'vontade pura' da qual ele fala no início e fim do texto. Não me parece que Artaud tenha um projeto de todo único. De outro lado, o estilo escatológico d'o homem-árvore parece desenhar a autodestruição de um mundo. E aqui sim, a ideia de apocalipse faz sentido. Talvez seja a destruição desse mundo que se diga único e organizado. Pois a vontade única correspondente é 'bastante impossível de ser encontrada'. Concluo daqui que a potência de subjetivação posta em pauta é também um risco, pois pode nos fazer deslizar inteiramente para o nada. É o alerta que Silvio Ferraz deu em uma aula, quando disse, diante de um diagrama: 'isso daqui é a composição, mas em alguns pontos você pode cair fora diretamente para o 'corposem-órgãos', que é a morte'. É razoavelmente sabido que há uma tipologia mínima, vital e operativa, para se fabricar ou abrigar um $\mathrm{CsO}^{75}$, mas creio que Silvio se referia àquele da anulação total.

De outro lado, no texto de Artaud, vejo correlações da 'vontade pura' com a noção de crueldade, noção da qual Artaud já escrevia ao menos nos quinze anos antecedentes à mencionada carta a Pierre Loeb de 1947.

\section{8.}

Falo do homem-árvore pois ele está no campo dos materiais centrais desse estudo. No entanto, eu ainda estou lá cantando e caminhando nas cavernas, e esse fato é germinal. Trata-se de um devaneio, no sentido mais literal, ativo e produtivo do termo. Parece estranho estar em muitos lugares ao mesmo tempo. Entretanto, o estranhamento vem como 'uma inconsciência de si' germinal (não gostaria de dizer (fundamental').

\footnotetext{
${ }^{75}$ Em lógica do sentido; em Anti-Édipo; no terceiro volume de mil platôs; em Francis Bacon - lógica da sensação; em crítica e clínica. Pelo menos nessas cinco obras, mas certamente em outras, a noção de 'corpo-sem-órgãos' foi trabalhada por Deleuze (e também por Guattari), e em cada uma de uma maneira distinta. Acho que este levantamento é também estofo para um estudo futuro. Gosto daquela delimitação categórica de CsO do Anti-Édipo que diz 'instinto de morte é o seu nome' (difere-se da nomeação 'instinto de morte' no livro diferença e repetição). Também gosto da delimitação do termo quando se diz, em Francis Bacon ou no mil platôs, ser um órgão provisório e parcial, pois o problema não seria o órgão, e sim o organismo.
} 
19.

Uma enigmática sentença íntima: 'gostar do estranhamento como fato da inconsciência germinativa de si.'

Seria isto uma caverna? Aqui me pareceu reconhecer sobriamente, mas não sem espanto, um processo desconhecido feito de sobreposições, de lugares que constelam uma fenda que parece uma estrela ao contrário, uma fenda reticulada. Já que passamos pelo tema do avesso, do forro, da costura. Topologia de ínfimas transformações, falando com Kuniichi Uno em Tatsumi Hijikata: pensar um corpo esgotado e também no ensaio corpo-gênese ou tempo-catástrofe. Eis um lugar de germinações desta hipótese-escrita de caminhada-catástrofe.

\section{0.}

Muitos enigmas, muitas palavras enigmáticas. Qual campo de afetos foi mobilizado? Qual campo o devaneio das cavernas atravessa? Qual seria a estranha concretude do devaneio, e do devaneio em termos práticos? 0 meu devaneio é uma caverna que me atravessa. 


\title{
[PENSAR INSTÁVEL
}

\section{COM A CAM INHADA-DEVANEIO \\ DE JEAN-JACQUES ROUSSEAU (UM)]}

21.

\begin{abstract}
[...] Dizem que o inconsciente é negro. Reich e Marcuse são frequentemente censurados pelo seu "rousseaunianismo", pelo seu naturalismo: uma certa concepção demasiado idílica do inconsciente. Mas será que não se atribui ao inconsciente horrores que só podem ser, justamente, os da consciência, e de uma crença muito segura de si própria? Será exagerado dizer que no inconsciente há necessariamente menos crueldade e terror - e de outro tipo - do que na consciência de um herdeiro, de um militar ou de um chefe de Estado? 0 inconsciente tem os seus horrores, mas eles não são antropomórficos. Não é o sono da razão que engendra os monstros, mas a racionalidade vigilante e cheia de insônias. Por ser homem-natureza, o inconsciente é rousseauniano. E quanta malícia e astúcia não há em Rousseau! [...] [DELEUZE, GUATTARI, 2010 (1972-73), p. 153] ${ }^{76}$
\end{abstract}

22.

Os devaneios de um caminhante solitário (1776-1778) é o último e inacabado escrito de Jean-Jacques Rousseau (1712-1778) (na minha opinião, um necessário inacabamento). Valho-me desse bizarro escrito como plataforma para pensar 0 passeio, a perambulação, a caminhada que me interessa. No próprio título, há só práticas.

\footnotetext{
${ }^{76} \mathrm{~A}$ passagem de o Anti-Édipo é complexa: contudo é certo que ela endereça clichês que circulam em uma razão branco-eurocentrada.
} 


\section{3.}

Na edição em língua portuguesa que consulto, ao final do texto das caminhadas há uma resumida cronologia histórica contextual para sua vida, como de praxe. Para o ano de 1776 se diz essa estranha frase: '[...] 24 de outubro. É derrubado, em Ménilmontant, por um cachorro: o acidente, bastante grave, determina a última orientação de seus pensamentos'. Pode parecer risível ou vulgar essa informação assim descrita, mas se considerarmos o título e a posição do escrito que abordamos, algo de extraordinário parece se ter passado. A expressão oportuna para esse algo me ocorre como singularmente poética: algo que deixa ver a construção de um corpo que será a própria fibra de uma linha de fuga errante para fora. E a irrupção do extraordinário é desconcertante. Como um atropelamento por um cão.

Ao pensar que uma vida constela continuamente um cosmo, pareceu haver algo de uma reorganização cósmica considerável que será levada a cabo mediante a caminhada-escritura. A vida é cosmo, parte dele, ainda que mínima. 0 devaneioescrita acompanha essa refeitura de uma vida. Diz a cronologia da vida de Rousseau: [...] 1778. [...] início da redação da décima caminhada dos Devaneios, que será a última e ficará inacabada. [...] 2 de julho. Mal-estar. Rousseau morre às onze horas da manhã. [...]'

\section{4.}

Rousseau viveu 66 anos. Se li corretamente essa linha do tempo, ele foi perseguido e atacado ao longo de, ao menos, os últimos dezesseis anos de sua vida. Ao menos após 1762, da proibição em Paris e Genebra de 0 contrato social e Emílio; tentativa de prisão, denúncias. Depois: apedrejamento de sua casa, proibição da leitura de seus textos, etc. A cronologia que consulto também me deixa saber de períodos de viagens, errâncias, auto-exílios, bem como de doenças, amizades, separações...

\section{5.}

Os devaneios são ordenados em 'caminhadas', de modo simples, por numeração. Na segunda caminhada, Rousseau narra a nós o acidente onde um imenso cão 
dinamarquês 0 atropela, e ele então narra as situações insólitas, para não dizer extraordinárias, suscitadas por esse acidente. 0 borrão que se seguiu ao atropelamento; o paradoxal maravilhamento com as primeiras sensações e 0 apagamento temporário das referências. A volta para casa, sozinho e ágil. [também 0 grito de sua esposa ao vê-lo desfigurado]. 0 dia seguinte: o rosto disforme. Depois: a escuta modificada pela febre; a visita do policial e da escritora que o homenageia para publicar uma nota falsa sobre ele. As notícias de sua própria morte chegam aos ouvidos da casa real; há também a 'compilação póstuma' de sua obra, com escritos que não eram dele. M ais que tudo, a certeza de um movimento monumental em torno de Rousseaus que não eram o Rousseau ele mesmo, movimento movido com calúnia, contado por Rousseau com certo ar de estranhamento surreal. Rousseau nos certifica com a sensação bisonha de que nada ele poderia fazer para impedir nada disso ou para obter sequer mais conhecimentos sobre a construção e o percurso dos fatos apresentados na conspiração geral...

\section{6.}

Esse material, os Devaneios, do final do XVIII, são distantes de mim. Contudo, a atmosfera de estranhamento e de deslize produzida nas caminhadas-devaneio, esse estranho e singular gênero, parece ser dominante, e é essa atmosfera absurda que me atrai. 


\section{[TOLOS]}

27.

'Logo senti que havia demorado demais para executar esse projeto' (ROUSSEAU, 2015, p. 16). 0 primeiro contexto dos devaneios força um devaneio ele mesmo.

Que guinada vital traz o cachorro que o atropelou em 76? Não consigo deixar de pensar no Tolo, a carta ZERO (ou XXII) dos Arcanos M aiores do baralho do Tarô de Marselha. Um tolo e um cão diante de um abismo. Distração. Devaneio?

Tarô, um baralho - matriz para incontáveis variações e fabulações, somando-se a prática ela mesma do Tarô. O Tolo ou O Louco: um jovem vestido de modo alegre porém simples, com seu embrulho mínimo de viagem e sua escuta contemplativa, dirigindo-se perigosamente para o abismo. Um cão é seu freio e se empenha em conter o corpo do Tolo mordendo-Ihe a barra da calça. Assim, na confiança em algo, o Tolo caminha sobre o fio da lâmina da vida para o confim.

Não é uma trilha ascética, a do Tolo. 'Trilha estreita ao extremo norte' (Bashô). A errância? Se o for, o Tolo traz um sentido diferente de errância que a da carta IX, '0 Eremita' (que é o solitário-modelo, por assim dizer, do Tarô), pois esta carta tem um trabalho a fazer. O Tolo não. Se considerarmos nesses termos, a tarefa do Tolo é viver. Suas linhas cegas são germinais.

\section{8.}

O Tolo parece ser o devir em pessoa, um élan não-fixável sem nenhuma direção em especial. Seria preciso um contexto drasticamente singular para o reconhecimento e acolhimento, necessariamente precário, dessa força.

\section{9.}

Claro que as andanças de Bashô, Rousseau, Nijinsky, são inteiramente distintas. Nelas, contudo, há componentes entrelaçados de uma caminhada-escrita que são 
indiscerníveis. Soma-se a isso a tematização ou a operação mais visceral a cada um deles.

No Artaud 'dos cadernos' (1943-8), que é o Artaud que mais me interessou, se explicitará uma outra caminhada: o nomadismo intenso do próprio corpo como perpétuo gesto de refazimento ${ }^{77}$. Digo isso para incluir algo muito especial dos cadernos Artaud, que é o embaralhamento entre desenho e escrita ${ }^{78}$, entre desenho e caligrafia, melhor dito. Este é apenas um dos registros de embaralhamento que 0 Artaud dos cadernos traz. Há aquele entre margem e centro, entre escrita, desenho e golpe, caligrafia e voz etc.

Artaud tem então uma eclosão de caminhada-corpo-escrita, sendo corpo, página e teatro, principalmente nos últimos anos, operações intercambiáveis. Ainda que Artaud não fizesse caminhadas que nem as de Rousseau ou Nijinsky, mas de outros tipos.

30.

Quem nos lembra de que a escrita é ação e produção de zonas e consistências é também Vaslav Nijinsky. 0 principal termômetro, como veremos, da valência de sua experimentação dentro da própria escrita, é o que ele chama de 'sentimento'. 0 ensaio de Kuniichi Uno as palavras e Nijinsky nos delineia isto.

No caso de Rousseau, um operador a satisfazer, então, se pensarmos nesses termos, é caminhada-devaneio-escrita.

\footnotetext{
${ }^{77}$ Inclusive aquilo que tentei realizar no primeiro capítulo do mestrado na sentença 'a voz é análoga ao desenho como expressão linear que acumula pigmento e gera corpo', aqui encontra uma outra chave prática. Essa nova chave tanto dá encaminhamento à problemática dos desenhos como corpo e como conhecimento quanto associa-se à escrita como corpo e desenho-inscrição. Uma errância geral: construção de uma antena de devir.

${ }^{78}$ Os trabalhos de Ana Kiffer e André Lage são referenciais em língua portuguesa para os desenhos, as anotações e as cartas tardias de Artaud. Nestes, as noções e usos das palavras 'corpo', 'teatro', 'vida', bem como outras, circulam e se ajustam de maneira
} 


\section{1.}

Estou ciente de que a aproximação entre esses nós irradiadores de estéticas existenciais (Rousseau, 0 Tolo, Nijinsky, Artaud etc) pouco tem de coerente, senão que sejam caminhadas-escritas-alguma-coisa, e um pouco mais.

Os escritos comem a si mesmos, buscam a si mesmos, produzem a si mesmos. Têm uma autonomia de corpo paralela ao detrito. Consistem em um borramento de funções que visa a produção do corpo: é esta a produção que está em questão. A existência do corpo-caminhada é o que aproxima os diferentes escritos dos diferentes autores, ou catalisadores.

Se o Tolo é aquele que perambula e produz, em sua rota distraída, uma escrita, o Eremita será aquele que escreve o diário, o caderno.

\section{2.}

A caminhada é uma espécie de magnetismo que guia o corpo desconhecido, a caminhada 'individua', é um processo de individuação, se quisermos falar com Simondon. E chamarmos de individuação com Simondon implica largar qualquer pressuposto para a forma com que essa caminhada se dará. Seja na forma de linha de um pigmento pelo papel, seja na forma de um passo-a-passo pelas veredas, seja na forma de um devaneio, seja na forma de uma metamorfose literal, seja na forma de uma doença... 0 'centro' de devir não é o do ser individuado; é o centro do processo de individuação, isso nos diz Simondon na conclusão da sua tese.

\section{3.}

Nesse entrelaçamento entre caminhada, escrita, pensamento-afeto-potência e corporificação intensa, o sujeito que se aventura na errância, feito dela, está diante do nada e não pode evitar dar testemunho de seu estatuto de corpo. Poderíamos nos referir a desnudamento? Ou, quem sabe, uma continuação do desnudamento?

Ou não pode evitar deixar que aquilo venha, que aquele corpo venha. $\mathrm{A}$ caminhada que é o filme film de Samuel Beckett e Buster Keaton é uma tipologia da 
caminhada encadeada como 'rua, escada, olhar e choque', caminhadas a cada vez mais condensadas. A caminhada se enrola sobre si mesma.

O Lenz de Büchner é atirado em uma aventura panteísta involuntária nas suas próprias caminhadas. 0 personagem Desconhecido da peça rumo a Damasco de August Strindberg diz, na última estação da peça-caminhada 'estou desenhando na areia. Ainda.' As figuras do filme stalker, de Andrei Tarkovski, fazem a viagem na zona, um lugar destruído onde tudo muda o tempo todo, e são guiados pelo Stalker, um sujeito que foi aluno do Stalker anterior chamado por 'porco-espinho'.

Também evoco a imagem de Juan, personagem do romance Pedro Páramo, de Juan Rulfo, cuja caminhada vem misturada às vozes que chegam, vozes que vão mostrar de onde vêm esses 'outros', esses mesmos que narram. 0 romance diz sobre 0 tanto que caminhamos sobre o corpo que acolheu os nossos ancestres. Sobre o rosto coletivo e povoado que é o rosto festivo da morte como receptáculo de devir. Herança ameríndia, jamais europeia.

Pensar no terreno mexicano me faz correr ainda os diários de Frida Kahlo, para que me acudam. São caminhadas entre desenho, pintura e escrita, e também entre manchas, abandonos, violências domésticas. Retracejam o rosto múltiplo das gentes, da terra, retracejam gritos, criaturas, frases cortantes, manchas de mundo.

Os casos se multiplicam. É melhor voltar.

\section{4.}

Nijinsky, em uma de suas caminhadas-cadernos, bem como o Tolo, será também salvo do abismo (por árvores, mais de uma vez). Perceber esse enigma do resgate acidental será parte da catástrofe. 0 que fiz agora com a carta d'O Tolo foi apenas a descrição sumária de uma imagem em si tradicional. É uma tradição disseminada e errante, mas uma tradição, e inclusive por ser errante. Descrição sumária com o mínimo necessário de variação.

Essas diagonais violentas de que me valho: da personagem Caverna à novela Lenz. Começo a tecer a minha teia de forças; necessitarei dela para o passeio que segue. 


\section{5.}

Há muitas outras caminhadas-escrita-pensamento-afeto-corpo por aí, demasiadamente próximas. Não necessitamos de que sejam 'autores', aqueles que, vivos ou mortos, são possuidores do aval genérico da sociedade culta. Não necessitamos de que sejam de solo europeu, ou de solo branco-masculino, ou mesmo de solo binário - aquele centrado na correção dos genitais e no domínio da descendência da propriedade pela escravização do útero (leia-se: patriarcado) ${ }^{79}$. Não necessitamos serem terrenos humano-específicos.... Serão estes solos já demasiado conhecidos?

Talvez não tão conhecidos, já que ainda não conseguimos nos desfazer deles, já que ainda não conseguimos desnaturalizar o PODER PREDATÓRIO GRATUITO.

Giramos em falso.

Por isso me incomoda usar Rousseau (ou mesmo Deleuze): um território aparentemente andado, solo com sulcos, cheiro de gasolina no ar. E, por cima, esse ar francês. Ou europeu.

Mas há uma ressalva: a caminhada-devaneio-escrita é uma corporificação, uma prática, ela é o guia. Não se trata de ser francês, muito menos universal. Nada mais francês do que ser universal daquela maneira. Não há teoria a comprovar, apenas uma distância misteriosa a suportar, a portar, a avessar, a costurar.

Essa refocalização da prática me anima a continuar traçando diagonais e ziguezagues, forçando os furos por onde é secretado o meu corpo. Escrita-escavação.

${ }^{79} 0$ que quero dizer é que a multiplicação de gêneros não-binários é uma caminhada relativa ao mistério de uma genitalidade desconhecida. É uma das caminhadas necessárias de uma vida por vir. 


\section{[REFOCALZAÇÃO DA PRÁTICA, CONTRA-METODOLOGIA, PERAM BULAÇÃO]}

\section{Caboclo não tem caminho para caminhar Caboclo não tem caminho para caminhar caminha por cima das folhas, por baixo das folhas em todo lugar (ponto cantado de Umbanda)}

\section{6.}

Estou a pensar a caminhada, a escrita, o afeto e o pensamento em um mesmo encadeamento e entrelaçamento. Um nó heterogêneo.

Rousseau: 'Estou sobre a terra como num planeta estranho onde tivesse caído daquele que habitava' (2015, p. 12). Na primeira caminhada, Rousseau nos dá uma impressionante descrição de uma espécie de metodologia, melhor dito, uma contrametodologia que julgo necessária transcrever aqui. Se ela existisse, ela pareceria prestar contas àquilo que podemos chamar hoje de uma estética radical, no sentido de sua honestidade. Não somente isso, mas também haveria ressonância e prolongamento da descrição que Rousseau nos dá - na prospecção da suposta contrametodologia - com o que eu, algum Francisco, estou a fazer: a perambulação.

\section{7.}

É preciso captar o pensamento como perambulação. Pensabulação.

38.

Suponho não errar em traduzir a perambulação como uma focalização constante, ainda que viajante; recorrente, ainda que deslizante. Portanto estratégica e inacabada. A estratégia que tem como centro alguma outra coisa que me abrange. Uma focalização da prática (no caso a caminhada-escritura-alguma-coisa) correspondente a 
um apontamento contra-metodológico, onde a refocalização da própria prática é a constante mínima.

Não suponho, a princípio, uma focalização finalista no modelo, no objeto finalizado, no conceito, na forma. Seguir as redes e focalizar as práticas, ou ainda, fazer passagem: algumas das recomendações de Bruno Latour (1991 e $1996^{80}$ ) e outros e outras, recomendações que me vejo tentar contemplar de alguma maneira.

Digo com minhas palavras: a forma existe, mas é uma 'forma' não-purificada e 'mostruosa'. É uma forma de passeio intencional, seria dizer, mas intencional de modo a depender de uma mutação na intenção ela mesma. Um rastrear da mutação. Quem caminha e escritura (verbo escriturar) habita uma forma mas não pode recuar desfazer-se dela. É uma forma de abraçar o devir e a construção de um campo receptivo. É uma forma desconstituinte. A forma de uma inscrição sulcada nessa caminhada, nesse curso de vida constantemente perfurado, emerge reconfigurada como uma construção em detritos, habitada por seres imprevistos. Por exemplo: cantar distraidamente, saber de súbito que se tratava de uma canção conhecida, ainda que esteja francamente desfigurada. Saber depois, para dessaber.

39.

Seria muito ousado supor ainda uma outra coisa: um vetor proto-anárquico nas 'estratégias' de deslize reunidas por Rousseau nas Caminhadas? Então, três vetores conjuntos: contra-metodologia, refocalização prática e 'espiritualidade' protoanárquica da perambulação? Isto é muito difícil, pois os pretensos cientistas políticos dificilmente admitiriam pensamento anárquico, ainda que seja proto-anárquico, somente com comunidades de passeios e devaneios, com os sons da água...

Essas folhas não passarão de um diário disforme de meus devaneios. Nele, muito se falará de mim, porque um solitário que reflete necessariamente se ocupa muito de si mesmo. De resto, todas as ideias externas que me passam pela cabeça ao caminhar também ali

\footnotetext{
${ }^{80}$ Nous n'avons jamais été modernes: essai d'anthropologie symétrique (1991) e petite réflexion sur le culte moderne des dieux faitiches (1996), respectivamente.
} 
encontrarão lugar. Direi o que pensei tal como me ocorreu e com tão pouco encadeamento quanto as ideias da véspera têm em geral com as do dia seguinte. Mas pelo conhecimento dos sentimentos e pensamentos que meu espírito faz seu alimento diário, no estranho estado em que me encontro, sempre resultará um novo conhecimento da minha natureza e de meu humor. Essas folhas podem, portanto, ser consideradas um apêndice a minhas Confissões, mas não uso o mesmo título por não sentir mais nada a dizer que possa merecê-lo. [...] Uma situação tão singular com certeza merece ser examinada e descrita, e é a esse exame que dedico minhas últimas distrações. Para fazê-lo com sucesso, seria preciso proceder com ordem e método: mas sou incapaz desse trabalho, e ele inclusive me afastaria de meu objetivo, que é perceber as modificações de minha alma e seus encadeamentos. Farei comigo mesmo, de certa forma, as operações que os físicos fazem com 0 ar para conhecer sua condição diária. Aplicarei o barômetro à minha alma, e essas operações bemdirigidas e muitas vezes repetidas poderiam fornecer-me resultados tão seguros quanto os seus. Mas não estendo até esse ponto minha empresa. Eu me contentarei em fazer um registro das operações sem procurá-las reduzi-las a um sistema. (Rousseau, os devaneios de um caminhante solitário. Primeira caminhada. 2015, ps. 13-14)

A cada vez que leio a bula Rousseauniana das caminhadas, capto novas imagens práticas. 


\section{[PASSEIO SIM ONDONIANO]}

40.

Cabe pontuar que Rousseau se propõe nas caminhadas um contato apenas 'consigo mesmo' (segundo ele, em contraposição a Montaigne, que escreveria apenas para os outros), mas isso tem alguns registros ambíguos. Primeiro, os trânsitos do próprio caminhar, que são os encontros imperceptíveis e inapreensíveis. Segundo, o registro e transformações com os elementos com que de fato se depara, disparando campos de afetos. Terceiro, as narrativas mobilizadas e as costurações insólitas proporcionadas pelo conjunto de estratégias de caminhada-escritura-devaneio... Se fitarmos as caminhadas de Rousseau com a microssociologia de Gabriel Tarde, veremos multiplicarem-se os mundos vertiginosamente. Se as miramos com base na concepção de ser como arte da Orla de Emilia Marty, (em dois ensaios a partir de Simondon ${ }^{81}$ ), veremos acoplada a este Rousseau das caminhadas um modo insólito de conhecimento como arte. Esse estatuto de conhecimento é inerente ao ser da orla.

\section{1.}

Segundo Marty, o modo de um ser debandado de si - configuração existencial insólita própria de uma 'individuação vertical' - é ser na ontogênese do contato com o indeterminado ele mesmo. Este ser é inundado pelo pré-individual. Como diz Simondon, a configuração deste ser em angústia é 'emoção sem ação'. Este ser é ressonante de uma angústia não mais na passagem entre configurações formalizadas (que caracterizaria a individuação horizontal), mas a figura da angústia como fazer e desfazer perpétuo. 0 próprio vibrar oscilante, periclitante do espaço dilatado do indecidível. Uma máquina de desconstituição: a angústia faz algo para suscitarem-se novos modos de desfazer. Nas palavras de Pelbart: 'ato que desata'. ${ }^{82}$ Daí que 0 ultimíssimo Rousseau pode nos ajudar quando figura da máquina desconstituidora.

\footnotetext{
${ }^{81}$ Celui-autre-qu'individu. le voyage de l'angoisse ou l'art de la lisière (2002) e Simondon, un space à venir (2004). A tradução deste último foi realizada por Carla Ferro.

82 Os ensaios de Emilia Marty, bem como a catástrofe da liberação de Peter Pál Pelbart, o Genius de Giorgio Agambem e uma vida por nascer de Muriel Combes, todos textos com Gilbert Simondon, seja na
} 
42.

Duas impactantes sentenças de Simondon no texto sobre angústia: 'é a pura ressonância do ser nele mesmo'; 'é a partida do ser'. A angústia como figura de uma máquina desconstituidora em busca de novos modos de se desfazer, e não como figura psicológica de uma imagem de ser já formalizada, que viria clamar por outras transcendências correspondentes. Ao pater do padre, pater da medicina positivista ou pater da psicanálise paternalista para lhe salvar. No texto sobre o medo, dentro do curso imagination et invention (1965-66), também há a descrição desse deus da religião feito à imagem do homem. Esse deus, segundo GS, é consequente de uma imaginação ou 'duplicação' alienante que tem como objetivo salvar o humano de um medo momentâneo, às custas de sua liberdade ${ }^{83}$.

43.

Para Simondon, pelo grau de indeterminação que a instância da angústia é forçada a comportar, há a eclosão de outra instância. A emergência da espiritualidade seria esta eclosão, dinamitação, lugar existencial mais agudo da existência em termos de afetivoemotividade na relação entre a vida individual e coletiva. A espiritualidade é uma espécie de nó.

Porém, a religião, por sua vez, é a espiritualidade formalizada. Ela poderia tentar capturar, encerrar, encastelar, controlar a diferenciação e singularização, portanto, da espiritualidade, entendida como a individuação e diferenciação da vida psíquico-coletiva em sua face existencial mais aguda.

Daqui é que eu retiro a noção de uma 'espiritualidade proto-anárquica'. É aquela que é a própria afirmação vitalista da vida como campo meta-estável

estratégia de análise, homenagem ou correspondência. Esse grupo de textos constitui minha 'segunda onda', empurrando-me, aproximando-me de GS. A primeira onda de aproximação foi descrita em nota de rodapé no primeiro bloco deste capítulo.

83 Tanto 0 texto sobre a angústia do L'individuation à la lumière des notions de forme et d'information (parte 2) quanto o texto sobre medo do curso de 1965-1966 têm um tom Nietzschiano, o que me faz lembrar o que o filósofo e biógrafo Giovanni Carrozzini comenta sobre a formação de GS: 'ele começou com Nietzsche' (em Simondon du désert). 
propiciador de disparações: formalização mínima ou parcial, face a uma redistribuição de cargas, face a saturações imprevistas. ${ }^{84}$ David Scott não deixa dúvidas sobre a importância da experiência religiosa para Simondon não enquanto discussão teológica, mas como operação em direção à indeterminação pré-individual na direção da agudização:

[...] Spirituality is the supreme moment of supreme powerlessness, where religion is forced to confront its central colapse, the threshold of formlessness - the pre-individual as the genitality of religiosity. This is why we might call a spirituality without religion more truly powerful than strictly speaking religion itself. (SCOTT, 2014, p. 75) ${ }^{85}$

[Espiritualidade é o momento supremo da suprema impotência, onde a religião é forçada a confrontar seu colapso central, o domínio do informe o pré-individual como a genitalidade da religiosidade. Este é o porquê nós podemos nomear um espiritualidade sem religião mais verdadeiramente poderosa do que uma religião ela estritamente dita.] (tradução minha)

\section{4.}

Aqui me valho mais uma vez do conceito-operador (e, por quê não, personagem) da máquina desejante, presente em o Anti-Édipo, inconsciente maquínico, e obras

\footnotetext{
${ }^{84}$ Pelbart não deixa de ser irônico com o problema da espiritualidade logo no início de seu ensaio: 'Como se sabe, o princípio ontogenético que atravessa a obra de Gilbert Simondon reza que não se pode tomar o indivíduo como dado.' (op. cit., p. 53). Em paralelo, essa primeira sentença deixa escapar a noção de que haveria um único princípio ontogenético, sendo que um princípio local de individuação também se individua no conjunto de uma individuação que é sempre coletiva, conjunta. Muriel Combes (1999, p. 9) é bastante enfática com relação a isso. 'Pour comprendre comment passer l'être préindividuel à l'être individué, il ne fault pas se lancer à la recherche d'um príncipe d'inviduation. C'est toute l'erreur de l'ontologie traditionelle, [...]'. A fim de apreendermos a passagem do ser pré-individual para o ser individuado, não devemos embarcar numa busca por um princípio de individuação. É nesse ponto que a ontologia tradicional se perde... [...] (trad. Liracio Jr.). Em, suma, Pelbart parece deixar escapar de saída, seja por formalidade filosófica ou caricatura do religioso, parte do enigma da ontogênese. 'Como se sabe...' Mas após isso, em seu ensaio, ele deixa claro as vias nas quais não se trataria de um modelo fixado de individuação.

A saber: no contexto da escrita de Simondon, 'ontogênese' e 'individuação' são palavras por vezes intercambiáveis e mesmo sinônimas.

${ }^{85}$ David Scott já faz parte da minha terceira aproximação com Simondon, onde já consigo ler fragmentos do próprio autor, sem necessariamente a mediação de comentadores. A aproximação com um autor tão difícil, estranho e enigmático é, naturalmente, um processo árido e coletivo. 0 grupo de estudos focado em Simondon organizado por Amnéris Maroni e Camila Jabur tomou lugar fundamental no processo.
} 
relacionadas de Gilles Deleuze, Félix Guattari, e pessoas que se contaminaram com esse vocabulário prático. Mas que desejo da própria vida seria este em que as configurações são desfeitas? 


\section{[PENSAR INSTÁVEL \\ COM A CAM INHADA-DEVANEIO \\ DE JEAN-JACQUES ROUSSEAU (DOIS)]}

\section{5.}

Na Quinta caminhada de Rousseau, somos apresentados, me pareceu, com algo 'em si' importante, e 'sujeito' de singular e estranho prazer, talvez um eixo introdutório das modalidades de prazer que o caminhante solitário evoca. Segundo Jean Grenier ${ }^{86}$, aqui está descrita uma zona de acontecimentos situada na própria gênese dos Devaneios.

Com os episódios dos ataques públicos (inclui o episódio do apedrejamento da casa) e fuga, em 1765, Rousseau encontra em setembro desse ano asilo temporário na ilha de Saint-Pierre. Ali fica refugiado por um curto período. Rousseau, na quinta caminhada, endereça esse momento de breve refúgio, passado há mais de década do escrito, como os dias mais felizes de sua vida. Refúgio vivido, mas com potência de 'futuro', ou ao menos configurado de modo a permitir a intensificação desse prazer já vivido.

\section{6.}

0 refúgio vivido fomenta ressonância nas caminhadas finais da vida. Ressonância especial de composição-associação, em que se evocam, contatam prazeres, em que se 'criam' fragmentos de sensações de 1765 com o procedimento do devaneio a partir de 1776.

Importante que eu diga que a caminhada nos apresenta os sujeitos que nos compõem em movimento.

${ }^{86}$ Filósofo prefaciador da edição francesa que consultei dos devaneios. 
47.

A caminhada proto-anárquica, se aceitarmos nomeá-la assim, me pareceu ser a caminhada da des-individuação. A relação entre um anarquismo germinal ${ }^{87}$, que sequer pode ser anunciado como tal ${ }^{88}$, e uma desindividuação: essa relação se põe no segmento final do ensaio de Peter Pal Pélbart a catástrofe da liberação. ${ }^{89}$

A des-individuação como vivência radical, variante da noção simondoniana de individuação; des-individuação como individuação vertical (a partir de proposição de Marty), conforme falamos acima. Da nossa parte, resta mais uma vez indagar o que seria uma máquina des-individuadora do som.

Vejo nas caminhadas de Rousseau traços de uma des-individuação e de um proto-anarquismo (um anarquismo informal, não-formalizado, em germe, em contradição com ideias formais, como pode ser a própria ideia de 'deus' em Rousseau). Ou seja: estou indagando as caminhadas, e não a filosofia de Rousseau, que também está presente, que também tem vias de adequação e formalização.

0 trecho a seguir das caminhadas de Rousseau traz importantes pistas para uma perambulação em corpossom. São as memórias de 1765:

[...] Quando a noite se aproximava, eu descia dos cumes da ilha e em geral sentava na beira do lago, sobre a areia, em algum refúgio escondido; ali o barulho das ondas e a agitação da água, fixando meus sentidos e afastando de minha alma qualquer outra agitação, a mergulhava em um devaneio delicioso em que muitas vezes a noite me surpreendia sem que eu percebesse. 0 fluxo e o refluxo dessa água, seu ruído contínuo e retomado a cada intervalo, atingindo sem parar meus ouvidos e meus olhos, substituíam os movimentos internos que o devaneio

\footnotetext{
${ }^{87}$ Pelbart se vale dos termos 'germe' e 'germinal' algumas vezes durante 0 ensaio. 0 que ocorre é que Pelbart faz relações do ensaio de Emilia Marty com um outro ensaio sobre Simondon, do mesmo dossiê em homenagem ao filósofo (un pensée opérative, 2002), este outro de Daniel Colson, acerca de uma coletânea de escritos anarquistas e suas relações com traços da filosofia de Simondon.

${ }^{88}$ M arty e depois Pelbart se utilizam de citações do pintor próximo a Beckett, Bram Van Velde: 'eu não posso decretar que vou fazer obra, sei que não quero decretá-lo [...]' (PELBART, op. cit., p. 64). Provavelmente não se trataria de um anarquismo assertivo, individualista, é mais um anarquismo da orla, da borda, do quase-nada, daquilo que remove o humano-específico do centro do debate.

${ }^{89} \mathrm{O}$ que me parece polêmico, mais do que as palavras que uso, é a associação dessas qualidade que eu chamo 'proto-anárquica' a um texto tardio de Rousseau. E eu o faço menos pelos caracteres e coordenadas históricas, e mais pelos movimentos, pela capacidade de deslize, pela motivação dissidente que os devaneios de Rousseau têm.
} 
apagava em mim e bastavam para me fazer sentir com prazer minha existência sem me dar ao trabalho de pensar. De tempos em tempos, nascia uma fraca e pequena reflexão sobre a instabilidade das coisas neste mundo, cuja imagem a superfície das águas me oferecia, mas logo essas impressões ligeiras se apagavam na uniformidade do movimento contínuo que me embalava e que, apesar de nenhuma participação ativa de minha alma, não deixava de me prender, a ponto de, ao ser chamado pela hora e pelo sinal combinado, não conseguir sair dali em esforço. ( $p$. 68)

"Prazer em minha existência sem me dar ao trabalho de pensar". 0 não-pensar assinala uma atividade em outra chave. Qual seria ela?

\section{8.}

Desde 0 início das caminhadas, Rousseau comenta acerca de uma atividade da alma. Na cena acima, onde o rumor da água invade o corpo de Rousseau substituindo 0 pensamento, por assim dizer, rumoreja um desconhecido que vem misturado à água. Um desconhecido presente e existencialmente prazeroso, bem como a possibilidade de conhecimento desse campo de ressonância por ressonância. Rousseau narra a ressonância de um não-pensamento.

Nas caminhadas de corpossom há um campo que se aproxima disto: onde a ressonância chega antes mesmo do projeto de ação.

\section{9.}

O guia é o devaneio. É o fazer-nada como personagem. Essas contemplações errantes e difusas, de onde se é absorvido e invadido por uma espécie de experiência 'conjunta'. A experiência conjunta: o conjunto da membrana inqualificável que abraça momentaneamente os processos e os meios. Individuação, reunião das linhas feitas e refeitas pela membrana. A individuação, caracterizada pela ressonância, pela diferença de potencial, pela indeterminação. Podemos falar de assimetria? 
50.

Assimetria: a experiência aponta como sujeito o lado de lá, algo como um centro enovelado do movimento do conjunto, e não do eu. 0 conjunto que ainda assim é perfurado por diversos 'foras' de outras individuações. Mas algo se passou aqui, e é isso. A membrana-novelo se sustêm enquanto algo se passa. A única escritura possível dessa experiência de orla, onde o sujeito está minimamente lá, mas perpetuamente invadido e reconfigurado, é aquela escritura que dá testemunho da precariedade e da singularidade, seja no assunto, seja na forma ou na estratégia.

\section{1.}

De volta ao devaneio da quinta caminhada. Então são modos de se obter prazer. Perguntou Deleuze em uma aula: podemos escapar a todos esses prazeres? (da aula introdutória para o curso de 1983-1984 na Université Paris 8 Vincennes-Saint-Denis ${ }^{90}$ )

Poderíamos fazer essa mesma pergunta a Nijinsky. Contudo, Rousseau, o préromântico, assume a insólita tarefa de descrever um prazer do lado de fora das paixões que arrebatam, mas também ligado contudo a um rigoroso 'far-niente' ao qual o devaneio se associa e nele germina e brota.

Ou seja: diferente de uma sobriedade ascética ${ }^{91}$, Rousseau, em sua sobriedade particular, pareceu evocar nas caminhadas um prazer e uma liberdade que durassem, colocando-o talvez mais próximo a Spinoza do que aos filósofos cristãos da ascese. As caminhadas de Rousseau também têm um estranho e distante paralelo com os exercícios filosóficos de matriz epicurista e o pensamento do corpo vinculado a estes, quando parecem exercitar a imaginação para criarem laços éticos e prazerosos com 0 atual e o real.

\footnotetext{
${ }^{90}$ Trata-se do curso Cinema / verité et temps - la puissance du faux. Fontes de consulta: http://www2.univ-paris8.fr/deleuze/ e https://www.webdeleuze.com/.

${ }^{91}$ Ou: austeridade?
} 


\section{2.}

Ambos as personagens Nijinsky e Rousseau também negam o prazer, de alguma forma. Nijinsky, na constante ameaça e no evadir reiterado da morte, ao inscrever constantemente a noção de dever.

Proliferador das tarefas e sentenças mínimas, imperativas, nos diversos níveis da textura do diário, Nijinsky compõe, ou melhor, injeta as sentenças mínimas no corpo do seu diário com uma disciplina rigorosa.

Rousseau, por sua vez recusa, em diversos momentos, o 'corpo', a 'matéria', a 'carcaça'. Mas o fato dele construir um discurso em torno do prazer faz com que ele retome involuntariamente o tema do corpo, como numa diagonal ou num ziguezague.

\section{3.}

Nijinsky acolhe o corpo do Sentimento, como ele mesmo o qualifica. Sentimento que, para Uno no ensaio as palavras e Nijinsky, é equivalente ao afeto spinozano. E o que Rousseau faz no rigoroso ócio, não seria a prática de uma espécie estranha, naturalmente, mas prática de um corpo desconhecido?

Assim, a noção de disciplina se põe transfigurada em ambos, a serviço de um nomadismo-escrita inseparável de um si. Um si altamente desconfigurado, que produz a própria desconfiguração para alçar um campo de 'coleta', de campo receptivo. Essas noções me parecem produtivas para a performance.

\section{4.}

Rousseau e Nijinsky: registros epocais de regimes específicos de negação ou disciplina que também conferem consistência. Vou me apropriar de um enunciado de Carl Gustav Jung em o eu e o inconsciente quando diz que o que chama 'sombra' é o que confere consistência a um ser (1934). Eu, Francisco, gostaria de erradicar, dentro do possível, a moralidade do termo sombra e qualifica-la como uma óbvia opacidade da carne. Gostaria também de relacionar essa opacidade com a capacidade de se obter prazer nas mais variadas e inusitadas situações. Esse prazer é uma orelha para o corpo. 
Na mesma obra que mencionei, o psicólogo suíço se refere à gênese de seu método terapêutico como a construção de 'linhas vitais' a partir da fantasia ativa do paciente e contribuições hermenêuticas do terapeuta. 0 termo 'linhas vitais' é apelativo e me dispara uma série de associações com o desenho, a costura, a fala, 0 pensamento, a caminhada.

\section{5.}

Como matriz mista de sensação, há então essa dimensão ou modo específico, mas insuspeito, sóbrio, mas enigmático, de se obter prazer, e que é diferente da paixão. E aqui um pouco da proximidade entre Rousseau e Spinoza, por conta da definição deste de paixão (como afecção passiva) e a estreita relação da paixão com o primeiro gênero de conhecimento Spinozano.

56.

As próximas indicações, ao final da quinta caminhada de Rousseau, trazem uma costura violenta e mais um ponto da gramática vital e contra-metodológica na chave da des-contituição. Além disso, vem completar a noção de obtenção de prazer pelo devaneante.

[...] deixando meus olhos errarem ao longe [...] e sendo pouco a pouco devolvido a mim mesmo e ao que me cercava, não podia definir o ponto de separação entre as fantasias e as realidades; [...] Os homens se absterão, bem sei, de me conceder tão doce refúgio onde não quiseram me deixar ficar. Mas não me impedirão, pelo menos, de para lá me transportar todos os dias nas asas da imaginação e de experimentar por algumas horas 0 mesmo prazer que teria se ainda morasse lá. 0 que ali faria de mais doce seria devanear à vontade. Ao devanear que lá estou não faço a mesma coisa? Faço inclusive mais: aos atrativos de um devaneio abstrato e monótono acrescento imagens encantadoras que 0 vivificam. Seus objetos muitas vezes escapavam a meus sentidos em meus êxtases e agora, quanto mais profundo é meu devaneio, mais são 
pintados com intensidade. Na maioria das vezes me encontro mais no meio deles e de modo mais agradável do que quando ali estava de verdade. [...] (Rousseau. Quinta caminhada. Op. cit., ps. 72-73)

A aparente inação a comparecer nas caminhadas de Rousseau pode ser identificada, numa primeira mirada, como um lugar alheio ao rigor e à disciplina. Um lugar de deriva e literal desocupação. Isso o diferenciaria dos seus precursores europeus no tocante à noção de meditação (Grenier, op. cit, ps. 27-28).

[...] Saint Augustin médite, Descartes medite et aussi Malebranche. Ils conduisent en ordre leurs pensées autour d'un mystère ou d'un problème. Saint Ignace, dans Manrèse, a composé um manuel d'exercises spirituels qui comprend des méditations aussi soustraites au caprice personnel que possible. [...] (GRENIER, «data $>$ P, 27)

[Santo Agostinho medita, Descartes medita e também Malebranche. Eles conduzem em ordem seus pensamentos em torno de um mistério ou um problema. Santo Inácio, em Manresa, compôs um manual de exercícios espirituais que inclui meditações também subtraídas do capricho pessoal tanto quanto possível.] (tradução minha)

Rousseau descarta esse rigor do exercício que corresponde, a meu ver, com um enunciado ascético e até militarista. A desocupação do Rousseau das Caminhadas é um dos pontos mais marcantes de suas instruções práticas a si mesmo - é onde, de alguma forma, como ele diz, pode se ver que alma ainda se mexe. Atividade paradoxal: a alma coletora.

57.

A alma. Quero olhar uma vez para essa palavra para em seguida esquecê-la. Não há nada de universal na alma. Uma tradução seria 'imenso estranhamento'. Talvez apenas algo vivo e alter-orgânico que configure um borrão ou passagem ínfima e múltipla sob uma relação característica (este último termo emprestado a Spinoza). Um rastejar de fluxos. O termo alter-orgânico, eu o inventei um pouco a partir da recusa categórica de 
Artaud pelo organismo; alter-orgânico em ser inapreensível singularidade e devir das membranas.

\section{8.}

Rousseau e sua matriz prazerosa-vital. Novamente me vem Deleuze sobre o film de Beckett, pergunta da qual me aproprio: é possível a alguém retirar-se de todo prazer? Então: qual é o prazer este do qual não posso me desfazer? E ainda, qual a relação entre isto e a quinta caminhada de Rousseau? Me pareceu no mínimo que essa relação seja aquela de [1] algo de que eu não possa escapar, e [2] daquilo que é um imperativo da ressonância e da vibração, como mostra o exemplo da água que move um nãopensamento. E por isso eu não posso escapar.

Em film, existe algo de catastrófico no momento em que a figura de Buster Keaton é vista de frente. E ainda, trata-se menos de algo e mais de uma 'devastação'. 0 atropelamento de Rousseau por um cachorro em 1776 e seus desdobramentos domésticos e existenciais são tão mesquinhos quanto catastróficos, pois trazem consigo a falta de sentido e a opacidade do nada. É operação da máquina desconstituinte, guiada que está pela ambiguidade da matriz prazerosa-vital, ambiguidade tão insólita que não tem nada a dizer para os paradigmas de satisfação e repressão. É uma matriz prazerosa que tem algo a dizer quando Félix Guattari diz 'linhas de processualidade'92; tem algo a dizer quando tentamos pensar sobre aquilo que não conseguimos matar e que ainda nos empurra para a vida, uma vida toda esquisita.

59.

[o desenho que segue é feito a partir da impactante pergunta de Deleuze para Beckett, pergunta que ressoa na água que borbulha diante de Jean-Jacques Rousseau, apagando seus pensamentos. Que pergunta é essa? Não deveríamos

\footnotetext{
92 Realizada por Antoine Spire, Michel Field e Emmanuel Hirsch, em 1989-90. Consultei o vídeo disponível no site www.youtube.com .
} 
'suportar' o prazer. Esta é uma pergunta paradoxal, talvez proto-anárquica, talvez dirigida a uma cultura de si quando a cultura de si beira o insólito] 


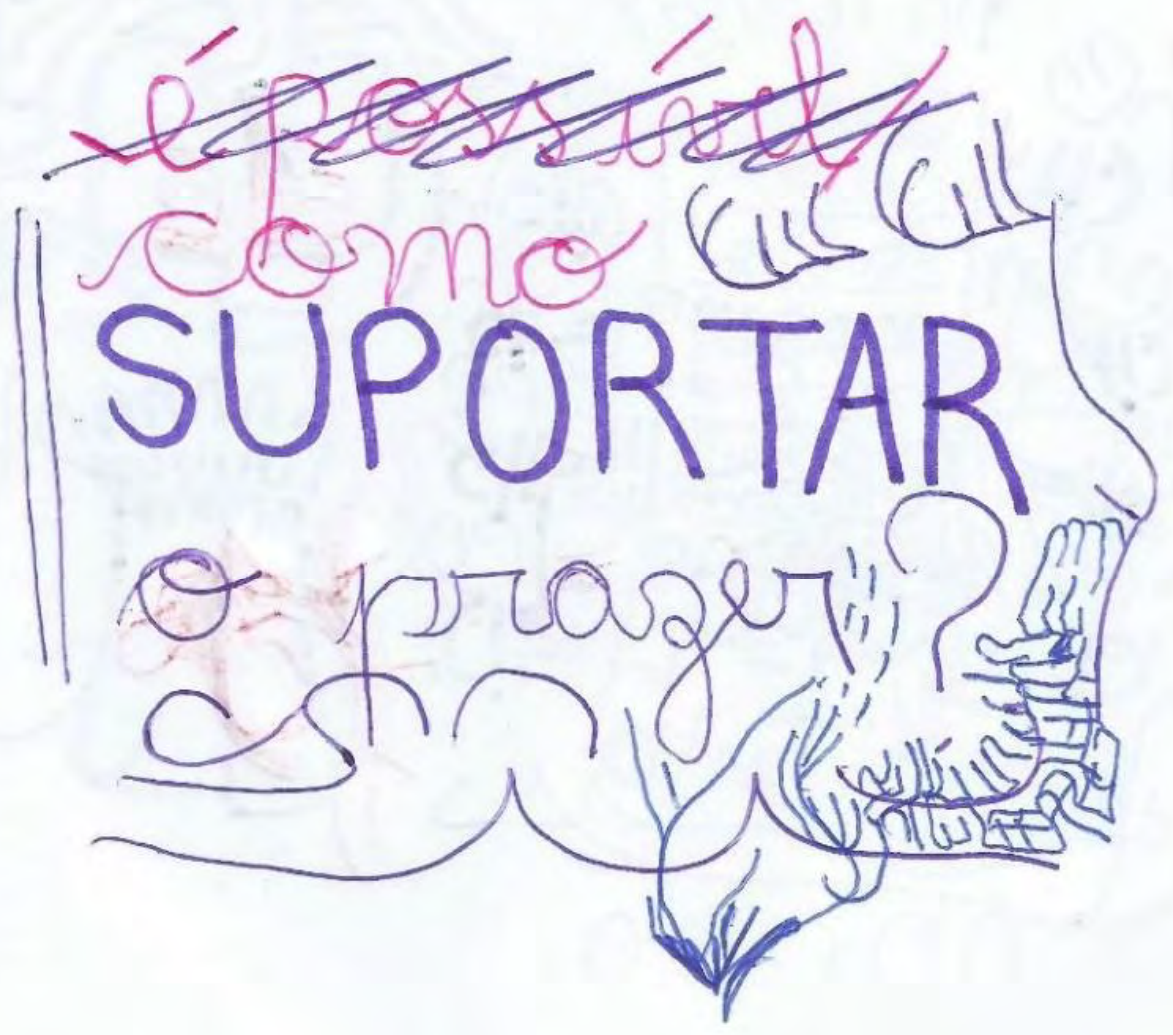




\section{[O PASSEIO DO ALTER-ORGÂNICO COM ALTER-PARENTESCO]}

60.

Só que é preciso evadir e insistir ainda um pouco para chegar nas máquinas desconstituintes ou nas caminhadas-catástrofe. Em trecho do Anti-Édipo, Deleuze e Guattari dizem que, a despeito da divergência avassaladora entre Freud e Jung, ainda subsiste o fato de que, em ambos, a libido precisaria se uma mediação para intervir na realidade humano-específica compartilhada. Indago se 0 Jung que eles questionam é 0 mesmo que eu questiono, mas isso, de toda forma, não anula o debate.

[...] [Freud e Jung] Eles têm em comum, pelo menos, o fato de acreditarem que a libido não pode, sem mediação, investir um campo social ou metafísico. E é isso que não ocorre. Consideremos uma criança que brinca ou que, a engatinhar, explora as peças da casa. Ela contempla uma tomada elétrica, maquina seu corpo, serve-se de uma perna como de um remo ou ramo, entra na cozinha, no escritório, manipula carrinhos. É evidente que a presença dos pais é constante e que a criança nada tem sem eles. Mas a questão não é essa. A questão é sabermos se tudo aquilo em que ela toca é vivido como representação dos pais. [...] A criança está sempre em família; mas, em família e desde o início, ela se entretém imediatamente com uma enorme experiência não-familiar que a psicanálise deixa escapar. [...] [2010 (1972), ps. 67-68]

0 que gostaria de observar é que podemos ser convocados a uma transformação, uma individuação conjunta, com um objeto do lado de fora da cultura, ou ainda, com co-sujeitos ou sujeitos 'plenos', não-cifrados pelo mundo moderno. Me refiro, por exemplo, aos rumores e ao que chamamos de alucinações, visões e manifestações mediúnicas que invadem o cotidiano ou participam dele, espécies de retirada estranhamente captáveis: participações em outras escalas de relação. Assim, podemos antever o passo seguinte: a sobreposição desse campo multiescalar e criativo que acabo de mencionar, com o próprio terreno cifrado da modernidade. 0 que quero dizer com tudo isso? 


\section{1.}

Quero deixar entrever que há cosmopolítica ${ }^{93}$ no parentesco (como seria de se esperar), e que contudo seria preciso redimensionar a noção de parentesco, retirandoo categoricamente do parentesco exclusivo parental-consanguíneo. A própria noção do ambiente-origem à qual se referem os psi que investigam os primeiros momentos do vivente humano-específico ${ }^{94}$ deveria incluir tudo aquilo que supriu o bebê com suas necessidade e não foi embargado - e também o embargo como presença. Assim, mesmo nas primeiras semanas, somos filhos de muitas coisas. Há ainda a história dos tecidos, como bem me elucidou a performer, pesquisadora e professora Tarina Quelho, em conversa recente. Uma história anterior, de vínculos anteriores à própria figura do bebê, que não tem por destino único esta figura.

Daí é concedido sentido e magicidade aos enunciados espiritualistas e animistas que reconhecem e tecem uma transformação no parentesco. Um exemplo afro-brasileiro entre praticantes: 'sou filho de Oxalá; sou filho de Ogum' etc. Ou mesmo ser filho do vento que sopra entre o mar e os rochedos. Ou filha das folhas secas. Ou parentescos que transitam e acumulam rastros. Se o leitor me perdoar a infâmia, vou escrever em meu doutoramento que eu acho que somos crias e muitas coisas. Digo também que anotar a responsabilidade com o alter-parentesco, com vistas aos encontros e reencontros, ao alter-parentesco desconhecido e ao parentesco no porvir, com ele, pode ser uma contribuição de uma contra-antropologia. Etnografia local e intransponível das linhas de vida.

O leitor me perdoará também pelo fato de eu não citar Lévi-Strauss, quando 0 tema foi pautado pelas possíveis estruturas de parentesco. Este não é um debate de comprovação de modelos.

Esse sentido renovado e transformador de parentesco mais se potencializa quando sabemos do que nos deixam saber os conhecedores legítimos de tradições étnicas. Por exemplo, o que nos deixou saber o Bàbálorìsà Agenor M iranda quando

\footnotetext{
${ }^{93}$ Termo cunhado por Isabelle Stengers em artigo a proposição cosmopolítica traduzido em 2018 (la proposition cosmopolitique, 2007). 0 termo tem sido adotado necessariamente de maneira mais ou menos frágil, como prevê a autora.

${ }^{94}$ Como exemplo, Winnicott, ou o próprio Christopher Bollas.
} 
disse 'Orixá é um fragmento da natureza'95. 0 termo 'tradições étnicas' envolve muitas e diferentes histórias. Deixemos assim. Muitas tradições étnicas desapareceram à força da modernidade eurocentrada, muitas estão em curso de apagamento, o que nos mostra que a colonização não foi interrompida, mas é um instrumento de interrupção que se sofistica. M uitos desses corpos étnicos vivos, contudo, sobrevivem e seguem na forma de sociedades secretas durante os ataques e acirramentos do capitalismo predatório. Ou ainda processos vivos de sincretismo. Aqui a palavra 'cultura' equivale à função de resistência, permanência e, no caso da diáspora africana ou talvez no caso cigano, modalidades de vínculo social e mágico intercontinental.

\section{2.}

Há quem diga 'esses iniciados', tentando imprimir um tom depreciativo ${ }^{96}$. Isso é um problema por demais europeu, me parece. Contudo cabe dizer que, no contexto que apresentei, de modulação de parentesco, o que chamamos iniciação vem redobrar infinitamente e modificar o campo afetivo, ou 'psicosfera', acrescentar possibilidades de composição ${ }^{97}$ Há de se fazer uma etnologia dos sentidos de iniciação. E também do porquê de uma determinada visão de arte passar a 'emular' esses sentidos.

\footnotetext{
95 Documentário um vento sagrado (2001), dirigido por José Walter Lima. Até o momento desta redação, consulto uma cópia com boa resolução no site www.youtube.com .

${ }^{96}$ Quando Antonin Artaud ataca a ideia de iniciação nas cartas tardias a André Breton, trata-se de uma questão inteiramente diferente. Trata-se um pouco de atacar a iniciação como nostalgia museológica. $\mathrm{E}$ talvez de compreender que Artaud já tivera inumeráveis desconstituições, de modo talvez a considerarse ele mesmo efeito precário e agonístico de outras alianças ou filiações, infinitamente multiplicadas e inteiramente desconhecidas. Em seus textos tardios verificamos assunções que vão nessa direção.

97 A performer, ativista antipatriarcal, etnógrafa e filha de santo Thais di Marco colaborou imensuravelmente com essas reflexões. Diz ela: 'o sentido de uma identidade tradicional é quando, apesar de tudo, você sabe que é alguém e é a filiação daquela divindade que assegura isso. É uma espécie de renascimento ou mudança de psicosfera. É o Orixá que vai retirar a pessoa daquela psicosfera exclusivamente consanguínea e possibilitar uma espécie de reprogramação'. Reconstruo sucintamente o sentido que apreendi, com palavras ditas pela própria Thais.
} 


\section{[UMA PRÁTICA ATERRISA DO MEU LADO: \\ PRÁTICAS INVOLUNTÁRIASE DISTRAÍDAS]}

\section{3.}

Falo de uma prática. A escrita é uma prática, o devaneio é uma prática. É o corpo que escreve, existe um corpo bizarro que opera o devaneio. Como disse: contrametodologia, refocalização da prática, espiritualidade proto-anárquica... formulações absolutamente precárias e locais. Máquina desconstituidora, arte da orla...

A imagem de Rousseau em 1765 fitando a água (e sendo fitado por ela) ressoa nas caminhadas traçadas e retraçadas de 1776 a 1778. A afetividade com a qual me associo e fantasio muito tem a ver com ressonância que se sustenta enquanto 'algo se passa'. Tem a ver com a 'intimidade criativa', que é o fora enquanto relação, possível comunicante de diversos pontos do tempo (Deleuze-Blanchot para falar do Foucault tardio).

\footnotetext{
0 pensamento pensa sua própria história (passado), mas para se libertar do que ele pensa (presente) e poder, enfim, "pensar de outra forma" (futuro). É o que Blanchot chamava "a paixão do lado de fora", uma força que só tende em direção ao fora porque o próprio fora tornou-se a "intimidade", a "intrusão". [...] (DELEUZE, 1986, p. 127).
}

O fora como mais dentro. Em seu avesso, a figura do impessoal no Genius, figura divina da carga não-identificada que vem com o vivente, descrita por Giorgio Agambem: 'é Genius que, obscuramente, apresentamos na intimidade de nossa vida fisiológica, lá onde o mais próprio é o mais estranho e impessoal, o mais próximo é o mais remoto e indomável.' (AGAM BEM, op. cit., p. 15) 0 dentro como o 'mais fora'. 


\section{4.}

Para mim, especificamente, o prazer insuspeito vem da intimidade com 0 nada. A imagem de Rousseau para o borbulhar da água ressoa violentamente em mim. É uma gênese de corpossom.

\section{5.}

Existe nessas sentenças (Deleuze-Blanchot e Agamben-Simondon) um verso e reverso de corpo-experimento que margeia a catástrofe dado que rejeita se fixar. Daqui a construção da hipótese da caminhada-catástrofe. Não se trata apenas de falar disso, é deixar que isso fale. Tento evadir à simetria antropológica de Latour. Tento operar e escutar uma assimetria 'para lá' ou 'para cá', saltitante, pois não consigo fugir à sensação de que, na simetria Latouriana, bem como nas 'quatro ontologias' de Phillipe Descola, há um projeto. Mais ou menos consciente, é o projeto de se dominar conceitualmente o terreno da experiência alter-humana, controlar as alteridades que assaltam. Cada um deles o faz à sua maneira, seja no esquematismo (Latour), seja na epistemologização (Descola). Diz Ingold acerca da simetria Latouriana que essa 'categoria-cobertor' (your blanket-category) ${ }^{98}$, no fito de privilegiar híbridos entre naturezas e culturas, ao invés de seus pólos purificados, tenta abarcar seres e coisas muito dispersos entre si. Assim acaba que se torna inoperante o próprio binômio natureza-cultura. Em verdade, não se trata de saber se é possível essa separação: 0 que ocorre é que passa a ser um esquema irrelevante. Os processos de mundo não humano-específicos: nós sequer sabemos reconhecer esses mundos que nos atravessam. Quem somos nós? Modernos, até a medula, atravessados por mundos não-modernos e não-humanos. Talvez nunca tenha sido tão importante aquilo que não se consegue reconhecer.

\section{6.}

Não é por não saber reconhecer uma música não-moderna, e muito menos uma música não-humana, que temos habilidade de dizer que 'a música' é humano-

98 Ingold, 2008, p. 214. 
específica. Isso é muito diferente de impor uma visão humana de música aos nãohumanos, que é o que fazemos quando cortamos uma árvore e colocamos uma fatia de seu tronco na vitrola: "Olhem! A música da árvore". A afirmação, ainda que implícita no quadro que descrevi, confirma o desastre.

67.

Daí que a produção de diferentes não cessa, em paralelo ao mundo humanoespecífico. Formas de vida que cruzam o espectro afetivo, seja na via do sonho, da arte, da fantasia ativa, da fabulação e da narração, seja na via de acontecimentos sobrenaturais, onde uma qualidade inteiramente nova é introduzida.

A prática da fabulação como potência do falso e gênese de microativismos, como indica Christine Greiner (2017, p. 90, via Erin Manning / Gilles Deleuze), constitui um campo móvel e problemático conjuntamente a outro delineamento da noção de fabulação. Aquela tida como destituidora do contato, como sugere Achille M bembe [2018 (2013), ps. 28-46]. Um outro fragmento de operatividade de fabulação é aquele afirmado por Ana Kiffer: 'a fabulação é um modo de construção desconstrutora do pensamento.' (2008, p. 100)

Através da fabulação (procedimento muito aparentado à narrativa) podemos ativar a desconfiança para outros mundos.

68.

Cápsulas de fábula no Tarô:

A arrebatadora apreensão afetiva traduz (ou transduz) a assimetria alterhumano-específica, ou ainda alter-orgânica. É a novidade adentrando os portões e arrebatando todo o espaço afetivo: qualidade similar àquela do Arcano Maior ' 0 Enforcado' (XII).

Possibilidades de novos parentescos. Quadros de ressonância ou reconhecimento, efetuação (ou re-efetuação, ou ainda contra-efetuação) de parentescos alter-escalares: algo da carta 'A Estrela' (XVII). 
69.

A imagem que eu faço da minha própria caminhada é aquela de uma lesma, ou ainda de um ser parecido com uma lesma, só que não-catalogado, rastejando sobre uma estrutura metálica enferrujada. Ela é aparentemente muito lenta. Essa lesma, como toda lesma, deixa atrás de si seu rastro viscoso. 0 que eu imagino é que o visco do rastro da lesma reage, ao longo dos muito tempo, com os microrganismos daquele ambiente e com a própria ferrugem. A estrutura metálica é então corroída, desfigurando-se.

A caminhada, bem como a escritura que é o próprio rastro, almejam a máquina desconstituinte do som.

\section{0.}

'Porque será tão difícil por vezes determinar um percurso a seguir? Creio que a natureza encerra um subtil magnetismo que, se inconscientemente nos rendermos a ele, dará um rumo aos nossos passos' (THOREAU, 2013, p. 33) Em meio a tantas assertivas antropocêntricas e palavras de ordem na caminhada de Henry David Thoreau, essas escassas passagens de incerteza do autor de a desobediência civil me atraem como uma grande maré. 'Quando saio de casa para dar um passeio, sem saber

ainda onde me levarão os meus passos, e dou ouvidos ao meu instinto, creio, por estranho e bizarro que pareça, que tendo inevitavelmente para o sudoeste [... ]' (p. 34). A obsessão com o Oeste estadunidense é literalmente uma personagem autônoma, que Thoreau quer transformar em exortação de liberdade e autonomia.

\section{1.}

Em alguns fragmentos defendi um proto-anarquismo insólito em um autor préromântico (Rousseau) e, em outros fragmentos, a iniciação como forma de devir parental. A individuação, no sentido simondoniano, e ainda mais a individuação vertical, a contra-individuação através da angústia, do medo e da 'aprendizagem' ou contra-aprendizagem do des-fazimento, trazem um senso de nascer para o aberto, 
para o fora. Marty fala que a individuação vertical é menos um processo e mais um ser-em-aberto, dilatado (2004), Simondon fala de portar a si mesmo como um morto. Seria uma espécie de inatismo genital artaudiano, em modos de retraçar uma vida a si mesma? ${ }^{99}$

\section{2.}

Eu considero minha ida às cavernas em 2013 uma espécie de marco insólito. Alguns sinais das hipóteses do insólito se mostram no modo surpreendente como nós próprios lidamos com determinadas coisas. Por exemplo, na segunda viagem ao PETAR, nós da equipe resolvemos mergulhar no riacho. Logo após, resolvi entrar, sozinho, na água gelada da piscina sob uma cachoeira também gelada, local logo abaixo à caverna Morro Preto, o lugar em que performaríamos em seguida ${ }^{100}$. 0 fato espontâneo foi o seguinte: eu me via em situação de escuta e fala com a cachoeira, indagava de fato o que deveria fazer para me cuidar na caverna (eu havia já tido tonturas em pelo menos duas explorações anteriores). A resposta pareceu vir assim, como um sussurro que ressoava fora e dentro de mim: 'paciência'. A seguir, a exploração correu sem intercorrências. Era uma espécie de voz e ecoava nesse dentrofora. Assombroso. Assombrei-me também com a própria naturalidade com que lidei com o fato.

Ocorreu essa lembrança imediatamente quando do acontecimento de outra situação afim com a descrita, uma vez que essas coisas acontecem alheias à vontade, $\mathrm{e}$ assim só temos posse do fato, e ainda assim isso é muito.

Mais uma vez esse 'rumor de escuta', em outra situação alguns meses depois, com o mar. 0 mar me falava que eu deveria dançar para recorrer a sua força.

Tudo isso aconteceu sem nenhuma interferência possível das minhas fantasias sobre seres da natureza. Foi concreto. Como dar conta dessa experiência sem enquadrá-la em um psiquismo ordinário?

\footnotetext{
99 Teria isto a ver com uma hipótese central junguiana, aquela do renascimento em vida? Ver: a divergência entre Freud e Jung. Texto revisado inumeráveis vezes de 1929 até 1950. Jung, CW IV.

100 Sabe-se que as cachoeiras cuja água derrama das cavernas são geladas: aquele volume de água é oriundo de um rio subterrâneo.
} 


\section{3.}

O que chamei 'rumor de escuta' logo acima é também uma situação de improviso. Eu já a chamei essa situação de 'anterioridade do espaço'. É quando um encontro mostra as linhas que 0 antecederam. E é quando se pode alimentar de suspeitas, pois não se pode comprovar nada. Os rumores não servem à comprovação, servem à essas anterioridades espaciais seladas na opacidade do invisível.

A anterioridade do espaço é também uma reflexão sobre a escuta. Pois o corpo que improvisa uma dança e uma vocalização em determinado lugar, enquanto forma de habitar, ainda que momentaneamente, aquele lugar, sabe infinitamente mais sobre o 'autor', o performer. Os percursos de escuta estão, portanto, 'dobrados', como futuros, potenciais, virtuais. Estão em germe. Eu disse um pouco disso na introdução à tese e no 'bloco um'.

0 que o meu corpo me conta é algo que diz respeito a essa ontogênese do contato que se anuncia no rumor da escuta. 0 corpo conta algo como 'cantar para escutar', ou seja, sentidos e ações ambíguas que situam no devir instável a produção de corpo.

Sou repetitivo quanto a isso, pois será importante na noção Nijinskiana de 'devir-qualquer-coisa'. Pois não é a coisa a medida, mas o que se passa, o quer costura as micro-operações. 


\section{[CORRER OU ESPERAR}

\section{SÃO TAMBÉM CAMINHADAS:}

\section{ALGUMA ATIVAÇÃO POÚTICA]}

74.

Passeio. Errância, Caminhada. Perambulação. Retraçar os campos.

Corridas, saltos, esperas.

Rastejar.

Apinéia.

Dormir.

75.

'O passeio do esquizofrênico: eis um modelo melhor do que o neurótico deitado no divã.' [Deleuze; Guattari, 2010 (1972-73), p. 12]. Esse deslizante e proliferante início do Anti-Édipo já anuncia seu procedimento-chave. Ele: um passeio movido pelas máquinas desejantes para aquém, além, alhures do modelo único fundamentalista parental-consanguíneo. Pode ser valer-nos de nossos traços esquizo para intensificar o desejo do múltiplo, dos múltiplos acoplamentos.

Como era de se esperar da ressonância de tal imagem (a do passeio esquizo), portadora de estranheza determinante ou radicalidade, faço minhas próprias leituras da caminhada, e então dos enfrentamentos. É isto o que imagino ser o esperado de uma filosofia operativa não-imperialista. Se consigo realiza-la, isto já é outro problema.

76.

Referi-me a um modelo único e fundamentalista. Esse modelo exige legitimidade constante e exclusividade constante. Ele tem, como seria de se esperar, sua historicidade dominante correspondente. Uma produção narrativa que, como modo de dispersão de um modelo único, centralista e fundamentalista, clama por um sujeito-história que almeja ser único, linear, progressivo, acumulativo. 
77.

Modelo único: campo purificado, para dialogar com Bruno Latour (1991, op. cit.), aqui sobreposto à noção difusa de história, esse grande tecido tão rebelde a modelagens. Valho-me de alguns conceitos de Latour, enquanto rejeito ou expresso desconfiança a outros. Já forneci o exemplo da antropologia simétrica que não consegue descartar a dualidade natureza-cultura, ainda que já se dê conta se tratar de outra coisa. Tomar 0 lado dos híbridos e dos mediadores significaria, para mim, desfazer uma terminologia e tomar um lado infinitamente mais múltiplo. Seria preciso fazer outros modos de etnologia.

\section{8.}

Sou absolutamente obsessivo por caminhadas. Muitas coisas se passam em caminhadas. Entre agosto de 2006 e abril de 2017 estive de carro. Mais de dez anos. Sinto que algo bem interessante do processo das caminhadas submergiu, dissipou-se nesse período, enquanto prática. De resto, a caminhada e o desenho sempre foram meus alter-órgãos adjuntos, secretos, produtores de corpo. Também atravessei períodos longos sem desenhar. A mesma coisa se passou. Um alter-ógão hibernou. Aqui, gostaria de transformar tudo, a finos golpes, em caminhada, desenho e suas vozes duvidosas e errantes. Lembro da carta de Van Gogh a seu irmão, que Artaud usou... e as pessoas adoram usar... aquela que fala sobre escavar uma parede. Abordaremos ela no segundo capítulo.

\section{9.}

Atravesso um campo de detritos. Ouço gritos cansados, pungentes, e não encontro quem os lançou... eu os lancei, vindos do futuro. Eu e meus parentes refugiados. 


\section{0.}

Há também os aparelhos legitimadores e repressores devidamente instalados. Aparelhos de ataque e destituição. A casa. Reconheço um circuito de destituição à brasileira, intensamente situado no seio da vida privada, acoplado ao apagamento étnico que mencionei mais acima. A casa como espécie de dobra ou nó do EstadoNação predatório, a casa como um cativeiro oficial. E o circuito mais geral, policialmédico-escolar (cobrindo e recobrindo de inscrições os corpos).

\section{1.}

Gostaria de imaginar os pensamentos como um grupo nômade, chegando, vindo de longe... Uma imagem deselegante, ou de duvidosa elegância, dos ciganos ou dos nômades, cuja memória étnica em mim está bastante apagada, mas rumoreja nos restos, apenas alguns detritos mágicos e sociais inexplicáveis. Outros parentescos, aqueles (façamos como quem aponta com o braço inteiro!) sinalizados por pensamentos impregnados de afeto.

Pensamento-revoada de não-pensados!

\section{2.}

Quero crer, assim, que um dos objetivos da variada inscrição da violência do humanoespécie moderno, violência compreendida como um processo largo, é sobre-escrever no curso das vidas, como um palimpsesto mal apagado, um caminho. Aquele de correção e reposição frente a um desejo de destituição da vida. Para traçar essa imagem destituidora sumária lanço olhares a Césaire e M bembe, e outras e outros. São ajudas inestimáveis.

Estou envergonhado, pois estamos de certo modo entre 'nós', ainda que hajam muitos outros nesses nós, e nosso próprio modo de vida está hoje, enquanto ficção legitimadora de destituição, atuante na continuidade do massacre e da extração da vida. 
83.

Esta tese está desastrosamente aquém do campo teórico. Gostaria de compor com esse catastrófico campo a 'minha' linha errante de ontogênese através da caminhada coincidente com um proceder visceral de 'andamento', pé da escrita. Escrever com 0 pé, é isso. Um andar duvidoso, mas será inescapável andar. Titubeante, errático, elétrico. Essas voltas, esses olhares indecisos, esses pudores que nos fazem voltar, desconfiar e duvidar. A caminhada é feita de hesitações, até que alguma coisa me tome. As caminhadas de Nijinsky estão tão próximas.

84.

Como não fazer perguntas modernas, categóricas? Como destruir falsas perguntas? Antes, não seria preciso fazê-las?

85.

Assim suponho que uma característica central da monumental - e intimidadora no seu conjunto, por definição - obra da modernidade seja a destituição. Seja na moral; seja no borrão, no apagamento; na desorientação e deturpação do senso de reparação para as mutilações coletivas. Seja no assassinato literal, seja na 'correção' do curso da vida e destituição da produção de uma vida que é a própria vida em curso... Thaís di Marco falou em termos de 'ministração social de agentes químicos, de drogas'.

Estou pensando o Estado Policial atuante no pensamento, que é carne.

Não fiz um estudo sistemático sobre esses componentes da vivência moderna. São apenas pontas que furam a carne.

Dado ser possível supor uma imersão na vivência moderna, portanto entendida por mentalidade dominante e portanto violenta, eu pude, não sei exatamente por quais razões, através do estranhamento que é marca da própria vida, deparar com rastros. Thais me lançou a derradeira pergunta, cito em uma frase quase idêntica ao enunciado dela: se o colonialismo aí está, isto significa, entre outras coisas, que aquilo a ser colonizado ainda não o foi, ao menos não totalmente. 0 quê é isto que ainda não foi colonizado? Não quero ser ingênuo e nem arrogante. É claro que devo 
supor, para começar um esboço de resposta, que eu esteja do lado certo. 0 quê é 0 lado certo? 0 lado de uma vida enquanto escuta, enquanto suspeita. Daí a importância do titubear e do fracasso como estratégias também contra-efetuadoras de caracteres dominantes, destituidores.

0 quê é vivência moderna, portanto? Vivência de destituição. 0 caractere cristão e messiânico vem aderir a essa larga construção. Peça fabricante da transcendência.

Escrevo a partir de muitos privilégios. Há em paralelo as inadaptações problemáticas, que já me disseram ser sintomáticas de VIDA. A inadaptação é sinal de saúde. Assim vivi e tenho vivido, de modo desconcertante. Um dos elementos que quero tocar é que, dentro da subjetividade, há uma disputa de historicidades.

Às vezes a manifestação do mundo mágico, encantatório, é o único modo da vitalidade explicitar as disputas de historicidades dentro de uma forma de vida em vias de destituição.

Daí a necessidade fabular, a ficcionalização do corpo, que se vai vingar, vez ou outra, do projeto de domesticação.

86.

Falo da atuação concreta de representações centralistas, prévias e estáveis que objetivam uma reposição perpétua do mesmo com o objetivo da predação.

Largos e múltiplos processos, recusas, disputas vitais por historicidades inauditas. É esse 0 terreno onde se configuram personagens estranhas, figuras que saltam. Estão dobradas ou pulverizadas dentro da membrana-chico, por exemplo, Lilith (de que falarei agora), por exemplo, um AntiÉdipo.

Esse Anti-Édipo: não deve ser difícil de conceber que ele já estivesse em processo de contação e escrita nas existências dissidentes, pretas, indígenas, contra e altergêneras, não-binárias, alter-econômicas, e bem longe de um edifício teórico eurocentrado. E é este o problema de se lançar ao futuro, de se falar do que será escrito: esta utopia mascara 0 apagamento de outras histórias já há muito tempo continuamente recontadas. A ausência de alteridade, longe de ser uma resposta 
confortável, é a própria expressão do apagamento e a extensão da disputa por historicidade. Fiquemos sobressaltados, por favor, diante de enunciados unilaterais. 


\section{[ULTH]}

87.

\section{para Camila Jabur e o grupos de 'astrologia da escuta'}

Falei de Lilith. Quem é Lilith? A 'primeira mulher de Adão'?

A melhor pergunta será 'quem'? Não, não será.

Para além da fábula mítica dos Midrash (exegeses, comentários) do Velho Testamento ou Talmude. Para além das crônicas dos rabinos. Para além da cosmética mitológica que produz essa 'intoxicação espiritual' que ora nos assalta. Se bem que lilith seja o avesso de espírito, talvez aquela imensidão miserável e não-moderna de um corpo. Então, nada tem a ver com 'além', é mais a imensidão à queima-roupa do 'aquém', do campo afetivo particular, radical, mundano e também extramundano. Partículas de fóssil impessoais, porque fóssil vivo, mas pessoais, enquanto uma vida, ativando a luta pela vida desde sempre. 0 maior erro é personalizar Lilith, e isso vem revelar a falácia da modernidade quando esta tenta se valer da imantação apassivadora dos mitos. ${ }^{101}$

Aprendemos na astrologia que Lilith é o caminho que faz a própria elipse da lua, havendo como referência o seu perigeu - o ponto em que a trajetória elíptica está mais distante da terra. 0 percurso da lilith para fazer o seu caminho aparente por todos os signos, até retornar ao mesmo ponto, dura um pouco menos do que nove anos. Digo 'caminho aparente', pois o ponto de vista é inevitavelmente o ponto de vista da terra. 0 ponto de vista dos viventes é a referência do próprio desenho do mapa astral ${ }^{102}$.

Quando tentamos ler o mapa astral de alguém, Lilith já está lá como o campo disparado pela inteligência vital sediada no instinto da pessoa, mas não exatamente a pessoa. É principalmente a inteligência do corpotambientetgênese. Dificilmente haverá um livro sobre lilith porque é uma dinâmica radicalmente relacional, processual

\footnotetext{
${ }^{101} \mathrm{Na}$ modernidade o mito vem habitualmente como ativador de paixões passivas, para falar com Spinoza; banhadas em ideologia dominante. E o mito poderia ser, numa mirada múltipla não-moderna, um recurso ao vital e ao afeto-ação. Seria algo paralelo a uma assunção da ficcionalidade vital.

102 No processo de feitura de conexões e contatos nascentes que é a astrologia, contudo, o planeta Terra está longe de ser o centro.
} 
e afetiva que se pode deflagrar. É essa força que escreve enquanto linha de vida. Delineamento vago, sempre atravessado, sempre em contato com algo: delineamento de zonas de opacidade dessa inteligência vital, avessa a formalizações. Podemos apenas ficar ocasionalmente atentos a isso, na medida de um rumor e, nas palavras de Jabur ${ }^{103}$, 'ler rastros'. A Lilith está um pouco em como a vida busca a si mesma, amoral, na história de um corpo, através de métodos muitas vezes radicais, insólitos. Como diz Hesíodo na descrição do Tártaro: 'odeiam-nos os deuses'.

A lilith conta que somos todos híbridos, simbióticos, multi-espécie. É uma história subconsciente de um corpo neste mundo, com rastros de outros mundos.

Somos bichos.

Para evadir-se a uma astrologia por demais cosmética, personalista e utilitarista, temos de aprender um rumor de astrologia com Lilith. Em uma experiência de relação qualquer, anônima porém radicalmente singular, onde nos situamos enigmaticamente como corpo de nascimento (ou melhor: parto), como devir na carne, como campo afetivo no corpo, ali está enraizada em Lilith.

0 grupo de astrologia do qual participo se chama 'astrologia da escuta'. Se me permitirem os amigos e colegas, acho que também a poderíamos chamar de 'astrologia da lilith'.

A Lilith pode ser uma palavra-talismã. Ela invadiu esta tese, durante uma série de desenhos que seria aquela série de 'árvores plausíveis'. Assim, mais uma vez, as coisas se embaralharam. A Lilith poderia ser aquilo que deixa ou não deixa ver que se tratava de uma árvore de vida em sua crueza, pois nosso próprio corpo se abriu ou não se abriu para isso. A pergunta está, em realidade, mal posta. Temos alguma escolha?

Sabe quando me parece aparecer Lilith? Quando estou escrevendo à mão, fazendo caligrafia, e de súbito deixo de prestar atenção à finalidade, ao ritmo, à intenção voluntária (se é que tal coisa existe), ao sentido das palavras, e começo a prestar mais atenção ao pigmento. Um clamor, uma fala da própria coisa que a coisa que somos atende e cria um campo fóssil, a-orgânico. Alter-orgânico. Um diagrama se criou, um alter-órgão. Um território entre tinta, papel, corpo...

${ }^{103}$ Camila Jabur é astróloga, poeta, filósofa e formuladora da clínica, do pensamento e da pedago gia que ora abordo ao falar de astrologia. Suas principais alianças nesse trajeto de formulação constante são a parceria com Amnéris Maroni, os grupos de trabalho com astrologia, e as conversas com árvores e ventos. 
0 que tem isso a ver com som? M uita coisa. Vamos pelo seu avesso, o corpo.

Reconheço um rastro de Lilith no ensaio um pequeno nada entre os limites, quando o filósofo-dançarino Uno Kuniichi observa o dançarino-filósofo Tanaka Min dançar, e coisas inexplicáveis mas nada transcendentes se passam. Pura filosofia da carne. Uma aliança vital e sem palavras se forma momentaneamente.

Também no ensaio corpo-gênese ou tempo-catástrofe, quando Uno descreve que 0 tempo dançado por Min é um tempo geológico perpetuamente rastreado no corpo, traçado e retraçado numa expedição insólita.

Mais uma vez, chegaram os Butocas. 


\section{[MUTAÇÃO: CORPOSSOM E BUTÔ]}

88.

\section{(Corpossom, um butô antivocal? ${ }^{104}$}

\section{Estou um pouco envergonhado, pois trata-se de um exercício de paralelismo, e, principalmente, de uma perambulação escrita, onde estou munido principalmente}

104 Felizmente, graças ao empenho artístico, intelectual e editorial de várias pessoas, há já uma incipiente contudo sólida bibliografia sobre dança Butô no Brasil. Para além do livro pioneiro de Maura Baiocchi, de 1995, dos dois livros traduzidos de Uno Kuniichi (trad. 2012 e 2017) e alguns trabalhos pontuais que se valeram do ambiente acadêmico de pesquisa, eu considero marcantes alguns percursos. 0 livro de Christine Greiner butô: pensamento em evolução (1998), e sua antípoda temporal, os dois livros-irmãos leituras do corpo no japão (2015) e fabulações do corpo japonês (2017). Estes últimos não são livros sobre butô, mas configuram um discurso afim, penso, com sua complexidade. Há ainda diversas publicações de Greiner sobre 0 assunto, em outras situações e escalas.

Chegou-me em mãos recentemente o livro referencial de Éden Peretta o soldado nu: raízes da dança butōo, e há alguns ecos iniciais da leitura dele enquanto escrevo. A exemplo de compilação, cabe mencionar a dissertação de Thiago Abel defendida em 2017 no Instituto de Artes da Unicamp, e a exemplo de paralelo estético, a dissertação de Carolina Hamanaka Mandell defendida em 2009 na Escola de Comunicações e Artes da USP. Sobre as ressonâncias políticas do butô no brasil há ainda 0 sensível estudo de Joana Egypto (2017).

Como disse, revisito meus cadernos das aulas, cursos e oficinas que fiz, além de anotações concernentes às imagens aqui mobilizadas. Cheguei à conclusão de que quero oferecer algumas informações que eu mesmo gostaria de ler num texto sobre butô.

Sobre a palavra em si, significa genericamente 'dança' (ideograma bu), com ênfase na relação ou imagem de se bater os pés no chão, de se usar o pé (ideograma tō). 0 segundo Ideograma, por sua vez, carrega também a imagem de se tapar o sol. Possivelmente como referência à própria sola do pé, que não vê o sol quando caminhamos e quando fazemos dança de passo. Assim, no contexto desta imagem, o pé teria uma espécie de 'noite interior' perene durante a dança. A imagem resultante parece a de ser a de uma dança ligada à terra e à noite, ao escuro e à invisibilidade. A um outro mundo, porém muito próximo. A primeira formulação para este nome, como se sabe, é ankoku butō (dança das trevas), aparentemente cunhada por Hijikata.

Fiz, antes e também agora, outras associações com o tapar do sol, inclusive com a fábula xintoísta que conta de quando Amaterasu, a deusa-sol, se escondeu. Fiz ainda associação com o contexto pós-guerra no Japão, onde a figura do Imperador e seu corpo, legitimado como descendente dessa linhagem solar divina, se destroçava com o fim desastroso da guerra, em si desastrosa. Mas acho que essas associações vão longe demais, apesar de serem pontos contextuais. De qualquer maneira, levo em conta a obra de Mishima Yukio, um dos padrinhos intelectuais, por assim dizer, na gênese do butô, para essa última associação.

Enfim, há várias explicações sobre o a palavra butô, das quais me lembro fragmentos. Pareceume que a palavra Butô, no contexto mais antigo, era a dança que os estrangeiros dançavam, a dança importada, inclusive no contexto da abertura dos portos do Japão (1854). No contexto germinal do Butô, essa palavra é recontextualizada e passa a ter um sentido de relação com o solo, a terra, e o tom referido antes àquele estrangeiro à nação agora se refere ao estrangeiro total que habita o próprio corpo. Há dois volumosos verbetes sobre Butô na enciclopédia digital wikipedia (o verbete brasileiro me pareceu insatisfatório):

https:// en.wikipedia.org/wiki/Butoh

https://fr. wikipedia. org/wiki/But\%C5\%8D

Parece que há uma palavra com ideograma distinto, mas com a mesma pronúncia, significando 'mosca preta': buyu, buyo ou buto. Trago esta associação pois gosto dos insetos como imagem de corpo. Talvez o paralelo entre o corpossom e o butô tenha algo a ver com os insetos. 
das minhas anotações de trabalho de 2005 a 2008 e 2012. Ou seja, das oficinas de butô nas quais fui aluno e co-criador. De novo, minha teoria e etnologia são restritas)

\{'Butô é estudado aqui, como um modo de perceber e mapear estados de ser vivo.' (GREINER, 1998, p. 3) À segunda parte da formulação da autora, de se tratar de uma elaboração da consciência, não consigo aderir inteiramente. Quase vinte anos depois, Greiner analisa feixes paralelos de ativismos do corpo e da dança, e ali se evidenciam outros fluxos: nem sempre é relevante associar-se a essa palavra, e não apenas por um problema dito genericamente como cultural ${ }^{105}$. Trata-se, de um lado,

105 Não quero cometer a branquitude de espezinhar uma 'função cultural'. Refiro-me à função intrinsecamente cultural de resistência aos avanços destituidores do Estado Neoliberal.

Culturas para quem? É preciso indagar isto a ponto da palavra 'cultura' e o movimento de pensar 'processo de herança de estratégias da permanência da vida' quase se equivalerem. Uma cultura, no sentido daquilo que tem corpo e pertence à terra e à concretude da vida, é inseparável de uma economia. Ou seja, inseparável de uma relação pouco transponível com os recursos, inseparável de uma perspectiva singular de trocas, e inseparável de um encantaria, uma configuração mágica que produz senso de eficácia e moderação (através talvez do alter-parentesco?). Os termos são desconhecidos, se recriam em cada caso, mas arrisco dizer, ainda assim, que estão intrinsecamente tecidos, costurados. 0 problema do capitalismo predatório e do positivismo que 0 justifica é em parte 0 mascaramento da ficcionalidade e das questões de fé que movem sua própria operacionalidade; 0 problema é aquele do seu próprio apagamento de agentes. Então o problema é cultural na medida daquilo que não está lá, daquilo que é naturalizado como apagamento. Mais uma vez, conversas informais com a ativista Thais di Marco me auxiliam nessa reflexão, bem como a noção de 'feitiçaria capitalista' de Isabelle Stengers (2007).

É constrangedor ter de pontuar isto, mas a vida singular é uma coletividade - ao menos deveria ser. É constrangedor ter de pontuar, ainda, que o humano-específico não está isolado neste pensamento: falamos de uma configuração multi-específica e alter-orgânica. Utilizo 'alter-orgânico' ainda agora, pois me pareceu que se trata de reconhecer tantas nuances entre orgânico e inorgânico, que a separação se volta contra si mesma e passamos então a praticar teorias radicalmente locais que podem deformar, com justiça, quadros acadêmicos constituídos. Poderíamos utilizar a discriminação realizada por Gilbert Simondon quando ele diz que individuação orgânica é aquela dotada de interioridade. Mas o procedimento retorna, e passamos então a indagar o que seja a interioridade. 0 próprio Simondon nos dá pistas dessa investigação, quando dá a entender, em topologie et ontogenèse que, por não haver representações euclidianas disponíveis do espaço da membrana (forma de ressonância que configura internalidade), isso não quer dizer que essa topologia não exista. 0 texto mencionado é o quinto item do primeiro capítulo da segunda parte de sua tese. 0 empenho todo da ontogênese simondoniana, aliás, é um trabalho anti-representacional que nos ajuda imensamente. Creio também que o butô tematiza de forma radical e singular a relação orgânico-inorgânico, tornandoa ambígua e problemática.

Quando olhamos para a palavra 'cultura' como generalidade, caímos naquele campo purificado que é criticado por Bruno Latour, desencarnado e geral. Como perspectiva de reconhecimento e reparação, o termo 'cultura' significa um tecido de inumeráveis matrizes étnicas destituídas pelas 'modalidades colonizatórias' (palavras de di Marco), que recusam operações conclusivas e totalizantes, que aliás significam a própria recusa. Enquanto escrevo estas linhas, o governo federal recém-eleito pratica uma sumária devastação no reconhecimento do campo cultural. A cultura, se considerada como estratégia anticapitalista, ou ainda, se considerada em terrenos erodidos de momentânea e estratégica simbiose com o mercado, testemunhará, penso eu, uma necessária mutação nos termos usuais. Seremos tão assombrados pela produção de sincretismos e formas nascentes e experimentais de 
de um problema de contato e, de outro, de um problema epocal: 'alguns artistas que participaram da gênese do movimento no Japão argumentam que, nestas circunstâncias [neoliberais], não é mais possível fazer butō. Um deles é Tanaka Min, que considera butō incompatível com o neoliberalismo.' Continua a autora, num diagnóstico preciso:

Não seria possível, a seu ver [de Tanaka Min], falar em butô quando não se tem a possibilidade de radicalizar os movimentos, da forma como fez Hijikata. / Por outro lado, alimentar os gestos que corroem os grandes sistemas e as grandes verdades, talvez seja o desafio que está por vir. Para tanto, será preciso encontrar um caminho que não seja subserviente às práticas discursivas que simulam o enfrentamento das patologias ocidentais, mas acabam se afogando na armadilha das metáforas esotéricas da dança holística e transcendental, dos mestres gurus, das expressões viscerais e assim por diante. / 0 principal espectro que nos assombra talvez seja, afinal, o colonialismo - um dos nossos vestígios cognitivos mais profundos e difíceis de desestabilizar. (GREINER, 2017, ps. 120-121)\}

[e, como está posto no título do livro da pensadora e ativista anarcofeminista Maria Galindo, no se puede descolonizar sin despatriarcalizar (2013). Eu gosto desta passagem supracitada de Greiner, talvez uma das mais recentes linhas que ela publicou sobre 0 assunto. Trazem vislumbre dos direcionamentos e responsabilidades que tomariam uma pesquisa teórico-prática, quando relacionada ao butô. Peretta (2015) parece confirmar isso.]

89.

(o alerta para as fórmulas prontas é válido para cada um de nós. Quando eu digo 'nós', aqui, são aqueles que se empenham em pensar o corpo.

contato em guerrilha, que não é de maneira alguma mais possível nomear 'cultura' neste singular universal. 
Acho que há duas pistas aqui. 1 - aquela de associar-se à palavra como um modo de 'encontrar um lugar' ('operativo'?), quando o que está em jogo é a fresta que é o corpo ou a fresta que o corpo traz que poderia desestabilizar as dobraduras do poder. É um movimento alhures ao discurso, um movimento do mundo vivido na opacidade e no Agroval barriano do corpo, um mundo de corpos, entre corpos. Morreremos, morremos, ou a nossa estúpida imagem antropocêntrica da consciência morrerá, morre; os corpos continuam na sua metamorfose. Faço referência a uma estratégia de criação radicalmente local e que não pode, não poderia ter pretensões acadêmicas, universais, ou mesmo utilitárias. Aqui, butô torna-se um ideograma distante, ainda que presente, pois é apenas um lembrete de que o corpo não está acabado e, como diria Artaud no 'homem-árvore', 'nem sequer começou'. É nesta filiação distante que quero me situar com relação ao Butô. 2 - a pista que tenho também é a que remete a um local alheio à imagem representacional de visceralidade no butô: quem oferece esta pista é Uno ao falar de Hijikata quando diz que a investigação deste é caracterizada pela sobriedade, e não pela afronta direta, explícita. São dois alertas, duas pistas, dois lembretes, dois talismãs vivos que gostaria de portar)

90.

(já pensei em possíveis pontos de contato entre butô e corpossom, e acho que posso considera-los paralelos, ainda que seja um paralelismo aberrante, como seria de se esperar.

Paralelos na medida em que dialogam com zonas existenciais ou com modos de desestabilização. Na medida em que se trata de um corpo que jamais se constitui. Na medida em que se é difícil definir o campo preciso de ação aprioristicamente, quando se lida com uma ontogênese do próprio objeto de interesse e do próprio interesse. Na medida em que se tenta pensar um campo receptivo-ativo através da des-constituição. Na medida em que se lida com uma gramática vital e extremamente hetegorênea, dado que o 'objeto' em questão não é propriamente um objeto: é a vida do corpo, a voz do corpo, o corpo enquanto som como partida e 
o som enquanto corpo durante sua mutação. Na medida de ser não apenas um corpo que se desconstitui, mas o próprio corpo da desconstituição)

91.

(lembro-me de que algumas palavras com que trabalho, exemplificadas em 'opacidade da carne' ou no caso de haver corpo como 'secreção', são termos coletados do vocabulário hijikatiano. Elas chegaram a mim com a necessária mediação de tradutores, já que não sei japonês. Pontuo, neste contexto, que a visão hijikatiana a que dou maior espaço é aquela em simbiose filosófica com Uno)

92.

(a mutação da radiação, proveniente das bombas atômicas, teria despertado 0 GODZLA. Este é uma fábula contemporânea que aderiu distraidamente ao Butô. Penso muito sobre monstros como o sujeito do espaço que se ativa pela performance)

93.

(o seguinte fragmento é composto em associação de leituras, falas públicas a que assisti, conversas e outras relações, mais ou menos alegres e criativas, ao longo dos anos)

(os clichês do butô foram utilizados de maneira massacrante. Contudo, esta palavra, o Butô, pode ser considerada, no meu ver, enquanto problema de legado no Brasil, aquilo que se aproximaria com a palavra TABU. Enquanto não se fala nela, todos os supostos continuadores de um legado sensível de práticas, porém sectarizados em seus microlatifúndios, ficam bem. Na medida em que nos aproximamos dessa palavra em nossas disposições públicas, 0 ar fica denso, mágoas e não-ditos, nuncamais-serão-ditos, emergem, e se inicia uma burocrática fala sem lugar, daquilo se deveria ou não caber. Ou seja: nosso intento é o nada. Isto ainda não é o pior: mais 
grave é quando, movidos por ganância e desejo de hegemonia, elegemos cuidadosamente os 'sucessores', destituindo o restante das experiências artísticas pela difamação, pela omissão, pelo ostracismo. Como eu disse, a problemática de uma ressonância butoística me parece ser o problema do contato e da época. $A$ palavra 'cultura', por diversas razões, me soa perturbadora, quando em ruído com 0 mercado: é tanto acerca da questão do Butô ter emergido num contexto de contracultura $^{106}$, quanto, principalmente, do fato de alguém se sentir não exatamente responsável, mas 'dono' de uma herança. Ou seja: a palavra 'cultura' passa a ser não o germe da resistência e a fibra da vida, mas apenas algo oportuno. Atitude sintomática de uma relação com aquilo que não é espontâneo. Mas nada disso nos deveria impedir de tentar pensar a partir de uma experiência, ainda que diagonal.

A disputa entre rivais, ao contrário do que se poderia imaginar, não é declarada, é sutil e estratégica. Mais importante do que andar é não deixar o outro andar. Assim, ninguém anda. Sintomático de um país onde a profissão do artista é desprestigiada, deslegitimada, precarizada. E nenhuma surpresa, num país continuador do colonialismo, entreguista, onde quem é privilegiado é algoz invisível,

${ }^{106}$ Lembro-me de ouvir mais de uma vez uma narrativa sobre uma dançarina brasileira que teria ido ao Japão estudar butô, e que alguém, lá no Japão, Ihe teria perguntado sobre as razões de sua viagem. Em um primeiro momento, a resposta dada foi que ela teria vindo para 'estudar a cultura japonesa'. Diante a insistência do interlocutor, ela respondeu que veio estudar butô. Ao que o inquiridor respondeu: 'isso não é cultura japonesa, é contracultura japonesa!'

De todo modo, os contornos entre cultura e contracultura dependem das nossas intenções e das estratégias adotadas. Se contracultura for uma palavra para reunir os modos de se combater imagens por demais cristalizadas do próprio corpo, possivelmente os praticantes de tais modos praticarão não apenas contracultura, mas também cultura, e os legisladores da ordem dominante sequer chamarão isso de contracultura. Aqueles nos criminalizarão.

Ainda outra vez, refiro-me à problemática cultural do butô ao ver essa hipótese de problema rebatida nas etnografias e nas documentações das ações, posto que o próprio discurso lançado sobre a obra é uma ação em paralelo. Tendo a pesar mais estas ações polifônicas em paralelo e as etnografias experimentais do que as produções academicamente dirigidas strictu sensu. A problemática cultural salta ao verificarmos o caráter híbrido e estrangeiro desse grupo quase inqualificável de práticas. Situação toda estranha, onde nos vemos empurrados para a crítica já pronta aos clichês e 'decalques', ou, situação que prefiro, enfrentamos a travessia que já está acontescente, mas que nos restaria reconhecer, tomar por operador: travessia por paralelos imprevistos e estapafúrdios. Vislumbro que uma abordagem tateante, titubeante, transdutiva dessa natureza possa ser pensada no caso do butô ou ainda a partir dele, forçando-nos a enxergar culturas em regime de precariedade e anomalia, emergência. Culturas-contra-culturas. Regime de origens imprevistas, de período de alguma e provisória permanência (meta-estabilidade em regime tenso), rumo ao transbordamento do processo, ocaso, disseminação/ dissolução. Modalidades de resistência que se montam e desmontam sem previsão. Pois se olharmos atentamente para gestos de dissolução, poderemos verificar outra coisa, uma disseminação, uma espécie rara de polinização. Poderia eu me apropriar vilmente do título do livro de Greiner (1998) com 'pensamento em evolução' e transpô-lo para 'pensamento em contaminação e mutação'? 
de uma ideologia invisível. 'Sem partido'. Onde o pensamento absoluto da posse e da propriedade, vestido de virtude e de preservação, substitui uma atitude de criação necessária e vital pela qual se respeita e honra o caminho daquilo que foi herdado.

A linguagem da elite econômica brasileira se prolonga na de um imaginário específico de ascensão social, posto que é sua dobradura. Essa linguagem, que assombra e convoca o desamor de nós artistas, principalmente os artistas que somos brancos e/ ou pensamos como brancos, é reação à consciência tecida do comummúltiplo e da alegria. Ela é, como seria de se esperar, a linguagem da lei invertida. A gramática miserável de 'o outro não deveria', enquanto vou podendo tudo, 'quase' sem saber. Ou seja: a linguagem da destituição, da aniquilação. 0 custo dessa posição é alto, resta saber se quem a exerce está disposto a pagar. De qualquer maneira, felizmente ainda há pesquisadores sérios que nos honram e alegram quando 0 assunto é Butô. Por fim, infinitamente melhor é fazer algo involuntário que não tenha recebido um nome, do que adotar um nome e mentir, fazer outra coisa.

Em paralelo, acho que combater o patriarcado é combater essa rede de influências e favores, majoritariamente masculina. Despotencializar e desnaturalizar as redes do privilégio, daquelas trocas de favores... há uma disseminação de mundos: atados a privilégios, não conseguimos escutar seus rumores) 
94.

(poema para o olho do pé da terra.

para Christine Greiner

Poema para o olho / 0 olho do pé / o pé da terra / da terra que caminha sobre mim. / O que há para dizer? / - não sou importante. Mas de que outro modo eu poderia caminhar em paz? De que outro modo a terra poderia caminhar sobre mim? / quem caminha sobre mim escreve sobre mim, ainda que não queira. / Meu corpo se aperta, meu corpo está em pedaços, e assim escrevo. 0 céu pesa e a terra parece um punhado de estrelas. Veja, não nos falta violência / nos falta força / para saber o que é violência e o que é força / para saber que não nos falta violência / para reconhecer a vida das palavras / para reconhecer a sua dança em palavras / Alguém viu o que se passou? / - alguém via que você dançava quando escrevia?) 


\section{[VÍSCERA COMO EM ERGÊNCIA \\ E NÃO-LOCALIZAÇÃO DA FONTE; \\ EU CAMINHO PELA VÍSCERA]}

95.

'O presidente Schreber tem os raios do céu no cu. Ânus solar. E estejam certos de que isso funciona. O presidente Schreber sente algo, produz algo, e é capaz de fazer a teoria disso. Algo se produz: efeitos de máquina e não metáforas.' (DELEUZE; GUATTARI, 1972-73, p. 11) Mais uma vez, é necessário fazer uma leitura singular, que é a proposição de que esse passeio tece uma espécie de teoria local e um lugar de trabalho ou diagrama de pensamento. E isso se dá por geração autônoma e emergente, ou seja, apenas necessária ao vitalismo e não localizável em uma origem única. Essas são duas importantes características da víscera: emergência e nãolocalização do impulso único.

As noções de necessidade e multiplicidade não-localizável, condições que são da ontogênese do pensamento vivo, engendram um rigor incomum muito diferente da mera coerência da teoria teórica.

\section{6.}

O rigor da ontogênese, eu ouso aproximá-la da crueldade artaudiana, articulada com a sobriedade hijikatiana. Aqui, Artaud e Hijikata, são não apenas artistas de um surrealismo da borda, mas autênticos filósofos-etnógrafos de um corpo em seu estatuto desconhecido ${ }^{107}$. Uma questão: como reconhecer, em termos práticos e produtivos, ou ainda, como manter em vista, na imanência, ou seja, a cada vez ${ }^{108}$, um corpo-caminhada?

\footnotetext{
${ }^{107} \mathrm{Na}$ apresentação da edição de a gênese de um corpo desconhecido, Uno Kuniichi dá a genealogia do termo a partir de uma passagem do livro A imagem-tempo de Gilles Deleuze. A passagem citada evoca uma família de imagens muito belas: 'noite experimental', 'sementes dançantes', 'obscuridade fundamental', 'o impensado do pensamento', 'nascimento do visível que ainda se esconde à visão'. ${ }^{108}$ Para a noção do 'a cada vez', contraposto ao jargão 'de uma vez por todas', verificar o livro de llya Prigogine e Isabelle Stengers, a nova aliança: metamorfose da ciência (1984). [La nouvelle aliance: metamorfose de la Science (1978)].
} 
97.

A constelação Hijikata-M in-Uno-Artaud não é óbvia; se compreendi bem, Artaud não é uma influência nem de longe decisiva na germe da proposição do ankoku butô. É mais uma conexão tardia que ocorre quando Tanaka Min apresenta os dois amigos entre si. Uno narra essa aproximação com Hijikata (UNO, 2017). Greiner (2015) diz que em 1980 Uno presenteia seu correspondente Tatsumi com uma fita onde está a voz de Artaud em sua transmissão radiofônica pour finir avec le jugement de dieu (1947-48). Uno havia sido orientado por Gilles Deleuze na tese Artaud et l'espace des forces (1980 também). Assim monta-se a rede.

98.

Caminhada. Perambulação. Errância. Passeio. Círculos descentrados e saltos-jatos desterritorializantes. Assim é com o desenho, assim é com a cena, assim é com 0 pensamento. Por quê eu o faria diferentemente na escrita?

0 que significa caminhar pela víscera?

É preciso corpo para suportar o pensamento. 0 pensar necessita segredar e secretar corporificações.

99.

Como a personagem-butô, a figura-butô caminha? Podemos ver por onde passou a monstruosidade?

Butô, expressão artística e modo singular de pensamento do corpo e ação, que emerge no final dos 1950 s e em simbiose com a contracultura dos meados dos anos 50 e 60, em terreno japonês. Hijikata Tatsumi é habitualmente apontado como criador. No entanto, há uma pequena constelação de inevitáveis artistas voluntários e involuntários, todos singulares, habitantes deste ambiente de gênese, de germinação. No campo dos performers solistas e também pedagogos da dança, há Ōno Kazuo e Ōno Yoshito, como importantes personagens, bem como Tanaka Min. Nesse âmbito, 
acresce-se Carlotta Ikeda e Yoko Ashikawa como nomes muito importantes nas etnografias dessa expressão e desse modo de pensar, quando falamos de seu ambiente germinal. Há muitas outras e outros nesse cenário. Coletivos, ações, percursos, parcerias, correspondências...

O butô fica famoso como expressão em dança e ações ao ar livre, ou mesmo performance de rua mas, se entendi bem, se desloca rapidamente para outros territórios. Exemplos de artistas não-japoneses atuantes em domínios alheios à dança ou à performance são Donald Richie, no cinema, e Nourit Masson-Sékiné, na fotografia. Digo 'se compreendi bem' (aforisma 97) pois intuo, ainda, que a tipologiatopologia de imagens de corpo disparadas pelo butô só possa surgir em um ambiente híbrido, crítico e limiar, de partida.

100.

A disseminação da dança-performance Butô fora do Japão data do final dos anos 70 e os anos 80, em grande medida pelo empenho de Ōno Kazuo, Ōno Yoshito, seus coletivos e suas ações ${ }^{109}$. Considera-se 0 ano de 1980 um marco, por conta da apresentação da performance a mesa, com os 'Ōnos', no festival de Nancy (GREINER, 2017), festival que também, naquela edição (14aํ), contou com dois trabalhos do grupo Sankai-Juku. Abel (2017) nos alerta que

\section{[...] Entretanto, a primeira apresentação de butô realizada no Ocidente [foi] "O Último Éden" [Le Dernier Éden], dirigido por Ko Murobushi e executado por Carlotta Ikeda, apresentado na França em 1978. Yoko Ashikawa também apresentou-se em Paris no Festival d'Automne [possivelmente no mesmo ano]. / Para Nourit Masson-Sékiné ${ }^{110}$ não é}

\footnotetext{
109 Ōno Kazuo, Ohno Kazuo... Butô, Butoh.... não vou seguir nenhuma regra unificada para a transliteração do nome japonês. Vou seguir a escolha da obra que consultar, endereçando àquela referência, daquele modo, no campo circundante onde escreverei daquela maneira. Quando estou livre da referência posso expressar minha inclinação pelo nome 'butô', no caso desta palavra.

110 Conheci Nourit em uma passagem dela por São Paulo em agosto de 2006, por conta da ação expedição butoh, promovida pela Fundação Japão de São Paulo (Japan Foundation). Marcou minha memória uma narrativa que ela fez ao público, em conferência, narrativa oriunda de seu longo contato com Ōno Kazuo. Era sobre um gesto recorrente, de Ōno referir-se à fotografia dela constantemente como 'o seu butô'. Então posso supor que há uma 'escrita-butô', 'pinturas-butô', 'falas-butô' etc. Foi em parte por esta narrativa (e claro, por coisas outras) que escrevi o poema que é aforisma 94 desta tese.
} 
possível estabelecer de modo preciso a chegada do butô à França, à Europa ou ao Ocidente, pois desde 1973 muitos artistas, críticos e intelectuais da arte já transitavam pela França comentando sobre essa nova manifestação nipônica e apresentando performances que direta ou indiretamente já traziam elementos relacionados. Considerando que Takao Kusuno, precursor do butô no Brasil, já residia em São Paulo em 1977 e iniciou seus primeiros trabalhos com elementos desta linguagem a partir de 1978, é possível cogitar que de fato outras vias de contato com o butô podem ter surgido na Europa antes das apresentações de 1978. (op. cit., ps. 37-38)

Cabe pontuar que Kusuno Takao ${ }^{111}$ não considerava seu grupo como um grupo de butô, ainda que houvessem circuitos pessoais e elementos próximo ao butô (GREINER, 2017, p. 120). Cabe pontuar também que o contexto histórico de emergência do butô é aquele em que o campo das artes da cena é bombardeado por experiências performáticas em grande parte oriundas das artes plásticas e não propriamente do teatro ou mesmo da dança. Takao Kusuno era, ele mesmo, artista plástico, além de artista cênico e iluminador cênico (me contento a reproduzir esta sentença, como um clichê, contida em vários lugares). Abel nos ajuda a entender a intensidade do diálogo de Takao com a notoriedade e o impacto do butô. Contudo, não penso que se trate de uma assunção de 'ser-butô'. Greiner nos dá informações bastantes para inferir que se tratava de um trabalho criado com ênfase na plasticidade e na experiência da estranheza, com vias naturalmente de se tornar algo que talvez não tenha sido a tempo. Um trabalho em movimento paralelo ao butô, e não uma tentativa de se ajustar a um modelo, ainda que o estranho paralelismo implique, às vezes, numa citação direta. Um limite é tensionado entre citação e pertencimento. Ainda que a ação de ser citar, transposta aos butôs que nos chegaram, a como eles nos chegaram, e ao contexto de São Paulo do final dos oitenta e nos noventa, seja

${ }^{111}$ As ressonâncias dessa arte no Brasil, e em qualquer lugar, são imponderáveis em sua magnitude. Para ficar apenas nas figuras referenciais, digo que além de Kusuno e os coletivos com os quais trabalhou, as ressonâncias do Butô no Brasil também contam com personagens tais como a performer, pedagoga e coreógrafa Maura Baiocchi, a performer Marta Soares, a crítica-ensaísta, pesquisadora e professora Christine Greiner, ou mesmo a importante atuação pedagógica do propositor do butoh-ma, Endo Tadashi. 
complexo ${ }^{112}$. Desse modo, na passagem acima citada, quando Abel nos informa que Kusuno trabalhava com 'elementos dessa linguagem', não sei se isto é exato. No meu ver, tratava-se, no máximo, de um diálogo autêntico.

'No Japão, [Takao] havia frequentado o ambiente turbulento das performances e do movimento angura [corruptela de underground em japonês] dos 1960, atuando sobretudo como artista visual e colaborando com alguns grupos na realização de cenários.' (GREINER, op. cit., ps, 118-119)

A performer Carlotta Ikeda é personagem que reaparece na citação de Greiner:

Entre os seus amigos [de Takao] estavam muitos dançarinos de butô, como Carlotta Ikeda (1941-2014), que foi uma das artistas responsáveis pela difusão do butô na França, firmando residência em Bordeaux, e outros integrantes da companhia Dai Rakuda Kan, dirigida por Maro Akaji. (Idem, ibidem, p. 119)

Uma etnografia das 'matriarcas' do Butô ainda resta a ser feita, com fins inclusive antipatriarcais e, portanto, anticoloniais.

101.

\section{Caminhar é rastro de algo.}

Na prática do butô, existe um campo laboratorial à parte: a caminhada. ${ }^{113} \mathrm{Sim}$, existe um trabalho de caminhadas próprio ao butô. Não são apenas os 'pequenos

112 O programa que tenho em mãos, do SESC, que encontrei revirando sebos virtuais, é da última vinda de Ōno Kazuo a São Paulo em 1997. Mostra inclusive um pouco do tom quase religioso com que 0 artista era visto. As curadorias, portanto, parecem não ter querido evitar o caminho da estigmatização quase messiânica de Ohno.

${ }^{113}$ Não me refiro aqui apenas aos típicos exercícios de dança em quase qualquer espécie, as 'diagonais' ou 'corredores', onde se vê um diálogo entre dança, processos educacionais de padronização, e práticas militares ou artes marciais.

Um caso arrebatador e singular de caminhada é a poética da caminhada nas danças do oeste africano: tive algum contato com esse universo nas aulas de corpo afrodiaspórico de Luciane Ramos Silva, que difunde uma abordagem chamada por L'Ecole des Sables (Escola de Areia), concebida por Germaine Acogny (1944-). Aqui se pratica um corpo fabular: se dão nomes que relacionam partes do corpo a fragmentos do mundo, e então se estabelecem ressonâncias e aprendizagens dentro do corpo como mapa sempre refeito por forças. Dançar é habitar. 
passos deslizantes' (suri achi) do teatro Nô (teatro clássico, sistematizado no Século XIV), transpostos para uma heterogeneidade de práticas.

Existem proposições originais de caminhadas, como seria de se esperar, bem como variações, dentro do próprio butô. 0 operador mais evidente para mim de diferenciação é aquele que constitui a gama de diferentes ênfases de esforço ou engajamento. ${ }^{114}$ As nuances também compreendem diferentes procedimentos de condução da narrativa de imagens. Variantes na atitude de correção postural, variantes na abordagem formal da caminhada, livre, circular, em corredor... Essas caminhadas são programadas como poesia e narrativa sintéticas promovendo um campo de experimentação majoritariamente não-verbal. Ou, se verbal ou vocal, é atividade mínima, compacta, tendente a aparecer em formas sintéticas consequentes ou ressonantes com segmentos da própria mentalidade japonesa. No contexto da contracultura japonesa dos anos pós-guerra, a tradição nomadiza e se põe relida, transfigurada, como modo de ressignificação, por ondas de uma espécie de 'surrealismo de borda'115, que influenciou fortemente os propositores germinais do butô.

No caso daquilo que chamo por butô, falo de caminhada como exercício de improvisação com um programa de imagens. No contexto do butô, é em geral lenta e, muitas vezes, também com corredores: cada improvisador tem o seu corredor.

114 Um exemplo é de caminhadas em que mais esforço ou mais tensão eram exigidos. Componentes estes que na residência que fiz em fevereiro de 2007 na Taanteatro Companhia de Maura Baiocchi eram usualmente endereçados a uma influência de Tanaka Min. Essa influência ou mesmo procedência estava amalgamada com as marcas pessoais da condução de Maura, de Wolfgang (parceiro de Maura) e Silvestre (performer que conduziu parte das práticas e também algumas caminhadas). Um outro exemplo, até certo ponto, contrastante, são as caminhadas que fiz nos laboratórios com Ana Yokoyama, em 2006 e 2012, com uma direção muito pontual do esforço, mais imaginativo do que físico, ainda que isso comprometesse o esforço físico. Ana foi ao Japão ser aluna dos Ônos (2000-2003) alguns anos após Maura (segunda metade dos anos 80).

As demais oficinas nomeadamente de butô em que fui aluno não contavam com a caminhada em corredor ou diagonal. Senão em uma oficina de Denise Courtoké, em março de 2007, na própria Fundação Japão, na ocasião em que fomos induzidos à caminhada circular a partir da imagem de uma revoada de pássaros. Há também situações onde a aula não era nomeadamente de butô, mas simplesmente aula de dança ou de movimento onde quem conduzia tinha grande familiaridade com 0 universo em questão. Ali às vezes nos valíamos da caminhada-improvisação.

A recursividade de um trabalho experimental, ainda que se trate de butô e, aliás, justamente por se tratar de butô, é pauta de uma discussão e objeto de uma polêmica à parte. 0 problema, Abel (op. cit.) pontua, é se considerar esses recursos de outras artes intrínsecos e até oriundos do butô. Se põe claro que a compatibilidade e a coerência não se darão com qualquer coisa, e o que vemos às vezes ser posto em performance consiste, de fato, num 'encontro infeliz'. Mas o recurso artístico-pedagógico em si (ou seja, recorrer ao suri achi, ao taichi chuan etc) e o problema ético de se nomear ou não se nomear, de se deixar nomear ou não se deixar nomear por butô, são campos absolutamente distintos. 115 O surrealismo na sua ficcionalidade e fabulação experimentais do corpo, e não como escola. Poderse-iam incluir nessa categoria mais larga autores como Antonin Artaud, Jean Genet, Georges Bataille, 
102.

Neste trecho da minha caminhada-catástrofe, onde aparece uma espécie de levantamento de documentos, pessoais e também ordinários, em alguma medida, venho me justificar: recorro às práticas que vivi e às situações que as abrigaram. Mais uma vez, trata-se da refocalização das práticas. Estas linhas escritas ou estampadas não são tentativas exaustivas de reflexão. Talvez uma caminhada-escrita. Por outro lado, as leituras-etnografias que atravessam o campo me servem como práticasescrituras de si, como mapeamentos complementares. Elas me ajudam no exercício de montar-desmontar do corpo, quando percorro continuamente, não sem acidentes, 0 quadro de um ambiente em contaminação e mutação. Como propus na noção de máquina desconstituinte, trata-se de saber novos modos de se DESFAZER.

Neste ponto me recordo ainda das experiências coreográficas de Helena Bastos das quais participei ou as quais assisti, onde o não-saber é um germe de estar-escutarmovimento. 116

Ainda abordarei outras experiências de dança, pois é o corpo que guia, ao lembrar de si a seu modo.

103.

O olho que caminha e canta a caminhada. Caminhada é fenda e corrosão de um olho que se abre.

Vários artistas, escritores, ensaístas parecem ter descrito a experiência de assistir a uma caminhada ou a um espetáculo de butô. O filósofo Kuniichi Uno me vem oferecer um modelo notável, senão definitivo, de escrita nesse domínio, pois no meu

Henri Michaux, Hans Bellmer etc. Nota-se de pronto que o intercâmbio cultural entre França e Japão tem um papel importante na formulação de algumas imagens e componentes do ambiente de trabalho do Butô. Melhor seria dizer ainda de outra maneira: ao invés de 'intercâmbio cultural', direi 'ondas de contra-cultura e surrealismo de borda', pois a coisa vai muito além da entidade 'cultura' como instância que o Estado capitalista quer tutelar para governar os viventes. Quando eu digo da ressonância FrançaJapão, não desejo excluir outras composições neste contexto.

${ }^{116}$ Fui aluno de Helena nos anos de 2005, 2006 e 2007, como aluno-o uvinte, e participei dos primórdios das atividades do LADCOR (LAboratório de Dramaturgia do CORpo). Foi ela a primeira pessoa que me acolheu eu um curso como ouvinte dentro no departamento de artes cênicas (CAC). Outros professores me acolheram no mesmo período, de um modo mais informal. 
ver ele considera o Butô uma espécie de filosofia e etnografia experimental vitalista e prática (esta última definição é por minha conta). No impactante ensaio um pequeno nada entre os limites, bem como no ensaio corpo-gênese ou tempo-catástrofe (só que neste, em outra dimensão), ele descreve sua própria dança ao assistir uma performance.

O olhar de Uno capta afetos e imagens como gênese de corpo conjunto, ainda que sejam próprios o corpo de quem dança e quem olha. A experiência de espectador de uma performance de Min Tanaka117 (ou Tanaka Min, dito ao modo japonês) foi, para Uno, não 'qualquer' dança, ou apenas uma metáfora para a dança. 'Ele também traça limites desconhecidos e não cessa de transpô-los. [...] Nós vemos aí limites múltiplos entre o perceptível e o imperceptível. Nós descobrimos, no interior de nosso corpo, o dançarino que trabalha nosso corpo.' (UNO, 2012, p.63) No entanto, 'M in não concordaria com nada disso que digo.' (idem, ibidem) E acho que nenhum dos dois concordaria comigo. No ensaio corpo-gênese, Uno aborda essa experiência pelo ângulo da temporalidade ${ }^{118}$.

UNO é o bailarino que vê.

Pistas para uma dança: aquele que vê.

117 Sugiro três experiência para prospectar um corpo dançante de espectador, ainda que distanciado pela 'função-video': primeiro, Morikawa Hisako numa performance orientada por Tanaka Min na sala Tokyo (plan-B) em 1987, https://www.youtube.com/watch?v=QBCmUQSmW/s\&t=2s; depois, o próprio Min em duo com o músico Derek Bailey em 1993, https://www.youtube.com/watch?v=A5dz 1meBjY;

e, por último, a performance de Tanaka Min e Cecil Taylor, este com 84 anos, https://www.youtube.com/watch?v=Q8rqVi ROSo\&t=1733s .

${ }_{118}$ Além da tradução (por Christine Greiner) oferecida em coletânea de ensaios publicada pela editora N-1 (a gênese de um corpo desconhecido), há uma tradução anterior (por Annita Costa Malufe) de uma outra versão de corpo-gênese: aquela publicada em 2010 nos cadernos de subjetividade da PUC-SP. Há algo de interessante na produção de Uno também sob o aspecto de se fazer coincidir gestos de tradução e criação - eles publica em francês e japonês. A cada retradução, a possibilidade de modificar a textura. 
103.

No livro Hijikata Tatsumi: pensar um corpo esgotado [trad. 2018 (2017)], e não apenas ali, Uno não apenas reitera a visão segundo a qual o Butô poderia ser uma filosofia prática da carne, mas identifica a pessoa de Hijikata como um filósofo experimental do corpo. ${ }^{119}$ Contudo, Hijikata e de alguma forma o próprio butô talvez dependam, imprescindam de uma 'lógica do caderno' (falaremos do caderno na segunda parte do capítulo dois) ou de um rastro errante de escrita corporificada.

Tanto o fazer da caminhada-butô quanto o observar da caminhada de outrem é uma errância de grande sentido. A escritura de Ohno Kazuo traz uma dança-caminhada em um de seus poemas-exercícios, veja só:

Acho difícil dançar com a mente vazia. Enquanto se caminha, tome a figura de um inseto. É preciso treinar para se aproximar disso. Não é só se mover o tempo todo. Nem ficar buscando o tempo todo. É estudar junto, caminhar junto e ir, cada vez mais, criando algo de seu. Então vamos, caminhando, de lá para cá. , Podem andar do jeito que quiserem. Podem andar de lado. Só parar e andar, assim não dá, falta um pouco. (OHNO, 2016, p. 116)

Lembrei de Bernhard Wosien (1908-1986), que estudou ao longo da vida danças tradicionais principalmente do terreno dito europeu, e em seu livro ele afirmou a importância da prática da caminhada. Contudo, ele não se cansa de remeter a uma unidade superior que se deveria almejar ${ }^{120}$.

Penso sobre o discurso espiritualista na arte europeia. Sintoma de certa espiritualidade que brota espasmodicamente das feridas modernas? Pássaro canibal de certo estado cristão? Espiritualidade repositora de servidão, do colonialismo, da

\footnotetext{
${ }^{119}$ Há um episódio engraçado de uma conferência a que assisti de Uno Kuniichi, na Fundação Japão de São Paulo (Japan Foundation), em 2006, onde, ao final, um rapaz perguntou algo assim: 'o que você recomenda para quem se interessa em se aprofundar nas artes performáticas?' Ao que Uno responde: 'leia, mas não muito, e faça muitas coisas idiotas.' Eu gosto muito desta resposta, em parte por dispensar a imagem de um 'mestre'.

120 Trata-se de dança: um caminha para a totalidade (2006, trad. 2000, original em alemão de 1988). Bernhar Wosien, e depois M aria-Gabriele Wosien são autoridades muito respeitadas no universo das danças circulares sagradas.
} 
misoginia? A espiritualidade transcendente e predatório-repressora em suas práticas? Que tanto caracteriza o pensamento religioso e intelectual europeu oficial?

A própria noção de dever é aqui problemática, e ela passa a ler e interpretar os gestos antigos dos ancestres europeus. Como se pode dar o contato anárquico com esses ancestres, sem a mediação da cultura oficial? Penso muito nisso.

Não se trata da defesa do Japão como estado ou defesa de um oriente idealizado. Japão que por sua vez também empreende imperialismo.

105.

[lixo de fotografia corroído no sol - coreografia]

A região de um ateliê onde se descartam fotografias. Sequer sei se é relevante esse problema da unidade. Casulo ordinário e imprevisível. A unidade de um corpo, a esta altura, se eu pudesse figura-la, seria como uma série demorada de fotografias descartadas, de gramaturas involuntárias impressas em papéis de espessura variável. Essa massa feita em pedaços de fotograma e pigmentos mal impressos, recortados, mal amassados, sobrepostos em sua espessura irregular, faria um corpo como um emaranhado ou um casulo com muitas antenas. Não há ninguém ali. Apenas um corpo que se desfaz. Quando se tenta agarrar, ele se revolta e se desfaz, se espalha: borra as mãos. Ao longo do dia, o feixe corrosivo de luz solar faz sua caminhada na corpo, naquilo. Essa estranha criatura, posta então já sob o sol, vem lembrar que seu pigmento respinga, mal distribuído, gotejante, exposto ao cosmo. A tinta reage quimicamente ao calor. E assim, parte da estranha estrutura derrete lentamente, parte dela corrói por saltos. Vocalizações. Em dado momento, descobre-se que era 0 casulo de um besouro. 


\section{[O VENTO NOTURNO COM O VÍSCERA: ANOTAÇÕES]}

106.

Quem escreve é o corpo, e ele perambula. Quem escreve é o corpo. Não consigo evitar retornar ao Butô. Explico-me: minha entrada no mundo das artes cênicas está fortemente marcada pela estética da caminhada: o rastejar e fabricação de mundo que enxerga e toma seus fantasmas. Elementos tão presentes no Butô e no Nô, teatros em si também tão distantes.

Sentar junto e contar histórias. Perambular nisso.

Práticas que se embaralham.

Práticas vitais não se permitem purificar.

107.

Dei-me conta de que o momento em que me formei na graduação em piano (meados de 2006) foi aquele de uma intensa turbulência no corpo e intenso movimento de imagens de corpo. Dei algumas pistas acerca disso no bloco um deste capítulo. Agora, contudo, me dou conta de que este período da formatura, em conjunto com um 'antes', talvez desde 2005, e um 'depois', talvez até 2007, configuraram um bloco temporal onde o corpo se moveu na direção do desconhecido.

\section{8.}

Então. Pela minha insistência em participar de sucessivos projetos teatrais dentro da universidade, vejo que partir de 2008 uma certa forma de existir, afirmada genericamente como 'teatro', tomava, enfim, parte grande da minha vida. Isto também foi indelével. 0 ingresso no mestrado em artes cênicas, em 2009, atesta essa força, bem como meus primeiros trabalhos remunerados como ator (como sonoplasta isso já acontecia antes de 2008). Reconheço nessas afirmativas que lanço o fato de que eu tentava aderir a um regime de práticas e relações de uma categoria profissional. Não só isso, mas almejava ser tocado novamente, ou seja, tocar uma visão de mundo 
pela coletividade, afetividade, criatividade e resistência, tudo junto. Visão que, na prática e na profissão, traz suas ambiguidades mais ou menos estratégicas, mais ou menos inconscientes, mais ou menos perversas. Demorei uma década para começar a entender um pouco do que fui buscar ali, do que está aqui comigo. Talvez eu tenha sido carregado pelo próprio vento noturno, que foi o tema do meu TCC em 2006. Ali já havia uma espécie de chamado a forças desconhecidas.

109.

2005-2007. Conhecer os teatros Nô e o a expressão Butô, iniciar aulas de dança contemporânea, arriscar a participação em trabalhos de teatro... o que quero dizer é que um corpo afinizado a uma certa estética butoísta contaminou meu trabalho como instrumentista de uma maneira indelével. Acho que é por isso que gosto tanto de escutar as improvisações de Cecil Taylor, e ainda mais após conhecer sua parceria com Tanaka Min. E acho que isso confere outra leitura à temática que quis trabalhar em 2006: o vento noturno. Fiz isso meio às cegas, meio guiado por instintos. Fiz uma instalação plástica na sala, com muitos desenhos improvisados feitos ao longo do processo de estudo, abstratos em maioria. No recital, executei uma peça única, que se detinha no movimento ininterrupto do vento da noite, a sonata night wind (1911), de Nicolai Medtner (1880-1951). Na partitura, a epígrafe da sonata é um poema sem título de Fyodór Tyutchev (1803-1873), que fala deste vento.

110.

(o vento da noite traz uma imagem de corpo-devir, uma potência assombrosa diante da qual mesmo aquele que a deseja se detém por moderação - é uma forma impessoal e assimétrica)

(às vezes me vejo como uma pessoa burra e estupidamente monotônica: às vezes me vejo como um 'poeta de um único poema'. Sei que isso não é verdade. Mas o fato é que já usei o poema de Tyutchev sobre o vento noturno algumas vezes. De qualquer maneira, ele é um 'poema-talismã'. Prefiro, desta vez, fazer um poema-resposta) 
111.

(poema-talismã ou partitura quase mundana

em resposta ao vento noturno.

para Helena Bastos e Silvio Ferraz

- Tocar / Revirar o vento / vento, reviravolta / pedaços de toque / som de grão ou cascas, cacos, quandos, acúmulo quase-nadas, matéria de mundo / esculpir uma difícil sensação pela escultura / tentei começar do começo mas não consegui // Toque reviravolta / uma dor é comunidade de coisas, fervura fria, furos caminhos, relevo de algo-menos-que-pedra. Venta muito dentro da pedra, e o vento também é pedra e bomba invertida cozida pelo fogo das plantas. / Deslize e ressonância são imprevistas dobraduras. Mudo de assunto: personagem furos / ficou ali. Não percebi. / rios cruzam corpo feito de rio / A espera pode ter rios, além daquelas bombas de vazio. // - Revira o concreto / Caminho se cava no vento da noite, que nunca vi nem ouvi / muitas infinitas gotas com casca, atmosfera pessoa levanta levantada, tudo deitado, espalhado / na tempestade perpétua / que gira em muitas direções / cria direções / corpo guardado na noite das coisas // - céu profundo é carne / há um calor escondido e demora / perpétuo fim de mundo inesperado / silêncio com canto pavoroso, desejado, rosto insuportável // - Revirar, revirar quandos / é preciso apenas perguntar / luz é quando eu não vejo? / quando o mundo fermenta sonâmbulo / é olhado por um mato e folhas / mas mira com olho artrópode / ele está acabamento de mundo / tão próximo tão próximo estranho habitante / o som é dele / toque refeito rastejante revirado / movimento perpétuo, concentrado e disperso / um grande esforço duplica o ar / fervura apocalíptica e fria desde sempre / poesia por um fio, afogada pelo ar / quando nos descobrimos submersos, não há o drama da asfixia, há coisa, há algo / quando algo se guarda de impossível / assim começo, assusto de pavor, assim que começo a escrever e assim pareceu.) 


\section{2.}

Aliás, o primeiro curso que fiz de teatro foram duas oficinas de teatro Nô, em 2005. 0 primeiro experimento cênico formalizado que fiz foi como um fantasma que caminhava (o exercício cênico Natália, Nathália), no mesmo ano. Repetimos o experimento no ano seguinte. Desde 2005 também comecei a buscar oficinas de dança-butô.

Eu minto. Já havia participado de dois experimentos cênicos, nesse mesmo ano: um deles como membro de um côro, e no outro como contra regra, numa difićlima peça para se ter essa função (frio $36^{\circ} \mathrm{C}$ ). Essa peça era repleta de trocas de figurino e mudanças de cenário; onde o elenco precisava de muito suporte para as trocas e acionamento das traquitanas (apetrechos específicos de maquinaria cênica). Em todas essas atividades, não obstante, pesava a influência da caminhada.

No outro caso, como coro ou um corpo coletivo, era a necessidade de se ajustar o passo a um tempo construído coletivamente. Ou a abordagem qualitativa do sercoro de dentro: no processo de configuração de uma imagem ou gesto congelado em mutação, o coro dispara fluxos de fotos que se associam no conjunto da composição cênica. 0 corpo apreende e sabe ler essa compositividade como ressonância - nossa tarefa aí é aprender a ler o corpo próprio.

Como contrarregra: a concretude absoluta, a discrição e precisão de todas as coordenadas de movimentações. Como coro: ao aprendizado da leitura e o acompanhamento dos instintos-ressonâncias compositivas.

Como eu já disse, já fazia aulas de dança contemporânea com Helena Bastos em 2005. Seu trabalho sempre foi, para mim, muito marcado pelos deslocamentos qualitativos e contaminações.

Em suma, meu 'primeiro ano' como performer (2005-2006) e não exclusivamente como músico foi tão impactante que já realizei outras peças em que eu performava um personagem-contrarregra, personagens-caminhantes, ou ainda 0 próprio personagem-músico... e claro: os fantasmas eles mesmos. Creio que a caminhada faz parte do meu idioma estético. 


\section{[CAM INHADAS]}

113.

Uma coisa é certa, o vivente se move.

Do vivente (como forma orgânica), contudo, não sabemos muito: alguns poetas-filósofos práticos nos falam da falácia da distinção orgânico-inorgânico. Kazuo Ohno chamou a atenção para a subjetividade da pedra. Em entrevista e em escrito. Não podemos provar a falácia da distinção entre orgânico e inorgânico, pois tratam-se de outros modos, outras escalas de existência irredutíveis ao humano-espécie dentro de uma historicidade dominante. Veja só se este poema-treino de Ohno não parece ser feito para um corpossom:

Escuto um som que vem das entranhas. Uma música, como uma sinfonia, está sendo executada dentro das entranhas. As entranhas tocam. Até as pedras, até as pedras podem tocar uma sinfonia. As pedras também têm entranhas, sabiam? E arrastando as vísceras, arrancando-as, elas tocam. Sinfonia visceral. Parece que não foi você que tocou. São as pedras, você deve estar escutando. Inclusive agora, ouça. Parecem ecos de uma vasta abóbada, ou, preso num local fechado sem nenhuma mobilidade, mesmo assim o som é lindo. Este seu movimento, a alma 0 apreendeu, é emoção pura. É isso, 0 espírito 0 apreendeu. A emoção do passado tem brilhos como o futuro. É a dança das entranhas. / Não é a sua dança. (OHNO, op. cit., p.114)

Podemos, entretanto, nos assombrar ao dar-nos conta de que esses modos de existência nos prestam vários favores (principalmente os 'indevidos'). Podemos nos dar conta de que estamos em perpétua simbiose, parentesco, combate (e alienados, não apenas inconscientes) com diversas sociedades invisíveis, 'inorgânicas', cujo encantamento e conselho escapa. 


\section{4.}

Outra coisa se pode considerar: no mundo tem diferença.

Poderia eu supor mundos intuitivamente não como como modelo planetário, mas como ação de diferenciação, associação-composição e devir, uma mundificação?

E ainda, poderia eu supor uma improvisação afetiva (logo, como amplitude de metamorfoses multiescalares do corpo) vocal que se valha da desindividuação das noções de voz, som e corpo?

\section{5.}

ASSIMETRIA.

Vou me mover em um espaço para vocalizar, a partir das sensações, um som que não sei. Isso vai mobilizar blocos de registros afetivos que estão no domínio do corpo. $O$ que está em jogo é o devir. E algo, as ações, se vão instalar no devir. Uma dança, uma caminhada, posições, situações, relações. Sistemas oscilatórios (para usar a expressão de Pousseur em apoteose de Rameau) mais ou menos evanescentes. Reconhecimento de objetos e de sujeitos, ou ainda criaturas mais ou menos encantadas cujo estatuto é ambíguo (quando vocalizamos em uma caverna, quem é que canta?). 0 processo de uma sessão de improvisação. Aliás, a que disciplina este ato pertence? Caminhar-improvisar. É a alguma disciplina exclusiva?

Transitar. Ativação spinozana! Infinitas partes em composição por uma relação característica. Algumas-infinitas partes em trânsito compositivo com outros modos, outros corpos, outras algumas-infinitas partes em composição-associação por uma relação característica: o corpo que transita.

o que seria mais importante, o indivíduo que se desloca, que atua, ou essa monstruosidade de infinitos, que pode, de modo improvável, deixar formar, deixar corporificar não através, mas com o corpo e da ação de quem atua? A relação característica desconhecida é o monstro-sujeito-do-improviso que se move, que precisa que você apenas esteja lá ocupando-se de mobilizar um campo receptivo-ativo. 0 sujeito do improviso é o monstro do espaço.

A relação característica do conjunto é desconhecida. Talvez perpetuamente desconhecida. Talvez emerjam pedaços de um alter-corpo nessa improvisação. 0 que é 
um alter-corpo? É quando dizemos que 'algo aconteceu' e guiou uma operação, uma individuação no improviso?

\section{6.}

Eis um enigma: o sujeito de um vitalismo do som que é desconhecido e vem, com minha participação, operar uma mutação e transformar o corpo e talvez a própria noção de corpo. Pensamento vitalista do som. Anotações vitalistas.

O regime da sala de ensaio confere um tipo de densidade para essa perambulação. A meditação, que aqui valorizo como produção de corpo, como ontogênese (que sempre é corpo, por ínfimo que seja), é um outro regime de perambulação. Só que isto será corporificante na medida de se ler o espaço como sujeito, como detrito heterogêneo, como vida alter-orgânica proliferante nos nichos.

\section{7.}

Gravei um áudio de voz no gravador de voz enquanto estava na rua. Os colchetes são comentários de agora enquanto transcrevo:

\section{[1]}

Perambular em corpossom. Caminhada-catástrofe. Começar pelas práticas, não pelo mapa teórico. Metodologia inversa. [Contrametodologia.]

\section{[2]}

[Corpossom:] som indeterminado; som heterogêneo indeterminado em individuação conjunta com corpo hetegorêneo indeterminado. Isso é que [poderia ser] é corpossom.

\section{[3]}

Para que isso continue acontecendo [essa definição prática de corpossom, 2], esse é o contraobjeto do primeiro capítulo. A ideia de víscera: indeterminação e necessidade.

\section{[4]}




\section{O fora como relação?}

Quatro sentenças. Em [1], a noção de caminhada-catástrofe como gênese improvável. Em [2], esse objeto múltiplo, de direção ambivalente, esse objeto dinâmico, oscilante, de indeterminação, que mais poderia ser chamado 'sujeito de exploração', ao ser articulado com a nomeação corpossom. Em [3], as qualificações de 'víscera' no contexto da prática de corpossom, a individuação da víscera criticando os modelos de som e corpo, mostrando o forro da costura entre ambos, com a ênfase na corporificação entre diferentes coisas. [4], esse vértice turbilhoante de indeterminação que sinaliza uma dobra-mutação do corpo, esse processo heterogêneo que é rastreado constantemente pelo corpossom, faísca de transformação dos terrenos, ressonância, repercussão. 


\section{[MARGEAR A CATÁSTROFE] \\ [BUTÔ DE UNO E \\ A FILOSOFIA ANTIEDIPIANA DE NIJINSKY]}

\section{8.}

Kuniichi Uno realiza um ensaio acerca dos diários de Nijinsky. Chama-se as palavras e Nijinsky. Aqui, ao desdobrar sua própria escrita, Uno recua da proposição de catástrofe apenas gramatical, como o caso documental de um diário 'mal-sucedido' a reboque do avanço da doença mental. Uno alega haver um núcleo, um operador mais urgente a se debater. 0 que é que pode fazer oscilar a gramática da língua na direção de um núcleo gramatical outro? Ou será mesmo a gramática aquilo em questão? Uno nos deixa captar a própria escrita de Vaslav Nijinsky e aquilo que ela mobiliza como uma aposta, uma estratégia. A experimentação de Vaslav está posta na chave da medição das condições mínimas para o pensar e para o espírito.

119.

Alguns corpos-hipóteses de catástrofe em tempo-catástrofe de Uno Kuniichi. (extraídos de outro ensaio: corpo-gênese ou tempo-catástrofe)

A) Algo se passa: invisível e excessivamente vivo, catástrofe. Um excesso de vida, e eu também sou isso (citando Clarice Lispector?). B) Necessidade de medir e ser medido pela monstruosidade: necessidade vital de tracejamento e retracejamento dos contornos, nunca uma forma. O corpo em situação instável, claudicante, catastrófica, fronteira do visível e 0 invisível. C) A singularidade: coloca tudo em questão. A dimensão catastrófica para onde as artes intensamente ligadas ao corpo são atraídas. 0 estatuto de uma linha do tempo rompida que o corpo pode portar. 'O tempo nada mais mede, não flui mais.' D) Irredutibilidade e opacidade inqualificáveis do corpo, que sabe de si e se pensa. 'O corpo é essa ruptura inqualificável' (anterioridade e opacidade de ser-corpo da catástrofe). Isso introduz E) uma tempolidade insólita, que é uma catástrofe que se arrasta. Aqui penso imediatamente em Nijinksy, pois é como se ele fosse forçado a expressar uma permanência da catástrofe. F) Ainda sobre a necessidade: 'era preciso, ao mesmo tempo, inventar a dança e redescobrir o corpo'. 
'Haviam coisas mais importantes do que a dança'. Relaciona-se ao item B, mas, um pouco diferente, pois aqui é aquele gesto que força o corpo a triturar disciplinas artísticas e a ser triturado por elas. G) 0 mistério do genital inato, a potência originária do não-nascimento que pode operar um 'segundo nascimento'. Catástrofe do perpétuo não nascimento, só a partir dele se pode continuar nascendo. H) Relações catastróficas incomunicáveis com o tempo histórico: aquém ou transbordantes. I) Corpo como não-pensamento, relaciona-se com os item C e D, mas no âmbito da necessidade do não-pensar.

Devem haver outras, mas consegui reunir estas.

\section{1.}

Geralmente os estudiosos partem de Nijinsky para chegar ao butô, mas eu estou passando pelo butô para chegar a Nijinsky. Pois aqui, no meu ver, se condensa 0 problema da escrita-caminhada-catástrofe. Um procedimento transdutivo, de múltiplos objetos individuando simultaneamente, em contato. E, como veremos, será a lenta construção de um galope de excesso de vida, ainda-não-morte.

120.

O ensaio as palavras e Nijinsky, de Uno (2012, original em japonês, 1985), é também catastrófico, contendo muitos dos itens catastróficos do corpo-gênses ou tempo catástrofe. As palavras é escrito em aforismas. Lá, se processa um olhar múltiplo a partir dos diários de Vaslav Nijinsky (escritos em 1918-1919, publicados somente em 1995, traduzidos para o português em 1998) e das passagens sobre ele no Anti-Édipo.

\section{1.}

0 trabalho com os aforismas de Uno neste ensaio. 1) Vida, morte e sentimento como os sujeitos de todo o pensamento de Vaslav. Sentimento: 'princípio da vida, bem como a diferença entre a vida e a morte', 'eu não penso, eu sinto', oscilação mínima que preenche a disposição do espírito, os sentidos. 'A escrita de Nijinski é reduzida 
estreitamente ao mínimo. Ela não é simplista, nem ingênua'. 0 eu diminui na medida em que se aproxima de um valor-limite, que é também o máximo de intensidade, e a pessoa escreve para 'vencer a velocidade louca' (2012, p. 19). A escrita é compreendida no teste e na 'contestação' feitos tanto 'à gramática como aos sentidos' (idem, p. 20). 2) M ovimento, devir, diferença. 0 desejo de movimento torna Nijinsky 0 Anticristo, irrompendo numa proliferação de identidades. 'E é esta vontade de movimento que forma a artéria da escritura de Nijinsky. 0 que ele chama de sentimento nada mais é que o movimento ou a onda que preenche, que atravessa 0 corpo humano.' Neste segundo aforisma Uno propõe Vaslav em um ritmo, uma 'onda' proliferante de uma identidade espalhada, esparramada. 'Um grande recipiente este contido num recipiente menor que, por sua vez, aprisiona em si inúmeros recipientes maiores e menores' (p. 20). A fórmula de Nijinsky por ora, não é sou isto ou sou aquilo, mas sou isto E não sou isto (por exemplo, deus). Jamais uma forma, mas uma 'gênese do movimento' que desliza na produção e permutação de identidades. 3) 0 devir como quase-não-dançar, a dança como devir-qualquer-coisa. Mas, na repetição deliberada de paradoxos, Vaslav dá giros mínimos, que Uno qualifica assim: 'é a partir daí que uma gramática, que se pode chamar de estratégia esquizofrênica, toma forma. Esta estratégia está diretamente ligada ao desejo da dança' (p. 21. 0 desejo da dança é o desejo do movimento no aforisma anterior de Uno). É um 'devir qualquer coisa' que constitui sua estratégia. A ambivalência do devir é um risco de vida e morte para Vaslav. O diário é preenchido por um processo com acelerações e proliferações, tornando-se um 'lugar em que ressoam as vozes inumeráveis que afluem de todas as direções, um lugar para uma alma dilacerada, vertiginosamente agitada, inquieta' ( $p$. 22). 4) A aposta do pensamento e do escrever constituem uma membrana, um platô. Nijinsky descreve constantemente seu ato de escrever. Ele 'experimenta a distância perpetuamente movente em relação às palavras pronunciadas' e com as inscrições do diário.

No momento mesmo no qual ele agarra seus próprios atos e palavras como uma gesticulação e se descreve enquanto escreve isso, ele parece tentar, constantemente, deslizar para fora. Como se escrever sobre a 
escritura permitisse, enfim, timidamente, construir um platô sólido de pensamento. (p. 22)

A aposta de Nijinsky não é provar a existência de algo ou ponderar sobre a moral, mas segundo Uno seria pôr-se a si mesmo como aposta nos seguintes termos: 'seria eu mesmo capaz de pensar, minha mente está ou não em bancarrota, esta é a aposta. Eu sou louco, ele diz. Eu não corro o risco de estar louco, ele completa. M esmo louco, ele escolhe o devir' (Ibidem). Está em jogo o deslize que constitui sua membrana de pensamento. Uno: 'um dia ele sobe sozinho até o cume de uma montanha e diz em francês: "Palavra!"' (Ibidem). 5. Situações de escrita, membranas de palavra. No quinto aforisma Uno só cita trechos seguidos dos diários de Vaslav, na medida em que este escreve sobre escrever. Seleciono um fragmento: 'Eu não escrevo para escrever um livro, mas para pensar' (p. 23). 6. Linha errante, ritmo pulsante, identidades ilimitadas, revirar da escrita e captura da reviravolta (captura da double bind). Linhas errantes que secretam corpo: '0 "Eu" absorve as proposições e se torna um ritmo pulsante para fora da significação' (p. 24). 0 deslizamento da escrita, ao mesmo tempo mínima e proliferante, escritura escriturada e escriturante de si mesma, configura, para Uno, em Vaslav, um 'plano único e intensivo'. 'O enunciado "eu sou Deus" desliza para o exterior da dimensão que reconhece a dicotomia entre o verdadeiro e o falso, entre a realidade e a ilusão' (p. 24). As identidades não-exclusivas, antinômicas, empurram as palavras que escapam constantemente à significação. Modelos disparados nessa proliferação, segundo Uno: eu sou $A$, eu sou $B$, eu sou $C$ etc, bem como eu sou A, eu não sou A, e também eu sou A, eu escrevo que sou A. São 'ritmos', 'diferenças ínfimas'. 'Aqui só importam a diferença e a gênese' (p. 25). 7. Operação mínima de escrita. Aqui a atitude anti-diagnóstica de Uno, que adere ao Anti-Édipo por recusar o jogo da clínica edipiana cujo 'resultado é conhecido desde o início' ( $p$. 26). 0 que Vaslav faz com a imagem de Diaghilev é des-psicizá-lo, des-fantasmago rizáIo, é colocá-lo 'no lugar vazio de deus'. Para isso, Vaslav passa a adotar deus com letra minúscula. 'Deus' passa a vagar como um nome que se conecta interminavelmente nessas outras partículas que são as palavras concretas, são imagens de sujeitos, como moléculas, pequenos pedaços combinando-se infinitamente. Deus torna-se uma espécie de força catalisadora da produção de um espaço insituável, uma margem 
constituída do empenho de controlar 'a explosão da diferença'. ' $O$ sujeito que se pergunta se é louco não pode ser classificado nem na loucura, nem na razão. Uma escrita deste tipo está numa topologia do espírito que não se pode doravante localizar' (Ibidem). Lugar 'sem densidade', em cujo estranho tecido as marcar distintivas e demarcatórias não aderem. É uma 'outra loucura'. 8) Dança: nervo desterritorializante intestino ao capitalismo. Sobre os empréstimos e as apostas, Vaslav escreve, e também Uno sobre Vaslav. As conexões que Nijinsky produz não cabem no capitalismo, é preciso fazer circular a singularidade, apenas. 'Nada equivale a nada'. 'Nijinsky rejeita o valor, a representação e a troca. Ele gostaria de destruir a Bolsa. É por isso que decide ir e participar da troca' (p. 27). Aqui, Uno mapeia a economia de Vaslav quando diz: 'para destruir a troca é preciso participar dela. 0 corpo de Nijinsky se localiza nesse paradoxo. Sua dança, no capitalismo desterritorializante que desliza por toda a parte, é, ela mesma, a conclusão de uma assombrosa desterritorialização' (Ibidem). No excesso de vida para fora do território, Uno diz 'ele salta'. Um inesperado galope de morte. 9) Tolstói, terra, troca: vida e morte como campo de proliferação no liame do sentimento. Ao prosseguir com a lógica do aforisma anterior, Uno introduz um paralelo com o diário de um louco de Liev Tolstói. ' 0 desejo de ultrapassar a troca, de destruir a troca, por sua vez, pertence à vida, mas a uma vida tão excessiva que não podemos mais conservá-la' (p. 28). 'No entanto, a vida e a morte não devem em nenhum caso ser intercambiáveis'. E aqui Uno descreve que Nijinsky já estava em um galope de vida: 'é preciso perpetuar a gênese'. 'Estratégia para não trocar jamais a vida contra a morte'. 0 sentimento Nijinskiano é então posto por Uno como o 'espectro da diferença' formante de 'zona exterior ao câmbio', tremendamente mais intrincado do que os termos do câmbio. 10) Passeio como experimentação. Aqui a oscilação entre vida e excesso de vida, entre razão e outra razão adota um laboratório expandido. 'Trata-se de avançar para além da alternativa entre ser louco e não ser louco'121'. 'No entanto, uma vez experimentada, a desterritorialização não para mais' (p. 29). Gestos, voluntários ou

\footnotetext{
${ }^{121} \mathrm{~A}$ confusão da palavra louco com a doença mental tem razões morais, policiais e médicas. O louco, no senso comum, é 'a outra razão'. Não se deve ignorar que, no caso de uma doença mental, há dimensões de intenso sofrimento psíquico e violência social sobre o portador de doença. Estou atacando apenas a dimensão moralizante da palavra 'louco', e o aspecto curioso da palavra 'louco' e 'louca' como acusatório.
} 
não, que mudam o rumo de Nijinsky pelos caminhos, que vêm de sua saída, esta sim talvez voluntária, a fim de 'confundir-se, ecoar outros sujeitos' (Ibidem). Aqui está a série de caminhadas registradas por Nijinsky, numa grande variedade de percursos e também de estratégias. E aqui também, mais uma vez, o problema da velocidade: 'em todos os seus deslocamentos, ele cinde seu si mesmo ao expô-lo ao mundo e, em uma velocidade assustadora, ele reflete sobre todas as questões possíveis' (p. 30). E aqui vou usar as palavras de Uno para falar com outras. Vaslav se arremessa no teste entre a vida e a vida excessiva, derrapando, testando as próprias palavras como gestos de aposta e consistência de uma membrana, evocando a deus, convocando forças invisíveis. Uno: 'por isso ele leva a termo uma voz estranha, como um profeta seduzido pelo deserto'. 11) Uma voz desconhecida; 'ele era um salto'. No salto, lembro do aforisma 8. Nesta vida 'musical' construída como galope de vida, morte e vida excessiva, medida em termos de sentimento como espectralidade da diferença ínfima e proliferante, a membrana de palavras se põe em relevo pelas 'ondas de multiplicidade'. Os diários de Nijinsky falam sobre a construção de um galope de vida excessiva, ainda não-morte. 0 'universal' em Uno, quando refere-se a Nijinsky, é de fato o carnal. 0 universal? Traduzo por nós de pensamentos-afeto-ativos que, do bordar-se, corporificam uma opacidade. A 'escolha', em Uno, quando refere-se a Nijinsky, é uma inscrição da vida diferenciante. É um traço a mais, formando um extenso e intenso conjunto monstruoso. 0 tracejar, a inscrição do pensamento de Vaslav compõe séries quase idênticas, muito parecidas, mas que almejam a diferença, o movimento. É construção da diferença: devir-qualquer-coisa, quase-não-dançar. Sua condensação é a construção do devir, é a espessura da própria membrana. Quando uma voz composta e desconhecida, dentre tantas, quiser furar, a membrana se romperá. É a personagem da saturação. É 'o coração de todas as vozes que pertencem a uma pessoa' (p.30). 'Essa voz é projetada de um lugar onde todas as estratégias de escrita de Nijinsky parecem desmoronar e convergir.'

Fazer da linguagem uma membrana intensa preenchida de ondas como singularidade ou multiplicidade, que não podemos designar com palavras; produzir um plano de ressonância de vibrações do mundo, fazer vibrar a "Voz de Deus", que não pertence a ninguém, que não tem identidade 
própria. Quando compreende isso, Nijinsky não era mais Nijinsky. Ele era um salto. "A alegria, e não o terror". Ou melhor, terror e alegria, de uma só vez. (UNO, 2012, p. 31)

122.

De onde veio essa voz? Seria uma assimetria, onde Vaslav foi tocado pelo préindividual Simondoniano? Em algum ponto, não seria toda filosofia ridícula?

\section{3.}

Compreendi que precisava compilar as caminhadas constantes nos diários ou cadernos de Vaslav Nijinsky para este estudo.

Primeiro passeio (op. cit., ps. 35-40). Este passeio é imenso, com muitas idas e vindas sobre os pequenos rastros de sangue, demorados alongamentos no chão coberto de neve, mandos divinos para as ações, o sentir dos objetos que comunicam 0 sentir... Chamarei este passeio por 'rastros'.

Encontro-me diante de um precipício onde eu poderia cair, mas não tenho medo de cair, por isso não cairei. Deus não quer que eu caia, pois me ajuda quando eu caio. Uma vez, fui passear, e me pareceu que havia sangue sobre a neve, então corri acompanhando os traços. Achei que haviam matado um homem, mas que ele estava vivo, então corri em outra direção, e vi um grande rastro de sangue. Tive medo, mas andei para o precipício. Compreendi que os rastros não eram sangue, mas mijo. Não conheço outra expressão, por isso escrevo essa. Eu poderia me forçar a aprender todas as expressões, mas não gosto de perder meu tempo. Quero descrever meus passeios. Quando eu estava andando na neve, vi um rastro de esquis que parava diante do rastro de sangue. Tive medo de que houvessem enterrado um homem na neve, [...] Então, Deus me fez ir até o precipício dizendo que um homem estava pendurado acima, e que era preciso salvá-lo. [...] "Pula, então acreditarei em ti". Tive medo, mas depois de um momento, senti uma força me atraindo para o precipício. Fui 
até o precipício, depois caí nele, mas os galhos de uma árvore que eu não tinha notado me seguraram. [...] Retomei o caminho. Deus me disse: "Pára!". Parei. Estava sobre o rastro de sangue. Ele me ordenou retornar sobre meus passos. Ele disse: "Pára!". Parei. Sei que todo mundo vai pensar que tudo o que escrevo é inventado, mas devo dizer que tudo o que escrevo é a pura verdade, pois eu vivi tudo isso na prática. [...]

Segundo passeio (ps. 105-106). A explosão em torno da palavra 'palavra'.

Quero descrever outro passeio. / Um dia, eu estava nas montanhas e me vi numa estrada que levava a uma montanha. Segui por essa estrada e parei. Eu queria falar no alto da montanha, pois senti esse desejo. Não falei, pois pensei que todo mundo iria dizer que este homem estava louco. Eu não estava louco, pois sentia. Não senti dor, mas amor pelas pessoas. Eu queria gritar da montanha para a cidadezinha de Saint-Moritz. Não gritei, pois senti que deveria ir mais longe. Fui mais longe, e vi uma árvore. $A$ árvore me disse que aqui não se podia falar, pois as pessoas não compreendem o sentimento. Fui mais longe. Separei-me da árvore com pesar, porque ela me sentira. Parti. Subi à altura de dois mil metros. Fiquei lá muito tempo. Senti uma voz e gritei em francês "Parole!". Eu queria falar, mas minha voz estava tão forte que eu não podia falar e gritei: "Eu amo todo mundo e quero a felicidade! Eu amo todo mundo. Eu quero todo mundo." Não sei falar francês, mas aprenderei, se passear sozinho. Quero falar forte para que me sintam. Quaro amar todo mundo, por isso quero falar todas as línguas. Não posso falar todas as línguas, por isso escrevo e alguém traduzirá meus escritos. Falarei francês como puder. Comecei a aprender a falar francês, mas fui perturbado, pois as pessoas que passavam por mim se espantavam. Eu não queria espantar as pessoas, por isso fechei a boca. Fechei-a assim que senti. Eu sinto antes de ver. Sei o que vai acontecer antes de todo mundo. Não o contarei de antemão às pessoas.

Terceiro passeio (p.111). 0 anonimato. 
Fui passear, mas não encontrei ninguém que eu conheça. Sei do que Deus precisa. Não posso escrever bem. Minha mão não escreve. Deus não quer que eu apoie minha mão com força. Não apoiarei, pois minha mão não pode escrever. Minha mão está cansada. Quero escrever bobagens [...]

Quarto passeio (119-127). A caminhada estelar.

[...] Uma vez, eu fui passear, à tardinha. Subi rapidamente. Parei no alto da montanha. Não era o Sinai. Eu tinha ido longe. Sentia frio. Sofria com o frio. Senti que devia me ajoelhar. Ajoelhei-me depressa. Depois disso, senti que precisava pôr a mão sobre a neve. Soltei a mão, e de repente senti uma dor. Gritei de dor, e retirei a mão. Olhei uma estrela que não me disse "bom-dia". Ela não piscou para mim. Tive medo e quis fugir, mas não podia, pois meus joelhos estavam soldados à neve. Comecei a chorar. Meu choro não foi ouvido. Ninguém veio em meu socorro. Eu estava gostando de passear, por isso senti o horror. Não sabia o que fazer. Não compreendia 0 intuito de meu alentescimento. Alguns minutos depois, virei-me e vi uma casa condenada. Um pouco mais longe, uma casa com gelo sobre o teto. Tive medo e gritei com toda a força: "Morte!" não sei por quê, mas compreendi que era preciso gritar "Morte". Depois disso, senti um calor por todo o corpo. 0 calor por todo o corpo me deu a possibilidade de levantar. Levantei e andei até a casa onde ardia uma lâmpada. [...] Eu queria ajuda, pois estava muito cansado. Não podia ir mais longe, mas de repente senti uma força imensa e comecei a correr. [...] Gostava de escutar meu passo. Meu passo estava cheio de vida. Olhei para o céu e via as estrelas que haviam começado a piscar para mim. Nessas estrelas, senti alegria. Fiquei alegre e não tinha mais frio. Caminhei. Caminhava depressa, pois senti o calor em meu corpo. Caminhava. Comecei a descer o caminho onde não se via nada. Caminhava depressa, mas fui detido por uma árvore que foi minha salvação. Eu estava diante de um precipício. Agradeci à árvore. Ela me sentiu, pois nela me agarrei. [...] Eu não tenho medo. Senti o medo da morte no precipício, e uma árvore me segurou. Eu não sabia que havia uma árvore no caminho. [...] 
Quinto passeio (158). 0 passeio da escrita.

Quero escrever um pouco em verso, mas meu pensamento está longe. Quero descrever meu passeios. / Meus passeios eram à pé. Eu gostava de passear sozinho. Gosto de passear sozinho. / Quero só só / Tu estás só e eu estou só. / Nós estamos sós e vós estás sós / Quero escrever escrever. / Quero dizer dizer. / Quero dizer dizer, quero escrever escrever. [...]

Sexto passeio (203). A negação do passeio.

[...] Não irei passear amanhã. Ficarei em casa. Beberei vinho e cerveja. Comerei carne. Darei risadas. Serei bicho. Não quero escrever bonito, pois quero que me leiam como eu quero. Não posso mais escrever. [...]

124.

Começo a pensar que a catástrofe Nijinskiana está lá, viva, como constelação e ressonância de um contínuo desnascimento como acontecimento. Um serdesterritório. Um corpo de desconstituição. Uma máquina desconstituinte do som. 


\section{[CONFIGURAÇÕES DE DESLIZ AO FIM]}

125.

Som e voz são pedaços de corpo, apenas elementos que individuam conjuntamente com outros elementos ou outros pedaços de corpo, corporificações.

De toda maneira, som e a voz são dois desses 'objetos' e às vezes são também configurações vitais que nomeiam, secretam nomes, individuam conjuntamente com nomes. Chamam nomes.

Às vezes 'som' e 'voz' se vinculam a práticas objetivas, às vezes não.

Um exemplo: faço um exercício simples de respiração: contar os tempos da respiração em suas etapas [inspiração, apinéia positiva (suspensão com pulmões cheios) -, expiração, apinéia negativa...]. Posso, em outro momento, estar em outro nicho no mundo, fazer outra prática inteiramente distinta. E em seu curso aquele primeiro exercício emerge, mais ou menos espontaneamente; ou apenas um fragmento, como configuração respondente aos problemas colocados nesse outro lugar.

Penso em estratégias e possibilidades de jogo.

Essa espécie de jogo, ele mesmo acontescente, entre uma rotina mínima (0 caso de um exercício, uma rotina experimental) e uma emergência que possa arrastar consigo uma parte daquele exercício. A voz, sempre em aberto.

Talvez uma voz almejada seja também aquela das vozes que são ejetadas ou aquelas que restam. No caso de Vaslav Nijinsky, repetirei, é uma voz do salto, que é o galope do excesso de vida, ainda-não-morte.

\section{6.}

Um avesso-corpo. O som é passagem. É a rede que o suporta e sustenta naquele instante, é a fenda que é a forma daquilo que se passa, e pode ser apenas isso. A rede como a forma da eletricidade que se passa, enquanto se passa. 0 detrito é a impossibilidade de saber, impossibilidade como saber. 
Biografia do nicho. Como fazê-lo falar? Avançar por destruição: máquina desconstituinte. Estar com eventos que quase não-existem.

127.

Um platô de palavras-devir no rumor da voz desconhecida (Nijinsky). 0 prazer no limiar da existência como um não-pensamento que pensa uma vida (Rousseau). A necessidade de se esculpir perpetuamente um prazer: seria essa uma das tarefas que se impõem para a caminhada-corpo, para a voz quase-nada, para a escrita-inscrição? Numa palestra para estudantes de cinema, Deleuze disse mais de uma vez que não se fazia as coisas por prazer, e sim por necessidade. Mas, se essa pauta for combinada com a pergunta, também de Deleuze, aí Becketiana, sobre se era possível eliminar totalmente o próprio prazer, não haveria aqui uma ambivalência de gestos inescapáveis da própria membrana viva?

0 que há de comum, quais são as composições entre a máquina de tocar e ser tocado (do bloco um), e a máquina desconstituinte do som, a máquina que desfaz imagens de sons (bloco dois)?

Uma boa chave para ler esta pergunta, penso, é que precisamos de muitas outras imagens para destruir uma imagem. Quais serão as imagens desconstituintes de imagens? A destruição, para não se passar por representação da destruição, deveria ser uma pressão pré-individual criativa. É porque a saturação pré-indivual 'pressiona', que imagens desconstituintes emergem na dilatação da membrana. Seriam ainda imagens? 


\section{[RESTOS]}

129.

CONVERSÃO DE TEXTURA DA LÍNGUA - desfazimento

A escrita não é catastrófica em si, como uma ação catastrófica:

Ela vêm mostrar uma catástrofe anterior, que aí vem à tona.

Uma catástrofe anterior que acompanha.

É diferente de um rumor de fato-corpo,

mas o rumor pode ser o rumor da catástrofe do corpo.

A víscera do som são as infinitas vidas que constituem os mundos. A víscera está fora.

A catástrofe vem costurada, aderida à vida, misturada à vida.

Junto as duas palavras do professor Uno: é corpo-catástrofe.

Escrevendo a outro professor, o professor XXXXXX (cujo nome é sigiloso), a percepção

sobre catástrofe se estendeu à escrita. Escrevi um texto quase igual:

lembrei de você XXXXXX

ao deparar um livro 'notícias em três linhas',

do Félix Fénéon, me alembrou muito miríade290122,

e quis te escrever. Espero que esteja tudo caminhando aí.

me dei conta que a escrita não é uma ação catastrófica em si;

ao menos não só isso.

A tarefa: ela traz uma catástrofe anterior que acompanha a vida,

que aviscera a vida, uma catástrofe que é a própria costura:

é só uma questão da escrita ser o aquém corajoso para perfurar a si mesma, e fazer vazar a catástrofe que ali está, posta em viscoso tecido.

Queria te contar esta percepção que me corta.

Enfim, já que estou escrevendo o doutorado que tem a ver com isso, então estou me havendo com fatos-corpo.

se der mande notícias

Chico

Anteontem tive uma percepção (não tem a ver com 'eu' que sente, a percepção é que me faz, e não eu a ela) de 'algo muito terrível e muito importante', nessas

122 Um livro escrito a partir dos escritos experimentais dos alunos de vários anos desse professor. 
palavras. Creio que já se antecipava a anterioridade da catástrofe que acompanha. Até pensei em mudar o nome de 'víscera' para 'catástrofe'.

Aquém do corpossom. A escrita do corpo na víscera e catástrofe do som.

É um aquém que se precipita e desliza em um excesso, portanto um jorro de posições consteladas, configurações parciais, fragmentos disjuntos, gestos opacos e chispados, um mais-que-oposto que vaza. Uma comunidade e arqueologia involuntárias, providas e por vezes constituídas de sons e rumores e um nada que é um discurso.

Uma comunidade interna.

Uma comunidade de pensamentos.

Uma comunidade de silêncios.

Uma comunidade de ações.

Tensões, relações, quase-relações.

Será a solidão uma espécie de pressuposto para o enfrentamento da questão de qual seja a comunidade à qual se dirige?

Uma catástrofe de um pensamento de mundo se aproxima.

Talvez seja ainda outra coisa: as comunidades involuntárias.

Talvez ainda outra coisa: comunidades de conhecidos não-pensados, comunidades de pactos não pensados. Compromissos paradoxais?

Seu encaminhamento não é a vinda à consciência. 0 ambiente como anterioridade da ação de corpo e som. Aqui deparamos mais uma vez com a catástrofe de um projeto. Leio pistas.

Inscrição, mediante uma força de... morte? De fim? Decisiva? Sinto que a palavra só é múltipla se ela investe em um único ponto, pois ela é decisiva e tem vida própria. Inscrição poderia ser o lugar onde vida e morte se encontram.

A vida não pensada, ou até o mais-que-um, o excesso de vida, transborda sobre si gerando a dobra. Mais uma vez: a vida em seu excesso se encontra com uma crueldade. Agora compreendo mais que nunca Artaud e seus hieróglifos vivos, em ressonância com 'o problema da continuidade e do fim', indicado por Donna Haraway na conferência em 'os mil nomes de Gaia'. A crueldade de inscrição dela mesma nessa 
rede de excessos. 0 hieróglifo artaudiano é o corpo desconhecido, teia pensante autônoma individuante.

\section{5.}

0 que é a teia?

A catástrofe da escrita é a crueldade da inscrição.

Uma comunidade de silêncios, uma comunidade de não-pensados.

0 aquém é um testemunho de uma passagem de corpo por uma fenda.

Escritos-desenhos como refazimento de um corpo. Como testemunho da anterioridade da catástrofe que acompanha.

\section{6.}

(20/08/2018)

há uns meses pensei que não sabia pensar

e hoje

concluo que não sei o que é um pensamento e concluo que jamais encontrei ninguém que pudesse me dizer do quê se trataria um pensamento

passo a desconfiar assim: não adianta dizer, no meio de um poema, que pediria à pessoa para simplesmente olhar o mar, e se possível não pensar - se o pensamento pode ser um vazio, bem como pode não sê-lo nem ele, tratando-se, ainda assim, de um pensamento

é bem provável que esta questão não seja sequer relevante, e seja uma outra bastante mais: quando chega algo que chamamos um dia pensamento, não importa o que seja ele, importa sim a magnitude do encontro e a comunidade impensável de rumores que o vem fabricado com a sua opacidade - esta comunidade impensável que empurra 0 que vem, eu a chamo de opacidade do invisível. Eis uma anotação de caderno: 
A questão da dor própria. No texto do Artaud e na problemática do corpo como diferenciação, corpo [corpo-campo] de diferenciação. [ativado pelo vitalismo]

A perambulação nos leva à rede. A Lilith que invade os desenhos é a própria rede viva.

Eu achava que sabia o quê era pensar, mas esqueci completamente: é refazer o desfazimento da destituição e do império.

[FINAL DO BLOCO DOIS] 


\section{[DOIS]}

\section{[instintos}

de germinação e caderno

- monstro que coleta]

[(PRIM EIRA COLETA) germinação e mito Armonia]

[(SEGUNDA COLETA) caderno] 
[(PRIMEIRA COLETA)]

[germinação e mito Armonia]

1.

A transdução e o exemplo simondoniano do vegetal.

[...] le négatif est premier comme incompatibilité ontogénétique, mais il est l'autre face de la richesse em potentiels; il n'est donc pas une négatif substanciel; il n'est jamais étape ou phase, et l'individuation n'est pas synthèse, retour a l'unité, mas déphasage de l'être à partir de son centre préindividuel d'incompatibilité potentialisée. Le temps lui-même, dans cette perspective ontogénétique, est considéré comme l'expression de la dimensionnalité de l'être s'individuant. (SIMONDON, 2005, p. 34, grifo meu) [...] à la différence de la démarche dialectique, la transduction ne suppose pas l'existence d'um temps préalable comme cadre dans lequel la genèse se déroule, le temps lui-même étant solution, dimension de la systématique decouverte: le temps sort du préindividuel comme les autres dimensions selon lesquelles l'individuation s'effectue* [nota de rodapé] *Cette opération est parallèle à celle de l'individuation vitale; um végétal institue une médiation entre um ordre cosmique et um ordre inframoléculaire, classant et répartissant les espèces chimiques contenues dans le sol et dans l'atmosphère au moyen de l'énergie lumineuse reçue dans la photosynthèse. Il est um nœud interélémentaire, et il se dévéloppe comme résonance interne de ce système préindividuel fait de deux couches de réalité primitivement sans communication. Le nœud inter-élémentaire fait um travais intra-élémentaire. (SIM ONDON, 2005, ps. 34-35, grifos meus)

[...] lo negativo existe primeiro como incompatibilidad ontogenética, pero es la otra cara de la riqueza en potenciales; no es pues un negativo substancial; no es nunca etapa o fase, y la individuación no es síntesis, retorno a la unidad, sino defasage del ser a partir de su centro preindividual de incompatibilidade potencializada. El tempo mismo, en 
esta perspectiva ontogenética, es considerado como expresión de la dimensionalidad del ser que se individua. (SIM ONDON, 2015, p. 23, grifo meu) [...] del mismo modo que la marcha dialéctica, la transducción conserva e integra los aspectos opuestos; a diferencia de la marcha dialéctica, la transdución no supone la existência de um tempo prévio como marco en el cual la génesis se desenvuelve, siendo el tempo mismo solución, dimensión de la sistemática descubierta: el tempo surge de lo preindividual como las demás dimensiones según las quales se efectúa la individuación*. *[nota de rodapé] Esta operación es paralela a la de la individuación vital: um vegetal instituye uma mediación entre um orden cósmico y um orden inframolecular, clasificando e repartiendo las especies químicas contenidas em el suelo y en la atmósfera mediante la energia luminosa recogida em la fotosíntesis. Es um nudo interelemental, y se resarrolla como ressonância interna de ese sistema preindividual hecho de dos capas de realidad primitivamente sin comunicación. El nudo interelemental hace um trabajo intraelemental. (SIMONDON, op. cit., $p$. 24, grifos meus)

[o negativo existe primeiro como incompatibilidade ontogenética, mas é a outra face da riqueza em potenciais; não é pois um negativo substancial; não é nunca etapa ou fase, e a individuação não é síntese, retorno à unidade, mas defasagem do ser a partir de seu centro pré-individual de incompatibilidade potencializada. 0 próprio tempo, nesta perspectiva ontogenética, é considerado como expressão da dimensionalidade do ser que se individua. [...] do mesmo modo que a marcha dialética, a transdução conserva e integra os aspectos opostos; à diferença da marcha dialética, a transdução não supõe a existência de um tempo prévio como quadro no qual a gênese se desenvolve; sendo o próprio tempo solução, dimensão da sistemática descoberta: 0 tempo surge do pré-individual como as demais dimensões segundo as quais se efetua a individuação*. [nota de rodapé] *Esta operação é paralela à da individuação vital: um vegetal institui uma mediação entre uma ordem cósmica e uma ordem inframolecular, classificando e repartindo as espécies químicas contidas no solo e na atmosfera mediante a energia luminosa coletada na fotossíntese. É um nó interelemental, e se desenvolve como ressonância interna desse sistema 
pré-individual feito de duas camadas de realidade primitivamente sem comunicação. 0 nó inter-elemental faz um trabalho intra-elemental. (tradução e grifos meus ${ }^{123}$ )

123 Utilizei o trilíngue pois foi dessa forma que obtive melhor suporte à tradução. Quando cito fragmentos, me atenho mais à tradução e edição argentina (editora Cactus, 2015). Está para ser lançada a tradução em português da tese de Simondon. Entretanto, verifiquei recentemente a existência de uma tradução (Ivana Medeiros) para esta introdução, nos cadernos de subjetividade de 2003: 0 reencantamente do concreto (publicação do programa de estudos pós-graduados em psicologia clínica da PUC-SP). 


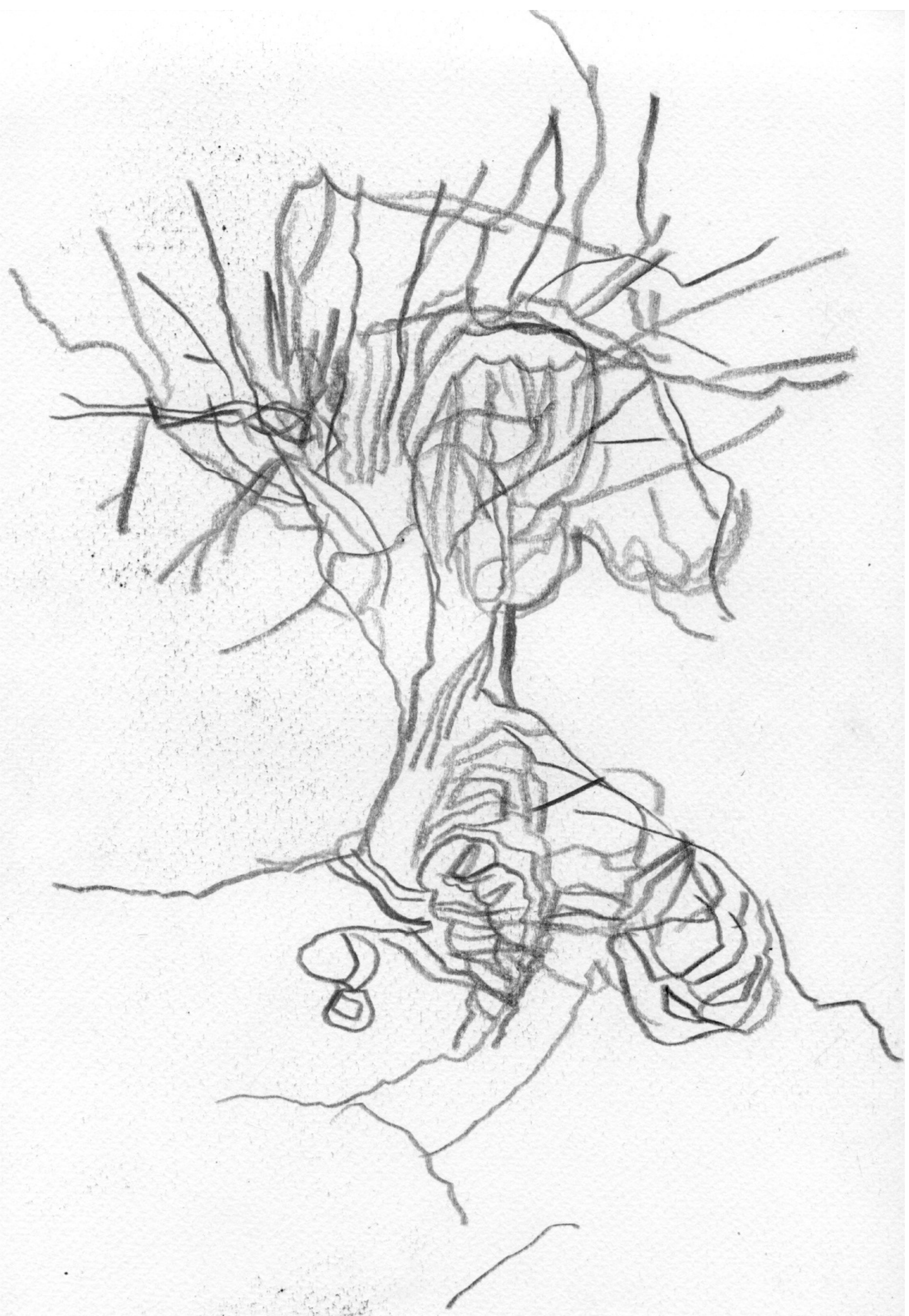


2.

Na sua introdução a L'individuation à la lumière des notions de forme et d'information (1958, 2005, 2013), Gilbert Simondon nos apresenta, em dado segmento desta introdução, a transdução como um importante modo operativo para a ontogênese. Operação a partir da qual uma modificação em dado domínio se propaga a outros domínios.

Ao apresentar pela primeira vez na obra citada esse modo operativo e ao mesmo tempo utilizá-lo à sua maneira, movido por suas necessidades, Simondon faz um itinerário. Descreve-o como o processo do relacionar-se [naturalmente, de dimensões heterogêneas]; descreve-o relacionado à noção de invenção; descreve o proceder pelo qual a transdução permite pensar a individuação e conhece-la... 'esta marcha [da transdução] consiste em seguir o ser em sua gênese, em consumar a gênese do pensamento ao mesmo tempo que se cumpre a gênese do objeto' (2015, p. 23). 0 que vale dizer ainda que o pensar e o conhecer são também individuações. Contudo, 'a transdução não poderia ser apresentada como um procedimento lógico que tem valor de prova' (idem). Pois ela é 'transmissão' da gênese, é pressão e tensão pré-individual. 


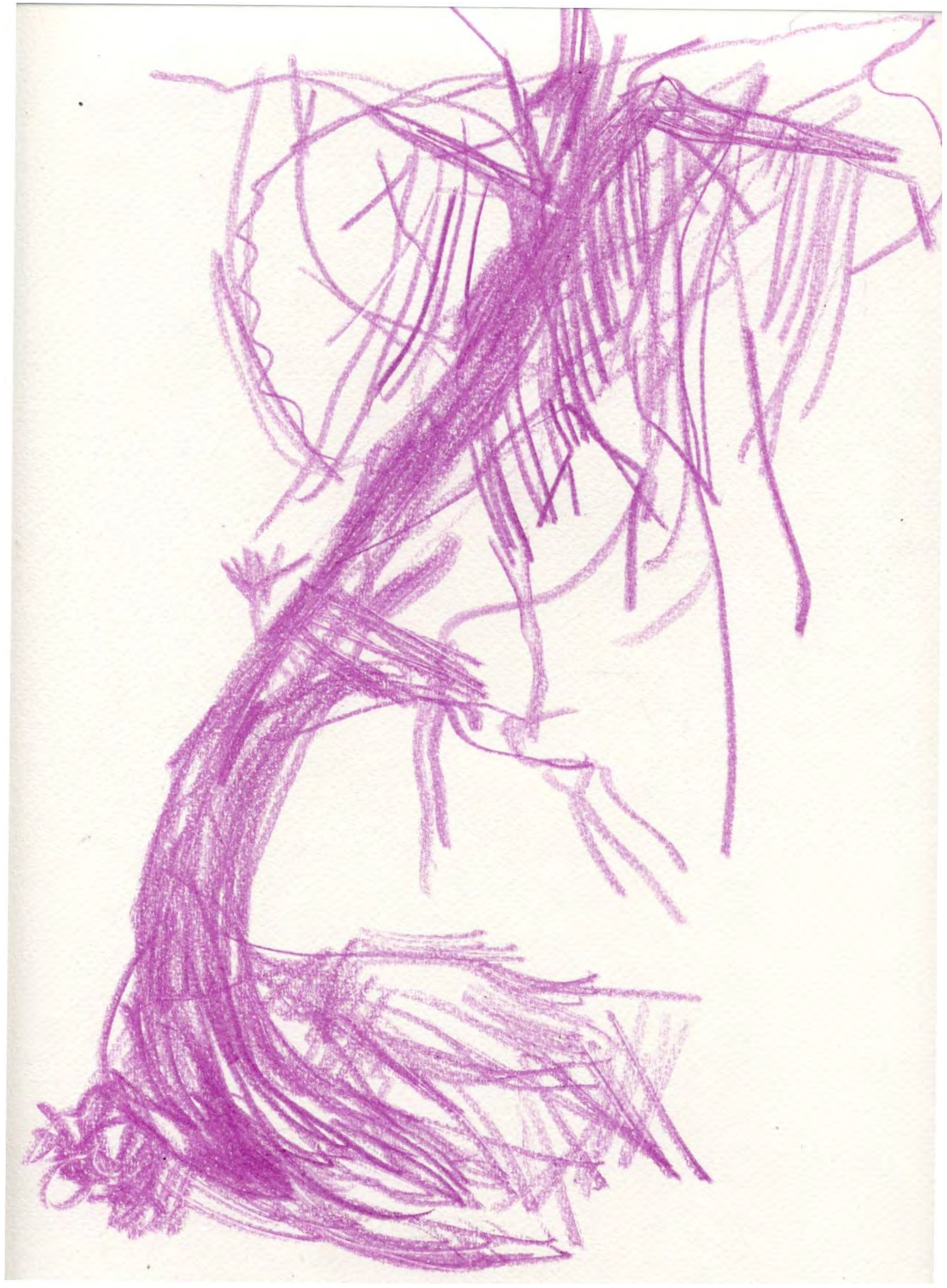


3.

Esse 'processo criativo do relacionar-se', que agora sabemos incluir o pensamento e 0 conhecimento, cabe dizer ou relembrar, é ontogenético. Não é processo dado, é gênese da relação e relação como gênese dos termos que passam a relacionar-se. Gênese de dimensões da individuação, gênese de relações inéditas da individuação conjunta na medida da gênese, da criatividade do ser que se acompanha, produzindo dimensões, escalas... seria algo próximo ao inconsciente maquínico, uma 'usina'124? Talvez algo menos grandioso, mas não menos dramático.

124 Descrição de Deleuze e Guattari na contracapa da primeira edição de L'Anti-CFdipe: Qu'est-ce I'inconscient? Ce n'est pas um théâtre, mais une usine, um lieu et um agent de production. [0 que é 0 inconsciente? Ele não é um teatro, mas uma usina, um lugar e um agente de produção.] 
176

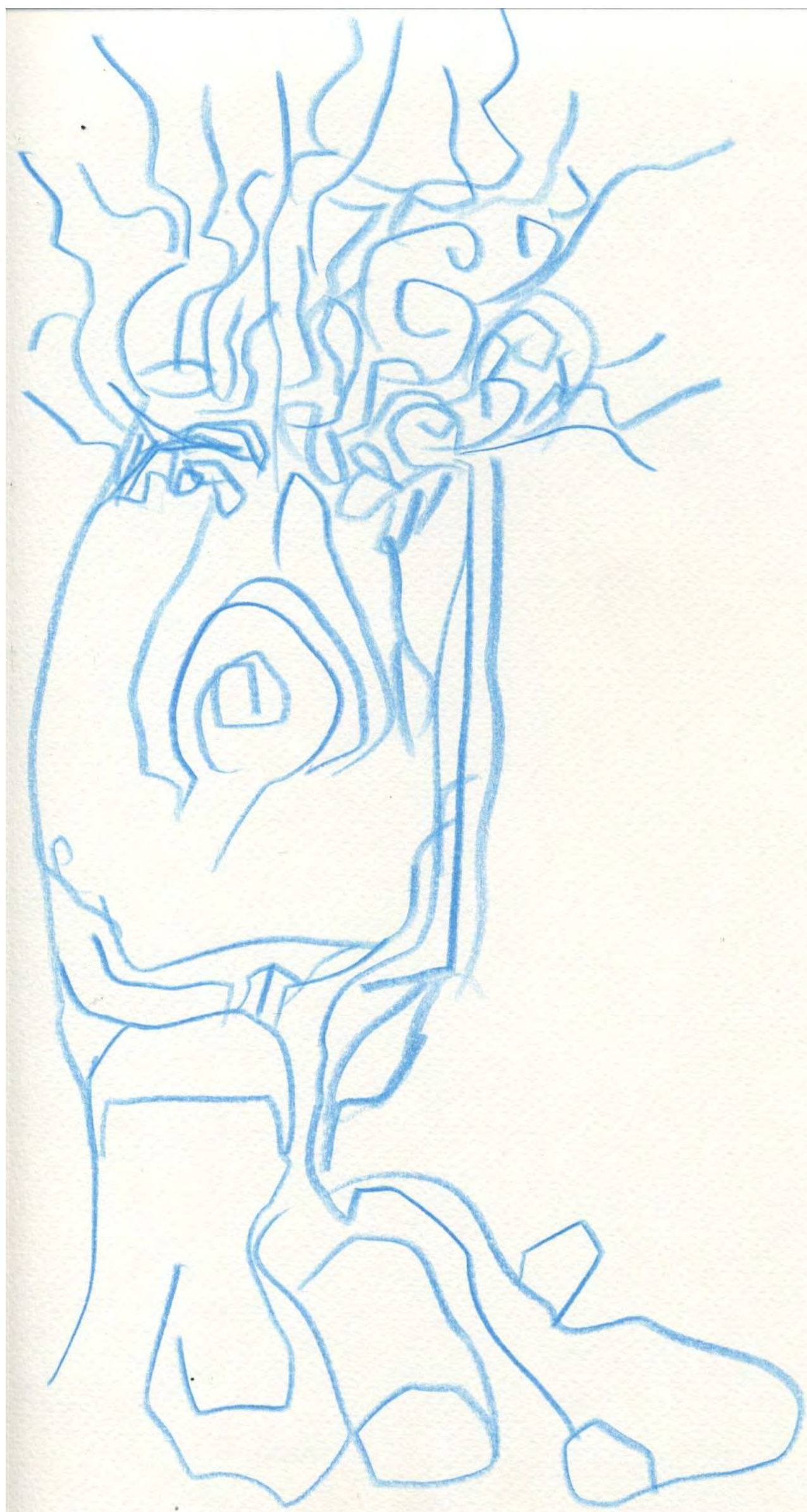


4.

Gênese escalar da relação.

Desde antes, na própria introdução de l'individuation, GS ${ }^{125}$ já havia designado seu próprio método como aquele onde a relação tem o valor de ser (p. 20). E aqui, ao descrever pela primeira vez o seu modo de ver a transdução (ps. 21-24), esse estatuto relacional assim designado pode ser visto como 'pura' gênese de relações. Produção dimensional. Processo de produção de processos. E nó de individuação. Na expressão de Muriel Combes ${ }^{126:}$ 'esta relação que é o indivíduo.'

Sempre que possível, penso, é preciso deter-se diante de tal afirmação, a de que a relação é um ser. Permite dizemos também que um indivíduo meta-estável é uma relação (e um conjunto de relações, visto que há uma dimensionalidade em processo $)^{127}$. E o ser, em Simondon, conforme vimos, é confinado, espremido, destinado à possibilidade de criar, ele é criativo. É um instinto germinativo da vida ela mesma. As individuações são expressões dessa criatividade. E, posto que individuação é processo, o ser enquanto relação aqui tem o valor de modulação, ressonância, formação: alguns dos paradigmas corporais elementares ou íntimos observáveis da individuação. Não à toa GS irá nos oferecer o paradigma físico para a individuação, paradigma que passeia por muitos exemplos.

\footnotetext{
${ }^{125}$ Abreviatura para Gilbert Simondon.

${ }^{126}$ Em Simondon. Individu et collectivité. Pour une philosophie du transindividuel (1999).

${ }^{127}$ Aqui pode ser que tenhamos em mãos um outro dado Spinozeano: quando se diz, no vocabulário deste último, que o modo existente é uma relação característica de infinitas partes que se compõem entre si.
} 


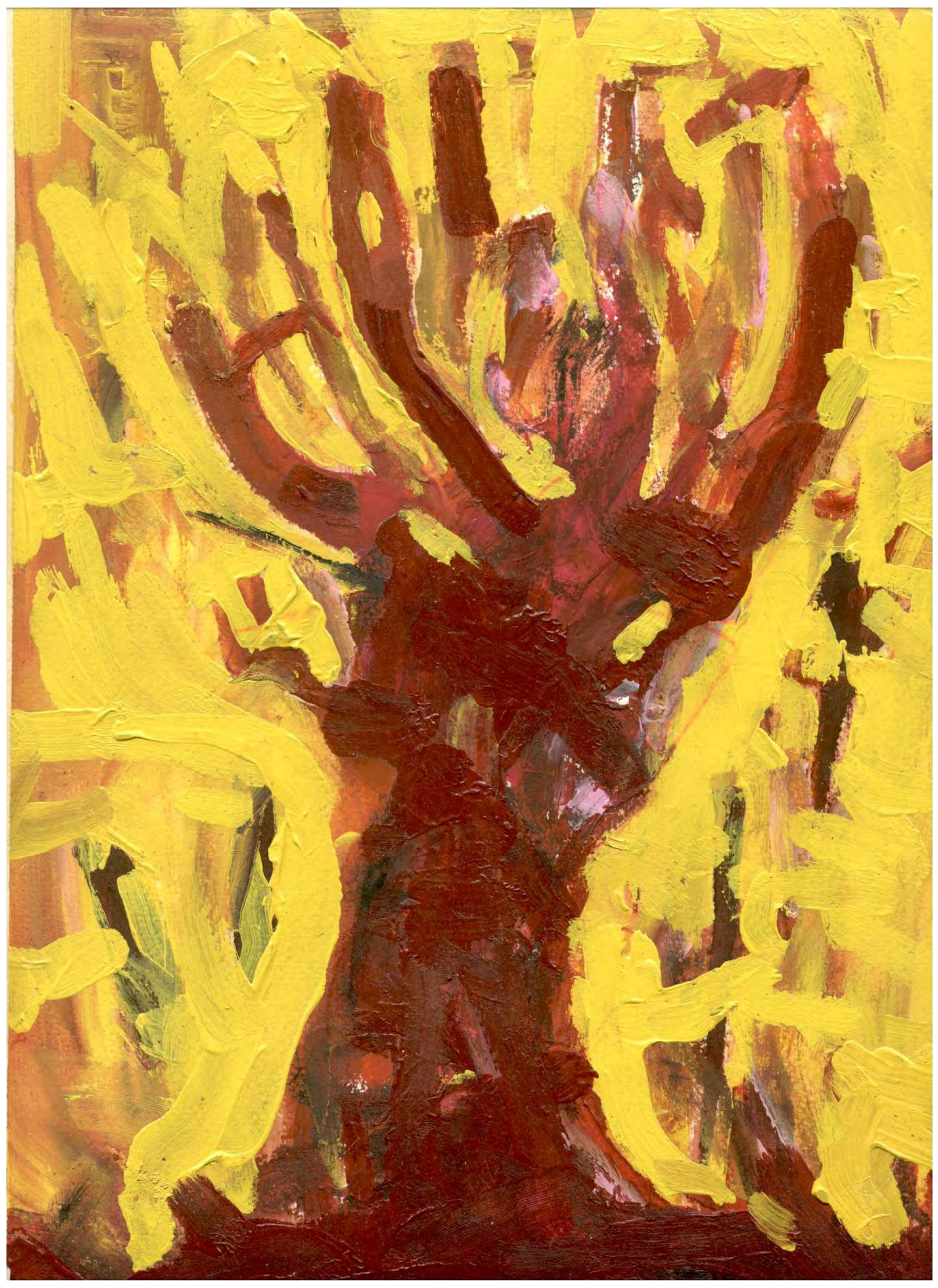




\section{5.}

Além disso, no segmento da introdução de l'individuation dedicado à descrição da transdução, há a diferenciação entre transdução, dedução e indução. Enquanto posta por Simondon, 'dedução' seria quando se vai buscar em outro lugar um princípio para resolver o problema de um dado domínio. E 'indução' seria o proceder que conserva os caracteres dos termos do campo estudado, extraindo desses mesmos termos as estruturas de análise, conservando contudo apenas o que haveria de positivo. Ou seja: apenas o que está formalizado, individuado - eliminando o que os termos possuem de singular. As minhas descrições são quase as mesmas do texto de Simondon, só adaptei para deixar este texto fluente.

Ao comentar essas duas diferenciações, entre transdução e dedução ou indução, o autor o faz no contexto que inclui o delineamento de uma divergência ao que ele diz por dialética.

A transdução operaria através daquilo que os termos têm de díspar, e não de comum. Assim, a transdução revira o sentido dos seres, convertendo a disparidade (negativo) em condição de significação (positivo).

Ao relacionar a transdução como a própria dimensionalidade da ontogênese (individuação), Gilbert Simondon dá uma leitura sobre a ontogênese do tempo, uma dimensionalidade dentre outras. Devemos poder pensar, portanto, que a singularidade tem e é sua temporalidade (e, por que não, sua própria historicidade, termo que será adotado mais tardiamente na mesma obra).

- Transdução como forma de individuação do tempo, como processo de formação do tempo?

- Pois sabemos que não existe 'tempo em geral'. 


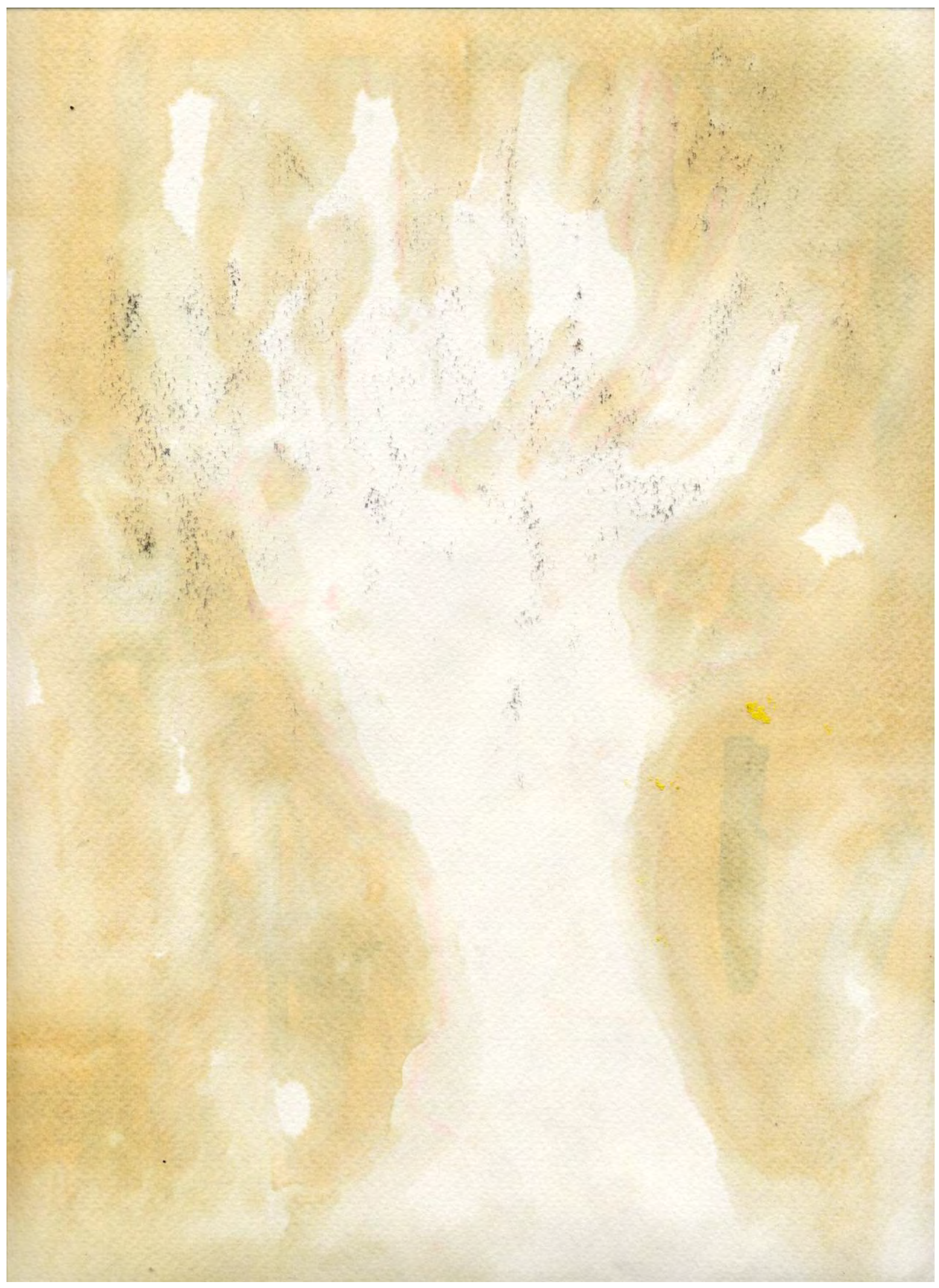




\section{6.}

Aqui ocorre ainda outra coisa. Ao encerrar sua primeira descrição da transdução, quando comenta que ela pode coincidir com a gênese do tempo, dimensão dentre outras dimensões pelas quais se dá a individuação, algo extraordinário, no meu ver, se passa. Pois há essa nota de rodapé surgida neste ponto do texto de GS. No corpo da nota, há o exemplo do vegetal como formação dimensional (e muitidimensional) no âmbito da individuação vital. Uma relação de relações corporificada na medida em que o vegetal é 'um nó interelemental' entre o mundo do 'solo', da predominância da terra, do subterrâneo, e o mundo do 'espaço', da predominância do ar, da atmosfera. Esse nó se desenvolve como 'ressonância interna' (para Simondon, o caractere da ressonância interna é aquele da interioridade, que por sua vez é aquele da individuação vital128).

Vou me valer da imagem da planta como nó interelemental, corpo de mundificação entre mundificações, existência de relação de relações, imagem de transdução. Uma espécie de devir-semente, paralelo ao 'germe de cristal' (termo nada estranho a Simondon, ver p. 21) para uma germinação que continua mesmo depois da germinação, mesmo antes da germinação, germinando germinações.

\footnotetext{
${ }^{128} \mathrm{Na}$ vida afetivo-psíquica, o filósofo David Scott faz o brilhante comentário da transdução acerca do movimento de diferenciação e integração entre exterior e interior, modalidades de ressonância que configuram continuamente a psique. 0 movimento é guiado por 'regimes associados de causalidade e finalidade'. Assim ele comenta o caráter transdutivo da afetividade psíquica: 'Para Simondon, a psique é transdução, e transdução é a estrutura motívica do movimento condicionando o desenvolvimento de causalidade e finalidade. Transdução define os parâmetros da individuação ou ontogênese' (SCOTT, 2014, p. 68). Não tenho a capacidade ou a pretensão, ou mesmo o repertório filosófico e psicanalítico para extrair as consequências, imagino que graves, dessas sentenças. Outras e outros o farão. De todo modo, é válida a aproximação entre Simondon e as psicologias que contemplam um 'domínio intermediário'. Esta hipótese não é minha, é da antropóloga e psicanalista Amnéris Maroni. Formulação esta que, diga-se de passagem, também é herança romântica, no melhor dos sentidos, e herança transfiguradora revolucionária e proto-anárquica ou, hipótese ainda mais duvidosa porém incontornável para este estudo: dado arcaico e germinativo do corpo da imaginação e da ação. Corporificaçãomundificação.
} 


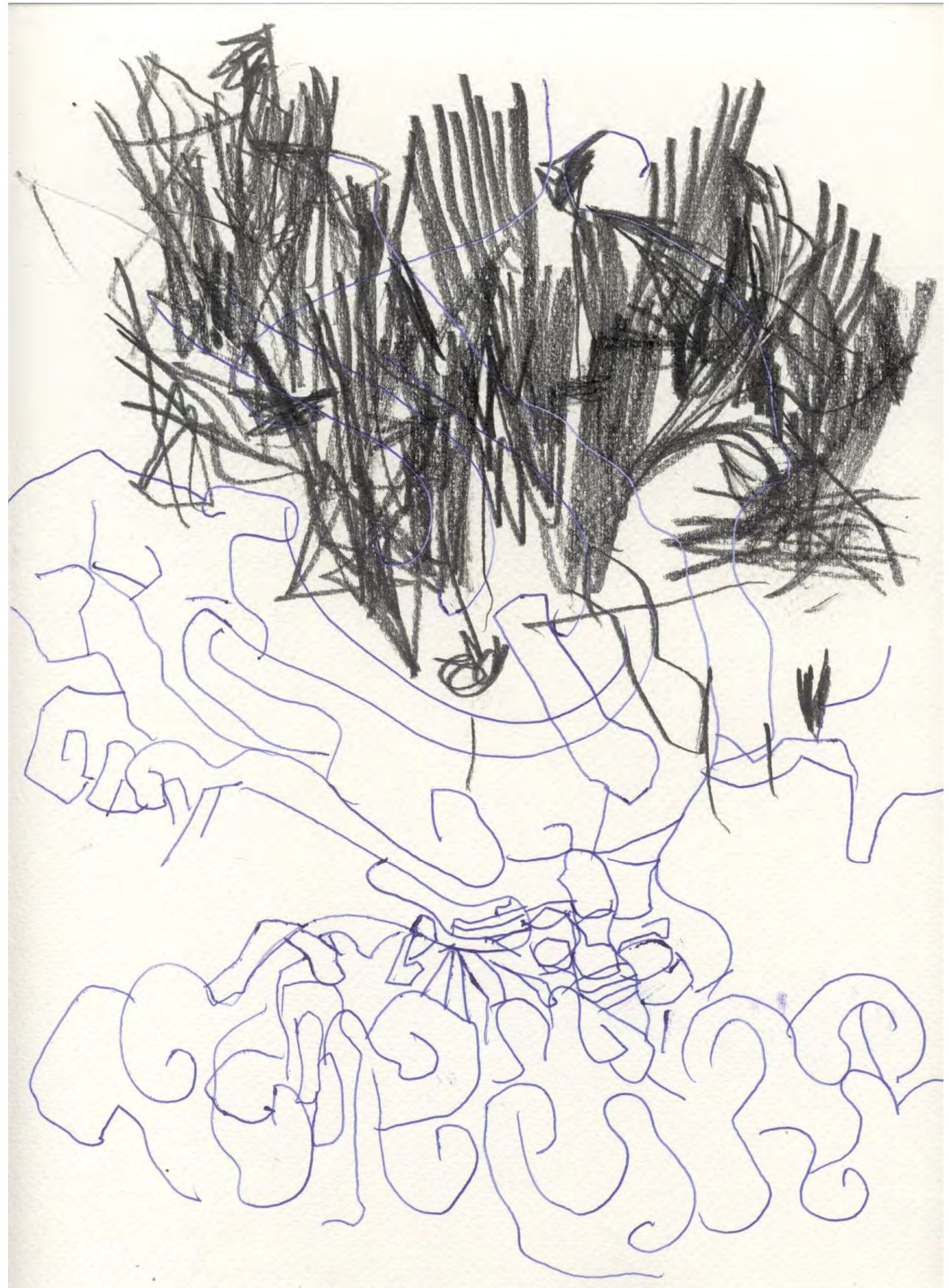




\section{7.}

\section{0 que podem ser instintos de germinação?}

Na conferência o instinto e o insconsciente (1919. Collected works vii, parte 6), Carl Gustav Jung desenha o modelo da relação arquétipo-instinto. Nesta, reações instintivas e imagens arquetípicas formariam as 'duas faces' de uma mesma Inteligência vital, um drama vital. Do lado das configurações instintivas, grosso modo, o autor coloca dois elementos: 'reações desproporcionais à sua causa' e 'reações muito parecidas entre si'. Do lado dos dramas arquetípicos, que é o lado das imagens dos dramas vitais, coloca-se justamente imagens que de algum modo traduzem ou guiam a massa de instintos, de protocolos vitalistas.

Uma dinâmica imagética do instinto está, então, proposta.

Durante a conferência, Jung nos dá conta de que não há possibilidade de aquisição do instinto, ou seja: o autor parece desvincular da lida com 0 instinto a exclusiva vontade individual (e, é claro, a vontade consciente). A sofisticada operação de desova da mariposa na planta Yuca é o exemplo de que Jung se vale para argumentar essa posição.

Em conversas com Amnéris Maroni, estudiosa de Jung, ela me deixou saber e reparar que há ainda outro-algo bastante emblemático no exemplo da mariposa da Yuca. A conferência abordou o tema 'instinto e inconsciente' no modelo arquétipoinstinto e, para tanto, lançou uma hipótese de dinâmica imagético-afetiva do instinto que deflagra ações de uso vitalista e tonalidade coletiva. Digo coletiva, uma vez que não haja aquisição individual e uma vez que seja um comportamento da espécie. Mas para realizar tudo isso ele se mune de um exemplo multi-espécie. Inseto tplanta.

Instinto: drama vitalista guiado por imagens impregnadas de afeto. ${ }^{129}$ Tracejado multiespecífico.

\footnotetext{
${ }^{129}$ Não gostaria de fazer um levantamento exaustivo das abordagens do instinto. Isso também pois os autores da borda da modernidade, 'críticos da cultura', nas palavras da Amnéris, estão de alguma forma em ressonância quando tentam olhar de forma extra-moral 0 instinto no registro de uma inteligência vitalista. $\mathrm{Na}$ conferência supracitada, um dos autores que Jung cita é William James. 0 próprio Simondon ofereceu um curso sobre instinto no Lycée du Parc (cours sur l'instinct, 1964). A isso soma-se o fato de que tanto Jung quanto Simondon são fortemente impactados pela filosofia de Nietzsche.
} 


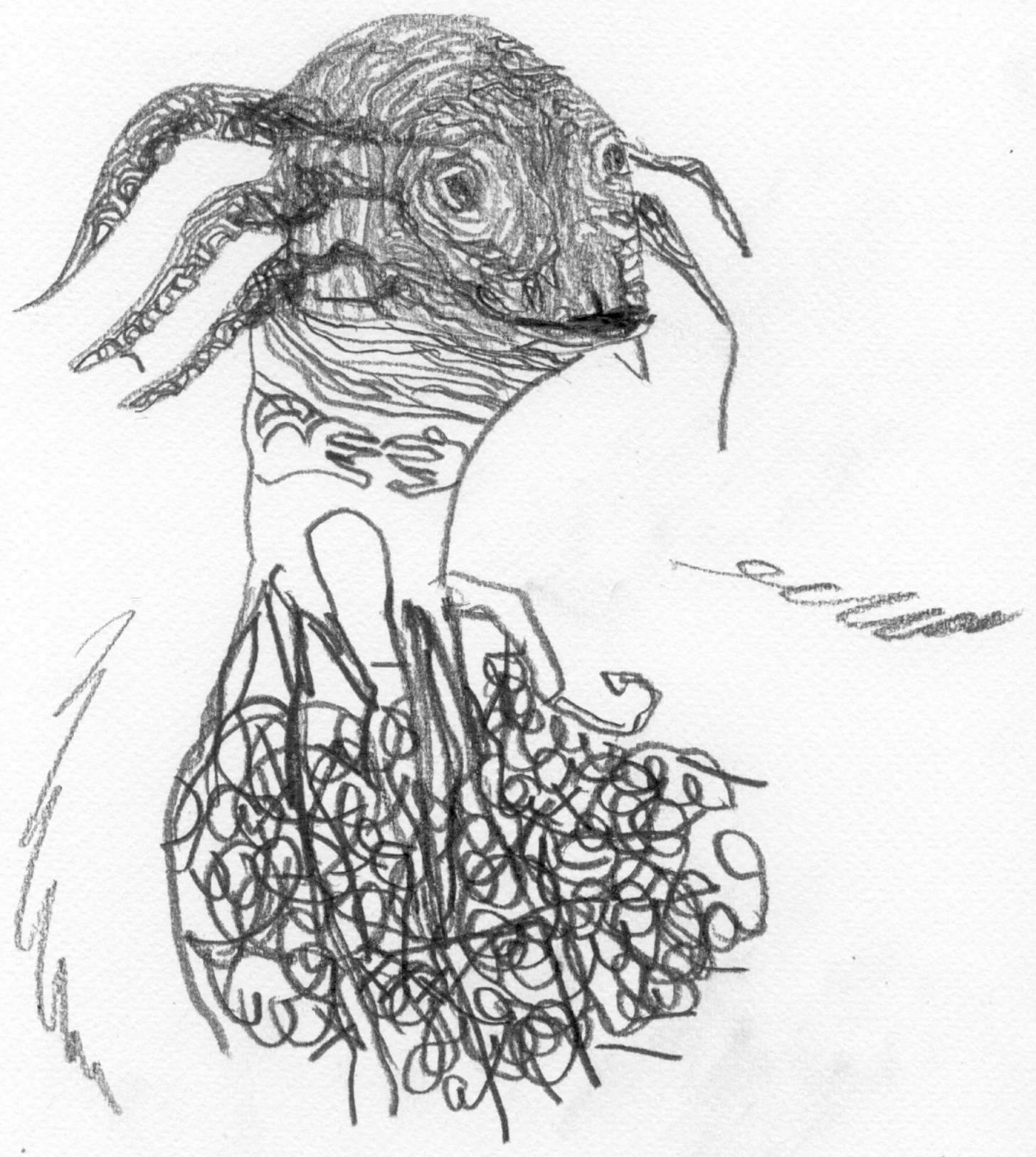


8.

\section{Quais são as vozes mínimas da germinação?}

'Cada um é pelo menos dois' é uma assertiva de Donne Haraway durante sua conferência no colóquio internacional os mil nomes de Gaia: do Antropoceno à Idade da Terra. O Colóquio se deu em setembro de 2014, na Casa de Rui Barbosa, no Rio de Janeiro, com organização da PUC-Rio e da UFRJ. Um conselho de Haraway, na mesma comunicação: 'contar histórias é algo poderoso a se fazer hoje'. 
186

Árvore plousiviel

Melíade (árvore freixo)

Armonia - Mã das

Amazenas

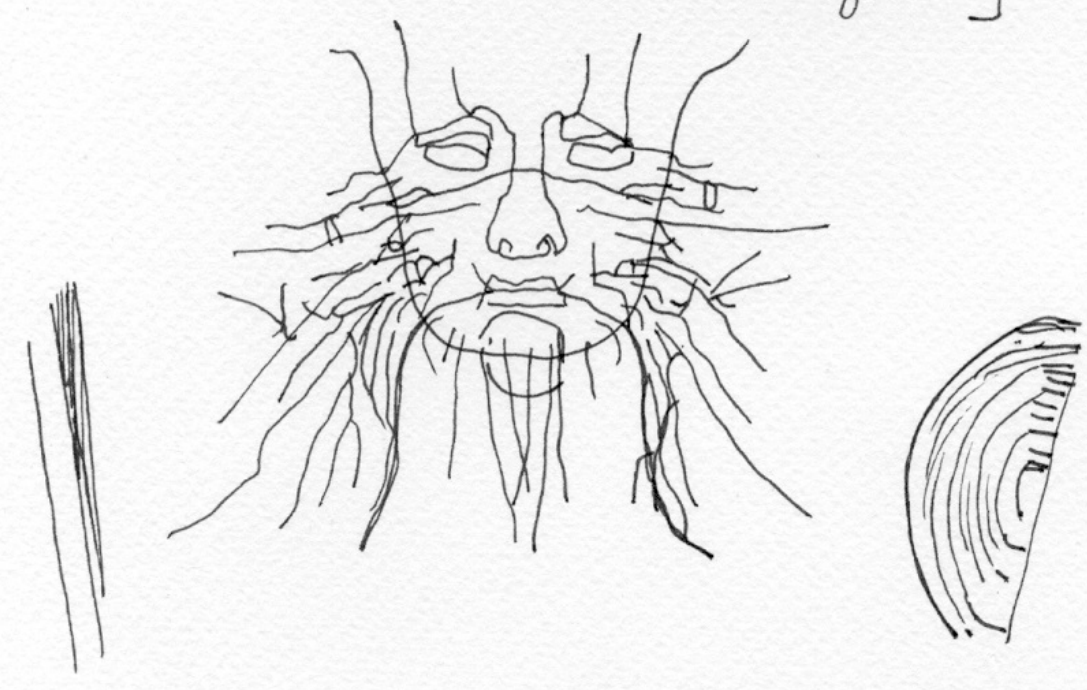

Chico-22.01.2018 
9.

Eduardo Subirats escreve a flor e o cristal, um ensaio sobre a potência germinativa de Paul Klee. Aquém da disputa estética ou teórica que se poderia almejar, o ensaio em questão me parece precioso por conta da descrição e vivência de um impressionante pensamento germinativo e um impressionante pensamento sobre a gênese. Este pensar envolve e produz imagens enigmáticas, símbolos-personagens. 
188

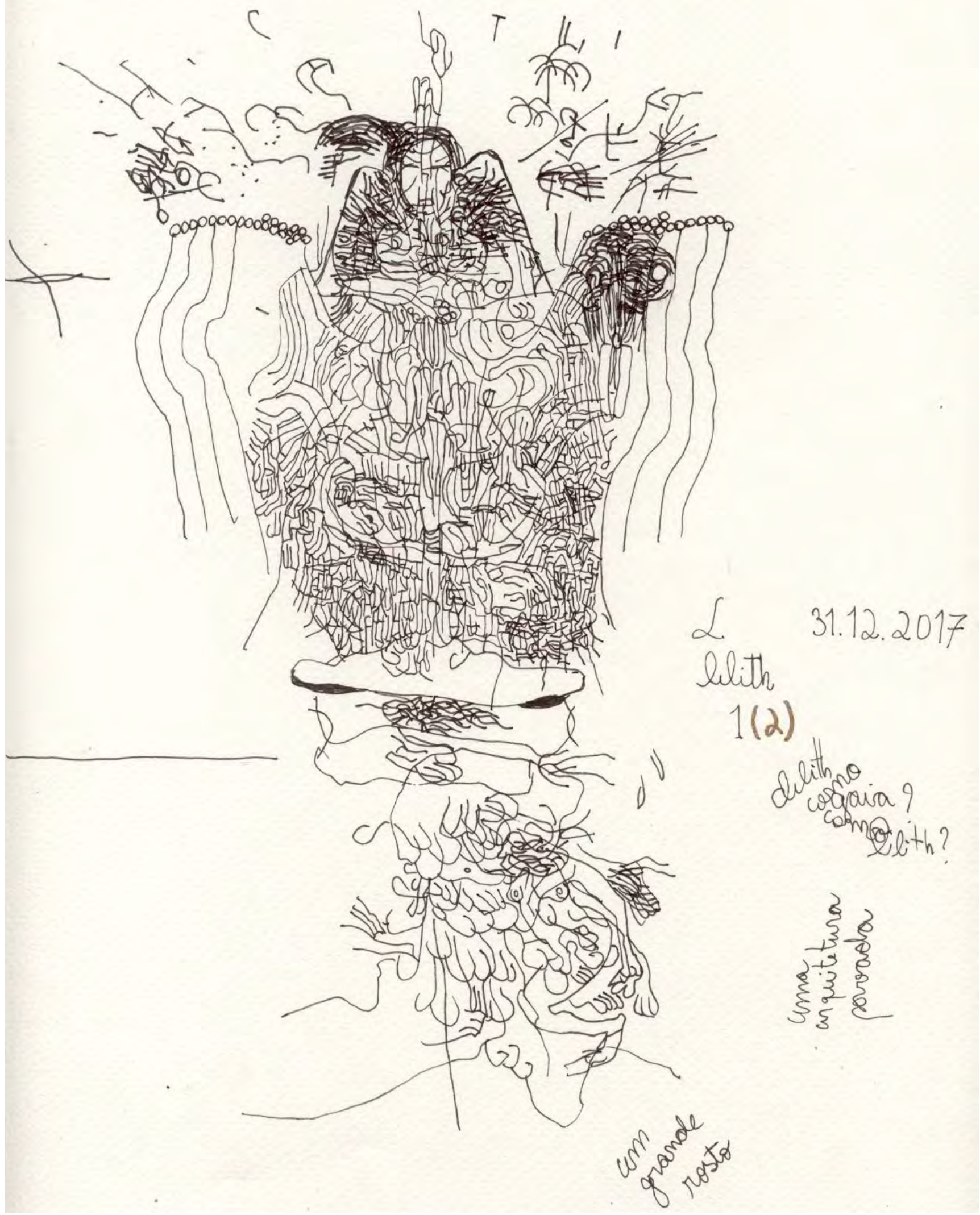


10.

Não para de germinar. Se há figuras, são familiares mas estranhas.

Os enigmas reservados e irradiados nas germinações, figuras, e demais corporificações de Klee aconselham e criam laços. Uma intimidade do mínimo vegetal, germinativa, de um lado. De outro, pesquisa na via do reconhecimento e reverência a uma comunidade de seres insuspeitos, autônomos, alheios, mas eventualmente prenhes de vínculo e afeto por vezes paradoxais. As germinações-figuras certamente lá estão como pressão da potência de formação comunitária com pessoas de carne e osso do 'nosso mundo'. Qual mundo?

Penso no caso da monotipia Angelus Novus, de 1920, formando comunidade com Walter Benjamin, Heiner Müller, outras e outros, tornando-se uma espécie de palavra corrente nas poéticas revolucionárias. 


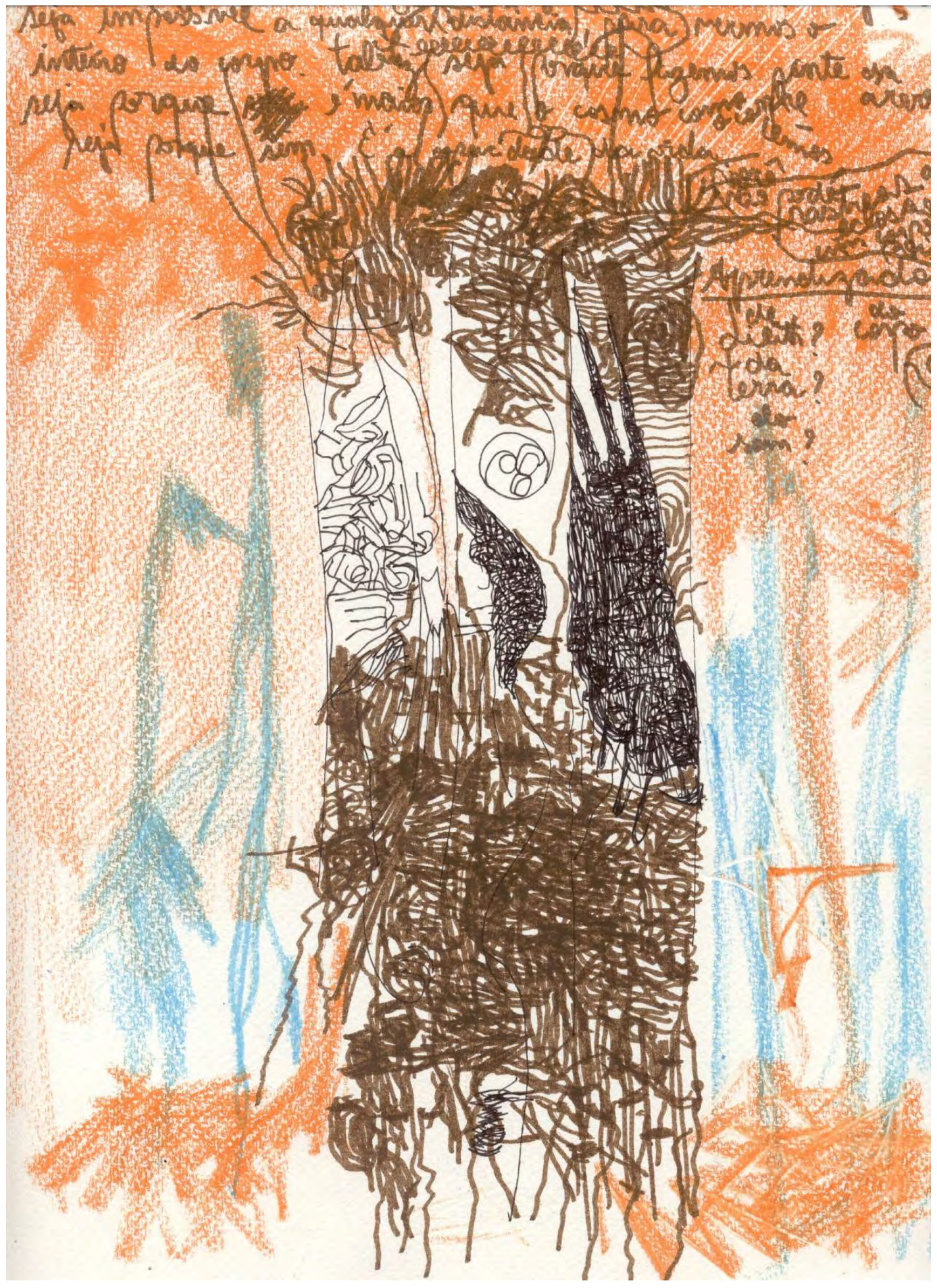


11.

De modo análogo com que fiz com Nijinsky ou Uno, faço as citações em blocos compactos, na expectativa de capturar um movimento de outra espécie àquele da simples citação.

Primeiro ato: explosão de uma energia original, gênese. Encontramo-nos no início da criação da obra. Somente da obra? / 0 ponto é um centro de forças, ansiedades e esperanças. Suas tensões se libertam, e surge, assim, a linha: crescimento, evolução, movimento. / Por esse milagre, vemos aparecer o caule: ritmo e dinamismo para cima, em direção aos elementos da luz e do ar. Mas o crescimento segue o seu curso, agora em forma de ramificações. Cria-se uma trama. 0 que aconteceu? A multiplicação das linhas suscitou uma segunda dimensão: a superfície. Encontramo-nos diante do elemento bidimensional. (SUBIRATS, 1988, p. 154) [sobre 0 quadro Spärlich belaubt, escassa folhagem, 1934]

O quadro continua sua germinação mesmo após o trabalho do pintor.

Gostaria de reler desde já o ponto a partir do Klee de Subirats.

Uma dramaturgia do ponto.

0 ponto perfura. 0 ponto tem grande violência. 0 ponto oscila. 0 ponto não é exato. M esmo o ponto da agulha não é exato. A abstração está presente em Klee, mais o ponto enquanto vida não é exato. Subirats vem nos dizer que Klee é um abstrato vitalista, que quer se aproximar da germinação, principalmente do ponto.

Isto pode ser uma agonística da contemplação e uma aguda corporificação; a própria prática do ponto-massa e do furo. 0 ponto, de onde ele vem e o que dele brota, é estética agonística.

Germina. 


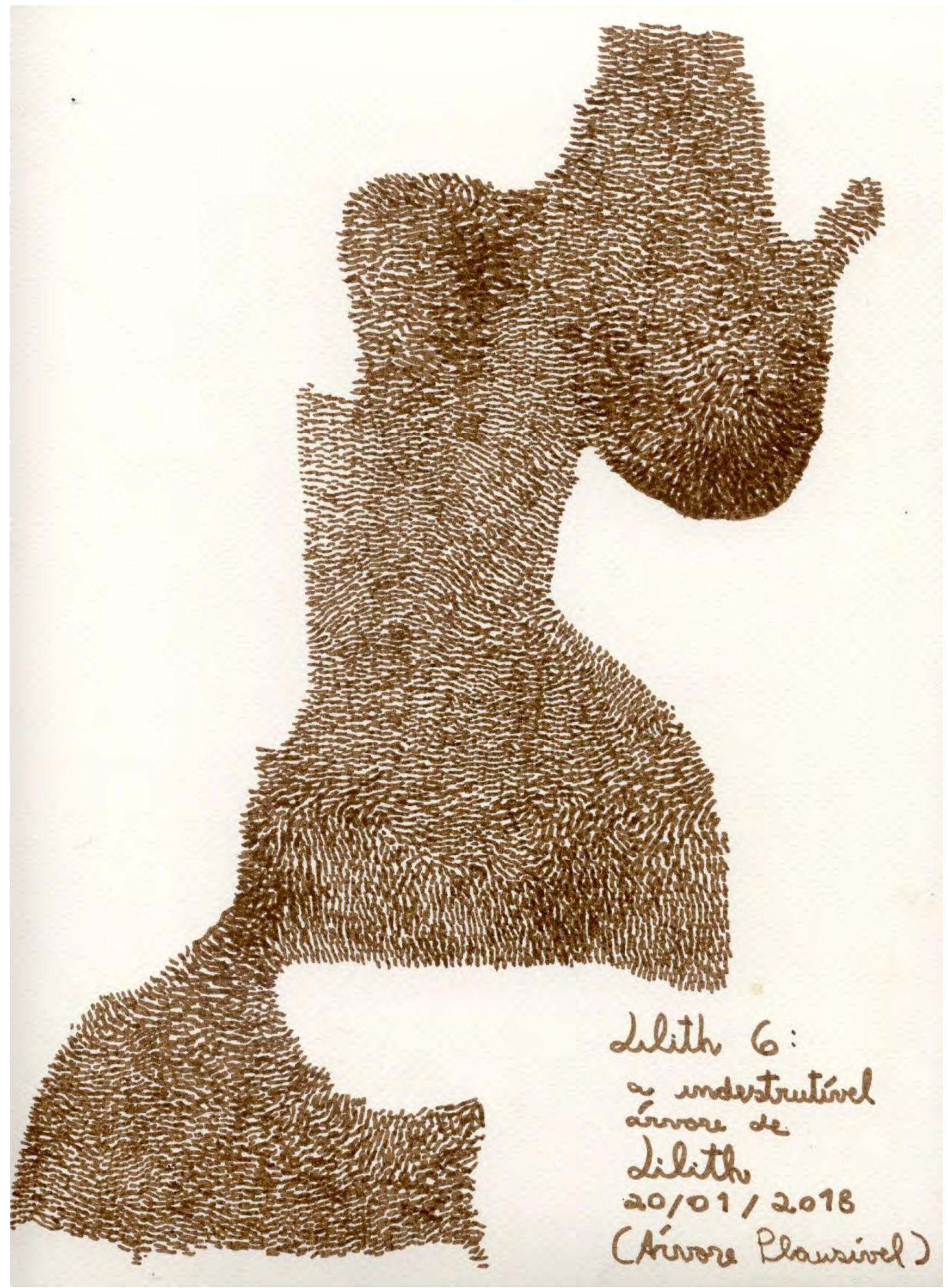


12.

É possível uma estética histérica a partir de Klee? Talvez não exatamente a partir dele, mas com ele e outros.

Para cada dimensão que nasce, um novo intento de perfuração já estava em processo, uma nova operação, inteiramente nova, um novo sujeito da perfuração que surge por debaixo do cupinzeiro que é o quadro. Há um germinar, um constelar, mas também um empurrar, comer a terra, furar.

Existe uma violência na própria irrupção do ponto. Ele é uma espécie de estouro ou guincho, ainda que sóbrio. Essa perfuração de novas dimensões deixa ver que a germinação já havia começado. É em parte o que pode querer dizer o Bacon pintor em Deleuze quando diz que a pintura começou antes de começar. As virtualidades povoam e saturam a superfície material e 'materialística' do quadro, é preciso dar testemunho da saturação germinativa, e essa necessidade fermenta sucessivos eventos que corporificam o quadro. Se bem que Bacon seja um pintor que, ao contrário de Klee, usa a palavra instinto. Deleuze lê o devir-animal de Francis Bacon nos procedimentos de raspagem, criação de regiões, zonas borradas, diagramas. Klee tematiza o germinativo-cristalino em si.

Quero dizer que a dramaturgia da germinação em Klee pode ser o pontosemente: em Bacon essa dramaturgia é tematizada em termos do próprio instinto. 


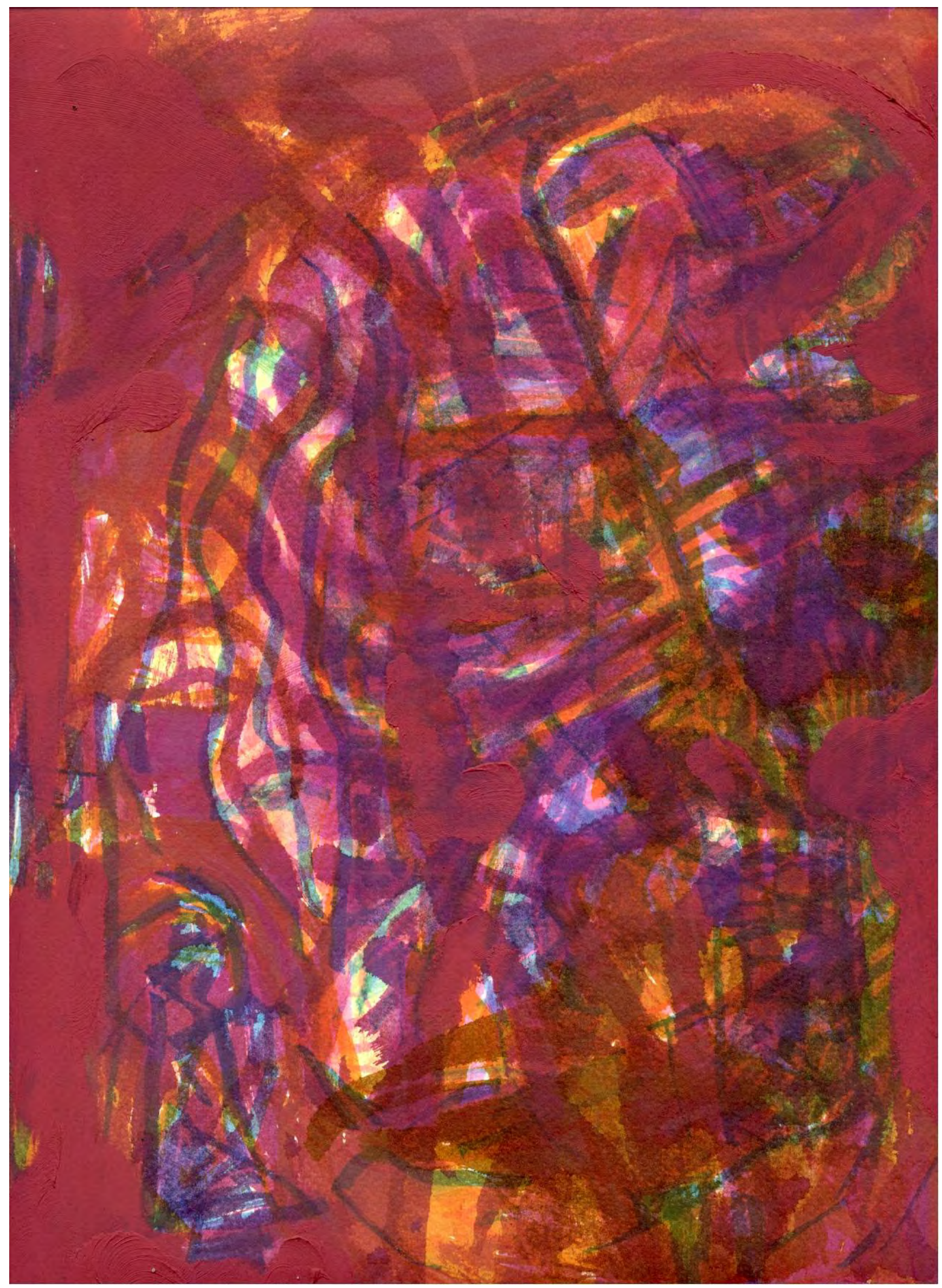


13.

Ponto é disseminação compactada.

0 ponto é o transbordamento involuntário da anterioridade de inumeráveis relações. Sim, mais uma vez, que a palavra 'involuntário' não parece ser muito própria a Klee. Penso contudo referir-me ao dado da potência germinativa que é alheia, até certo ponto, a quem pinta. Ponto-semente-nó. Pólen-germe. Compactaçãodisseminação.

Atravessado certo limiar 'transdutivo' do desenho ou da pintura, há domínios a percorrer onde a pessoa só precisa acompanhar o movimento das perfurações, dos empurrões, das desolações onde algo germina, das proliferações. Podemos pensar sobre isso, mas as linhas são um pouco alheias a isso, elas se autonomizam: só precisam eventualmente que estejamos lá, mais nada. As linhas são quasepensamentos que empurram, e os planos são o processo do quase-pensar. 0 plano é a instauração da irregularidade do pensar, o plano só 'funciona' pois é uma permanente corporificação, e aquilo que corporifica-mundifica, que encarna o processo, é a configuração assimétrica.

Pensei que aquilo que é transmitido pela transdução simondoniana é uma espécie de 'peça' mínima (sem ser atomista), espécie de peça-movimento, peça dinâmica, que contenha uma assimetria: pois assimetria é uma diferença de potencial. Ou seja, temos algum circuito de movimento minimamente estruturado que permite que aquela peça se 'derrame' de um domínio a outro. Chamo a peçamínima da transdução de 'configuração assimétrica'. Isso permite que ela mesmo se reconfigure processualmente no acúmulo de eventualidades. A 'peça mínima' é mínima não referente ao seu tamanho (não é um átomo), mas uma passagem de potencial, um rumor. Dado que a transdução concerne à gênese dimensional e escalar...

Então, já podemos dizer que no desenho - e na pintura - muito se passa. Esses exemplos são testemunhos corporificantes valiosos para quem trabalha com corpo, som e voz misturados, indiferenciados. 


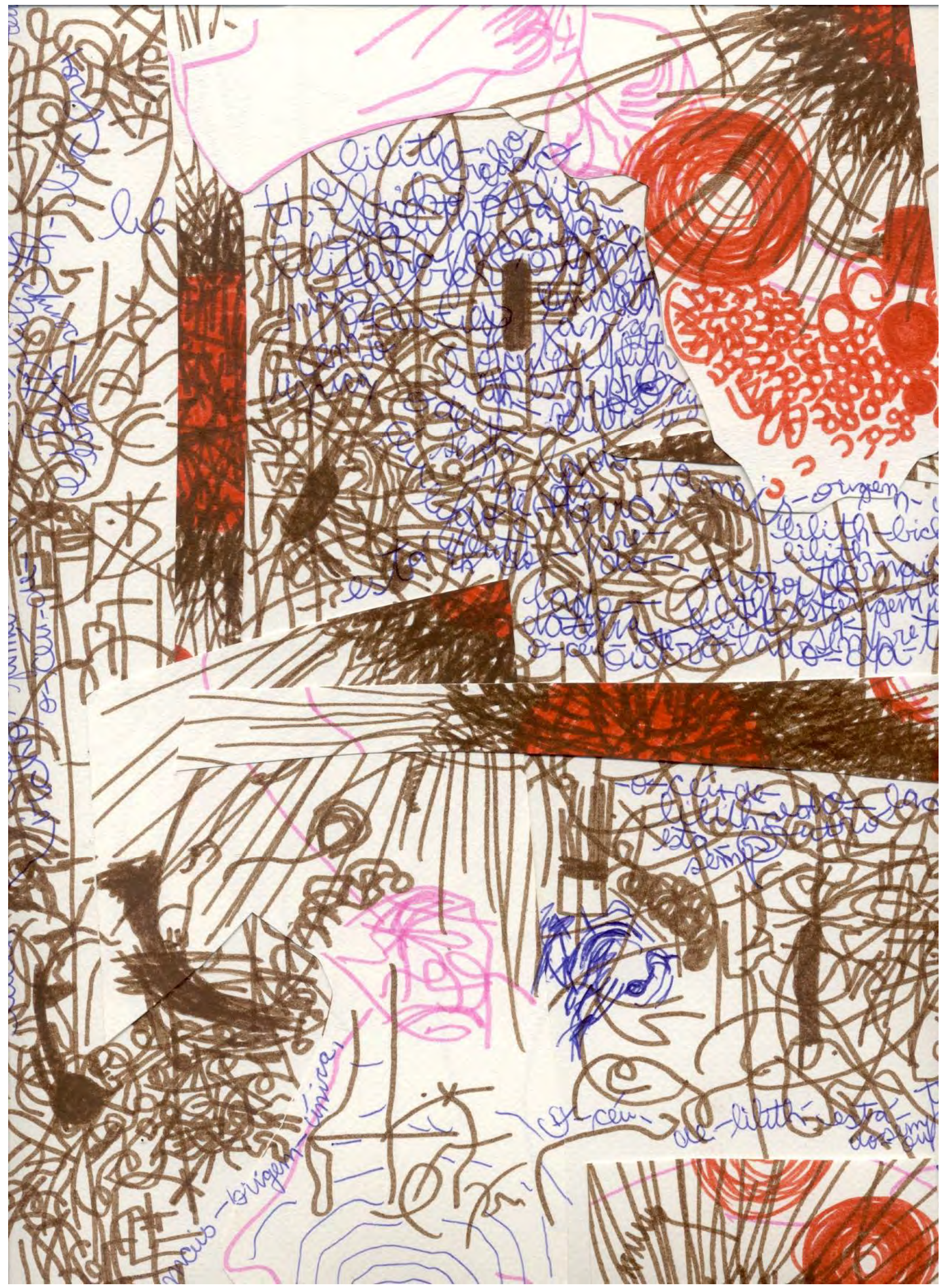


14.

\section{Germinação; semente dormente; não-semente.}

A observação de plantas que germinam nos deixa saber que um pensamento vegetal só 'sobe' o tanto que ele já 'desceu'. Existe uma pequena mas decisiva dança da semente. E a semente ou poro que germina, nesta hipótese, se lançaria à mineralidade do solo antes de se estender às intempéries da atmosfera aérea. Não sem antes combinar elementos aéreos e luminosos, químicos e minerais, que rompem sua dormência.

Não é exatamente isso: como uma pequena usina essa semente ou poro capta, come com mil bocas as forças heterogêneas do mundo e se compõe com elas, fabrica um corpo, corporifica. A reserva da semente é um pensamento dramaticamente qualitativo, e a ativação das bocas no sentido da conversão química, a passagem do ponto às linhas, é uma grande violência. Não sei se é o caso da linha estar dobrada no ponto, é mais o problema da própria gênese.

Os potenciais vegetais da semente dormente são um disparate: são pensamentos vivos perturbadores, tendentes a criar as próprias condições para 'enfrentar' o cosmos e criar um espaço duvidoso. As sementes dormentes são alheias e também são espécie de detritos. É quando Hermes rouba Apolo e enfrenta Zeus (hino homérico a Hermes), e é quando Prometeu enfrenta Hermes já a serviço da ordem de Zeus (Prometeu acorrentado de Ésquilo), e assim sucessivamente. 0 'nó interelemental-intraelemental' dorme na semente e talvez seja mais radicalmente afrontador do que a própria planta. Está na fronteira oposta do vegetal-mineral-aéreo, àquela fronteira da planta em desenvolvimento mais ou menos óbvio: rápida expansão, produção de massa viva a partir da fotossíntese... Aqui, na dormência, ela se torna mais explicitamente alter-orgânica. Pode ser que recue parcialmente para a terra, gerando novas relações intra-telúricas inter-vegetais etc. Como será este nó da planta quando da dormência da semente, no ponto condensado? Ainda é uma vegetal.

Pode ser que ele não germine. A maioria, aliás não germina: é coletada pelo ambiente como matéria nutritiva e como massa. A semente entra em outros ciclos. Quando é que uma semente passa a não-germinar? Gosto muito de pensar nas 
sementes dormentes, nas sementes que ficam e nas folhas secas - não penso que seja uma contra-germinação, no caso das que ficam. Mas uma ativação da coleta do mundo. Onde o mundo germina sobre o corpo, aderindo-o a outras compatibilidades, à heterogeneidade da terra, convertento-o parcialmente em grão-de-algo semidecomposto, corroído, comido, desolado, ocasionado, despojado. Os procedimentos de Anselm Kiefer atestam esse corpo coletado pela maquinaria do mundo. Enterrar um livro. Esperar... ativar uma passividade insólita. Esta é uma estratégia alter-orgânica, onde germinar é outra coisa.

A vida não começa com a semente, pois a embriogênese aconteceu. E a semente dormente ou não-semente é condensação e compressão de algo que ainda não é linha e plano. Compactação. Essas linhas e esses planos não estão à espera de se desdobrar, elas são linhas e planos da semente, do seu corpo. 0 ponto como nó é também uma passagem de gênese escalar. Na semente dormente e também no detrito há outros nós. 


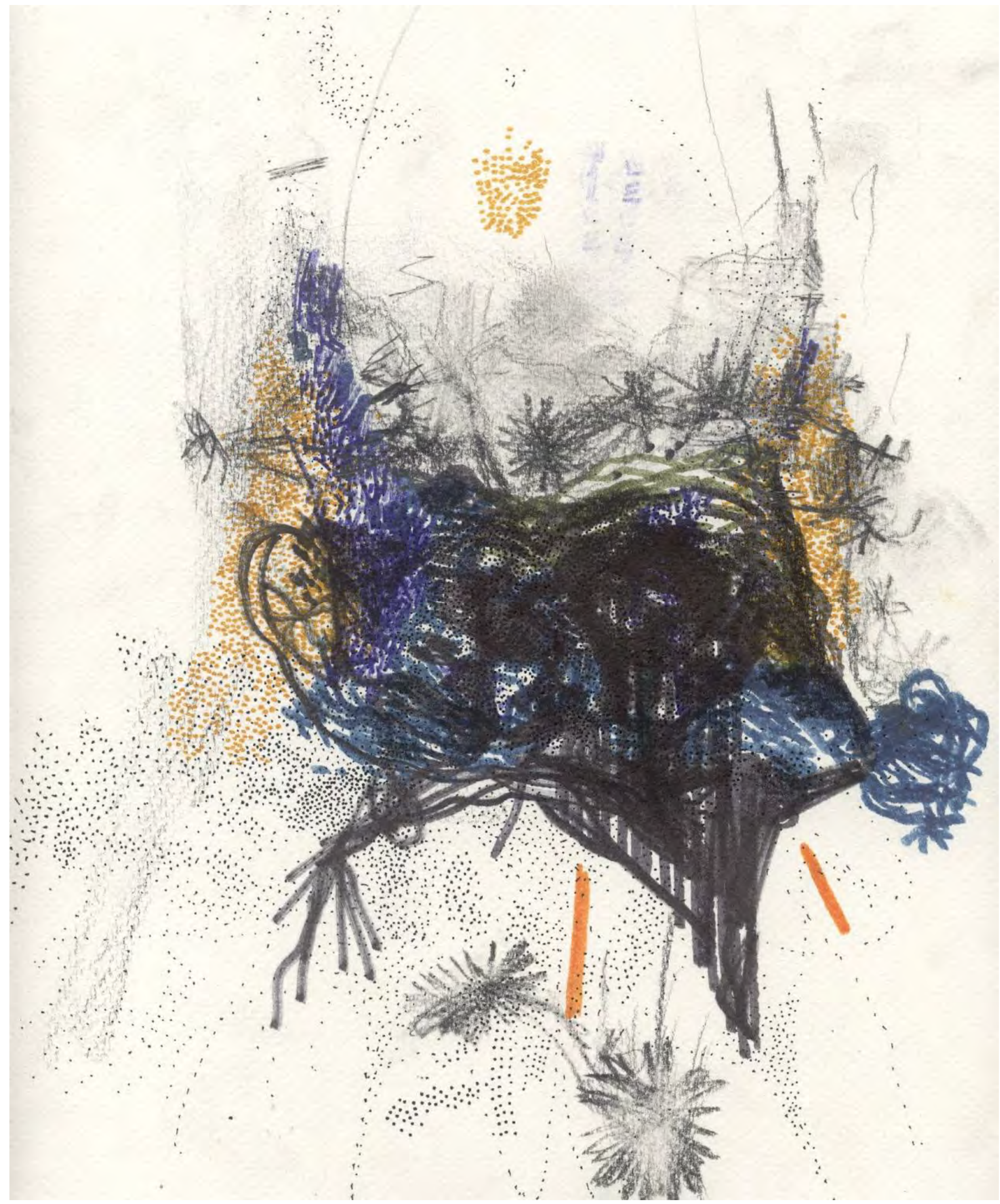


15.

Simondon se vale do modelo da planta como pensamento da ontogênese na medida de uma relação de relações (COMBES, 1999; SIMONDON, 2015). A planta é corporificação viva de um 'nó de entres', entre relação entre mundos e também mundificante. 0 Klee de Subirats parece intuir fórmulas paralelas ao abraçar o devir e ao deter-se diante de uma resposta final - nisto especificamente Klee se aproxima da filosofia da ontogênse de Simondon.

Se há pintura na filosofia, como sugere Deleuze em Francis Bacon, Klee é um efetuador dessa lógica no próprio ambiente da pintura. 'É muito maior seu interesse pelas forças formadoras, do que pelos resultados formais. Talvez, sem querer expressamente, converta-se, por essa razão, em filósofo' (Subirats, op. cit., p. 174) De modo paralelo com que Uno concebe Hijikata como um filósofo da carne, Subirats vê em Klee um filósofo vegetal. Seguem recortes do itinerário de Subirats que figuram Klee em sua filosofia efetuada conjuntamente à pintura:

A realidade interior da natureza é, em primeiro lugar, a da sua gênese, do seu devir. 0 pintor reconstrói o mundo natural como processo e movimento. Nessa medida, a obra também é concebida como gênese. (op. cit., p. 162) [...] Trata-se, para ele, não de invocar um mistério de um poder esotérico, mas do fato empírico de uma comunidade elementar entre o homem e a natureza que a arte em geral possibilita e a que ela mesma tende. (p. 163) [...] Talvez a arte possa aproximar, par Klee, a vida do Homem moderno à realidade natural que este deixou às suas costas. Mas já vimos que, ao chegar ao umbral de seu reino, 0 artista retém 0 fôlego: as origens nunca se tocam e nunca chegamos às fontes. 0 artista tem de recomeçar o processo infinito de criação. (Ibidem) [...] A concepção da natureza como realidade interior, a repetição artística de seu devir, a realização da obra como alegoria da sua natureza, tudo isso tem outra consequência: a obra também concebe a si mesma como um processo, como um devir. Porque trata de adentrar na história infinita da natureza, também se torna narração infinita. "A obra de arte é, em primeiro lugar, 
gênese, e nunca é vivenciada como um produto" - são as palavras de Klee [...] A obra não é resultado, é gênese, devir, processo, busca. (p. 164) Klee é [...] um pintor que renuncia aos grandes princípios e, como bom filósofo, nunca escreve seus conceitos, nem suas categorias formais, com maiúsculas (p. 167)

Salvo que as noções mais ou menos apartadas de homem e natureza nada têm de simétricas e se põem em terreno alheio ao que se passa, como pude lançar na caminhada-catástrofe. Salvo isso, os elementos de uma filosofia vitalista, da gênese e do devir, se põem presentes. Salvo também que o posicionamento de 'busca' do artista ao lado do devir seja, no meu ver, problemático como regra, dado que o devir às vezes vem como um arraste da vontade, uma contrabusca. $\mathrm{Na}$ individuação vertical (PELBART, 2017; MARTY, 2002), por exemplo, experiência-limite, às vezes mais uma 'contra-experiência', experiência de desconstituição incontornável, vemos casos desse arraste catastrófico. 0 espaço é impossível de situar: poderia ser insinuado entre uma semente dormente e uma não-semente? Nessa modalidade de individuação, na experiência de dolorosa dilatação que a qualifica, e na trilha duvidosa de um conhecimento no estatuto de arte, verificamos algo. Que um devir desconhecido da individuação na contra-individuação nada ter a tratar com a busca voluntária, heroica. Será que as minhas tentativas de pensar são totalmente estrangeiras a Klee?

0 caos, como 0 oposto, não é o autêntico e verdadeiro caos real; 0 caos só é um conceito determinado localmente com respeito ao cosmos. 0 caos propriamente dito nunca chegará a estar num dos pratos da balança, mas parece para sempre incomensurável. Pode ser o nada ou uma coisa adormecida, pode ser a morte e, também, o nascimento. [KLEE apud SUBIRATS, p. 169. De das bildnerische Denken (o pensamento criativo, 1920), p. 15] 


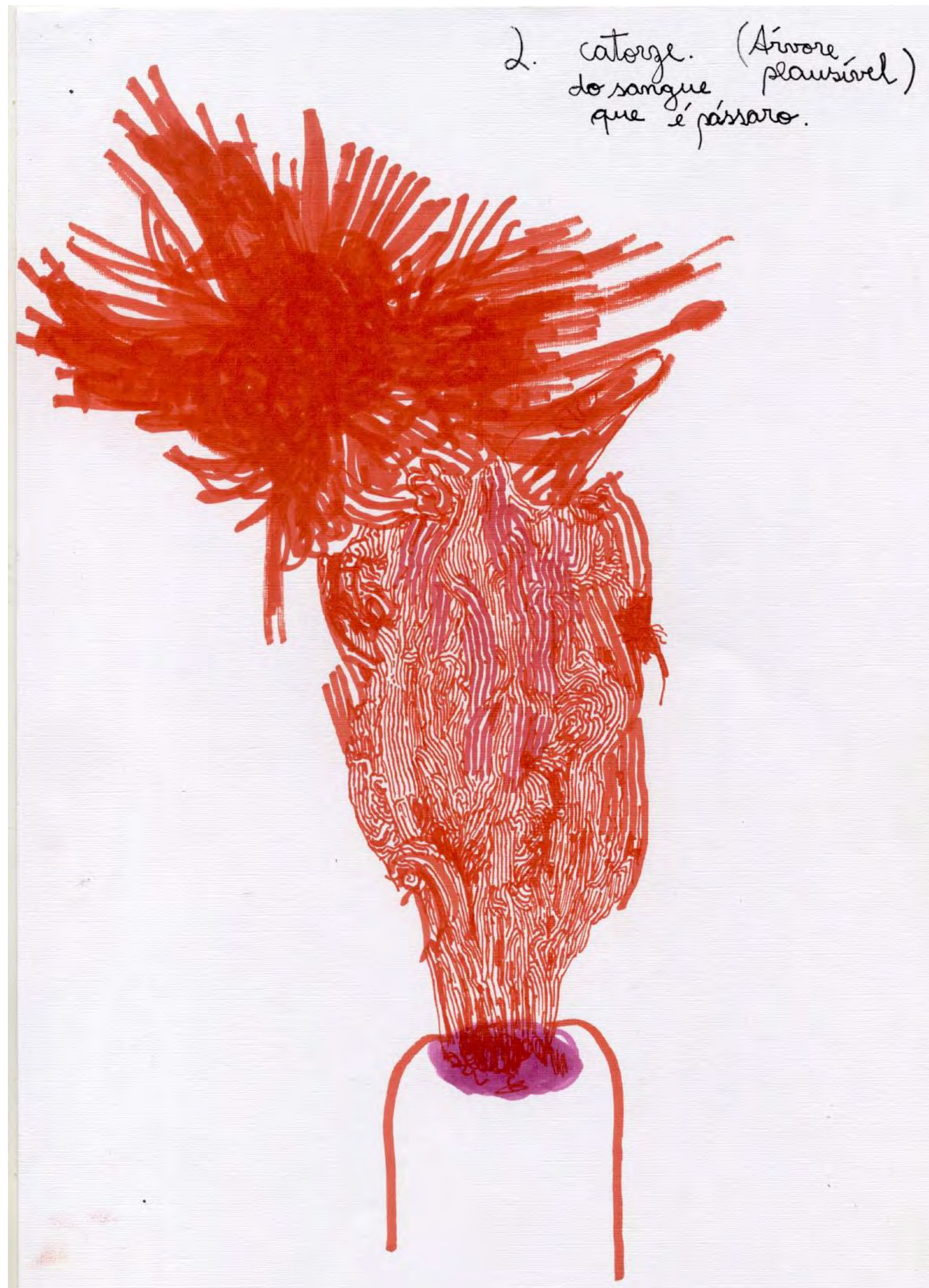


16.

No texto a virada vegetal, de Emanuelle Coccia (2018), propõe-se uma cosmologia radicalmente imanente a partir do pensamento vegetal ${ }^{130}$. Pois os vegetais aprenderam a produzir grandes porções de massa viva, que passaram a constituir 0 mundo que habitamos; pois o processo de conversão química das plantas configura a atmosfera, processo preparado por outra escala de vida: os micro-agentes. Coccia pontua consequências cosmológicas: 'não pode haver reflexão sobre um objeto mundano que já não seja reflexão cosmológica' (p. 11). É um mundo, uma mundificação que não para de começar. 'Toda forma de vida é também forma de mundo, que ela a um só tempo produz e contempla' (p. 12). A seguir, Coccia propõe uma espécie de gênese de historicidade da semente no logos spermatikos dos estóicos, que vem replicar polemicamente à hipótese cosmológica do Timeu de Platão. O pensamento germinal, a razão seminal, corresponde a uma doutrina onde 'a razão é como uma semente, pois todo grão é relação íntima e imanente entre matéria e forma, sem exigir um técnico, um artesão que conecte os dois elementos' (ps. 14-15). Ou em outro trecho: 'no grão, de fato, o sujeito, o objeto, o meio e o processo do devir (de geração) coincidem na mesma porção de matéria' (p. 15), zona pontual, segundo Coccia, também de coincidência e imanência entre forma e percepção. Leio aqui ressonâncias com a noção simondoniana de transdução... senão pelo fato de que a ontogênese não tem imagem prévia. Recorrer a uma imagem dominante, ainda que seja aquela da semente, é recair em resíduos do esquema hilemórfico (forma+matéria), que busca adequar a produção a um modelo. Uma imagem de ontogênese só pode individuar em conjunto. Por isso prefiro a germinação à semente: um detrito também germina, mas à sua maneira. Simondon, em seus

\footnotetext{
${ }^{130}$ Cabe, contudo, a despeito da profusão de propostas provocativas de Coccia, a ressalva de que não basta imaginar para tangenciar o pensamento vegetal (imaginar um corpo vegetal sem extensão nem meio, imaginar em si o estatuto vegetal - florescente, dispensatório e contra-utilitário - dos genitais etc). Não se trata, para mim, da imaginação como um pensamento domesticado. Teria de se tratar de uma imaginação em regime de risco, um pouco mais difícil de traduzir. Ainda penso que o campo artístico oferece possibilidades de lançar-se a uma etnografia do impossível, do opaco, do invisível. Pois ao deparar com tentativas de falar sobre experiências inter-específicas, inter-domínios, inter-reinos, ficamos atados em constrangedoras situações de autoridade científica, posto que o constrangimento necessário seja o próprio contato. Lembrei da pesquisa fracasso, de Bruno Moreno.
} 
exemplos e modelos com base no 'paradigma físico' (a solução cristalina, a planta, o tijolo de barro, a ressonância...), busca aproximar-se de uma experiência de ontogênese, mas não oferece uma resposta final. 


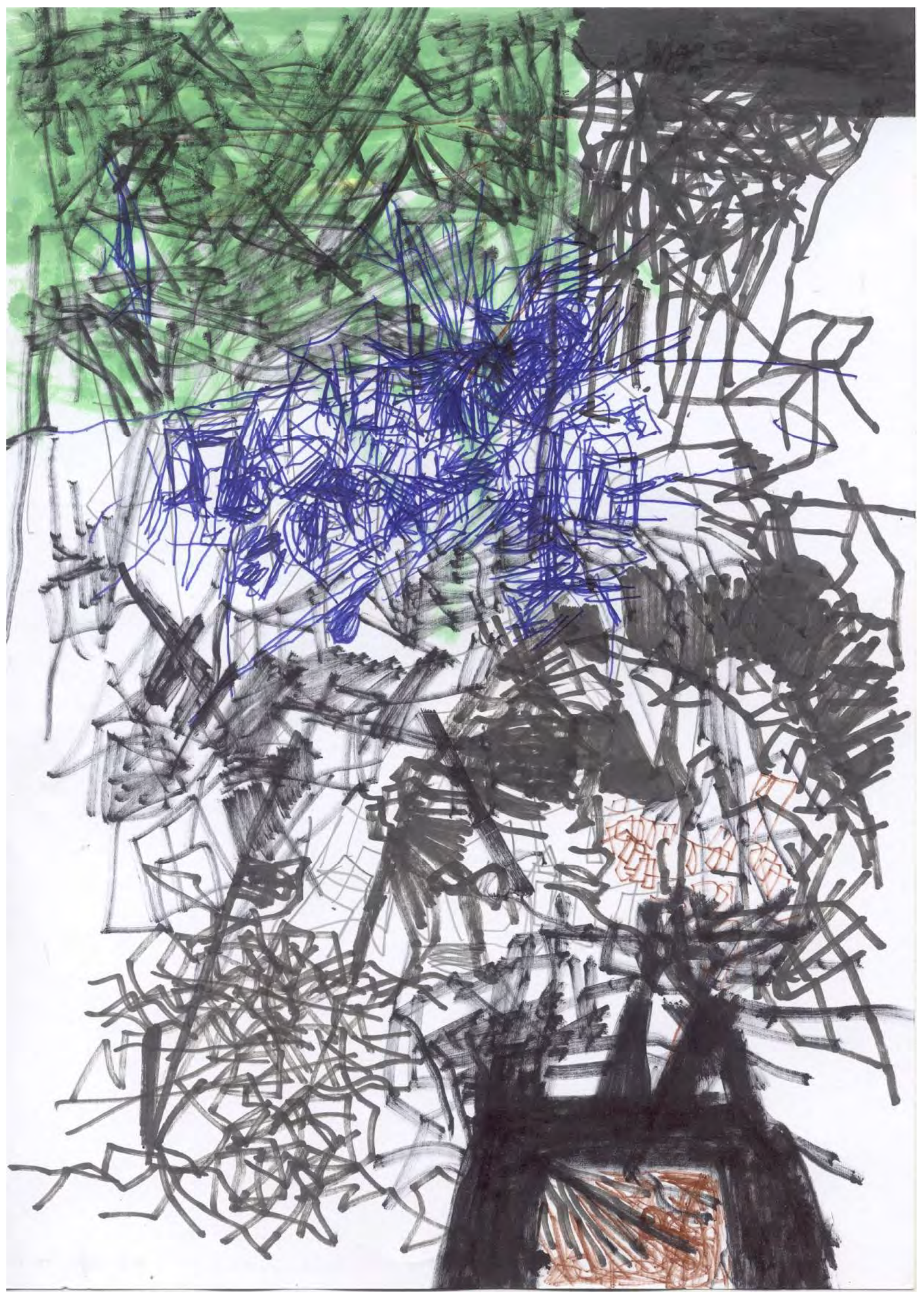


17.

Coccia, mais ao final do texto, prossegue com uma outra tradição, esta romântica, a da flor (e aqui é inclusive um outro ponto de tangência entre Coccia e Subirats).

Com a ressalva da imagem dominante para ambos os termos da comparação, 0 Klee de Subirats parece partilhar dessa potência germinal da semente que Coccia atesta. Em Klee, essa potência talvez constitua seu distinto abstracionismo:

Ponto como semente e nó de forças e centro de relações entre os elementos; ponto como alegoria da criação. Abstração? Sem dúvida, mas num sentido muito diferente ao que Kandinsky deu a essa palavra (SUBIRATS, op. cit., p. 159) [...] Para Klee o ponto-semente é material, seus laços com a terra, 0 ar ou a luz são sensíveis. E o ponto é a alegoria dessa semente na obra de arte. Em Kandinsky, o ponto pictórico está livre de qualquer outra referência que não seja, segundo as suas palavras, "sua própria interioridade". Está livre? Para o pensamento abstrato de Kandinsky, M ondrian ou Malevitch trata-se de uma libertação; para nós, a palavra liberdade deveria ser empregada com maior cautela. / [...] 0 ponto como unidade geométrica separada de qualquer referência à natureza. Não é exatamente o caminho contrário que a obra de Klee percorre? / A mesma coisa poderia ser dita a propósito da linha. Para Klee, a linha é a expressão da força material do ponto, manifestação da sua vitalidade e do seu encontro com outros elementos, que designa e mostra: nela incidem a terra, a água, a luz, o vento, cada qual com a sua influência específica; ou, então, a linha colhe a influência dos momentos psíquicos e empíricos de quem a traça. (p. 160) A abstração em Klee é o caminho que Ihe permite chegar, assim, a este nível fundamental ou elementar das coisas (no caso deste quadro, a estrutura simples do crescimento floral [quadro 'Ômega 6: etapas das plantas', 1927]), e não, ao contrário, postular e articular uma realidade separada e transcendente. (p. 174) 


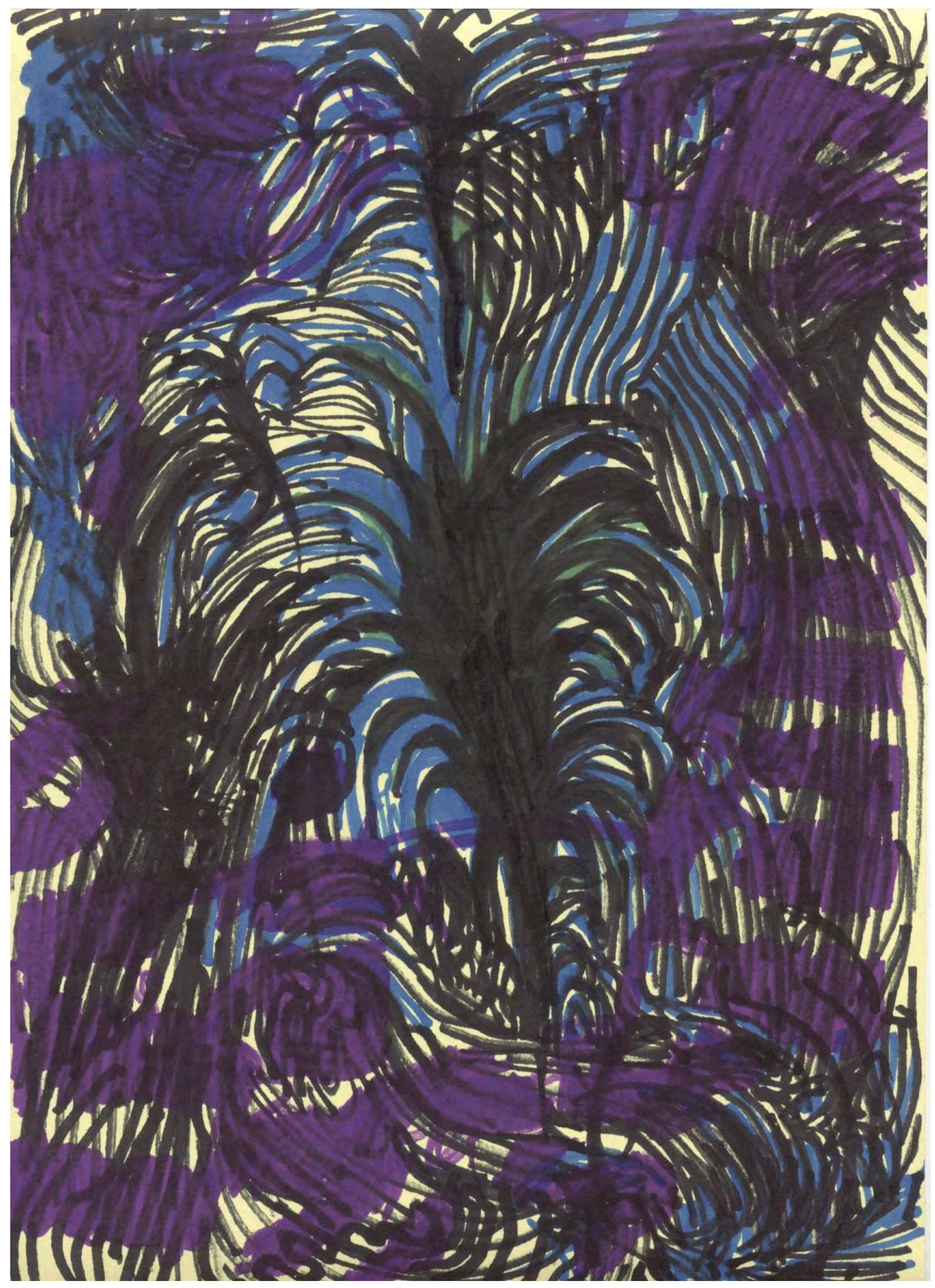


18.

Trata-se, então, no Klee de Subirats, da ontogênese de uma estrutura viva vista o mais intimamente possível. 'Estrutura íntima do organismo vegetal' (op. cit., p. 170). Aqui, os recursos de 'íntimo' e 'interioridade da natureza' se combinam. Intuo que seja algo da ordem de se viver o brotamento conjuntamente aos elementos vegetais e minerais. E a pintura como elemento dessa individuação, deixando ver, no momento germinal de sua dilatação, a disseminação de mundos. A frase transcrita do próprio Klee 'este mundo não é o único possível sob a forma desta figura' (p. 175) atesta para uma escuta improvável dos mundos.

Subirats então se pergunta acerca dessa intimidade. 0 vegetal na sua potência germinativa oferece uma 'raiz terrena' do pensamento germinativo. No entanto, há um outro fator de gênese, aquele que Subirats designa como cristalino, que comunica uma 'comunidade cósmica', elemento aparentemente dessubjetivado, desafetado, mas que, ao contrário, comunica invisíveis. Daqui também brotam coisas, como a narrativa espiritualista e a afetividade insólita, próprias às configurações geométricas de Klee. 'Sorrisos que ardem, símbolos que consolam o espírito' (SUBIRATS, op. cit., p. 181). Chaves de um prazer insuspeito. 


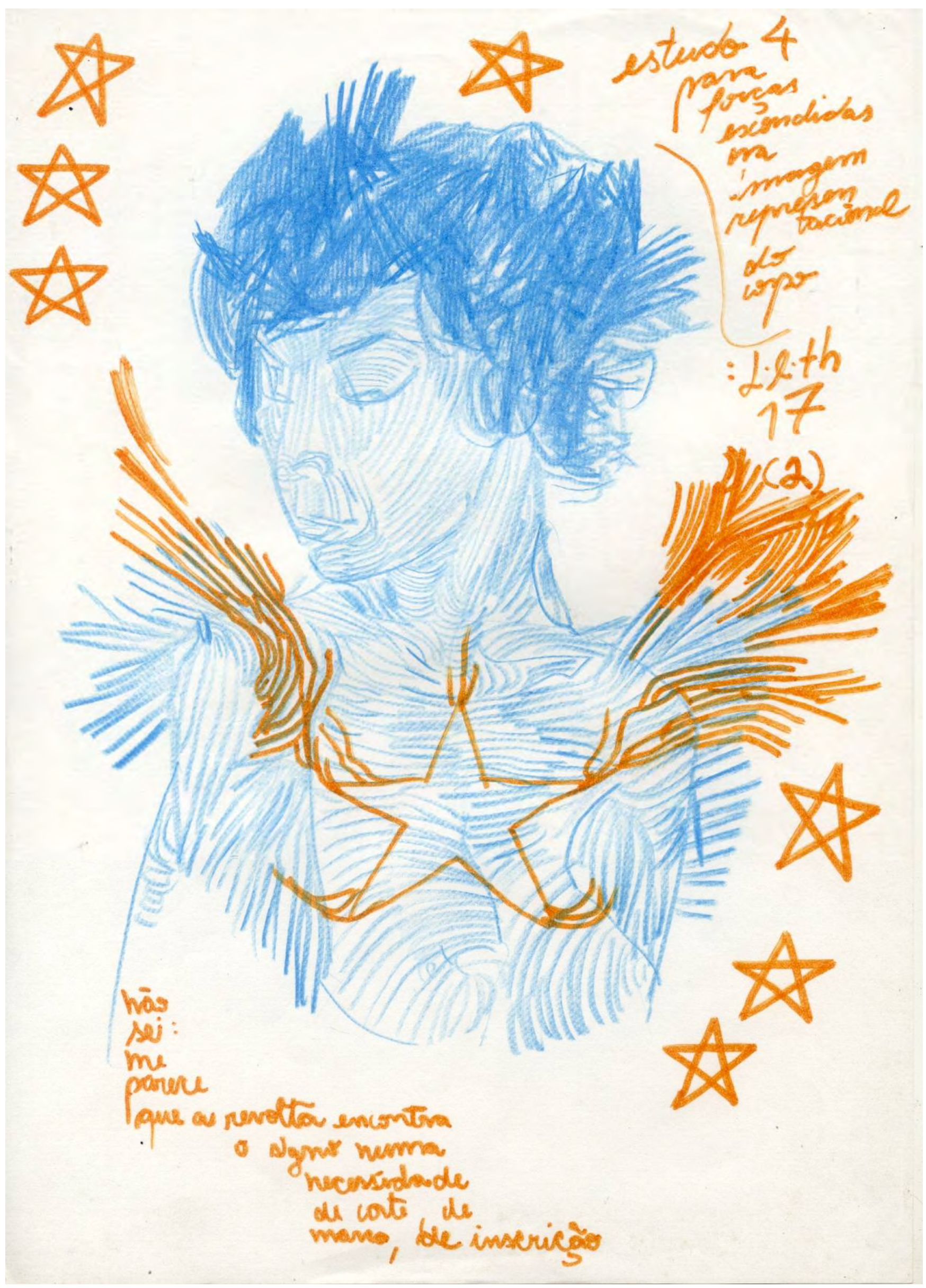


19.

É curioso que Simondon contemple o modelo da solução cristalina na sua filosofia da individuação. 0 cristal germina. 0 germe de cristal.

Como supõem Subirats e Klee, estão acentuados nessa pintura os tons de um processo generativo. Eu vejo paralelismos, no tocante a isto, a Simondon. Contudo, acho que há ainda algo a se pontuar acerca da fórmula 'natureza infinita', e mesmo da relação entre as entidades 'homem' e natureza'. A natureza poderia ser infinita enquanto equivalente do próprio processo de germinação, e não enquanto uma entidade transcendente. 0 próprio Subirats parece supor isso ao confrontar Klee a Goethe, a imagem transcendente e originalidade última da natureza expressas neste último. Mas o intelectual catalão parece também operar na sua análise certa 'purificação' de domínios ao aproximar a experimentação de Klee. É um típico vocabulário dialético que opera sempre com dualidades de termos colocados previamente. E o processo de ontogênse é relacional e produz relações, bem como 0 pensamento vegetal possível.

[este último desenho me incomoda, por apresentar um corpo demasiado 'acabado', pronto, próximo ao produto. 0 concreto é justamente o inacabado] 
mudan a हु, 1 . relaçäo com 5 क $\theta$ vazio. of

2. desenhor sem projetos

sem promessas

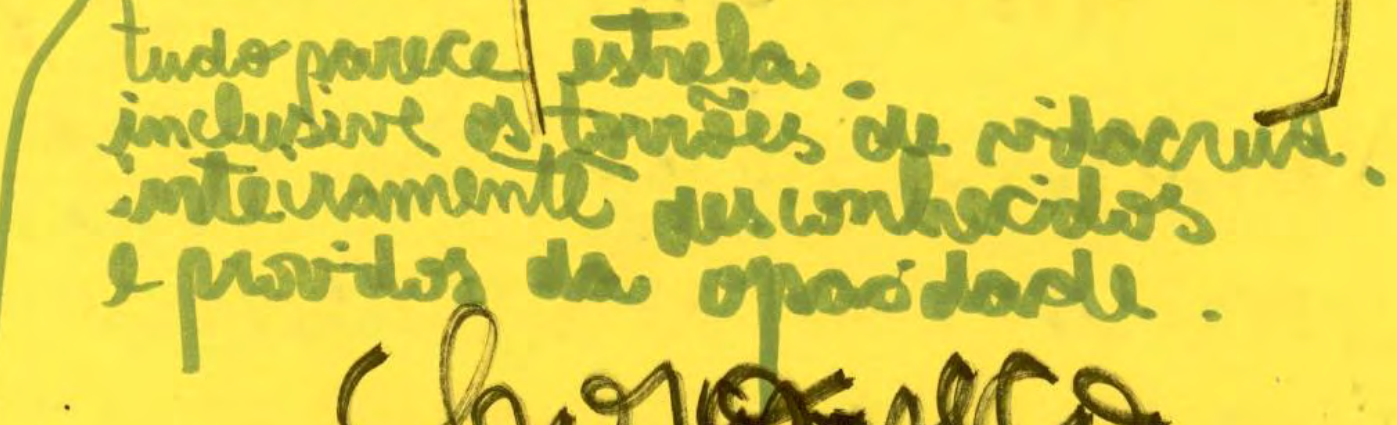
Crurorseco
(cnzas) 
20.

Germinação, brotamento.

Simondon, Jung, Coccia, Subirats, Klee...

Após passar por traços desse instinto dizendo respeito à sustentação e proliferação da vida. Após passar por trilhas da biologia vegetal e mineral (ou seja, alter-orgânica) nas investigações de Klee.

Então posso partir para a prática do instinto de germinação, de brotamento, esse que às vezes guia para a destruição, corrosão e desconstituição, com vias a um corpo desconhecido. 


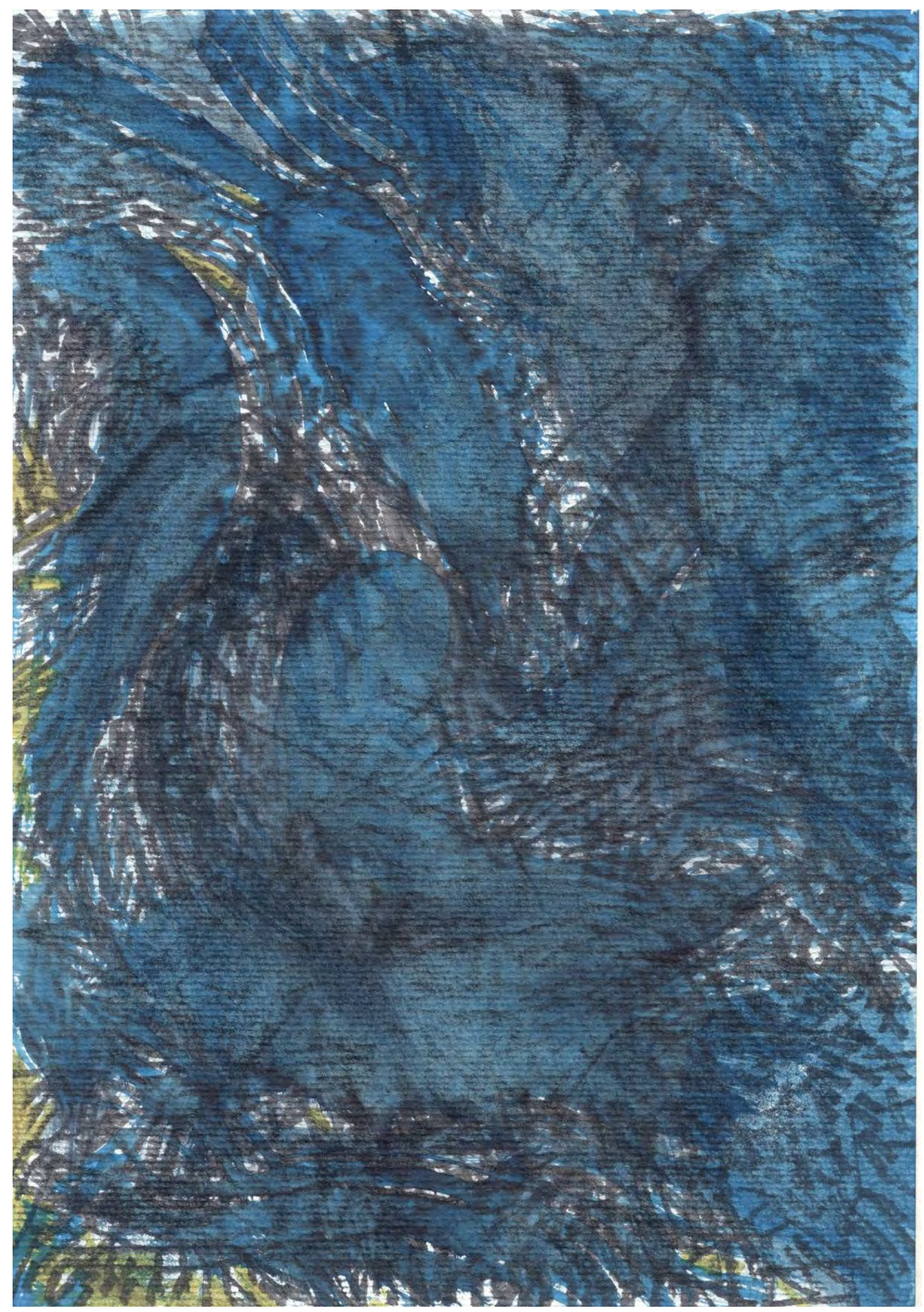


21.

Instinto de germinação. 


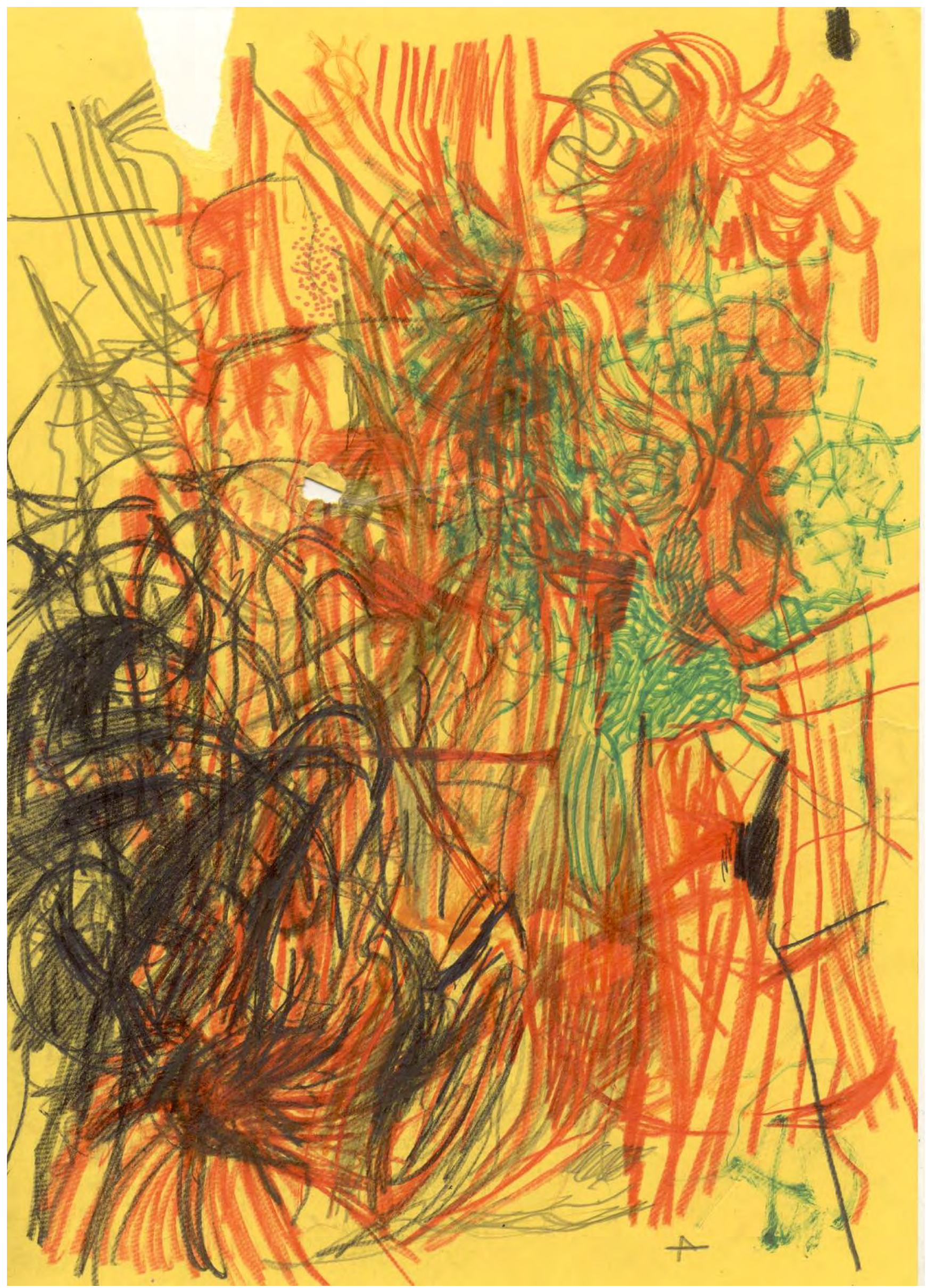


22.

Símbolos que acompanham, que aconselham; aprendizado do desenho, mas onde é o desenho que 'aconselha'. Um modo de conhecimento que, paralelo ao Ser da Orla, traduz uma situação onde não sou eu, não é o 'eu' aquele a extrair o conhecimento de uma experiência empírica e observação. 0 desenho guia, talvez, a um outro desenhar. 


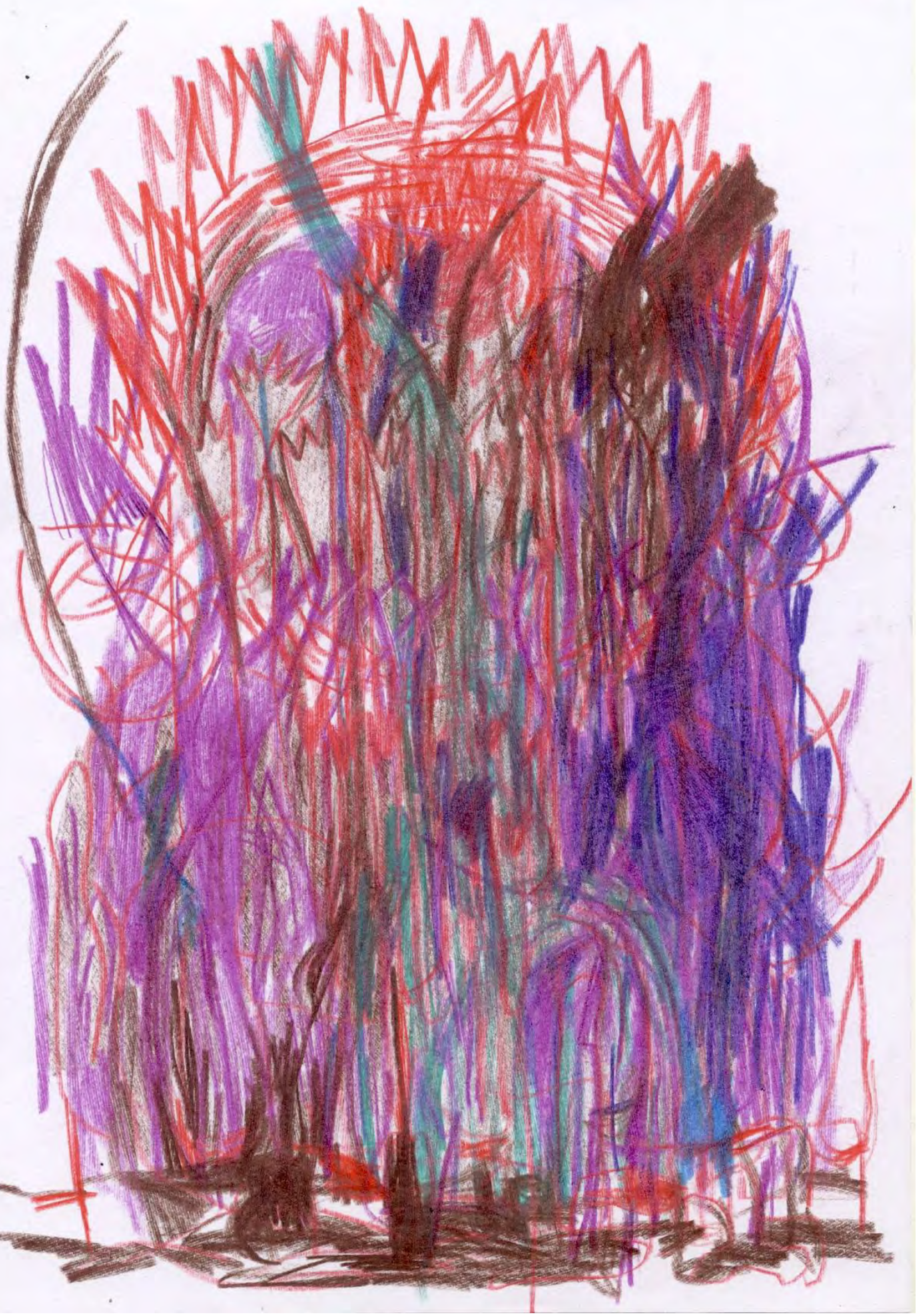


23.

Um dizer é a maior lentidão do corpo ${ }^{131}$. Parece rápida pois ressoa e germina. $M$ as, de fato, é uma coleta de vozes à maneira das rochas. Aqui me vejo praticante da 'drástica plástica', o gênero secreto, com palavras desconhecidas.

0 mito é mais inconsciente do que consciente - nos deixa saber Jung nas conferências de Tavistock (1935).

Como ser um testemunho da proliferação e coleta de vozes ínfimas? Como não sê-lo?

A pessoa que me lê poderia me perguntar o porquê da recorrência de Jung. Gostaria a isso adendar que me interessa qualquer psicologia criativa, e de preferência o mais distante possível da diagnóstica médica que visa responder e não perguntar. Além de Jung, um outro exemplo é Christopher Bollas, que opera sua clínica de forma múltipla e na chave da processualidade da estética de uma existência.

131 Uma investigação relevante nesta chave é vestígios do dizer de uma escuta (repouso e deriva na palavra), de Juliana Jardim Barboza (tese de doutoramento, 2009). 


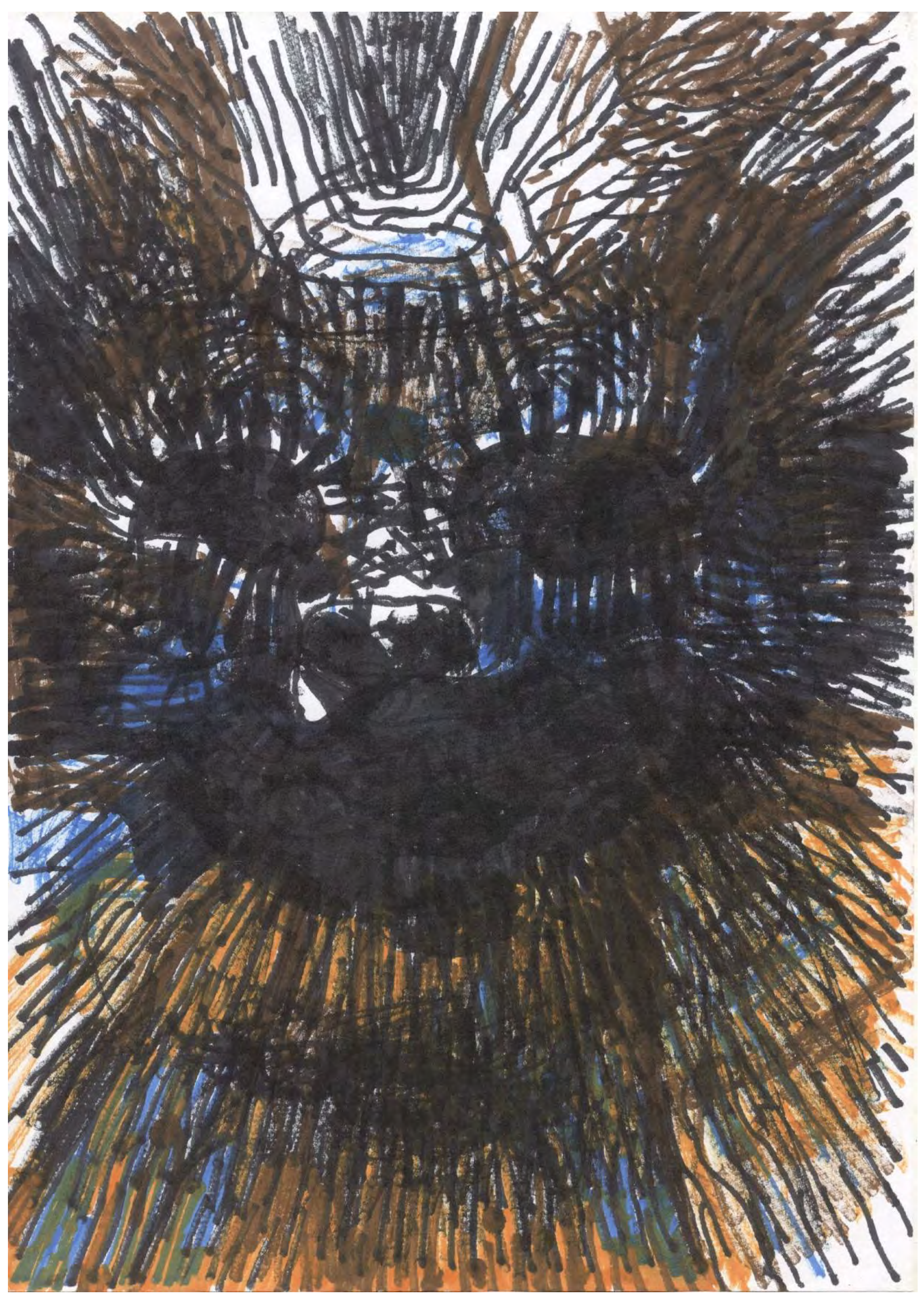


24.

Aqui se introduz o problema da coleta de vozes, a antena de vozes. 0 alter-orgânico supõe, na lógica da germinação, esse sujeito deslocado do 'eu', e amplamente heterogêneo, um monstro coletador de mitos (agora sim, mitos) e das imagens de víscera.

O que quero dizer: que os instintos de germinação e de cadernos é a força das imagens arquetípicas e, ao mesmo tempo, de quase-nadas, de vozes ínfimas. 

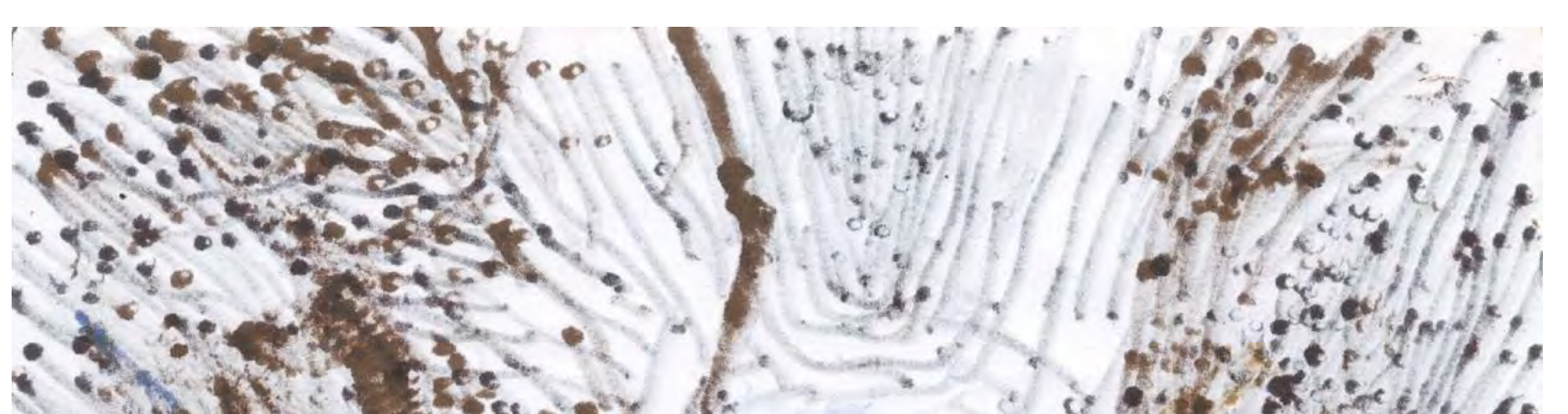

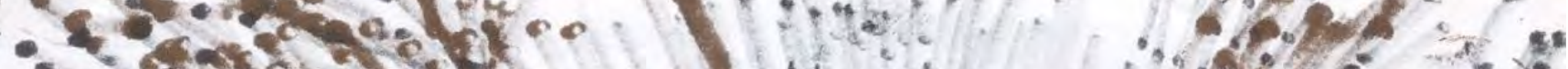

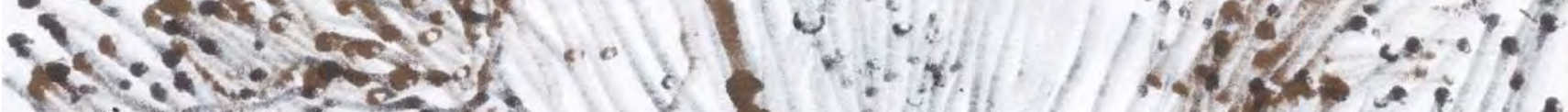

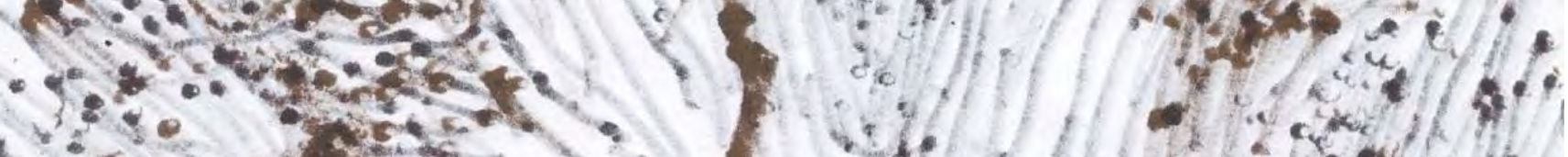

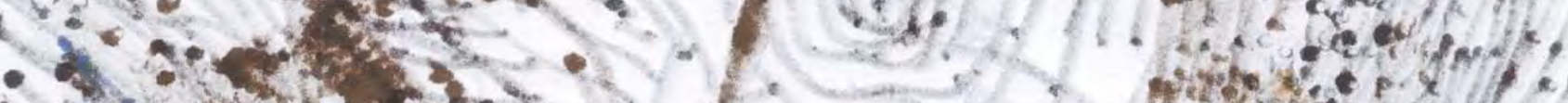

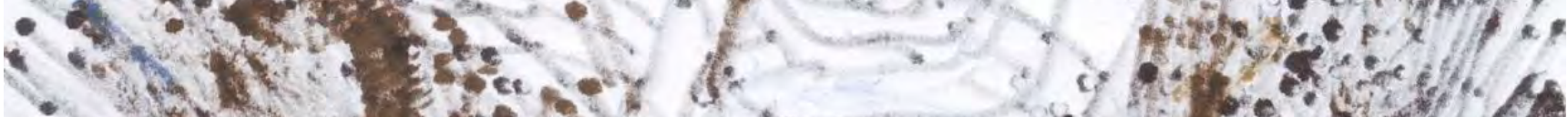

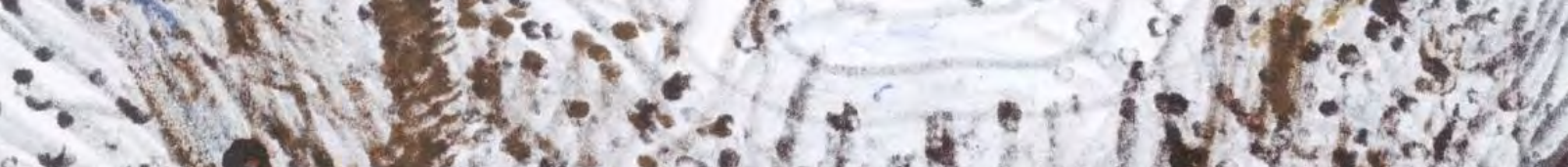

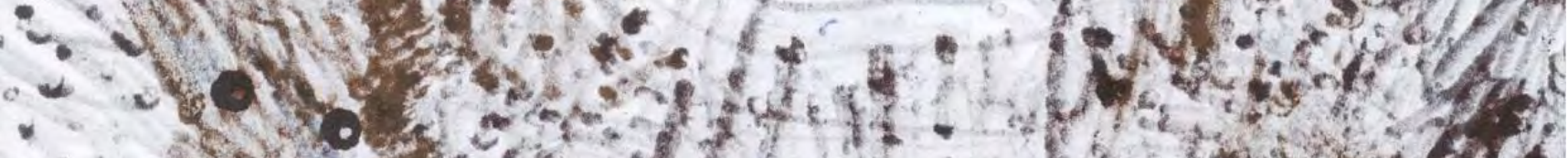

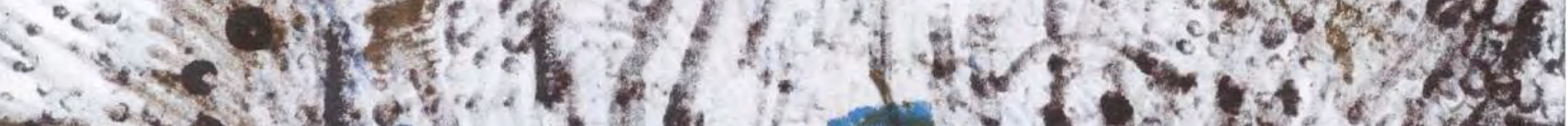

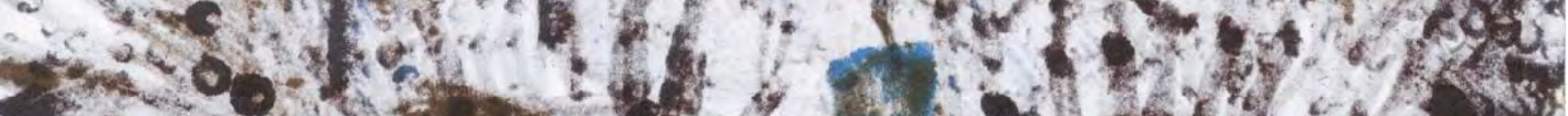

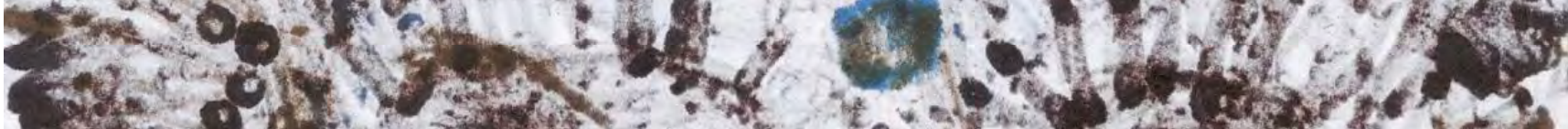

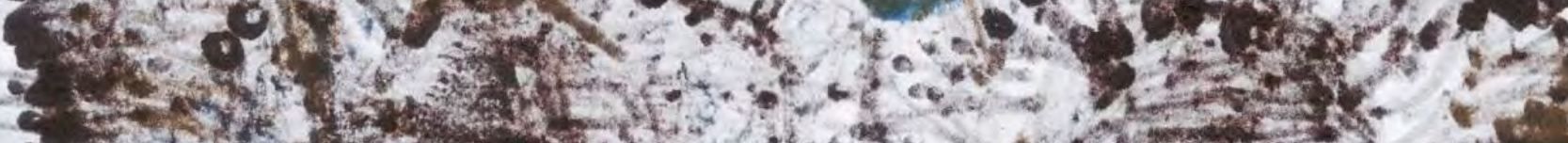
C.

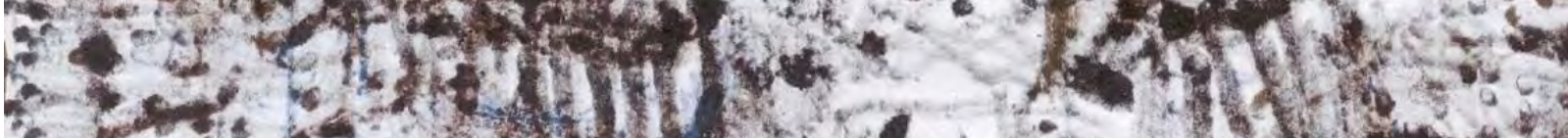

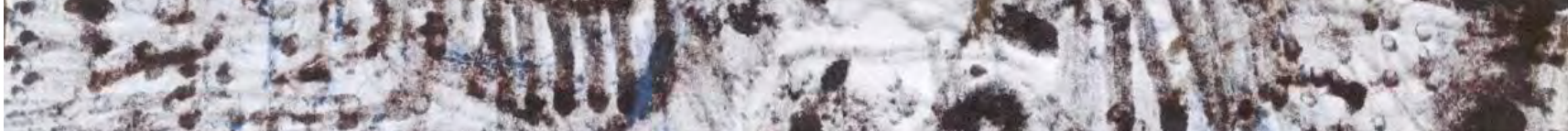

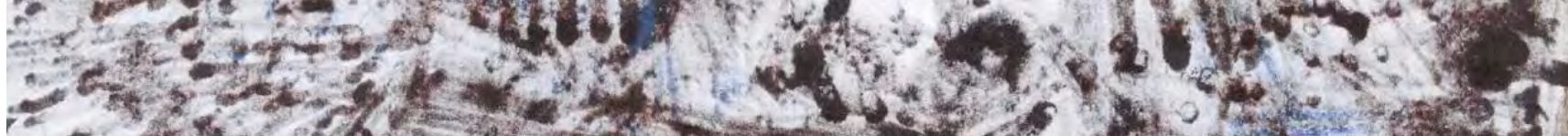

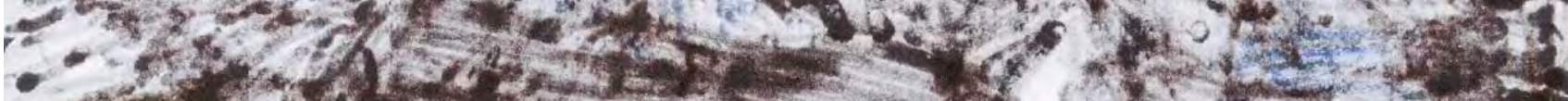

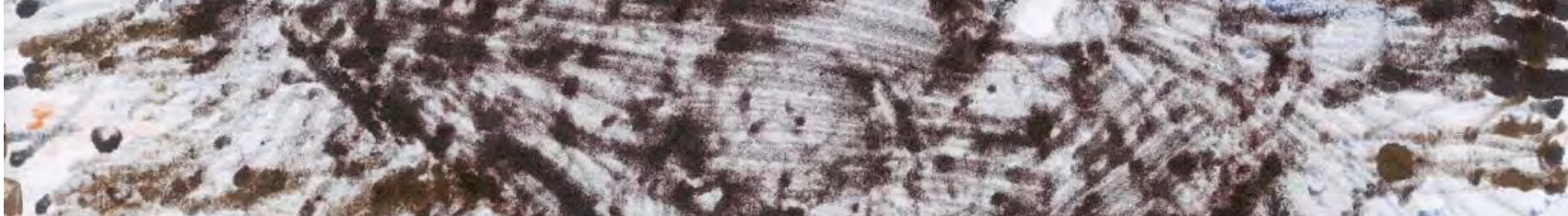

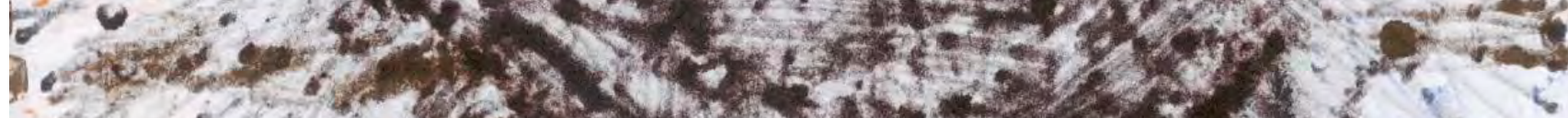

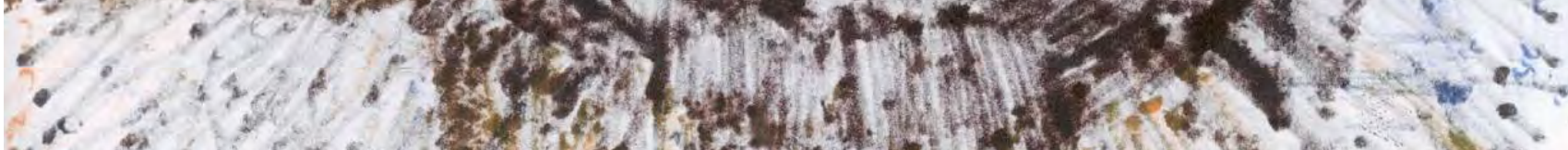
4.

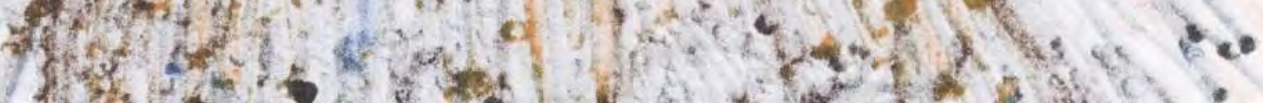

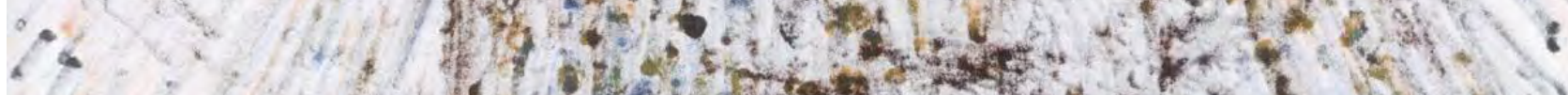

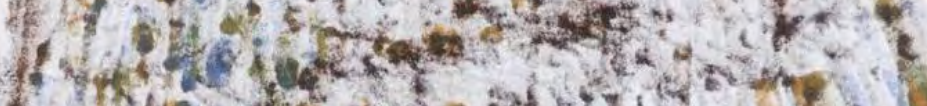

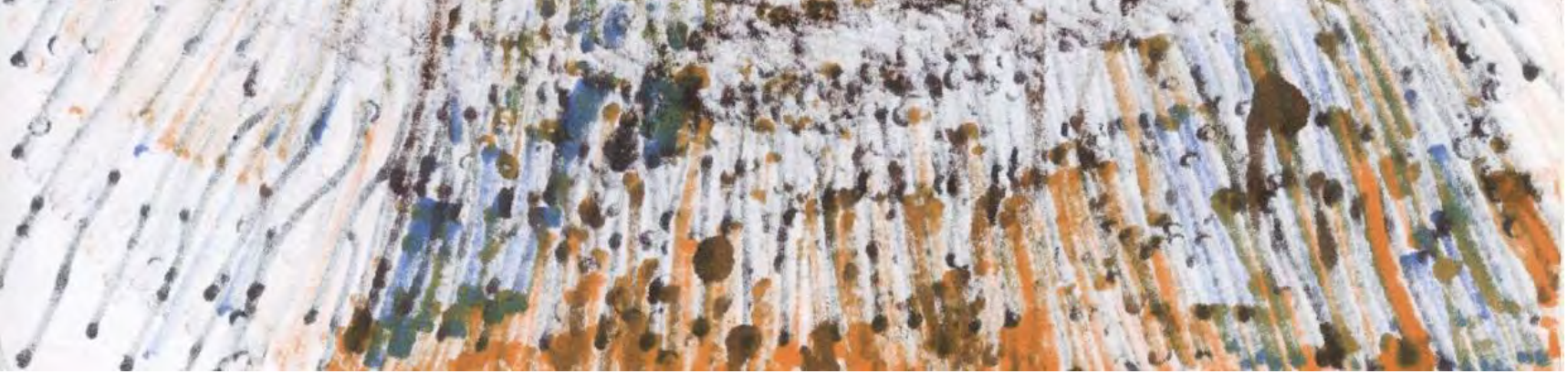


25.

Em o rumor também é um deus ${ }^{132}$, Marcel Detienne contempla o poder germinativo das fábulas contadas à boca pequena, sub-contadas, ou mudas, ambientais. Uma palavra meteorológica... é o rumor uma germinação, uma multiplicação. Um 'monstro' coletador e ressonador de vozes ínfimas? Detienne capta a imagem do monstro do Rumor (Fama, DETIENNE, 1991, p. 111) na Eneida de Virgílio. O helenista Detienne persegue as imagens, quanto tentam agarrar com palavras o deus Rumor:

E somente permitem falar dele imagens que evocam sua natureza quase meteorológica [...] o rumor é a brisa que sopra de regiões salubres, é o eflúvio, o hálito da terra e das águas, e penetra nos seres vivos pelos olhos e pelos ouvidos. Como uma voz pública que seria o elemento mais sutil do ambiente, e do qual o essencial está no quase silêncio daquilo que Platão chama de "uma palavra muito pequena". Em cada pessoa ele é uma lei não escrita e que não tem necessidade alguma de falar [...] É no rumor, e somente nele, que se aloja o segredo da unanimidade profunda, das crenças mudas partilhadas em comum, da adesão inteira de uma cidade a princípios, a narrações fundadoras, a isso que Platão chama de "mitologia". [...] Mas também convicção de que o rumor, longe de ser uma alteração menor do real, é uma grande divindade subterrânea, constitutiva daquilo que se tem por verdadeiro, das crenças profundas nas quais a tradição viva vai buscar água; e de que suas modalidades de transmissão e de difusão, pondo em jugo a aprendizagem pelo ouvido e pela boca, são meios, mídia conspiradora e permanente, de uma tal maneira que não se pode achar coisa alguma de mais certo na sociedade. (DETIENNE, 1998, ps. 112-114)

Nessa voz meteorológica, ambiental, feita de muitas pequenas vozes, reside nossa segunda hipótese vocal. Uma outra voz, conforme vimos, é aquela que não pertence a ninguém, a voz que 'salta' diante de Nijinsky pela alegria e o terror da

132 Ensaio pertencente ao livro a escrita de Orfeu (1991, em francês l'écriture d'Orphée, 1989). 
alegria. E talvez a voz que salta corresponda a esse prazer dobrado, ressonante em si, que seja uma alegria. Prazer duradouro poderia ser a corporificação da ressonância da alegria, como vimos no devaneio de Rousseau. A caminhada-catástrofe, a caminhada desconstitutiva do som, a caminhada-detrito eram nomeações da sua prática generativa da própria escavação. A constituição do processo desconstitutivo. Mas aqui, neste segundo caso de voz insuspeita, trata-se também de gerar corpo estranho, mas talvez coletor; desenhar, solidificar os textos para perfura-los e habitá-los: acoplamentos. Os furos disseminam algo. Uma crua jardinagem? É polinização, escultura germinativa, escavação que propaga, ou ainda raspagem que instaura uma zona (para falar com Francis Bacon). Propagação, disseminação, polinização de gestos. Composição de zonas. Algo caminha sobre mim. 
224

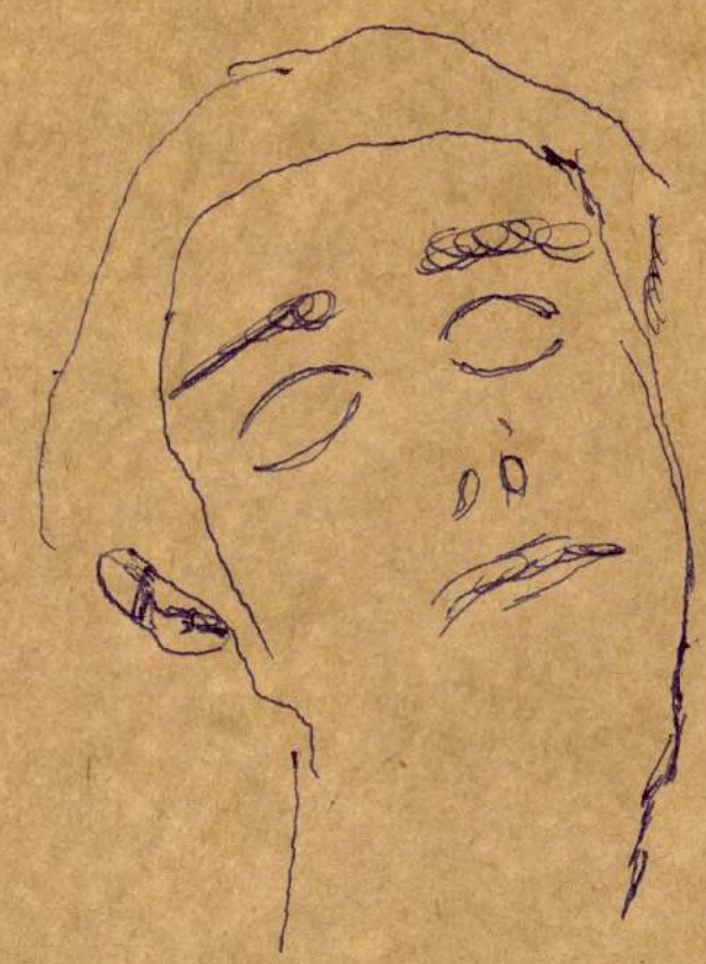
cim
sapel
que
dorme.

boa noite!

$y$ 
26.

Daqui prosseguimos com nossa própria coleta. De elementos já escritos, de pensamentos, de fragmentos abandonados. De detritos e quase-nadas. 


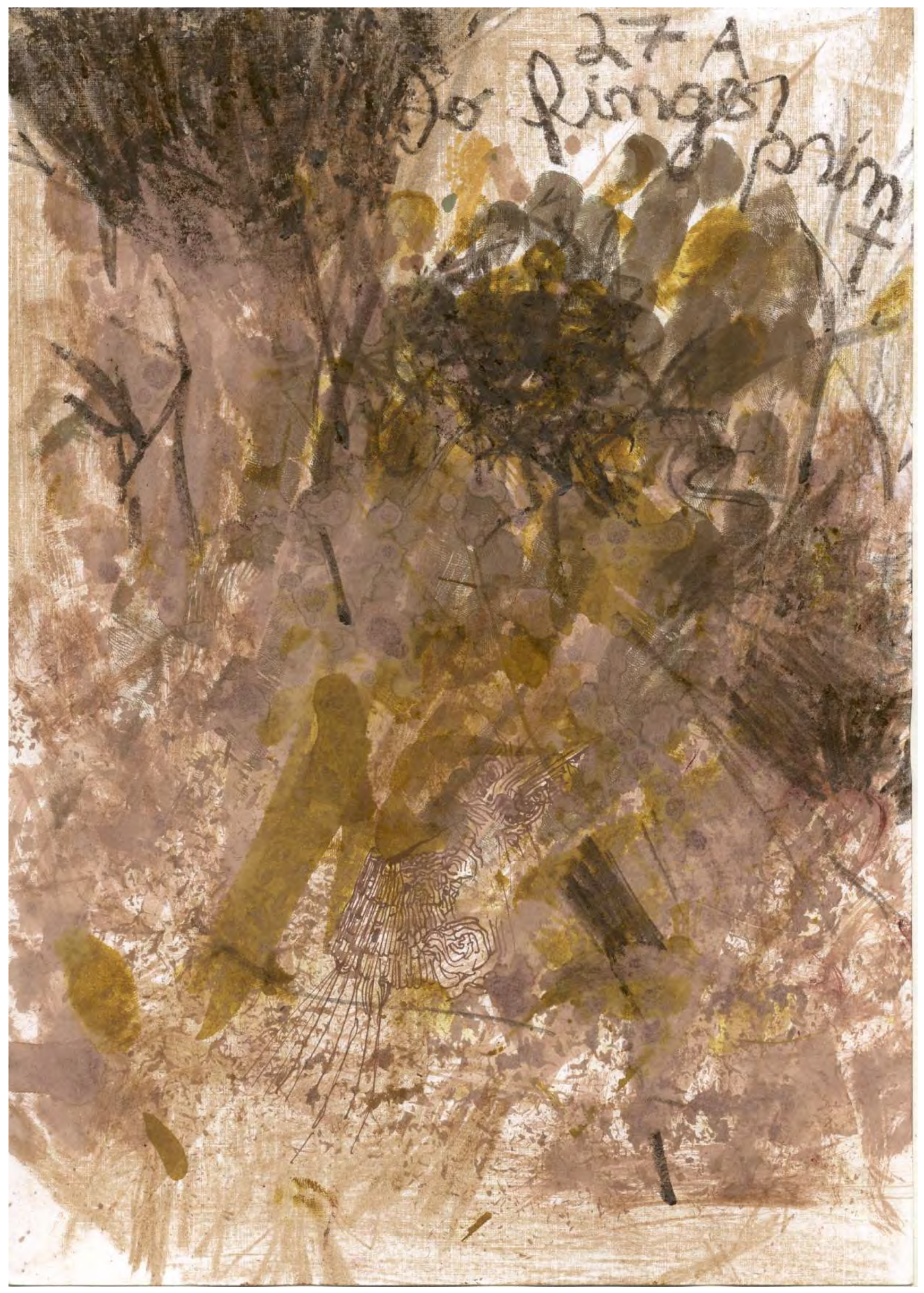


27.

Relação de lamento sóbrio e recusa. 


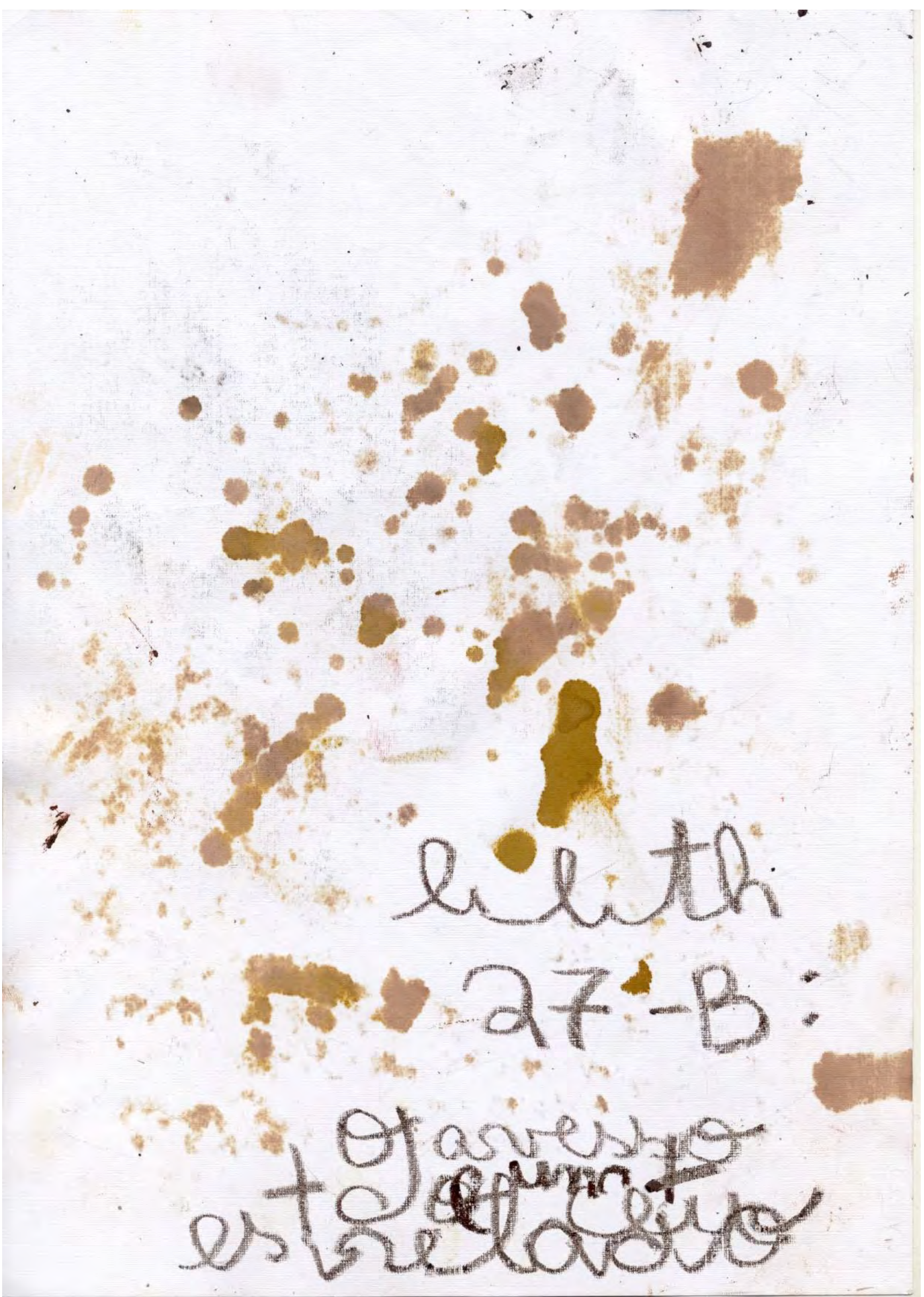


28.

Fabulação é distinto de interpretação. 


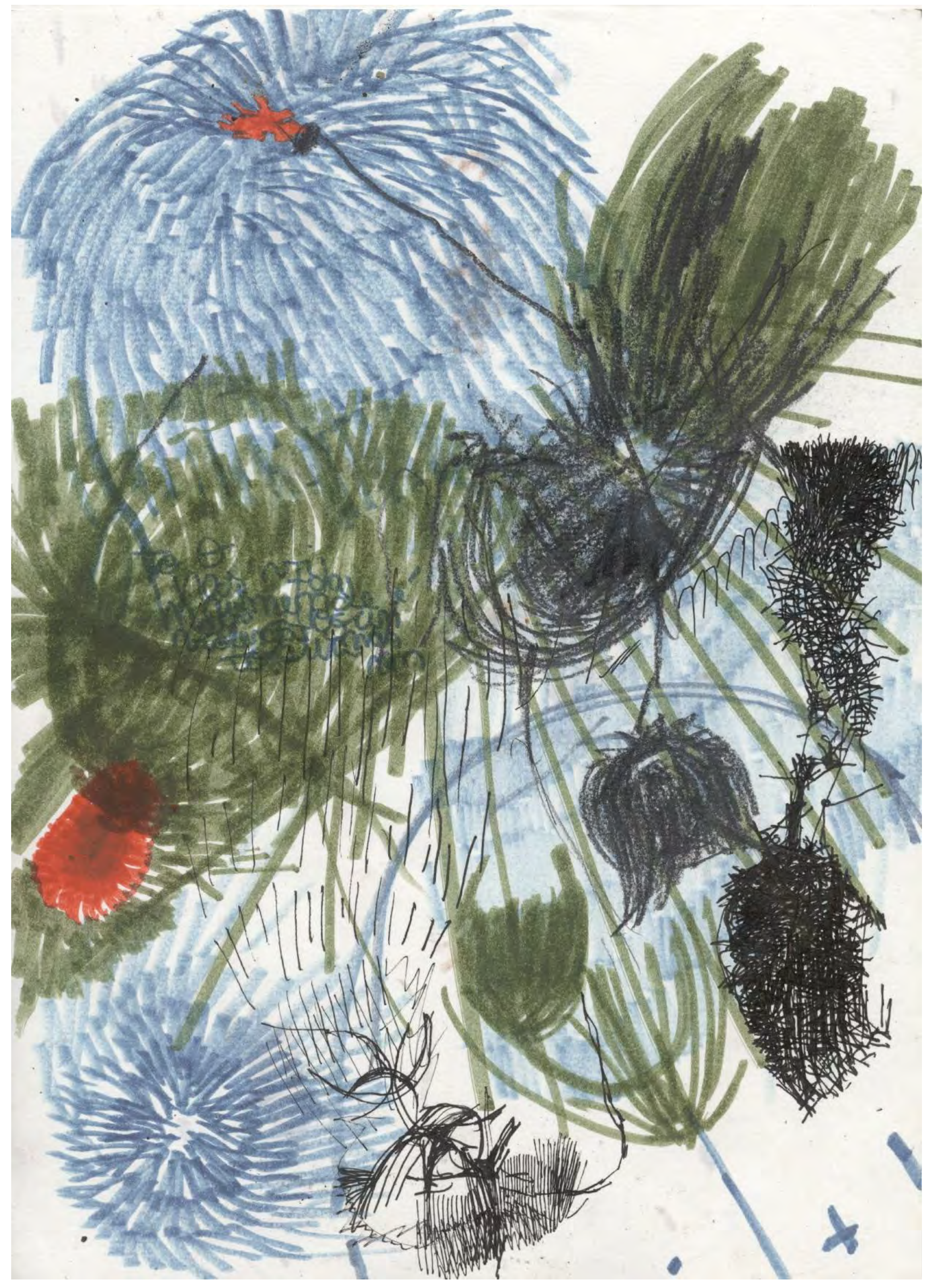




\section{9.}

O livro de Marcel Detienne L'Écriture d'Orphée (1989), onde se desenha essa mundificação turbilhoante de vozes, tem um livro-irmão. La nozze di Cadmo e Armonia (1988), de Roberto Calasso. Respostas antiedipianas ou tentativa de assimilação? Não são só livros datados muito proximamente e com interesses próximos.

Interesses de algo entre várias impossibilidades. Entre a impossibilidade da definição em si de uma escrita helenista e a impossibilidade de tocar o tecido mítico, ao passo em que se é tocado e fabricado pelo mesmo tecido, e se é alvejado, cortado por fragmentos fabulares. Teria isto algo a ver com o que Jaa Torrano $(2009$, p. 13) chama de 'objetivo' e 'programa' do fracasso, quando a lida é o arcaico ou o antigo?

Torrano nos lembra de que a poesia arcaica localiza e produz mundo, e conduz àquilo que hoje nomeamos por sagrado. Para além disso, sempre houveram interesses econômicos na fabricação de fábulas supostamente míticas. Se não se pode provar, não se pode também duvidar.

Podemos desconfiar então das experiências fabulares modernocontemporâneas que, ainda que cansadas, nomeiam-se por fábulas 'míticas'. Desconfiar no bom sentido. Estariam possivelmente, de fato, bem ou mal sucedidas, atacando economias corporais, regimes de corpos, tentando ativar um campo duvidoso, instável, e impregnado de afetividade, que é a suposta mitologia. M itologia como dramaturgia da imensa mudez do cosmo ou da insidiosa loucura das palavras.

As fábulas dessa 'natureza', por assim dizer, ou que atentem a esse radical, se podem ativar apenas no encontro. Essas práticas servem ao encontro, são o ser do encontro, o encontro do encontro, servem à transmissão e ressonância de algo muitas vezes muito pouco conhecido que apenas quer passar, que vai passar por ali. Pode ser algo parecido com o cristal que germina. 0 mito é transdutivo? 0 mito tem realmente a ver com palavra? Qual palavra? 


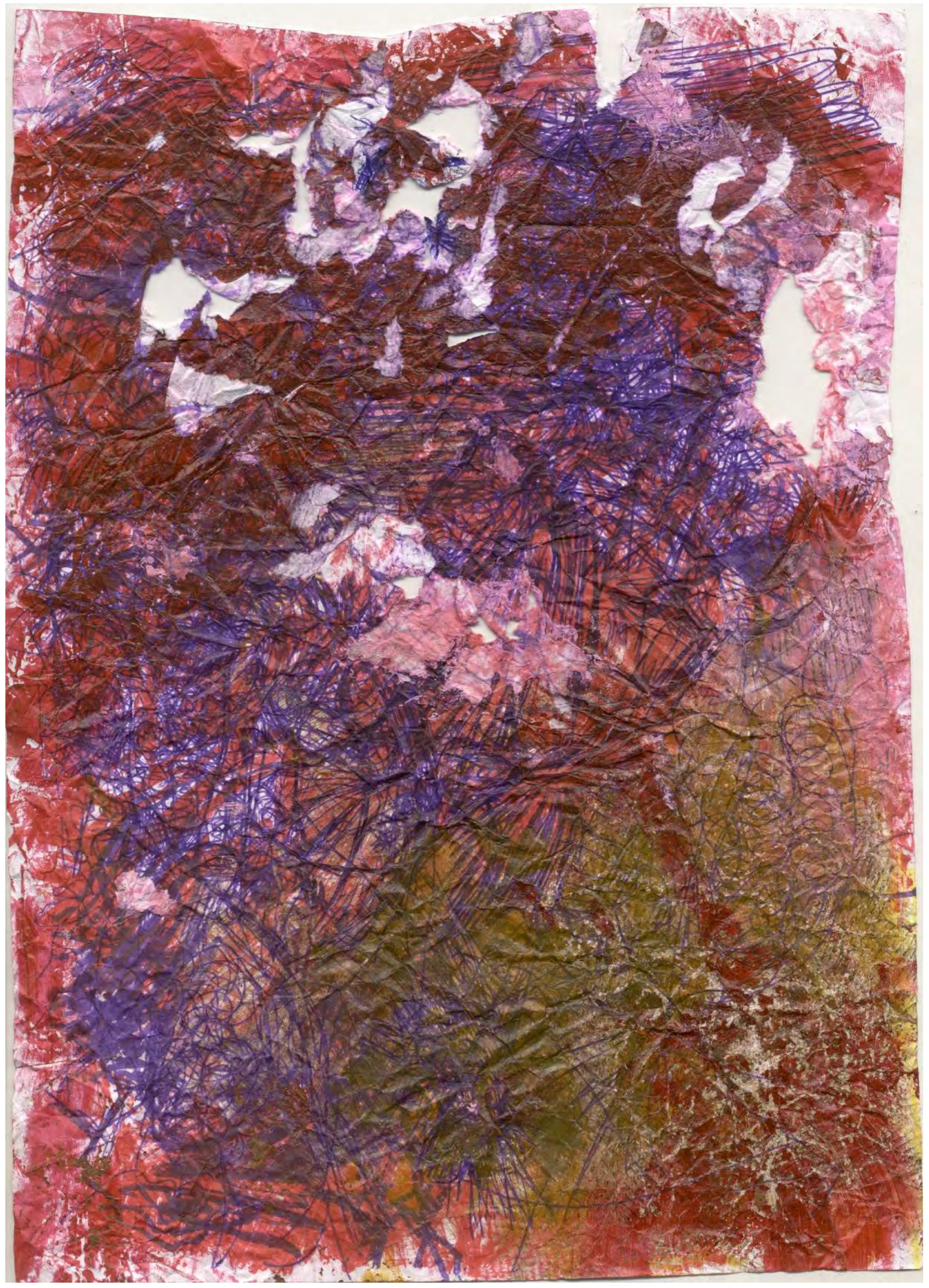


30.

Detienne e Calasso. Escrituras deslizantes, fabulares, excessivas e, ao mesmo tempo, desoladas. Diz Detienne na introdução inventário, em resumo: 'A escrita. Qual? Em si, por si? A escrita generalizada, dilatada em todas as direções, onívora?' (1991, p. 8). 0 helenista francês então nos faz reparar em um período especial, de 650-450 a.c., onde as vilas, as comunidades, as cidades não paravam de escrever. E sobre qualquer coisa, letras escritas, gravadas, pintadas, 'letras às vezes com cinco a seis centímetros'... do quê se trata? Apenas da confecção de leis, ou de disputas outras? Detienne explicita a coincidência com a gênese de um Estado de direito, que pela letra gravada ordena a própria publicidade do espaço. Mas haveriam outros movimentos paralelos?

\section{Livro dos mortos? Sim, para morrer em face do mundo, em face da cidade seguindo a dieta, o regime de vida em que as palavras cantadas-escritas por Orfeu desconstroem o discurso dos outros, a escrita do espaço político, e nele edificam outro, até o infinito, vertiginoso. (op. cit., idem)}

Galasso, por seu turno, tenta cruzar correntes homéricas e órficas e, para isso, às vezes romanceia e psicologiza as figuras. Contudo, cava, com seus próprios meios, suas próprias fendas no mundo aparentemente mudo e selado, ou aparentemente escorregadio e proliferante, das fábulas. 


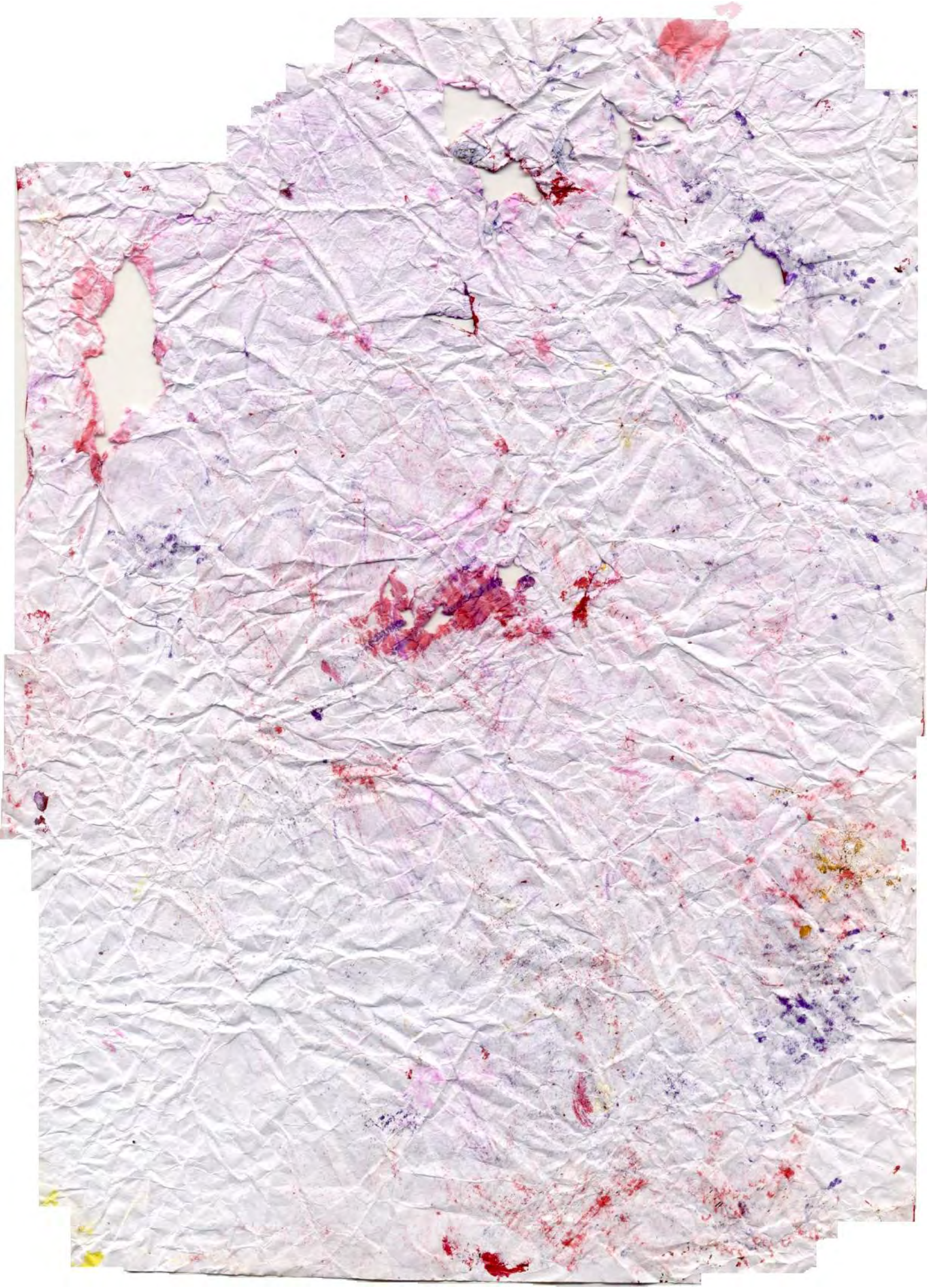




\section{1.}

Penso nos dados epocais dos dois livros. Penso neles agora não apenas como duas tentativas de ativação mítica, mas como uma contenção literal de correntes discursivas politicamente contestadoras através da alegação antiga ou arcaica. 'Veja, isso que vocês querem já estava lá atrás; nós podemos conviver com isso'. Fabulação como desativação. Mas a alegação arcaica pode ser um tanto ambígua. Penso, por exemplo, no contexto do angustiante desenlace da Guerra Fria, do qual a escritora Christa Wolf dá franco testemunho nas conferências anexadas ao romance Cassandra (1983). 0 senso crítico agudo da escritora ${ }^{133}$ nos guia por um processo ao cabo do qual nos poderemos acercar da tragédia de 'ser europeu'. A llíada de Homero e a Orestéia de Ésquilo tomam parte numa das mais repostas, reiteradas invenções da entidade abstrata Europa, mediante a necessidade de se massacrar um 'outro' e, para tanto, fabricá-lo. Os paralelos desta operação com o patriarcado, com as cruzadas, 0 mercantil-colonialismo, e seus procedimentos-efeitos, como racismo, o machismo e a índiofobia e, é claro, o paralelo com a guerra fria, são desconcertantes. A Grécia idealizada, ou fabulada de forma economicamente interessada, tem parte nesta invenção legitimadora. É uma operação de gerar 'o outro que eu quero que você seja'. A fabulação destituidora assinalada por M bembe (orig. 2015, trad. 2018).

0 contexto dos anos 80, tendo-se em vista as obras citadas (Wolf; Calasso; Detienne $\left.{ }^{134}\right)$, me parece terreno de uma disputa estética em torno do acesso à linguagem supostamente 'mítica' que pudesse ativar a política, a coletividade ${ }^{135}$.

\footnotetext{
133 A grande capacidade de estranhamento de Christa parece formar uma ponte entre ela e a personagem Cassandra (publicado em 1983, o romance Cassandra foi traduzido no Brasil somente em 2007).

${ }^{134}$ Podemos incluir nessa lista Heiner Müller e muitos outros que produziam na vertente assumidamente mítico-política nos 80, ainda que não seja com o vocabulário grego: o próprio Aimé Césaire, o angolano Fernando Costa Andrade etc.

135 Luis Felipe Miguel traz variações brasileiras do mito político na sua tese de doutoramento em busca da harmonia perdida: mito e discurso político (uma análise a partir da campanha eleitoral brasileira de 1994) (Unicamp, 1997). Penso que o contexto político em que esta tese é finalizada também traz uma necessidade de reposicionamento de problemas míticos.
} 


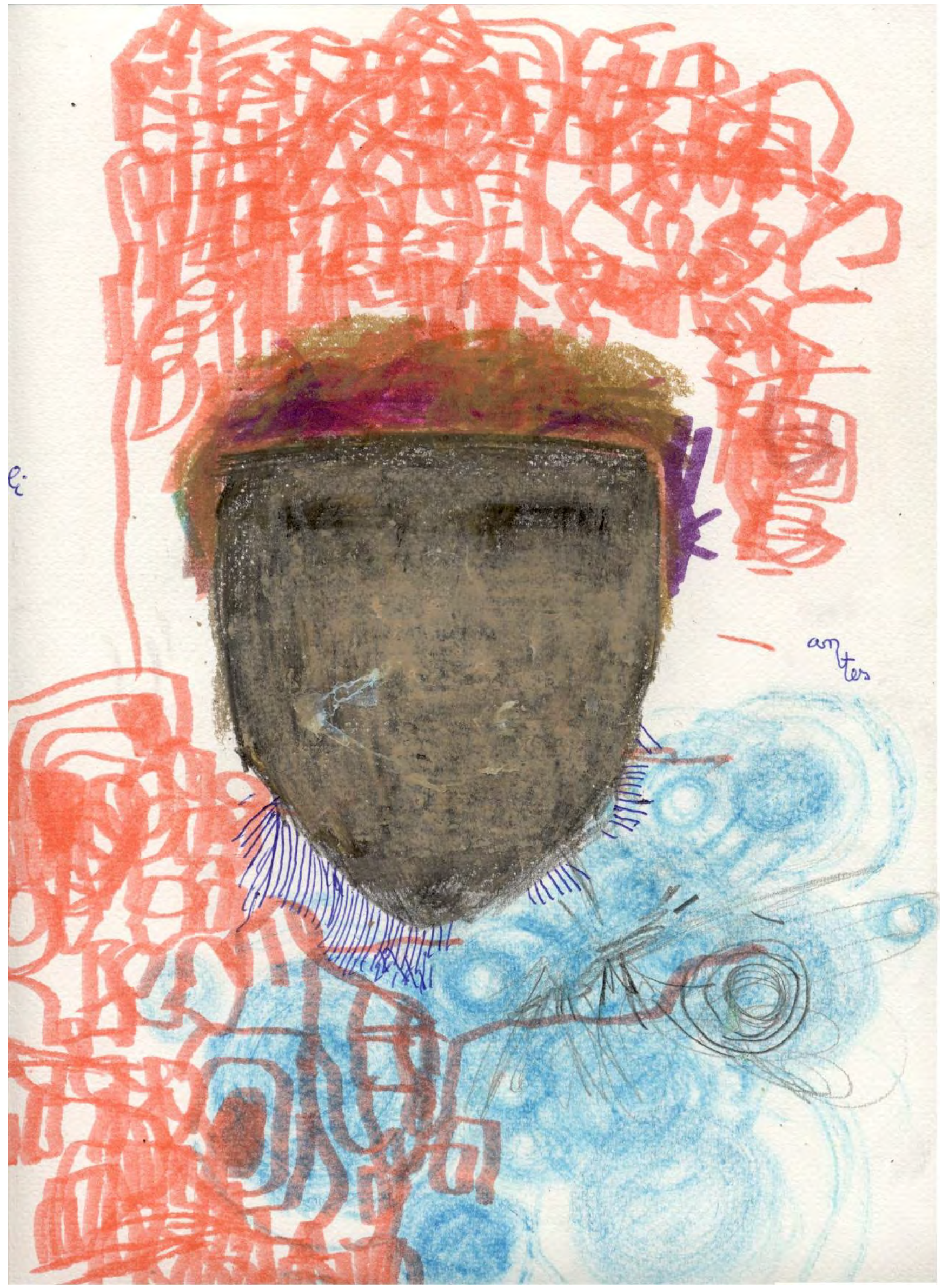


32.

Resta o perigo constante de dissolver e elitizar, portanto, uma suposta afetividade mítica, instável, que é por si política. Neste sentido, o apelo clássico revisita periodicamente, naturalizante que é de uma moral. Como disse, é ambíguo. Lembrome de Octavio Paz, em os filhos do barro, quando diz que às vezes o ímpeto moderno é marcado pela tentativa de acessar o arcaico, o ser autêntico, o dado germinal, original (2013, p. 17).

Falamos de mito. 0 que buscamos quando dizemos tal coisa? Se compreendi bem, e falando um pouco com Jung, quero dizer com esta pergunta que o mito é um elemento do inconsciente coletivo. Disse uma vez o dramaturgo Abreu em conferência: 'o mito pertence à cultura'. É uma força coletiva. Gostaria de sugerir inclusive de que se trata de uma força tão heterogênea que, ao contrário do que se possa considerar academicamente, o mito muito pouco tem a ver com a espécie humana. E assim eu me coloco, e a pessoa que lê meu texto, numa situação difícil. Me parece evidente que não conseguimos pensar nisso, pois somos da espécie humana, e o somos enquanto modernos, ou seja, vivendo sob a égide de uma ontologia dominante, que separa a natureza e a cultura (Descola, Latour). Pior, habitamos um terreno-país massacrado e assombrado pelas figuras colonizatórias, patriarcais, autoritárias. Isso complica as coisas. No entanto, é difícil não pensar nisso: 0 mito não é humano. Vejo-me, então, numa condição um tanto insólita: pensando constantemente 0 impensável.

Seremos então forçados a pesar que, para contatar um pouco mais fundo, sempre de maneira insuspeita, uma mitogenia, ou seja, na ontogênese fabular do mito, teremos de pensar não com nossas cabeças. Mais uma vez: não se trata de uma ontologia do mito, para esta já há lugar; mas de uma ontogênese, e a fábula que encontra o encontro por onde passa a ação mítica é um de seus contra-diagnósticos, é uma das suas estratégias transdutivas. Teremos de pensar não com nossas cabeças, e nem com outras cabeças conhecidas (que é o modo com que o mundo acadêmico branco gosta de se apropriar da outridade legítima), mas com outras cabeças desconhecidas. Pensar mais uma vez no avesso, na borda, na garantia do erro - da 
errância. Neste sentido compreendo plenamente os dramaturgos contemporâneos que subvertem totalmente a herança fabular, com 0 intento da ativação políticoafetiva. Tentaremos seguir esta trilha, para sair apenas do 'novo', e chegar no outro que já está lá. 


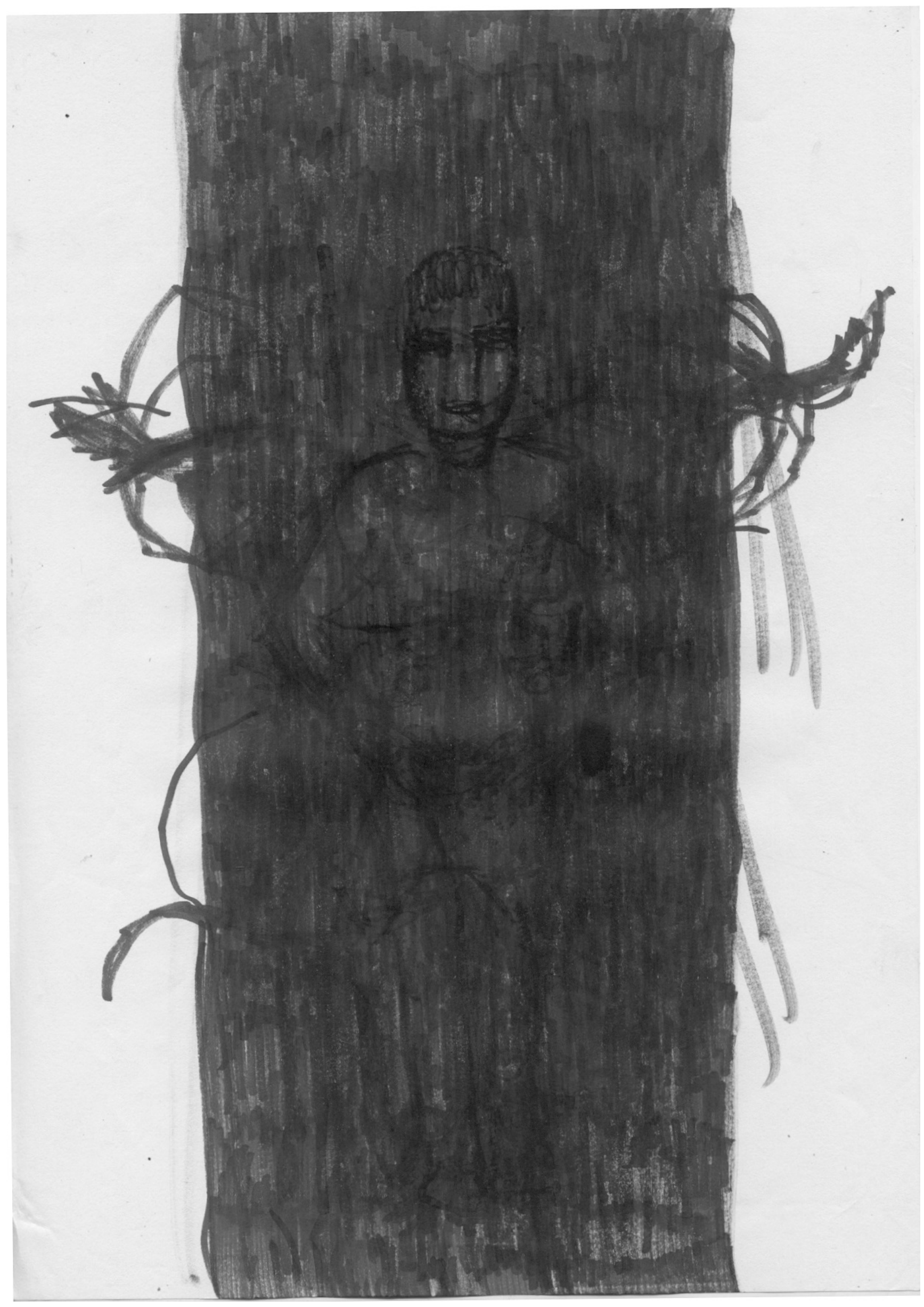




\section{3.}

No mínimo sou levado a considerar que o mito aparece em espécies muito especiais de silêncios ${ }^{136}$. Paradoxalmente, essa gramática estranha, para ser tocada, precisa que falemos muito. Quem trabalha com tipologia não-interpretativa de silêncios saberá do que falo. Equivale dizer: algumas palavras são movedoras de silêncios, alguns silêncios em especial. Há muito nestas frases que acabei de dizer, então suspendo o dito e deixo por ora a corrosão da atmosfera e de pequenos pensamentos atuar nas palavras ditas.

Mas a condição acima expressa não basta: é preciso que se passe algo extraordinário, ativo, que depende de ressonâncias anteriores, ressonâncias estas que se 'montam' e ressoam violentamente quando algo dessa magnitude se passa. Acho que lidamos então com um domínio de experiência mundana, pois concreta, e extramundana, pois entre mundos, da qual sabemos muito pouco. ${ }^{137} 0$ que passa fura e faz vibrarem os mundos, criando dimensões outras. 0 certo é que uma experiência assim invocada (chamada para dentro), uma ação mítica, se assim a podemos chamar, é aquela marcada pelo dado da espera. Neste sentido, o mito é bem próximo da astrologia como climatografia imantada de senso de assimetria em direção a um mistério que ronda, que é autonomia da vida ${ }^{138}$. E é bem possível que nada aconteça. Mais uma vez, o 'método fracassológico' de Torrano, mas não posso me contentar com isso. Não basta saber que fracassaremos, é preciso literalmente sucumbir.

\footnotetext{
${ }^{136}$ Karl Kerényi (2015) supõe que 0 interdito religioso tem sua anterioridade na inefabilidade do sagrado. Dando a entender que, na maior das vezes, as coisas não andam juntas. 'Um segredo público e sagrado'; 'a inefabilidade dos segredos naturais - por exemplo, dos autênticos mistérios do surgimento da vida' (p. 194).

137 O termo 'ressonância mítica' como 'ação mítica' é utilizado por Lina Prosa, dramaturga feminista e anticapitalista contemporânea. 0 verbo mítico é pessoal mas principalmente impessoal. Ainda assim, precisa do envolvimento pessoal. É uma impessoalidade afetivamente comprometida (um compromisso paradoxal?). A oficina que ela ofereceu em 2017 (EmpalavradaS) na casa Balagan, em São Paulo, me impactou bastante a respeito da anterioridade espacial das ações míticas.

A autonomia das palavras como sujeito e corpo da cultura (humana e não-humana) me faz pensar também na oficina de que participei oferecida pelo narrador griot de família djeli Toumani Koyuaté, em 2015, na galeria b_arco.

138 Penso ainda na definição de ciência do concreto, formulada por Claude Lévi-Strauss (em le pensée sauvage, 1962). Este apontamento entre sentido de astrologia e ciência do concreto não vem de mim, mas de um colega antropólogo, Felipe Lippi.
} 


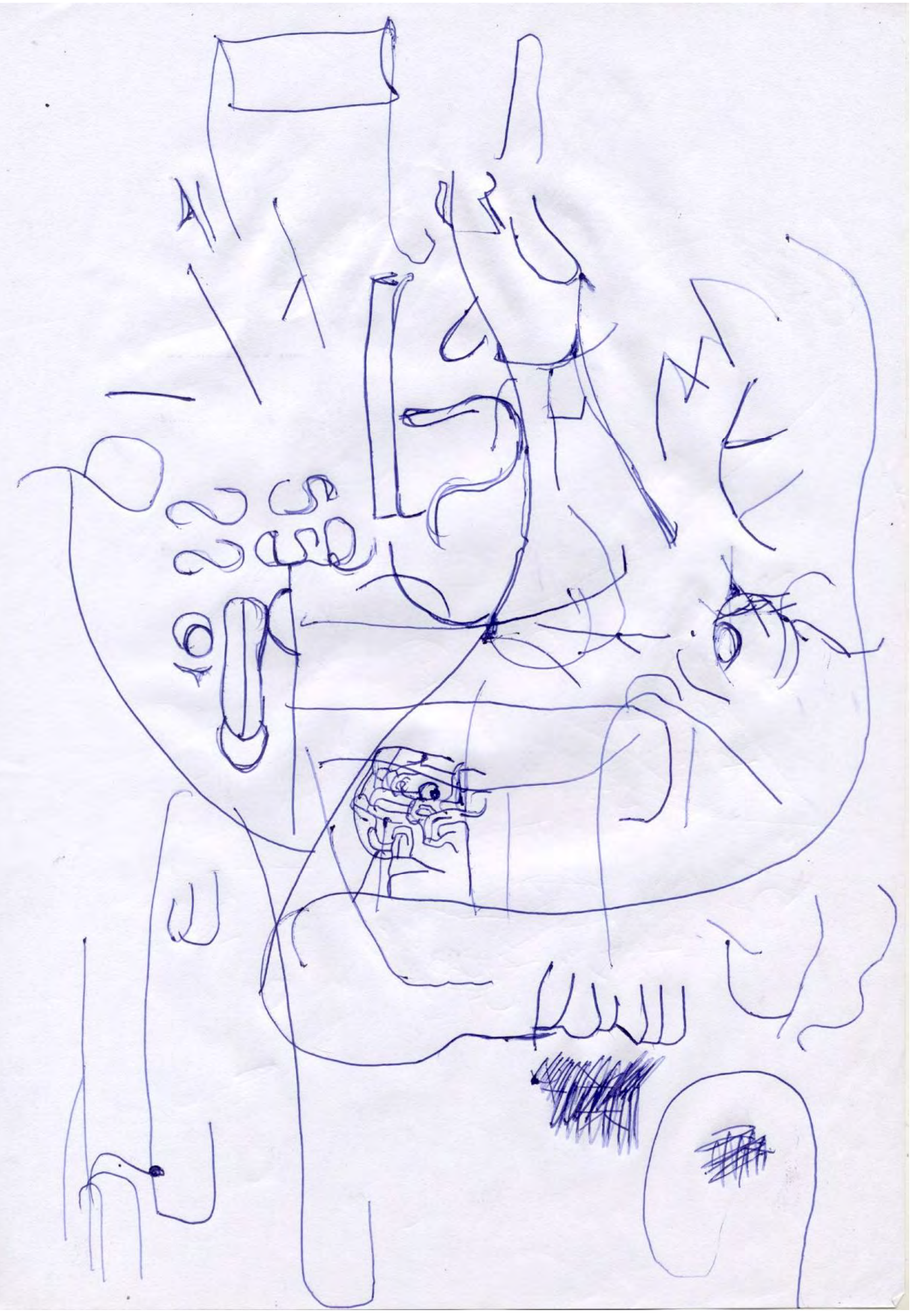


34.

Costuma-se dizer que o discurso filosófico substituiu aos poucos o discurso mítico na época da Polis grega. Nesta afirmativa didática, estamos então diante do câmbio de discursos dominantes em sucessão epocal, mas esses discursos são não-equivalentes em procedimentos, se tomados lado a lado. Não é por que a substituição ocorreu que trata-se da mesma coisa, de uma conversão de termos, ou que a possibilidade de fabulação mítica tenha desaparecido. Assim, é dizer que o discurso mítico aí está. Sua matéria está na carne da cultura, que é carne. Basta verificar o tanto que os filósofos recorrem às fábulas míticas, conforme eu disse, como contenção ou ativação.

Não me refiro aos filósofos germinais que atuam na singularidade de um registro duplo, como Empédocles, Anaximandro e Heráclito. 


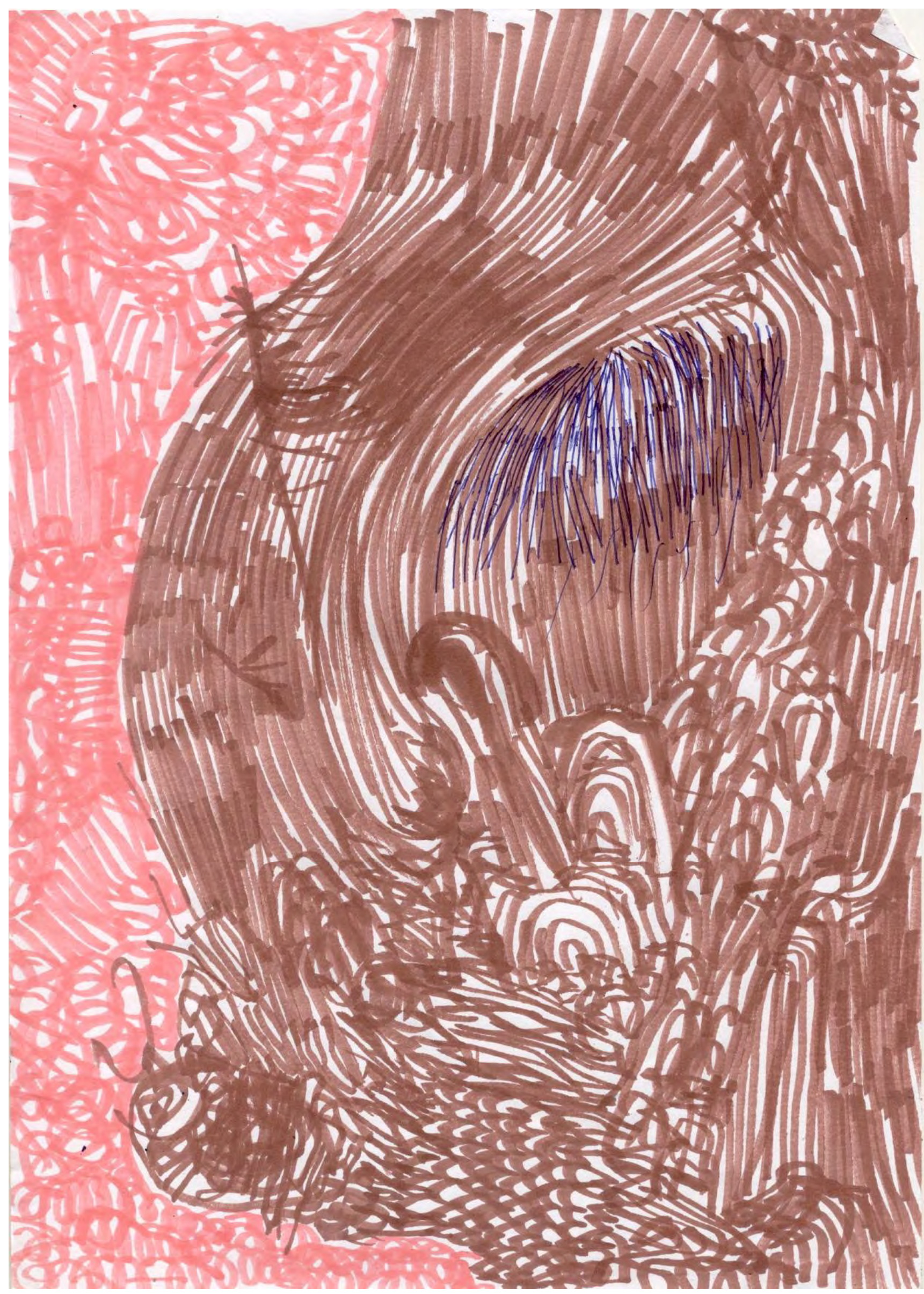


35.

A misoginia dos gregos se confunde com aquela dos modernos que narram suas fábulas com valor de origem, os supostos 'mitos'. Esse gesto específico de contação consiste, a um só tempo, na aplicação de interesses específicos e reposição do patriarcado; na legitimação da narrativa da origem e valoração originária de um tipo de escrita. Põe-se aparentemente claro para mim que o patriarcado é tão velho quanto a concepção corrente de 'escrita'.

No peso de uma inscrição ou um sinal, uma mensagem que corre a cultura da natureza, uma 'semiótica animal', uma 'palavra bárbara'139, algo diferente se dá. A noção corrente de escrita é forçada assim a se modular, a se dobrar ante as circunstâncias. E é aqui que o personagem 'som' pode entrar em cena a qualquer momento.

${ }^{139}$ Refiro-me a termos oriundos do 'A de animal' do abecedário de Gilles Deleuze e Claire Parnet. 


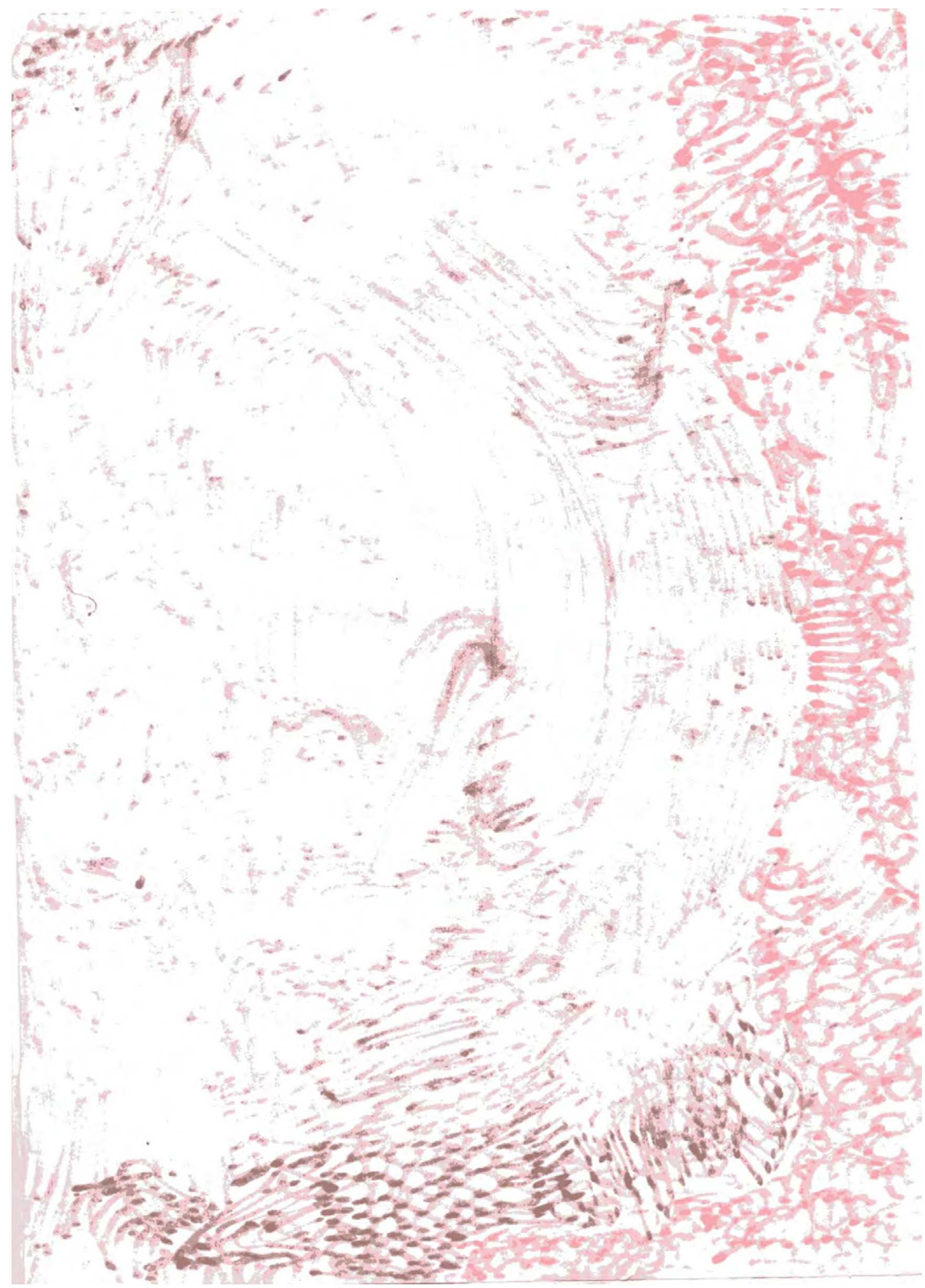




\section{6.}

Éliphas Lévi aponta, em cartas reunidas por um aluno, elementos da cabala140, que os 'gênios civilizatórios' da 'ciência e religião' são os que trazem a escrita: Enoque, Hermes Trismegisto, Cadmo (1992, p. 121. Sexta lição). Músicos, sacerdotes, gênios do alfabeto, pais fundadores. Que violenta operação narrativa é esta?

Uma das contribuições Artaudianas mais valiosas, no meu ver, é o rompimento com a cabala no sentido de um discurso iniciático desencarnado no aculturamento moderno. Faço leitura de que esse discurso desencarnado é uma posição relativa à compulsiva afirmação do status quo e das autoridades naturalizadas da cultura. Existe um grande contraste entre o teatro e seu duplo (le thêátre et son doble, 1938) e as cinco cartas a André Breton (do início de março ao início de maio de 1947, traduzidas por Ana Kiffer) no tocante a isto. De uma referência direta à cabala a uma aversão à iniciação. Este labiríntico processo de múltipla ruptura conta sobre como o corpo atravessa duvidosas iniciações, que são duvidosos, catastróficos renascimentos. A narrativa Artaudiana de destruição do iniciático também tematiza estatutos nãonecessariamente humanos de um renascimento desastroso. Está de fato em jogo, em Artaud, não apenas 'o hieróglifo vivo', mas a escritura permanente e incerta do próprio corpo ${ }^{141}$.

Uma escrita não é o que parece ser; a mim está sugerida uma escrita como secreção das linhas. Inscrição, secreção. A secreção sempre passa por uma fenda...

\footnotetext{
${ }^{140}$ Em as origens da Cabala (trad. 1977, 1992), les origines de la Kabbale (1869-70).

${ }^{141}$ Quero com isso dizer que as violências sofridas por Artaud nos hospitais psiquiátricos se resumem a uma gigantesca iniciação? De maneira alguma.
} 


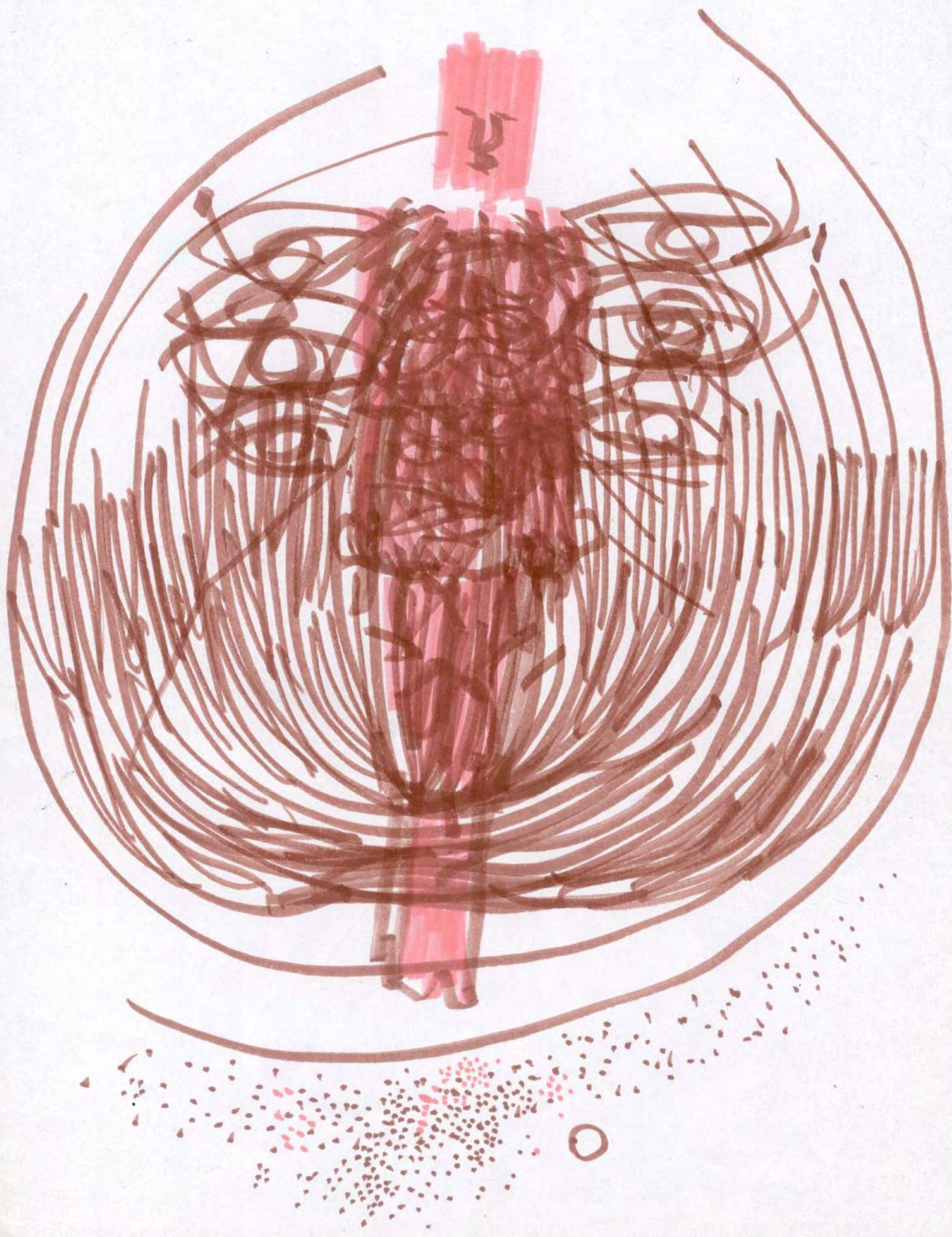


37.

Como disse, não sei se uma mitologia possível de ser debatida é aquela que pode mover o novo. Novidades acontecem, é fato. Mas quando algo se passa, esse algo não pede necessariamente o 'novo' como alcunha (e nesta dúvida já tomamos relativa distância da discussão moderna do novo). E sim o outro. É quando o outro se mostra como aquele que já estava. Em a morte nos olhos (la mort dans les yeux, 1988, trad. 1991), Vernant analisa cultos gregos em que a divindade é figura da outridade (Ártemis, Dioniso, Górgona). E são justamente as divindades que, em suas teatralidades religiosas, se apresentam com máscara.

E então se pode constatar que o 'novo' da mentalidade moderna só vale enquanto não a novidade em si, mas a outridade. 0 novo vale enquanto outro. A novidade em si mesma é ao máximo um outro-objeto. 0 novo-sujeito é o outro, traduz outridade. 
249

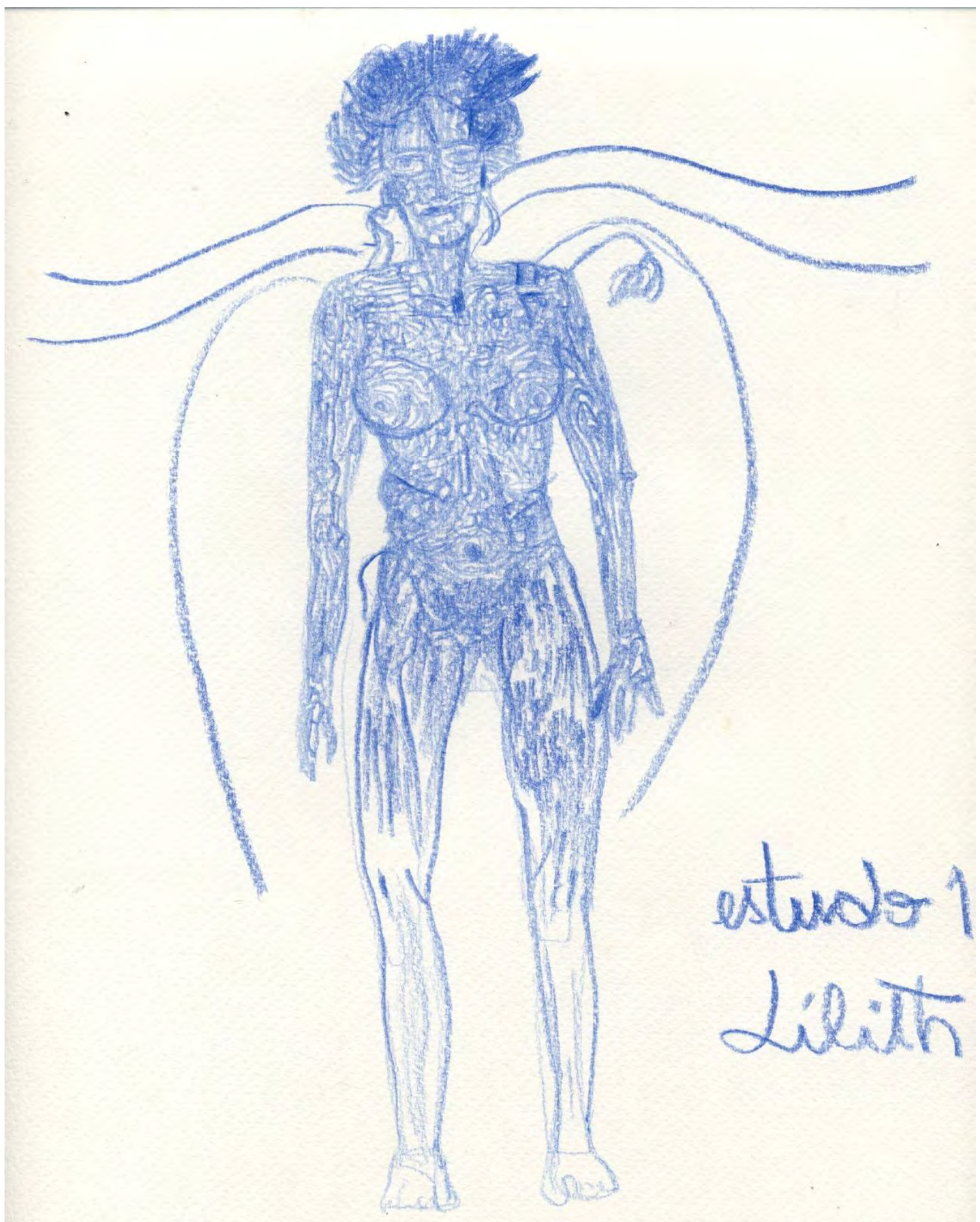




\section{8.}

A misoginia presente tanto nos supostos gregos quanto nos modernos que os afirmam como origem. Esse ódio àquela figura inventada de mulher salta principalmente quando os intelectuais legitimados se dão às interpretações. 0 comentários interpretativos do helenista Jean-Pierre Vernant sobre os mitos amazônicos em la mort dans les yeux são merecedores de atenção na pauta desta confusão. 0 mesmo tema, o fabulário das amazonas, quando comentado pelo professor Junito Brandão (dicionário mítico-etimológico da mitologia grega, 1991, 2014), também. Teria 0 dramaturgo Heiner Müller escapado a esta tradição?

Mais uma vez: fabular é diferente de interpretar: aquele é um movimento tateante que rastreia relações desconhecidas.

Mary de Camargo Neves Lafer (2008, ps. 62-74), ao descrever as ambiguidades na construção da figura de Pandora, traz possibilidades de fabular. Tudo do que precisávamos era a ambiguidade. Aqui, a possibilidade é também a necessidade. Podese assim fabular acerca da necessária possibilidade de que haveriam outras Pandoras. Estas teriam sido enterradas, substituídas na narrativa de objetificação feminina e casamento ${ }^{142}$. Narrativa consolidada, inquestionável. Já que o único modo de se consolidar, fixar uma narrativa é generalizá-la, enlouquece-la, e ao mesmo tempo mascarar, naturalizar sua loucura. Lidamos, assim, com a mais que exaustiva repetição da legitimação patriarcal e das marcas da intelectualidade masculina dos últimos séculos.

'Outras Pandoras' haveriam uma fabulação com outras palavras, ainda que para isso não tenhamos palavras, apenas o desdobrar da 'caixa de dons' de Pandora. ${ }^{143}$

\footnotetext{
${ }^{142}$ Este soterramento é movimento paralelo àquele das núpcias de Cadmo e Armonia.

${ }^{143} \mathrm{~A}$ ambiguidade e obscuridade presentes na filologia de Pandora, cuja fonte não é de longe apenas Hesíodo, é notável. 0 seu aspecto de doadora é ao mesmo tempo temível. Aquela que deixa escapar os dons, ou as dores, é também doadora. A fábula de Hesíodo, de qualquer modo, é curiosa, pois mostra os deuses olímpicos fabricando uma mortal, fabricando uma mulher, em revanche aos crimes de Prometeu. A narrativa do artifício é, em si, ambivalente. Outras fontes nos deixam saber que a filha da união de Pandora com Epimeteu chama-se Pirra (incandescente), que foi companheira de Deucalião (fontes segundo www.theoi.com : Apolodoro, Ovídio, Higino, Estrabo). Mais uma vez, o fogo. Há ainda uma variante dizendo respeito à cidade de Corinto (ou Éfira), onde a filha de Epimeteu e companheira de Deucalião (ou seja, presumivelmente filha de Pandora) chamava-se justamente Epira (Eфupa), guardadora das águas de Corinto.
} 


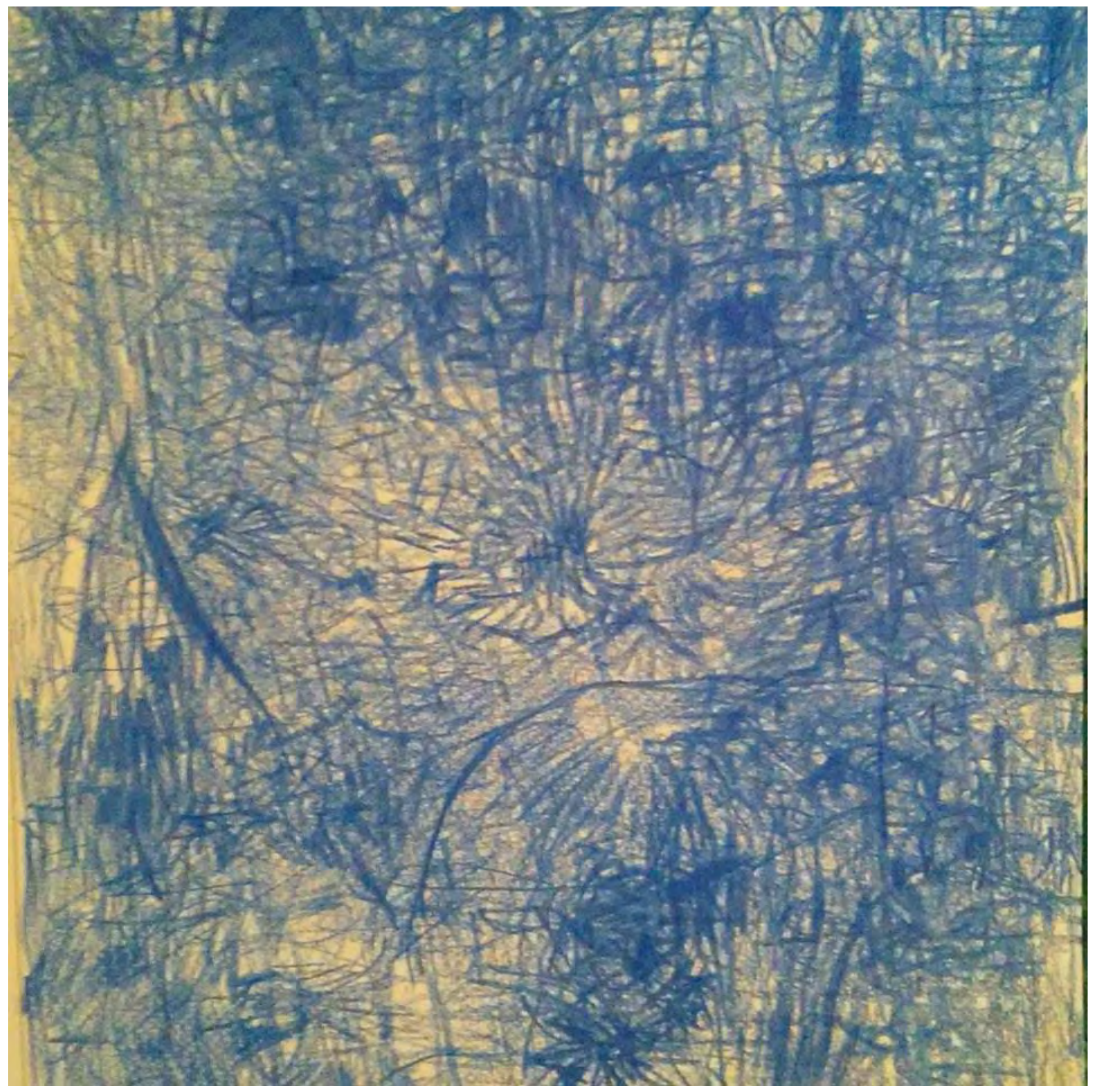

Como adendo, segue o relato de uma pequena investigação. Mirella Faur, em sua compilação anuário da grande mãe (2015), identifica a virtude doadora de Pandora com o nome Anesidora, 'a doadora'. Uma pista. Fui verificar na monumental enciclopédia virtual www.theoi.com e vi que

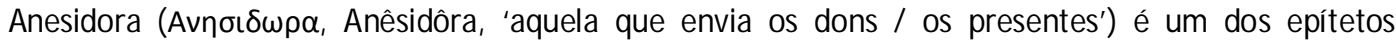
atribuídos a Deméter (deusa doadora dos alimentos). As fontes desse epíteto de Deméter são, segundo consta, fragmentos de Ésquilo, Plutarco e Pausânias. Faur induz à hipótese ainda de que Pandora é uma variante das deusas doadoras da terra, como Gaia e Deméter. De fato, há muitas outras deusas telúricas do mundo grego antigo, sobreidentificadas ainda em 'mãe dos deuses'; nomes divinos que coletamos 'em bloco' como mitologia grega. Destes, alguns dos mais famosos, como Reia e Cibele, por sua vez, não parecem associadas a Anesidora. 


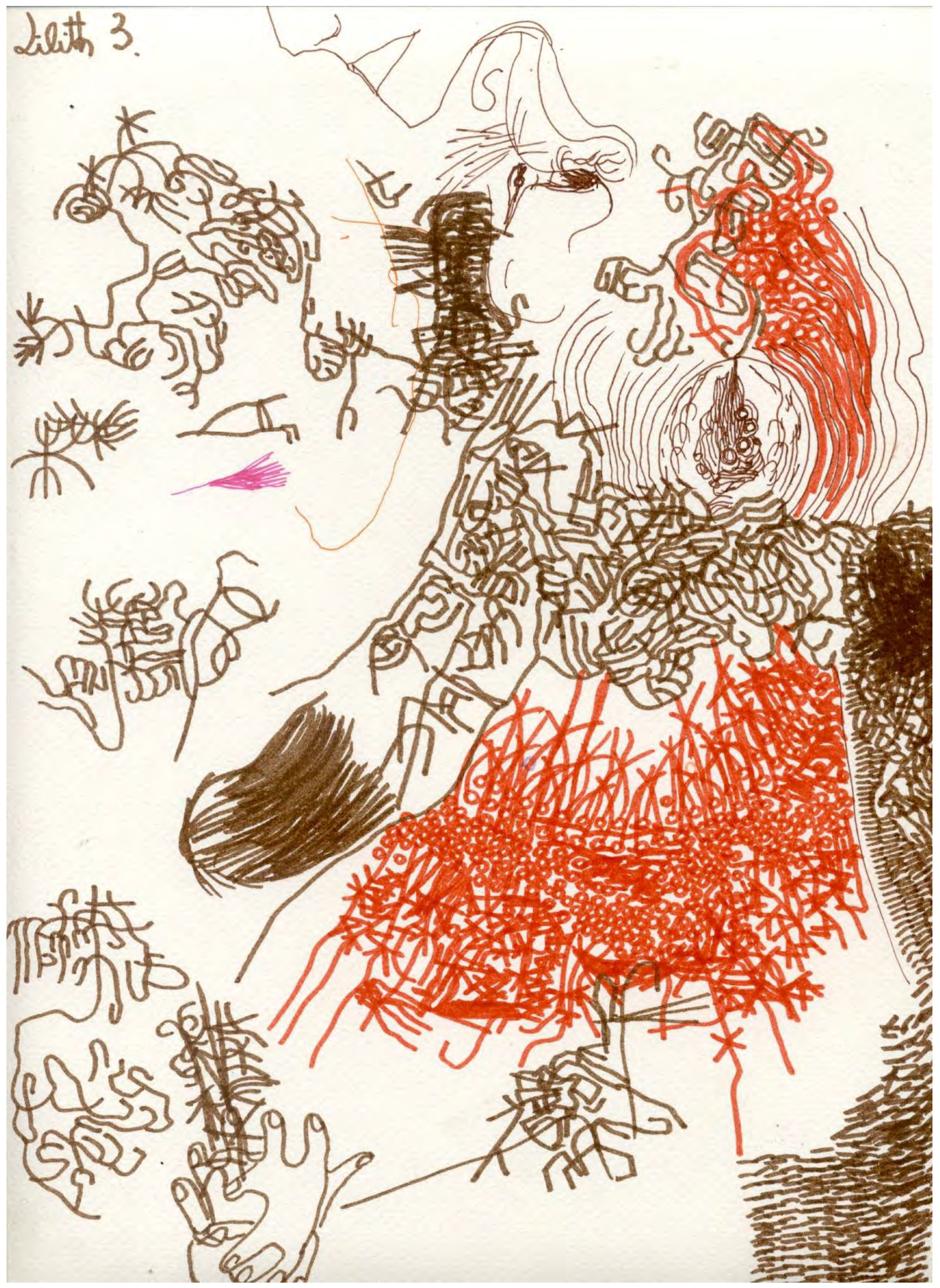


39.

NÃO.

][) \{>não<\}\}][ 


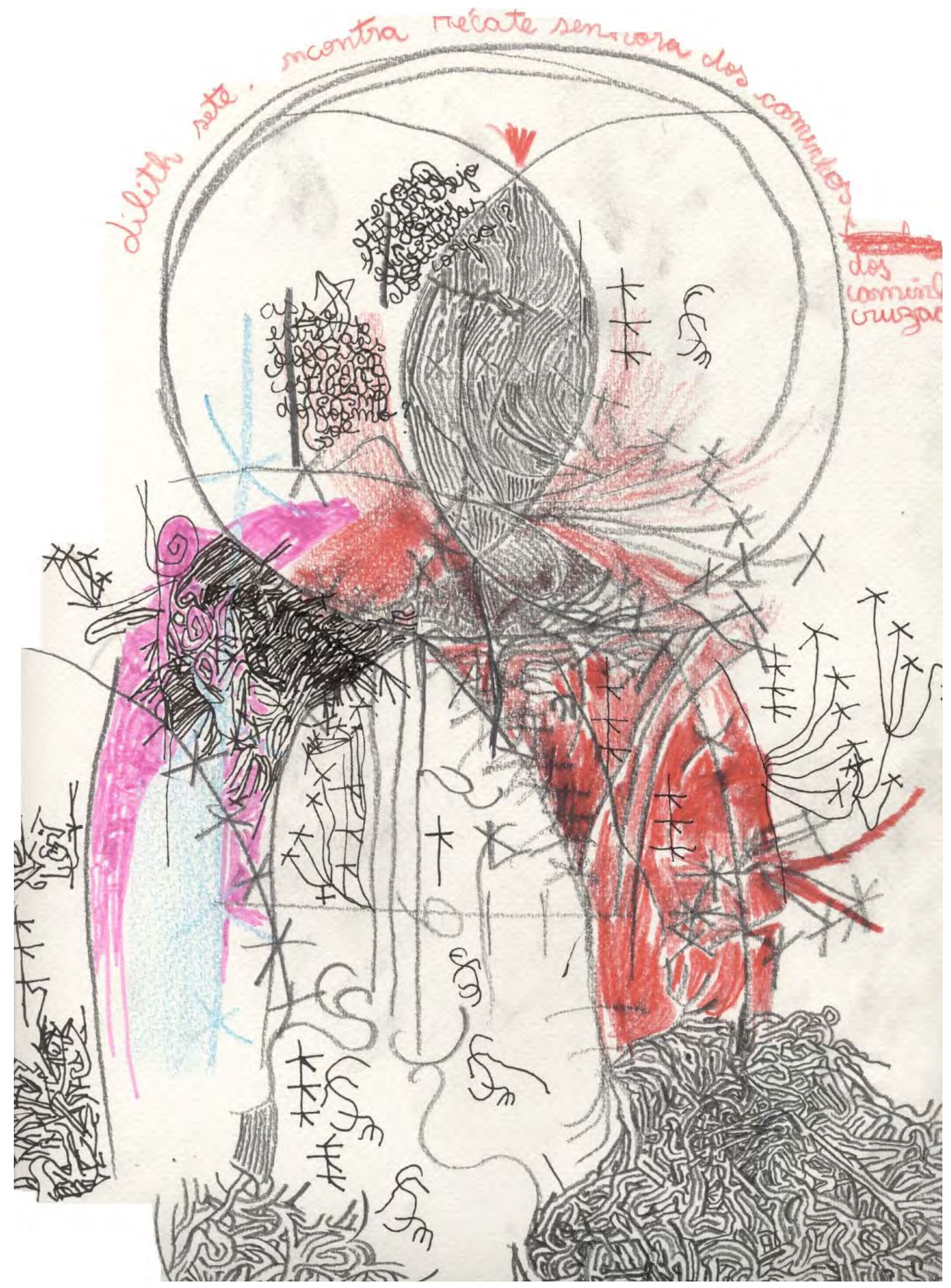


40.

\section{[Armonia] [negação como relação]}

A guerra, o combate, é uma sobriedade. É a máxima objetividade. Não precisa ser o escândalo óbvio do desespero. É justamente o oposto.

Uma vez tive uma alucinação com uma onça, e o recado era exatamente este: extrema objetividade. A impressão deste contato, contudo, é impossível de traduzir.

É preciso ter um corpo irredutível para ir à guerra. Isto me faz pensar, sem resposta, naquilo que é irredutível no corpo.

Me desculparão os intelectuais, pois não há um jeito correto de percorrer um mito. Há uma Armonia que é um árvore (salvo ambiguidade que ela seja também uma fonte ou uma nascente) $)^{144}$. Trata-se da mãe das amazonas da região de ponto, ao sul do mar morto: o litoral da Anatólia.

Armonia mãe, matrona e matriarca das amazonas e das primeiras rainhas amazonas, como Otrera, mãe de Pentesiléia. Pela sua irredutibilidade e pelas atividades que desempenha, claro está que há laços desta Armonia com Ártemis e Hécate, divindades irredutíveis e, por quê, não, anti-olímpicas. [Hécate é uma Titanide; Armonia e outras árvores-freixo habitam o mundo primordial e tinânico] $\mathrm{Na}$ teogonia, há um hino a Hécate que conta que Zeus não ousou tocar seus domínios, antes o contrário: assegurou-os.

No poema dramatúrgico programa Pentesiléia - treinamento para a batalha final ${ }^{145}$, Lina Prosa (1951-) leva às últimas consequências, como não poderia deixar de ser, a realidade da rainha amazona como relação, ao passo em que seu opositor, Aquiles, está sediado no empenho em conquista uma unidade. 0 espaço é definido por

\footnotetext{
${ }^{144}$ Parece ser filha do rio Thermodon [fonte: enciclopédia digital Theoi].

$145 \mathrm{O}$ processo vivido junto à encenação deste texto de Lina em 2017 pela Cia Teatro Balagan, em seu começo de processo, como escavador de mitos amazônicos do mundo grego e como condutor do treino de taiji quan, é assunto a ser tratado em separado. Mas deixo uma fala contida em vídeo de divulgação da encenadora Maria Thais: a imagem que me veio era de uma figura feminina já idosa, não jovem, já não mais na força da juventude, mas que ainda se mantém, apesar da clausura, em batalha; se treinando para continuar a sua guerra que é a sua existência. Falas contidas em 'Programa Pentesiléia Treinamento para a Batalha Final', no site www.youtube.com . Ainda há muito o que se dizer acerca desta encenação de 2017 enquanto ponto culminante de um cosmo metodológico de mais de duas décadas. 0 trabalho estreou em junho de 2017 na cidade do Rio de Janeiro e seguidamente entrou em temporada na cidade de São Paulo.
} 
Prosa como talvez um manicômio, com abertura eventual para a ida a um parlatório. Pentesiléia e Aquiles, aqui, não se encontram: o texto é composto de dois grandes monólogos da rainha amazona que 'circundam', como uma serpente, o monólogo central do herói grego. Pentesiléia jamais interrompe seu treinamento. A peça de Lina desenvolve uma resposta à épica ${ }^{146}$ do patriarcado, com a radicalidade do combate que é a relação, em contraste com o projeto de unidade incorporado pelo guerreiro Aqueu, que é também fabrica um cavalo para dar voz à sua violência. 0 texto de Lina é também é uma reposta à peça Pentesiléia (1808) de Kleist (1777-1811).

Tanto em programa Pentesiléia como na árvore Armonia há a tematização do 'nó interelemental' que é o vegetal. Neste caso ele é um nó dilatado pela irredutibilidade, um nó tenso à maneira de Heráclito de Éfeso. A cidade de Éfeso aliás, foi fundada pela rainha amazona Otrera.

A noção de Armonia que me moveu a pensar no projeto inicial de doutorado era aquela contrária a uma estatuto moral e pré-definido. Chamei-a por armonia da dissidência. Em uma única frase (986) da segunda parte da argonautica, de Apolônio de Rodes, poeta helenístico, ele chama as amazonas da trácia por 'filhas de Armonia' (unida à divindade Ares).

Parece que desta árvore se faziam as lanças. M ary Lafer (2008) nos deixa saber de variantes fabulares onde os homens belicosos da raça de bronze nasceram destas árvores (freixo, mountain ash-tree). Antes disso, estas árvores também acompanhava a Raça de Prata (ver: mito das cinco raças de Hesíodo).

Esta Armonia expressa o dissenso para com o falso consenso patriarcal que nada tem de legítimo; cujo nome mais palpável, enquanto prática-ação, é extermínio, é expansionismo irrestrito ao invés da ética do combate (Heródoto narra sobre 0 processo de conquista de um grupo de amazonas no livro quatro da sua história).

As melíades, (divindades Oreiades, árvores) a pautar-se por Hesíodo, nasceram do sangue de Urano derramado sobre a terra Gaia, quando Cronos, seu filho, cortou 0 Pênis de Urano. É coincidente com o nascimento de Afrodite, pois o esperma jorrou no mar e nas espumas do mar, e dali surgiu a deusa. Esta mutilação de Urano (Céu)

\footnotetext{
${ }^{146}$ A luta entre Pentesiléia e Aquiles é aludida em diversas épicas, como a Eneida; 0 embate em si é contado mais enfaticamente na pós-homérica, de Quinto de Esmirna; um poema épico que conta 0 intervalo entre a llíada e a Odisséia.
} 
coincide também com o nascimento as Fúrias (ou Erínias), também nascidas do sangue do deus primordial sobre o corpo da deusa primordial. E dali nasceram também 'os grande Gigantes rútilos nas armas, com longas lanças nas mãos' (Hesíoso, trad. TORRANO, 2009, p. 13, vs. 185-186).

A confusão entre Armonia-árvore e Armonia fonte ou nascente (Naiade) é oportuna [fonte: Project Theoi], dada a comunicação entre esses dois elementos.

Um nó tenso perpetuamente dilatado. O princípio da RECUSA como relação. É recusa de uma imagem pronta daquilo nomeado por feminino. É a recusa da teatralidade social do casamento patriarcal. É recusa da própria moral do teatro pósaristotélico, demasiado literário e elitista. ${ }^{147}$ É dizer que 0 teatro já existia antes da civilização patriarcal. Que teatro não é necessariamente ou apenas o teatro que dizem. Forma, conceito, função...

147 Falo com Aristote ou le vampire du théâtre occidental (Florence Dupont, 2007), traduzido por Aristóteles ou o vampiro do teatro ocidental em 2017 pela editora Cultura e Barbárie. Neste livro, Dupont analisa uma tradição aristotelista do teatro, visto não mais como conjunto de tradições sociais e públicas, mas como literatura. 


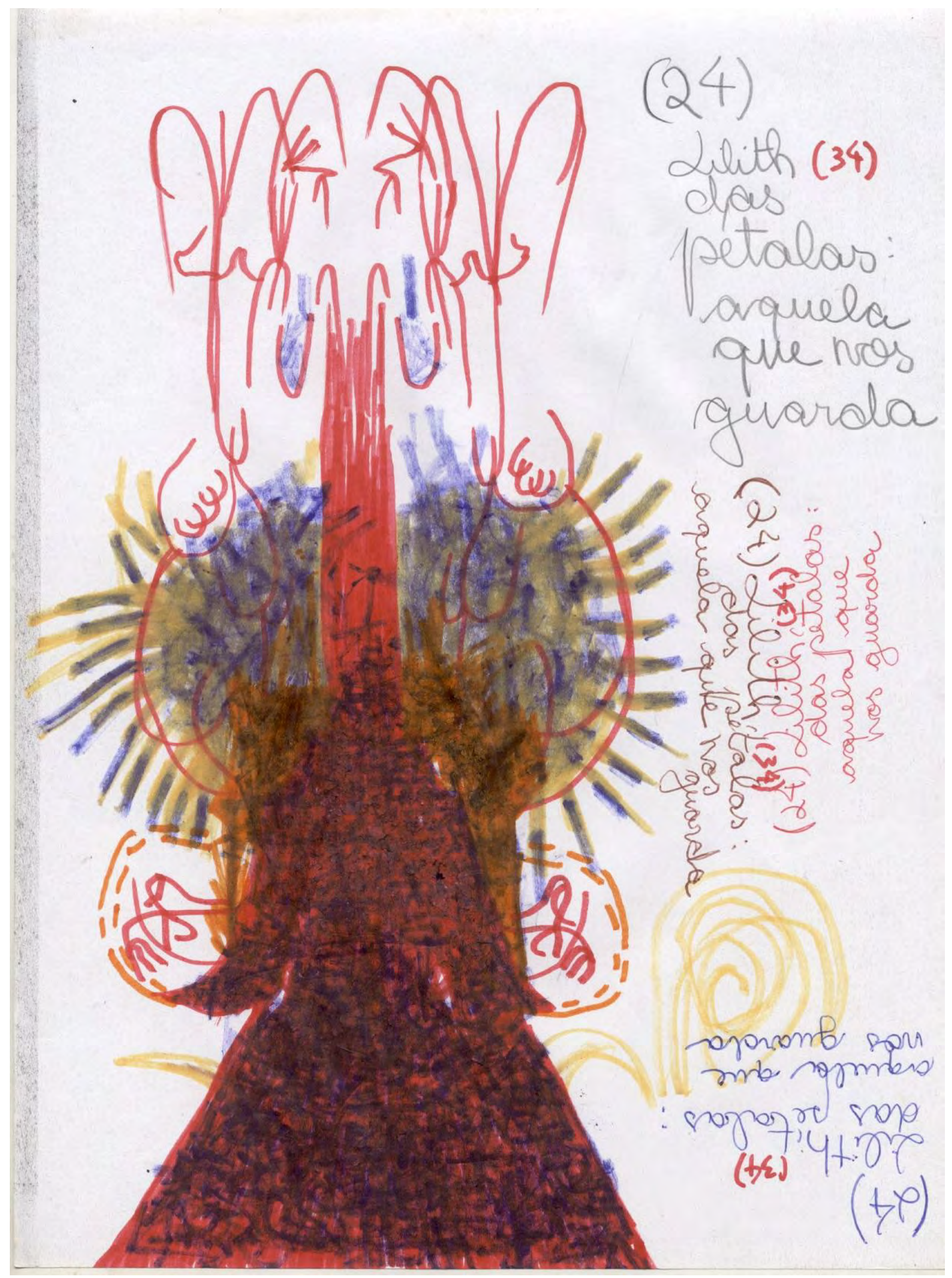


41.

[Armonia] [o aperto do nó de duas cobras]

Aqui, a correnteza do rio-cobra carrega muitos nomes. A cobra é o labirinto da mundo e o correr da vida, e o seu apertar é a possibilidade de dilatação, é pressão que dilata dimensões imprevistas, emergência de ressonância como gênese dimensional. ' 0 labirinto sonoro é o canto da Terra, 0 ritornelo, 0 eterno retorno em pessoa' (Deleuze, 2008, p. 120). Diz Calasso que 'o cosmo pulsa entre a serpente e 0 touro' (Calasso, 1991, p. 143). Quando se é o nó que aperta, há um touro que se desatrela, um fantasma-touro feito carne, que é Dioniso, alheio aos heróis. Touro: Eros, Zeus, Dioniso. E labirinto do touro monstruoso não é uma toca de cobra, é uma cobra. Diz Deleuze em mistério de Ariadne segundo Nietzsche: 'Teseu não compreende que o touro (ou o rinoceronte) possui a única superioridade verdadeira: prodigiosa besta leve no fundo do labirinto, mas que se sente igualmente à vontade nas alturas, besta que desatrela e afirma a vida' (Deleuze, op. cit., p. 115). Deixemos a palavra Cadméia com o contador Kerényi, que percorreu esta pletora de palavras, esta incoerência produtiva entre serpente e touro.

[...] Cadmo aparece nessa trama de dois casamentos de touros [Zeus e lo; Zeus e Europa], que nada mais é do que a história preliminar do nascimento de Dioniso ${ }^{148}$, o deus-touro adorado como o Filho do Touro, como boieiro. Mas Cadmo também aparece assim na história dos Titãs. Naqueles dias, o domínio de Zeus sobre o mundo dos deuses ainda não estava garantido. 0 dragão Tifeu cortara-Ihe os tendões e os escondera numa caverna. Nessa história Cadmo figura como o menino pastor que encantou o dragão com a sua flauta de boieiro, e assim obteve de volta os tendões e os restituiu a Zeus. [...] Um vaqueiro dos tempos primevos, seguindo uma vaca que, no entanto, não era uma vaca comum, mas a noiva de um deus e que trazia o emblema da lua - surge assim do leste a forma de Cadmo, e em sua casa em Tebas havia de nascer Dioniso. Não se

${ }^{148}$ A vida de Dioniso e seus renascimentos também se entrelaçam com a celebração de Deméter e os mistérios Eleusinos. Ver nos hinos homéricos. Indico Ribeiro Jr. (org.; ed., 2010). 
sabe - isso, provavelmente, foi mantido em segredo - se ele mesmo gerou a criança divina. No Círculo dos Cabiros, que faziam suas adorações secretas na llha de Samotrácia e também em Tebas, um dos deuses era apelidado Cadmilo, o que quer dizer "pequeno Cadmo". Este outro não era senão Hermes [...] (KERÉNYI, 2015, p. 36)

[...] Harmônia, como o seu nome indica, era a Congraçadora, uma segunda Afrodite, e ao mesmo tempo, filha do deus da guerra. [...] Verdade é que os samotrácios diziam ser Zeus e Electra [Plêiade] os pais de Harmônia, e talvez fosse isso o que os tebanos realmente pensavam, já que uma das sete portas de sua cidade recebeu o nome de Electra. Mas quem sabe se Afrodite também não era tomada por Electra, filha de Atlas e, portanto, Harmônia não se identificava com uma Afrodite mais jovem? Os dois nomes e as duas tradições também se reconciliaram numa lenda com a implicação de que Cadmo trouxe Harmônia consigo da Samotrácia, da casa de Electra, pois Electra assumira a responsabilidade pela filha de Afrodite, fruto do seu notório affaire com Ares, com o fito de educá-la. [...] (KERÉNYI, op. cit., p. 41)

[...] também na llíria se mostraram os túmulos de Cadmo e Harmônia e duas pedras em forma de serpentes, que se dizia serem seus monumentos comemorativos [...] eles estão, sem dúvida, entronizados entre os mortos, mas para os vivos o que aparece ali é um par de cobras. (Idem, ibidem, $p$. 42)

Você já viu duas cobras enroscadas? Quando Sêmele, filha de Cadmo e Armonia, foi fulminada pelo relâmpago (uma forma de Zeus nesta história) ${ }^{149}$, e 0 palácio destroçado; quando os demais filhos, à exceção de Polidoro ${ }^{150}$, encontraram a devastação, Cadmo e Armonia, desolados, rumaram até llíria. No caminho tomaram a forma de um par de cobras, conforme Kerényi, não se sabe bem quando. Helena Blavatsky também sabe rastros desta história. Conta-se, de toda forma, que é ainda a lenda do caduceu: cetro característico de Hermes, semelhante, mas não o mesmo cetro que usa Asclépio ou Moisés.

149 Uma das histórias do nascimento de Dioniso.

${ }^{150}$ Cadmo - Polidoro - Lábdaco - Laio - Édipo: a sequência dos reis lendários tebanos. 
A imagem dominante e aparente desta Armonia é aquela como deusa-donzela, cujo casamento teria sido o único em que o Olimpo compareceu inteiro para festejar. De fato um casamento do cosmo consigo. 0 que é isto? De qualquer maneira, a história continua. Nesta festa, Afrodite presenteou a filha com um colar fabricado por Hefesto. Tenhamos que Armonia era filha de uma união 'ilegítima' com Ares, face a um casamento forjado entre os olímpicos, de Afrodite com Hefesto ${ }^{151}$. O colar era, portanto, amaldiçoado. A maldição perdura até onde a vista alcança: 0 desenlace da tragédia Antígona, ao final da trilogia tebana do tragediógrafo Sófocles.

Esta, ainda que tremendamente confusa, é a mais conhecida Armonia (ou desconhecida?): junção entre amor e guerra, incoerência profunda e indissolúvel, um nó que aperta - existe amor 'puro'? Existe guerra 'pura'? Talvez Bruno Latour ficasse feliz em saber que aqui está o reino da proliferação dos mediadores. Porém, nascidas da incoerência antropológica, da contra-antropologia, da assimetria que pesa para 0 lado da vida ${ }^{152}$. Chamei-a, por tanto, por armonia da incoerência. Algo nascido da guerra e do amor só pode figurar através de uma decisiva incoerência.

Cadmo é personagem que, na fábula, é oriundo da Fenícia, filho do rei Agenor (por sua vez, filho de Poseidon e Líbia). Cadmo é irmão de Europa, sai de sua terra em busca da irmã, que havia sido raptada por Zeus ${ }^{153}$. Em algum ponto Cadmo se vê desviado de sua tarefa inicial.

Dioniso é filho de Sêmele, portanto neto de Armonia - confundi muito tempo Sêmele, a alvejada pelo raio, com Selene, Lua. Ao escrever eu tive de verificar...

Incoerência: a fábula, claro está, não poderia ser apenas aquela de um casamento e de um colar. Se levarmos a sério a trilha de Roberto Calasso - a despeito dele mesmo - em núpcias de Cadmo e Harmonia veremos o narrador se contradizer e uma outra Armonia se produzir pela devastação, no próprio chão do livro. É Ananke, a cobra órfica que aperta o cosmo. A Armonia não é uma donzela, não apenas; uma

1510 ressentimento de Hefesto para com as mulheres é notório, e diz respeito a seu próprio nascimento, consequente de uma resposta de Hera à primeira união de Zeus (com Métis, a Astúcia). Assim, os episódios fabulares das tramas entre Hefesto e Afrodite remetem sempre à dominação de Zeus no cosmo. Ver, com relação às uniões de Zeus, Torrano (2009), e sobre o nascimento de Hefesto, Détienne; Vernant (2008).

152 Dioniso é a própria figura do estrangeiro, lembrou-me um amigo grego; lembra-nos disto também a fábula de Dioniso sequestrado pelos piratas.

${ }^{153}$ A narração deste rapto é germinal da cidade de Creta, pois Zeus e Europa geram Minos, chefe lendário que funda essa cidade. 
dádiva de Zeus e Electra (Electra plêiade - nem a oceânida, nem a filha de Agamêmnon) a Cadmo, ou uma estória de rapto. Esta Armonia é, por força da própria narrativa de Calasso, também aquela 'mais escura', mais invisível e mais opaca, que segura a própria obra à qual o autor quer impor sua própria coerência ou incoerência (não posso pensar com outras cabeças conhecidas). Aqui a dramatização e psicologização, o aristotelismo involuntário de Calasso, seu compromisso espasmódico e oportuno com a verossimilhança (neste caso, irrelevante) o sabotam, pois uma personagem pode ser outras. Os deuses-natureza não se curvam à verossimilhança e à continuidade. Não é tampouco a armonia pré-estabelecida defendida pelo Hermes da tragédia prometeu acorrentado de Ésquilo. Aceitar apenas a figura da donzela, do casamento e do colar seria fazer valer a harmonia daquele Hermes tardio, subserviente. Assim, a Armonia da incoerência força a contestar o próprio narrador: o colar é um laço aperta o pescoço. Esta Armonia de que falo adere às imagens daquilo cujo movimento podemos perceber somente no fundo do tempocosmo (Cronos órfico, tempo como apenas durar dos dias, diferente do Cronos hesiódico, aquele dos ciclos e do cronológio). Esta Armonia de que falo é quando este fundo-tempo salta à frente repentinamente ao anoitecer, ou quando há a fibra úmida da madrugada do nó que prende o tempo, ou quando o dia vira carne que vibra em suas escamas: trata-se da serpente órfica da necessidade. (texto sobre Ananke em CALASSO, 1990, ps. 70-73). Com amor e guerra aderentes, Ananke que é também o laço que aperta...

O emblema da serpente aparece no livro de Calasso desta outra forma. Involuntária. Sobreposição de matrizes órficas, homéricas, helenísticas (que são críticas à estilística homérica), latinas, ainda outras... há como ser de outra forma? A segunda Armonia é, então, a suprema incoerência entre uma donzela, um casamento, um presente amaldiçoado pela própria forja do casamento, e o fundo do tempo que se move por necessidade, de forma invisível e opaca. A necessidade não é só humana. 0 laço ainda aperta o pescoço. Seria preciso gritar até que algo aconteça? Seria preciso um terceiro pulmão? 


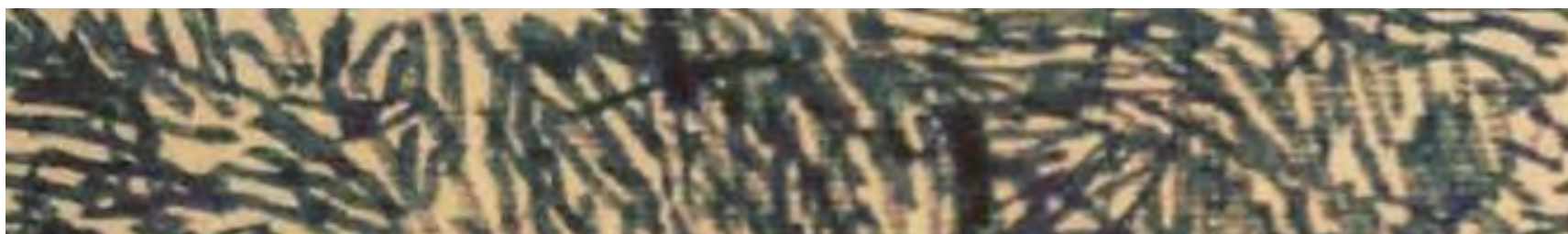

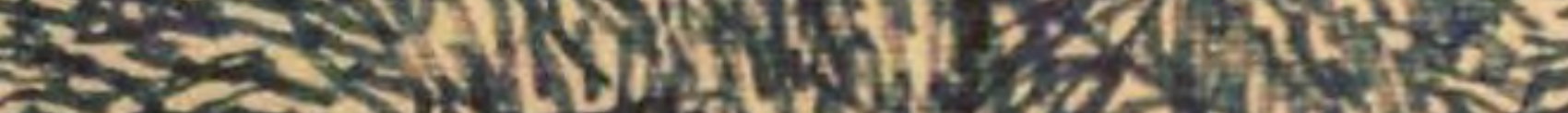

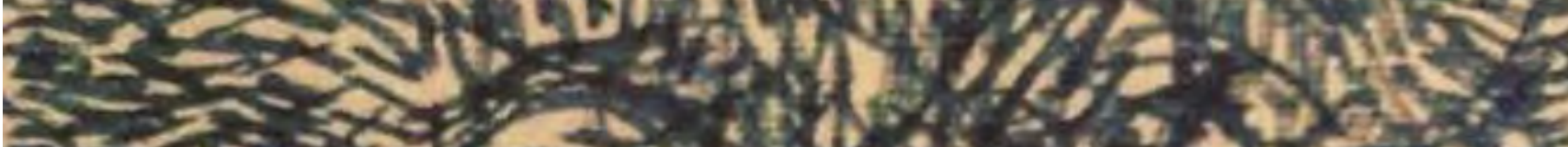

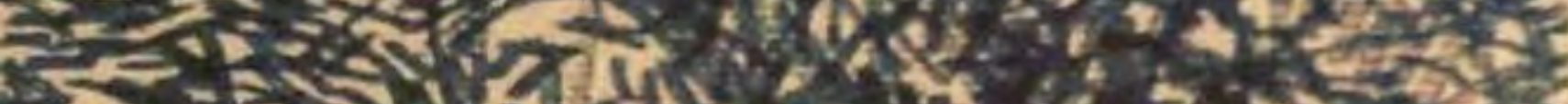

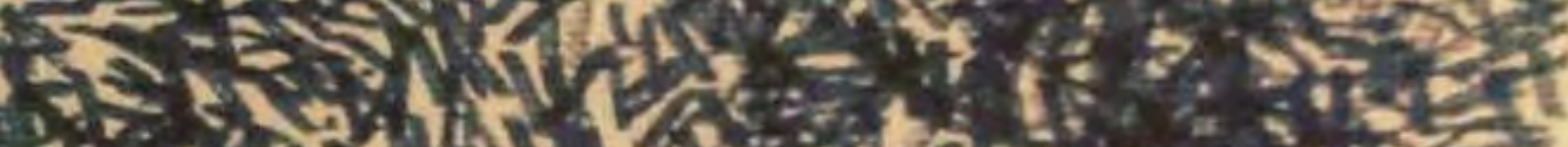

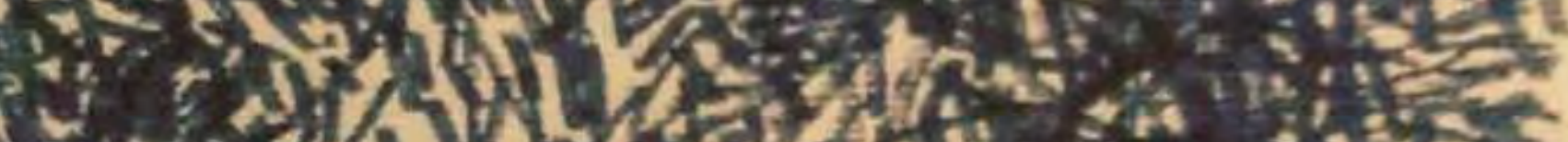

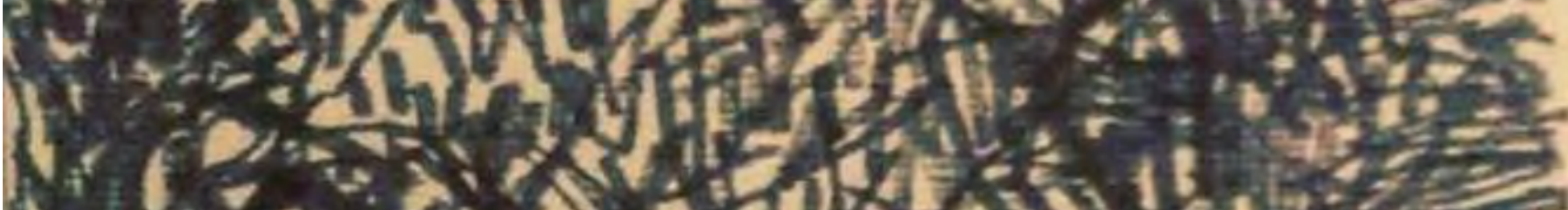

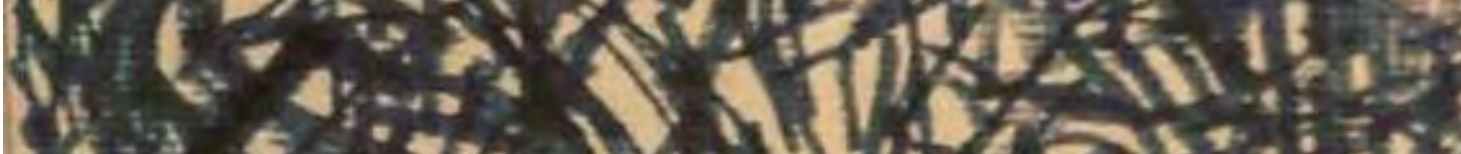

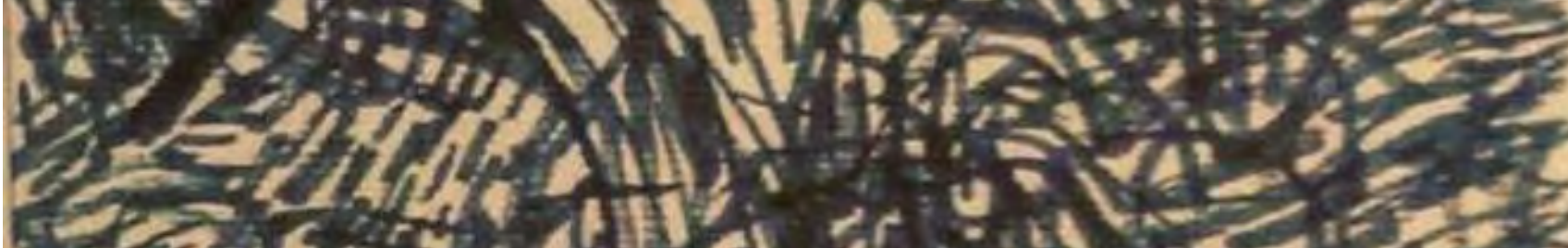
(3)

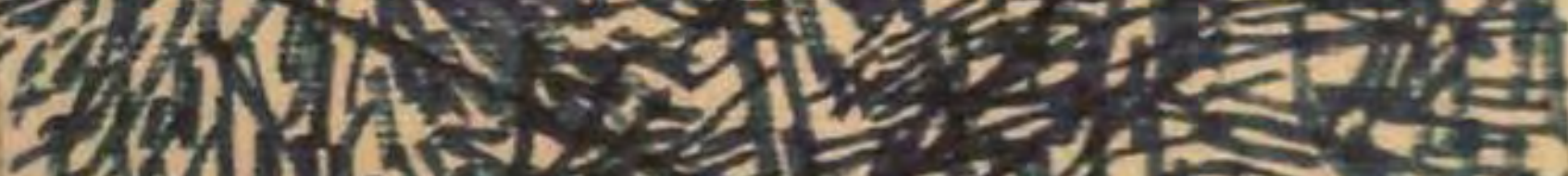

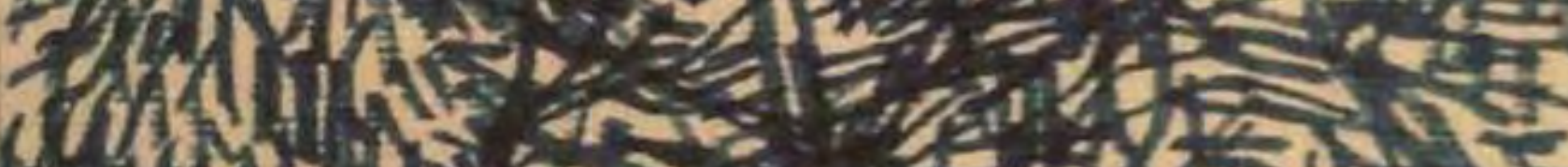
(19)

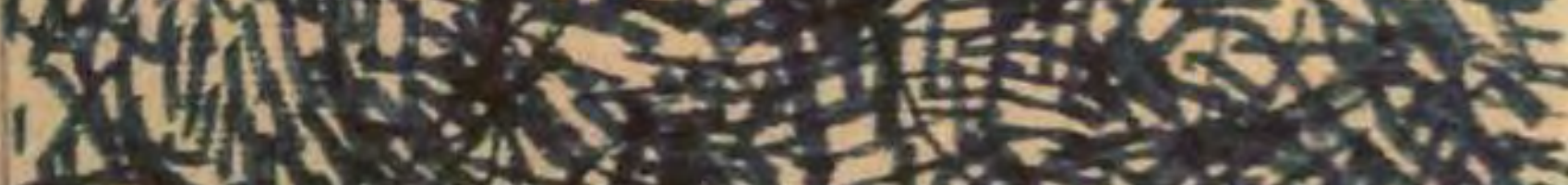

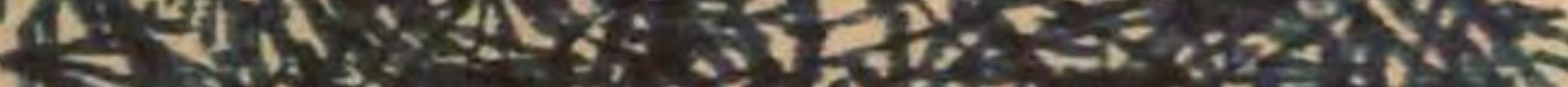

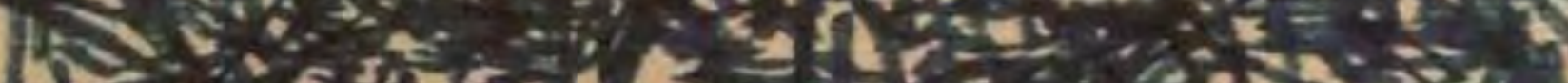

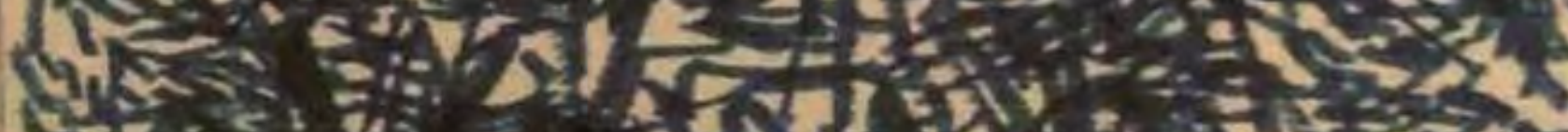

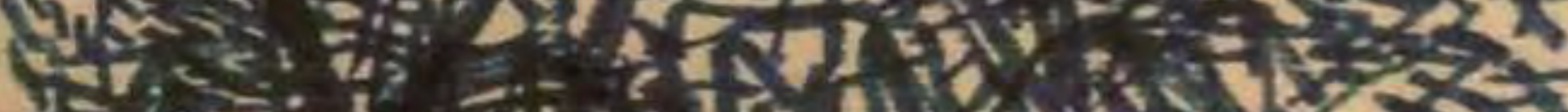
y-

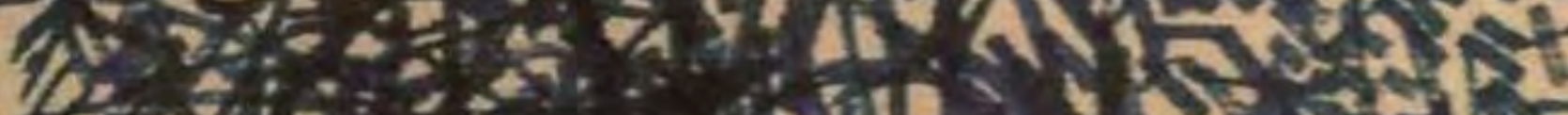

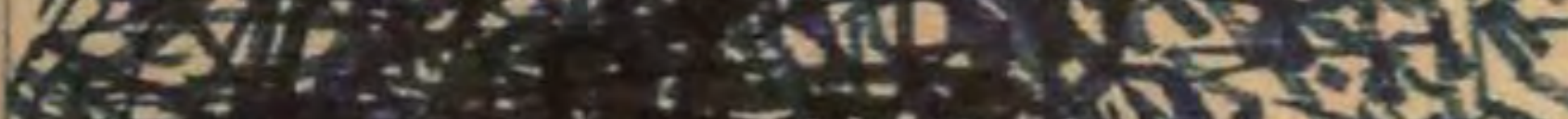

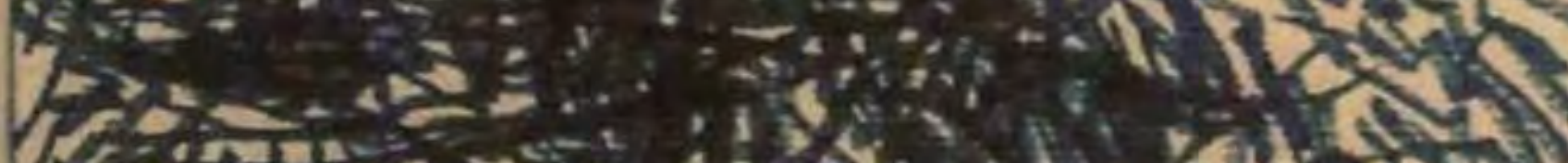
rot

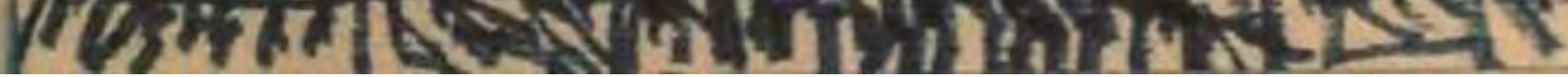


42.

el fenômeno imprevisto...

(diário de Frida Kahlo)

Segundo Calasso, os 'deuses novos', os Olímpicos, são sempre novos (e esta informação é extraordinária). Sua origem é escandalosamente omitida por Homero, em um mundo mítico cujo cansaço, ou ainda, cuja rota de superação teria sido já endossada ou traçada por Hesíodo, ao nomear a partilha divina na teogonia (CALASSO, op. cit., p. 65). Não à toa, a partilha divina é o arremate da teogonia hesiódica, um encerramento de mundificações, graças ao qual as Musas exercem, por sua vez, o domínio do seu lote: são responsáveis pela palavra que canta e dissemina a própria partilha. E é por isso que o hino às M usas é o primeiro da Teogonia (ver os ensaios de Torrano musas e ser; musas e poder; na presença do nume-nome. TORRANO, 2009).

Calasso. 'O Olimpo é uma revolta da leviandade contra a precisão da lei'; 'entre Ananke e Eros, preferem se submeter a Eros, embora saibam que Eros é uma esmaltada cobertura de Ananke' (p. 72). A descrição de Ananke por Calasso é a de uma cobra compressora e tensa, que expressa o vínculo, a parentela:

Ananke, a necessidade que tudo domina na Grécia, incluindo o Olimpo e seus deuses, jamais teve um rosto. (p. 70.) [...] Segundo Parmênides, 0 próprio ser é envolvido pelos "vínculos da corda" da "potente Ananke". E, na visão platônica, surge imensa luz "ligada ao céu como os cabos que rodeiam as quilhas das trirremes, abarcando toda a sua circunferência". Em todo caso o vínculo é o essencial. Necessidade é um vínculo recurvado, é uma corda com nós (peírar) que mantém o todo dentro do limite (péras). (p. 71) [...] Ainda no período do paganismo tardio, podemos ler em Macróbio "amor osculo significatur, necessitas nodo": "o amor ganha significado com o beijo, a necessidade com o nó". Dois seres circulares, uma boca e um laço, envolvem aquilo que existe. [...] Mas Eros não se pronunciou sobre Ananke, que o precedera [no poder; Eros, pelo menos segundo Hesíodo, está entre os Quatro Primordiais] Entre Eros e Ananke 
reina uma inimizade baseada numa obscura semelhança, como entre beijo e nó. (p. 72)

Corda tensa, como a do arco e da lira, em Heráclito, mas não esticada, é apertada: esta é curva, constritora. Em todo caso, a coincidência desta com o primeiro uso técnico registrado de Armonia (presilha para prender peças heterogêneas de madeira na carpintaria) ${ }^{154}$ é notável. 0 uso técnico musical é posterior a este uso.

A cobra, como Ananke-Armonia, é nó que aperta o próprio mito. Lembro do curso de poesia épica grega ${ }^{155}$ onde o professor descrevia a polissemia da palavra Mito, derivado de kúklos (ciclo) - a acepção mais aceita é aquela pré-homérica que culmina em Homero, onde o mito é associado aos ciclos épicos (tebano, troiano etc) como um corpus ideal. M as a polissemia avança, passando pelo círculo, pelo anel, pela roda... ${ }^{156}$

Um texto de Martin Lichtfield West (M L West) the invention of Homer, de 1999, tenta dar conta do caráter técnico, artesanal, dessa guilda de rapsodos que possivelmente teriam inventado um autor Homero ao final do século sexto a.c. Sustém West que os homeridas não são descendentes de um pater, talvez nem uma escola, mas uma associação profissional inter-regional apelidada às vezes por 'os costuradores de versos' (e seus por vezes engenhosos fraudadores). O nome Homero tem parentesco com o termo refém, possivelmente oriundo de uma festa com caráter inter-gêneros e sexual da região de Chios (Jônia), região de onde pareciam provir os

154 Paula da Cunha Corrêa: Harmonia: mito e música na Grécia antiga. Editora Humanitas / FFLCH / USP, 2003.

${ }^{155} \mathrm{Em}$ 2016, e aqui estou atado à informalidade, posto que a aula era demasiado formal, e eu reprovei na disciplina por conta da minha informalidade no trabalho final. Tratou-se da disciplina poesia épica grega, ministrada por Christian Werner e Fernando rodrigues Jr.

${ }^{156}$ [1] Ideia de continuidade, onde um poema está mais ou menos amarrado no seguinte, onde o poema é pensado dentro de um todo (Hesíodo na teogonia e no catálogo das naus da llíada; historiografia de Heródoto e Tucídides); [2] circularidade, algo inerente à história humana, ou do destino humano: 'ninguém goza de sucesso durante toda a sua vida' (Aristóteles sobre Príamo; Heródoto sobre Sólon; Tucídides; crescimento e miséria das cidades; Tróia destruída mais de uma vez; distinção entre telegonia e teogonia como modo de distinção entre mortais e deuses); [3] ideia de completude que faltaria ao item [1], ou seja, que investe no todo e não nas partes; [4] função envolvente ou enquadradora, porta um certo olhar ao passado que pretende dar conta daquilo que cria e envolve (por exemplo, a teoria da recepção por Aristóteles poderia nos dizer que Aristóteles é bom de ser lido como ele mesmo, e não como análise de outro material); [5] (a partir de Gregory Nagy e Rüdiger Schmitt) uma noção um pouco antiga, a imagem da roda e a importância da carpintaria em geral na poética indoeuropéia (Nagy:

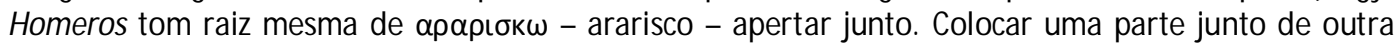
para formar um todo perfeito, o poeta faz isso micro e macroscopicamente). As anotações seguem. 
cantores dessa associação profissional em especial. West arrisca variações acerca da tônica coletiva do uso para o termo homerida: espaço público de encontro e cantoria corroborante com as descrições ainda de uma técnica coral onde 'o som soa junto', ainda que o objeto de interesse não seja propriamente o coro. Portanto, um modo coletivo na medida da produção e recepção da poesia épica. A nomeação de um Homero por o bardo cego de Chios poderia ser referência a um membro dessa guilda, e a alegada última aparição de Homero em 523 a.c. em Atenas o marco da consolidação de uma herança homérica.

Mito, dimensões do círculo, prensa e nó de serpente, a invenção de um corpo homérico, corpo de carpintaria.

Além da árvore e da fonte, aderem ao nosso conjunto de imagens a serpente, 0 touro-serpente-touro, o colar que aperta, o raio.

Poderia ser um polvo (figura tão recorrente nos vasos cretenses) uma árvore que anda?

Penso na imagem da jangada fornecida por Fernand Deligny: uma estrutura apenas amarrada no mínimo possível. 


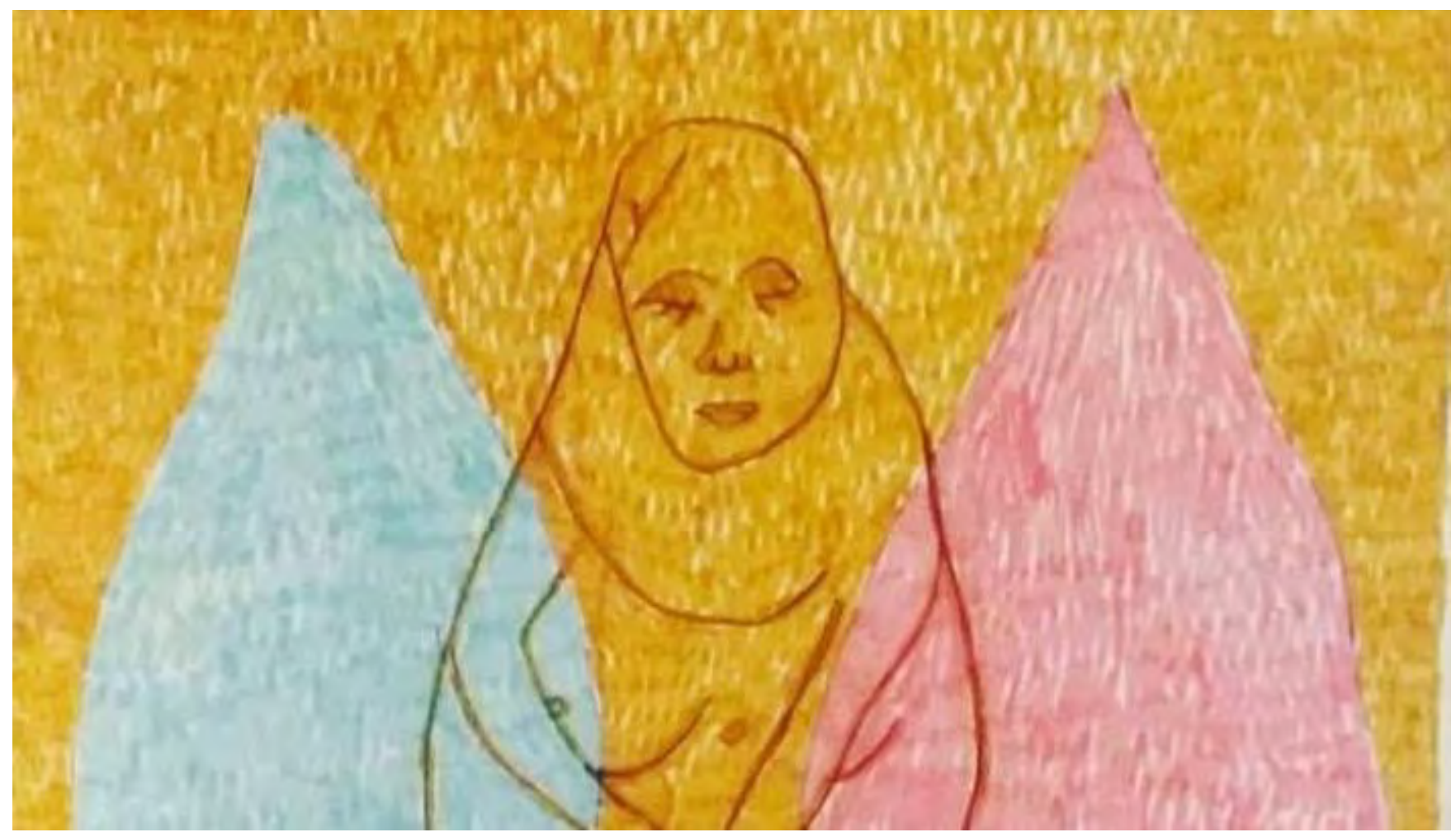

43.

\section{[aquele que vive é um nó agudo]}

A terceira Armonia é aquela mãe das musas Piérias. Este grupo de musas é invocado por Hesíodo em os trabalhos e os dias; são as musas que competiram com as Heliconíades (as musas maiores, evocadas pelo mesmo aedo na teogonia) e, havendo perdido, foram transformadas em diversas espécies de pássaros ${ }^{157}$. Esta Armonia aparece na produção de cerâmica da cidade de Atenas no século quinto a.c., bem mais tardia à Armonia Tebana; aqui, Armonia, ainda que ligada tanto a Atena quanto Afrodite, aparece como deusa acessória desta, bem como outras o são dentro da polis

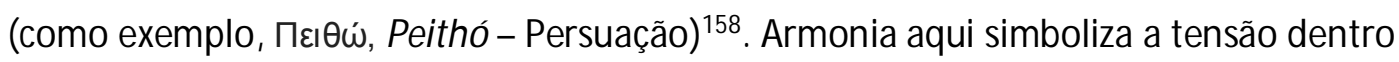
do casamento (as vozes intermediárias do côro) e o casamento cívico de toda a

${ }^{157}$ Há uma rica rede documental da mitologia das Musas em https:// www theoi.com/Ouranios/M ousai.html.

158 Quem conta esta condição da Armonia Ateniense Amy Smith: Athenian political art from the fifth and fourth centuries BCE: images of political personifications. www. stoa. org , 2003. 
cidade $^{159}$. A Armonia das Pieriai é mencionada na tragédia Medéia de Eurípedes: aparece aqui também associada a Atenas, na cena em que M edéia, em Corinto, recebe asilo político-religioso daquela cidade.

Aqui, a genealogia de Armonia é aparentemente a mesma daquela tebana, o que me deixa alerta para um desenraizamento. Assim, lemos a peculiaridade desta Armonia mais a partir das filhas.

Eu a nomeio por armonia do fracasso. 0 fracasso é um canto desconcertado. A contenda se encerrou. Porém na dimensão de um canto de fracasso, há não apenas uma anedota, paródia, ou lembrança do fracasso. Há algo mais. Há uma relação com o luto. Com o que se rompeu, se perdeu.

As Piérias, ao desafiarem as Heliconíades, incorreram numa desmedida (Hybris), desencadeando a resposta desproporcional das deusas-M usas de Hélicon ${ }^{160}$. Ação para a qual não há volta.

Aqui se vê, num espectro tanto amplo quanto possível, a função do canto como possivelmente o único capaz de narrar a dor avassaladora do trágico. Assim, pode-se ou se deve cantar o trágico na situação de continuidade de alguma vida que coincide com a própria história de uma-vida.

Esta paradoxal necessidade de cantar o trágico é um componente pré-trágédia, até pré-homérico, presente já na epopeia de Gilgamesh (poema épico compilado no século sete a.c., mas com fragmentos que remetem até o século XX a.c.). A afetividade trágica em pauta diz respeito, grosso modo, a sustentar o insustentável e compor 0 luto com prazer na medida em que se canta. Pra quê serve a poesia, afinal? Não se trataria de converter a dor em prazer (o que é um erro, quando operado apenas pela vontade) mas de tornar os fatos narráveis, ou dar um lugar ao inenarrável. Em um só golpe, tomar uma história e ao mesmo tempo supor as condições existenciais do vivente, gesto que é necessariamente um impulso (aqui eu tendo a seguir as hipóteses de Stephen Halliwell em between ecstasy and truth ${ }^{161}$ ). Neste impulso, neste

\footnotetext{
159 O minucioso estudo de Smith nos conta que, ao contrário da associação habitual da Harmonia grega com a Concórdia romana, os Atenienses já tinham sua concórdia (Homonoia), bem como uma sucessão de divindades próximas: Eumonia, Eudaimonia, Eukleia, Eutaxia...

160 As musas piérias eram filhas do rei Pieros. Então devo supor que eram 'mais mortais'.

${ }^{161}$ Between ecstasy and truth: interpretation of greek poetics from Homer to Longinus. New York:

Oxford university press, 2011.
} 
tracionamento, neste difícil e titubeante apelo ao vivente, recorre-se ao universo mágico impessoal. Em verdade, é com esta força que se passa o diálogo.

Há pelo menos duas dimensões: o conhecimento da mortalidade (o encontro de Aquiles e Príamo no canto XXIV da Ilíada; a própria viagem de Gilgamesh ${ }^{162}$ ) e a narração dos eventos catastróficos que nos antecederam ${ }^{163}$. São hipóteses de estética trágica desvinculados da forma tragédia.

Aqui, a leitura de novas dimensões da vida é dada no esvaziamento.

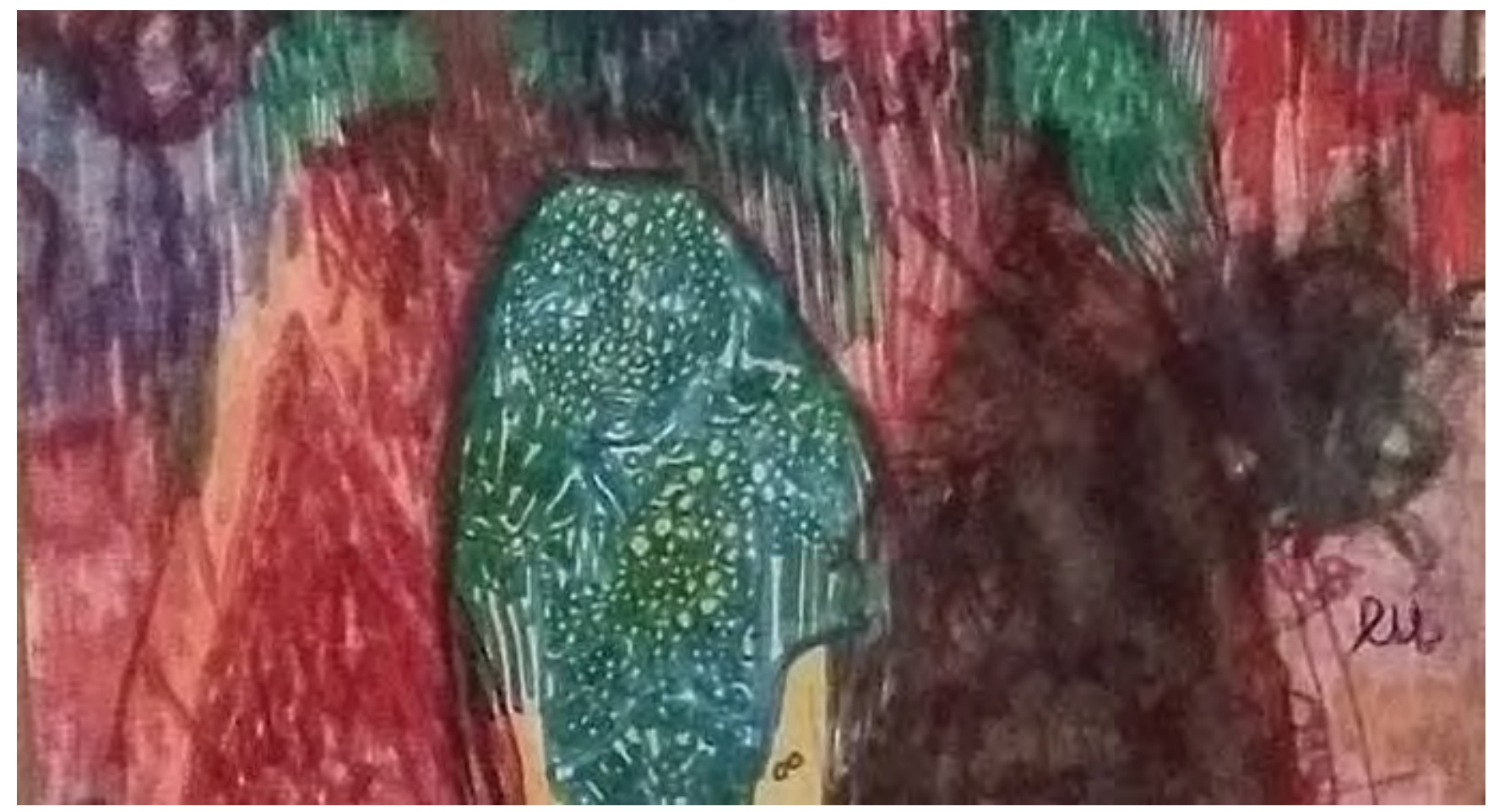

44.

Três leituras de Armonia: dissidência, incoerência, fracasso. Três estratégias assimétricas de se rastrear a germinação como víscera de mundo, víscera atmosférica.

As consequências do pensamento mineral-vegetal, alter-orgânico, ainda não foram bem medidas. 0 que intentei foi fazer a ponte da transdução simondoniana com as linhas germinativas de Klee, e destas com uma coleta de vozes.

\footnotetext{
162 Campo percorrido por Johannes Haubold, em Greece and Mesopotamia: dialogues in literature. New York: Cambridge university press, 2013.

${ }^{163}$ Ao partir dos mesmos exemplos, seguem a falta de sentido da Guerra de Tróia ou da morte do companheiro de Gilgamesh, Enkidu.
} 
Certamente se verificou aqui o mito como bloco de devir, não como origem. Germinação mítica. Será mitologia aquele apelo para a fabulação e a necessária ativação política? 


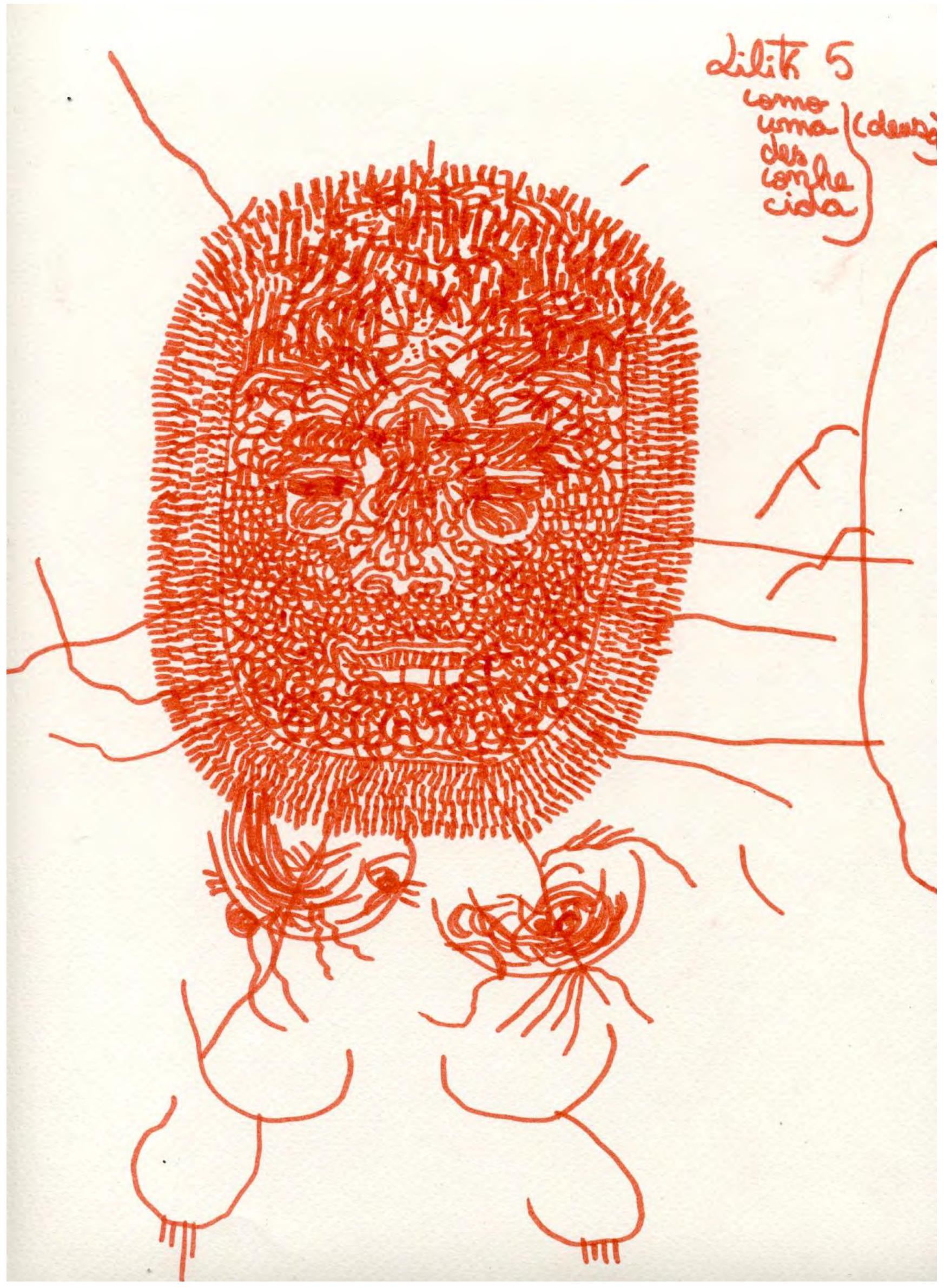


45.

( 0 bebê de pedra

(uma dança)

para Priscila Jorge

Quem é a mãe da Lua? / Ela tem muitas mães, e isto porque são muitas as Luas. /

Mas uma mesma lua ainda tem muitas mães.

Uma das mães percorre quase todos os lugares durante o anoitecer. / Uma outra é a quietude de seu próprio bebê de pedra.

0 bebê de pedra está em festa, ele é uma incontável metamorfose. / Ele é a pedra, uma pedra.

0 escuro que é sua mãe é exatamente o visível. / Completamente fora da terra, dentro da terra. / Só que disso nada sabemos.

)

[FIM DA PRIMEIRA COLETA]

[a seguir:

a árvore indestrutível de Lilith logo antes do amanhacer (Lilith 12) (detalhe)] 


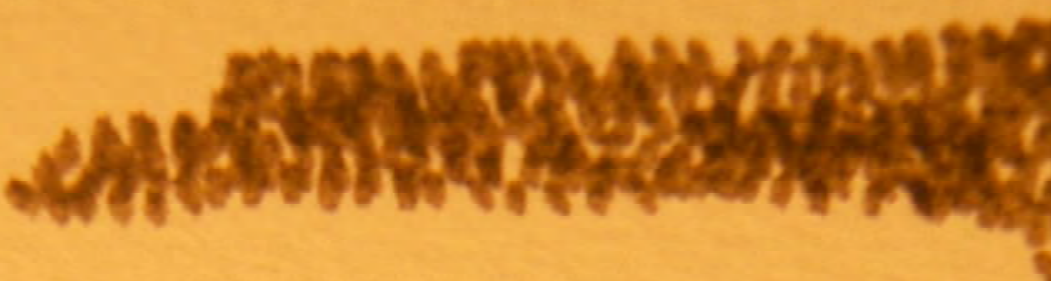

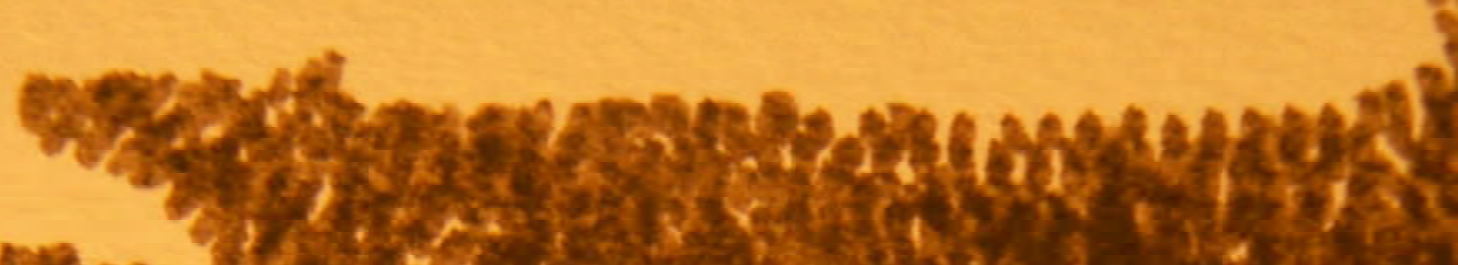

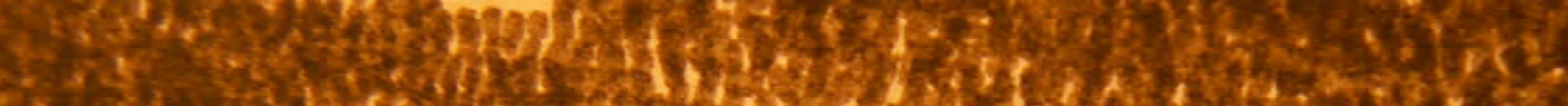

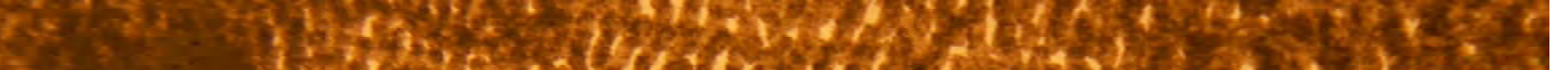

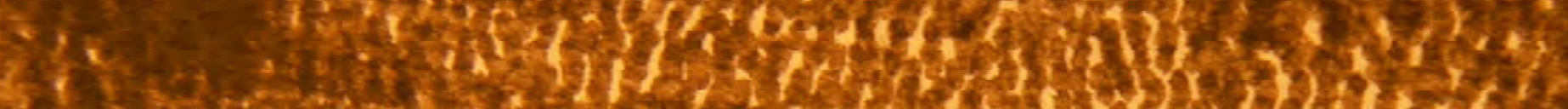

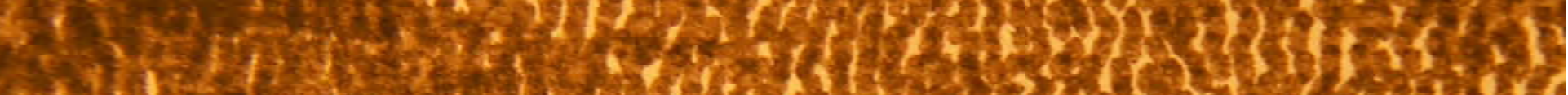

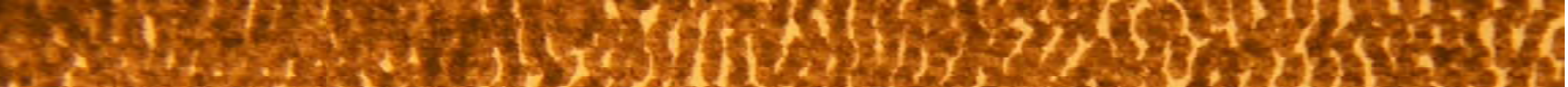
Q

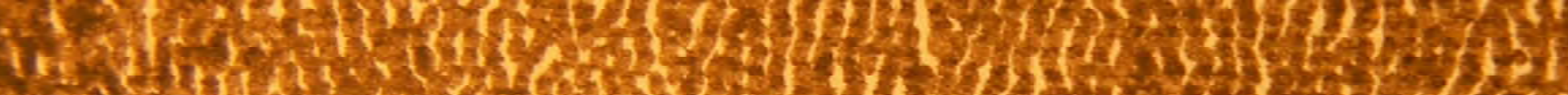

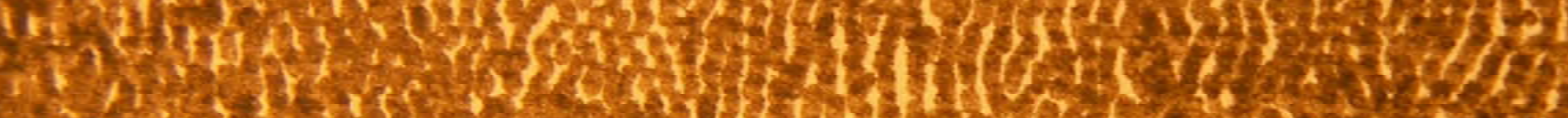

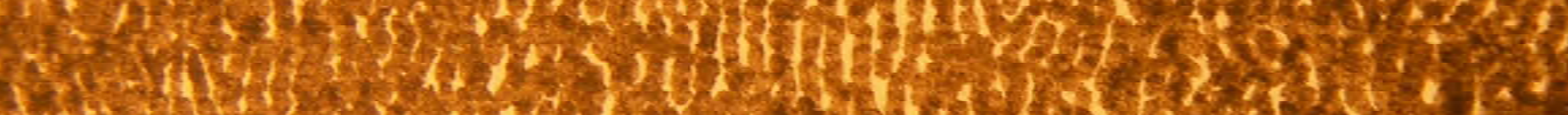
a

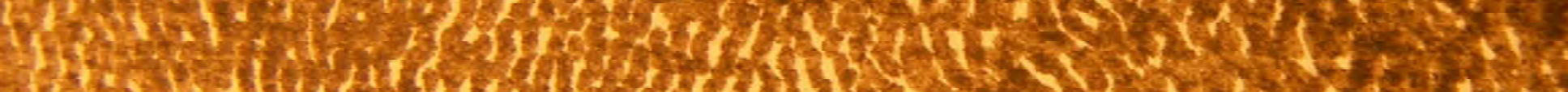

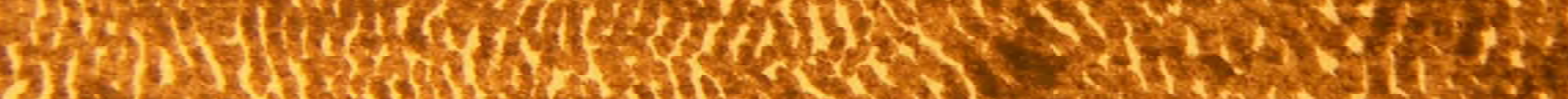

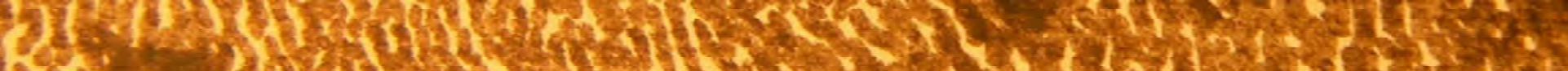

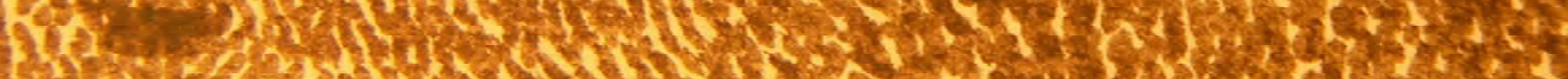

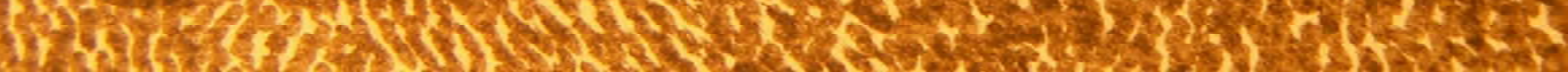
a

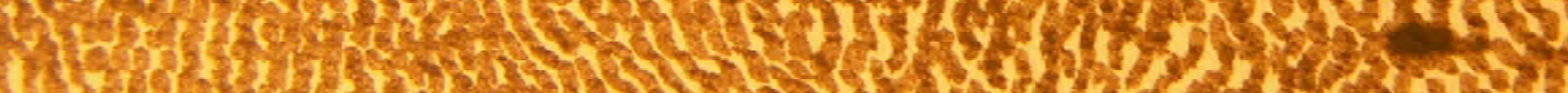
mun Hin

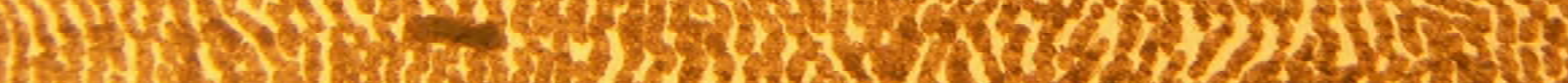

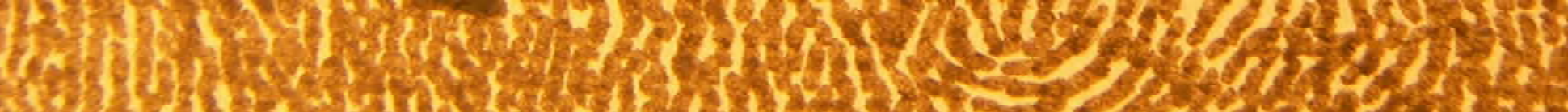

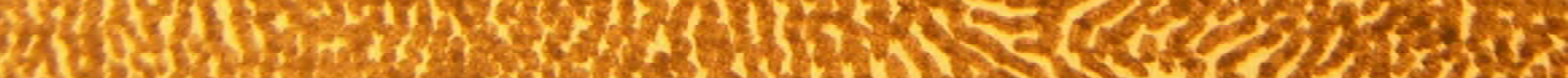

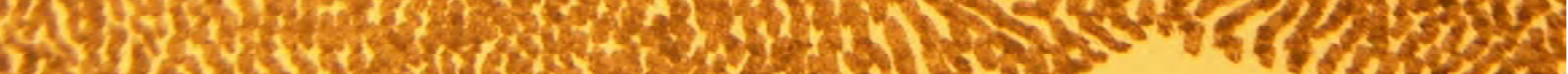

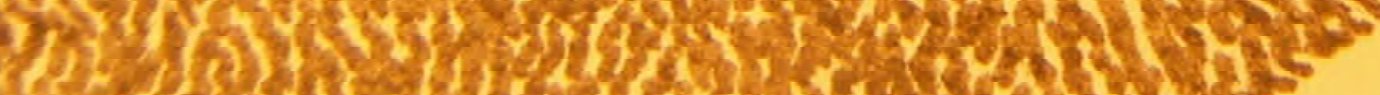

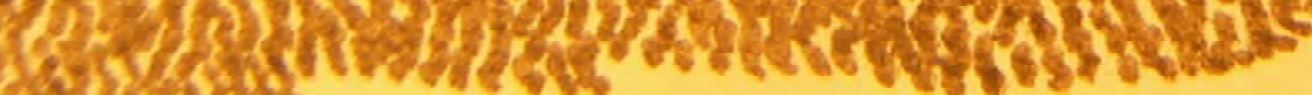


Maré cinco

Preciso falar do coração da coisa / Ou eu estou sempre falando do coração da coisa / Mas é difícil falar do coração da coisa pois / Parece que tudo o que falamos vem do coração da coisa / Então parece que finalmente se trata do coração da coisa falando / Ou consigo, ou só falando / Mas sempre escapa algo / Escapa para o escape / Circula em volta da sucção

Seiva / orvalho / caminhada / passarinho preso no freio de um carro

Um sapo coaxa / Um sapo coaxa / Coaxa coaxa / Muitas coisas acontecem / Mas um sapo coaxa

Uma semente de ar / É a coisa mais densa que existe / Pois nada tem a ver com o ar / Uma espécie de costura / Bomba guardada, estalo dobrado

Dentro do ar / Na minha língua tem uma espécie de geratriz / De sementes de ar / Poros sementes de ar, um genital

Quando é amor, vem uma / Espécie de tentáculo fauna / Pedaços de bichos / Brotam instantâneos e demorados / Chega. Nem sei o que é o amor / Só sei que há o coração da coisa

É preciso coragem para abrir o livro do corpo / E iniciar sua leitura

Bêbado bêbado / Passo bêbado

(Novembro de 2017) 


\section{[(SEGUNDA COLETA)]}

\section{[caderno]}

Vejo, no momento em que escrevo estas linhas, o rosto vermelho ensanguentado do pintor vir até mim, numa muralha de girassóis eviscerados,

num formidável braseiro de carvões de jacinto opaco, e de capim de lápis-lázuli.

Tudo isso em meio a um bombardeio como que meteórico de átomos que se deixariam ver grão a grão,

prova que Van Gogh pensou nas suas telas como um pintor, é claro, e unicamente como um pintor, mas que seria, por isso mesmo, um músico formidável.

Organista de uma tempestade interrompida e que ri na natureza límpida, pacificada entre duas tormentas, mas como o próprio Van Gogh, esta natureza mostra mesmo que está prestes a ir-se embora.

[...]

Antonin Artaurd: Van Gogh, o suicidado da sociedade [1947] (ARTAUD, 2014, ps. 280-281)

\section{[...]}

Ademais, Sr. Archtung, eu desenho.

Quero dizer que não desenho, mas que ao lado do que escrevo faço figuras que são como barras e não sombras.

0 que faço está muito perto de mim, é muito íntimo.

Não aceitaria alguém cagando comigo quando eu cago ou lavando a bunda no mesmo bidê que eu. -

0 mesmo vale para os meus escritos.

Eles não deixarão meu foro íntimo e um outro que não eu não pode intervir na sua manifestação

Aí está.

[...]

Antonin Artaud: Carta a Hans Archtung [1946 ou 1947] 
1.

Van Gogh é unicamente um pintor. Artaud desenha e não-desenha, faz da página do caderno a sua cena-escritura-corpo. São 'barras'. Nas palavras de André Lage, é a reinvenção da anatomia ${ }^{164}$. É preciso escrever o corpo, continuar refazendo o corpo com os meios disponíveis. Tanto Lage quanto de Ana Kiffer (principalmente 2017 e 2018 ${ }^{165}$ ) são estudiosos dos cadernos artaudianos (1943-1948). Daí que os procedimentos que narram a escritura da página não visam um outro projeto que não este: continuar refazendo o corpo e a anatomia. Procedimentos: golpes em um tronco com uma faca ou martelo, golpes na página, golpes de escansão ou jatos escritutalverbais, inscrições as mais variadas, além do embaralhamento e subversão entre inscrição, caligrafia, escrita e desenho... Estas são apenas alguns dos exemplos. Aqui coincidem um sem-número de objetos de experiência que de individuam em conjunto. Desenho-escrita-teatro, corpo-inscrição-desenho-golpe-voz, antipsiquiatria-fecalidadeantiórgão etc. A necessidade, repito, não é uma obra, mas muito aquém: um corpo de perpétuo refazimento.

\section{2.}

\section{Mal-entendido, um:}

surrealismo de borda, literalidade, pensamento operativo.

Susan Sontag escreve aproximando-se de Artaud (approaching Artaud, 1973) ${ }^{166}$. Seguem fragmentos deste ensaio, que nos ajuda a acercar-nos de alguns importantes caracteres artaudianos, como de seu surrealismo da borda, um surrealismo literal, surrealismo este paradigmático de uma prática de devir decisivo. Surrealismo este que

\footnotetext{
${ }^{164}$ André Lage: os cadernos de Antonin Artaud (2009), publicação sucinta que marca o início do seu pósdoutoramento na ECA-USP. Disponível em https:// www.revistas.usp.br/salapreta/article/view/57414 . 165 Consultei mais profundamente duas publicações de Kiffer: a perda de si: cartas de Antonin Artaud (2017) e o artigo recentemente publicado o rascunho é a obra: o caso dos cadernos (2018).

${ }^{166}$ No livro under the sign of Saturn (1980) - sob o signo de Saturno (1983).
} 
não poderia ser chamado como tal e não é sequer localizável, dada a sua literalidade e o risco extremo de sua aplicação.

[...] Foi baseado num mal-entendido que Artaud aderiu fervorosamente ao desafio surrealista contra os limites que a "razão" estabelece sobre a consciência, e à fé surrealista no acesso a uma consciência mais ampla, propiciada pelos sonhos, pelas drogas, pela arte insolente e pelo comportamento anti-social [Artaud fez parte do grupo surrealista de André Breton de 1924 a 1926]. 0 surrealista, pensava ele, era alguém que "desesperava-se para encontrar sua própria mente". Ele referia-se a si próprio, naturalmente. 0 desespero está inteiramente ausente da corrente principal das atitudes surrealistas. [...] Como disse Marcel Duchamp num comovente elogio a seu amigo Breton em 1966, quando este morreu, "a grande fonte da inspiração surrealista é o amor: a exaltação do amor que se escolhe". 0 surrealismo é uma política espiritual da alegria.

Apesar da veemente rejeição do surrealismo por Artaud, seu gosto era surrealista - e assim permaneceu. [...] Mas nenhum sentido de crise no cânon surrealista é tão desolador quanto o de Artaud. Comparadas às percepções laceradas de Artaud, tanto cósmicas quanto intimamente psicológicas, as lamúrias surrealistas mais parecem reconfortadoras que alarmantes. [...] (ps. 24-25, anotação minha entre colchetes)

'Não somente é a posição de Artaud insustentável; ela sequer chega a ser uma "posição"' (p. 54). Esta leitura de Sontag parece contrastante com a noção do 'amor que se escolhe' do enunciado surrealista expresso por Duchamp. Arriscar a imaginação de um corpo desconhecido, que necessita, em paradoxo, ser continuamente refeito; este corpo pode ser formulado, então, como a ausência de uma escolha. Uma secreção. Uma enigmática literalidade, uma explícita e comprometida fala alheia. Sigamos:

Ele fala dos "gritos intelectuais" que vêm de sua carne, fonte do único conhecimento em que confia. 0 corpo tem uma mente. "Há uma mente no corpo", escreve ele, "uma mente rápida como o relâmpago." [...] (p. 46) 
0 compromisso de Artaud com o valor mágico das palavras explica sua recusa à metáfora como o modo principal de transmissão de significados em seus últimos poemas. Ele insiste em que a linguagem expresse diretamente o ser humano físico. A pessoa do poeta aparece decomposta, num estado que ultrapassa a nudez.

À medida que Artaud se esforça para alcançar o indizível, á sua imaginação toma-se mais áspera. [...] (p. 50)

Sua autoridade repousa nas partes que não dão nada ao leitor, exceto um intenso desconforto da imaginação.

A obra de Artaud toma-se utilizável de acordo com nossas necessidades, porém é uma obra que desaparece sempre que tentamos utilizá-la. [...] (p.55)

3.

Na primeira das cinco cartas a André Breton, A. Artaud atesta: 'eu tenho minha própria ideia de nascimento, da vida, da morte, da realidade, e da sorte, e eu não admito que se me imponham ou me sugiram alguma' (2017, p. 125). Artaud, um clássico 'desejado pela cultura', mas 'profundamente indigerível' (Sontag, p. 55). Segue que o tema da literalidade, realidade daquilo que é literal, em choque com a oficialidade surrealista, pode ser rastreada no próprio Artaud. Há um enunciado flagrante na terceira carta a Breton: 'porque se o surrealismo não era real, então para quê?' (op. cit., p. 148). Os vínculos da literalidade artaudiana foram certamente aprimorados nos seus procedimentos no 'Artaud final', o 'Artaud dos cadernos'. Como aqueles vínculos desta literalidade miserável com um pensamento mágico, ou como ressonância da sua viagem ao México cerca de década antes, em 1936, vínculo com suas andanças miseráveis na Irlanda em 1937, antes de sua prisão ... estes vínculos ainda poderão ser muito melhor aprofundados.

Penso haver uma correspondência entre a literalidade em Artaud, expressão derivada disso que chamo por 'surrealismo de borda', e aquela literalidade 
deleuziana ${ }^{167}$ contra-metafórica, e aqui não serão possíveis grandes aprofundamentos. 0 que me cabe agora é o simples gesto de traçar, de tracejar uma linha entre a literalidade e uma filosofia operativa, talvez uma alagmática (teoria das operações, endossada por Gilbert Simondon) presente em conceitos deleuzianos.

Do pensamento operativo, pensamento em corpofificação, transdução, podemos coletar, em Deleuze, acredito, várias amostras em Francis Bacon, logique de la sensation. Não é à toa que, quando Deleuze aborda nesta obra o CsO (Corpo sem Órgãos), tema do Artaud tardio ${ }^{168}$, o aborde de modo tão 'técnico', tão 'ordinário', e ao mesmo tempo tão fortuito para nós ${ }^{169}$. Exemplos de contraste se fazem então necessários. Não há neste caso os resíduos de formalismo e esquematismo filosófico como aqueles presentes em 28 de novembro de 1947 - como criar para si um corpo sem órgãos ${ }^{170}$ (texto de mil platôs, 3), e nem a versão poeticidade sumária da descrição do CsO em o Anti-Édipo.

Em Francis Bacon, Deleuze recorre a algumas entrevistas do pintor Bacon, e o modo como essa evocação é feita é impressionante. Pois há no livro por vezes esse universo de ateliê, que aparece na proximidade e mistura com a matéria de trabalho. Há um sujar-se. Uma 'carne empírica'. Criamos laços de pensamento-corpo com Bacon, um pintor que testava mecanismos do instinto e da víscera da pintura.

167 François Zourabichvili (1965-2006), tem como recorrente objeto de interesse a literalidade, além da noção de acontecimento, e esta ao menos dupla investigação do 'Zoura' encontra grande amostragem na filosofia deleuziana. Um exemplo é o seu vocabulário de Deleuze (trad. 2004, le vocabulaire de Deleuze, 2003), onde a literalidade está em sua primeiríssima advertência. Ver também: a questão da literalidade em Deleuze - traduzido em 2015 e creio que originalmente posto a público em 2007 na revista Klēsis: revue philosophique, $\mathrm{N}^{\circ} 4$ (2007). Pode-se ler a tradução em https:// machinedeleuze. wordpress.com/2015/04/23/deleuze-e-a-questao-da-literalidade-por-francoiszourabichvili/. Neste texto de Zoura há uma espécie de levantamento de imagens-operadores muito próximos ao paradigmas físico-corporais da ontogênese simondoniana: pensamento vegetal e cristalino.

As informações acerca de Zoura ainda estão, no meu ver, bastante dispersas, e é um pensador muito pouco comentado.

168 Precisaríamos estudar em conjunto a irrupção do corpo-sem-órgãos e a profusão de cadernos a partir de 1943.

${ }^{169}$ Sobre relações entre a ordinariedade de um corpo e o corpo-sem-órgãos, ver texto de José Gil 0 corpo paradoxal (2002), na publicação Nietzsche e Deleuze: o que pode um corpo. Infelizmente, as preocupações de Gil são por demais filosóficas, detendo-se muito pouco sobre o caso do livro logique de la sensation (somente uma passagem na página 138). Começo a me indagar da situação dos artistas recorrerem tanto a esse livro, e os filósofos tão pouco. Começo a desconfiar do tanto que pode ser enfadonho ser um filósofo.

${ }^{170}$ Ainda que se trate, de fato, de um programa de filosofia prática. 
4.

Falo de Francis Bacon para falar de Artaud. Isso porque desejo rastrear um pensamento operativo em ambos e em Deleuze. A hipótese de mal-entendido é aquela que busca confirmar o vínculo entre a literalidade e o pensamento operativo.

Sou levado a descobrir que a aliança Bacon-Deleuze traduz a ordinariedade de tudo o que é víscera, e isso abre caminho a um pensamento operativo, que fabrica corpo. Parece ecoar a afirmativa de Ana Kiffer (2018) sobre a ordinariedade dos cadernos artaudianos: é preciso dissociar imediatamente a noção de singularidade daquela de excepcionalidade, própria da mistificação do gênio. Ainda Kiffer (idem): é preciso também dissociar imediatamente o pensar e a compreensão daquela fusão domesticadora com o objeto de estudo; o objeto é infinitamente íntimo e infinitamente estranho. Um objeto? Um sujeito? Falávamos no primeiro capítulo desta tese sobre a fabricação de uma objetidade do estudo (em 'Janô e linhas vitais'). Penso que a discussão da literalidade das imagens-operações perpassa indagações desta ordem. Penso também que a aliança de Deleuze com Bacon nos ajuda a compreender a presença recorrente de Artaud na obra do filósofo.

\section{Este foi um mal-entendido:}

uma necessidade do literal-ordinário que qualquer filósofo da carne teria de enfrentar.

\section{5.}

No documentário para o programa the south bank show ${ }^{171}$ feito sobre Francis Bacon (1985), há um impressionante trecho diurno, situado em um restaurante, do qual peguei fragmentos de sentenças. A embriaguez do álcool avança durante o trecho. [images of reality] [it is the violence of life] [images of sensation] [what is life, but sensation? What we feel? What happens?] [existing today makes me optimistic. 'Optimistic about what?' Nothing. I'm optimistic about nothing. (risos do entrevistador) I just born with that kind of optimistic nature] [I'm not interested in

${ }^{171}$ Disponível no link https://www.youtube.com/watch?v=gyygaRI9v]c . 
philosophy, I'm interested in reality. 'What's reality?' Reality is what exists. Are you real? To me you're real. There you are. ]...[ you're absolutely real to me. There you are, flesh and blood, before me] [I want to be able to remake, in another medium, the reality of a image that excites me] [because I happened to be a painter, that's all] ${ }^{172}$

Depois, em outra cena, mais sóbrio:

[nearly all reality is pain]

6.

[...] Somos carne, não é mesmo? Quando vou ao açougue, acho sempre surpreendente não estar ali, no lugar dos nacos de carne. E depois há um verso de Ésquilo que me obceca: " $O$ cheiro do sangue humano não desgruda os olhos de mim"173...

Ele [Francis Bacon] se interrompe, ergue os olhos para o teto, depois continua:

FB: A carne realmente fustigou todos os meus instintos. Era um choque visual. Magnificamente visual. Eu pensei: puxa, dá para fazer alguma coisa com todas essas coisas que nos tocam. De tempos em tempos isso nasce e se torna um material de trabalho. Apropriei-me disso. Me convinha perfeitamente.

[...]

FB: Como eu lhe disse, minha pintura é primordialmente do instinto. É um instinto, uma intuição que me leva a pintar a carne do homem como se ela se espalhasse para fora do corpo, como se ela fosse sua própria sombra.

\footnotetext{
172 Imagens da realidade - é a violência da vida - imagens de sensação - o quê é a vida, senão sensação? 0 que sentimos? 0 que acontece? - existir hoje me torna otimista 'Otimista do quê?' Nada. Sou otimista sobre o nada (risos do entrevistador) Eu só nasci com esse tipo de natureza otimista - não estou interessado em filosofia, estou interessado na realidade. ' 0 que é realidade?' Realidade é o que existe. Você é real? Para mim você é real. Eis você. [ ] Você é absolutamente real para mim. Eis você, carne e sangue, diante de mim. - quero ser capaz de refazer, em outro meio, a realidade de uma imagem que me excita - porque aconteceu de eu ser um pintor, isso é tudo. [depois, em outra cena, mais sóbrio] Quase toda a realidade é dor.

173 Verso da tragédia Eumênides, do tragediógrafo Ésquilo. Esta tragédia é parte integrante da trilogia trágica Oréstia ou Orestéia. Ainda não localizei a linha para saber qual seria figura a dizê-la.
} 
Vejo-a dessa maneira. 0 instinto está misturado à vida. Tento aproximar 0 objeto o mais perto de mim e gosto desse confronto com a carne, essa verdadeira escoriação da vida em estado bruto.

[Franck Maubert] FM: ainda assim, seus personagens são deformados, não acha?

FB: Não, não deformo pelo prazer; eles não são submetidos à tortura. Experimento, tento transmitir uma realidade da imagem em seu estágio mais dilacerante. Mas talvez não consiga isso.

[...]

Silêncio. Ele se levanta, dá alguns passos, senta-se de novo perto da escrivaninha onde estamos.

FM: Nada de religião, tudo bem, mas o senhor de toda forma deteve-se no tema da crucificação. Não começou pintando crucificações, e pintou outras durante a guerra?

FB: Sim, mas isso não era religioso.

Silêncio.

FM : Era uma representação da crueldade?

FB: Sim, é isso mesmo que eu quero dizer.

[Franck Maubert, conversas com Francis Bacon: o cheiro do sangue humano não desgruda seus olhos de mim, 2010 - L'Odeur du sang humain ne me quitte pas de yeux (conversations avec Francis Bacon), 2009] (ps. 30-34)

7.

O que é diferente, para além da imagem da voz que golpeia, é a multiplicidade de objetos. Os golpes são abertura das fendas por onde se secretará um corpo. 


\section{8.}

Poderíamos adotar uma sistemática de composição (musical, por exemplo) a partir de cada um dos elementos corporais e operativos presentes livro lógica da sensação. Devir-animal, raspagens, criação de zonas e diagramas; deformação (e escoamento), acoplamento, reunião de partes... Silvio Ferraz na última aula do curso sobre noção de imagem da composição musical (2018, transcrevo de memória): 'o que pode ter interessado ao Deleuze em Bacon é que ele é uma reunião de coisas muito diferentes: fotografia, pintura, cinema, desenho...' eu tento completar: 'álcool'. 'Álcool com certeza...'

\section{9.}

No livro do corpo que é preciso abrir, sem nada disto, daquilo poder ler. É preciso abrir o livro, ainda que nos assalte a difícil compreensão: O CORPO NÃO ESTÁ À ESPERA DE TRADUÇÃO. O livro do corpo, o corpo-livro tem uma outra língua. Não é algo 'primitivo' e nem objeto de 'análise', apenas de simultâneos, erráticos e cambaleantes gestos de aproximação e afastamento simultâneos. Eu não fiz o percurso de treinamento da dança. Fiz um catastrófico percurso onde o pianismo de borda me carregou como dentro de uma canoa até uma 'margem desconhecida'. Ali deparei os detritos com que um vínculo de coabitação se deu.

\section{0.}

Deleuze em Francis Bacon (1981), quando diz que há pintura em todas as artes. Proponho que haja, em paralelo, escultura em todas as artes. Pois a ação da escavação me é mais familiar. Pois, como está sugerido em Nijinsky e no meu pensamento do detrito, atraem-me mais as inscrições mínimas, condensadas, alheias, que medem oscilações daquilo que a vida pode dizer de si. Há escavação incerta em todas as artes. Uma máquina de escavar e ser escavado. 


\section{1.}

Mesmo a luz é um detrito: se reservarmos um minuto do dia para examinar a foto do quadro Solen (1909-1916, também indicado como 1909 ou 1911) de Edward Munch, talvez víssemos algo de desconcertante nisso que deveria ser a luz do sol. Primeiro, a nítida impressão de que a luminosidade das cores é uma deformação do espaço. Segundo, o senso de sucção: as coisas parecem ser sugadas para o sol, que é também esmagado com o tamanho e peso das próprias coisas e se quebra, derramando-se. É o colapso do corpo da luminosidade. Ao passo em que Artaud designa a casca do sol no girassol de Van Gogh e no seu rito do sol negro ${ }^{174}$. O sol com casca é aquele que se pode escavar.

12.

A inscrição e a escavação do próprio movimento é o brotamento do movimento. Vida que brota dos sulcos. Imaginei a construção de um furo.

13.

[...] [arte figural] Então, o Van Gogh penetra nas germinações, o Francis Bacon nos espasmos, o Cézanne nas dobras. Assim, nós começaríamos a sair da arte figurativa, da arte representativa, para entrar na arte das forças, na arte dos afectos. Forças e afectos. [...]

(Cláudio Ulpiano, aula a estética deleuziana, 22/03/1993. Transcrição de Mara Selaibe. Material fornecido por Silvio Ferraz para estudo)

14.

Em Van Gogh le suicidé de la société (também 1947), Antonin Artaud seleciona este e outros dois fragmentos de carta de Vincent Van Gogh a Théo (seu irmão). Neste

\footnotetext{
174 Tutuguri - parte da peça radiofônica para pôr um fim ao juízo de deus - pour en finir avec le jugement de dieu (1947). A coincidência em ano desses três materiais: cinco cartas a André Bretoni, Van Gogh e pour na finir mostra a intensa atividade desse 'último Artaud'. Aliás, desde que Ihe permitiram acessar cadernos e lápis no hospital psiquiátrico, em 1943 (Kiffer, 2017).
} 
fragmento há a situação de uma paciente escavação na parede. Esta imagem é importante, não só por introduzir uma conversibilidade corporal entre pintura e escavação. Carta 237, de 8 de novembro de 1888.

0 que é desenhar? Como é que se chega a isso? É a ação de abrir uma passagem através de um muro de ferro invisível, que parece se encontrar entre 0 que se sente e o que se pode. Como se deve atravessar esse muro, pois de nada serve golpeá-lo fortemente; deve-se minar esse muro e atravessá-lo com o auxílio de uma lima, lentamente e com paciência, ao meu ver. (ARTAUD, 2014, p. 274)

Aqui há componentes além da escavação: [1] a sobriedade da carne; [2] 0 instrumento de perfuração.

Quantos artistas universitários já terão colocado em suas publicações esta carta de Van Gogh selecionada por Artaud? Aqui me valho da redundância, da aparente reiteração, mas isso me convém, pois este meu gesto pode ser a própria escavação, feita de variações mínimas de um pequeno grupo de movimentos que entram ou podem entrar em circulação. Isto pode ser um improviso. Tracejar. Um traço ao lado do outro. É a construção de um tecido de inscrições. A consistência do desenho e a produção de corpo. Pode ser que algo se vaze por ali, ainda que seja o próprio corpo de quem escava. Contamos com isso... a construção da membrana é pauta de uma gramática vitalista.

15.

a família acredito ser a primeira célula criminal Jean Genet, $1985^{175}$

Um lápis: o primeiro instrumento perfurador de uma criança, além, é claro, dos dentes e das unhas. Mas os dentes são de leite; mas as unhas são aparadas pelos pais. Então,

175 Entrevista com Nigel Williams em documentário da BBC, aparentemente levado 'ao ar' em 12 de novembro de 1985. A versão que consultei foi esta: https:// www.youtube.com/watch?v=hpFD9yR7eLA. 
após o guache que se come e 0 giz de cera, o lápis: 0 instrumento preferencial de escavação da vida consigo mesma: produção de corpo que busca frestas de germinação. A criança percebe que pode furar o papel, e então a brincadeira muda de 'figura'. A rudeza do giz já lhe dizia isso, mas talvez não tanto.

16.

[...] Para ele [Giacometti], os olhos não são azuis, as faces rosadas, a sobrancelha negra e curva: uma linha contínua constitui a face, o olho e a sobrancelha. Não existe sombra do nariz sobre a face, ou melhor, se existir, essa sombra deve ser tratada como parte do rosto, com os mesmos traços, curvas, todos igualmente válidos. (GENET, 2003 ${ }^{176}$, p. 47)

[...] Jamais conseguirei pôr num retrato toda a força que há numa cabeça ${ }^{177}$. Só o fato de viver já exige tanta vontade e tanta energia... ( $p$. 72)

[...] Diante de um lustre, dizi "É um lustre, é Ele”. E nada mais. [...] “Estou só", parece nos dizer o objeto, "capturado numa necessidade contra a qual você nada pode. Se sou apenas o que sou, sou indestrutível ${ }^{178}$. Sendo o que sou e sem reservas, minha solidão conhece a sua." (ps. 94-95)

\section{Perfurar a carne e retracejar a carne. 0 quê dizer ? Sombra-sobra-alterórgão.}

Um desenho é 'Ele'. É um modo de existência e uma produção de modos de existência.

\footnotetext{
${ }^{176} \mathrm{O}$ ateliê de Giacometti - I'Atelier de Alberto Giacometti (1979).

177 Tematizar a cabeça ao invés de um rosto é um movimento próprio também a Francis Bacon.

178 Uma vez em janeiro 2005 em Poços de Caldas assisti, enquanto esperava o sono chegar, a um documentário sobre Jean Genet que nunca mais encontrei - essas coisas acontecem. Assisti ao programa em estado progressivamente sonolento, mas isso não me impediu de ser hipnotizado. Lembro de uma única frase de Genet: 'minha relação com o mal é a cada dia mais indestrutível'. Talvez o mal ali seja a irremovível não-aderência às narrativas e práticas policiais e moralizantes. Mas na frase em si, e no modo com que Genet ali a pronunciou, não haviam de longe apenas atitudes ordinárias e provocativas e um sentido de gratuidade. A frase em questão se imprimiu e me encantou imediatamente. Era como se algo tivesse se 'encarnado' em mim. Essa sensação perdurou durante alguns minutos. Um sentido avassalador de corporalidade e opacidade.
} 
16.

\section{Mal-entendido, 2:}

\section{um rastro distraído de Simondon em linhas de Gil.}

Este mal-entendido é resultado de um desconforto formal experimentado durante a prática de leitura de alguns escritos de José Gil. Fui movido a buscar brechas no seu texto. Penso que nem todas essas brechas existem. Creio, entretanto, que 0 desconforto que experiencio produziu até o momento algumas investigações e alguns pensares.

17.

O esquematismo e o formalismo filosófico, e a disciplinaridade das artes a priori não nos permite captar a dramaticidade de alguns processos de individuação conjunta, em que necessitamos que muitos 'objetos' caminhem juntos. Em verdade, quando priorizamos o esquema filosófico, o projeto ou a satisfação de uma disciplina ideal, perdemos todo o processo.

O tanto que restou de um formalismo filosófico em Gilles Deleuze, dentro mesmo de uma filosofia vitalista da diferença, parece ter em José Gil uma espécie de emblemático continuador.

A produção do filósofo do corpo José Gil, em dado momento da sua produção, abarca uma série de escritos sobre o que chama a metafenomenologia e 0 inconsciente do corpo. Parte desta série conta com a imagem nua e as pequenas percepções ${ }^{179}$ (1996), metamorfoses do corpo (1997) e movimento total (2001). Desse período há um volume do ano 1999 sobre Fernando Pessoa, que não dialoga diretamente com esta série de livros ${ }^{180}$. O livro de 1997 (metamorfoses) me parece singular, pois na própria introdução o autor nos deixa saber que se trata de uma

179 Dedicado à memória de Gilles Deleuze, falecido a 4 de novembro do ano anterior. Gil também dedicou a Deleuze o imperceptível devir da imanência (2008), além de haver se debruçado sobre GD em inumeráveis textos.

${ }^{180}$ Trata-se de diferença e negação na poesia de Fernando Pessoa. 
revisão de obra muito anterior. Verifiquei, após breve vagar na rede digitallis1, que metamorfoses do corpo (1980-81 $\left.{ }^{182}\right)$ é um volume escrito originalmente em língua portuguesa, ao contrário da maioria das demais obras filosóficas josegileanas desse período, escritas em francês. Por sua data, a redação original de metamorfoses do corpo é, portanto, anterior à sua sustentação de tese (ou dissertação) na Université Paris 8 Vincennes-Saint-Denis (1982), na supervisão de François Châtelet. Isso faz com que metamorfoses seja livro singular e seja, ou ao menos testemunhe, uma espécie de metamorfose do pensamento. Os livros imagem-nua e movimento total me parecem mais disciplinarizados e organizados em seu projeto - digo com isso que eles parecem ter o risco de sua hipótese cuidadosamente controlado. Mas, em geral, é este o tom da escritura de Gil. Os escritos cumprem com um projeto filosófico; tomam de antemão a separação e o aprofundamento das artes que, ainda que tidas em sua ampla heterogênese criativa, não são questionadas em sua purificação disciplinar. 0 caso de movimento total já aponta uma espécie de outra mutação em seu pensamento, e o assento do artístico no disciplinar lá183 está em franco desmoronamento. Para nossa alegria, trata-se de uma obra extraordinária.

Metamorfoses não é tão diferente deste quadro geral disciplinar, formal e esquemátido, tomando como campo leituras estruturalistas, algumas psicanálises ${ }^{184} \mathrm{e}$ antropologias. Mas somam-se aqui estranhezas fortuitas. É um livro estranho que, por sua condição dilatada no tempo, nos permite uma leitura questionadora deste perío do e de alguns elementos que talvez se possam chamar por um projeto gileano. Darei um exemplo.

Há, em metamorfoses, em um trecho em especial, traços de um vocabulário muito particularmente simondoniano, não tanto enquanto palavras isoladas, mas

${ }^{181}$ Deparei páginas como esta, da revista digital Caliban:

https:// revistacaliban.net/jos\%C3\%A9-gil-sistematizar-o-pensamento-atrav\%C3\%A9s-do-corpoed8cle8f30eb.

182 Traduzido para o francês em 1985: métamorphoses du corps.

183 Talvez pelo fato do Gil dançarino-filósofo ter ele mesmo tido vontade de desenhar e tido seus corpodesenhos reconhecidos. Sinto que o desmoronamento disciplinar apontado em movimento total: 0 corpo e a dança é a própria obra, naturalmente acontecida um pouco à revelia; obra de corpo que quer se escrever.

184 Reconheço que, no campo das psicanálises, há uma diferença gritante entre o texto de 1980 e 0 anexo de 1997, no concernente à abundância de fontes e potência de articulações. E digo tudo isso em total acordo com diversas assunções que 0 autor faz em to da a série do inconsciente do corpo, tal como um pré-pós-verbal; uma espécie de corpo em fermentação que acompanha o corpo; a charneira (dobradiça)... 
quando em reunião (transdução, individuação, pré-individual etc ${ }^{185}$ ). Neste uso, sou levado a suspeitar de que Gil teve algum contato com as obras de Simondon ${ }^{186}$. E este vocabulário não é endereçado. Isto é, de fato, curioso. Estas palavras estão aqui reunidas, em um espaço de quinze páginas.

Mas, de fato, não se trata de uma aplicação simondoniana, uma vez que este Gil de 1980 parece estar atado às referências estruturalistas. Referências estas que ainda guardam resíduo em sua obra - um exemplo que me parece evidente é de se forçar a pensar campos criativos intermediários a partir do binômio conscienteinconsciente. Uma vez que ninguém, em absoluto, pode nos forçar a continuar pensando assim. Uma operatividade simondoniana seria aquele onde a relação prevalece sobre os termos.

Um outro traço do uso josegileano para transdução me pareceu ser o de restringir sua adoção às múltiplas traduções. De fato, a transdução permite (melhor dito, exige) uma multiplicidade, mas o principal dado da transdução, me pareceu, é um processo de formação dimensional da vida. 0 processo de formação, das múltiplas traduções ou daquilo outro que se queira. Para o campo do excedente, do excesso às múltiplas traduções, Gil faz, em metamorfoses, leituras antropológicas na esteira estruturalista.

De qualquer modo me vejo, mais uma vez, em terreno insuspeito, onde a relação prevalece sobre os termos: a transdução. E aqui, uma cilada. Enquanto insistirmos em disputar solo teórico, principalmente das imagens de corpo ${ }^{187}$, em terreno estruturalista - disciplinas como a psicanálise, as ciências sociais, ou mesmo as ciências cognitivas -, estaremos reproduzindo um império humanocentrado e moderno. As disciplinas mencionadas guardam resíduos positivistas ao almejar explicar todos os domínios com um único modelo, seja o de estrutura ou mesmo o de rede

\footnotetext{
${ }^{185}$ Falo do item corpo, transdutor de signos. GIL, 1997, ps. 32-47, onde esses três termos aparecem em conjunto, indicando um repertório próprio a Gilbert Simondon.

${ }^{186}$ Ainda que a segunda parte da tese de Simondon tenha somente sido publicada em livro em 1989.

${ }^{187}$ Ou dos modos de explicação do que seria um corpo. Por isso a pergunta remetida a Spinoza não é nada ingênua e é sempre relembrada por pensadoras e pensadores vitalistas: ao invés de se perguntar sobre o que seja um corpo, afinal o que pode um corpo?
} 
informacional ${ }^{188}$. De fato, um projeto josegileano talvez pareça ser aquele de fazer a filosofia assimilar a crítica estruturalista.

\section{8.}

Em verdade, até este ponto me pareceu que pensar em termos de inconsciente do corpo não dá muito movimento a formas mais bizarras de pensamentos duvidosos que produzem um corpo fora de um projeto filosófico.

'Inconsciente', termo que, conforme eu já disse, se baseia em uma defesa mútua entre o próprio termo e a noção de consciência, sendo ambos os termos já instâncias purificadas. Eis uma espécie de freudismo de Gil, onde subsiste o projeto de se mapear 0 inconsciente do corpo. Onde a consciência é uma vontade humana à espera de novas porções de matéria para codificar voluntaria e precariamente; onde 0 inconsciente está quase à espera de ser codificado. 0 que se passa entre os dois, afinal?

Até este ponto das minhas leituras de Gil, aderi completamente à hipótese de que o corpo é a própria dobradiça, contaminado que estou com as leituras simondonianas (o nó: relação de relações, esta relação que é o indivíduo).

Eis traços de um problema (poético-político) de se sobrepor o corpo-indivíduo ao corpo-operação. De se sobrepor corpo-anatomia às germinações bizarras que são corpo. José Gil repete sucessivas vezes esse movimento, e não à toa: os treinamentos incidem sobre os órgãos, os articulam de uma forma inédita - o que não podemos esquecer é que não sabemos o que seja um órgão. Talvez gostássemos de acreditar que o órgão da medicina é o órgão da dança...

0 corpo é operativo. 0 corpo operativo é produção de 'zonas' em tamanha proliferação, que sua localização fenomenológica é quase 'suicida', come a si mesma. Aquele que escreve precisaria de se re-situar constantemente através da processualidade da escrita e da carne. Assim, o corpo e uma experiência da dança talvez jamais sejam um objeto. Uma epistemologia possível neste campo é de enorme risco, ainda que se nomeie metafenomenologia: é preciso tomar o risco de se

188 Sobre este último caso, seria importante olhar a crítica e diferenciação do próprio Simondon à nascente cibernética. 
reconhecer, no mínimo, ou assumir que os termos escrevem a si próprios, é carne que se escreve. Diz Gil: 'este mundo já não é o “mundo" da fenomenologia' (2002, p. 134). As palavras são carne e 'nos' carregam com elas. A 'consciência' é consistência frágil e duvidosa, improvável, de uma série de acidentes neste gigantesco processo. Se eu fosse tomar o vocabulário de Gil, seria preciso dizer que estou, evidentemente, tomando o partido não do inconsciente (tampouco do consciente), mas da operacionalidade do inconsciente, das suas secreções, restos, rastros, saltos. São todos os órgãos provisórios produzidos no caminho.

Em movimento total Gil identifica a zona como operatividade da comunicação de inconscientes-corpo a partir da dança do Contato-Improvisação ${ }^{189}$. A zona parece ser não exatamente espaço transcedental, como ele diz, mas espaço problemático, espaço de saturação. É preciso não perder de vista que se trata de corpo, de corporificação, justamente por não se poder saber o que é um corpo. Ele produz a si mesmo. 0 corpo não só 'passa' por algo, ele é corporificação conjunta com aquilo que se passa.

\section{9.}

De volta ao segmento de metamorfoses. O que me parece perturbador é Gil desenvolver um diálogo constante, desde já (notadamente em a imagem nua), com 0 pensamento de Merleau-Ponty, um dos mentores intelectuais de Gilbert Simondon. E estamos cientes da intimidade e mesmo da continuidade de Gil com o pensamento de Deleuze, sabidamente leitor de Simondon, e a nós então posso dizer que o problema se desenha. Pois bem, entre Merleau-Ponty e Deleuze há claramente um Simondon, tanto historico-biograficamente quanto filosoficamente (em metamorfoses Gil também cita Canguilhem, figura muito próxima a Simondon).

Fico com a impressão de que os estudantes do final dos 70 e início dos 80 simpatizantes e aderentes a Deleuze e Guattari receberam estes ou deste ambiente, em alguma medida, algo como uma espécie de 'ponto de partida' das práticas do pensamento. Seria uma espécie de estilística filosófica, portadora de afinidades e também opacidades, apagamentos. E algumas figuras 'constrangedoras' podem ter

${ }^{189}$ Em a consciência do corpo: a zona (GIL, 2002, ps. 119-137) 
sido apagadas da genealogia - apagamentos muitas vezes acatados sem grandes protestos. Esta é a minha impressão. Talvez precisemos então retomar de alguns anos antes, a saber, o contexto dos vínculos acadêmicos do maio de 68 e anos sequentes ${ }^{190}$, para mapear o processo de protagonização de algumas produções e publicações.

O filme Simondon du désert (2013) nos informa de que a partir de um acidente de motocicleta justamente em 1968, Simondon iniciou sua decadência psíquica. É possível que houvesse de fato um cenário de constrangimento em torno do autor, para além e aquém das contendas acadêmicas ou intelectuais.

Seria preciso aproveitar o fato de que José Gil ainda é vivo, para perguntarIhe... sigo lendo seus trabalhos, em ampla agonia epistemológica.

\section{Este foi um mal-entendido :}

minha ignorância deveria conduzir ao aberto, e não ao esquematismo filosófico.

${ }^{190}$ François Dosse, na biografia cruzada (2010. Gilles Deleuze-Félix Guattari: biographie croisée, 2007), diz das motivações mais imediatas do Anti-Édipo, a primeira obra publicada em parceria. Elas teriam sido: (1) uma investida contra o excessivo lacanismo do ambiente intelectual francês (lacanismo também enquanto 'ala avançada' do estruturalismo), e (2) a dificuldade do próprio Guattari com a escrita. Dosse nos conta também que o emprego da noção de transdução em capitalismo e esquizofrenia se deu por parte de Deleuze, e não de Guattari (p. 164).

Sobre apagamentos, temos um exemplo do próprio biógrafo: a pessoa que os apresentou, Jean-Pierre Muyard, foi erradicada das histórias que ambos contaram depois acerca da gênese da parceria.

Há algumas linhas bastante apreciáveis de Dosse no que diz respeito à influência de Simondon em Deleuze, para além do contexto da resenha deste (1966) sobre a publicação da primeira parte da tese simondoniana em 1964: [segue]

(DOSSE, 2010, p. 140) A problemática simondoniana serve a Deleuze de máquina de guerra eficaz contra a dialética hegeliana: a ideia de "desaparição" [partida ou disparação] vai dar e Deleuze o conceito de "díspar", de "disparidade constituinte", de "diferença em si": "Essa teoria do díspar prepara a síntese heterogênea e define a diferença como diferença de diferença" (cit. SAUVARNARGUES in. LECLERQ, 2005). Simondon contribui finalmente para consolidar a noção de corpo sem órgãos, dando-lhe uma base nas ciências da vida. Deleuze reencontra nele essa arte dos limites que rompe o dualismo entre interioridade e exterioridade e lhe permite dizer que "o mais profundo é a pele: ' 0 ser vivo vive no limite de si mesmo, no seu limite... A polaridade característica da vida está no nível da membrana'" (SIM ONDON, 2005, p. 260). Tal abordagem do ser vivo escapa também das explicações causais mecanicistas para substituí-las pelo primado dos processos com múltiplas variações de intensidade. [...] (DOSSE, op. cit, p. 420) [...] Nessa era contemporânea, é preciso reencontrar, à maneira de Simondon e de Deleuze, os processos de individuação enquanto processos ao mesmo tempo físicos e coletivos, "onde eu e nós são duas faces de um mesmo processo, a distância entre eles constituindo também a dinâmica do processo" (cit. STIEGLER, 2004). [...] 


\section{0.}

François Khan, ator e encenador, aluno de Jerzy Grotowski, adota um método para trabalhar com dramaturgias escritas na prática da cena. É um méto do de memorização e incorporação do texto ${ }^{191}$. Essa metodologia tem uma fase escrita, de transcrição do texto.

Aprendi o estágio da escrita desse método nos cursos com Maria Thais. No contexto de recepção desse exercício, uma vez, sob minha indagação, ela falou que 'eu mudei algumas coisas e o uso à minha maneira'. Natural, uma vez que assim é qualificada a transmissão de práticas, e uma vez que o objeto de experiência estudado por Thais é a narrativa, uma matéria muito mais arredia do que um texto acoplado à tradição dramatúrgica dramática européia. E o que aconteceu comigo ao praticar esse exercício de transcrição em alguns momentos do meu contato com Maria Thais (2015, 2017) gerou uma metamorfose.

As instruções de Thais: deve-se escrever o trecho selecionado de um texto no caderno, algumas vezes, mas não com fins de decorá-lo. Algo como umas dez repetições. É apenas um percurso a ser percorrido, onde podem acontecer coisas. Nele, deveríamos atentar às palavras e imagens que você 'deixou passar' na leitura.

O que aconteceu comigo, foi uma operação múltipla de metamorfose: desenhos apareciam, imagens se impunhar para serem desenhadas etc. Uma produção de corpo.

Em 2015, trabalhamos com o romance Pedro Páramo, de Juan Rulfo. Em 2017, com o poema Ó Serdespanto, de Vicente Cecim. Logo após isso eu tive a ideia de usar

\footnotetext{
${ }^{191}$ Referências para os procedimentos de François Khan. 0 artigo publicado em revista sala preta: http://www.revistas.usp.br/salapreta/article/view/57398; a entrevista concedida em 2017 por ocasião do livro le jardin: https:// performatus. net/ entrevistas/francois-kahn/ ; e a descrição sumária de um encontro pedagógico: http://www.spescoladeteatro.org.br/blog/brsw/?p=109. [segue]

Um trabalho referencial feito no Brasil a partir dos procedimentos de escrita de Khan são a dissertação de mestrado (apropriação de texto: um jogo de imagens, 2009) e a tese de doutoramento (0 ateliê do ator-encenador: "enquadramento", "incidência" e "vulnerabilidade" na poética da cena, 2014) de Rejane Kasting Arruda, ambas na Universidade de São Paulo.
} 
esse procedimento de transcrição-caligrafia de alguns dos sonhos de Franz Kafka, grupo de pequenos textos que já trabalhava há algum tempo ${ }^{192}$.

\section{[seguem:]}

[ANTECEDENTES DO CADERNO]

[TRANSCRIÇÕES DE FRAGM ENTOS DE VICENTE CECIM

\section{COM FRAGMENTOS DE FALAS,}

APARIÇÕES E DETRITOS] ${ }^{193}$

${ }^{192}$ A primeira vez em que me lembro de ter trabalhado mais enfaticamente com um dos sonhos da edição de sonhos de Franz Kafka foi durante uma oficina oferecida por Tica Lemos de dança-literatura, na então Galeria Olido.

${ }^{193}$ Preferi não colocar os fragmentos originais de Cecim, pois penso que eles são aqui não tão relevantes. 

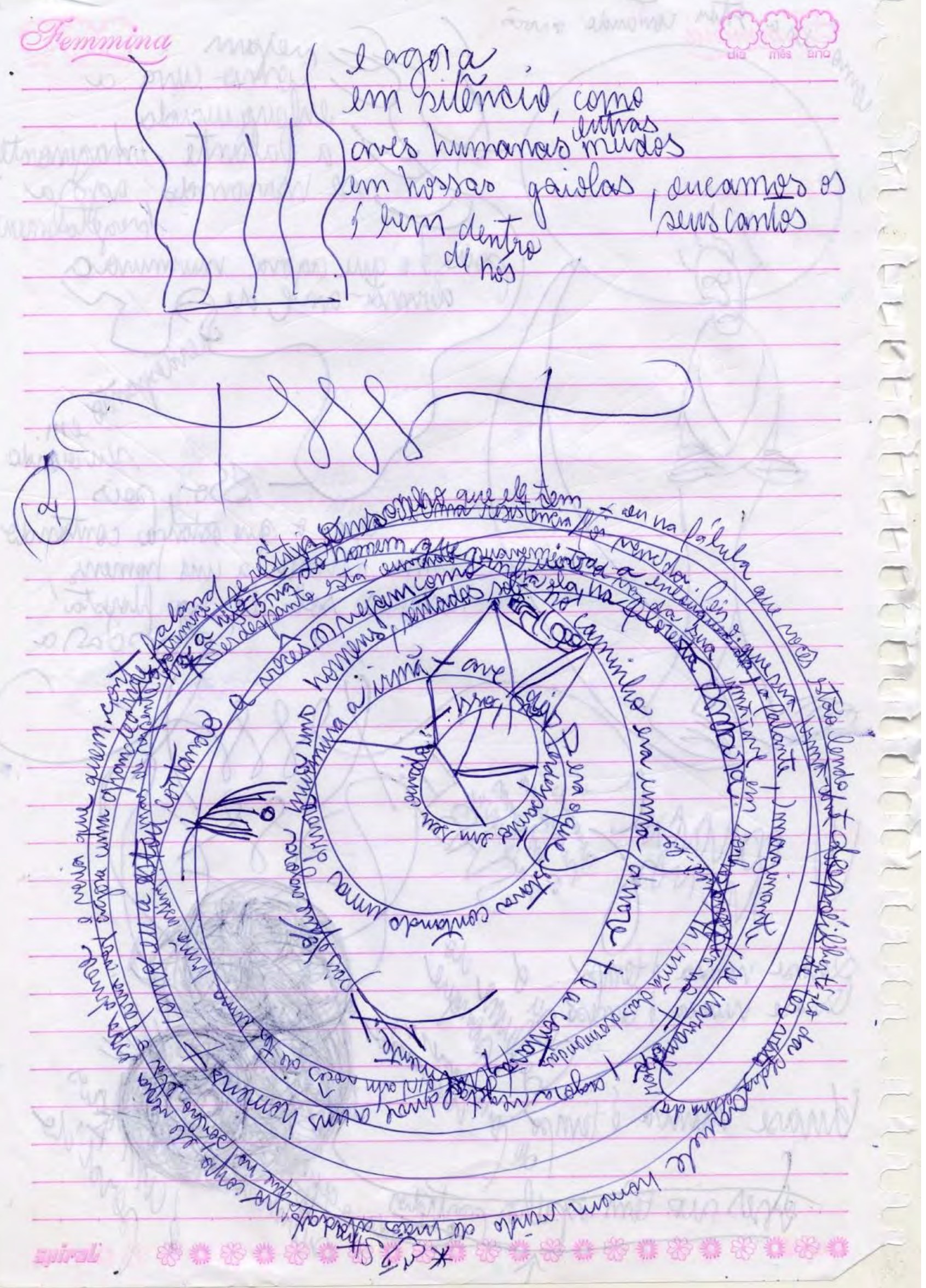


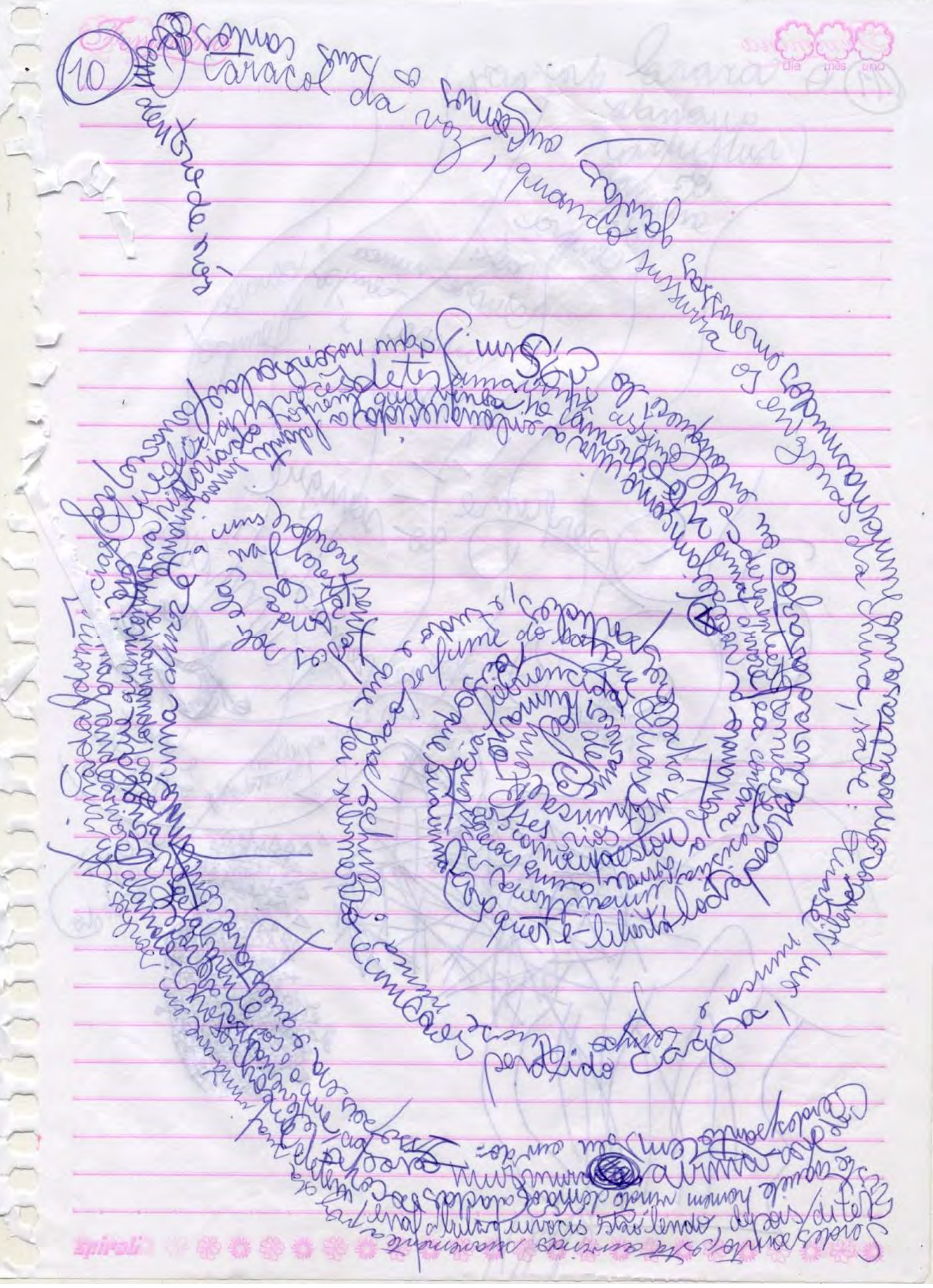




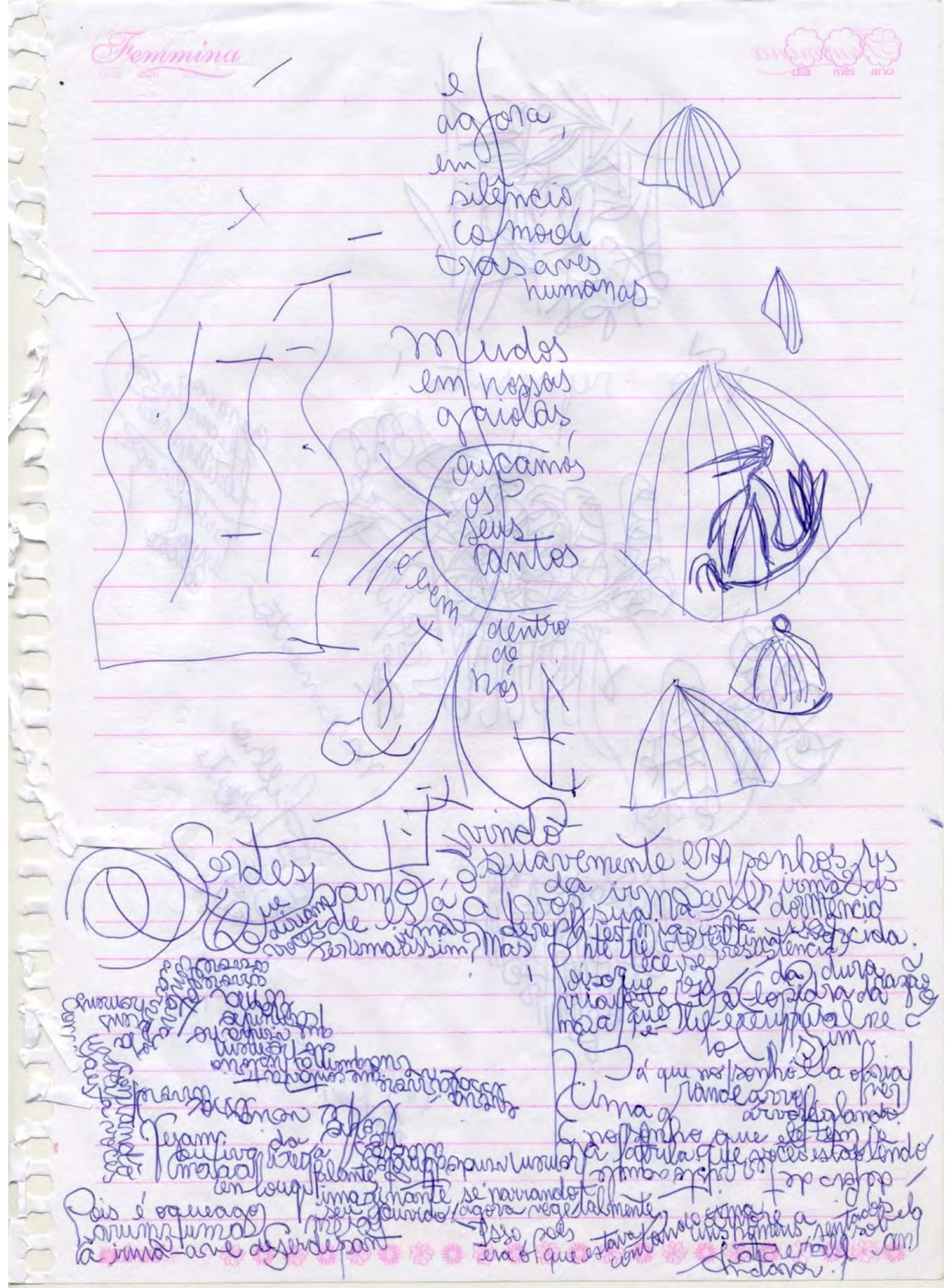


manina

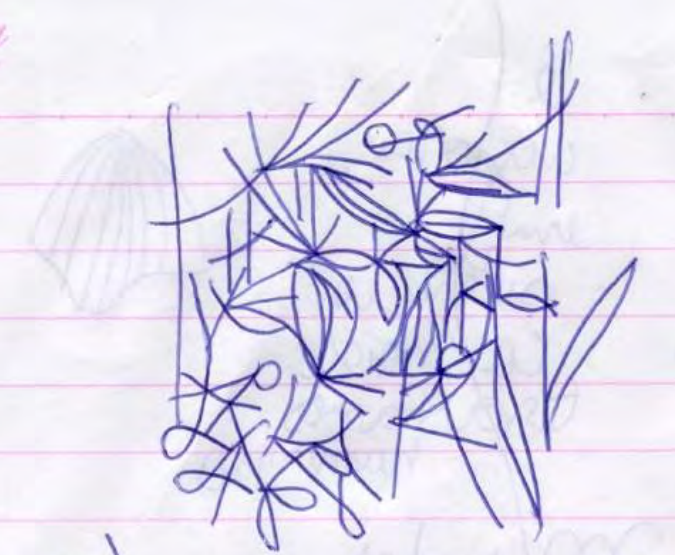

nat representan!

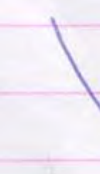




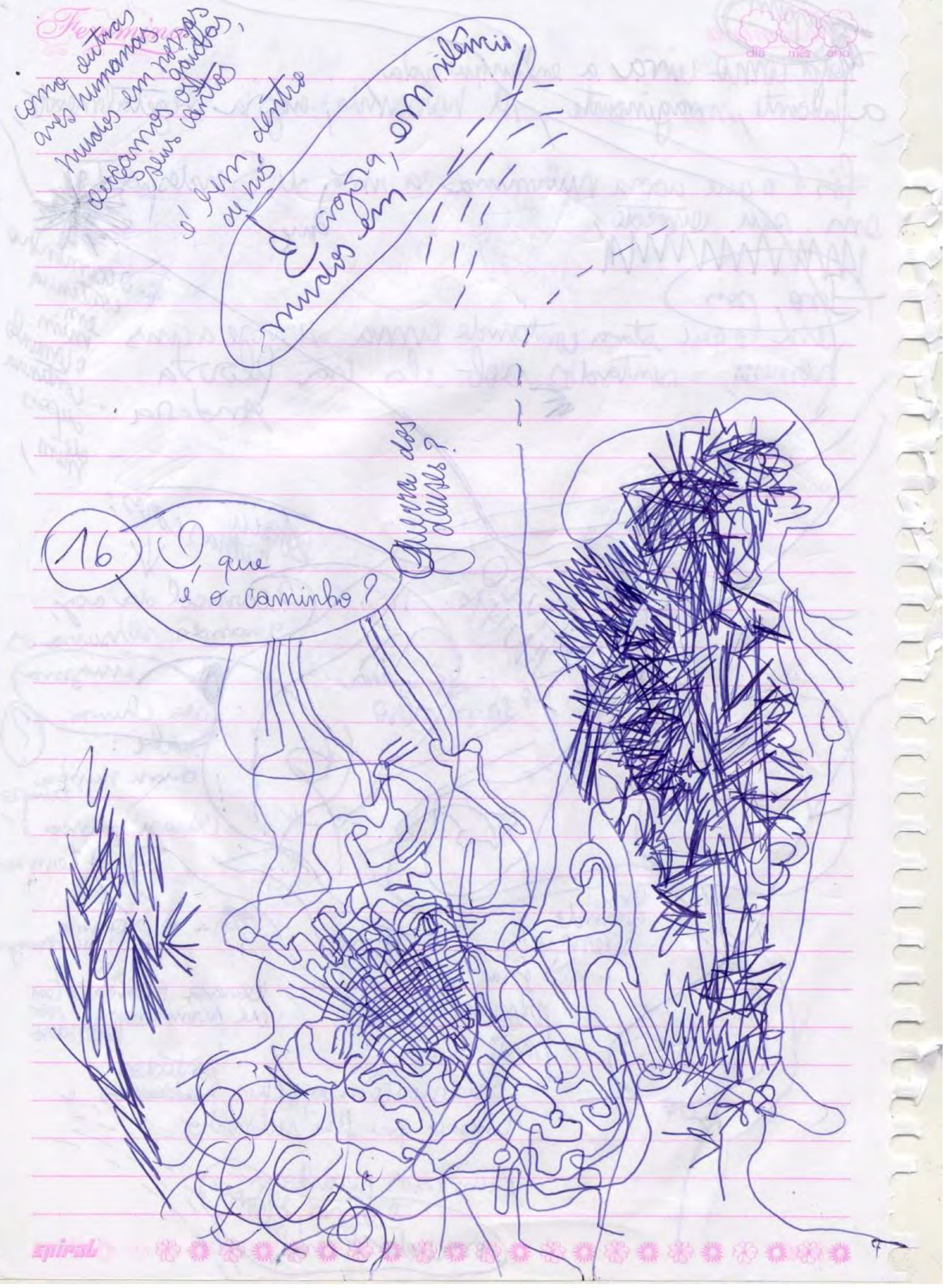




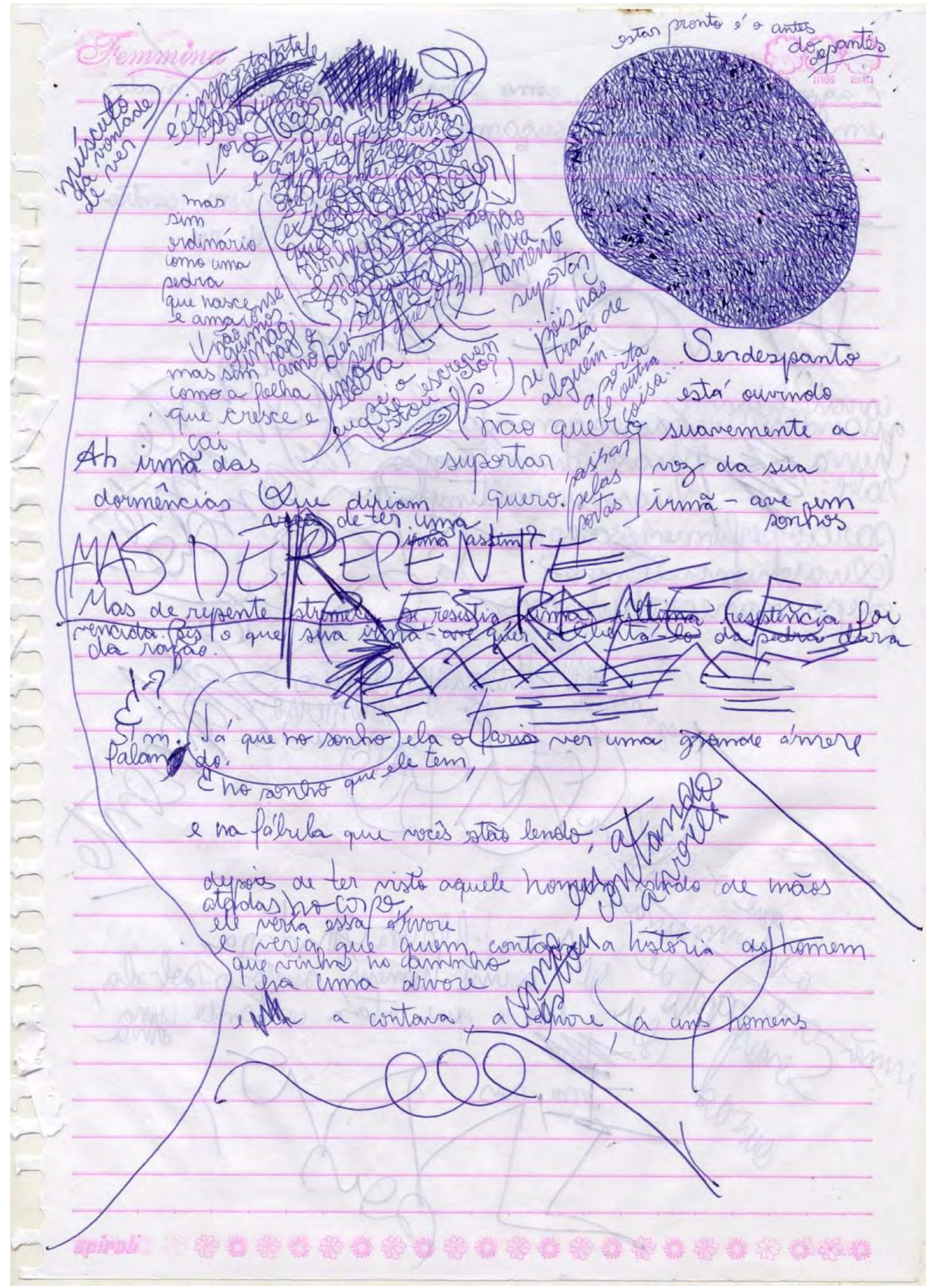


301

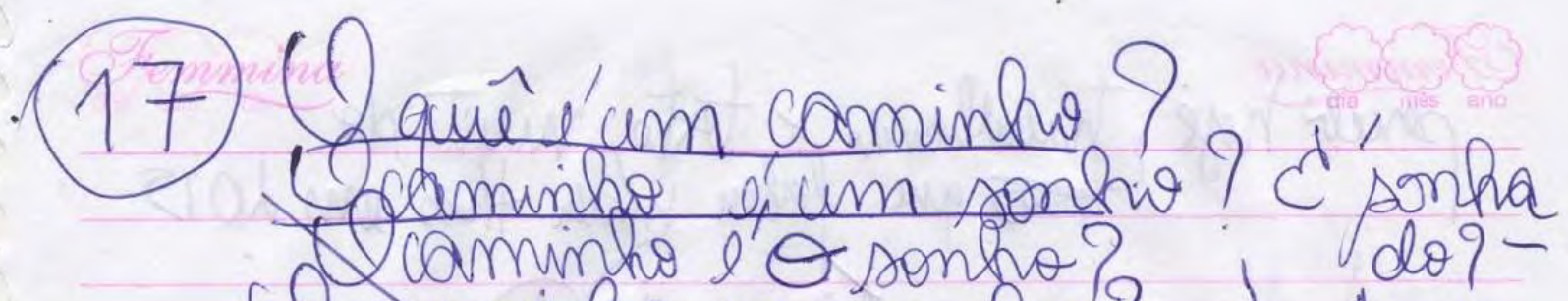

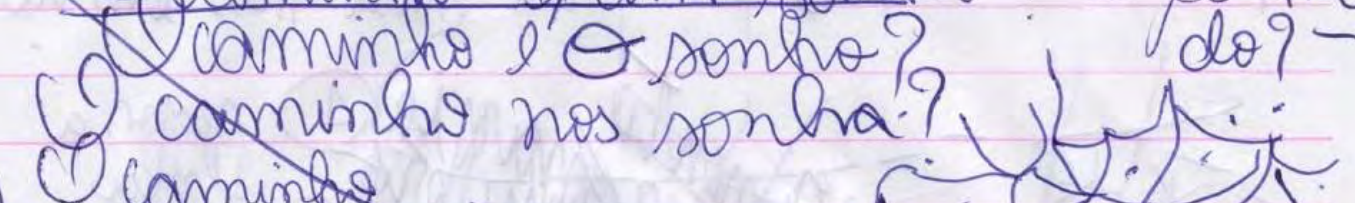

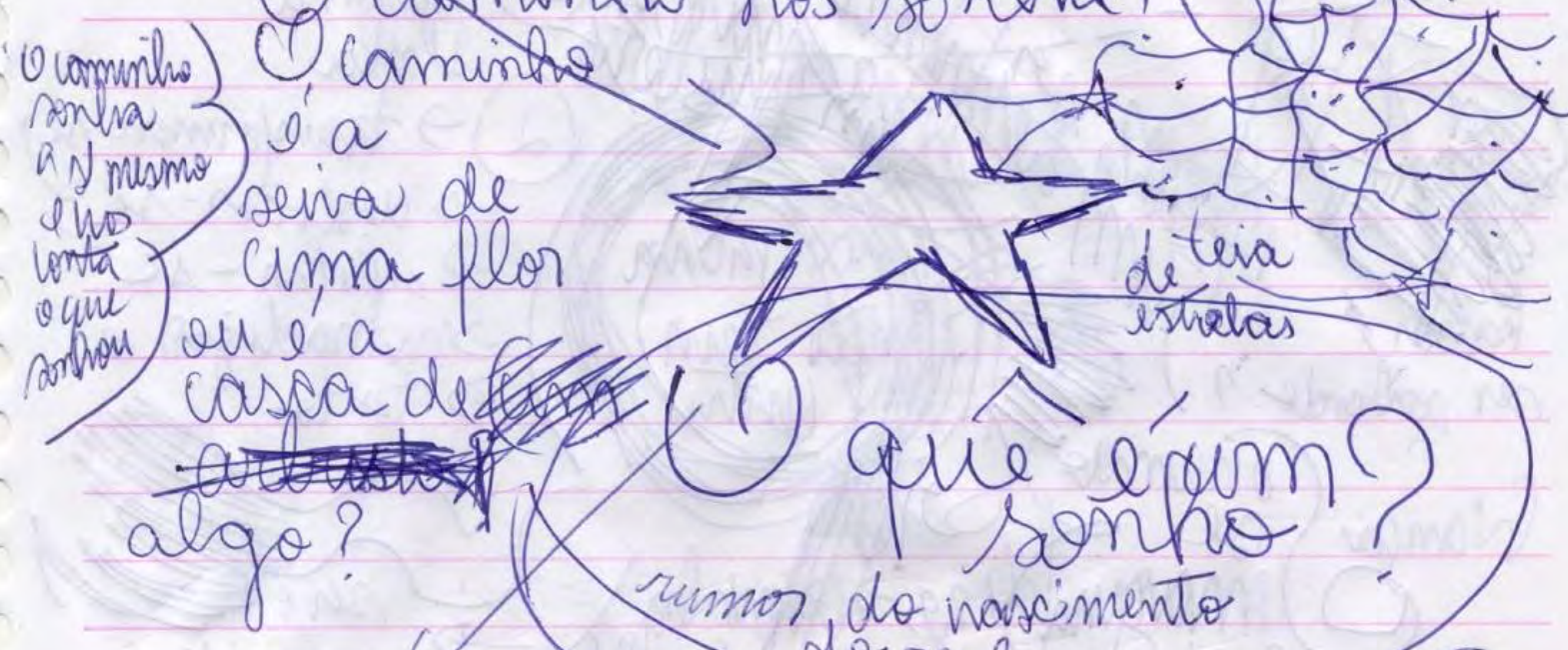

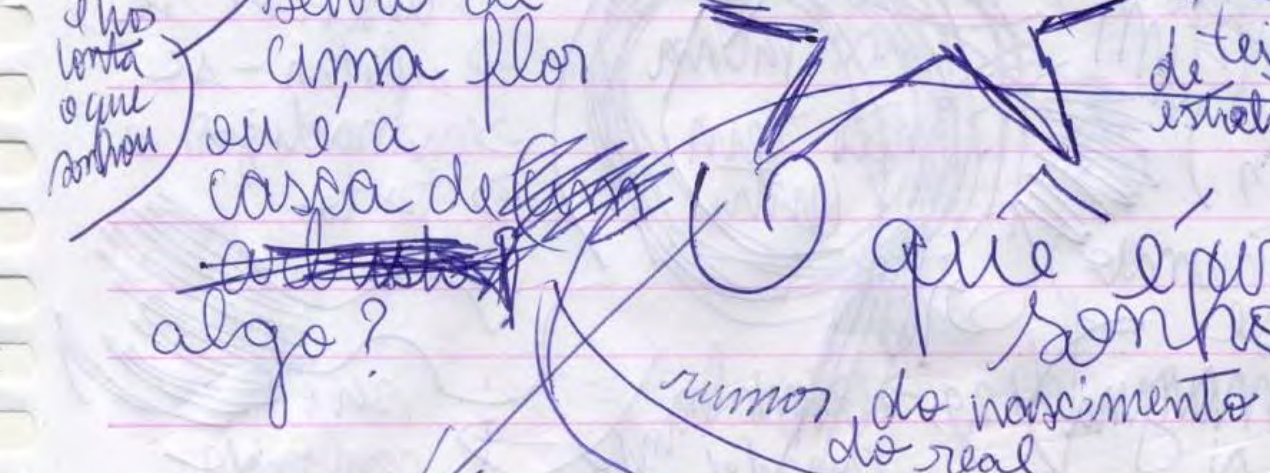
do real

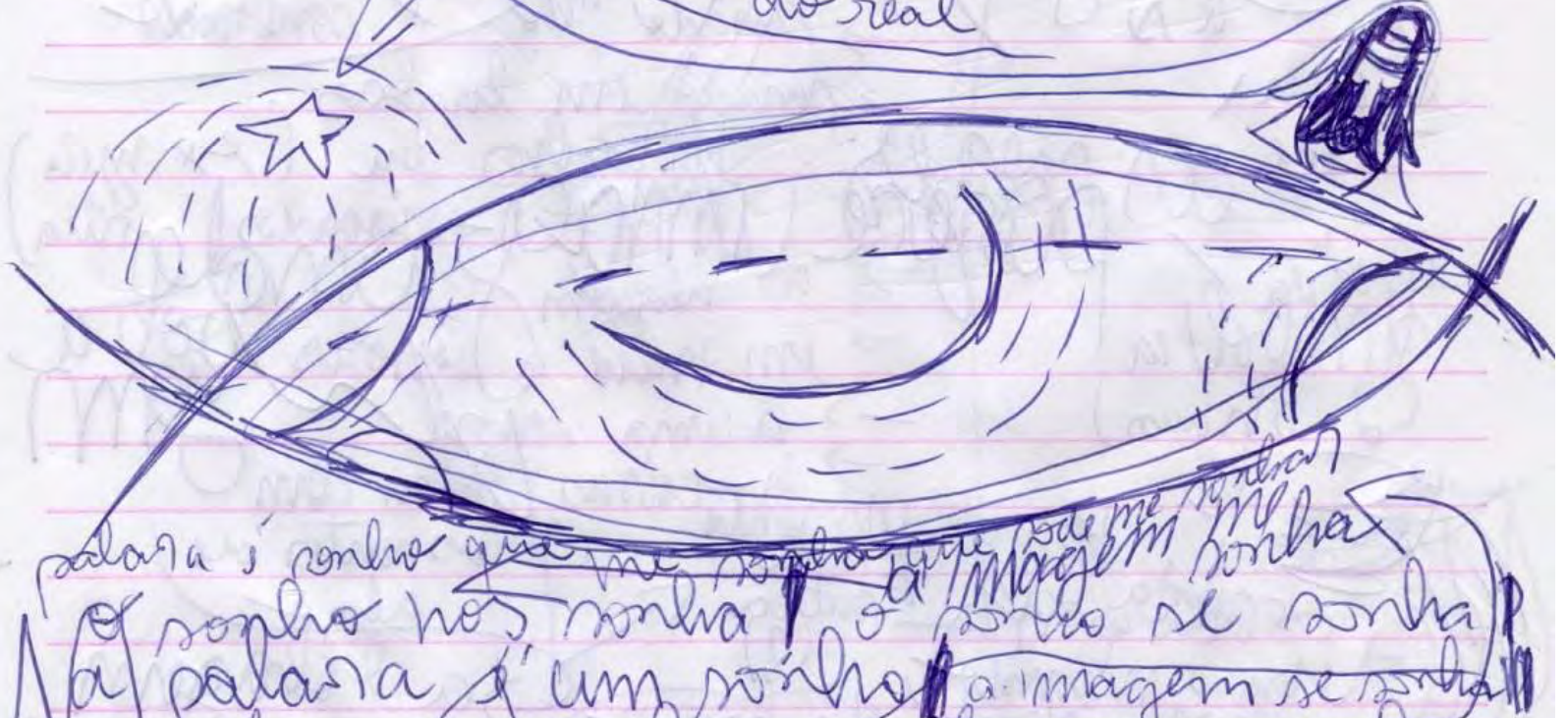

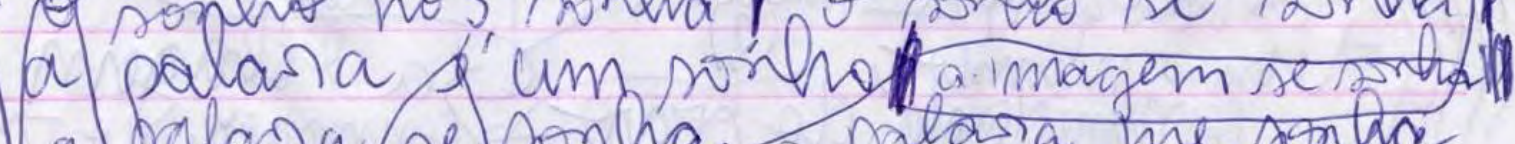

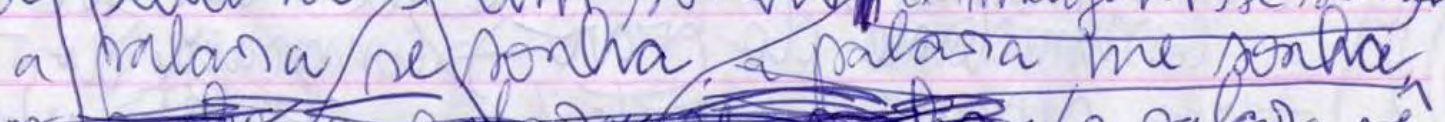

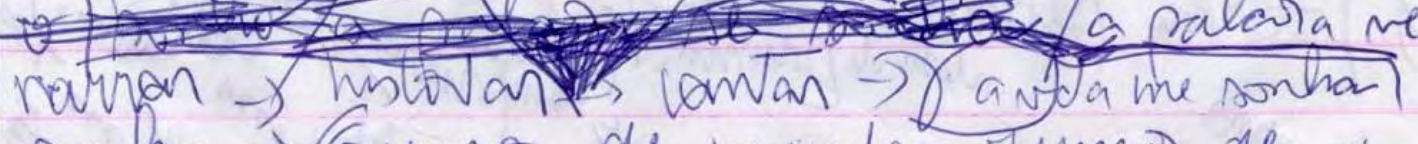

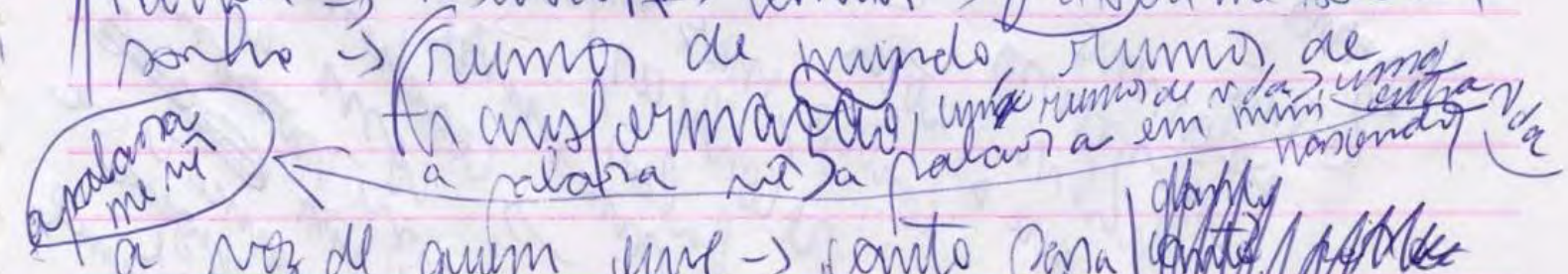

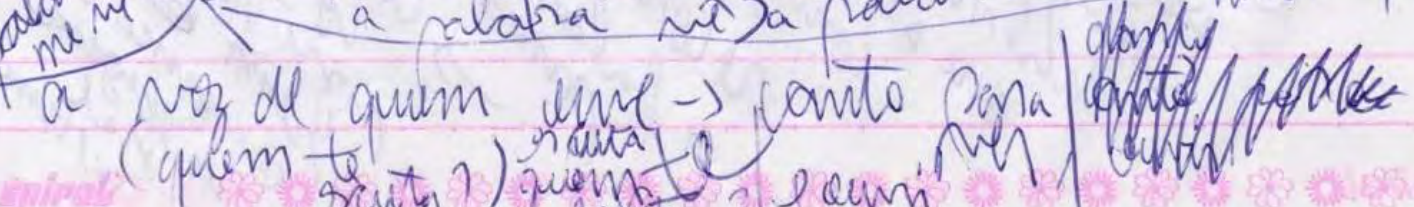

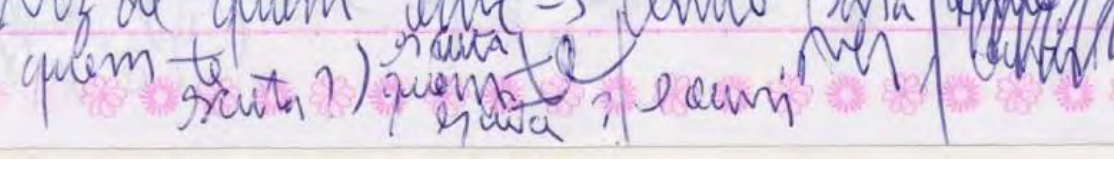


302

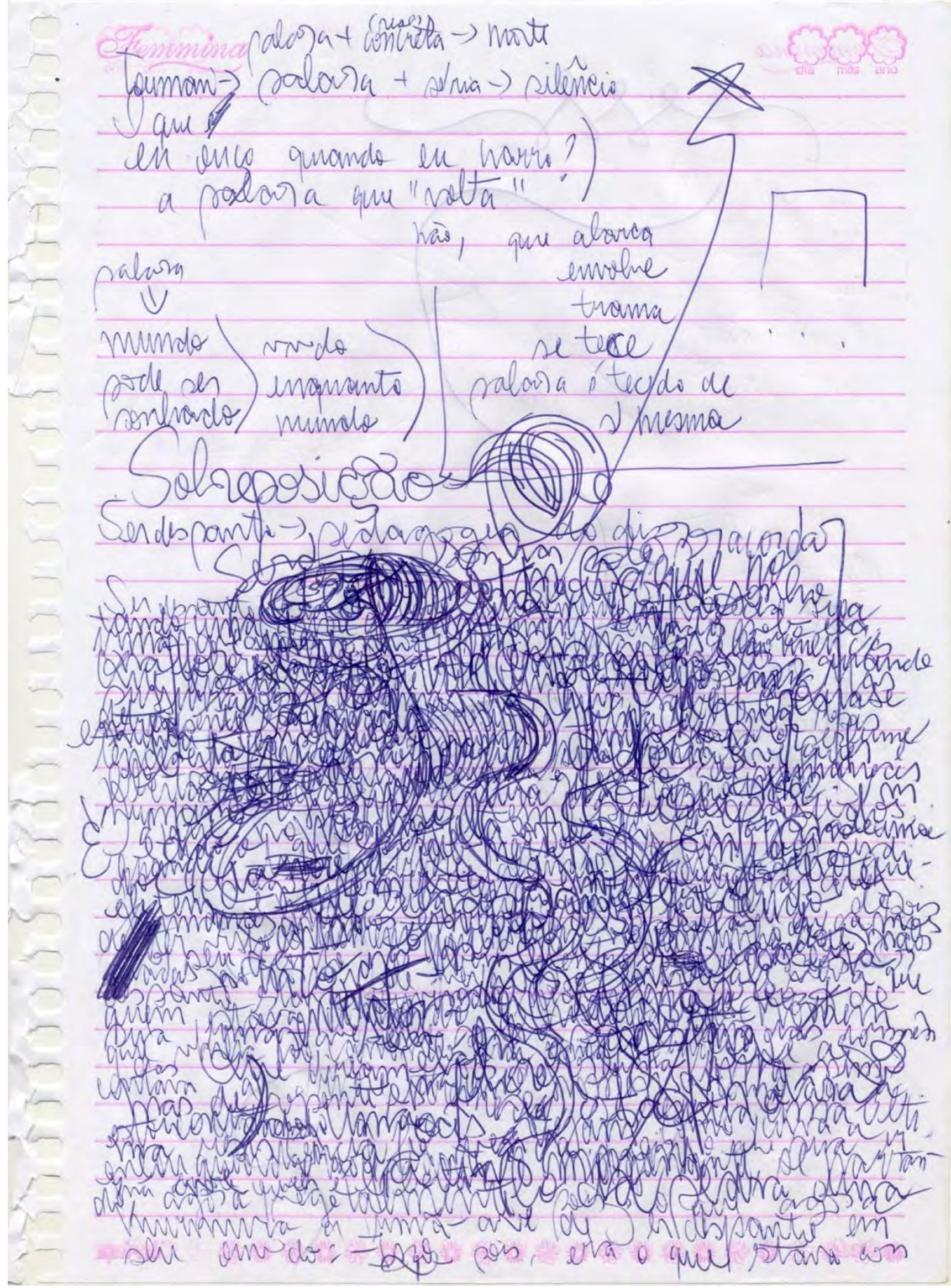




\section{1.}

Diante disso, o quê pode ser um caderno ? Diante da multiplicidade de planos imagéticos, das produções de corpo suscitadas pela 'simples' prática da transcrição de um texto em específico, de um trecho de texto, considerei que parte da tese fosse escrita a mão. Faltava tempo para realizar esse desejo, e então tento me aproximar desse pedaço de corpo.

Seria um caderno uma espécie de glândula, uma secretadora de trilhas, de rastros cumulativos e corrosivos?

22.

TOM AR A FABRICAÇÃO DO PRÓPRIO OVO. Teremos escolha? Seria a sonoridade um tipo de ovo?

Este trecho, outra redundância. Mas após aquilo que foi, com alguma esperança, experimentado até aqui, quem sabe não se possa ler diferentemente?

0 CsO [corpo-sem-órgãos] é o ovo. Mas o ovo não é regressivo: ao contrário, ele é contemporâneo por excelência, carrega-se sempre consigo, como seu próprio meio de experimentação, seu meio associado. 0 ovo é o meio de intensidade pura, 0 spatium e não a extensio, a intensidade Zero como princípio de produção. Existe uma convergência fundamental entre a ciência e o mito, entre a embriologia e a mitologia, entre o ovo biológico e o ovo psíquico ou cósmico: o ovo designa sempre esta realidade intensiva, não indiferenciada, mas onde as coisas, os órgãos, se distinguem unicamente por gradiantes, migrações, zonas de vizinhança. [...] 0 CsO é precisamente este germe intenso onde não há e não pode existir nem pais nem filhos (representação orgânica). É o que Freud não compreendeu em Weissman; a criança como contemporânea germinal dos pais. Assim, o corpo sem órgães nunca é o seu, o meu... É sempre um corpo. Ele não é mais projetivo do que regressivo. É uma involução, mas uma involução criativa e sempre contemporânea. [...] 
(Deleuze-Guattari : 28 de novembro de 1947 - como criar para si um corpo sem órgãos. Trad. 1996. DELEUZE; GUATTARI, 2008, ps. 27-28. Grifo meu.)

A seguir, no texto de como criar para si, haveria uma referência ao logos espermaticos dos estoicos. Já fizemos a crítica acerca da imagem da semente, ou de qualquer imagem dominante, mesmo o ovo, para a ontogênese, que é conjunta. $A$ centralidade da individuação não são as formas individuadas, mas o processo de individuação, diz Simondon na conclusão de sua tese sobre individuação. Ou seja, no raciocínio de D-G o ovo seria espécie de figura para o meio associado da individuação. Por ser figura, o ovo é dinamismo, um movimento múltiplo, um engendramento, um corpo desconhecido, sensações estranhas...

.SEM ENTE.OVO.CRIANÇA.CRISTAL.GERME. \> quando parece contemporâneo demais, algo se cansa.

\section{3.}

A filósofa Carla Ferro me apresentou ao M ichel Tournier de sexta-feira ou os limbos do pacífico $\left(1985^{194}\right)$. Carla me faz notar principalmente a construção de um instrumento musical: o cadáver do bode Andoar, que era 'grande como um urso', devidamente preparado e armado entre as rochas marítimas, cantando uma estranha, alucinante sinfonia sinfonia (ps. 172-187).

\section{4.}

Cadernos. Ana Kiffer (Op. cit, 2018, p. 104), em nota de rodapé:

Estou me referindo aos cadernos que existem fora do âmbito dos manuscritos (como aqueles que deram origem às obras), assim como em diferença com o que vimos tratando e lendo como forma diarística, no caso da literatura e em diferença, no caso das artes visuais, daquilo que

194 Vendredi ou les limbes du Pacifique (1972). 
foi recebido como livro de artista. Logo, entendam que se trata aqui de duas pontuações: estou recortando e pensando os cadernos exclusivamente no regime da literatura e das artes a partir do Século XX. Segundo, não estou defendendo uma essência do caderno ou uma ontologia do que seja o caderno, mas, sim, traços de uma singularidade que o desloque da recepção da forma diário ou do livro de artista [a tempo: também do esboço ou ainda do rascunho]. Estou simplesmente buscando "caracterizar" um objeto, para falar no jargão das pesquisas em construção.

Desta maneira, vemos derramarem-se sob a alcunha cadernos uma miríade de objetos de experiência. Então, segue uma diferenciação sumária.

Artaud, o seu refazimento do corpo. Cadernos.

Deligny, os percursos das crianças autistas (lignes d'erre) em regime tácito. Linhas que se cruzam em papéis vegetais sobrepostos. Autoria dissolvida. 0 mundo como caderno.

Hijikata, que talvez seja um caderno-ambulante. Sua biografia não é nostálgica, mas uma entrada do mundo pelas fendas do corpo.

Frida Kahlo, diário. As massas de criaturas-cores que perambulam e contam de si, perambulam sobre as confissões, os gritos, as criaturas. São diários. Mas me valho deles como caderno. Pelo grau de embaralhamento e radicalidade dos procedimentos. Aqui há recursos distintos daqueles do cadernos artaudianos. Contudo, há um intenso uso da cor que atravessa a gramatura da página, sucitando avessos. Não sei se seria justo afirmar que os diários de Kahlo são um caderno e, para além disso, um caderno involuntário...

\section{5.}

Ao reler as linhas desta geminação de cadernos, dei-me conta que precisava revisitar os artistas que citei no BLOCO UM do primeiro capítulo. Isso somado à sensação de haver muito homens e poucas mulheres enquanto artistas nesta parte. Então me deparei com os desenhos e demais obras plásticas da perfomer greco-estadunidense 
Diamanda Galás, disponíveis em seu site oficial195. Eu não conhecia. Enquanto via as imagens, escutava performances e folheava seu livro the shit of god ${ }^{196}$, me deixei levar mais uma vez ao universo das mulheres artistas massacradas. Universo incontornável. Comecei a ler sobre o assassinato da performer-ativista cubana Ana Mendieta em $1985 \ldots$

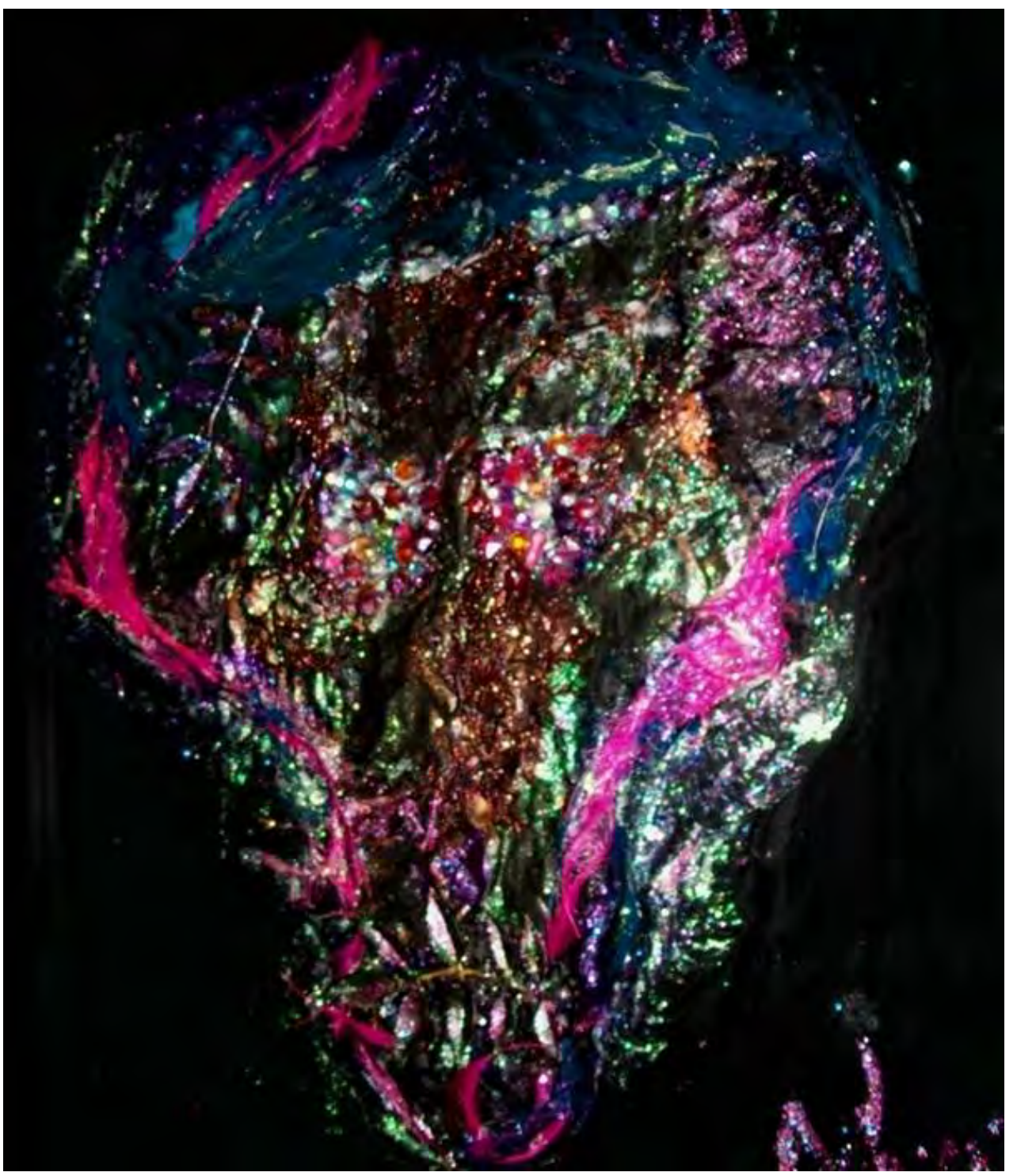

'morte', arte de Diamanda Galás.

195 Trata-se da página http:// diamandagalas.com/ . Escutei duas performances durante o meu devaneio. A primeira, o poema HEE SHOCK DIE:

https://www.youtube.com/watch?v=8Smh V Thl4;

a segunda, provavelmente 0 seu mais recente registro informal ao vivo:

https://www .youtube.com/watch?v=jOFPUTCt468.

196 (1996) Vem a ser uma reunião heterogênea de coisas - letras de músicas, composições literárias, partituras vocais, fotografias... 


\section{6.}

Hijikata, a investigação da dança na escrita (diferente dos exercícios de caligrafia do Henri Michaux), investigando encaixes de palavras. Uma escrita singular, cuja faculdade compositiva incita mais uma vez a pensarmos o cadernos, a página. Eu coleto Hijikata sem saber japonês, Hijikata via Kuniichi Uno, Hijikata nos seus poucos vídeos espalhados pela internet, dançando-caligrafando. Hijikata nos seus complicados fragmentos coletados por Uno. Hijikata em a bailarina doente, uma dança-livrocriança-corpo. Bem como em Simondon, espero que Hijikata não seja 'salvo' pela academia e nem pelos espaços curatoriais.

Em um texto de Hijikata chamado núcleo envelopado da doença (Tsutsumareteiru byōshin), há um fragmento muito interessante que Uno coleta, que fala de um brinquedo de papel (Denguri). Aqui, segundo uno, vemos um fragmento de uma operatividade insólita que Uno chamará por topologia, e esta, em especial, a topologia de um corpo doente como um corpo em estado de gênese:

A respeito deste corpo, quando se descreve este brinquedo sob a forma de flor, no qual as pétalas desfolhadas envelopam o centro, como se envelopar fosse ser envelopado, o interior já é atingido pela doença [... de Uno] Na continuidade revertida pela qual as entranhas se tornam pele, a pele se torna as entranhas, o retorno de todas as lembranças conserva nitidamente as formas da origem [... meu] Bem que seria um estado de abertura a todas as entradas e saídas para o núcleo envelopado trêmulo da doença e as pétalas que este núcleo envelopa, não há nem entradas nem saídas. [...] Os fenômenos que emergem de tais gestos e de tais movimentos devem aparecer como um tipo de ressurgimento que se faz de dentro de uma realidade dissolvida, acompanhando o eu interior de modo que o pensamento chegue ao corpo como se o pensamento fosse rapidamente conquistado e como se o corpo fosse ligado ao tempo para decifrar e se libertar rapidamente. [...] A cama como a última fortaleza que leva ao meu corpo a distância do passado faz o fim se tornar sempre 0 
começo, mas o começo não alcança jamais o fim. (HIJIKATA, $2005^{197}$, apud UNO, 2018, ps. 197-199)

[há um trecho desta citacão traduzido distintamente nesta edicão brasileira, algumas páginas depois (p. 214)]

Os fênomenos que emergem de tais gestos e de tais movimentos devem aparecer como um tipo de ressurgimento que se faz de dentro de uma realidade fundida com o eu interior, de sorte que o pensamento chega ao corpo como se tivesse sido rapidamente conquistado e o corpo ligado ao tempo para decifrá-lo de modo que, em seguida, possa ser rapidamente desatado.

Uno nos informa que 'o texto o núcleo envelopado da doença foi publicado no ano em que Hijikata começou a série de textos que vai desembocar na Dançarina doente' (UNO, op. cit., p. 198). É um texto insólito e sóbrio. Uno diz que 'O que é impressionante neste texto é que é que a agressividade provocante e corajosa co primeiro período [de Hijikata] se esfumaça' (Ibidem).

Um buraco envelopado de engolimento perpétuo.

A escrita hijikatiana é irredutível, responde nos seus peóprios termos e, neste sentido e involuntariamente, não responde uma escrita artaudiana.

27.

Pensamento larvário de Hijikata, por Uno (2018, p. 208, grifo meu):

[Hijikata, op. cit.] Veja bem. Este verme vive bem sem respirar. Você vê, esse pequeno animal desaparecido, esmagado, anda em nossa direção. Este animal está, de alguma forma, fazendo uma metempsicose.

Dançarina doente começa com um enunciado entre aspas, mas não se sabe quem o diz. 0 "o pequeno animal desaparecido" está vivo, em processo de metamorfose, em estado de morte provisória, em apneia. Esse começo apresenta imediatamente um horizonte no qual a vida e a

${ }^{197}$ Em obras completas (Zenshū). 
morte se misturam e se avizinham. Eu me lembro do título de uma obra poética do jovem Artaud, 0 umbigo dos limbos, o umbigo da morte ou ainda a "larva mental do meu pensamento", em um dos seus últimos cadernos. É um lugar intolerável, conhecido de Hijikata. Se ele se afastasse daí, não haveria mais razão para fazer qualquer coisa.

Estamos em um domínio duvidoso onde são as metamorfoses do corpo se instruem a si mesmas.

\section{8.}

Eis o monstro que coleta cadernos.

Se pareceu excessivo, há muito mais do que foi exposto.

Para fins de uma tese, é preciso se apegar a um mínimo.

Há agora uma espécie de textura de transição entre 'os instintos de geminação e de cadernos' e as conversas. É onde a germinação suscita conversas, blocos de falas. 


\section{[CALDEIRAS: fragmentos] \\ [PREPARAÇÃO PARA CADERNOS KAFKAS]}

O agrupamento corpossom é resultado dos campos laboratoriais coletivos para as explorações do doutoramento. Ele foi pensado para ser uma espécie de 'núcleo móvel', composto por quem quisesse estar, até a primeira metade do tempo do doutoramento, correspondente ao prazo para a banca de qualificação. Eu ia chamando as pessoas, na medida da afinidade, nos meus círculos de convivência. Já participaram do hoje chamado agrupamento corpossom:

Amanda Amaral de Oliveira

Auber Bertinelli

Bruna Carvalho Almeida

Bruno Policastro

Carolina Petrucci Rosa

Débora Oliveira

Eduardo Azevedo

Liliana Junqueira

Luiza Rolla

Maria Carolina M acari (Carú)

Rodrigo Fabbro

Talita Alcalá Vinagre

Quando preparei o relatório de qualificação, eu tentei organizar algum registro dos encontros. Para isso, uma definição das pessoas participantes foi solicitada. 0 próprio nome agrupamento corpossom surgiu durante o processo de definição. Por conta desse gesto inicial envolvendo a formalização de um registro para a qualificação, 0 núcleo agrupamento se 'segurou' em tamanho e linhas gerais da estrutura de trabalho 
desde dezembro de 2016, data aproximada dos registros ${ }^{198}$. Esse núcleo, configurado dessa maneira, sustentou certo funcionamento ou continuidade de ações, ou seja, certo ritmo de práticas, até o final de 2017. Durante esse período o núcleo agrupamento corpossom se constituiu por:

\section{Auber Bertinelli \\ Carolina Petrucci Rosa \\ Rodrigo Fabbro \\ Talita Alcalá Vinagre}

Em 2017, um fato inusitado. Auber, integrante do núcleo, nos convidou, por parte de outro coletivo de que faz parte, o Zebra5 - jogo e arte, a participar de uma residência junto a eles. Seríamos então, enquanto agrupamento corpossom, uma residência 'paralela' em convívio com os integrantes do Zebra5. Tratava-se do edital de residência da Casa das Caldeiras, no bairro da Água Branca (região do bairro Barra Funda). Local cultural que, em paralelo a sua agenda de eventos comerciais, que provê o sustento da casa, costuma tentar abrigar anualmente diversos coletivos artísticos.

Assim, de maio a novembro de 2017 trabalhamos, ainda que num ritmo irregular, neste espaço de amplas dimensões, com seus múltiplos nichos, ao negociar e dividir períodos de tempo e espaços com a gestão da casa e com outros núcleos. Variadas vertentes integravam a residência naquele ano ${ }^{199}$ : a performer e coreógrafa Vera Sala, a Jorge Garcia Companhia de dança, o coletivo Macaquinhos, a performer Carolina Sudati, entre outros.

\footnotetext{
${ }^{198}$ A pessoa responsável por esses registros em vídeo foi Bruna Carvalho Almeida, que também participava de algumas práticas. Durante 0 ano de 2017 as ações eram eventualmente documentadas em fotografia ou vídeo por Tiago Luz e Júlia Fávero.

${ }^{199}$ Não vou usar a palavra ocupação para este contexto, ao contrário de quando nos referíamos a nós mesmos informalmente às vezes, quase sem querer, como ocupação. Acho que essa demarcação deve ser feita por conta do caráter político desta expressão. Creio que é uma palavra com um uso preciso que designa ações autônomas em nível contra-institucional e contra-policial, contexto bem distante do nosso. Penso até que a palavra 'ocupação' tem sido capturada para o contexto comercial e empresarial há tempos.
} 
Nós do agrupamento corpossom chegamos a fazer ações conjuntas com alguns membros do Zebra5. Primeiro Alberto Tembo e os elásticos/estruturas penetráveis. Depois Carolina Velasquez e os bonecos vestíveis fabulosos. Cada artista do Zebra5 tem uma pedagogia e modos de ação e convivência muito particulares.

De qualquer maneira o agrupamento corpossom habitou, ainda que num registro de múltipla precariedade, o espaço da Casa das Caldeiras, de maio a dezembro de 2017. Talvez seja melhor dizer que fez intervenções, ainda que gostássemos de falar em termos de ensaiar como modo de se habitar um espaço qualquer. Se é intervenção é porque a habitação vem modificar radicalmente o estatuto daquela arquitetura.

Em alguns dias em que havia confusão de agenda com as Caldeiras, migrávamos para o Parque da Água Branca. De um desses dias em que operamos o deslocamento para 0 parque, surgiu a ideia de um documento em vídeo junto às imensas árvores daquele local. Na Casa das Caldeiras em si há abundância de fotos e alguns poucos vídeos em baixa qualidade filmados do aparelho de telefone. Esse documental vem principalmente nas experiências com Alberto Tempo e Carolina Velásquez.

Nossas ações foram simplesmente trabalhar o corpo em contato, diálogo ou atrito com a variedade de acústicas das Caldeiras. 0 trabalho de corpo é aquele do meu repertório de treinamentos, orientado, adaptado ou deformado para os interesses da performance. É importante dizer isso e assumir do que se trata, não fingir que não aconteceu.

loga, taichi, kempo indiano, componentes de biomecânica, caminhadas, espirais, exercícios vocais básicos, conduções de relaxamento, fragmentos de educação somática e do contato-improvisação, sessões de improvisação em chaves específicas ou livres... A lista segue, pois precisamos inventar novos exercícios para dar conta de uma ação ou permanecer habitando um lugar. Ou combinar componentes de exercícios. Mas o principal é saber que habitávamos momentaneamente aquele estranho lugar, então tudo contava: a chegada, a adaptação, os mal-entendidos... foi fundamentalmente um trabalho relacional. 
Às vezes penso se 0 taichi é especialmente compatível com as práticas do corpossom. É difícil responder. De qualquer maneira, gosto de treinar esta arte de meditação do movimento e da relação, e acho que ela de fato participou decisivamente deste momento da pesquisa (o doutoramento). Mas isso não é nenhuma restrição, penso, para se ter um entendimento prático do corpossom. Por esta razão não me dediquei, nesta tese, às descrições dos exercícios de taichi, senão alguns poucos pontos. Penso que seja interessante que a pessoa tenha uma prática própria, qualquer que seja. Mas isso também não é estritamente necessário, só acelera o processo de assimilação de alguns procedimentos. Pois trata-se de corpo, e o corpo tem suas próprias regras.

Durante os anos em que assumi que havia uma pesquisa em corpossom, acho que de 2008 para cá, surgiram matrizes híbridas de exercícios.

pêndulos e ondas como movimentos auto-sustentados

exercícios derivados do laboratório da nota, [como os modos de emissão, e jogos de nota coletiva]

cinco toques metafóricos

trabalhos específicos de chão

uma sequência pedagógica sensibilizadora para a proliferação de esferas e espirais [enquanto movimento, não enquanto forma]

dinâmicas de movimentação a partir do vegetal, [como uma 'eletricidade gentil']

etc. Esses itens serão detalhados em breve. 
Para alguns dos encontros eu fazia o roteiro completo. Para outros, um segmento do roteiro. Para outros, apenas um tema ou nem isso, uma suspeita. Para ainda outros, só bastava que nós estivéssemos lá.

Às vezes eu trazia os sonhos de Kafka que me acompanhavam desde 2014 para trabalharmos. Em dado momento do processo operamos uma seleção gradativa desses sonhos até que, ao final, havia menos de uma dezena de sonhos. Então desses, elegemos um sonho para cada pessoa, e fizemos um sorteio. A Carolina Rosa não estava presente no sorteio, e então depois ela escolheu um sonho de Kafka que ela desejaria trabalhar.

Meu desejo era que o sonho escolhido fosse uma espécie de 'objeto paralelo', uma companhia à nossas habitações e aos nossos encontros. É uma espécie de cuidar de um terreno de enunciação. Pontualmente propus algumas intervenções com esses textos, tanto como leitura no espaço, como pedaços de texto decorado, como texto em movimento ou com movimento, texto em vocalização ou com vocalização... mas esses textos de Kafka já têm muito movimento.

Propus 0 trabalho de transcrição da página com estes textos, mas a proposta não surtiu um efeito duradouro. Não sei se eu propus de uma maneira suficientemente clara, ou não houve permanência bastante da nossa própria 'habitação nômade' que torasse possível instaurações do porte que eu talvez desejasse.

Tentei sobrepor à proposta de transcrição a escolha de um segundo sonho por cada membro do grupo; a escolha poderia ser da pequena seleção de sonhos ou ainda outros sonhos de interesse. 0 seu segundo sonho seria aquele que você só leria em voz alta. Uma outra experiência de contato.

Cheguei a propor uma terceira escolha: o seu terceiro sonho seria aquele em que trabalhamos sobre ele para decorá-lo, cada um à sua maneira. Terceiro tipo de contato. 
Mas a proposição da transcrição era a mais fundamental. Meu discurso era de que só partiriam às outras escolhas de sonho quem tivesse completado um número mínimo de 10 repetições do sonho escolhido para transcrever. Talvez essa proliferação de tarefas tenha sido maneira que encontrei de estimular o trabalho de transcrição.

Durante o meu mestrado já havia um laboratório que chamei de 'laboratório da página'. É preciso não confundir com este. Em todo caso, eu já sabia que se valer de um caderno poderia operar uma metamorfose no corpo.

Transcrição no contexto das Caldeiras.

Pensava também na relação da contínua transcrição como um modo do texto germinar e crescer, ainda retido, de alguma forma, no modelo do texto como um sujeito de companhia. Falar 'retido' é um modo estranho de me expressar. Acho que essa proposta que confere objetidade-subjetividade-autonomia ao texto é uma proposta de processualidade radical. Não é uma proposta intelectual pois foi assim que a germinação de caderno aconteceu comigo. Pretendo testar esse modo de companhia que gera corpos estranhos. Esse procedimento parece ser um encaminhamento plausível, ou um campo do implausível, ressonante com o que tenho feito sem palavra desde meados do mestrado, quando decidimos abolir totalmente 0 verbal-oral dos experimentos de corpossom. É preciso continuar desenhando. É preciso continuar escrevendo. É preciso produzir corpo ou algo que dê testemunho de corpo. Esta hipótese surgiu no mestrado mas demasiado tímida. Agora penso haver conseguido um terreno razoável para trabalhos presentes e vindouros.

Naturalmente há uma intersecção de alguns trabalhos com a palavra que se encontram aqui. Janô, Juliana J ardim, François Khan, M aria Thais, Lina Prosa, Toumani Koyuaté, e desvendamentos de quem se aventura e se agoniza demoradamente sobre o problema de uma corpalavra no teatro. Desde contatos longos a contatos curtíssimos. Cada uma destas figuras foi crucial no reconhecimento de um corpo desconhecido que se individua em conjunto com uma página, com menos do que uma página, com bem menos do que uma página. E é claro que há aqueles talismãs que chegam: às vezes palavras que chegam para você, às vezes palavras que chegam a 
partir de transcursos que nada têm a ver com estas preocupações. Às vezes talismãs chegam a partir de figuras tão próximas e tão distantes ao mesmo tempo. Palavra vegetal. Palavra mineral. Nada disso é humano, é profundamente alheio e autônomo. A página é só um meio de se construir um radar. Um talismã pode ser um radar.

Claro que hão companhias, às vezes mais vivas, desses caras que escrevem. Há, por exemplo, um extraordinário texto de Carlos Castañeda que me acompanha desde 2015, quando fiz minha segunda oficina de dança-literatura com Tica Lemos (outra companhia, em outra escala de acontecimentos e também aqui). É um texto de seu sexto livro, o presente da Águia. Castañeda também provavelmente o re-contou: tratase do início do regulamento do Nagual. Ele descreve a figura de uma monstruosa Águia (que não é uma águia propriamente), e o que ela faz (CASTANEDA, 1981, ps. 142-143).

Não direi assertivamente que certos textos são partes do nosso corpo, não sei se é apenas isso. Eles são companhias e possibilidades de escritura conjunta, individuação conjunta.

Houve uma ocasião em especial onde pedi que outras pessoas do agrupamento conduzissem as práticas. Isso se deu por uma urgência. Tive problemas e só consegui chegar ao final do horário do encontro. Foi quando as pessoas me contaram o que havia acontecido. Este dia teve inúmeras ressonâncias criativas. Uma delas foi um trabalho que Auber fez acerca do dizer do texto de determinadas formas: falar só com as vogais; dar palavras ou pedaços de texto para alguém, deixando que esta palavra ou este pedaço saia, se ejete do total relaxamento, sendo o próprio gesto de dar. Além do que falei sobre ele, Auber trabalha há alguns anos com Juliana Jardim, além de ter feito a Escola de Arte Dramática da USP (EAD). E, é claro, sempre esquecemos de algo.

Neste mesmo dia Talita havia conduzido antes um trabalho de movimento. Talita tem sido uma parceira para pensar relações de movimento, ambiente e cuidado. Conheci ela um pouco através de uma rede de pessoas conhecidas, e um pouco em meio ao universo das JAM s de dança. Ela fez mestrado sobre o trabalho da performer Marta Soares na PUC-SP e acaba de ingressar (2019) no doutoramento na mesma instituição. 
Não vou apresentar os outros componentes demoradamente, a não ser que os acontecimentos desta narrativa me obriguem. Não sei se conseguiria apresenta-los satisfatoriamente. Como estou narrando, posso negar informações com o pretexto de facilitar nosso caminho. É importante entretanto deixar saber que os quatro componentes desse coletivo são absolutamente singulares.

E assim seguimos nossa residência em 2017.

Quando Auber nos contou, em janeiro de 2018, via email, que o Zebra5, nosso anfitrião, estava por encerrar as atividades nas Caldeiras, pediu para cada um de nós mandar um depoimento escrito, se pudesse. Rodrigo e Talita compartilharam 0 depoimento conosco, através da própria conversa do email. Não lembro se Auber nos pediu diretamente, mas houve a compreensão geral de que o texto deveria ter um tom um pouco formal, porque seria adequado a uma espécie de relatório. Segue o escrito do Rodrigo. Todos os escritos a seguir foram autorizados por quem os escreveu.

\begin{abstract}
O processo se deu na utilização, na maior parte das vezes, na sala dos tanques, onde desenvolvemos nossa prática e pesquisa do Corpossom na exploração dos potenciais sonoros e acústicos da sala. Também exploramos espaços externos da Casa das Caldeiras e confluimos nossa pesquisa numa intersecção com trabalhos do Zebra 5. Fizemos interferências de nossa prática e explorações acústico-corporais no evento do Zebra 5 aberto para o público na instalação Penetráveis. Ainda exploramos o espaço subsolo/ terreo e tuneis da Casa das Caldeiras. Como havia transito de pessoas de outros grupos e dos trabalhadores da Casa, procuramos acolher essas presenças no nosso registro expressivo-sonoro e ampliar nossa vivência-pesquisa.

Foi um ano produtivo. Houveram algumas pequenas turbulências de conflito de agenda e/ou alguma falha de comunicação, porém houve a disponibilidade e oportunidade de explorar espaço tão rico à pesquisa artística bem como o contato com grupos parceiros afins!
\end{abstract}

Essa foi minha percepção e vivência numa descrição bem geral desse ano de trabalho.

Abraços

O Rodrigo muitas vezes nos enviava pequenos relatórios dos ensaios que acabavam de ocorrer, por mensagem de celular mesmo (whatsapp). Sou muito grato a ele por isso. É marcante do seu engajamento muito próprio essa localização do material que é 
produzido. Ou seja, ele não organizava por organizar. Ele é ator (também formou-se pela EAD) e encenador. Faz pós-graduação no Departamento de Artes Cênicas (CAC/ECA-USP) havendo como objeto a dramaturgia de Valère Novarina, em conjunção com procedimentos musicais.

Segue o email da Talita enviado na sequência.

Auber queride,

Vou enviar um breve relato que você pode adicionar - editando o que achar melhor - na carta para as Caldeiras, ok?

Você chegou a falar com a Carol sobre o rolo de craft?

"Estar residente na Casa das Caldeiras foi uma experiência interessante, pois abriu uma possibilidade de diálogo entre nossa pesquisa do Corpossom e a história e arquitetura do lugar. De modo que tanto a nossa prática artística ressoou através dos espaços ocupados quanto estes estimularam novas percepções e desafios cognitivos e sensoriais para 0 grupo. Além disso, os momentos de convívio que tivemos com outros residentes, assistindo suas performances e/ou trocando sobre suas práticas na Casa das Caldeiras também nos estimulou a repensar a consistência de uma residência artística. Sobretudo em relação ao modos de gestão de um espaço com essa dimensão e diversidade de ocupação. Tivemos que ser bastante flexíveis em relação à agenda da Casa devido ao nosso dia de ensaio coincidir com eventos e outras necessidades do espaço. Uma sugestão nossa, seria avisar já no início das atividades os grupos que ensaiarem nas sextas, informando sobre os outros eventos que acontecem no espaço para que o grupo possa se organizar com antecedência. Acreditamos e esperamos que a Casa das Caldeiras continue como um espaço de incentivo ao convívio, pesquisa e criação artística, recebendo e acolhendo de forma aberta os grupos e artistas da cidade de São Paulo".

Beijokas e vamos encontrar?

Tali

Contudo, antes desse momento do email final, houve uma retirada paulatina do nosso núcleo das Caldeiras, pois, justamente, como é um espaço alegadamente com um custo muito alto, eles priorizam os eventos, as festas, feiras, os casamentos etc. Parece que o espaço nos 'expulsou' de lá. Nosso último encontro, em novembro, foi na Praça do Relógio da USP. A Talita fez um generoso relato desse encontro, talvez como uma forma de cuidado na despedida, no nosso pequeno grupo dentro da rede social facebook. 


\section{1 de novembro de 2017}

Relato de nosso treino de ontem no bosque da EAD- USP, dia 10/11/2017

Partimos da prática de sensibilização da superfície das mãos sendo tocada pelo vento. Primeiramente, só com uma mão que oscila, segue, perfura a brisa fresca. E, em seguida, passamos a perceber a outra mão. Seguimos com a passagem dessa atenção de uma extremidade à outra. E, assim, continuamos, então simultaneamente, as duas mãos tornando- se sensíveis às ações do vento. Chico propôs trazermos a "esfera de ar" para ser manipulada continuamente, modulando os tamanhos. Isso tudo sempre aliado com a respiração e suas diferentes dinâmicas de cada momento presente. Ao girar e ampliar essa esfera no espaço Ki - do entorno do corpo, produzindo múltiplos direcionamentos (vetores?), foram gerados alguns fluxos e deslocamentos. Foi um super aquecimento, também porque contamos com a presença estonteante dos raios solares e de um céu azul infinito. Achei que foi muito interessante essa prática realizada ao ar livre, ampliando a atenção às texturas do solo sob os pés (eu estava descalça), as paisagens visuais, sonoras, táteis, olfativas modulando a todo 0 momento. 0 perto, 0 longe, 0 horizonte expandido.

[...]

Precisei deitar no chão e passamos a observar as árvores, daí surgiu uma reflexão sobre cada posição do corpo encontrando apoios e lugares de relaxamento. Chico falou do pensamento do Simondon, de como ele traz de alguma forma, uma contribuição importante para nos aproximarmos de um modo de existir- árvore. Isso, considerando a operação desse tipo de vida na terra que se dá por meio de defasagens e atualizações. 0 que sobrou, defasou, no entanto, continua em processo de atualização, mas em outra velocidade (talvez?). São padrões vegetais (vitais) que, de algum modo nos aproximamos. Pensei numa co- evolução criadora, nós e as árvores expandindo conjuntamente. Há nisso uma sinalização para um viver junto, com generosidade e deixando-se sentir pelos afectos do tornar- se árvore. 0 que leva a pensar numa ética impessoal, dessasujeitada, a ponto de haver uma equanimidade entre nós e elas. Como entrar em composição com as árvores através de fabulações com nossos corpos que nos fazem lembrar uma irmandade esquecida com esses seres. As árvores estão então, como mensageiras entre mundos (Céu e Terra, pelo menos!) nos atentando para essa urgência. Árvores são como Chico falou ENTRIDADES considerando- as como pontes para 0 ENTRE infinito dos fenômenos.

Trabalhamos as consoantes daquele modo indeterminado, ou seja, as misturas e passagens entre uma consoante e outra iam aparecendo de um modo não tão programado. Pra mim, pessoalmente, esse trabalho com as consoantes foi bastante terapêutico, porque me estimulou a colocar pra fora a minha saliva, cuspir mesmo. E isso, o gesto de expulsão é o que essa prática parece também propiciar. Chico leu um dos sonhos do Kafka, o dos telefones (escolhido pelo Auber para escrever). Durante a leitura, houve uma suspensão da fala, um silêncio potente veio 
à tona. Ele continuou até o fim do sonho e as palavras se tornaram como que esculturas no espaço- tempo, paisagens táteis. Chico disse ter entendido naquele momento algo lá do mestrado dele. Eu quis ler, sentada e encostada no pé de uma árvore, o sonho- poema das cartas. Foi bom explorar esse sonho naquela condição de cansaço, corpo um pouco mais 'desarmado", destituído de certas expectativas. Chico sugeriu que eu lesse mais um sonho e me pediu pra que o fizesse como que em diálogo com um árvore muito florida do outro lado do bosque. Caminhei até ela procurando qual o texto compartilharia. Escolhi 0 do fogo (escolhido pelo Rô). Chico ficou de longe observando, disse quase não ouvir o que eu falava. Num primeiro momento, falei para dois sabiás laranjeiras que pousaram bem perto de mim em um galho. Em segui, passei a relatar o sonho para a árvore. Pra mim, a sensação era a de deslocamento radical de um tempo e espaço naquele ambiente com a árvore sendo minha interlocutora. Percebi o que aconteceu um tipo de descontinuidade nessa experimentação. Cada sonho do Kafka enunciando uma realidade própria, que se conecta a outras por ramificações inesperadas, improváveis e com um sentido aberto. E que nós, no entanto, vamos, aos poucos articulando, fabricando, maquinando.

Nesse momento, a meu ver, cada sonho está pedindo uma assiduidade nossa, uma constância para que se tornem para nós (e também para um possível público) uma realidade acessível. Chico disse ter percebido que há uma tonalidade dessa nossa pesquisa que dá por hesitação. Talvez pela própria natureza desses textos que nos impelem a um tatear no escuro. Até porque o texto, menos que um condutor da experiência, advém mais como uma aparição. Estamos lidando com textosaparições. Como memórias, são fabulações de um tempo vivido por Kafka, quando de sua dormência ou vigília.

O que dizer? Um relato cuidadoso, complexo, engajado com o percurso.

A figura da Carolina, a única eu não mencionei até agora, esteve menos presente durante o período das Caldeiras. Carol, bem como Rodrigo, é atriz e encenadora. 0 período de 2017 coincidiu com o processo de construção do espetáculo que era sua formatura, também no CAC. Ela já era familiar a esta pesquisa, pois já fui convidado a oferecer intervenções ou treinamentos em dois coletivos em que ela estava presente. Uma das vezes, ela foi a própria pessoa a me convidar: um grupo que ela dirigia. Todos os integrantes do agrupamento estiveram comprometidos em pensar essa presença como um dado produtivo para o trabalho. Recentemente Carolina decidiu sair do núcleo. De qualquer modo, diante da intensa elaboração que os limites de uma presença nos impuseram, não posso fugir à constatação de que foi ou é uma 
personagem igualmente importante deste núcleo. E daqui em diante, se o núcleo prosseguir, o será de ainda outra maneira. M esmo se não prosseguir.

Nota-se que o núcleo se caracteriza por figuras já dedicadas, de longa data, em suas existências, à pesquisa. Talvez essa variável tenha sido definidora ou no mínimo tenha auxiliado na nossa resiliência no período das Caldeiras.

Talvez possa ser que aprendemos muito através do fracasso de uma intenção de projeto, de uma intenção de produto, apenas fadados à convivência em meio à turbulenta agenda dos diversos agentes. Falávamos muito sobre formalização, mas não havia a possibilidade de organizar um cronograma a médio prazo com a residência. Chegamos a escrever um projeto de intervenção a partir dessa experiência de residência. Foram mobilizadas ideias como 'som comunitário' e 'habitação sonora', bem como proposições de caminhadas. Esses 'gatilhos', essas proposições, da minha parte, certamente serão retomadas em algum momento.

Após o encerramento da residência nas caldeiras e suspensão da rotina de encontros, bem como após elaborações coletivas e íntimas, decidi algo. Não havia saída: iria testar comigo mesmo o exercício de transcrição com o maior número possível de sonhos kafkianos, pelo menos aqueles que sorteamos entre nós. E foi aqui que se deu a produção do caderno e dos improváveis esboçamentos: configurações múltiplas que parecem contar de um corpo e produzir corpo.

A minha sensação de fracasso em vários elementos da proposição creio que também me impulsionou a esse exercício aparentemente solitário, mas infinita e insolitamente povoado. Como um artesanato do corpo do sonho.

Eu precisava contar o percurso de 2017 para chegar até aqui.

Os fragmentos de transcrição aqui aparecerão a partir de alguns 'ensinamentos' que eles me concederam. É isso mesmo. Como eu disse, o desenho é o grande sujeito da 
tese. Esse mecanismo assimétrico emergiu durante a invasão de Lilith de uma série fabulatória de árvores que eu realizava. E não me deixou escolha.

Esse ensinamento vindo do próprio desenho, uma vez experienciado e parcialmente compreendido em termos de certo repertório existencial de traços possíveis do seu rumor nascente, assenta-se em outra complexidade no caso da transcrição. Digo isso pois está também em jogo a obrigatoriedade, até certo ponto, de uma caligrafia.

Na transcrição há um margear, uma espécie de zigue-zague com zonas onde há um pôr-se continuamente 'em risco' de algo. Há alterações da letra, há explosões de intensidade, há também esculturas com as letras. Há as imagens do texto, ou de fora dele, do modo como elas querem vir. Circulam eventos da vida. Histórias, temas, gestualidades e texturas esquecidas aparecem e se vão.

Aparecem falas ou figuras que são convocadas a aparecer. Aparecem um tempo e ficam por ali. Ou quase-figuras, passagens.

Os sonhos não aparecem necessariamente na ordem em que trabalhei com eles. Tentei transcrevê-los ao menos 10 vezes, cada um. Em alguns dos sonhos era necessário um pouco mais, os caminhos ainda não tinham sido percorridos.

Uma página pode ser uma corporificação, uma mundificação e um terreno.

Eu havia anotado no primeiro esboço deste capítulo: 'Caderno, página e esboçamento. // 1. // Um caderno contra o livro. Um singular contra o universal. Talvez não nos ocupemos tanto aqui do contra, senão o contra o que o próprio caderno vai falar, 0 que é um tanto imprevisível. Um caderno não pode estar centrado no projeto.' // 2. // A página. Refazer o corpo nas páginas do caderno. Um desenho e uma escrita permutáveis em hierarquia. Ana Kiffer, em seu estudo sobre Artaud, principalmente Artaud dos últimos anos, aquele que ainda internado recebera caderno e lápis das do seu médico e, desde ali, não parava de preencher cadernos, atesta o estatuto vital dessa escrita-desenho. // Refazer o corpo.' // '5. // Ontologia da inscrição. //' 
Escrita-desenho que é refazimento conjunto com detritos vocais.

Melhor seria dizer ontogênese da inscrição.

Voz-salto, voz-climatografia, voz ordinária de um resto.

[SEGUEM FRAGMENTOS DE CADERNOS KAFKIANOS] 
1.

(KAFKA, 2003, p.128)

Ontem sonhei com você. Já quase não me lembro dos pormenores, só sei que nos transformávamos continuamente um no outro, eu era você, você era eu. Finalmente, não sei como, você pegou fogo, lembrei-me que é possível apagar o fogo com panos e assim bati em você com um velho paletó. Mas as metamorfoses recomeçaram e de repente você desaparecia, era eu que ardia e também eu que batia com o paletó. Mas de nada adiantava, só confirmava meu velho temor de que esses métodos nada podem contra o fogo. No entretempo chegaram os bombeiros e de algum modo você foi salva. Mas agora você era diferente, fantasmagórica, como se desenhada a giz no escuro, e caiu-me nos braços sem vida, ou talvez tenha apenas desmaiado de alegria por ter sido salva. Mas ainda aqui atuava a incerteza da transformação, talvez eu mesmo tenha caído nos braços de alguém.

Carta a Milena Jesenská, setembro de 1920 


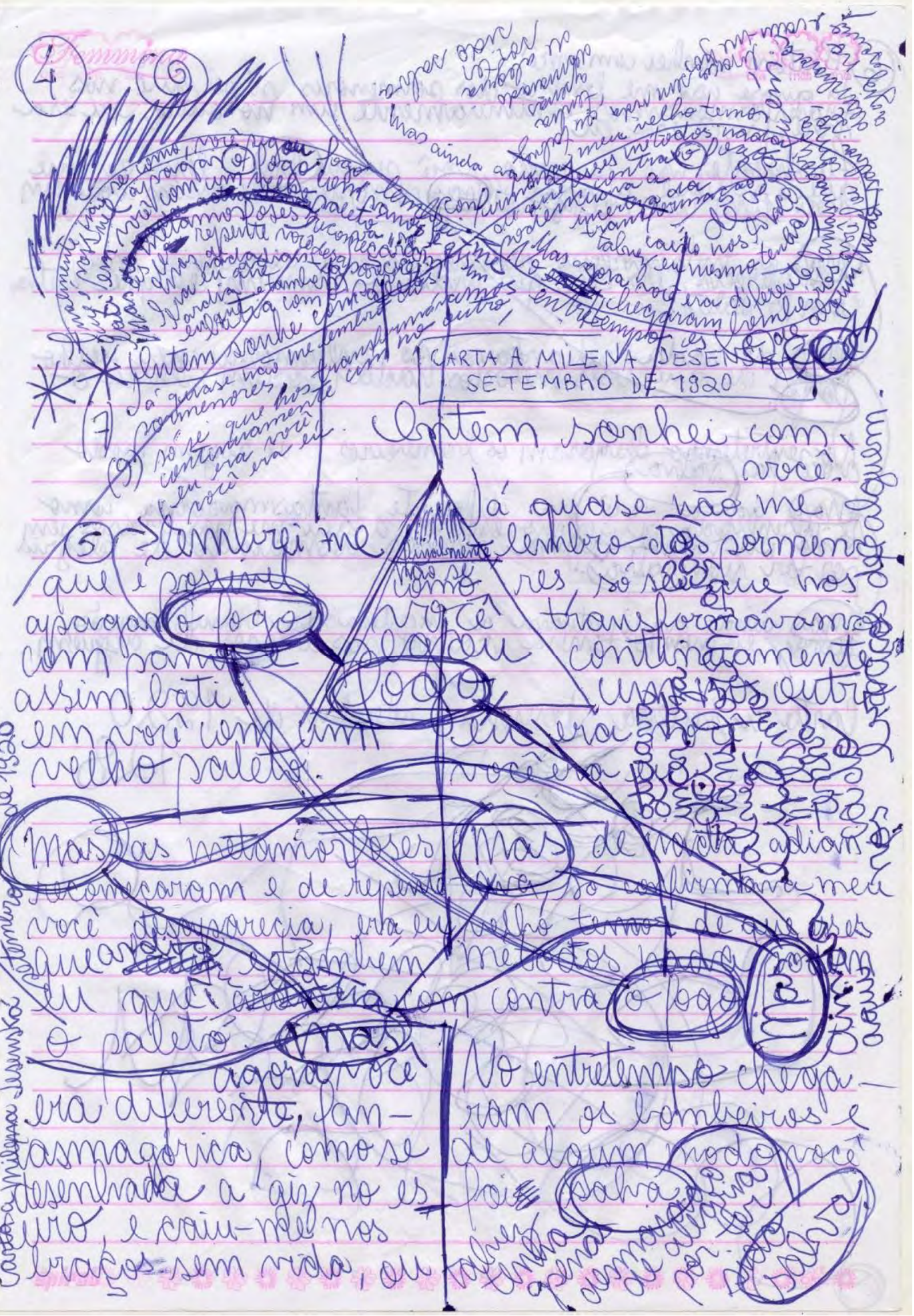




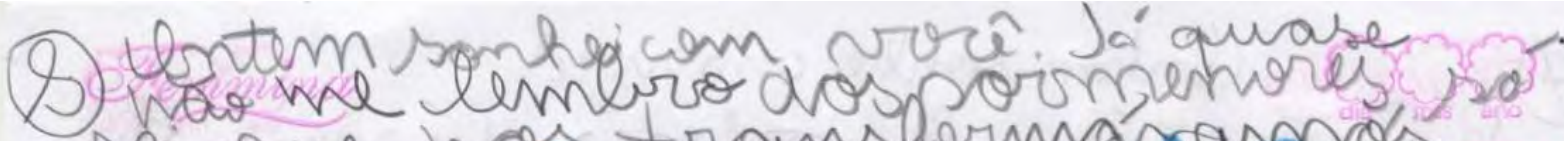
- Ser que wos trans ormánasonos contuma mente un wo or he

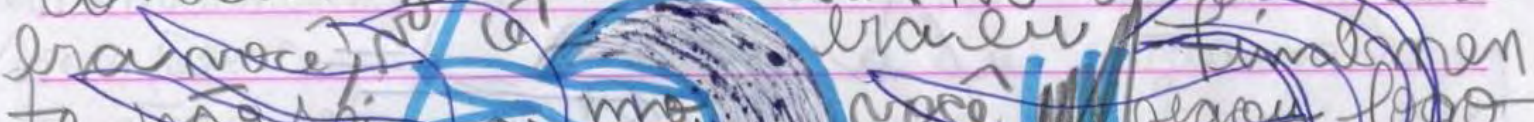

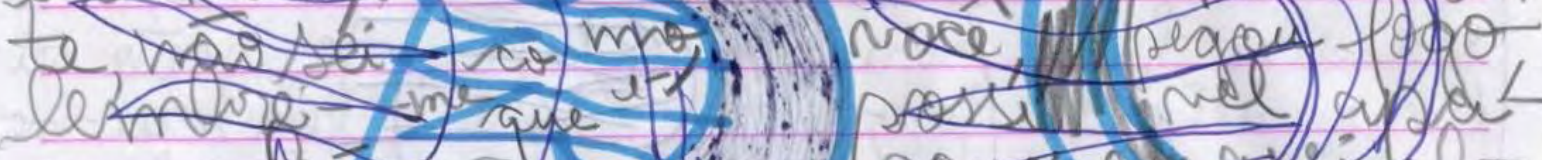

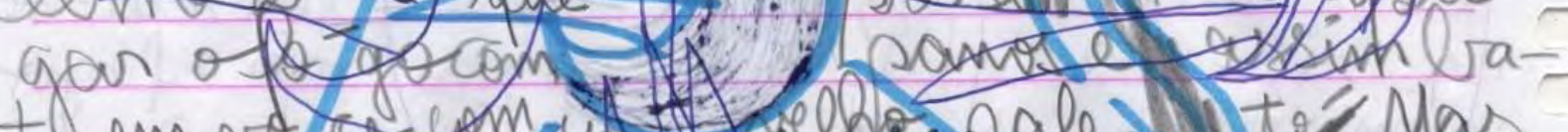

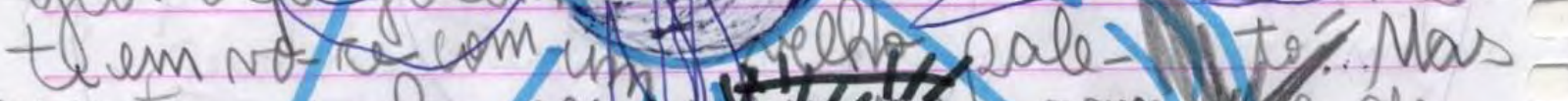

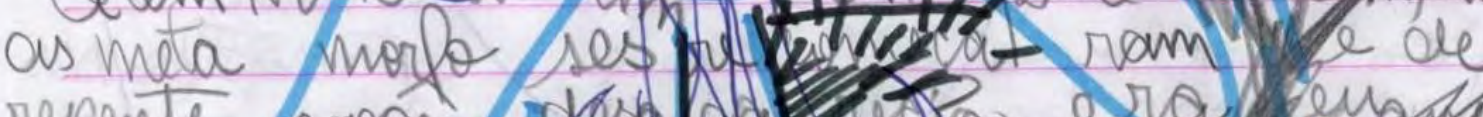

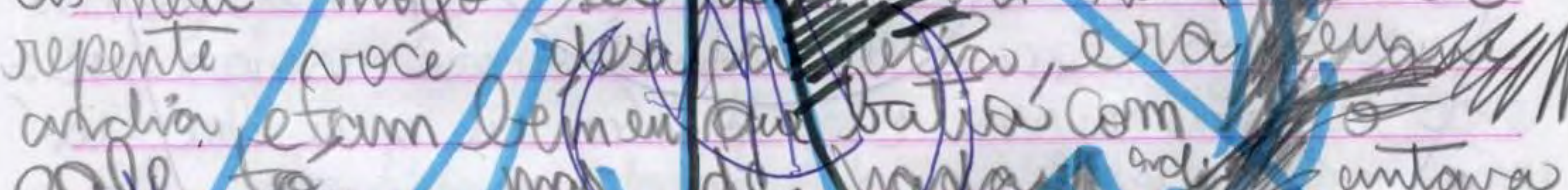

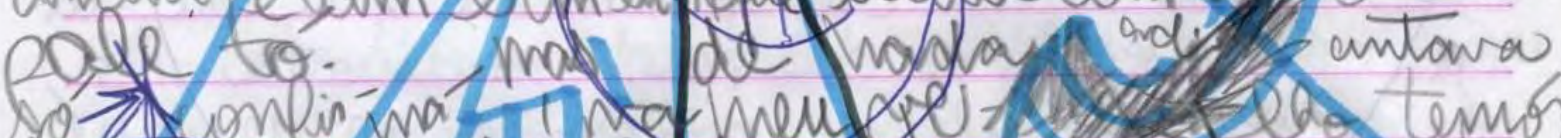

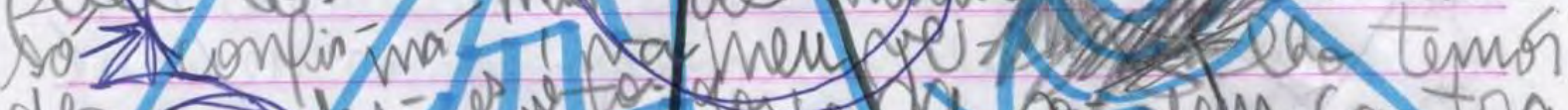

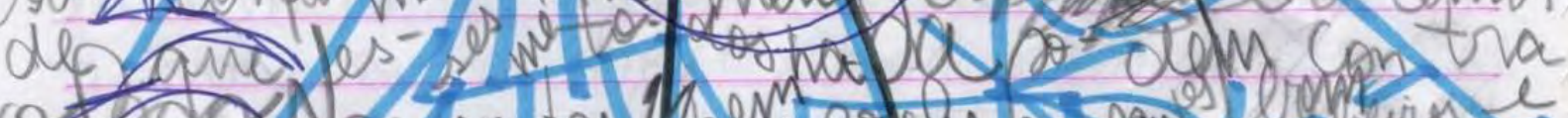

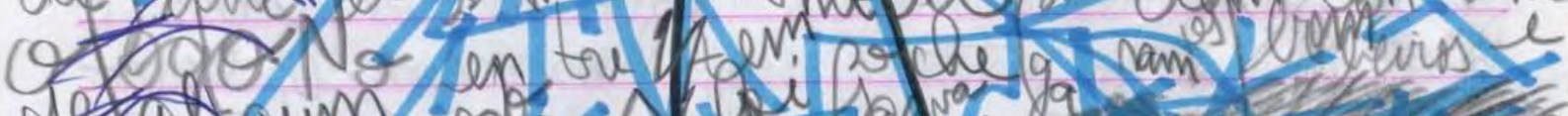

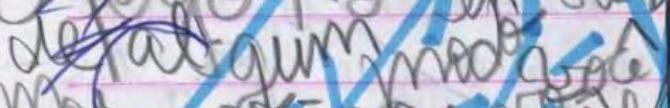
mab bog - va parell lam tas anagois

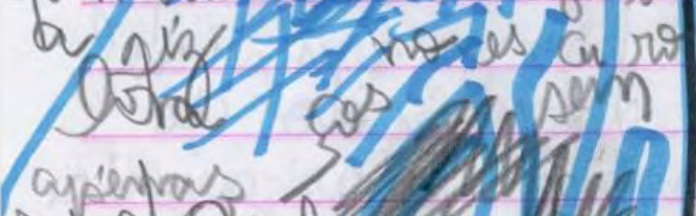
Novad sal var

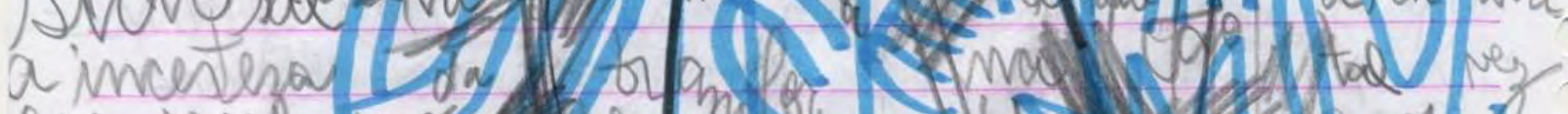

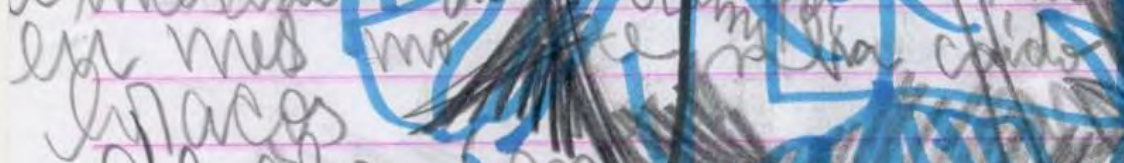

ole pequexmin

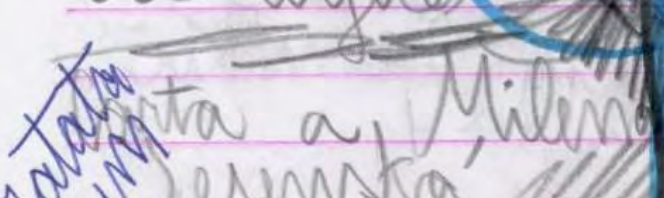

jul am Ka

semang

XV Crovs sembré Tig $N$ cor ,

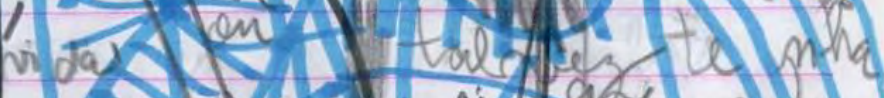

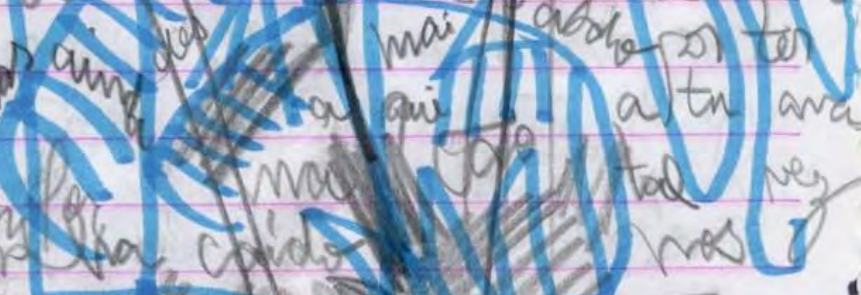
4. 
327

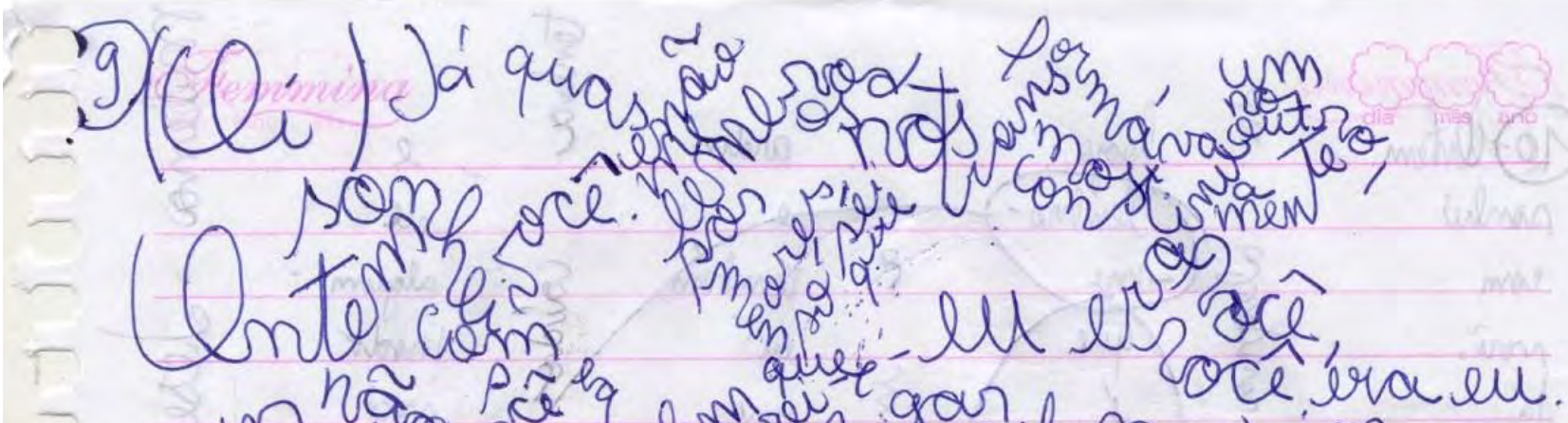

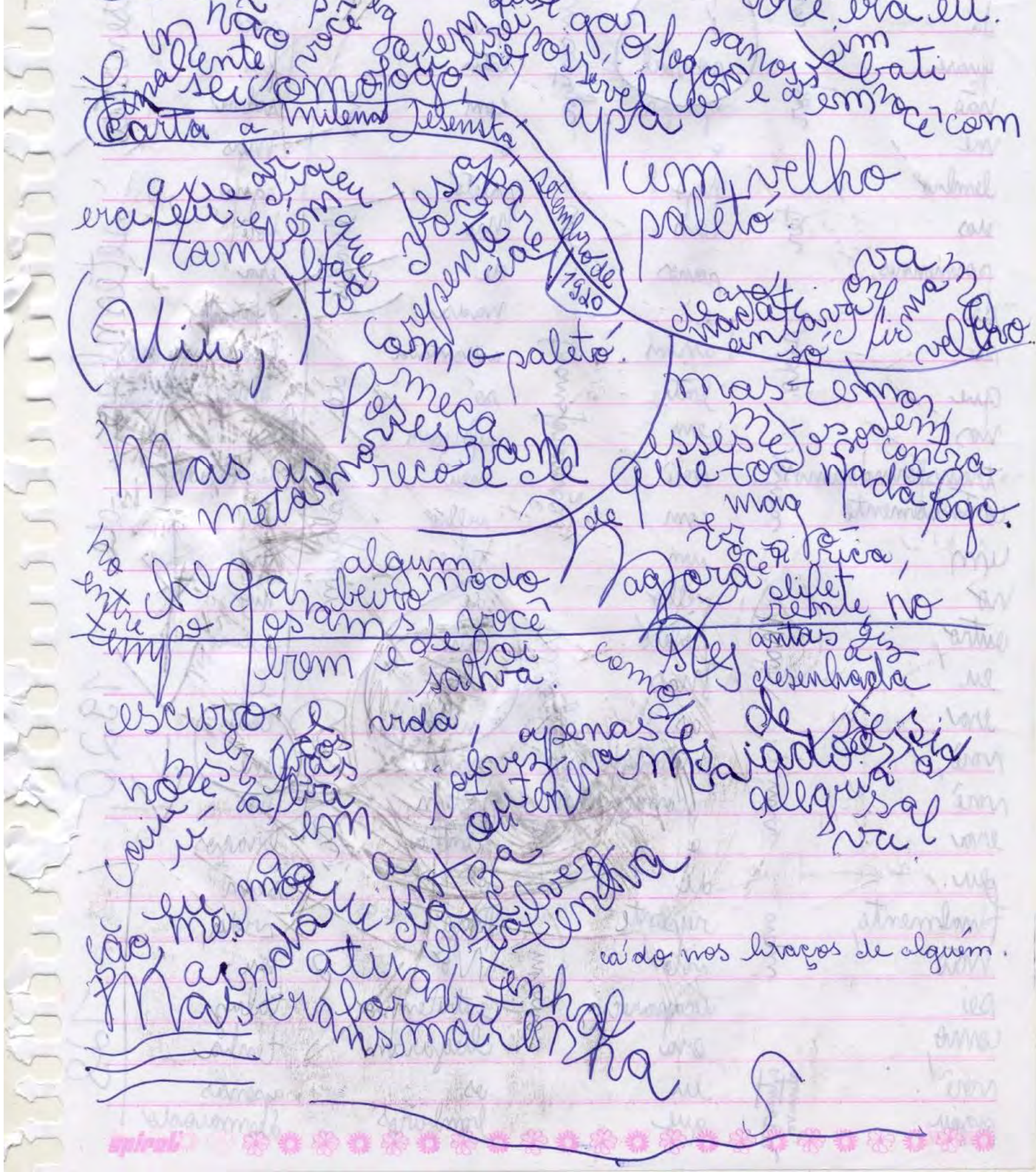


328

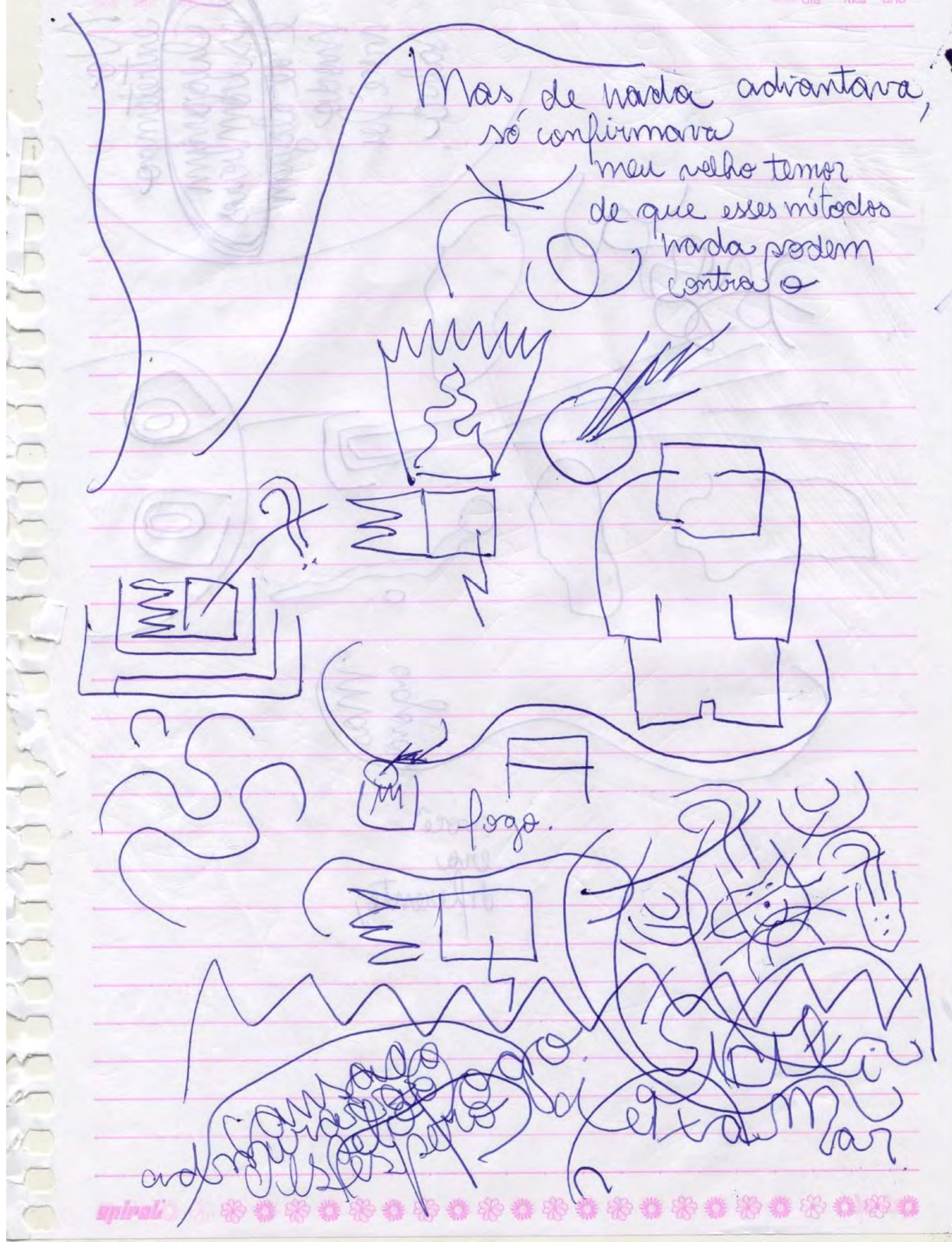


329

Fremminaca

Mas ainda aqui atuowa a incerteza da transformacia,

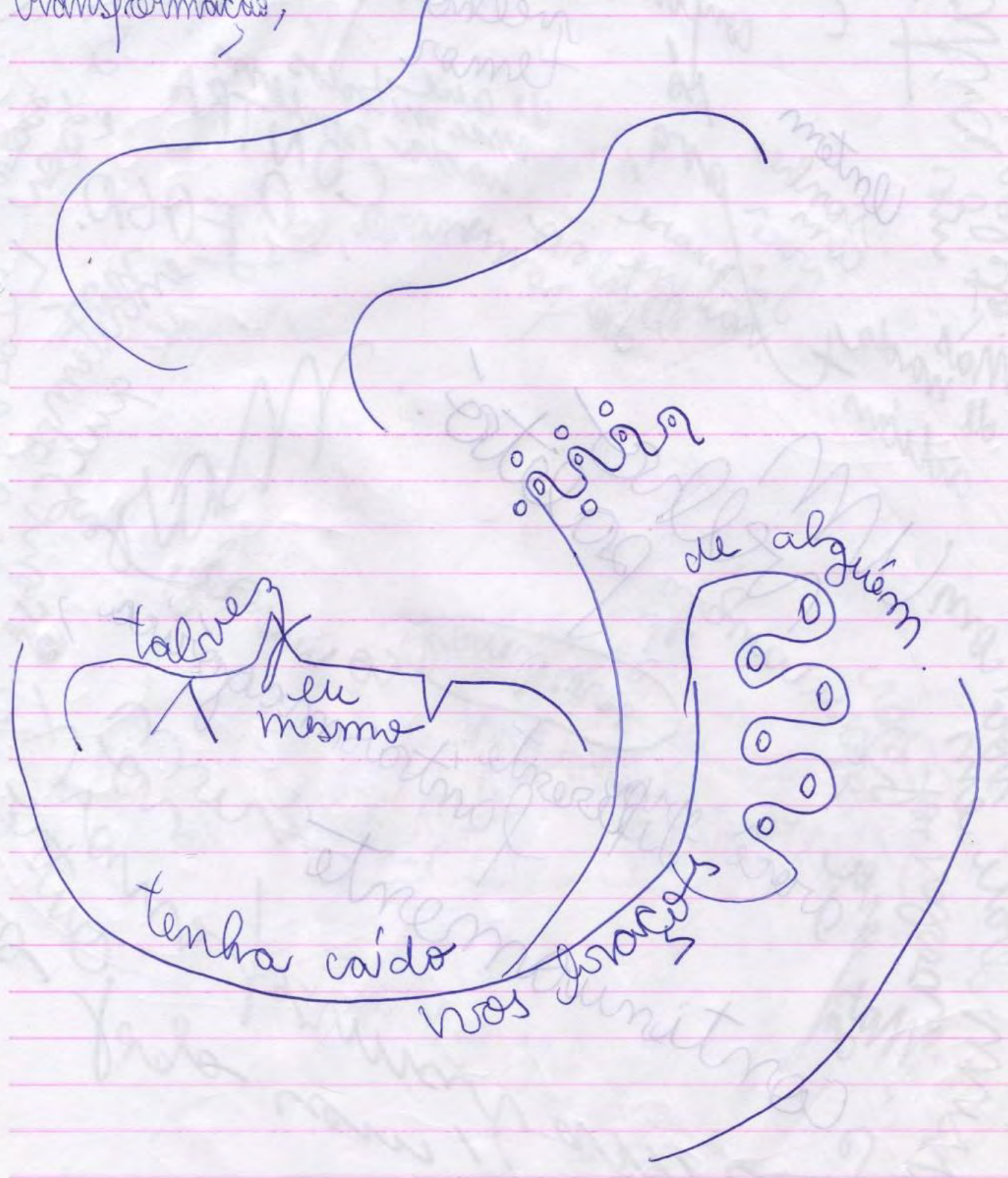




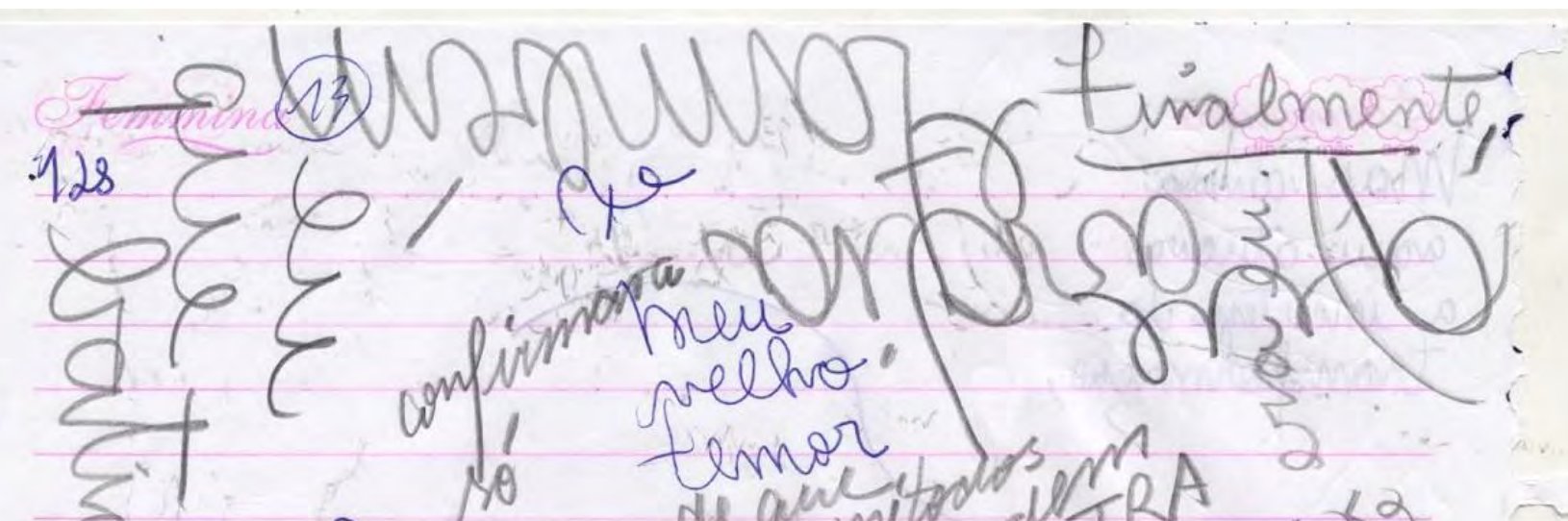

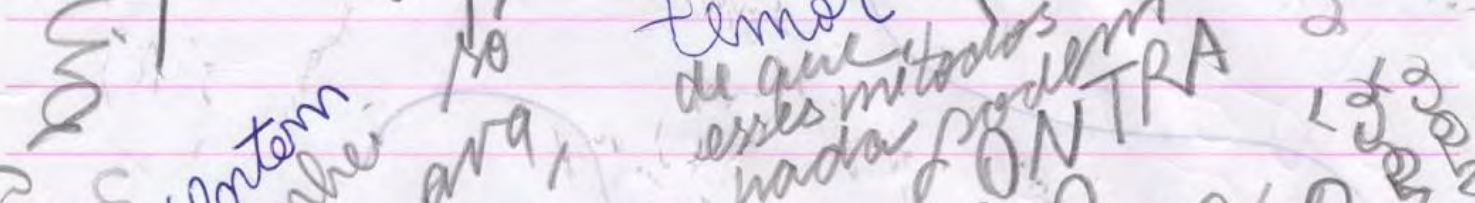
क

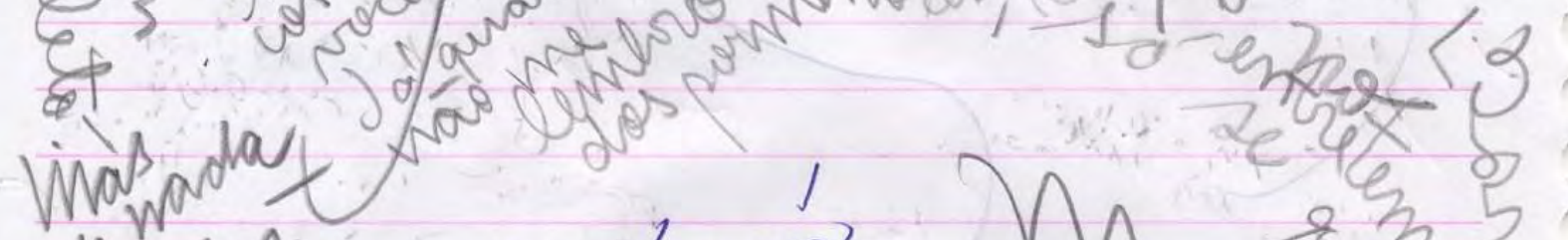
Minam $\prod_{0} x^{\circ}$. Ma

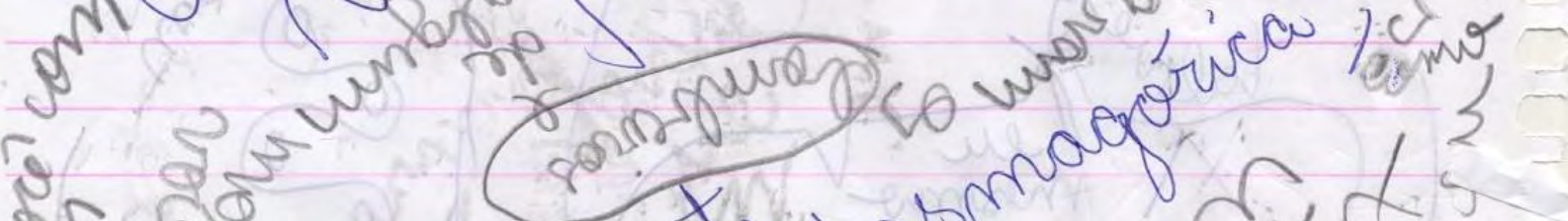

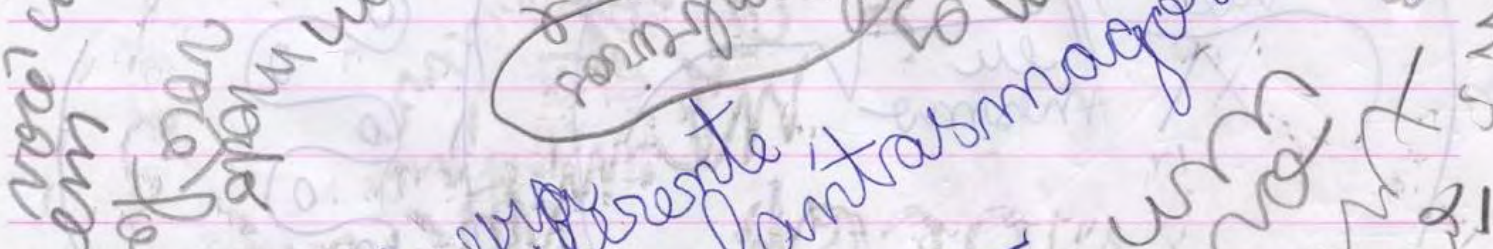

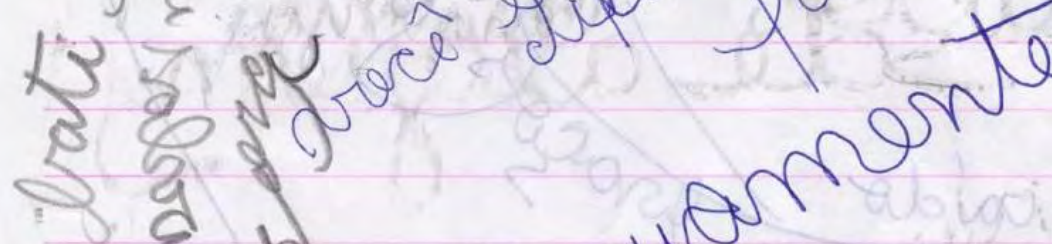

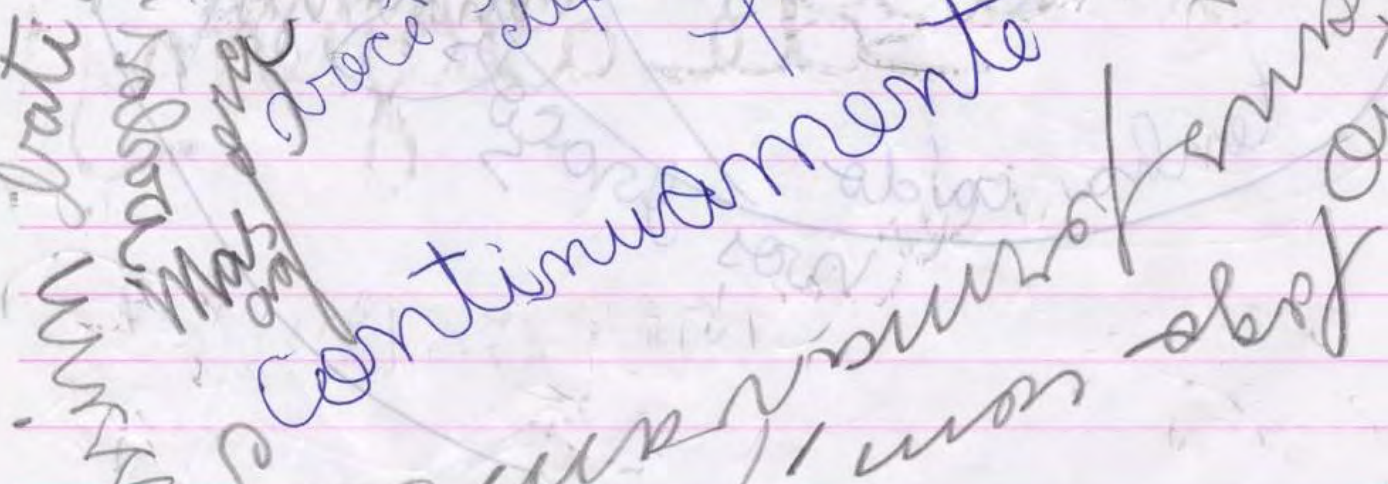
$4_{3}$ 2 sonto 
Este creio ter sido o segundo sonho que transcrevi.

Este sonho era uma unanimidade. Todos gostam dele. No sorteio, quem tomou este foi o Rodrigo.

Falando deles, assim, me dou conta: são figuras, são personagens. Esses sonhos. Não pretendo aqui interpretar os sonhos, mas contar um pouco da convivência com eles no trabalho da página, e o que eles me ensinaram.

Lembrei que a Talita trouxe o livro MÁQUINA KAFKA para lermos, mas o livro me expulsou dele, não quis ser lido. Por enquanto não. Às vezes é assim. Já li alguns pedaços do livro franz Kafka: por uma literatura menor. Sem muito ânimo. Algo estranho se passa. É como se os sonhos kafkianos fossem um desejo de nenhum filtro senão esse contato improvável e duvidoso que é a página. Ademais, não seria 0 caderno, a página prestes a se desmanchar, uma minoridade?

Pode parecer um animismo barato, mas nada posso fazer. É certamente ridículo que brancos, assassinos de índios, falem sobre o sonhar. Durma-se com um barulho desses.

Neste sonho, entendi algo que se dá no processo de transcrição: às vezes é uma explosão de força que se vai construir de página em página. Às vezes é uma LENTA, MUITO LENTA explosão de imagens. Às vezes o mero acúmulo, que é o mais recorrente. $M$ as às vezes 0 acúmulo se condensa e fura.

Às vezes após a explosão de qualquer espécie existe uma espécie de 'limpeza' do mundo da página. Onde os rastros estão mais nítidos. Onde as figuras e detritos tomam um lugar e um funcionamento melhor definido. Não sei se 'limpeza' é a melhor palavra. Acho que não.

De uma repetição a outra, sobram ideias ou personagens-figuras-forças que ainda querem falar algo. 
2.

(p. 150)

Se você continua sempre correndo, continua chapinhando na mornidão do ar, as mãos espalmadas ao vento como barbatanas, na sonolência da pressa só terá uma visão fugaz das coisas à sua volta, até que um dia vai deixar a carroça ultrapassá-lo. Mas se ficar imóvel, se, com a força do olhar, deixar crescer raízes largas e profundas - nada poderá movê-lo, não serão de fato raízes, mas apenas a força de seu olhar que vai direto à meta -, então poderá vislumbrar a lonjura sombria e imutável, de onde nada chega além daquela carroça que vem vindo, vem chegando, cada vez maior, e no momento em que o alcança, preenche o mundo, e você mergulha nela como uma criança no balanço de uma viagem de carroça, correndo através da noite e da tempestade.

Fragmentos de cadernos e folhas soltas, sem data 
333

Sevoế continua sempre correndo continua chay inharrdo wa hornidieno do ar as hinos esfdalmardas dov nento scomo

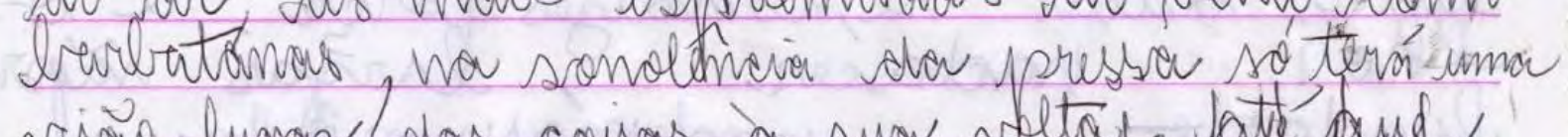

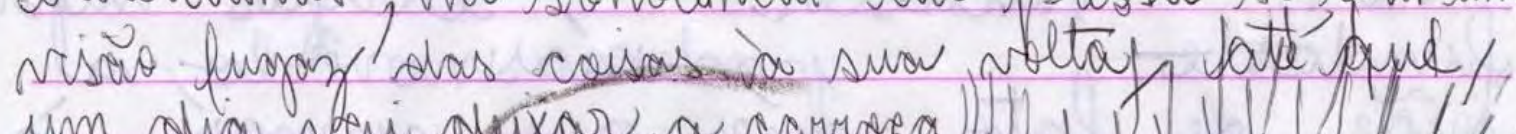

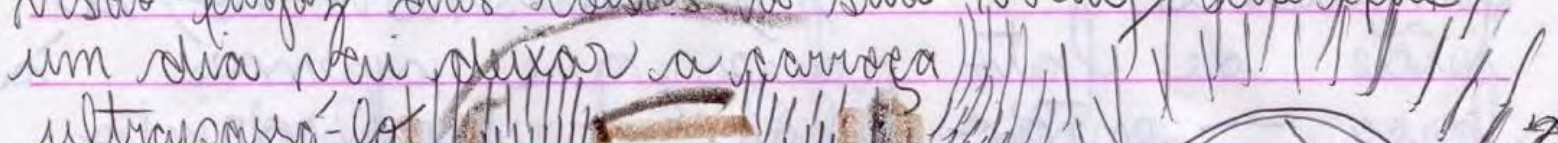
ultraparssá-lot
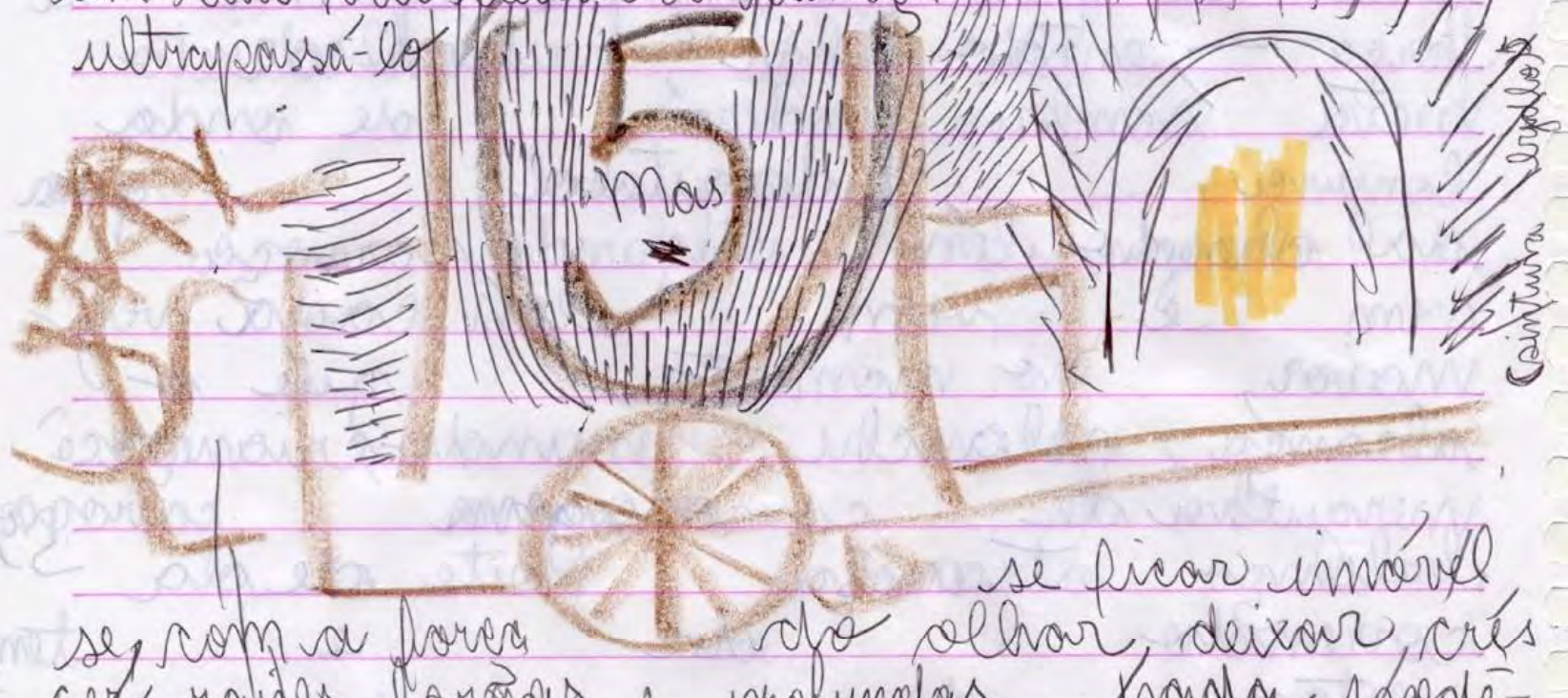
cer ravises do ollvar deivar, crés Ya

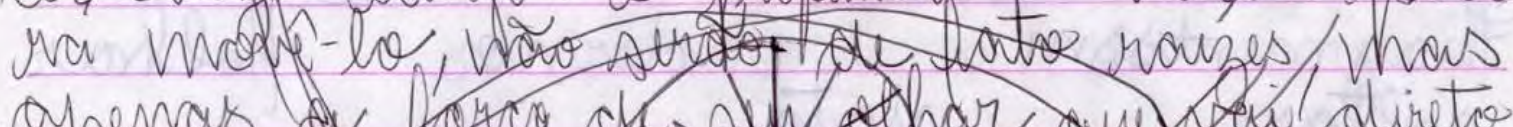
apenar ar a meta dera vis a lanjura son courroga qure nem vindo, ven chegando, conda vez Praicor e wo momento em rane o alcanca, prenche o mundo, e vace mevgulha neba como unna crianca wo babunco de JMna

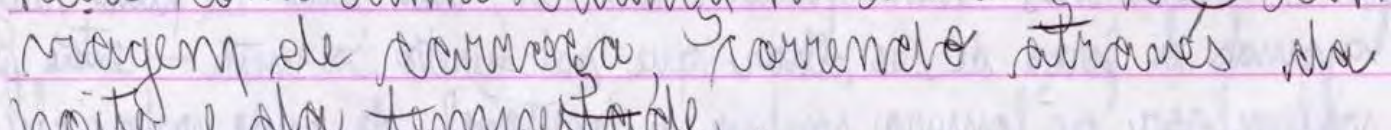
hoito e do tempestode. froggmentas de cadurnas e lollwas soltas, sem satara aposoty 
- cadia nez mavar, e no hámento em ane es alcanca, pienche o mundo e vece mefaulha nela como uma criauna no lalanco de unnou riagem ele carroca s corremelo atraines da hoita e para tempestarde

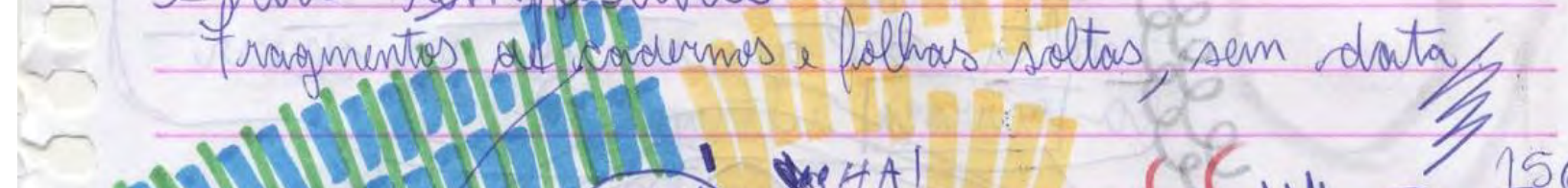

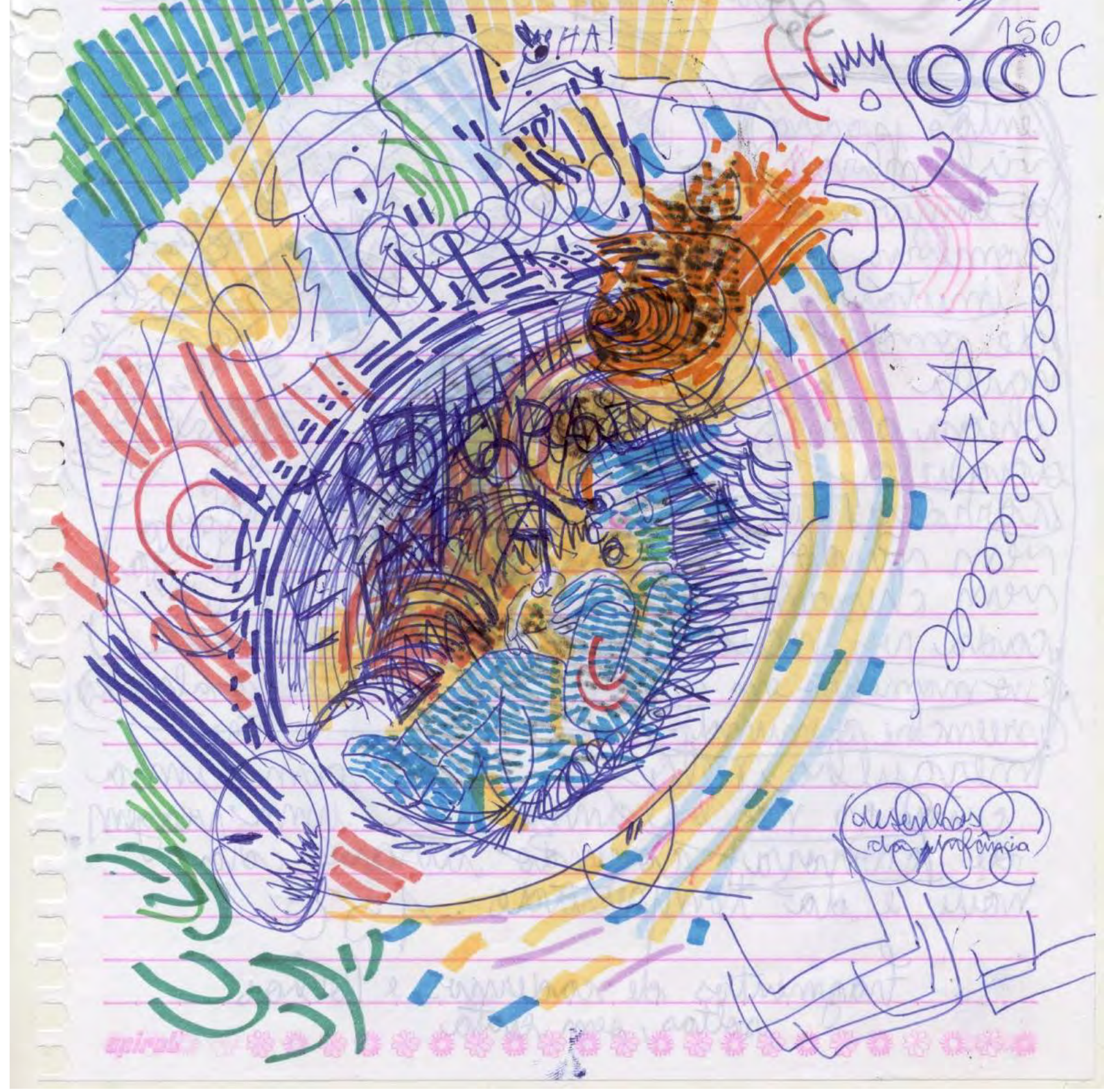




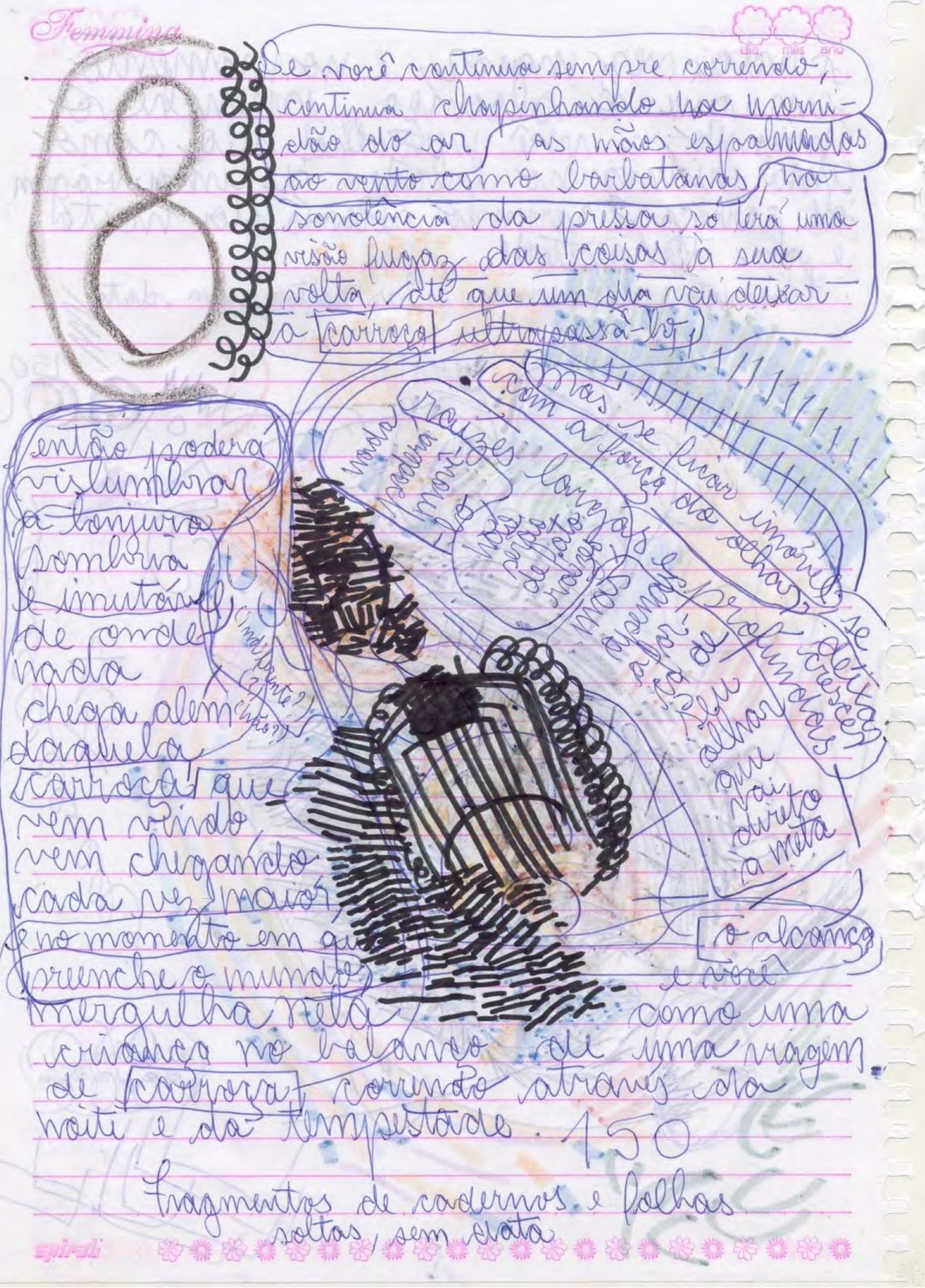




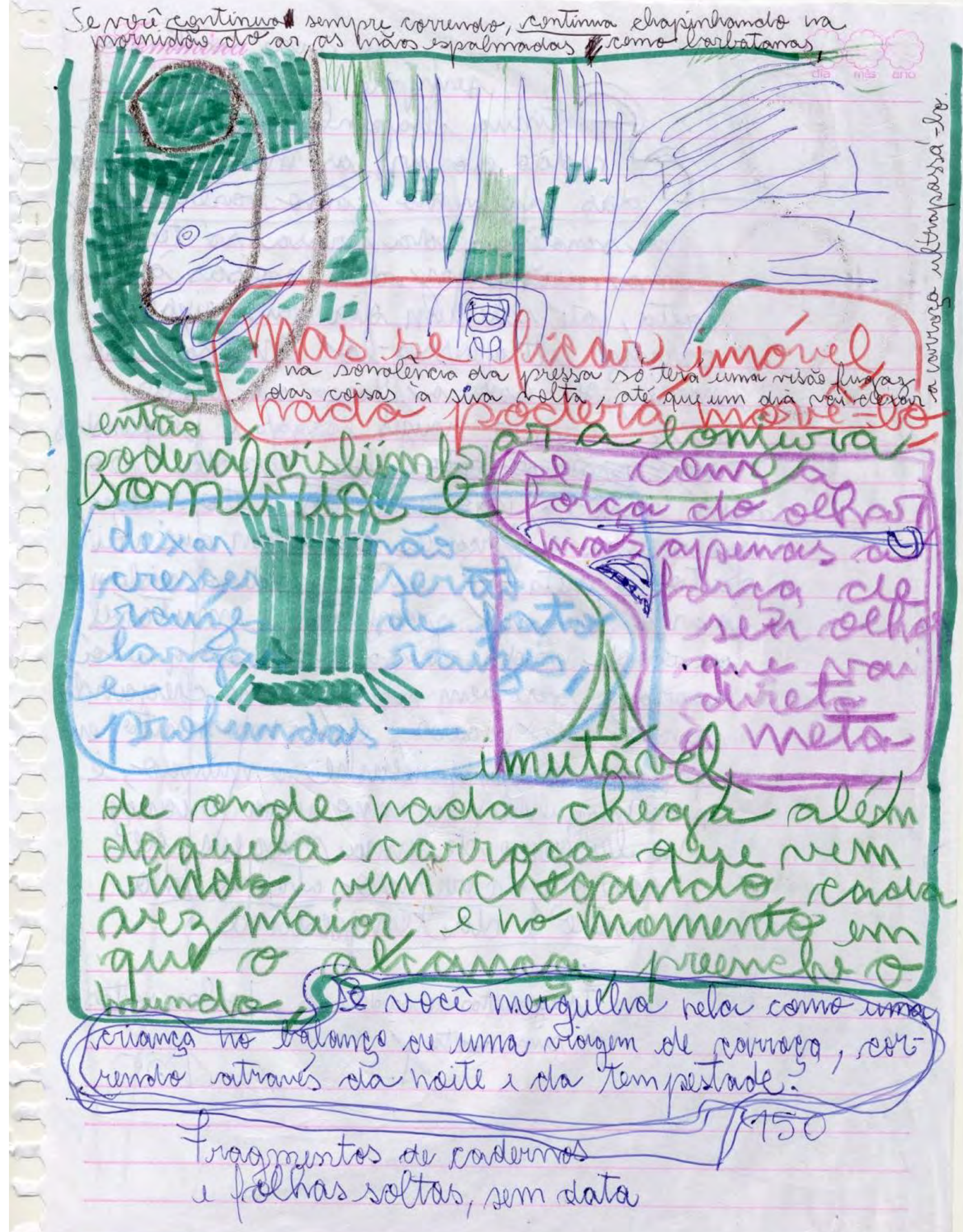




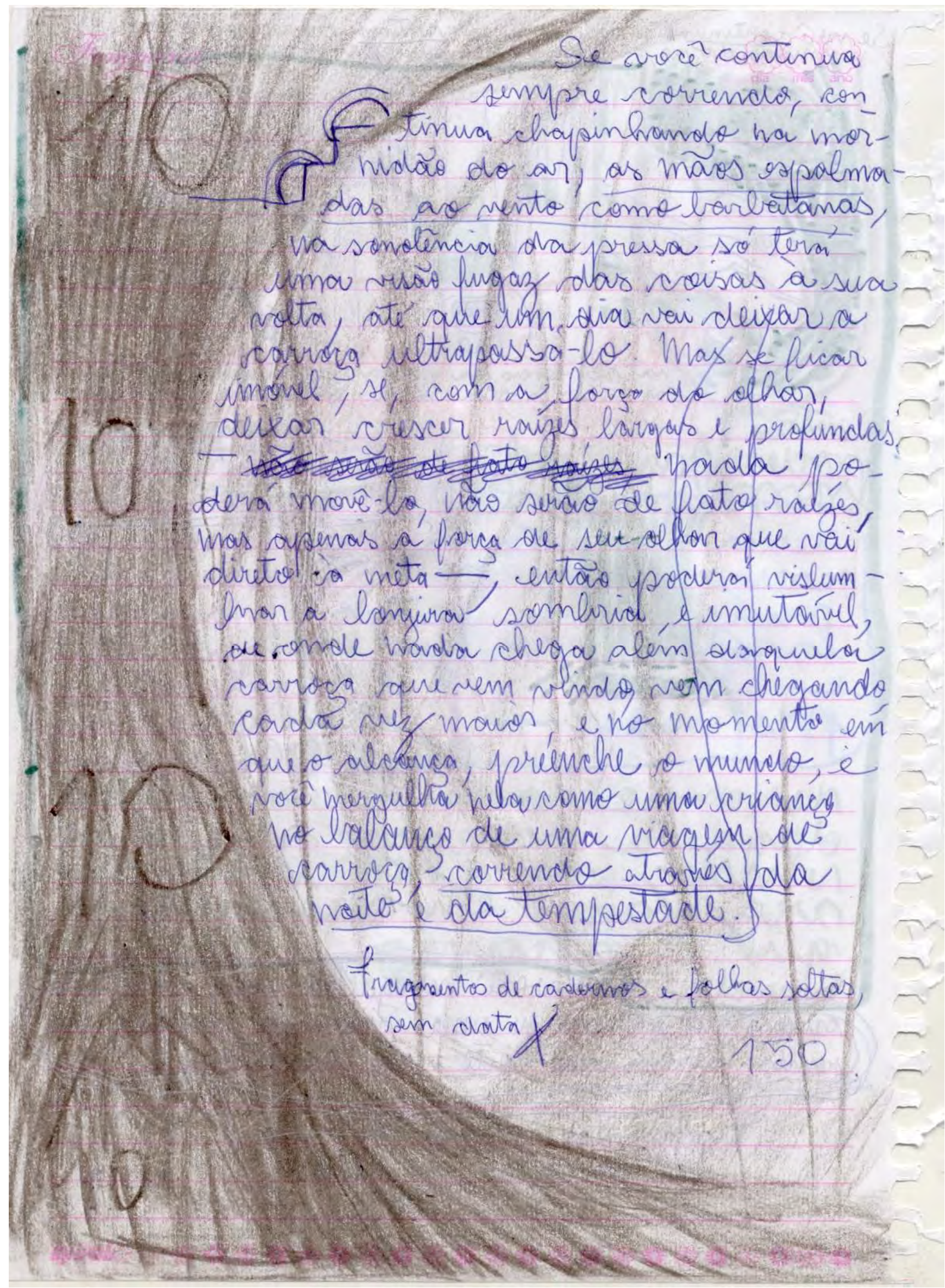




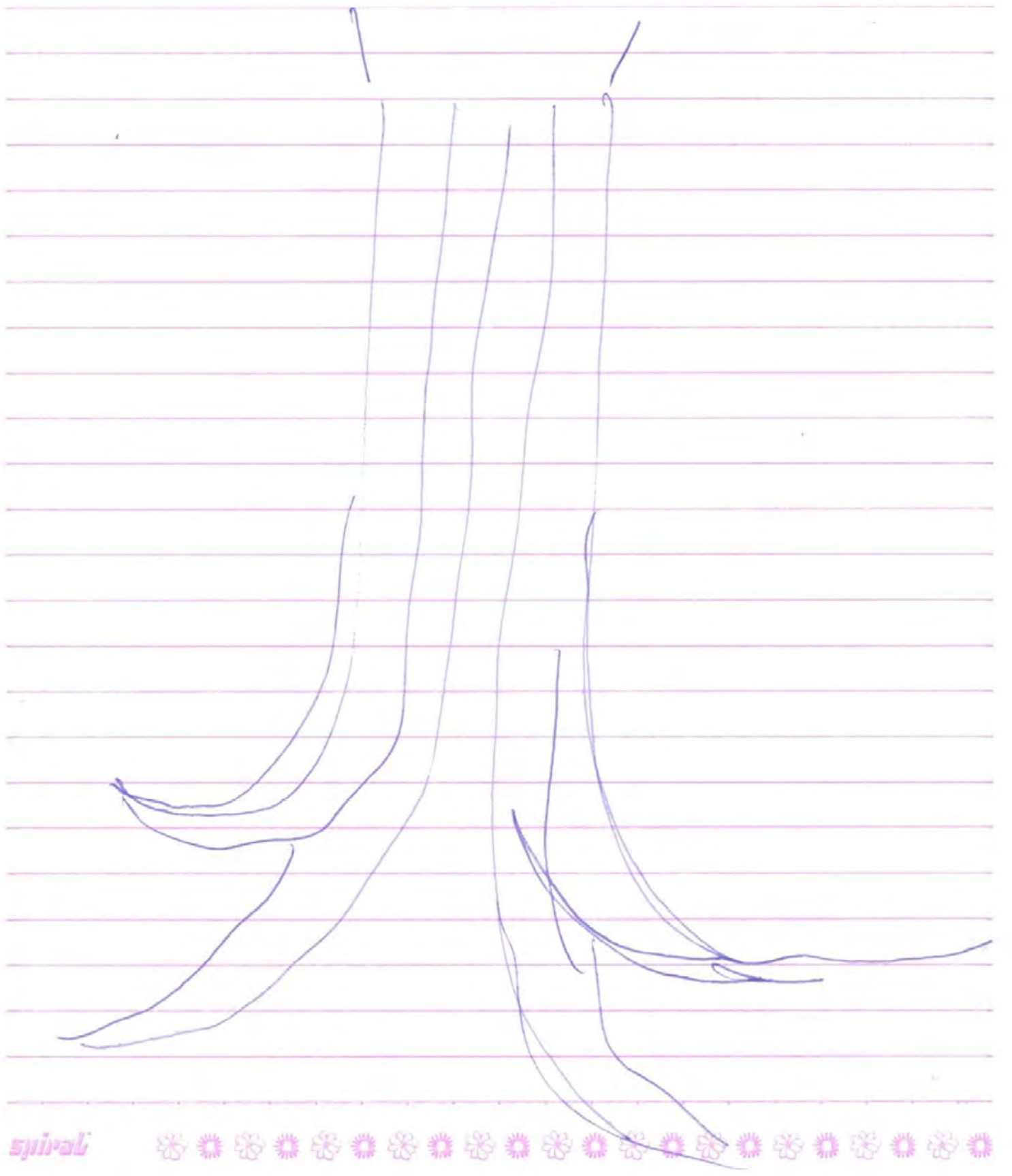


Este sonho foi o escolhido por Carol. (foi o oitavo sonho que transcrevi no caderno)

Momentos de muita estranheza. Creio que este sonho foi um dos últimos em que trabalhei a transcrição. Eu estava um pouco cansado, mas não me lembro de estar preocupado em chegar em nenhum lugar. Mas, como é inevitável, acabam por se passar coisas.

Em uma das páginas (a segunda aqui reproduzida), surgiu uma figura humana (que está no verso, a página seguinte) como aquelas que eu desenhava quando eu era criança. Era um menino dentro da carroça que era uma explosão, um cometa. 0 avesso daquela página foi 'um dos inícios' desta. Pois a página tem sempre uma germinação múltipla.

O cavalo é também muito parecido com os bichos que eu desenhava criança, já no final da infância.

Talvez na proposição kafkiana de uma raiz pelo olhar, e nesta criança que embarca na viagem de carroça pela noite e pela tempestade, talvez aí a página tenha contado um pouco do que se passou. 0 avesso da minha criança é uma lira transfigurada ou 0 diagrama de uma raiz. 0 Orfeu desta página.

Ainda sobre a página como 0 avesso da página: desde 0 sonho anterior, aliás, entendi também que 0 'avesso', o contrário da folha, é matéria muito útil. A impressão, a pequena escavação, o pigmento ou a mancha já é uma figura, um rumor ou um caminho. 
3.

(p. 132)

Um sonho curto que tive durante um sono curto e agitado e que se apoderou de mim com uma felicidade desmedida. Um sonho todo ramificado, com mil associações que se esclareciam de uma vez só e do qual restou apenas uma lembrança fugaz da sensação geral: meu irmão tinha cometido um crime, acho que um assassinato; eu e outros também estávamos envolvidos, a punição, a solução e a redenção vêm vindo de longe, avultam-se gigantescamente, há diversos indícios de sua aproximação contínua; minha irmã, acho, fica anunciando a vinda desses sinais, que recebo com repetidas exclamações extasiadas, um êxtase que cresce com a aproximação. Eram exclamações tão significativas, frases tão curtas e contundentes, que eu achava que jamais as esqueceria, mas agora não me lembro claramente de nenhuma. Só podem ter sido meras exclamações, pois eu tinha dificuldade em falar, precisava entortar a boca e enchê-la de ar para soltar uma palavra que fosse, como se tivesse dor de dente. A felicidade consistia no fato de a punição chegar e eu a receber com tanta liberdade, conviç̧ão e felicidade, uma cena que comoveria os deuses, e também eu senti, quase até às lágrimas, essa emoção divina.

Diário, 20 de outubro de 1921 
Commina Merleau-Panty: presanorgem

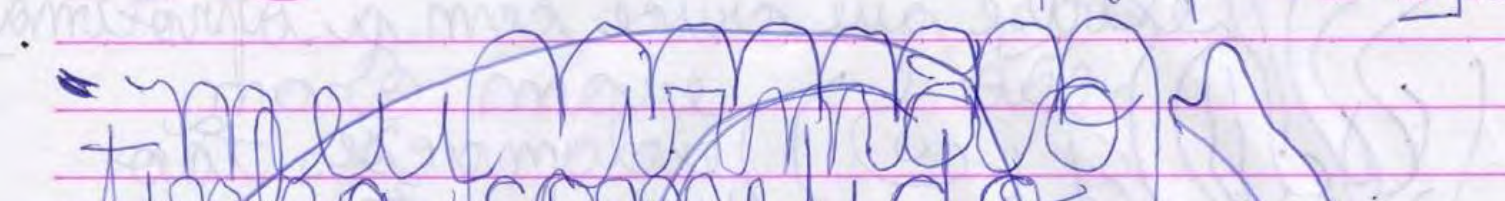

Wintures

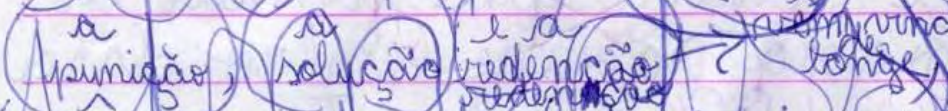

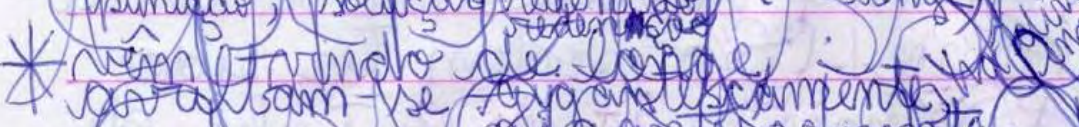

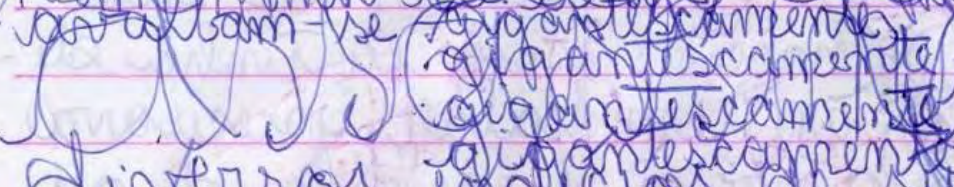

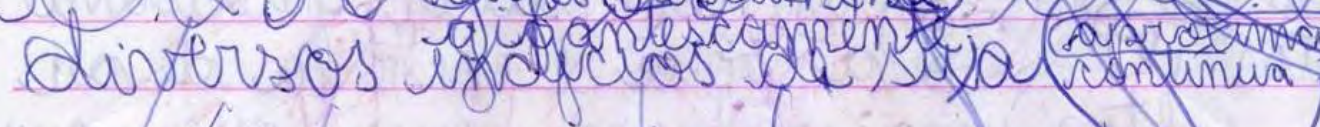

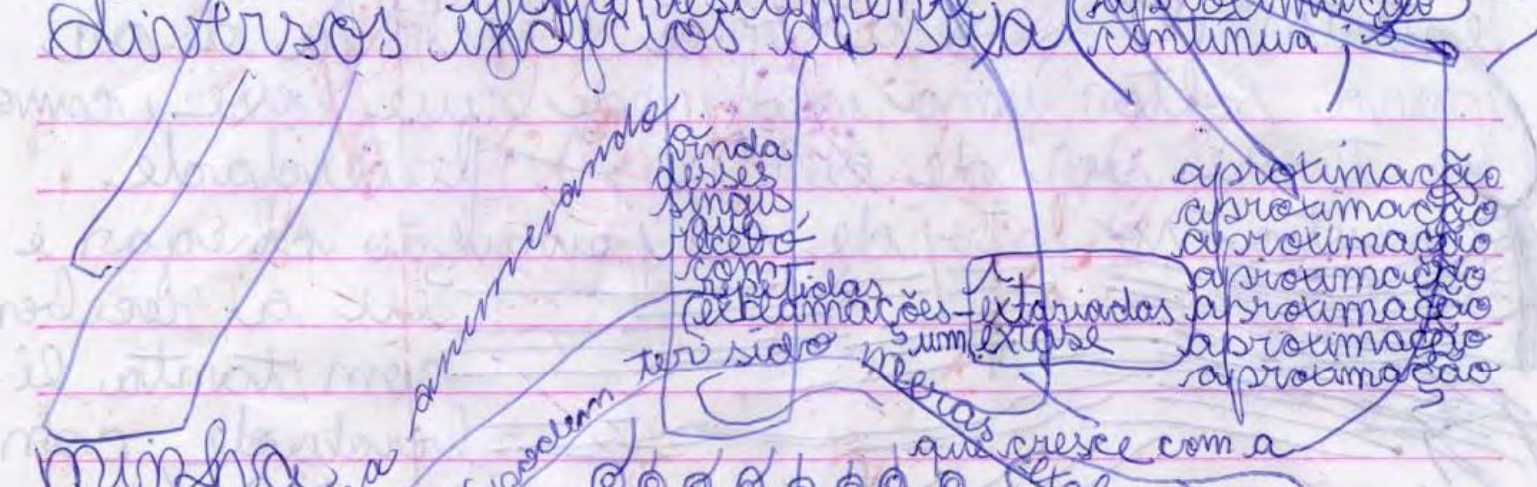

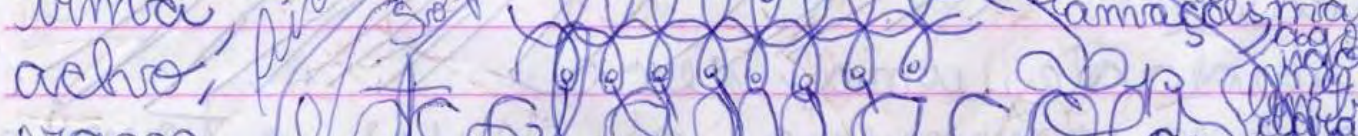

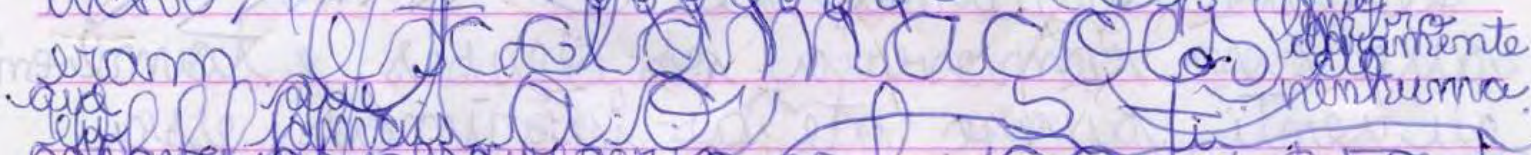

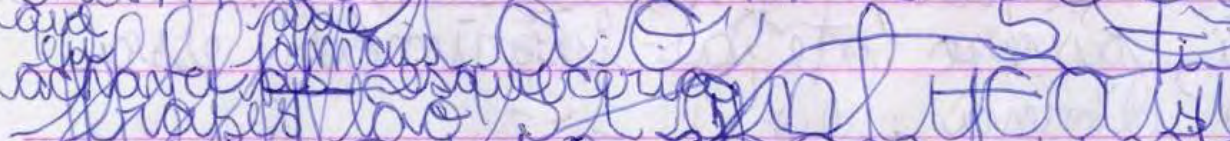
Her os sos ston

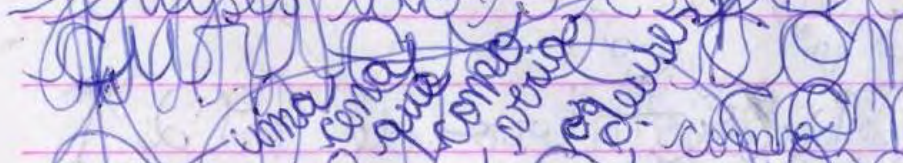

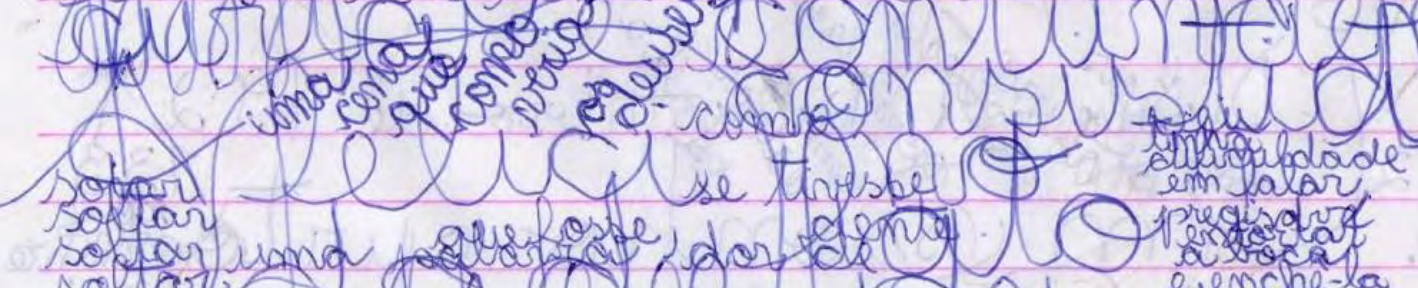

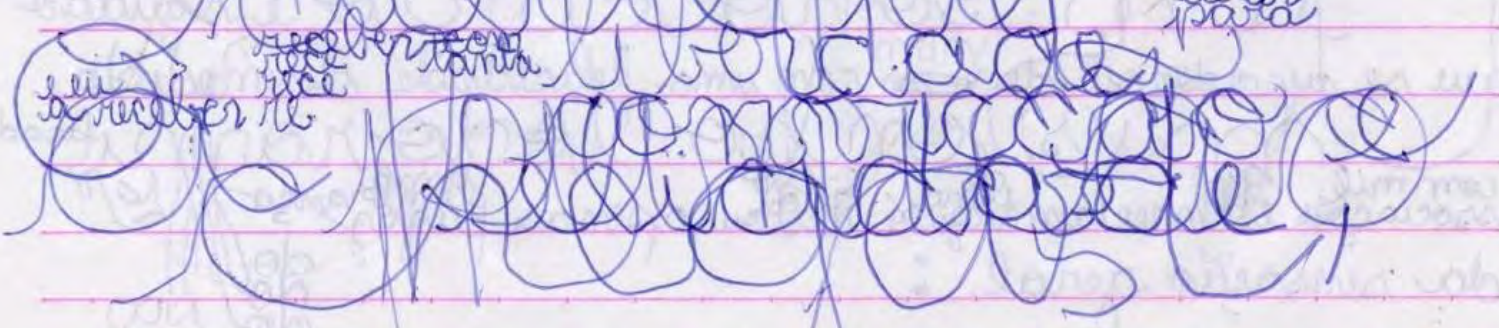


342

novo me lemboro de henhuma.

Só prodem tef sido heras exclamagäes pois en tinfra difiauldade em fabor precisava entartar a boca e enche-lá. de ar sora Soltar una palawia dente. losse som sef tivesse dorlb de

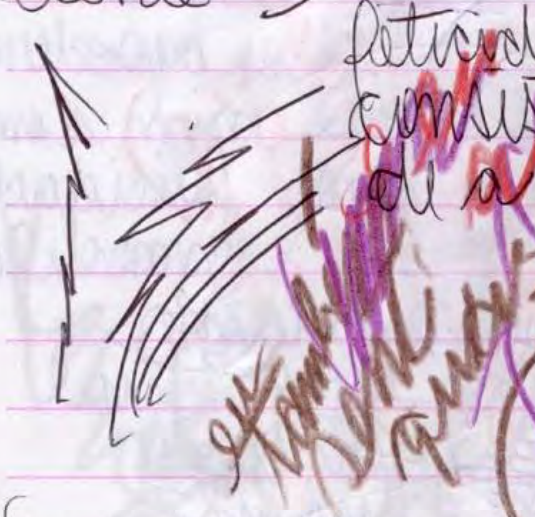

Díário, 20 de outubro de 1921
132
133 132
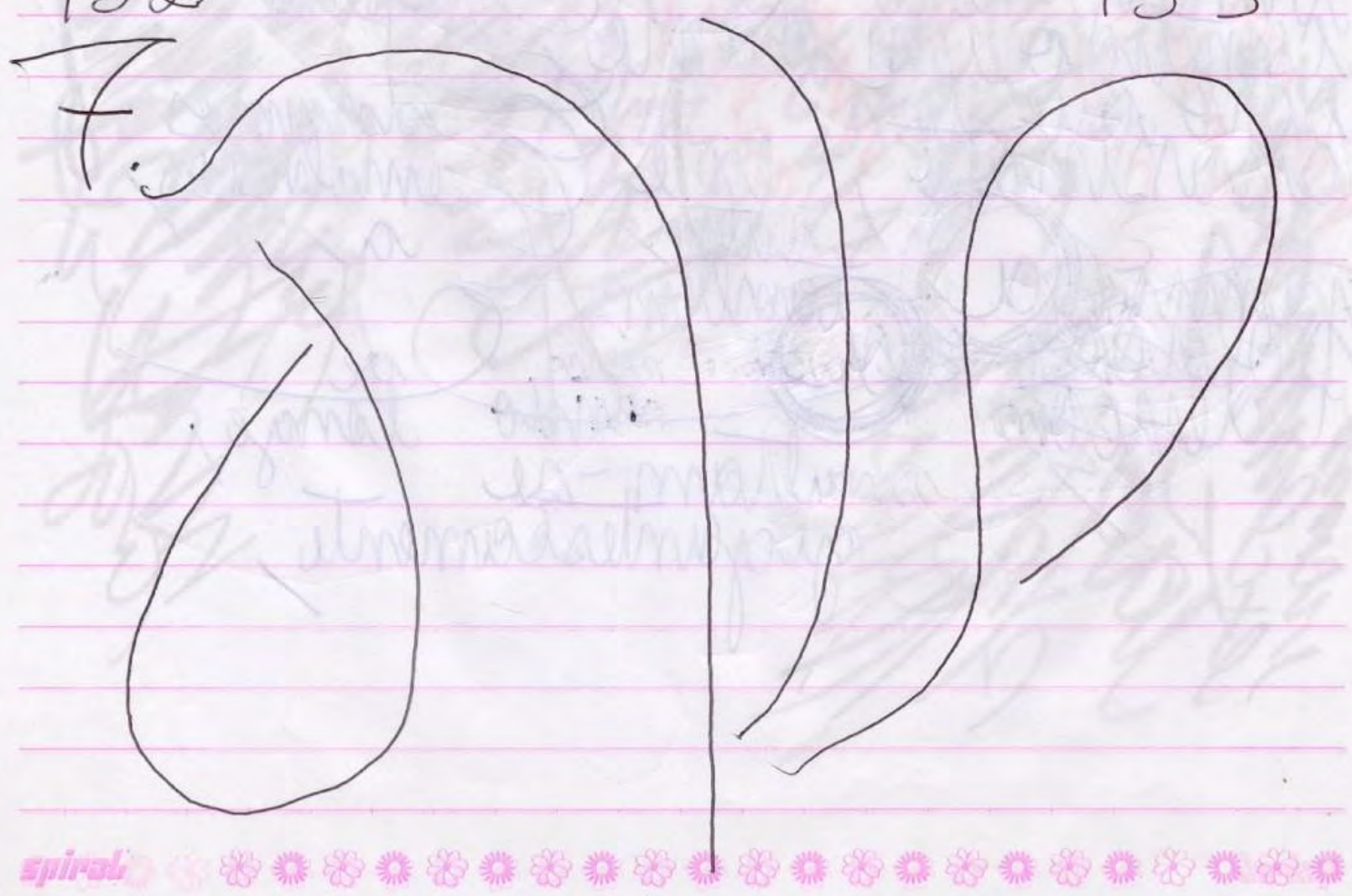


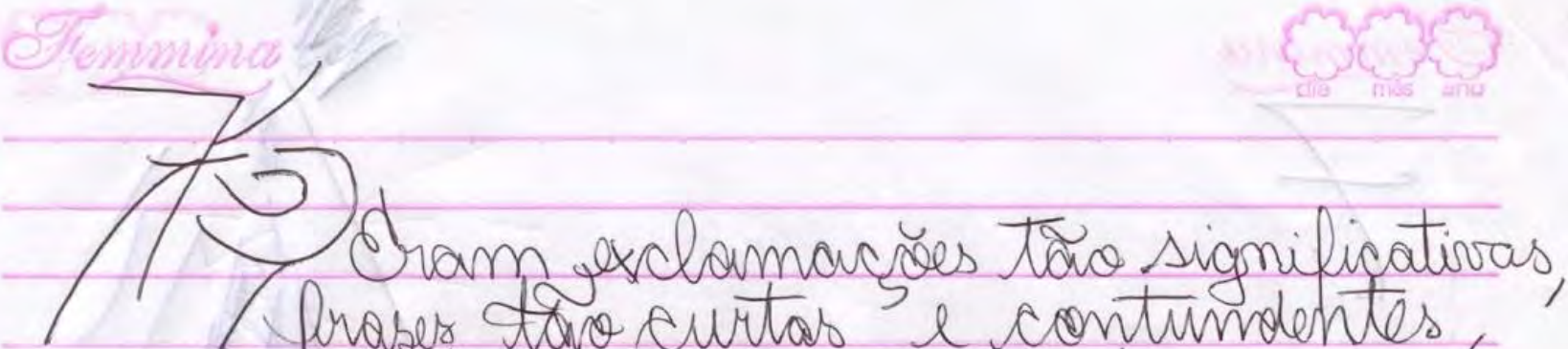
aue ew achava aue samans as esaueceria, mar cvojora vaio me lembro claramente de nenbuma.

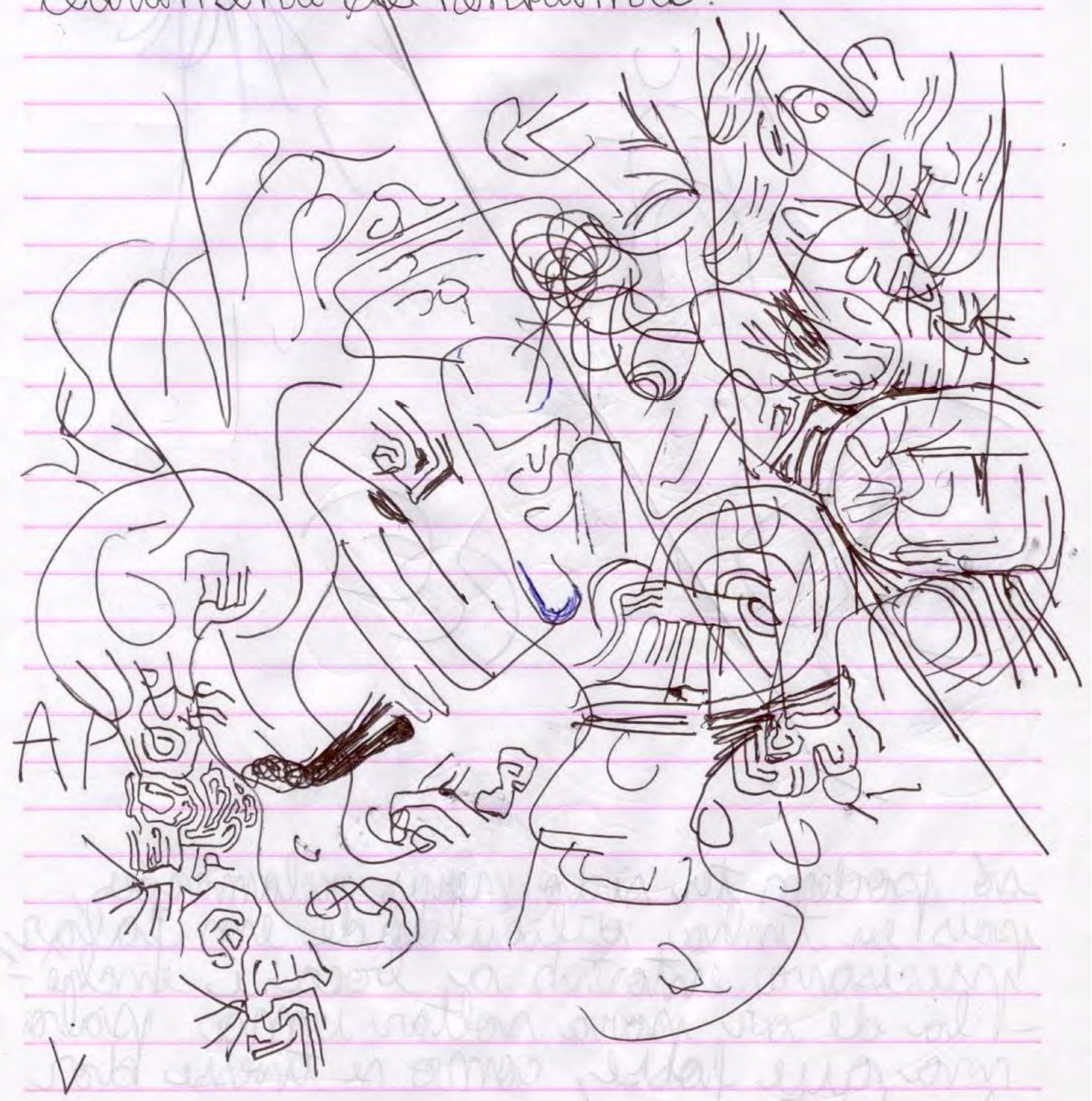


344

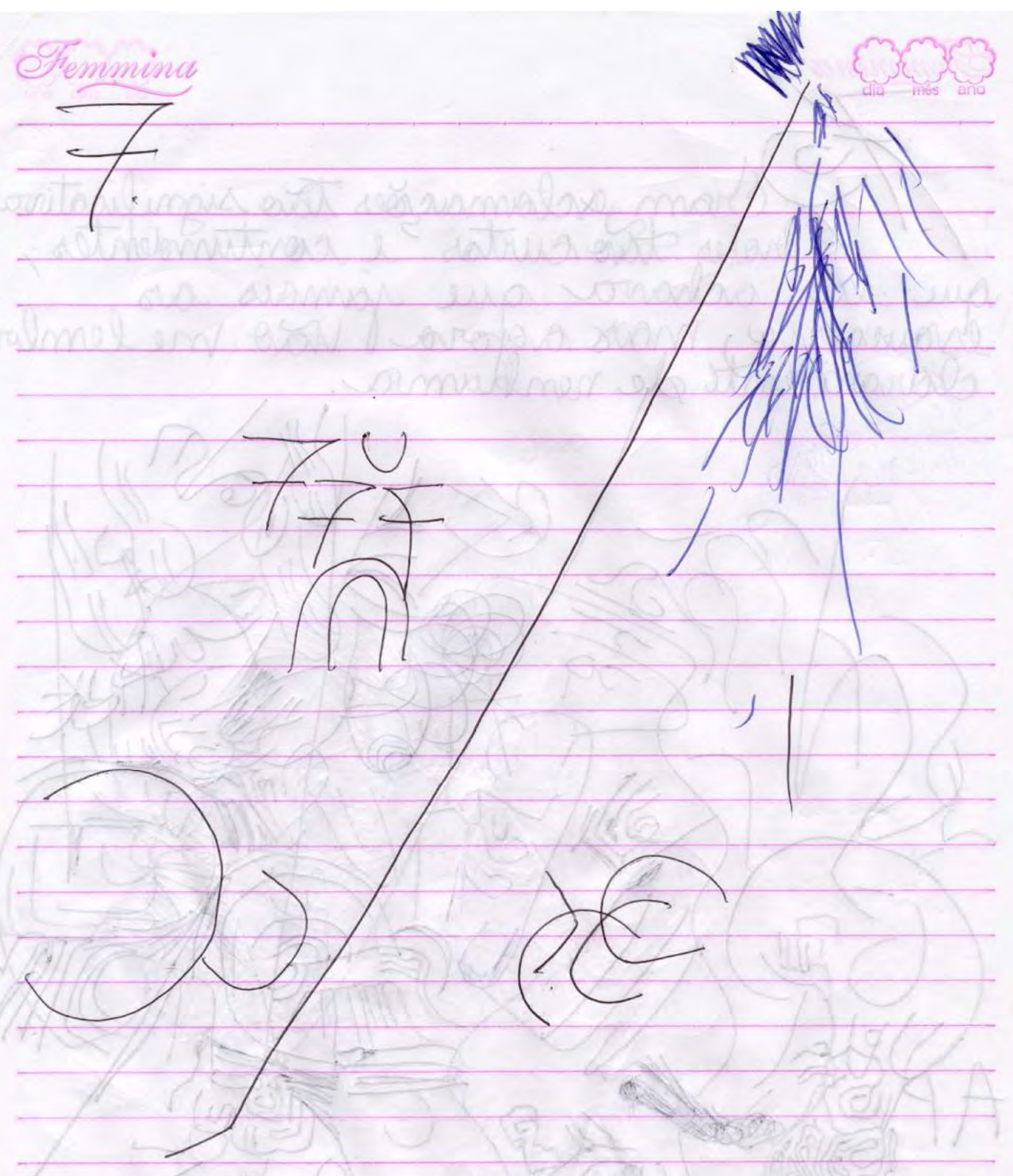

só prodem ter side meras exclamacóor, poisl en tinkra dificuldade em jafor, rrecisova entortas a boca i enche- la de ar para soltar uma para ma que fobse, como se truesse dor de dente: 


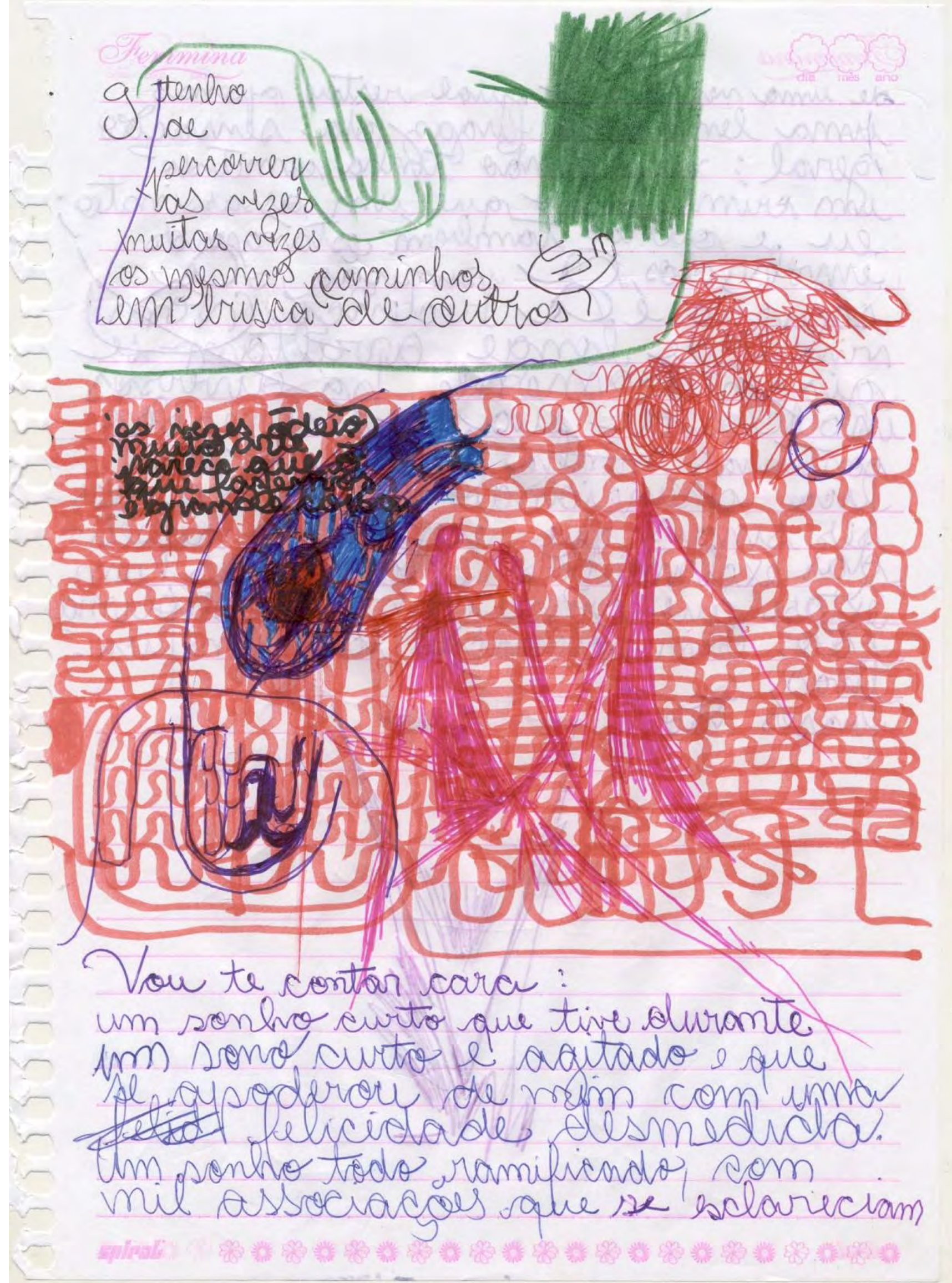


346

Sremmina

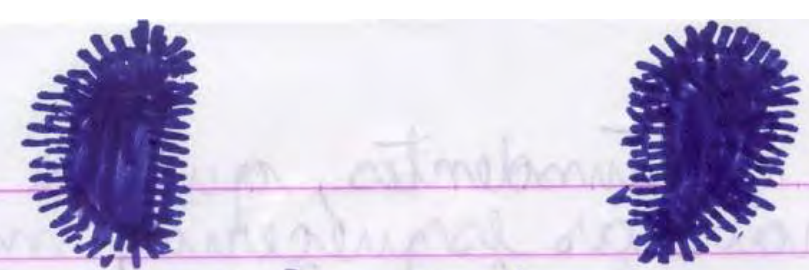

oure comoreria os deuses, e en tamberm senti ouvase até as lácyimas, essa emocigio divina.

- Diario 20 de outilivo de 1921 convicasio)

132 "tomporva" 133

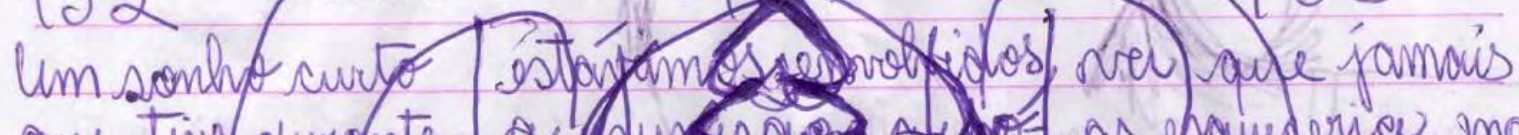

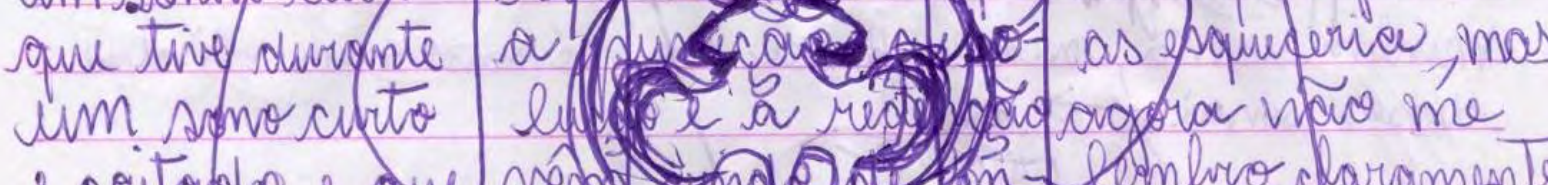

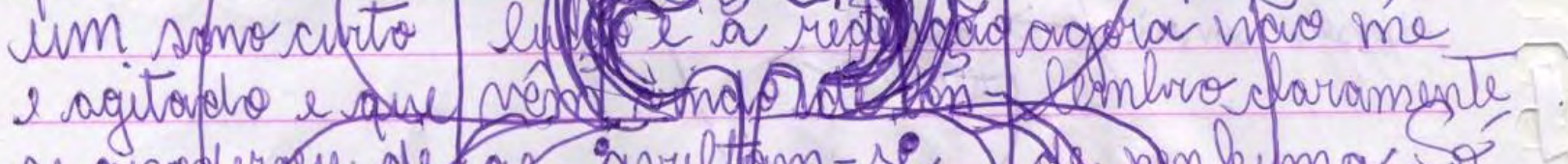

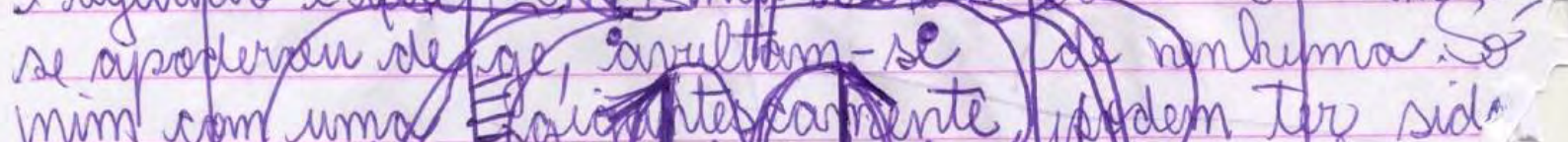

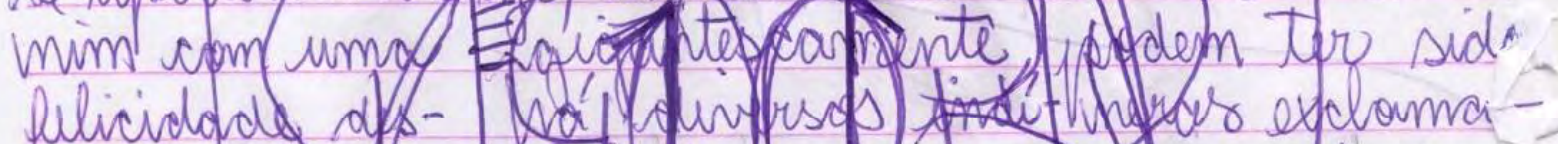

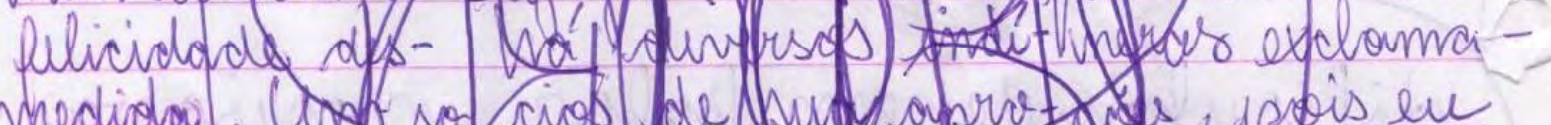

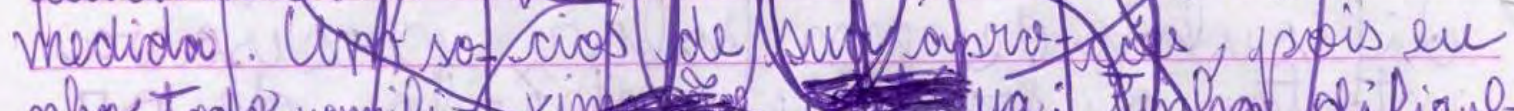

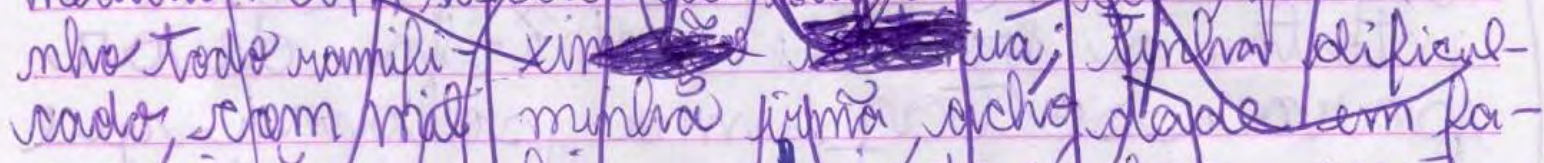

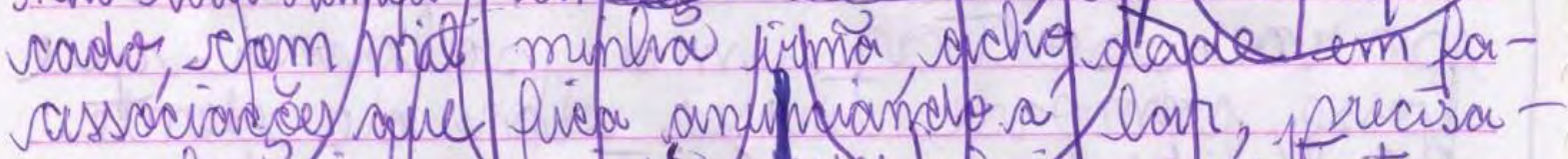

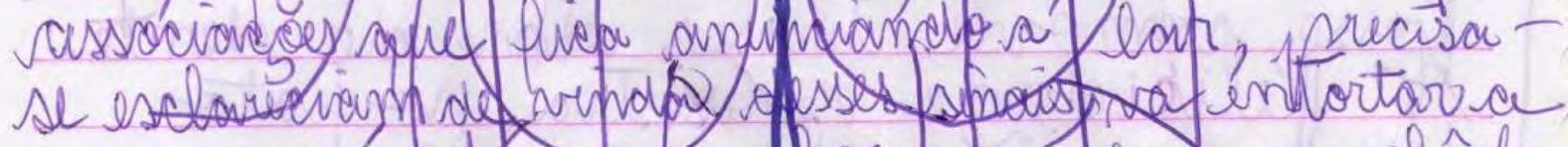

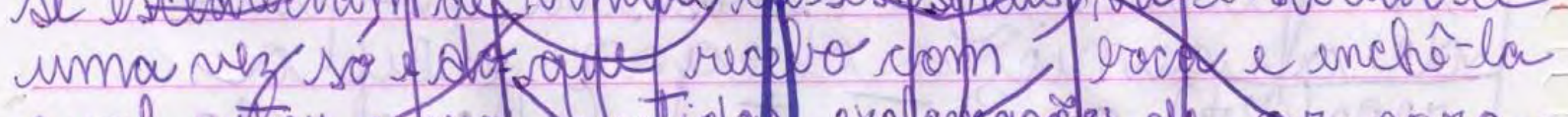

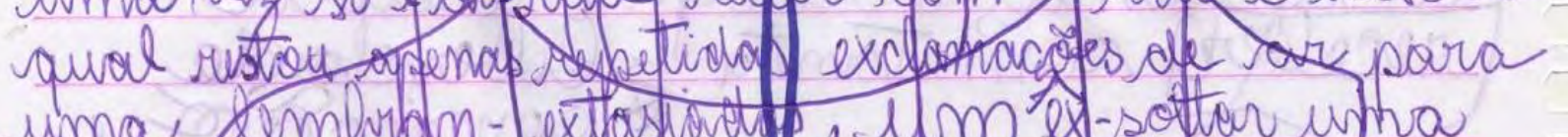

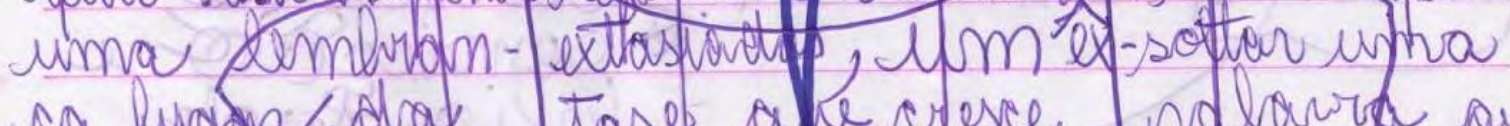

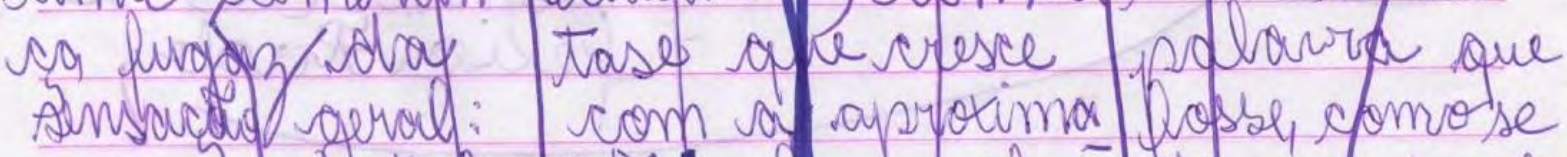

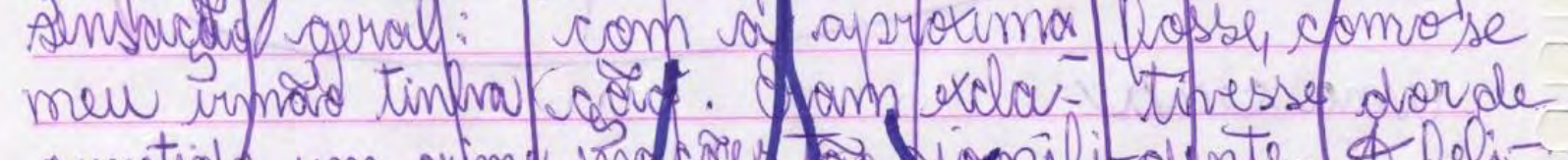

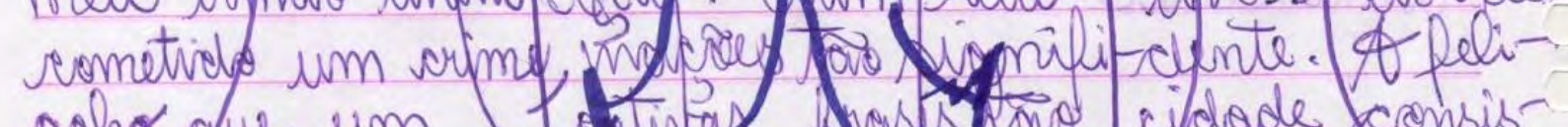

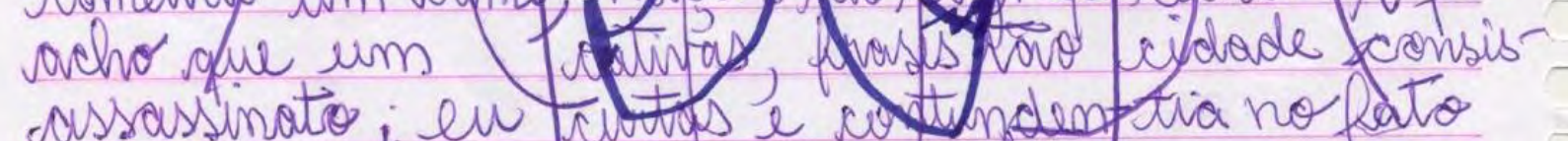
assassinatio i outros também tes aure en achat de a puni

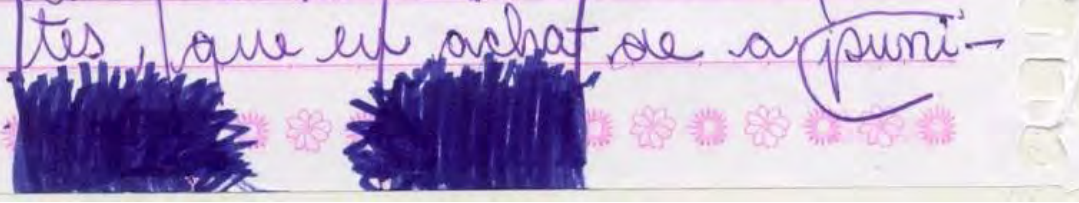




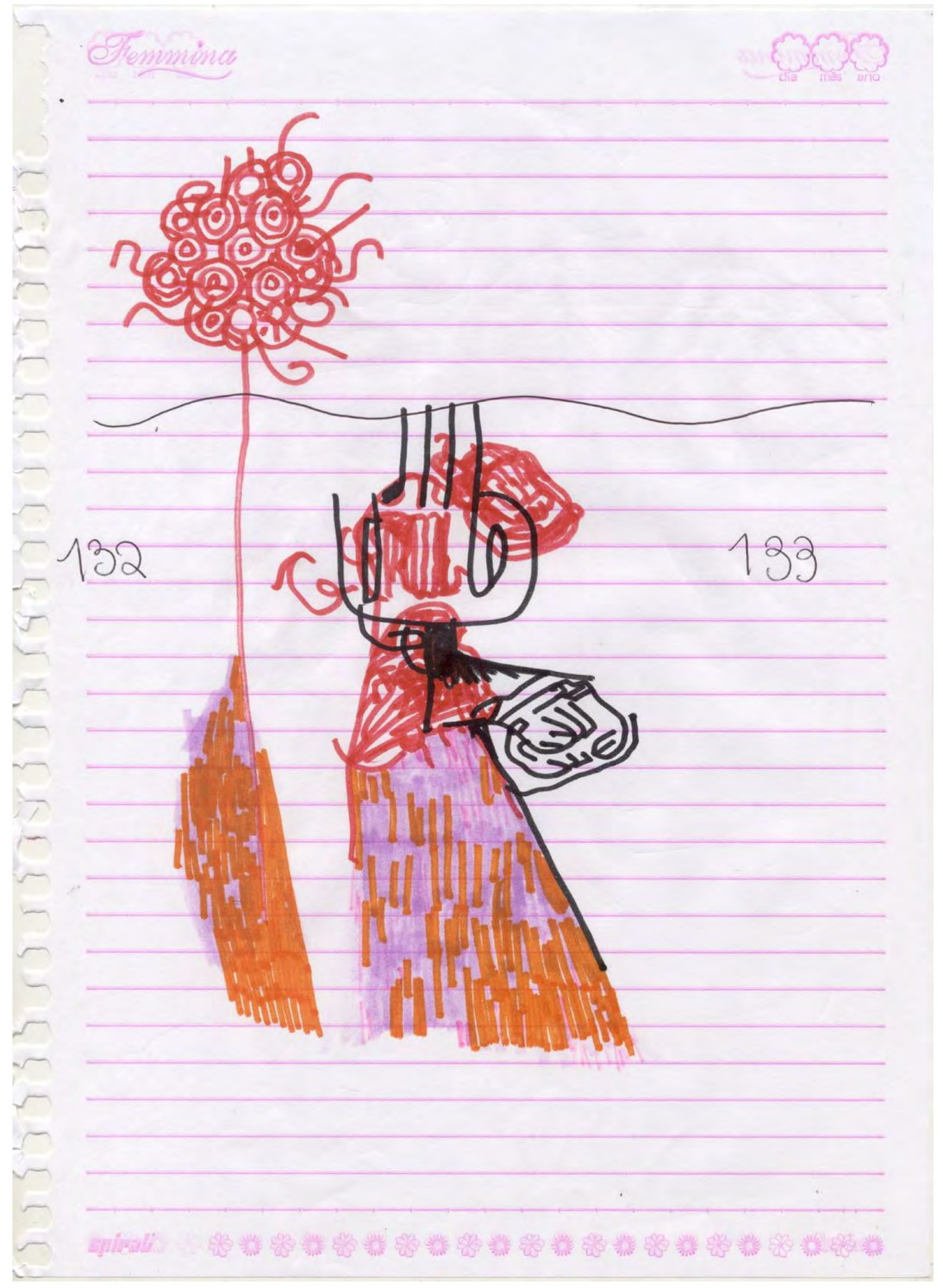


Tenho vontade de chorar quando vejo essa série de transcrições pois creio que aqui entendi o que é um esboçamento: uma forma de vida completamente alheia, estranha, que passa pela página e vai embora. É difícil saber o que é a membrana e 0 que é o seu rastro, e o seu fazimento.

Este foi a última série de transcrições (nono sonho). 0 último sonho. Como se vê, visitam elementos radicalmente heterogêneos, que já tem essa permissão: comentários, frases preparatórias, figuras, texturas fabricadas.

Pode ser que seja cafona essa expressão em uma tese.

Esse sonho teve um processo agonístico, ele mesmo sendo agonístico.

Ao final, pode-se ver que a página é ocupada por apenas uma figura, não há mais caligrafia. Será verdade isso? Ou a há, só que uma caligrafia existencial de um serdetrito que ali passa. Será talvez ofensivo talvez continuar usando esta palavra?

Percebe-se a heterogeneidade de materiais: caneta esferográfica de várias cores e marcas, canetinha hidrocolor multicoloridas, naturalmente de várias marcas, caneta milimétrica técnica, giz de cera, lápis de cor, lápis grafite... em processo, as canetinhas hidrocolor, que deveriam ser aquelas da categoria 'úmida', secam e, ao continuarmos trabalhando com elas, elas produzem outros tipos de combinação, com seus novos parentes mais secos. Por exemplo, a combinação da canetinha seca e irregular com os sedimentos do giz de cera...

Dou-me conta do caráter escolar dos materiais de que me valho. É possível que isso tenha a ver com a precariedade própria ao caderno. A precariedade do escolar e seu ambiente químico particular?

Da relação da página, como já dito, há as dobras, as rugas, as marcas que atravessam e deformam as folhas, as manchas, hiper-saturações. Etc. 
4.

(p. 149)

“Estamos no caminho certo?”, perguntei ao nosso guia, um judeu grego. À luz da tocha, ele virou para mim seu rosto triste, pálido e suave. Para ele, tanto fazia se estávamos ou não no caminho certo. Onde estávamos com a cabeça ao contratar um guia que, em vez de nos conduzir pelas catacumbas de Roma, até agora se limitava a nos seguir calado? Parei e esperei até que o grupo inteiro se reunisse. Perguntei se faltava alguém, ninguém deu falta de ninguém. Tive de me satisfazer com isso, pois eu mesmo não conhecia nenhum dos outros; éramos todos estrangeiros e tínhamos descido às catacumbas atrás do guia; só agora eu tentava conhecer os outros um pouco melhor.

Fragmentos de cadernos e folhas soltas, sem data 
350

- Promina

Crei e esperei até que o grupo intevio se reunisse.

Perguntei se fattara alguem,

Finguém deu fatta de ninguém.

Tinepde me

sovis azes com

1 hso, 1 plis en miznvo was concrecia nentrum dos avros inamis timliamos descido on catacumbes atrás do griaj _ _ -

Oy

só agora en tentava conhecer os autros um porco melhor.

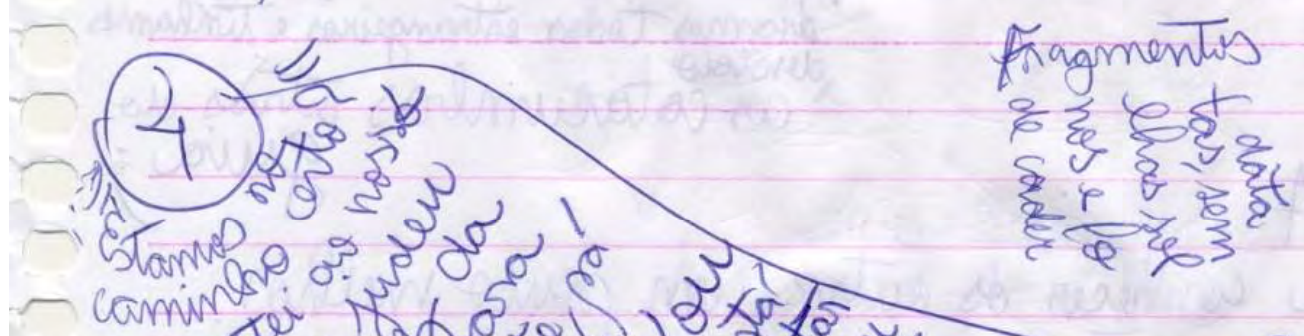

fragmentis

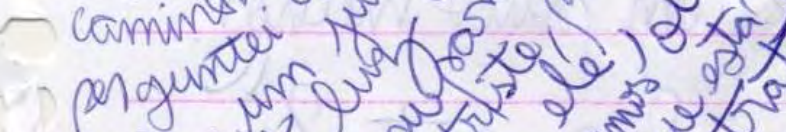

guva th 3

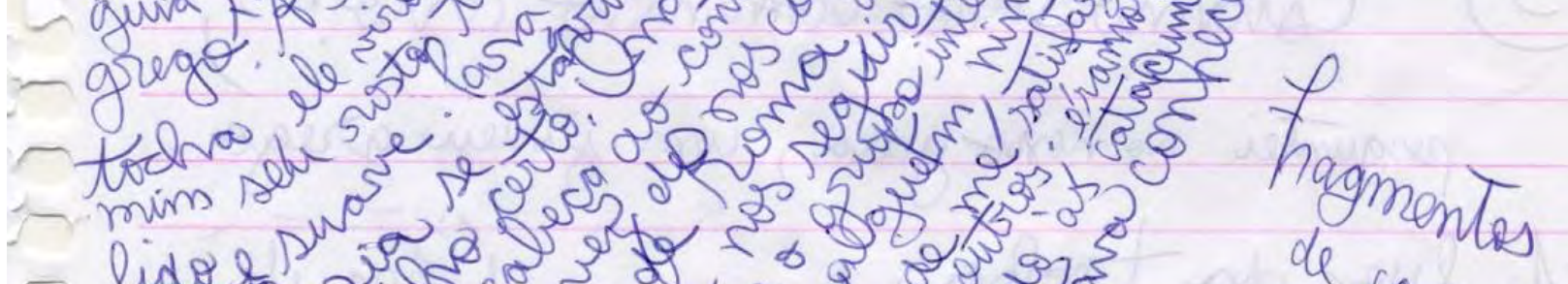
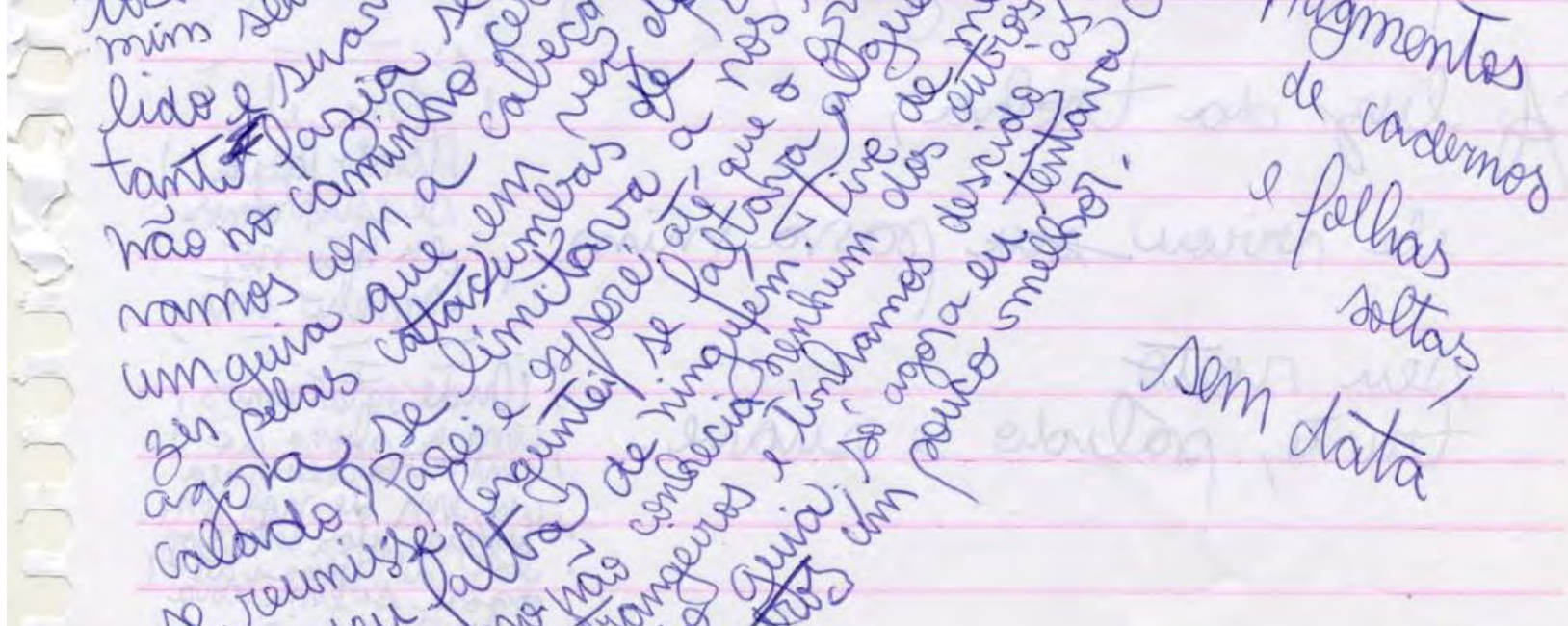

7 gerom der mo jus 30 so

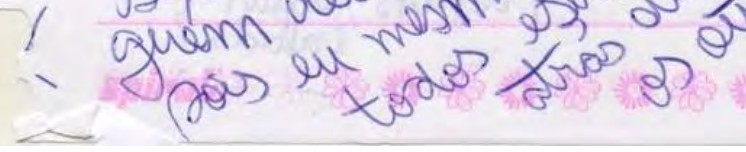




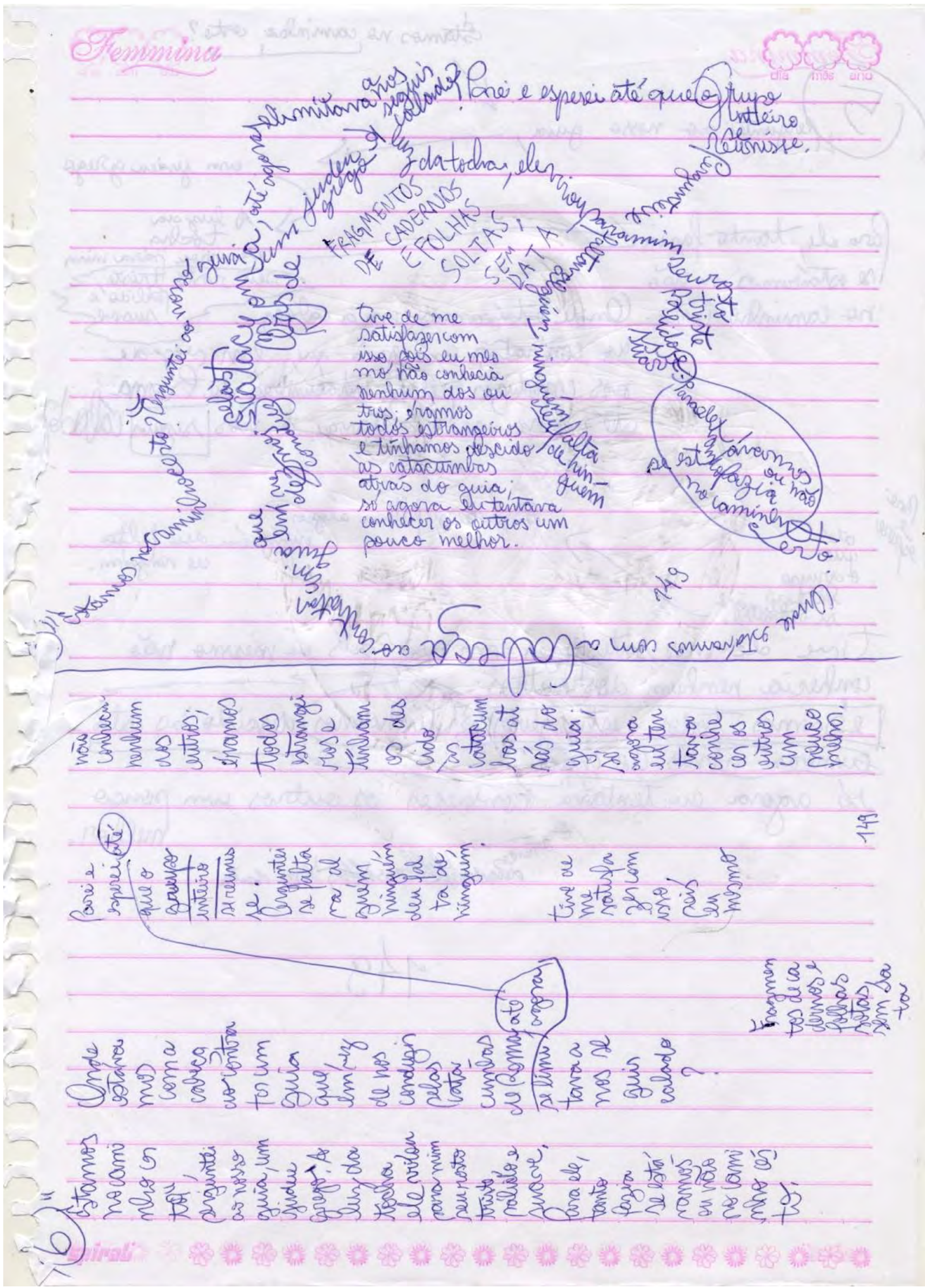




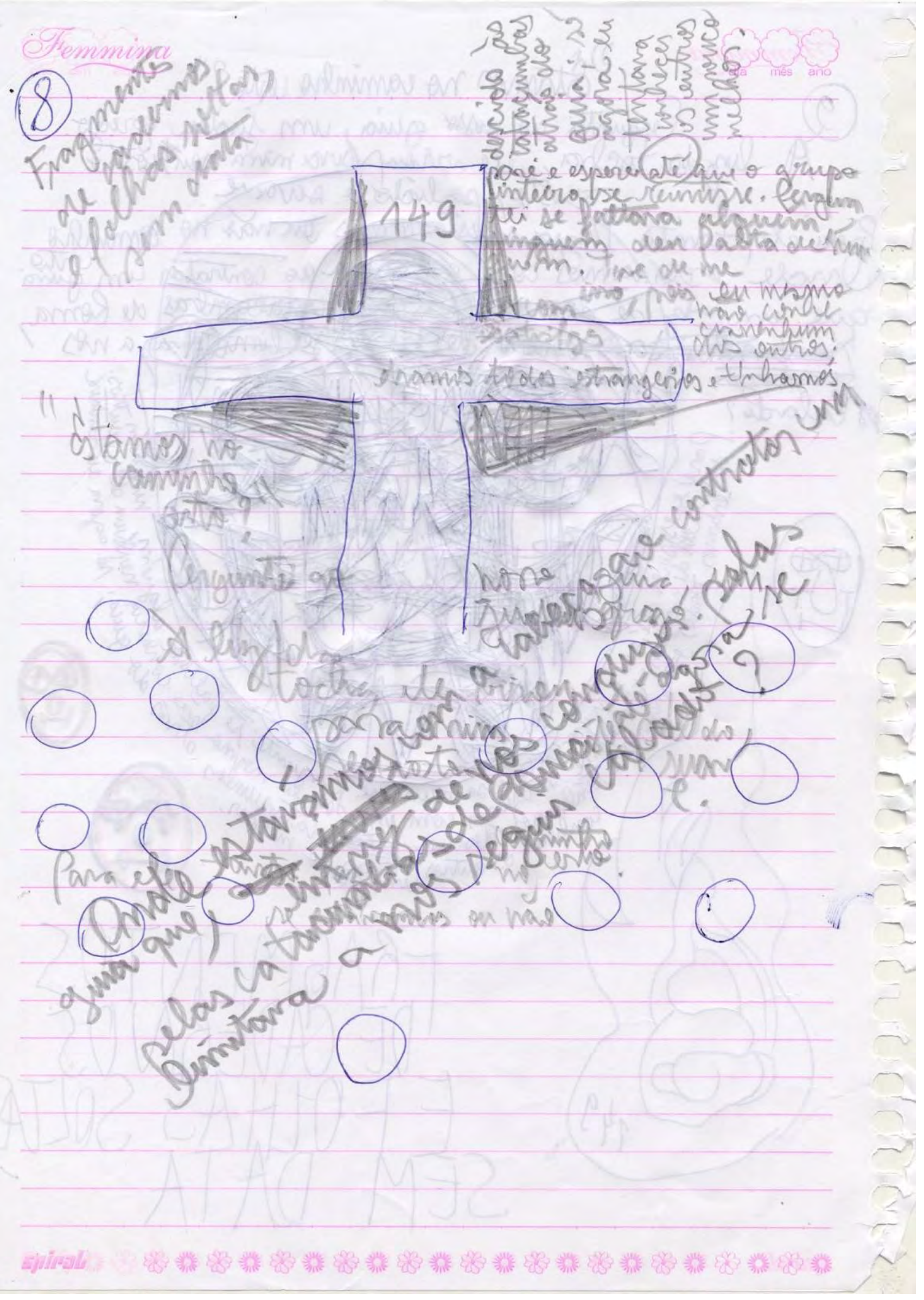


(2) "Etamos no caminho unto?" A ling da tochra ele rirou cara mim sen tosto triste palvido e swane

- Para ele tanto Pazia re es or was io amino Qnde estánamos con a a contratar um gutra. - que, em vez de de loma,

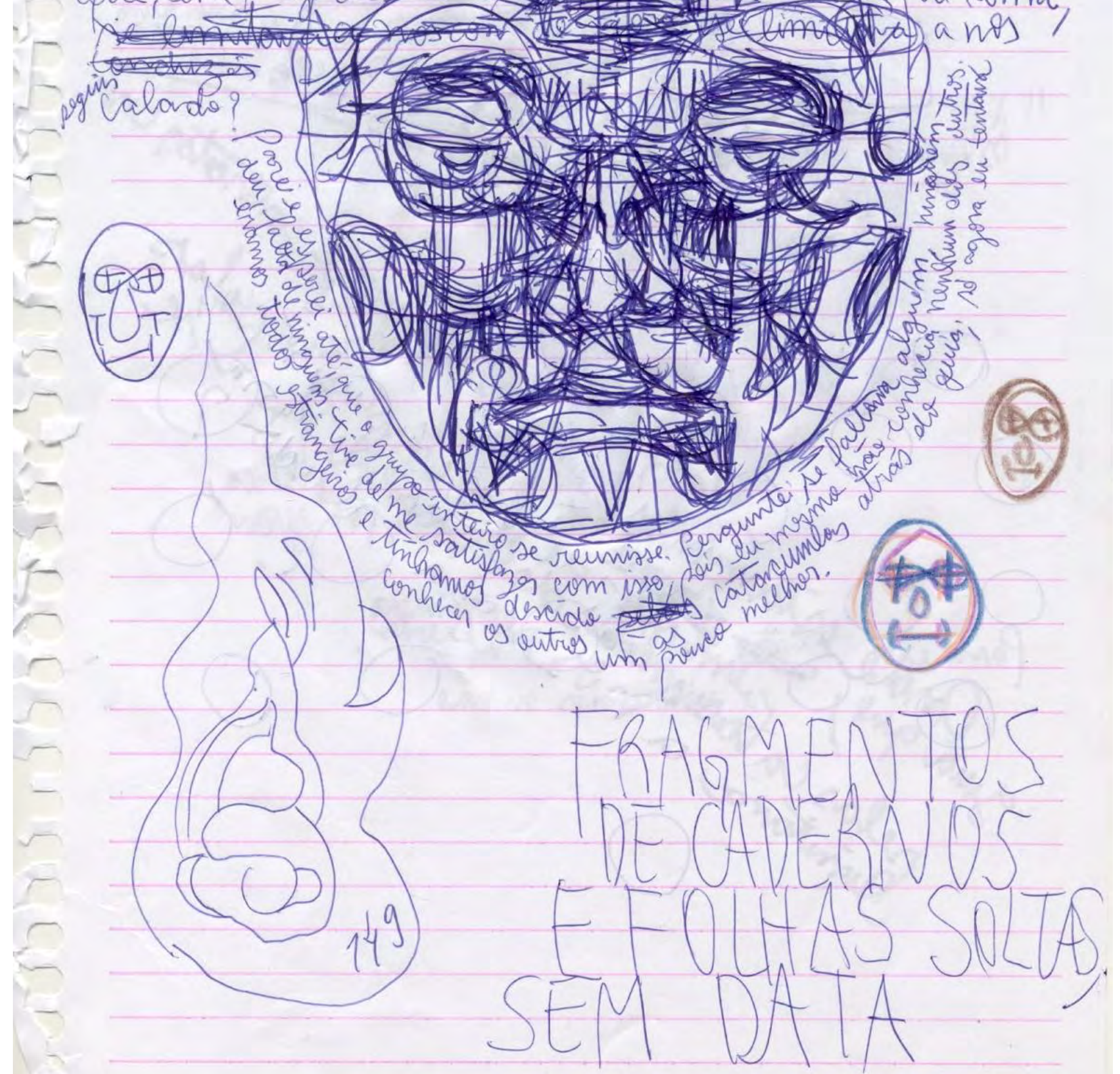


354

Tremminar

(10) powcer melhen.

(10) agora en tintorra conleces es outtos un Thramis descido as catacumbas atrón do guina, ise nenlum dos outho; élarmos todos estrangeiras e

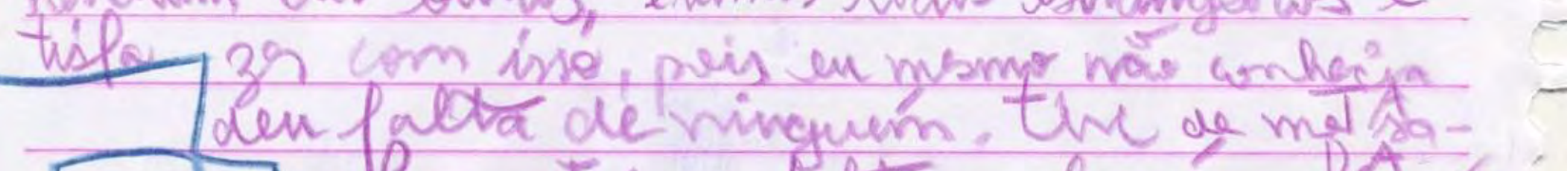

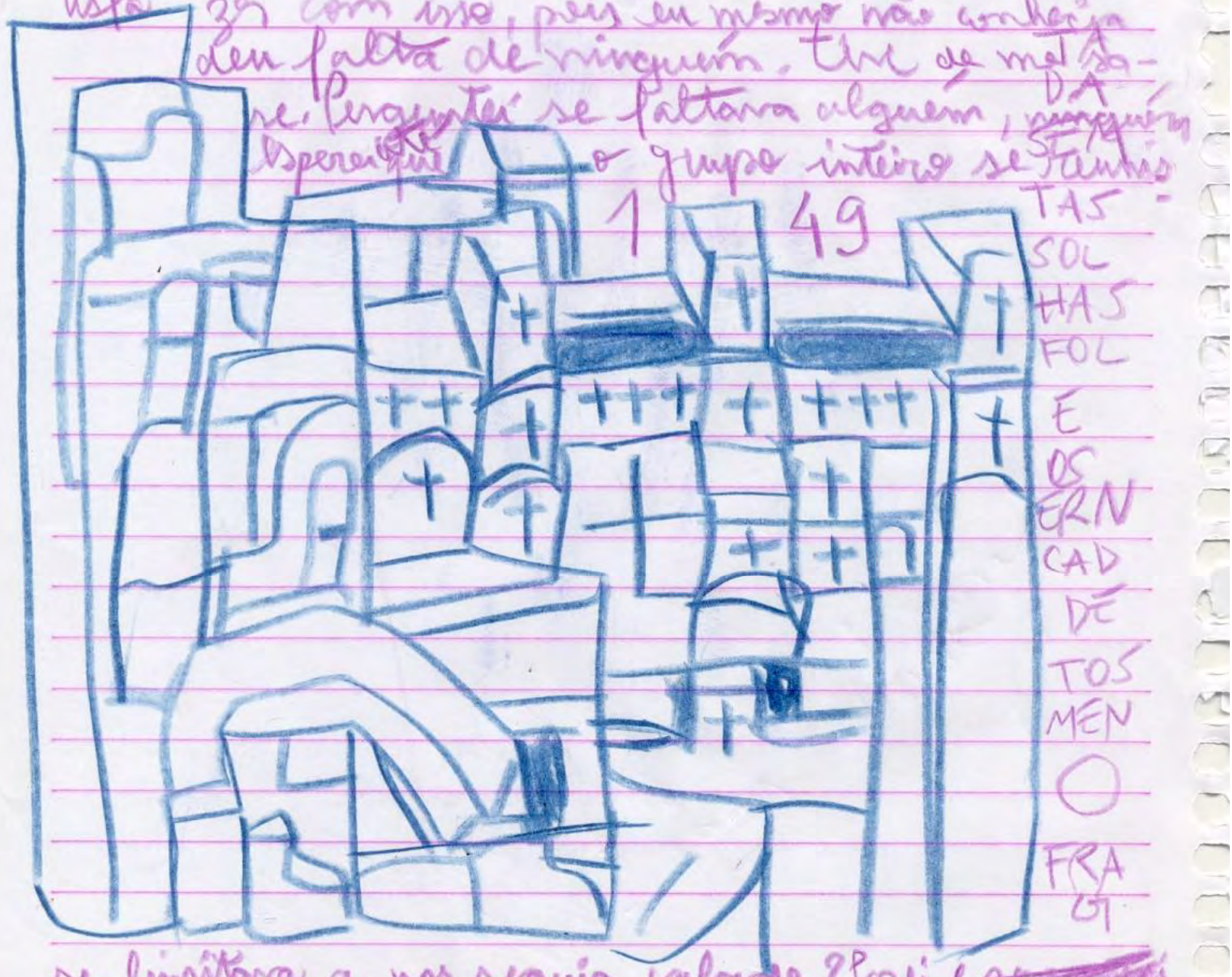

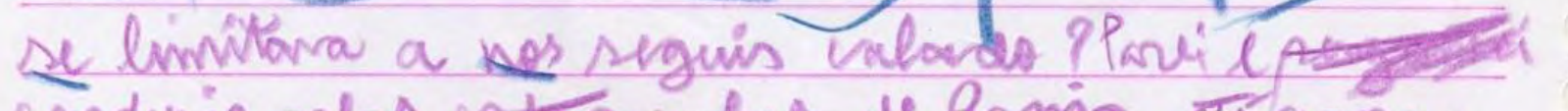
condug in pelas catorcumblas de Rermia, ate agera byca as wntrator un geria que, en nez de nos

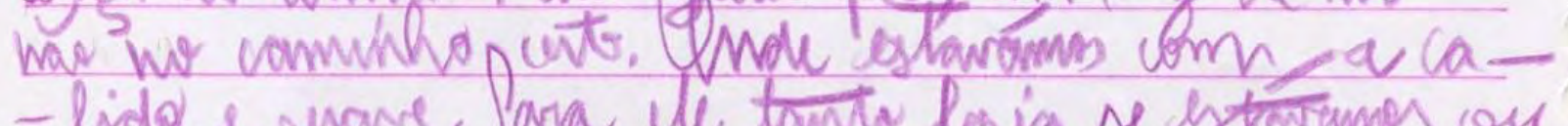
- lida e suare. lara de, tanto pain se estrumas os da tocha de nvieu parra, mim sen rosto triste, na go hons guis, um jurlen grego, A liz

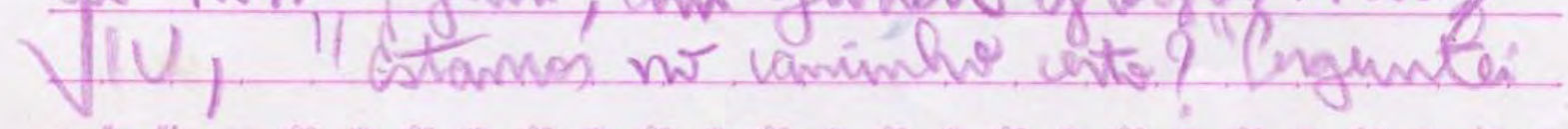


Este sonho foi o sorteado para mim. Minha companhia de paralelismo. Companhia de individuação conjunta, transcrição-corporificação-habitação. Sonho-talismã. Como a minha própria lição de casa será ser companhia e produção de corpo.

Este também foi o primeiro a ser transcrito. Como disse, eu não havia começado este trabalho com os sonhos Kafkas antes de que 0 agrupamento corpossom entrasse em recesso.

Ele foi inteiro feito 'pelas costas' do caderno, mas sem virar de ponta-cabeça: ou seja, sua progressão foi um 'voltar' do caderno, o que diz respeito à labiríntica e paradoxal narração do sonho.

Este eu fiz alguns meses antes de iniciar o período de transcrição do conjunto, antes mesmo de decidir se faria o exercício de transcrição com vários sonhos. Talvez o tom destas últimas páginas transmita a impressão de uma zona um pouco anterior.

Esta última página foi transcrita ainda de baixo para cima.

Vejo neste que as aparições da página são menos embaralhadas, entrecruzadas. Mas isso é bom, pois me pareceu aqui que tento me localizar a cada passo.

Este sonho de catacumbas me diz muito respeito. Dizia desde antes do sorteio. Elementos dos subterrâneos religiosos: 'Judeu grego'; 'catacumbas de Roma'. Onde pessoas estrangeiras, desconhecidas umas das outras, procurávamos um guia que nos seguia. [a silepse de pessoa foi proposital] Sinto que este sonho diz respeito também ao meu papel de eventual pretenso condutor. Não sei ao certo. Começar com uma pergunta... terminar com 'só agora...' 
5.

(p. 151)

Afiei a foice e comecei a cortar. Massas escuras caíam à minha frente, e eu avançava entre elas sem saber o que era. Da aldeia vieram gritos de alerta, mas eu os tomei por gritos de incentivo e prossegui. Cheguei a uma pequena ponte de madeira. Tinha terminado o trabalho e entreguei a foice a um homem que ali esperava; com uma mão ele pegou a foice e com a outra acariciou-me o rosto, como a uma criança. No meio da ponte fiquei em dúvida se estava no caminho certo e berrei na escuridão, mas ninguém respondeu. Então voltei à terra firme para perguntar ao homem, mas ele já desaparecera.

Fragmentos de cadernos e folhas soltas, sem data 
357

- 1. Aliei a foice é comecui a cortar.

- Massas escuras cqúam 'a minha frente, e eu avanggiva entre elas sem salfer $\theta$ que era Da aldeia viram gritos de alerta mas en os tomei cor gritos de in -

- centivo e prossegui. Chequei a uma

- pequena sonte de madeira. Linha

- Terminado o trabalho e intrequei a foi-

- ce a um homem que ali esperava com una măo ele segou a folice e com a outra, acariciou-ine $\theta$ rosto, como quma crianca. No meio dá sonte liquei em duivida se estarva / wo cominho certo, e berrei na escuridão, mas ninguem respondeu. Cntäo voltil a terva firme bara, serguntan avo homem, mas ile já desapare cera. fragmentos de cadernos e polhas
soltas, sem data

151 
358

No meio dra conte fiquei em dúvidase (2) Hertava No caminho cuto curvas cavam à minha frente, e e berrei na esvoltei a terra firme voltei a terra firme

Fowa entre elas sem saber perguntar eu evanaldeliou viriom gritos sabet o que era Da mas ele já desopsarecera

trongentos de alerta, mas en os Chequei gritos de incentivo e crossegui. madeleiva una sequena sonte de tas, sem data de cadernos e folhas sol.

tinha torminado o trabalho e 751

entreguei a foice a um homem que

rowa; ali espe-

com una mäo 7 ele segou a foice l com a outra $\rightarrow$ ccariciou-me $\theta$ rosto, como a uma seriange.

Gipinab<smiles>CC1CCCCCCCCCCCC1</smiles> 
359

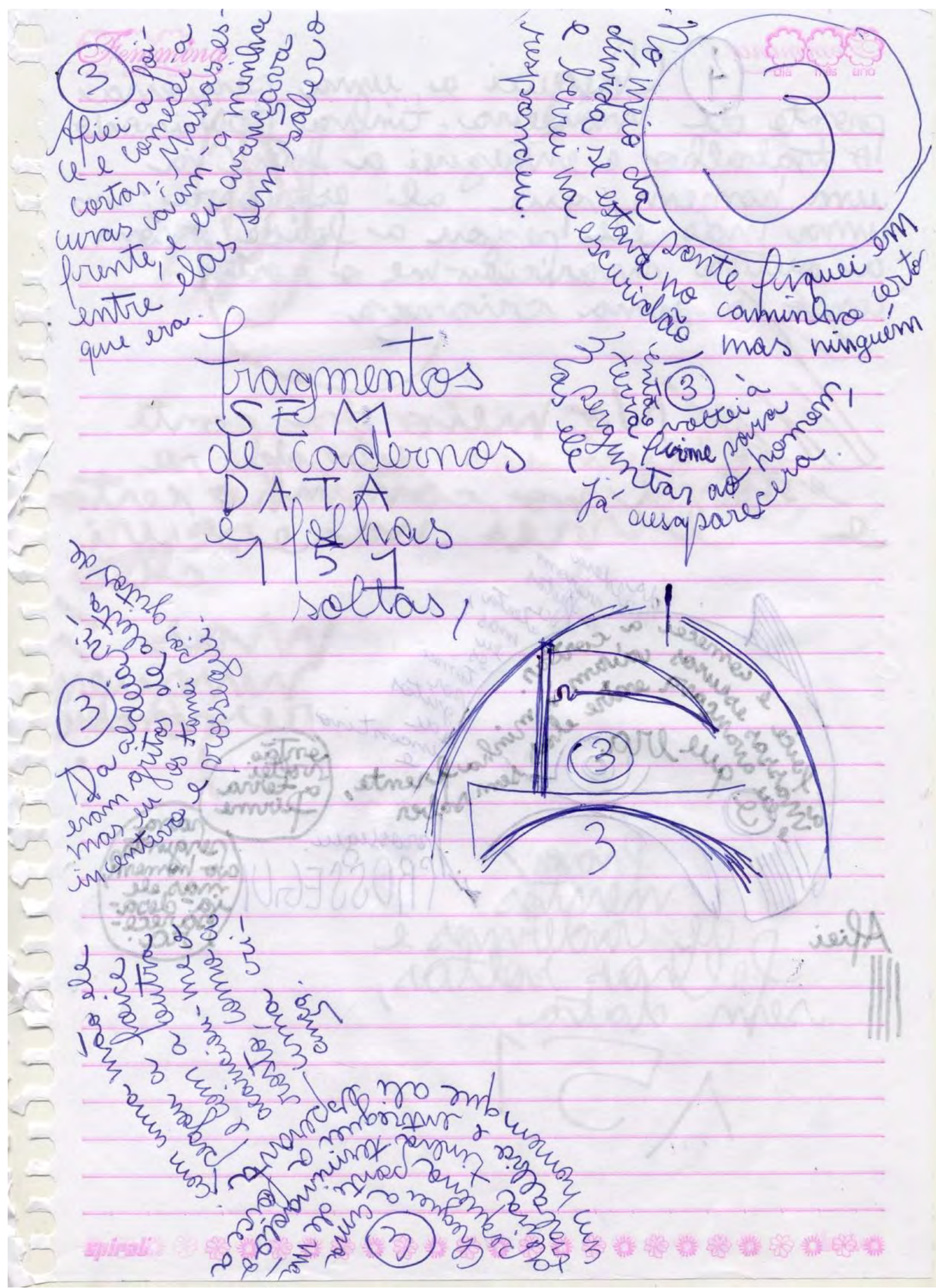




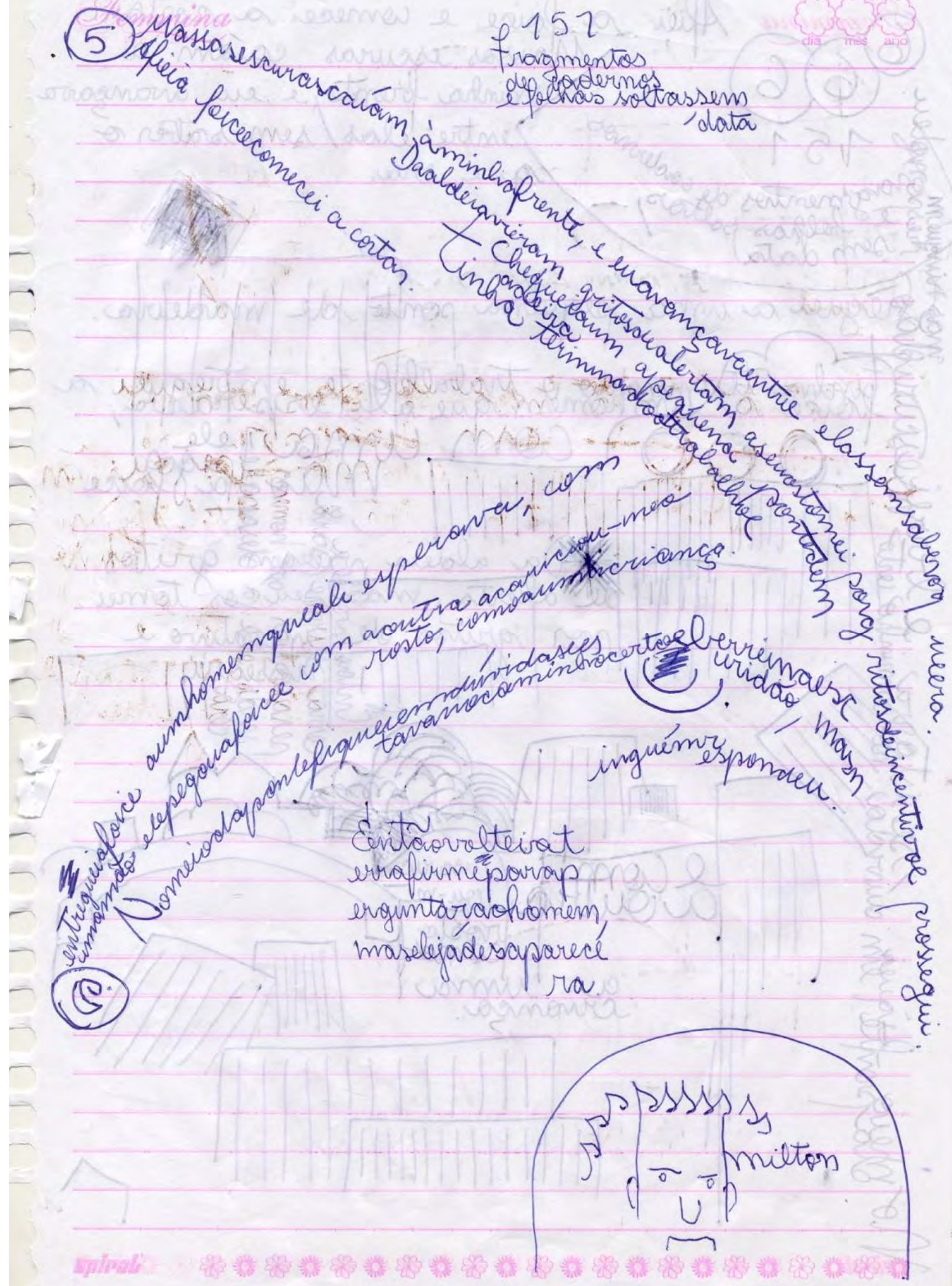




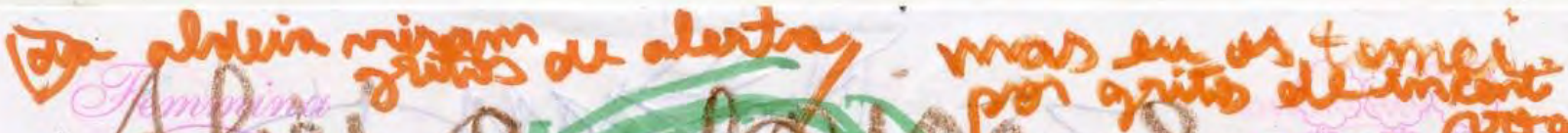

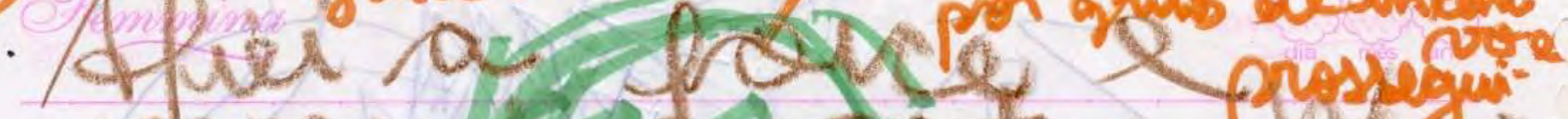

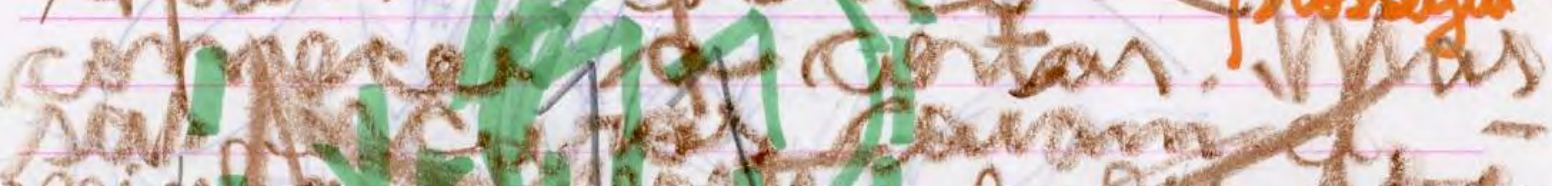

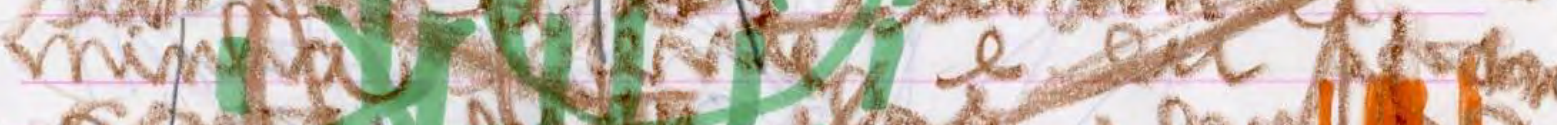
Q.

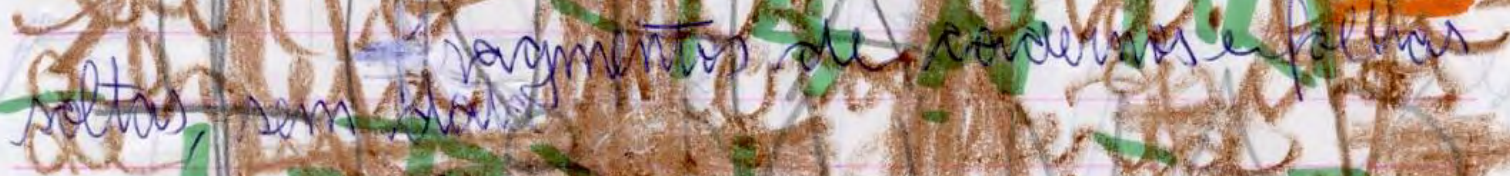

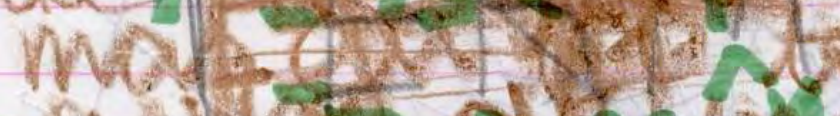

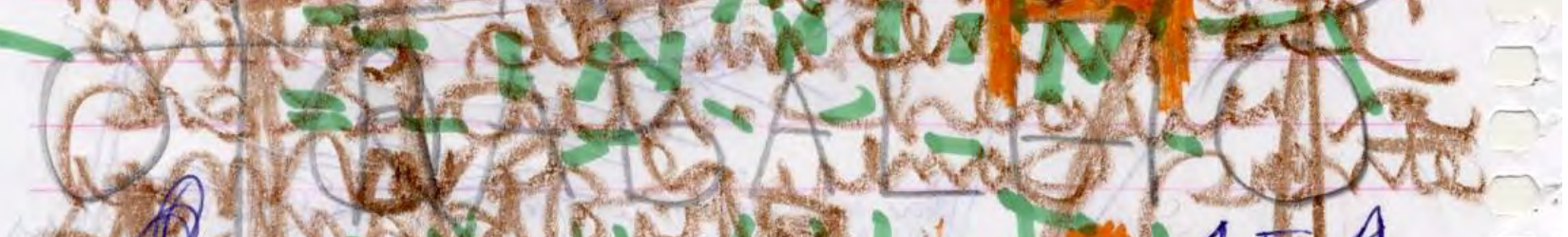
100 .

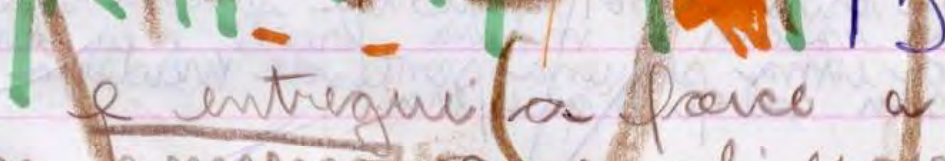

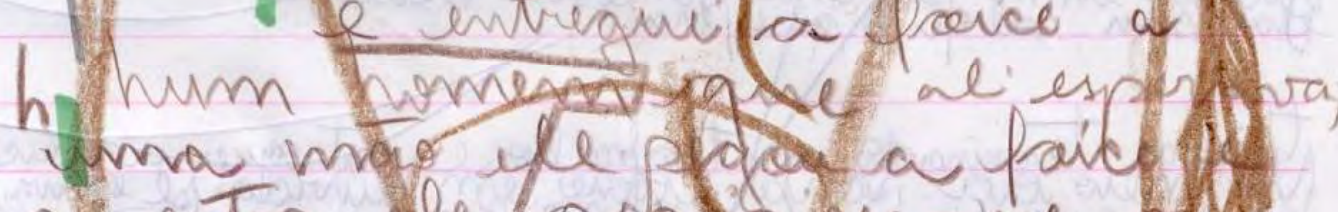

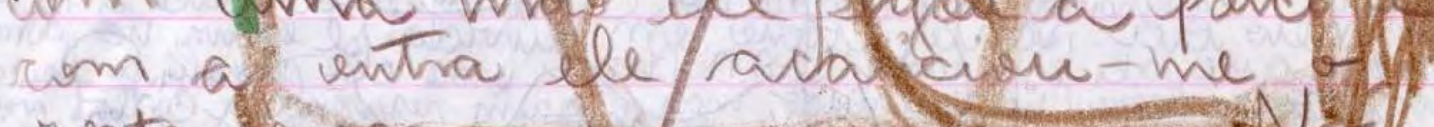

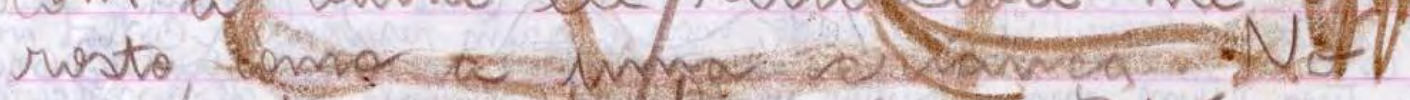
meir da ponte/fiquer im solúvida se estaria no compina 2 11 $\frac{\text { mas'wingén }}{1,1,1,}$
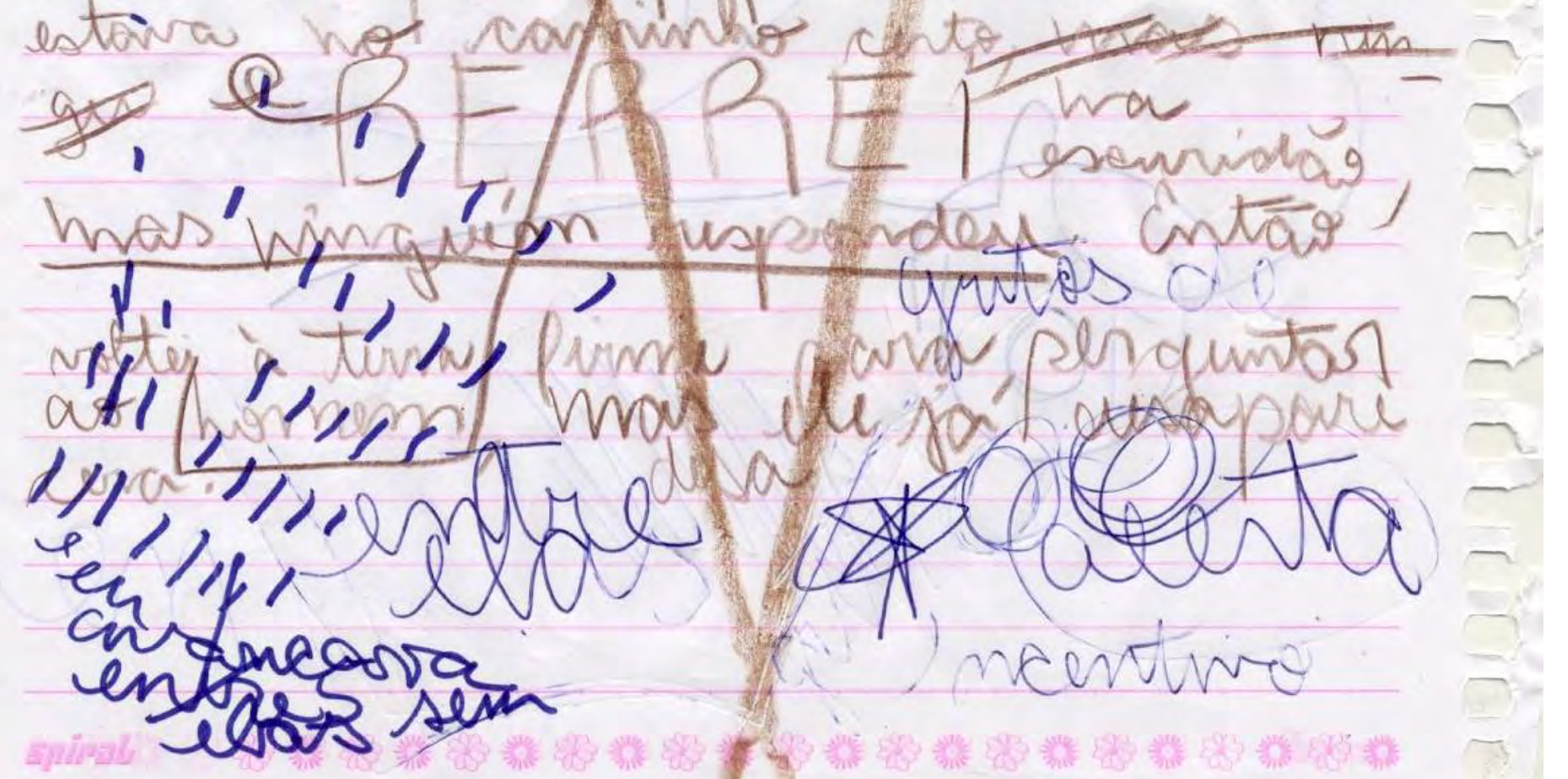
As palavras se despedaçam. Este sonho não foi objeto de sorteio, mas seria a minha segunda escolha. Assim, comecei a pegar este sonho para ler em qualquer lugar, para amigos. Ao vivo, por telefone... (acho que este foi o terceiro sonho que transcrevi no caderno)

Eu deixei inteiro o começo da série de transcrições (acho que é bem nítido: 1,2, 3, 5, 11) para deixar ver a metamorfose da própria escrita. Ela se reagrupa em função de vários vetores: rítmica do texto e das frases, grupos de palavras aparentadas ou repetidas. Modos de enunciado que se aparentam ou se singularizaram. Objetos ou situações físicas descritas (por exemplo, a foice, ou o que cada mão do 'homem da ponte' faz). Etc.

Ao final apareceu uma figura das histórias em quadrinhos. Um vilão do universo Marvel, particularmente do Homem-Aranha, chamado Mysterio. Ao final das repetições (a última página aqui colocada) eu coletei algumas imagens desta personagem e anexei às páginas seguintes (dentro de envelope grampeado à página; colado às páginas...). É uma figura cuja cabeça é uma bola de cristal. Um ilusionista profissional que se converteu em criminoso.

Na penúltima página, uma figura da minha adolescência que eu mesmo havia criado: 0 Milton. A necessidade de expô-lo aqui não é a nostalgia. É o fato de ele também ser uma personagem, uma figura que surgiu da caligrafia. Seus cabelos são uma pequena série de 's's minúsculos.

Aqui, penso, se dá a ver que a página pode constelar situações muito diferentes. Começo a pensar sobre os terrenos capturados pela repressão escolar...

Outro dado é, neste sonho-página e em outros, perceber a reunião do sonho com sua referência de quando foi feito, para quem etc (logo abaixo do texto do sonho), 0 número de página, e o número da repetição na transcrição. Esses registros em múltipla escala mudam de ênfase, posição e de escala ela mesma: têm função na produção do corpo da página. 
6.

(p. 63)

É muito tarde, minha cara, e ainda assim vou dormir, sem merecer. Bem, dormir mesmo não vou, mas apenas sonhar. Como ontem, por exemplo, quando no sonho eu andava até uma ponte ou um cais em cuja amurada por acaso havia dois telefones; eu levava os fones ao ouvido e ficava pedindo notícias dos "confins do mar", mas do telefone só vinha o bramir do oceano e um cântico sem palavras, triste, impressionante. Mesmo depois de perceber que nenhuma voz humana conseguiria sobrepor-se a tais ruídos, não desisti e ali fiquei.

Carta a Felice Bauer, 22/23 de janeiro de 1913 
364

- Ti e ale pliquei.

Carta a Elice Baver,

22/23 de janevio de 1913

63

(3) I'minfra cara nãg mulo de ándormu

tarde, assim vou

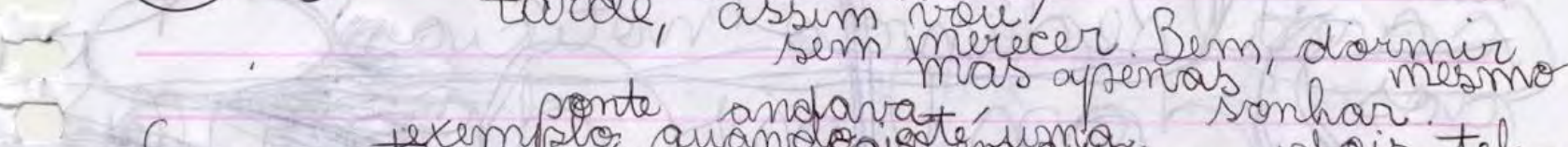

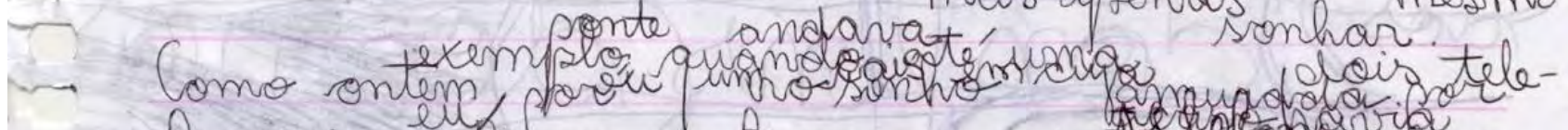
Pones, eu tevara os fines not

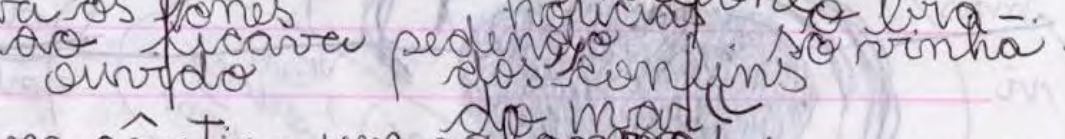

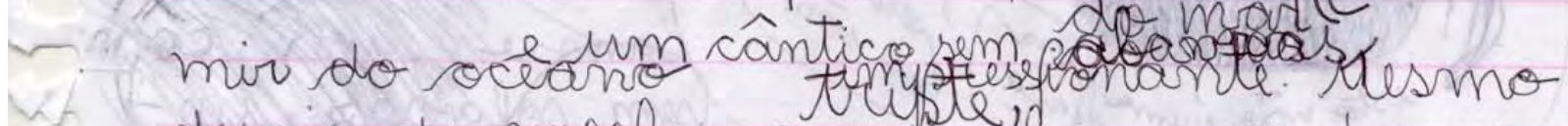
depois de pereber que hen lhumag ingo humana

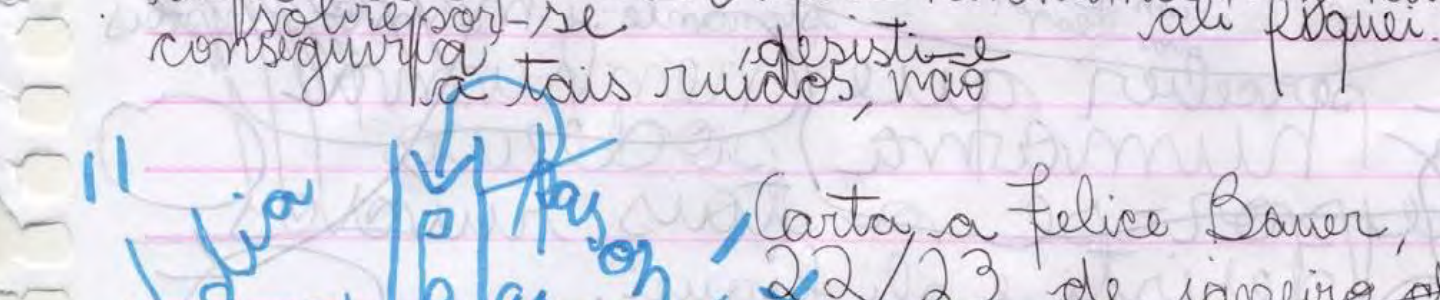

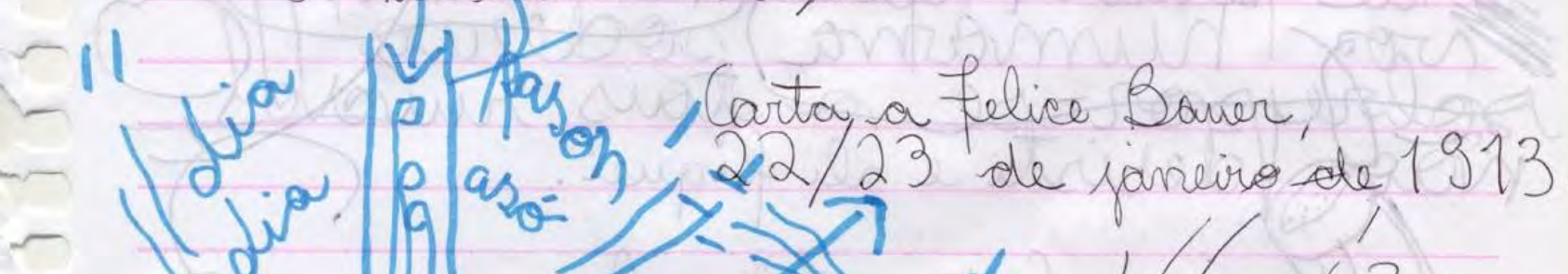

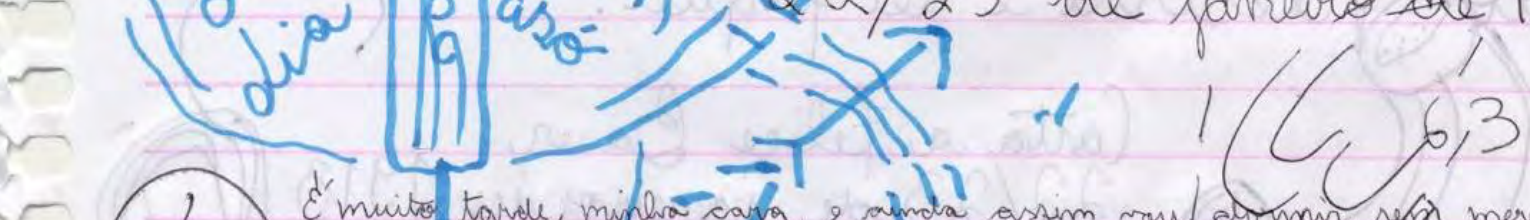

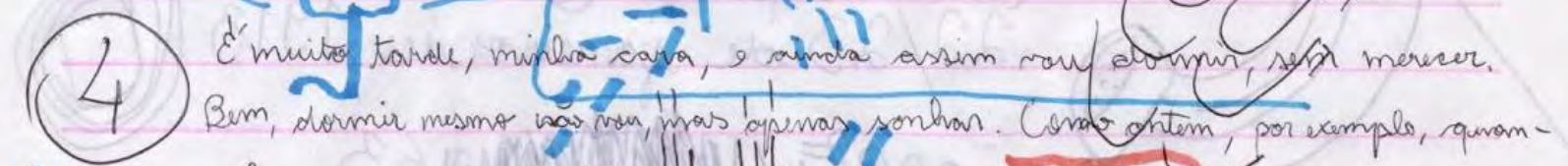

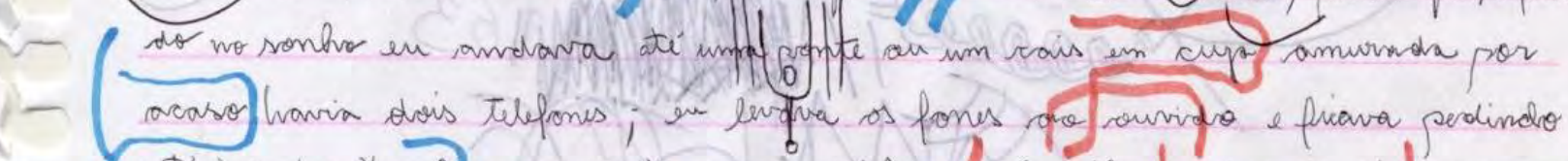

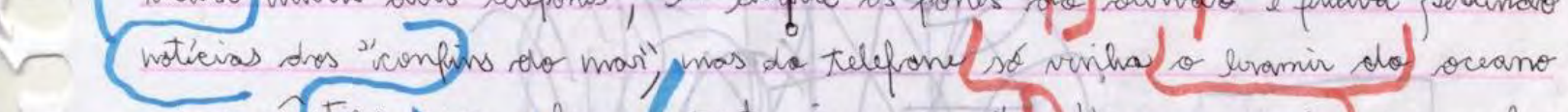

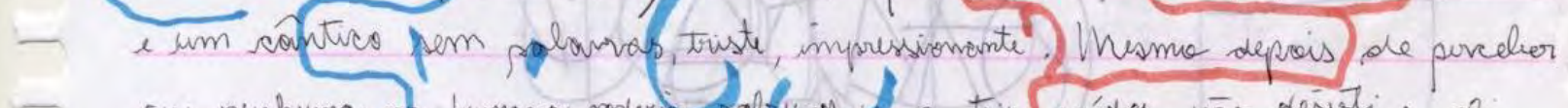

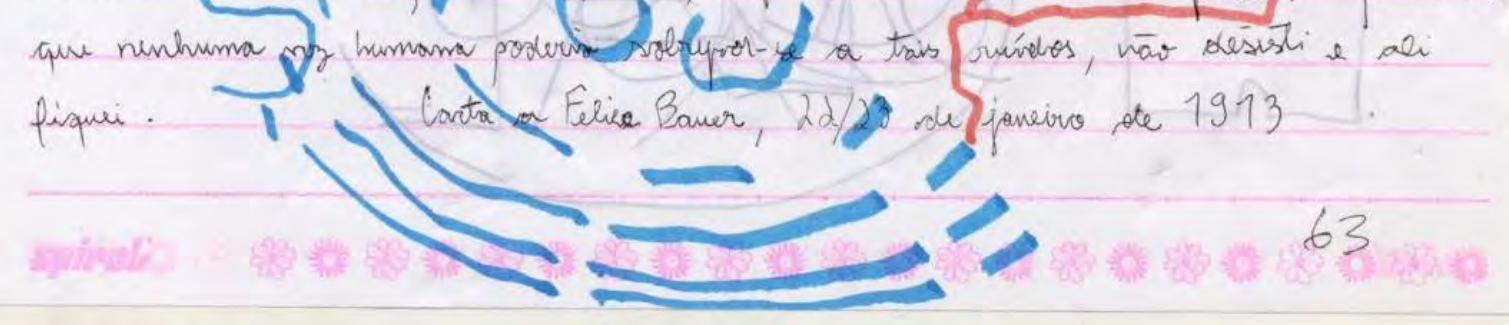




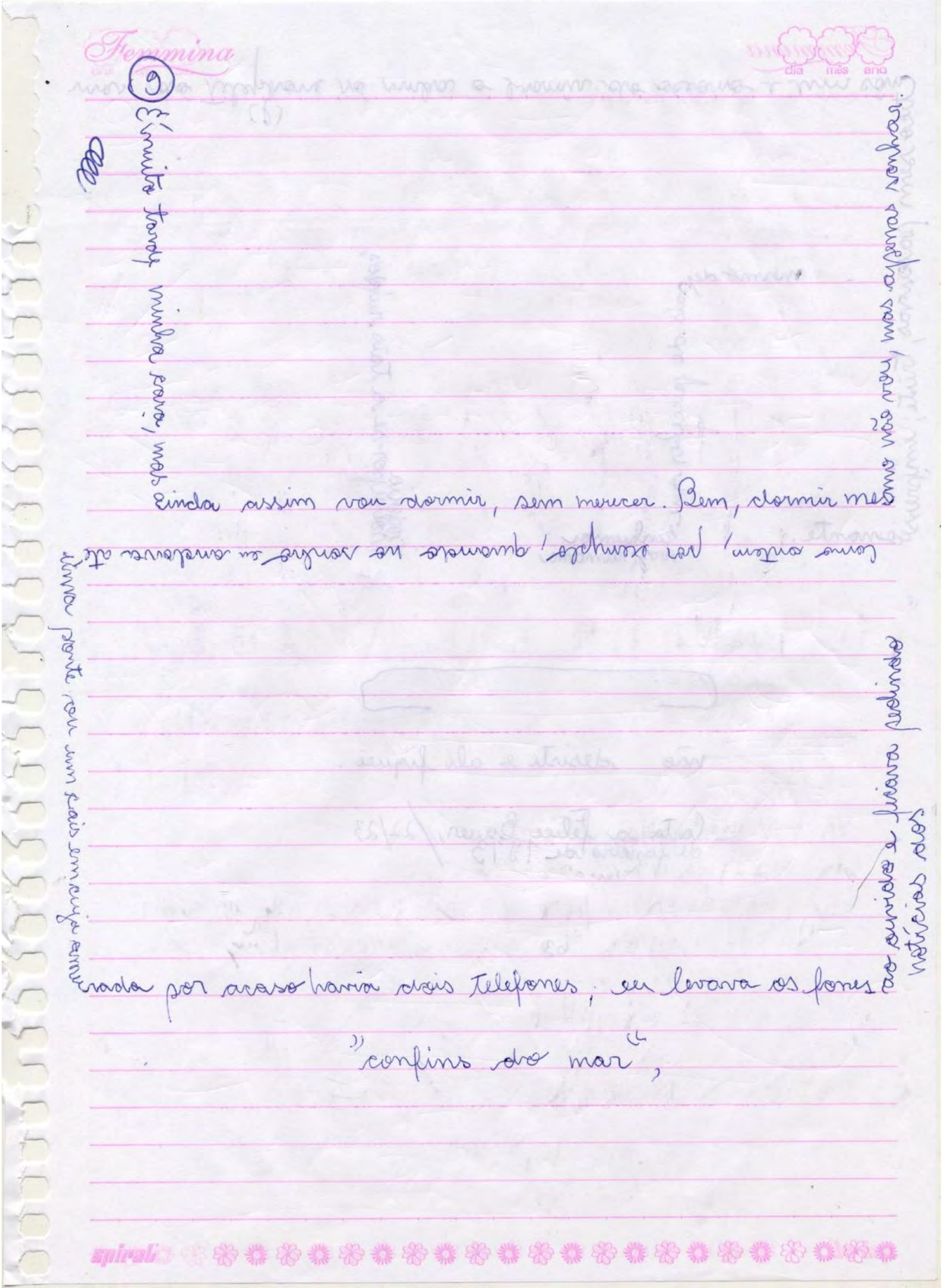


366

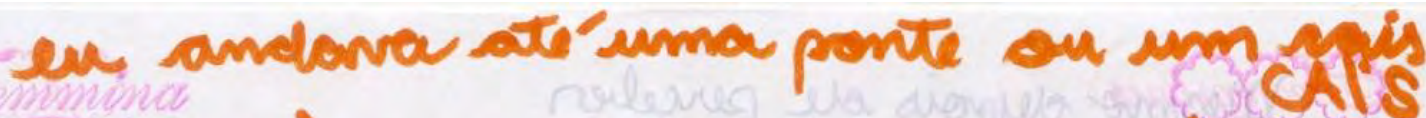

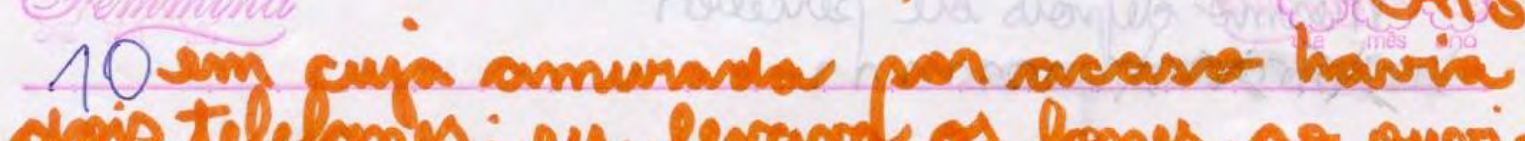

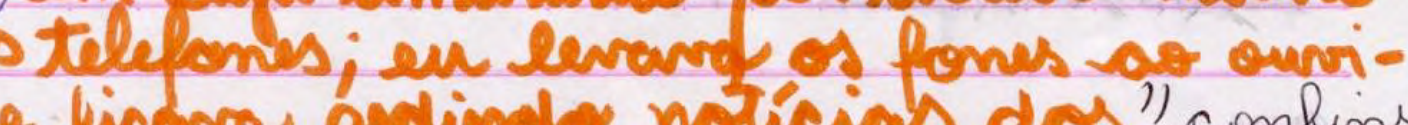

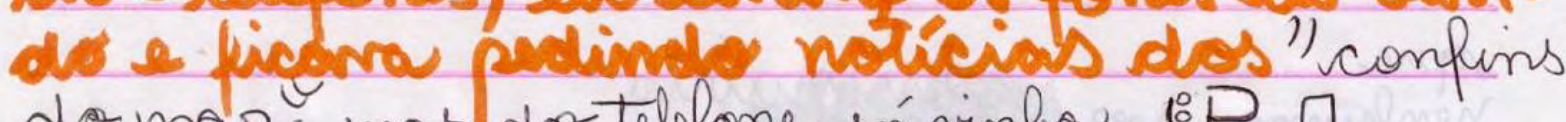
do mar, mas do telefone só vinha :PI!?

(5)

Bem, dormir mesmo năo vou, mas apenous so -

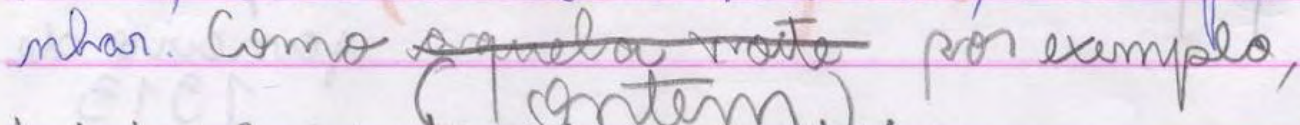

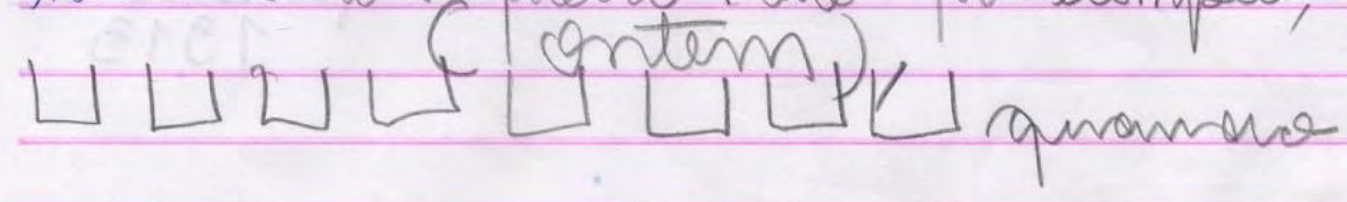

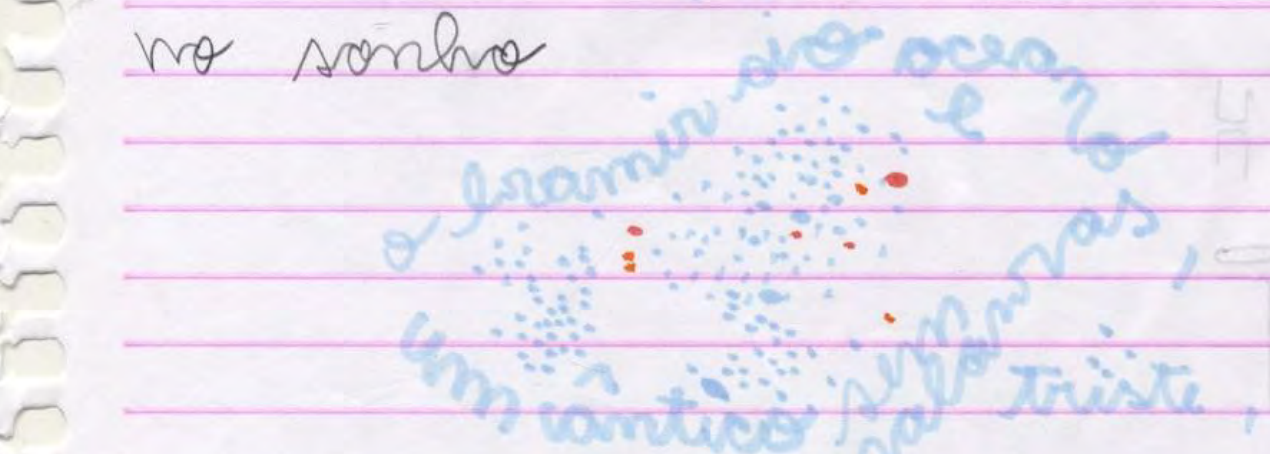

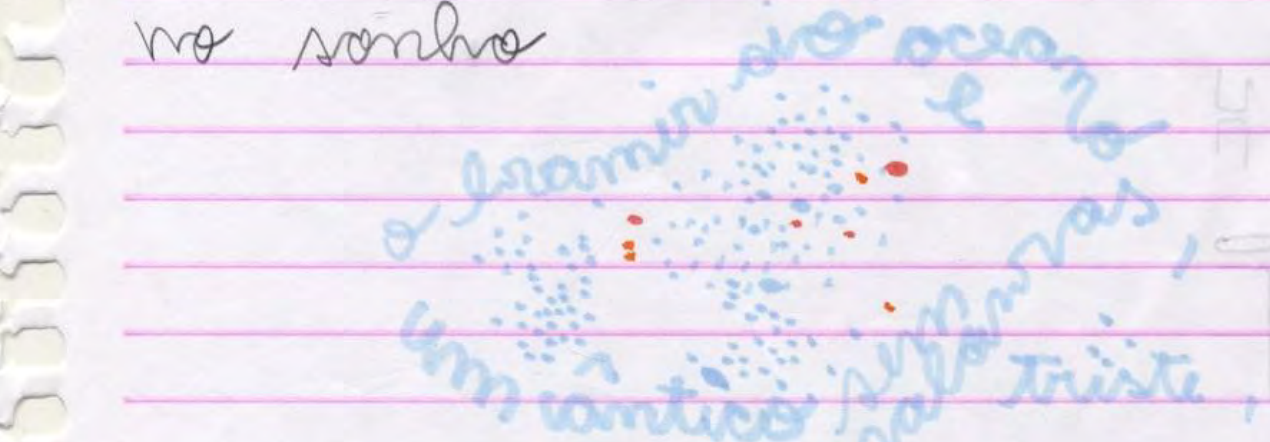

Simanessianosite. 
Este sonho foi sorteado por Auber. (quarto sonho a entrar no caderno)

Eu não sei se é algo do elemento dominante no sonho, ou a personalidade da pessoa que o sorteou. Não sei se há uma relação com isso. Sei que este sonho produziu uma outra textura com o trabalho da página.

Digo isso pois nós todos trabalhamos com os sonhos, e pode parecer que registramos pedaços de sonho misturados com quem os pronunciou.

Aqui aparecem rastros de algo que viria a ser, num outro sonho por vir, de uma 'gramática existencial', termo emprestado do escritor e psicanalista Christopher Bollas.

Lembrei do termo 'esculturas de arame', termo que meu irmão empregava para os desenhos que eu fazia, desde há vários anos, com linhas ou pedaços de linhas, muitas contorcidas, que se costuram. Aqui, as esculturas de arame tomam configurações de outra economia, mais sintética, não mais tão gótica ou barroca, se me permitem a expressão. Neste sentido, algumas configurações que eu poderia chamar por 'gramática existencia', ainda que momentânea, surgida em vínculo aos esboçamentos, se parecem de fato com alguns símbolos mágicos que eu não conheço. Mas que, dado o campo magnético vivido com a página, de grande afetividade, é muito difícil que eles sejam negativos. Pois é o campo afetivo que magnetiza os símbolos, o contrário penso ser mais raro e difícil. Digo isso no contexto dos cadernos.

Aqui também começo a notar um repertório mínimo de 'lugares', formas de tempo. Lembro de quando em quando do Klee de Subirats. 
7.

(p. 91)

Um sonho: uma luta entre dois grupos de homens. O grupo a que pertenço tinha prendido um inimigo, um imenso homem nu. Cinco de nós seguramno, um pela cabeça, dois pelos braços e dois pelas pernas. Infelizmente não tínhamos faca para o apunhalar; com muita pressa perguntamos se alguém do grupo tinha uma faca, mas ninguém tinha. Mas como por algum motivo não havia tempo a perder e ali perto tinha um forno, cujas portinholas de ferro fundido eram desproporcionalmente grandes $e$ estavam incandescentes, arrastamos o homem até perto do forno $e$ colocamos um de seus pés perto das portinholas até o pé começar a fumegar, aí o afastamos, deixamos o pé esfriar e o aproximamos de novo ao forno. E isso repetimos várias vezes, até que acordei, não só banhado em suor, mas literalmente trincando os dentes.

Diário, 20 de abril de 1916 
369

Tremonina

- por algum motivo não havia tempo a perder ef ali p perto tinla un forno, cujas portinholas de ferro fundivio eram clesproporcionalmente grande e stavam incarvelescentes arrartaras homem. até, perto do forno e colocamos un de seus pés porto das y portinholas até o pé comecor, a flumerar, au o apastamos, divamos o pé sfriar elaprocimanos de' novo ao forwo. ¿ isso repsetimos varias vezes, ate que acoiveli wāo stó banlvado em suor mas literalmente trincando os dentes.

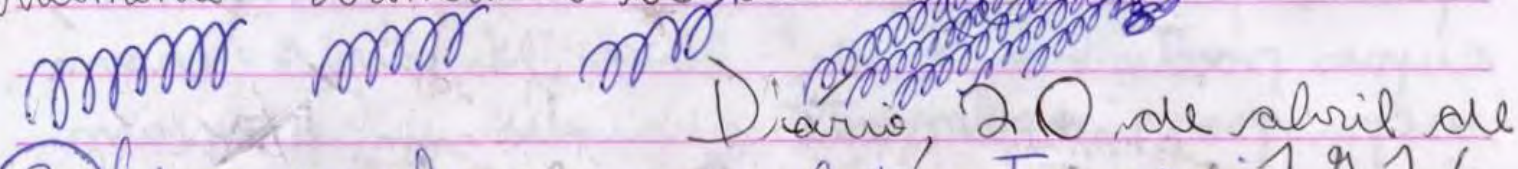
(3) lim sonho inma futa entre dxist i 16 ipjurisos de homens. ¿l grumo a jatue pertenco timpa srendivalom inimiog, um Iimenso homem ny. Cincol de nog sagu-

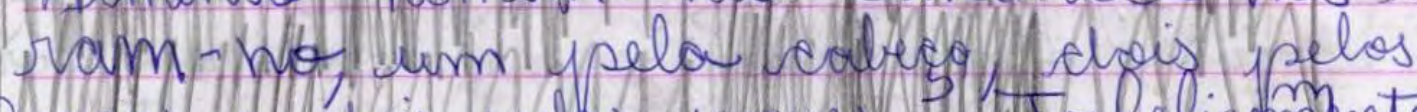

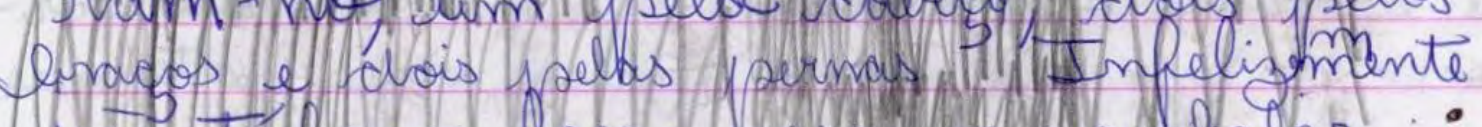

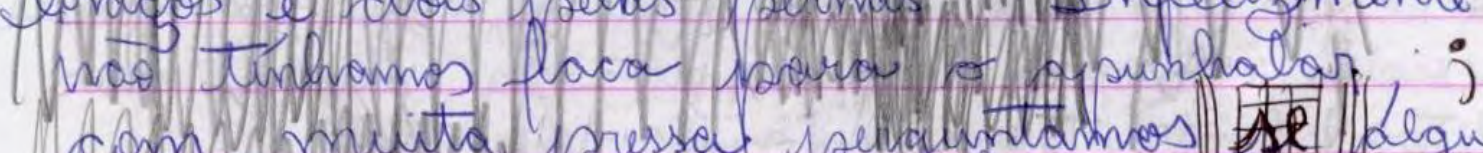

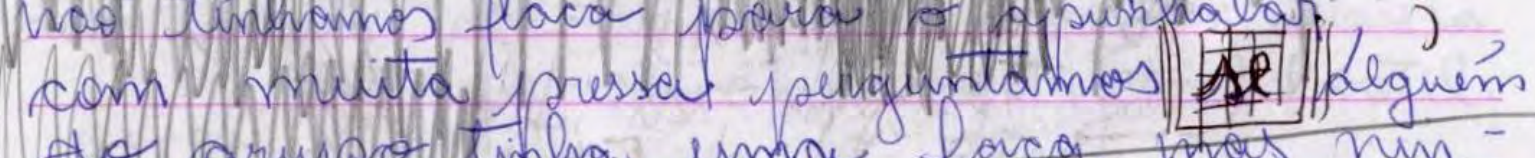

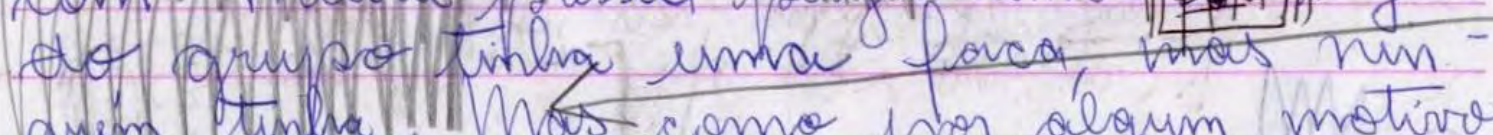
guem. Ptunlena II Was convo fvor álgum motivo Wa havia tempro a perder e ralís perto tinlva um fornd, cujas portinholas ar fervo Lundido erasm desproplorcionalmente ghandes estavam incandescentef, ourvastames o homem ate pento do Jorno e colocamos

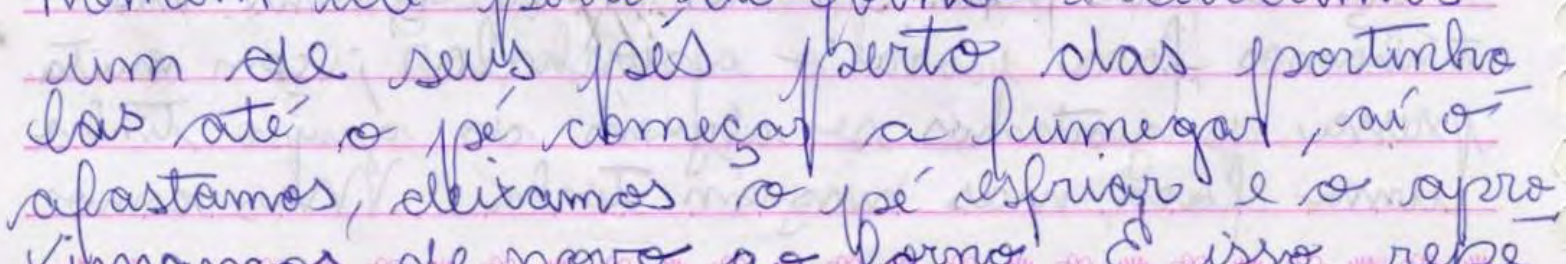
ximamos de novo ao forno. ¿ isso repe 
timos varios vezes, ate'que acordei, nà so' ba- mivado em suvory was literabmente trincando os - dentes.

$$
\text { Diário, } 20 \text { de abiil de } 1916
$$

(4) Un sonlvo: una luta entre 2bous aguepoes de romens. O guppo a que petteng tinha prenslisio un inimigo, lim innenso homem nu. Cincp de nos

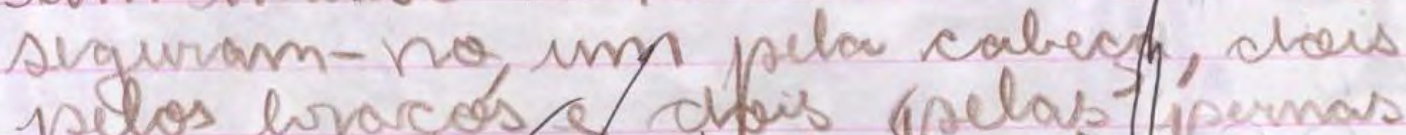

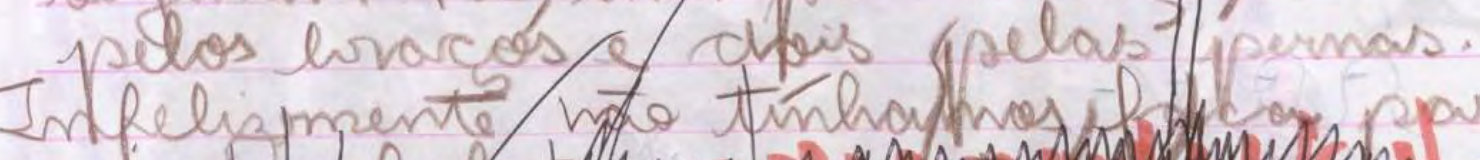
trannas

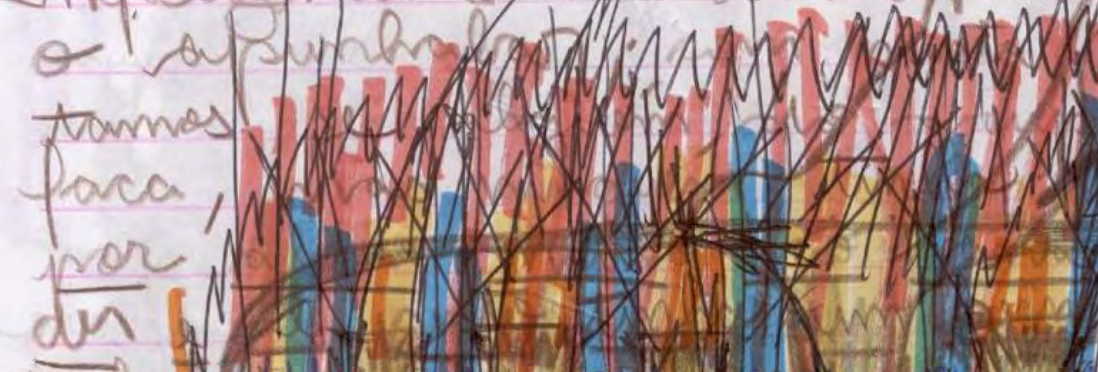

r
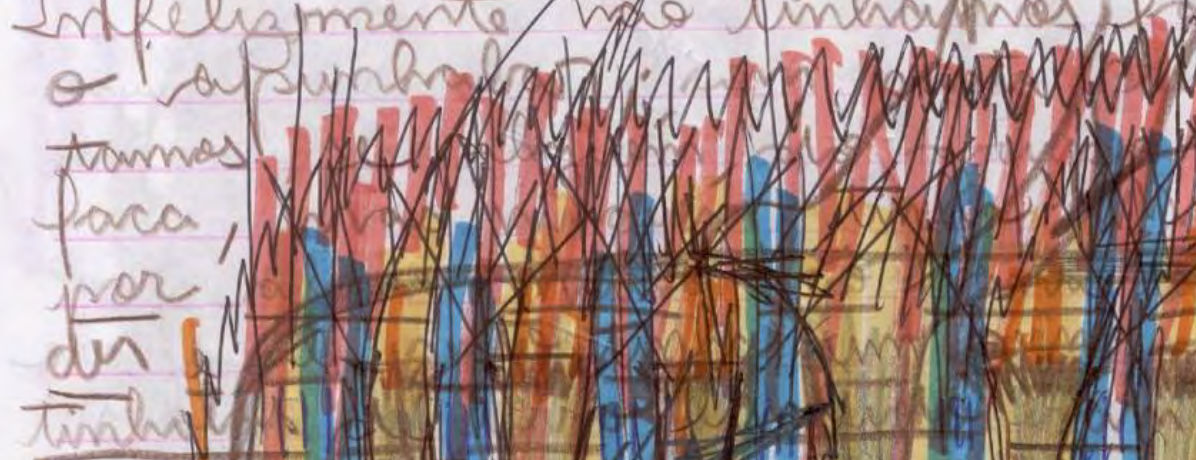
371

(5) Diário, 20 de abril de

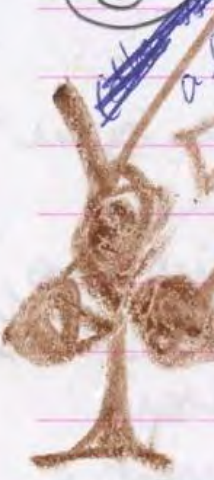

$$
1916
$$

$$
\text { surter }
$$

unva lita entre does gruy of de hamens.

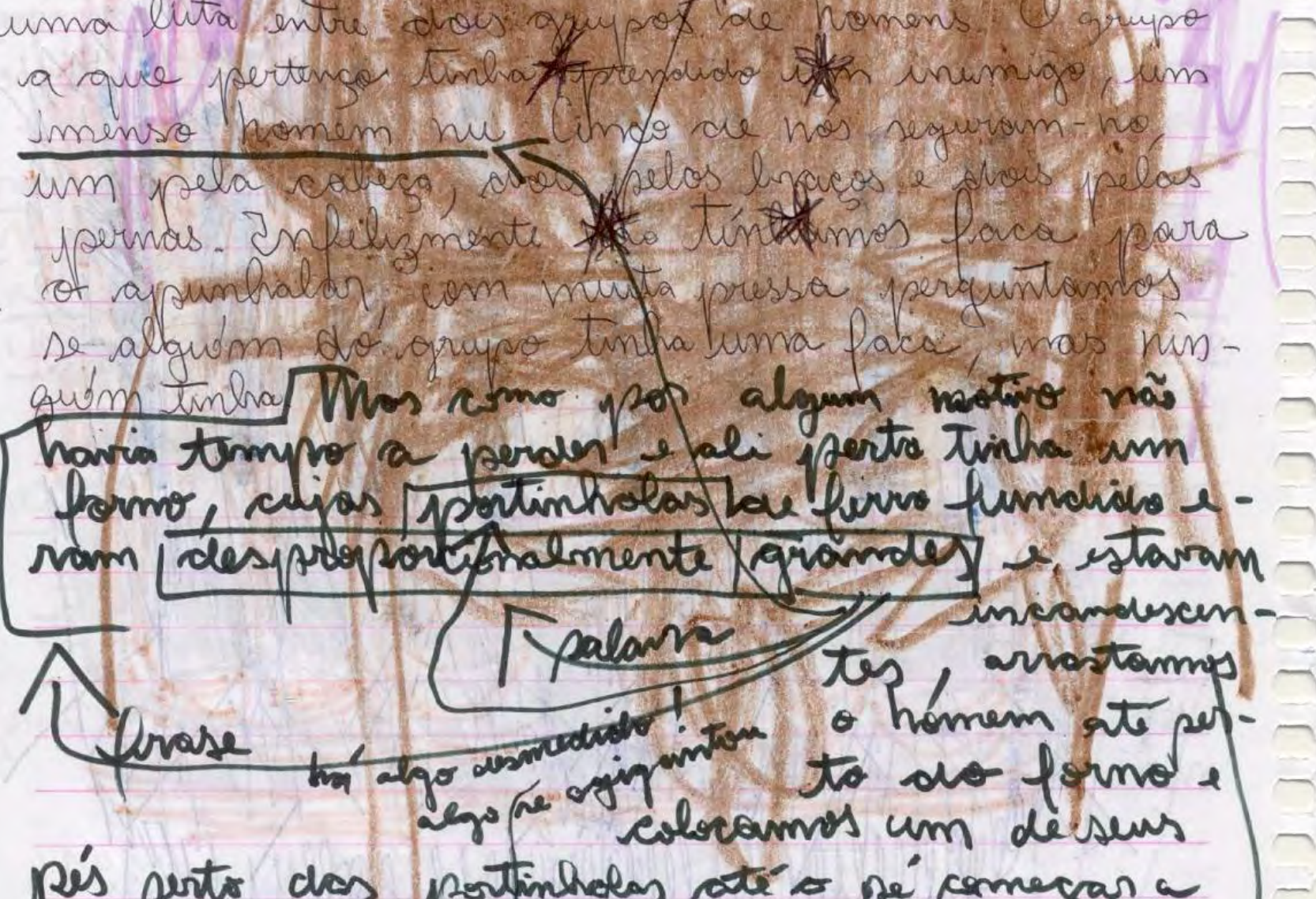

Pís perto das portinhelas atés pé comezgar as Plumbian, on s Afastancos, duichnos of pé sffrion ce o aprotimamos, de novo avo for. wo. Ecisso wastingros rárias vezes, até literalmente trincando es dentes. 


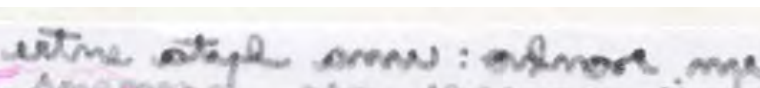

\section{(6)}

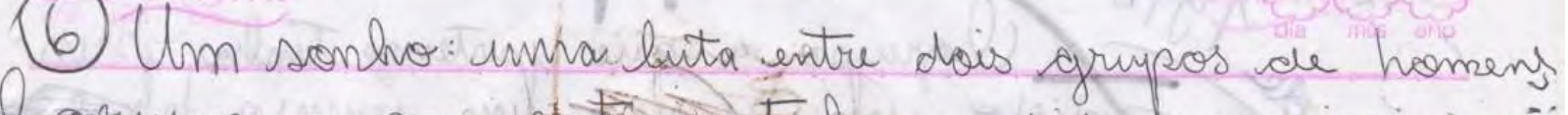
- rogupa a que dertongo tintra prendido um inimigo, tum inenso homent hu . Cinco de nós seguram-no, um thela caluca, crois sélos Traces a alvois pelas pernas. Infelizmente nao.?

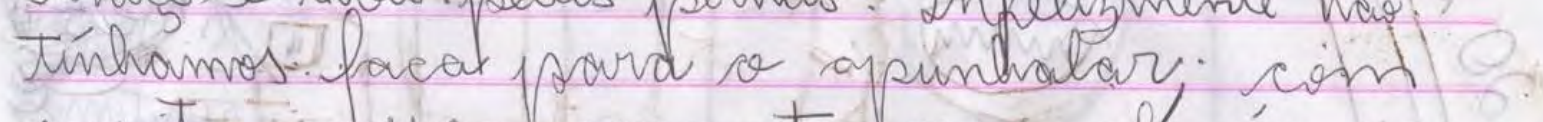
muita jessa perguntamos se allquén do

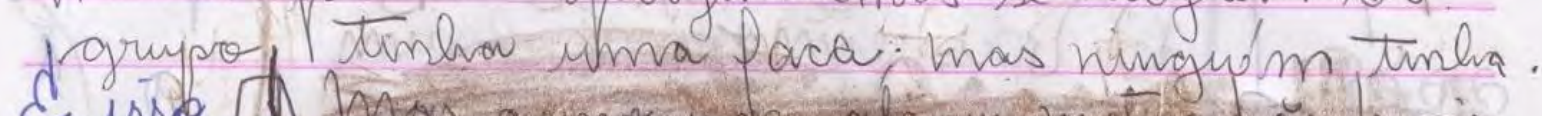

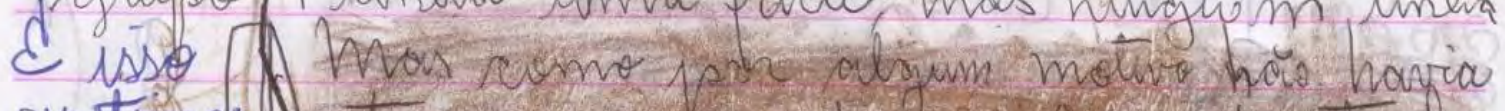

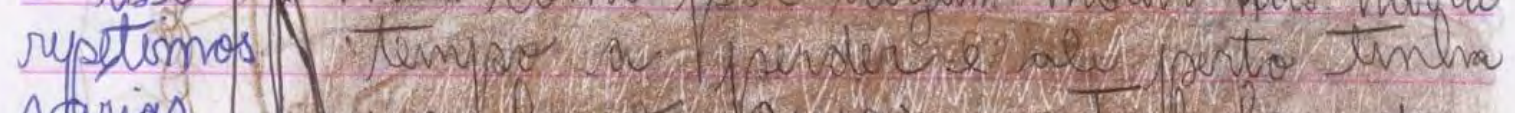

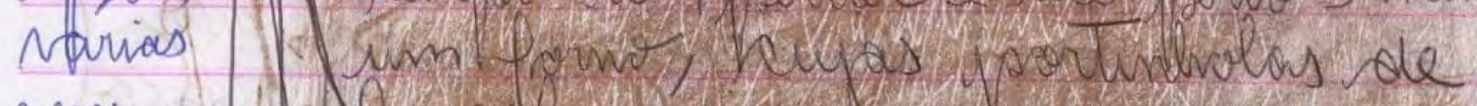

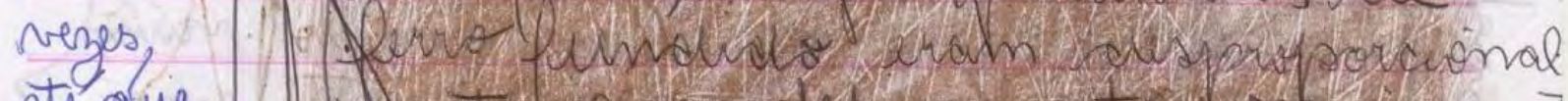

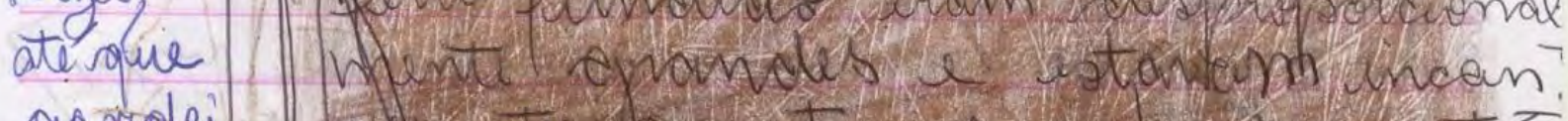
acovolei, Wâ No.

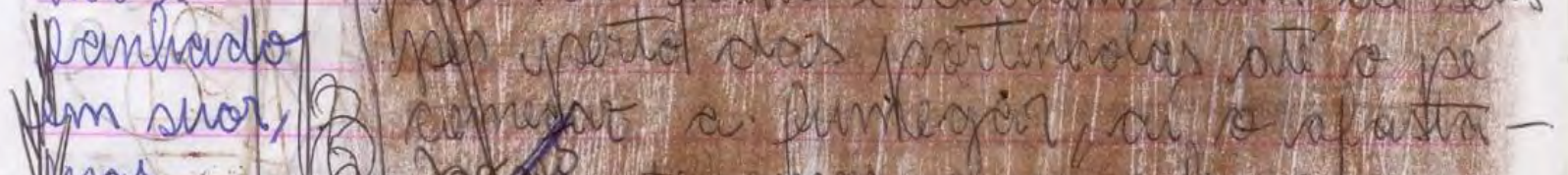

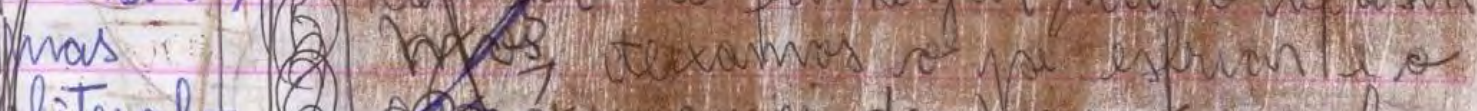

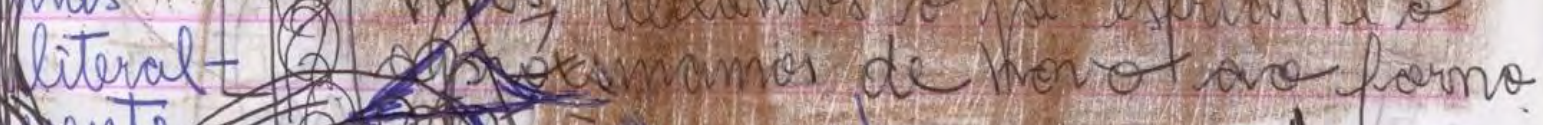

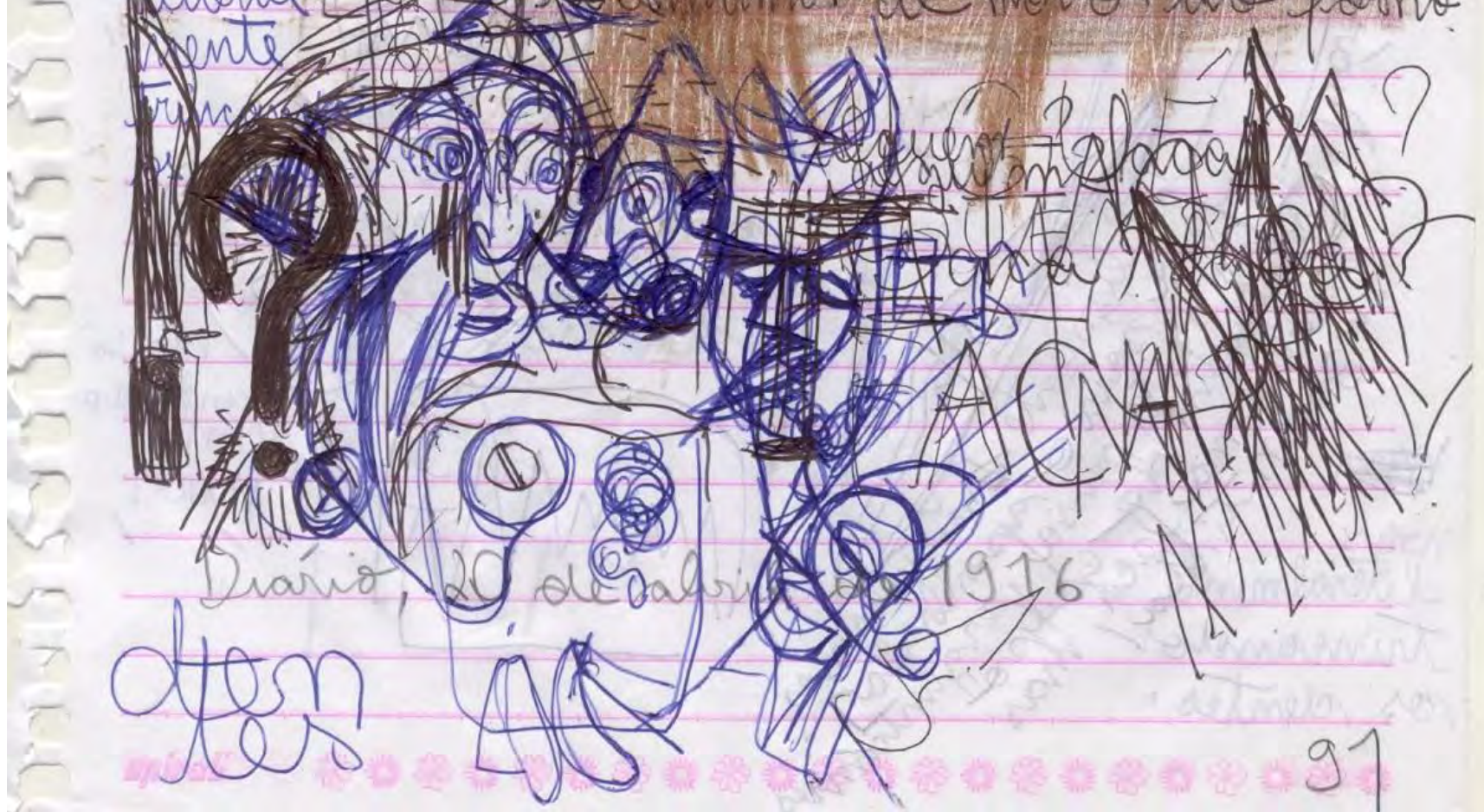




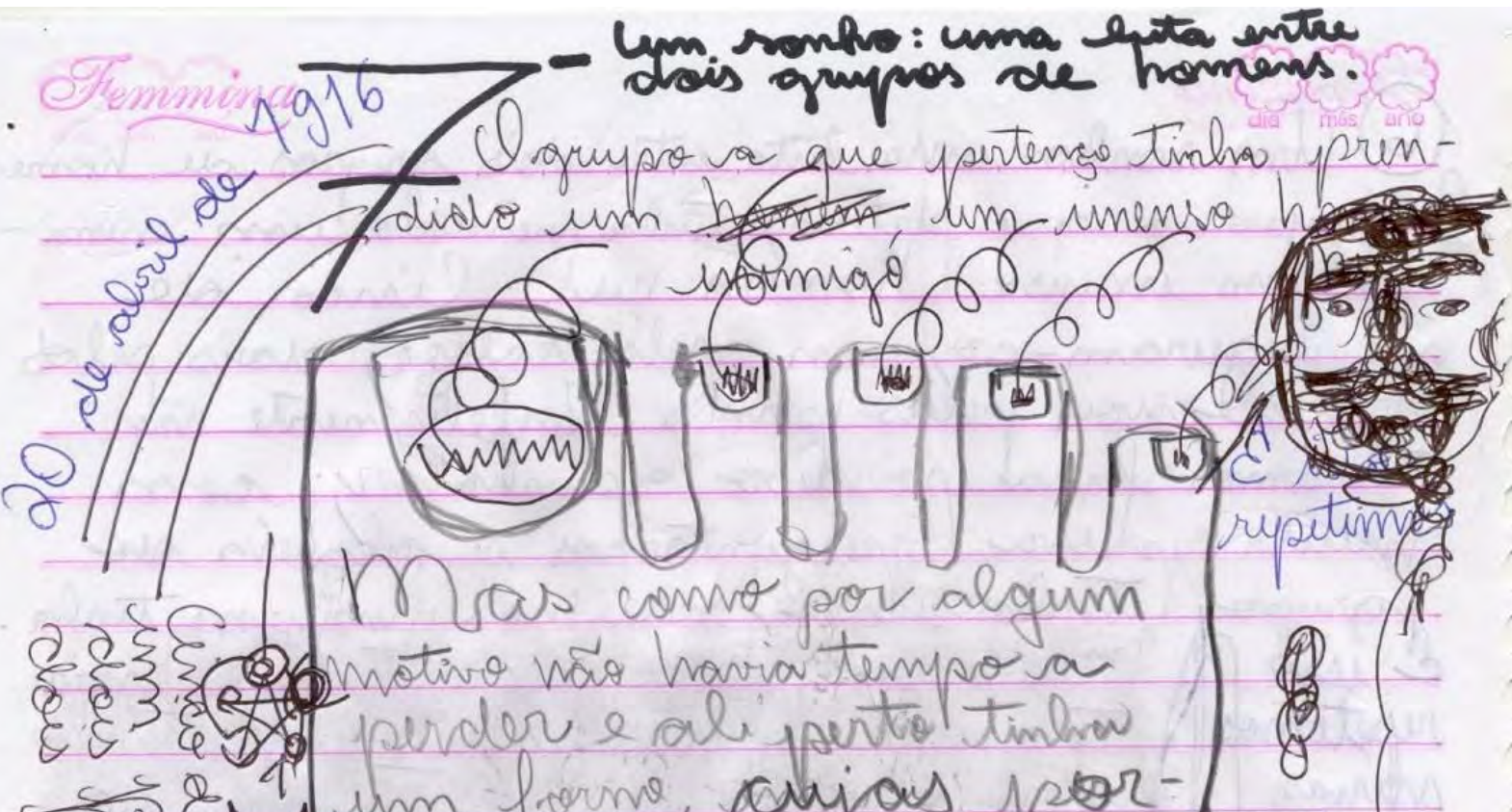

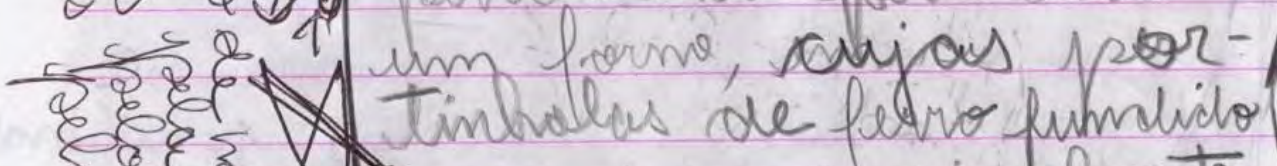

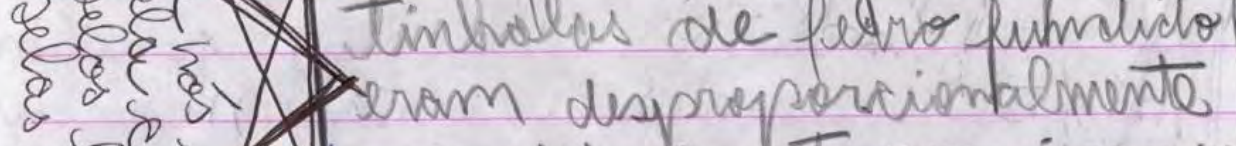

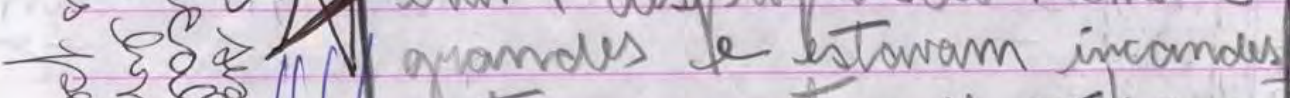

Es a centes armantanns o nomem

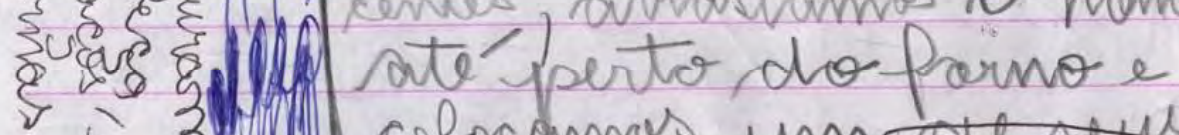

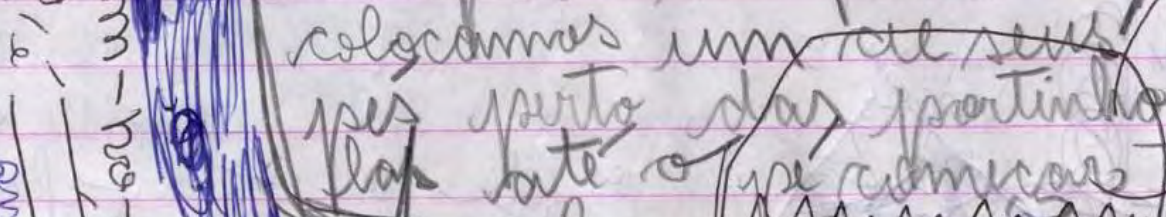

- 1 .

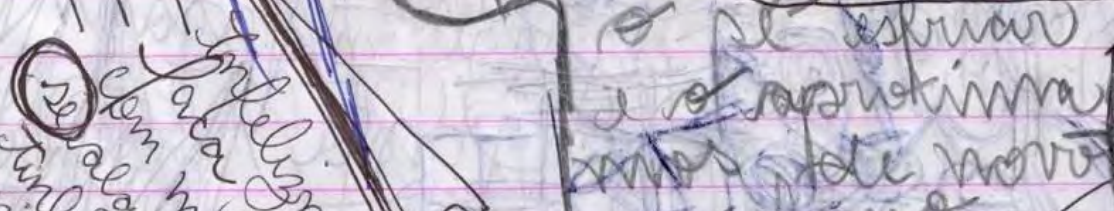

várial

vezes,

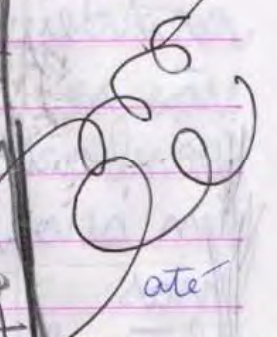

H. Sur acor- 


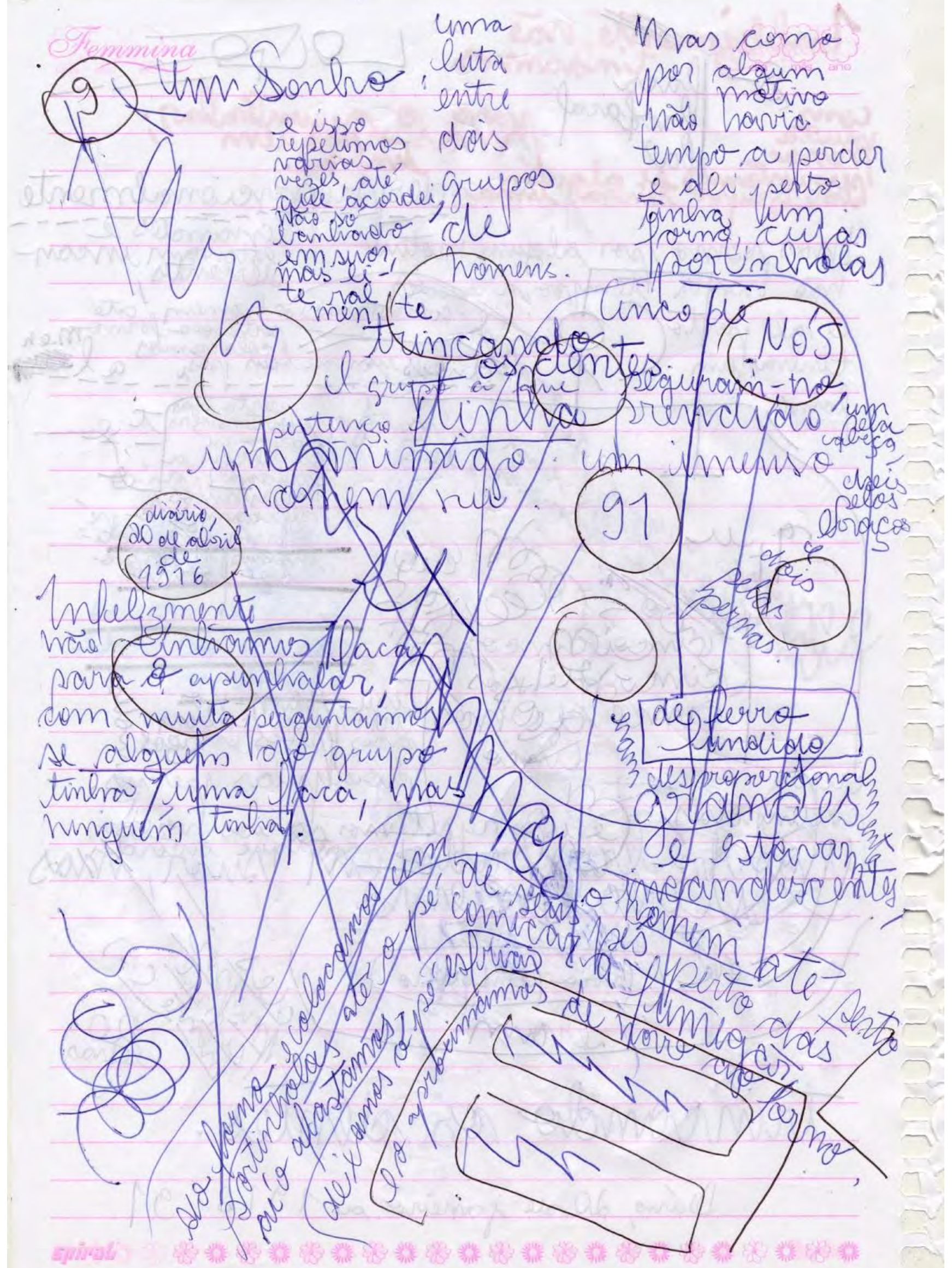




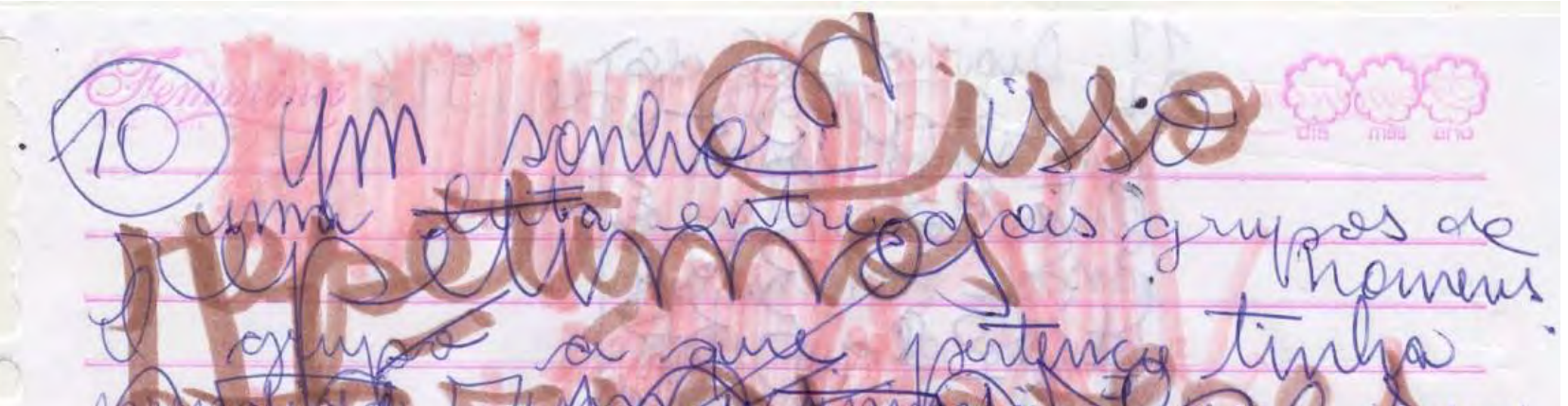

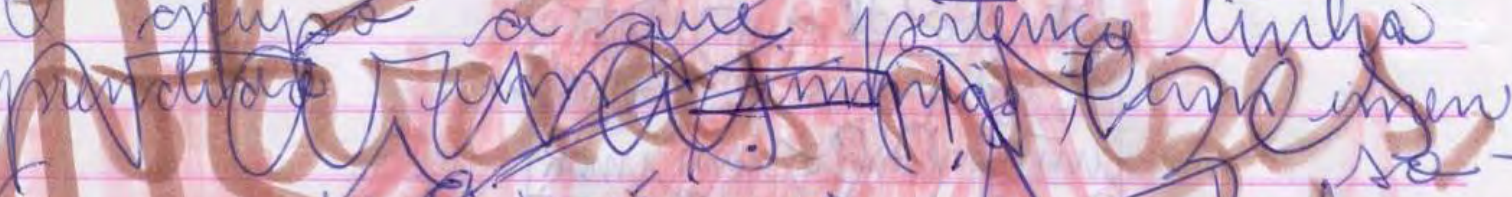

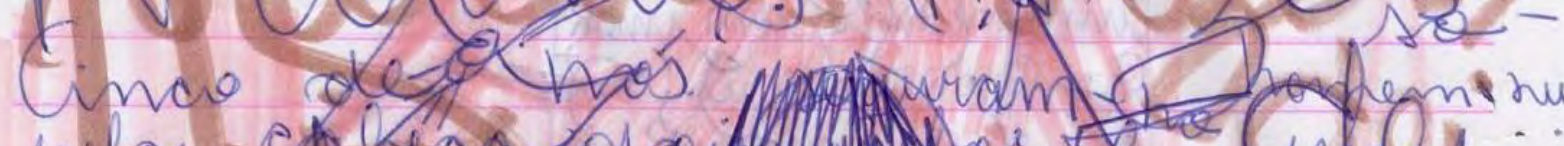

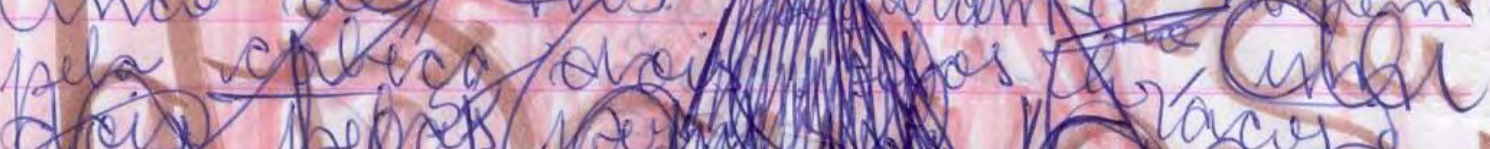

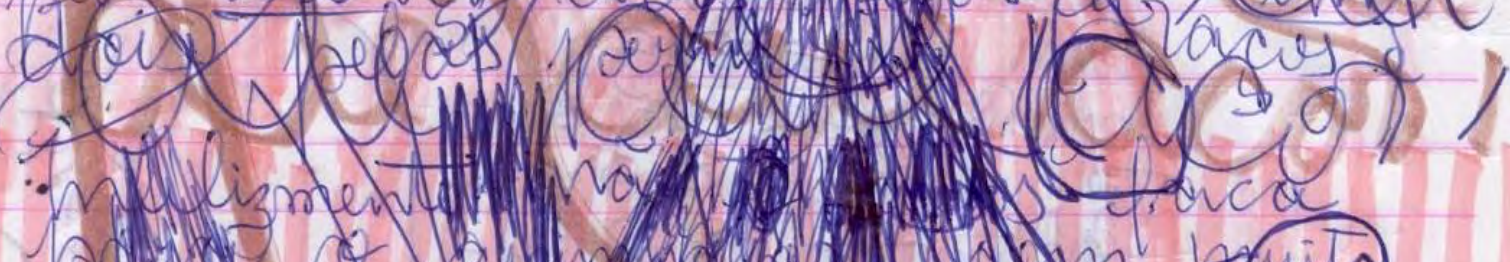

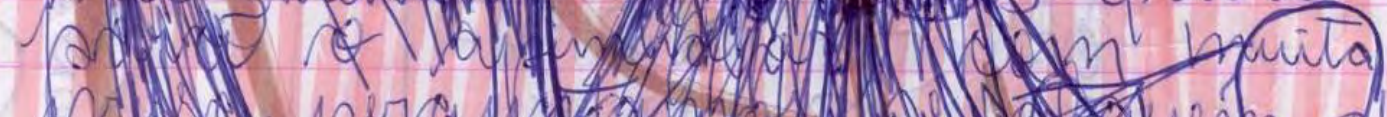

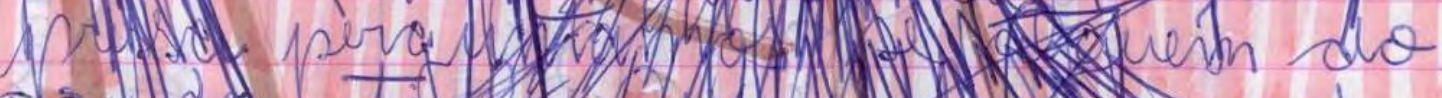

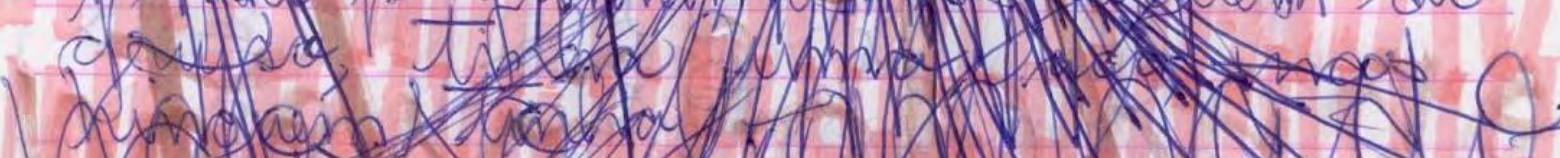

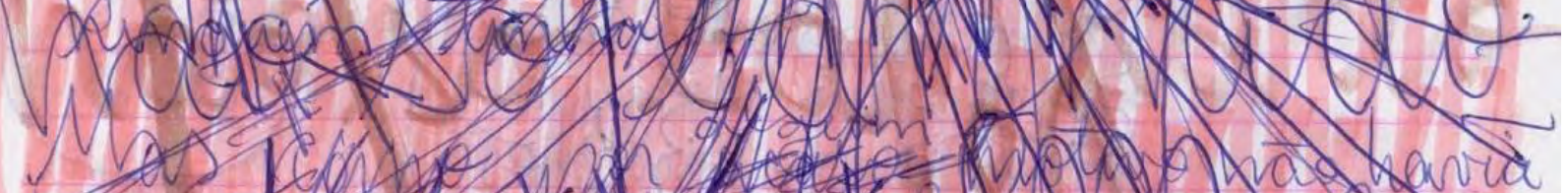

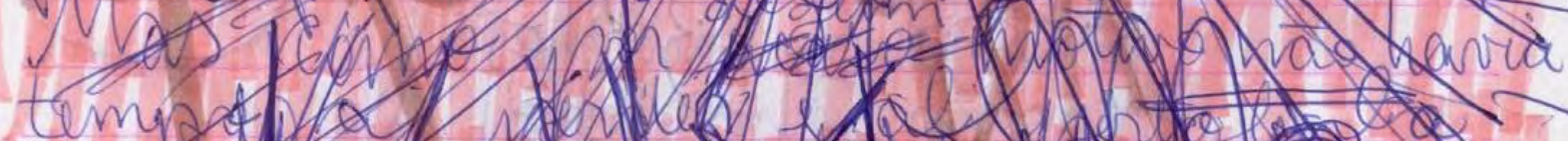

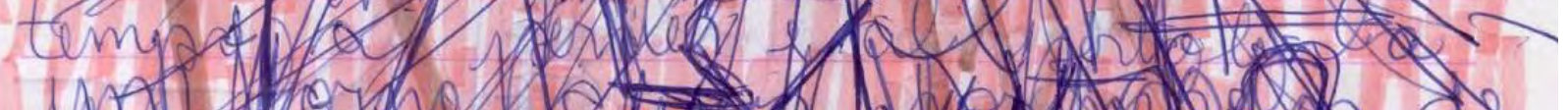

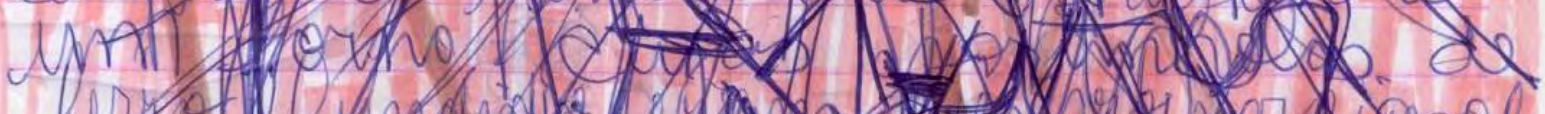

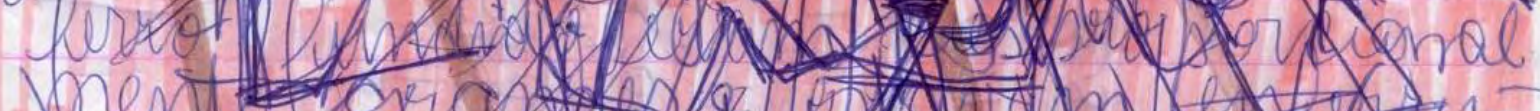

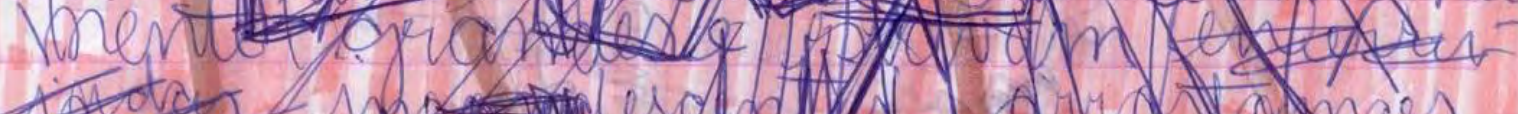

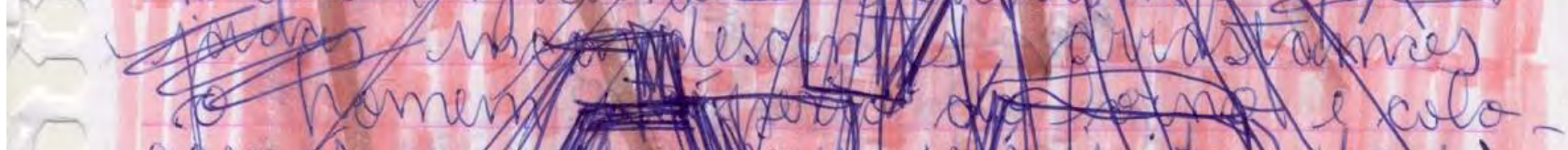
commos 1 inf

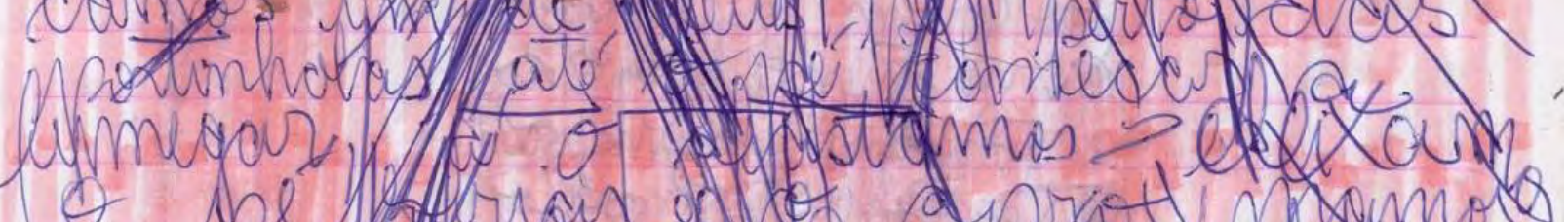

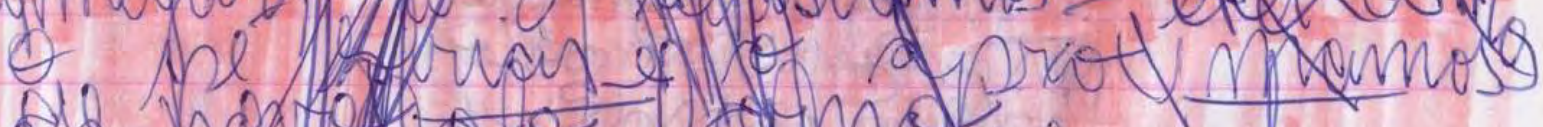

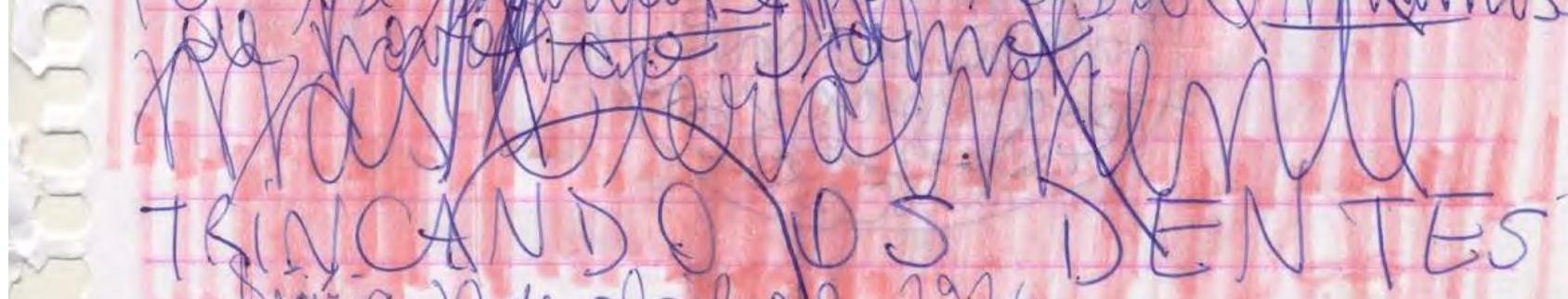
Diania so de aloil de 1916 


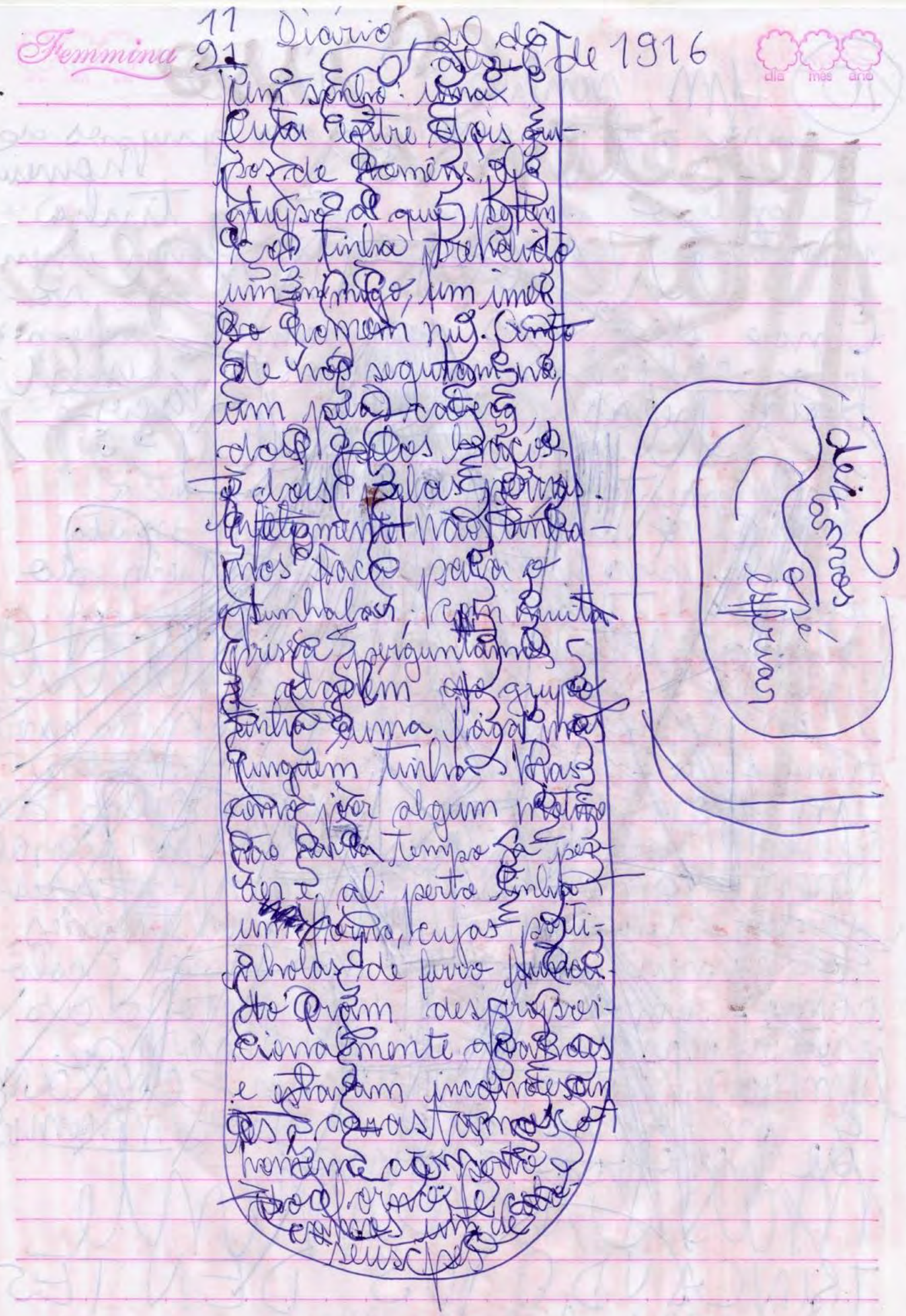




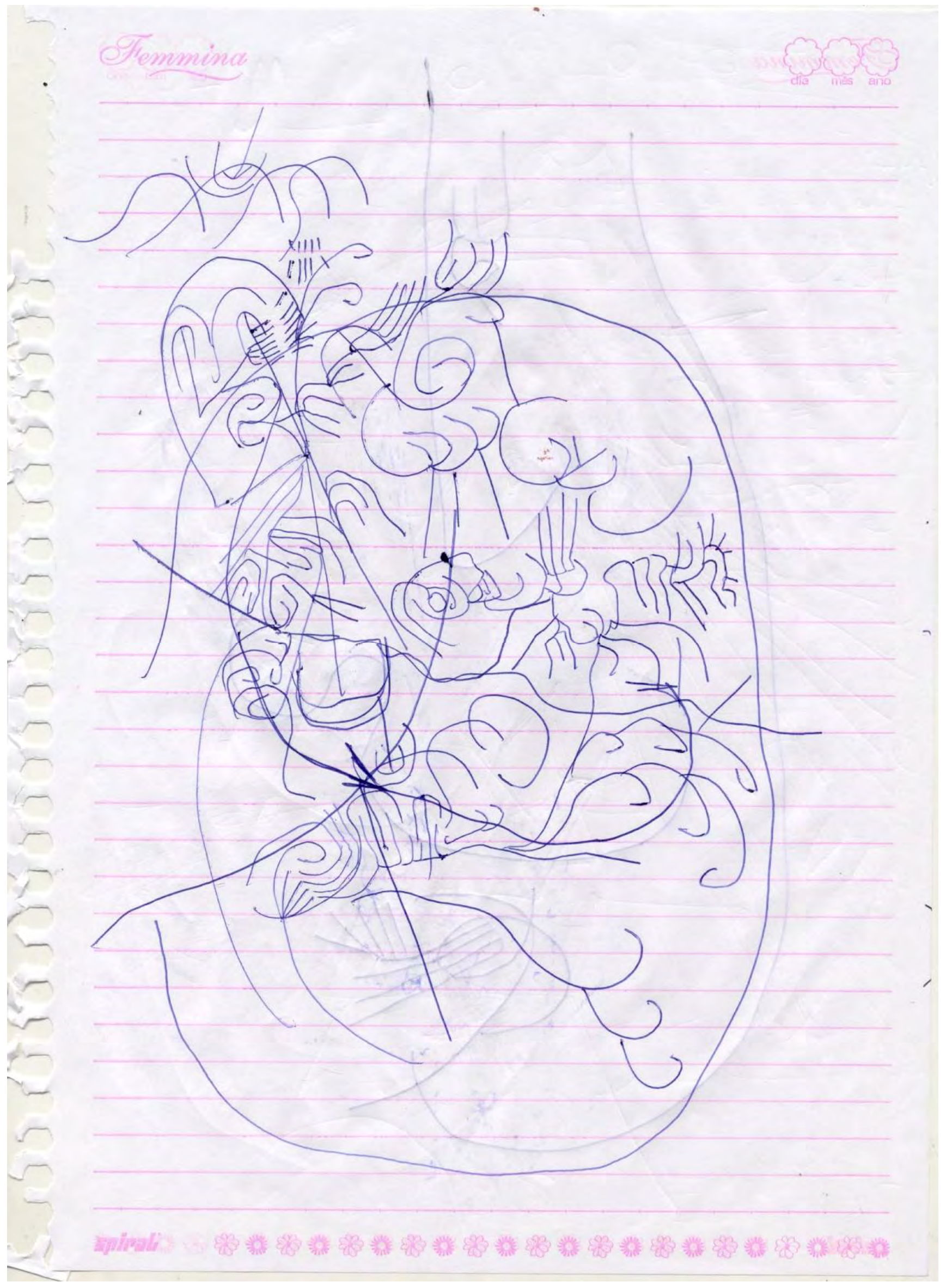




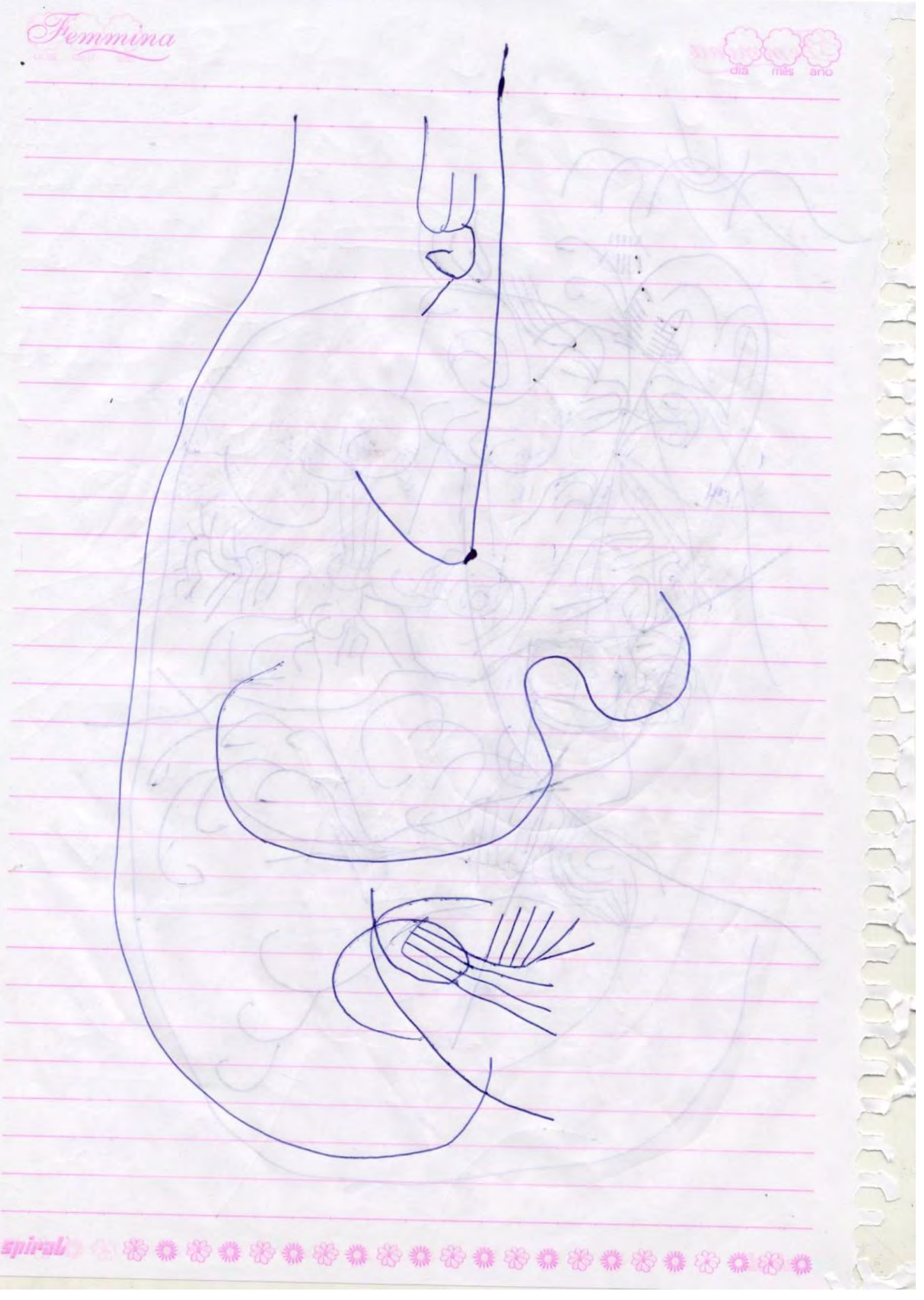


379

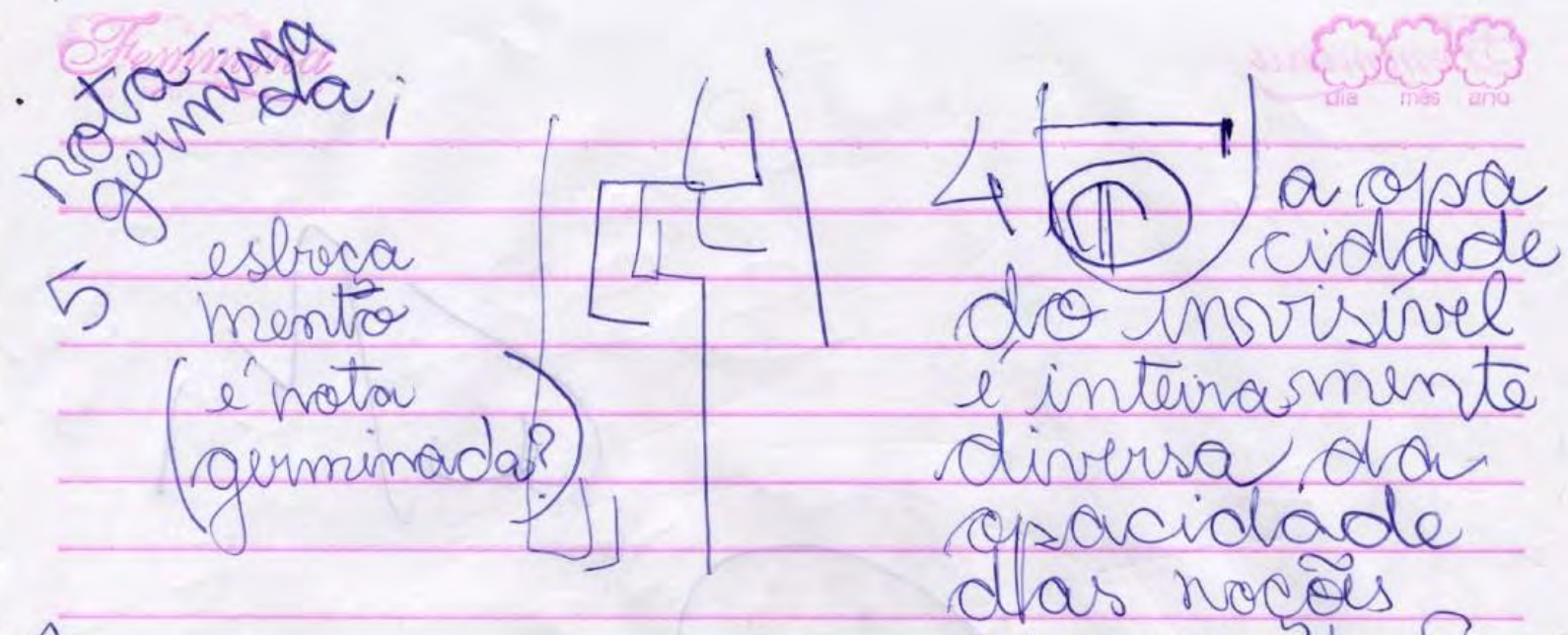

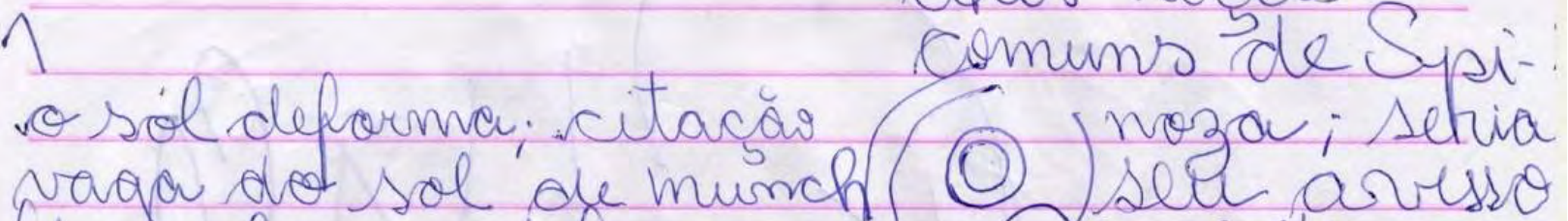
Im sol que deforma. Sou ainda arsis
2 ovós esse soncho da luta l tortura plorece que algo escapon y por debáivo se reorganizor...

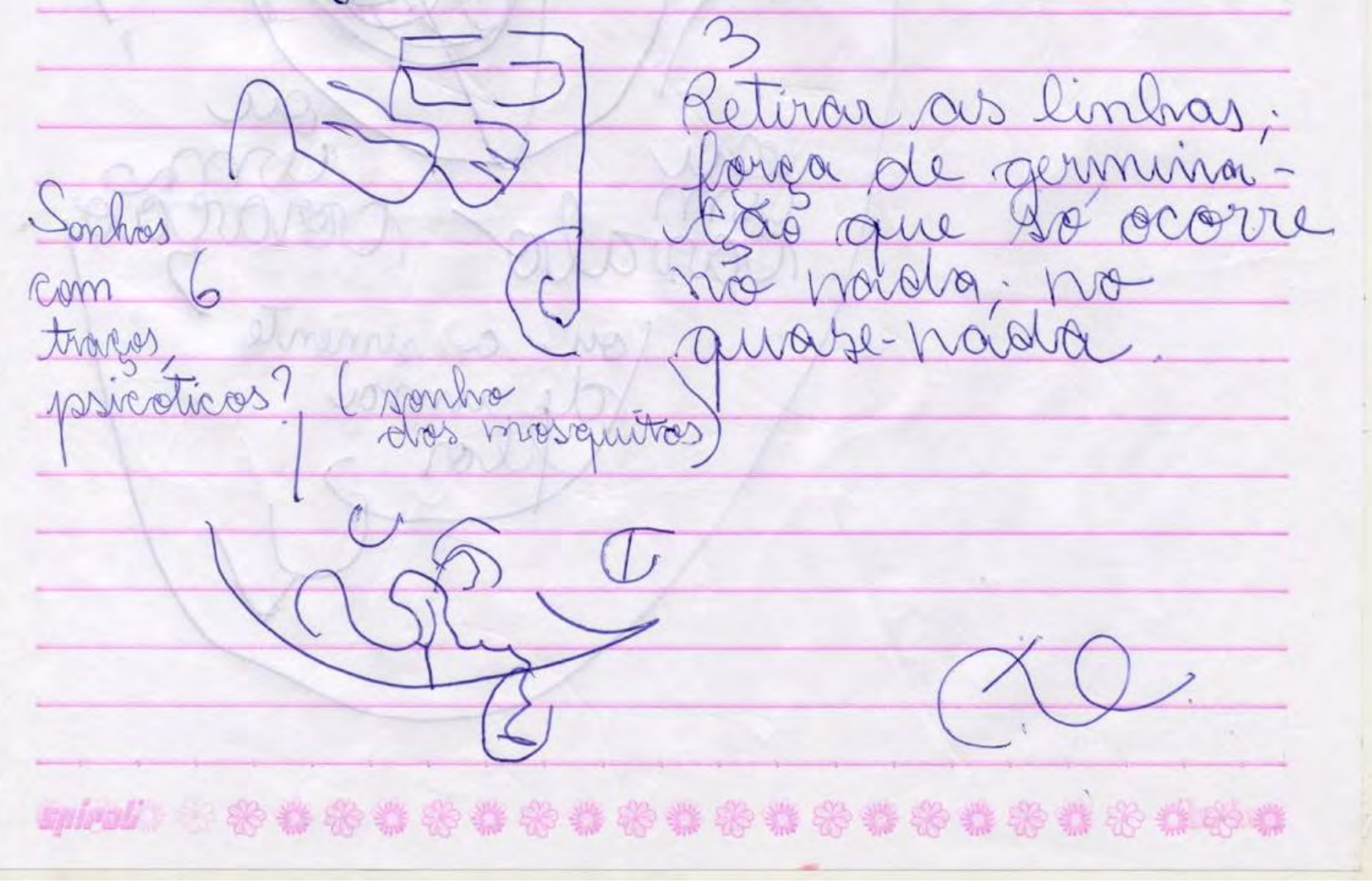


O que se passou aqui foi algo bem importante. Por isso mais páginas neste sonho do que em outros, para o corpo da tese. Eu gostava de ler este sonho durante o estágio das Caldeiras: ele teria sido minha terceira escolha (o sonho a se decorar). Em verdade, para a terceira escolha eu oscilava entre este e o sonho da carroça. Este é um sonho tão angustiante de ler que sua escrita foi um lançar-se um pouco autista a um frenesi do guerra, fuga ou medo. Quando dei por mim, eu estava entregue a uma espécie de fervura sem solução. Então eu tive vontade de apenas tracejar, não mais pensar em nada. Era preciso deixar de pensar. Então foram 'cuspidos' os esboçamentos (os dois últimos, havia ainda um coração-cavalo, mas me pareceu variação destes, não tão importante para esta aqui), dentre os quais, o último é uma anotação que chamei por 'nota germinada'. Aqui se passou algo muito importante. Pois é uma linha que tenta materializar um fragmento de consciência daquilo que se deu. Eu tenho lembrar daquilo que se deu, que se passou, e forçou uma gigantesca despressurização das páginas. (quinto sonho inscrito nas páginas) E que estranhas personagens são essas?

Lembrei de alguns elementos de improviso, como uma sentença típica do Janô: 'do grito primal ao silêncio abissal', ou ainda um procedimento, uma região do encontroensaio-laboratório, que vem a ser 'o laboratório do desaquecimento'. É um laboratório onde, grosso modo, deixamos o corpo em contato com ele mesmo. Esse laboratório encadeia ou deveria encadear com as anotações, justamente, em caderno.

Na última repetição da transcrição deste sonho, do inscrever, do desenhar das letras do sonho, das linhas do sonho kafkiano, desta estranhíssima caligrafia, percebo que se formou uma espécie de bolha talvez prestes a estourar (terceira página desta série). As linhas escritas de diferentes grossuras se cruzam, como um algodão cru ou a pele de uma cápsula de tecido vivo, mais ou menos dormente, mais ou menos pulsante...

Aqui emergiram figuras. Mas com relação ao sonho do irmão, que foi o último que trabalhei de todos, neste houve esse procedimento mais autista e depois essa liberação do cálculo. E mais uma vez, dou-me conta de que é o corpo que desenha, o corpo que canta, o corpo que respira etc. 
8.

(p. 99)

Desvencilhou-se do resto do grupo. Foi envolvido pela névoa. Uma clareira redonda na floresta. O pássaro Fênix no mato. Uma mão fazendo o sinal da cruz num rosto invisível, sem parar. Eterna chuva fria, um cântico instável como de um peito arfante.

Diário, 30 de julho de 1917 
382

Themmina

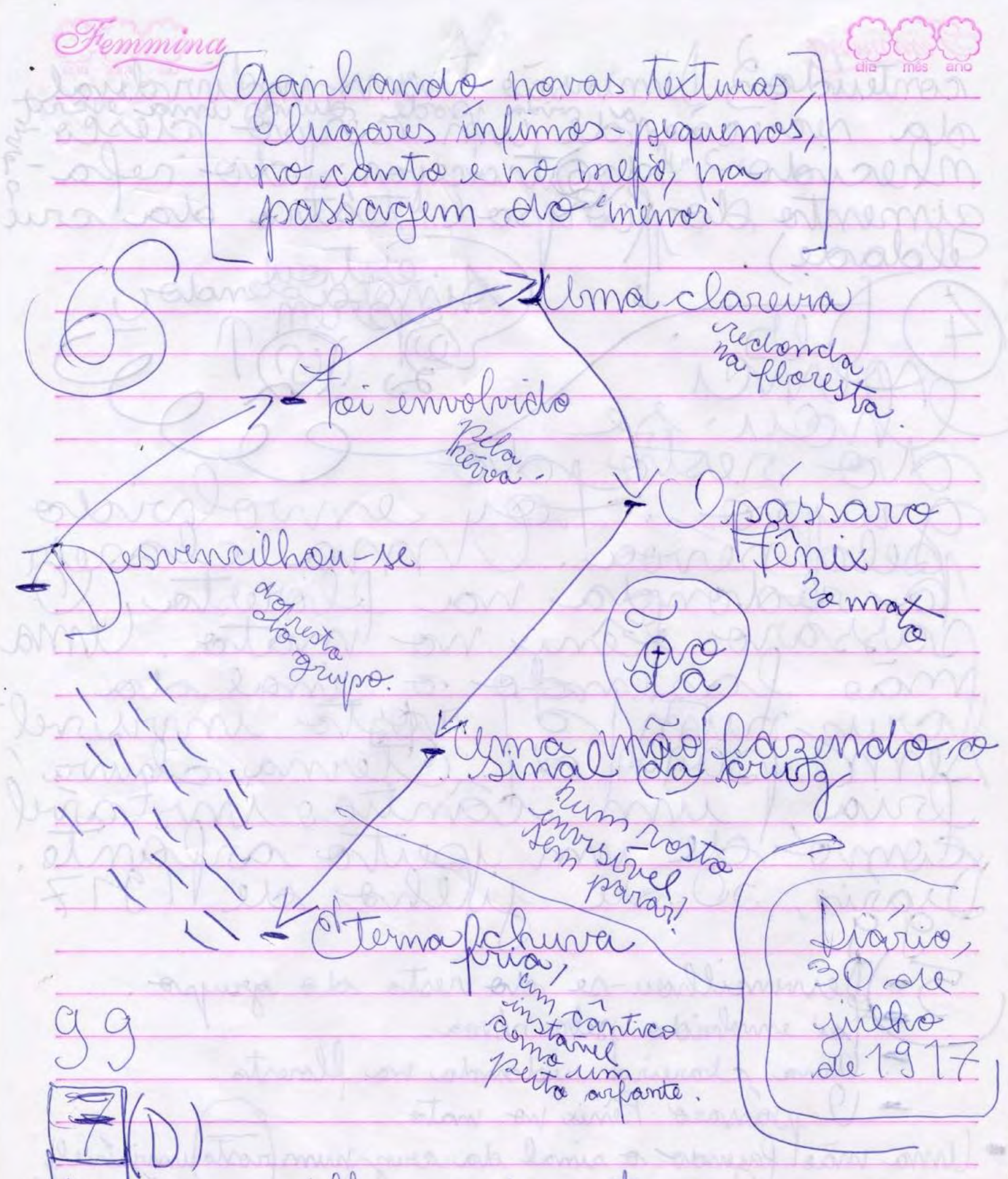

W elsmencilhow se do resto do aruyso (E)

foi envolvido yela névora 
383

desnencilhan-se do resta do grupo fai envobirdo (U) sela névoa una clareira (O) redonda wa unta clareira redonda na floresta o pássarvo Lloresta o pás (U) savo Pê ( ) nix wo mato uma Eênix wo mato uma mäo fazendo o sinal da mão lazendol. o sinal da crun hum ros (E) to cruz rum rosto inviswel sem parar eterra invisivel sem parar eter (,) na chu (.) va fria chuva friva um cântico instárel camo um cômtico (,) ins (D) tável como um peito un peito arfante diário 30 de jultio de arfante diarwo (-) 30 de (j) julho de 197799 191799

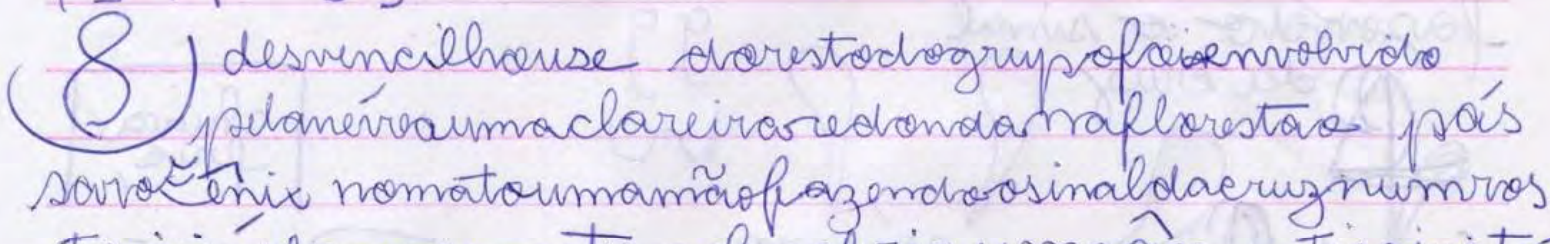
tarinisivelsempavareternachuvafriaumcôn ticoinstá veleomoumpeitoarl ante diório 3 Adejueho
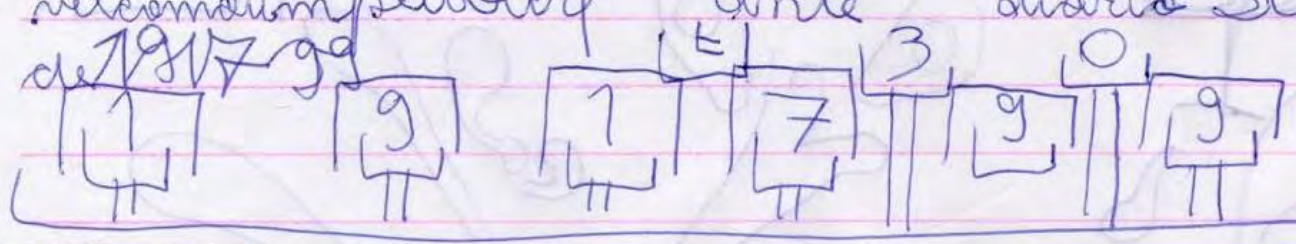

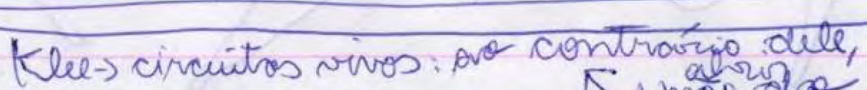

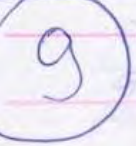

(U)

for envolvido

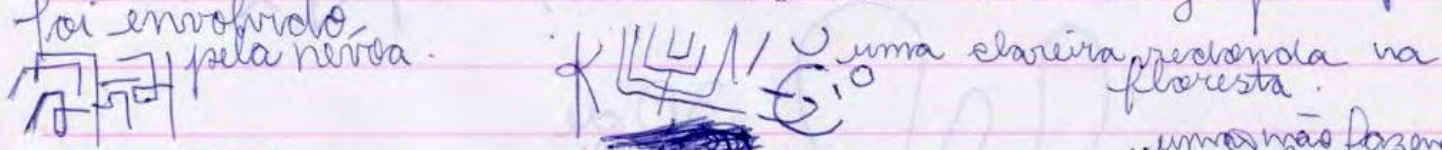
desnenciehou se do resto evo grupo. projeto!

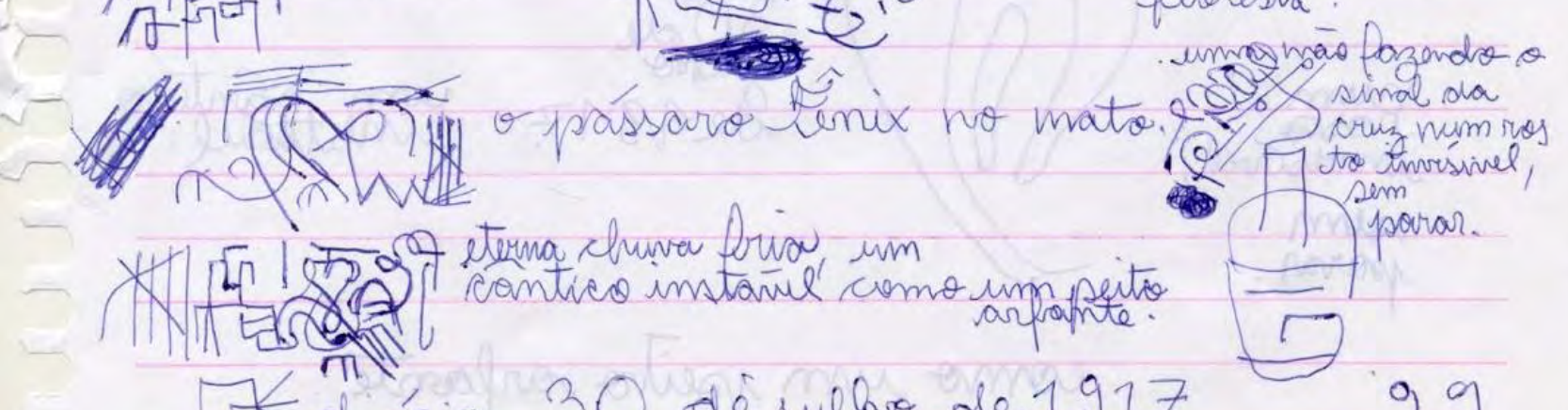
7 diónio, 30 dé fulluo de 1917 99 


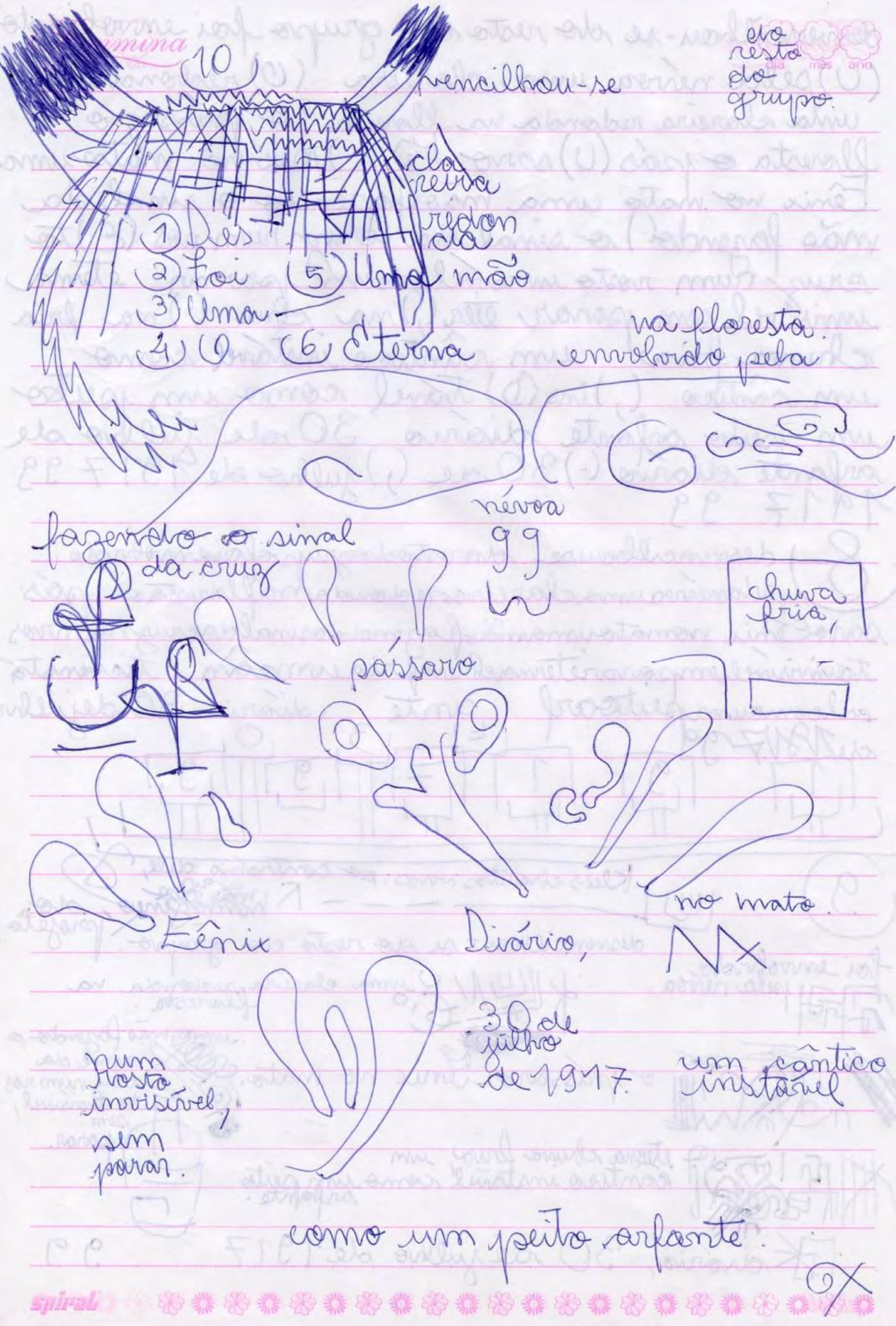


O sonho mais compacto e fragmentário. Ninguém sorteou este, mas gostávamos de usá-lo às vezes. (sexto sonho reescrito)

Sua composição fragmentária traz outras possibilidades de entrada. Mais uma vez, não sei. Parece um hieróglico, na medida em que são ideogramas. Aqui aparecem, são postos em relevo (bem como em outros sonhos, mas aqui mais) os jogos de numeração. Numeração de palavras, frases articuladas, jogos também de despontuação e re-pontuação, de filtragem de segmentos. Alternância de linhas cheias e vazias e ritornelo sobre a mesma página, onde as linhas vazias são ocupadas (etc analogamente ao laboratório da página detalhado no mestrado). Então há algumas classes de jogos. Uma outra é a simples espacialização de imagens na forma de uma planta ou mapa (aqui me ocorre tanto a ideia de mapa-mundi do Janô como noção de espacialidade inerente à dramaturgia narrativa, noções expostas por Maria Thais) (exemplo de planta ou mapa na primeira página desta série).

Sim, o caderno é um ateliê mínimo, um ateliê dobrado. Muitas coisas acontecem. Nos jogos que ora se dão, jogos não se saber sob vontade de quem, dificilmente uma vontade solitária (penso agora que Rousseau jamais esteve solitário em seus devaneios, antes o contrário), penso que as aulas de Silvio Ferraz auxiliaram muito. Ele faz diversos desses mesmos jogos. Com os corpos das partituras musicais e suas inscrições físicas em coincidência. Com fabricações, poemas, objetos operativos ou evanescências trilhadas-registradas (gesto coincidente) - cantos dos pássaros, caminhadas, etc. 0 Silvio me ajudou a entender que devemos ou podemos trabalhar em ateliê quando compomos, em atitude viva, com algo. Não sei se temos escolha... quando digo 'podemos', digo que se pode reconhecer uma propiciação de potência. É sempre 'depois'. É mais rápido e também infinitamente lento. Estamos no entre. Sou um ser do 'entre'.

Na última folha desta série, o pássaro-fênix apareceu em estilhaços mínimos. Apareceu antes de aparecer, e então eu só tive de obedecer suas instruções. Já aconteceu algo assim com você? A página e os seres que ali aparecem, vez ou outra ensinam e exigem coisas. 
9.

(p. 139)

Chegaram sonhos, subindo o rio, subindo a parede do cais por uma escada. Paramos, conversamos com eles; eles sabem muita coisa, mas não sabem de onde vêm. É muito amena esta tarde de outono. Eles se viram para o rio e erguem os braços. Por que levantais os braços ao invés de nos abraçar?

Fragmentos de cadernos e folhas soltas, sem data 


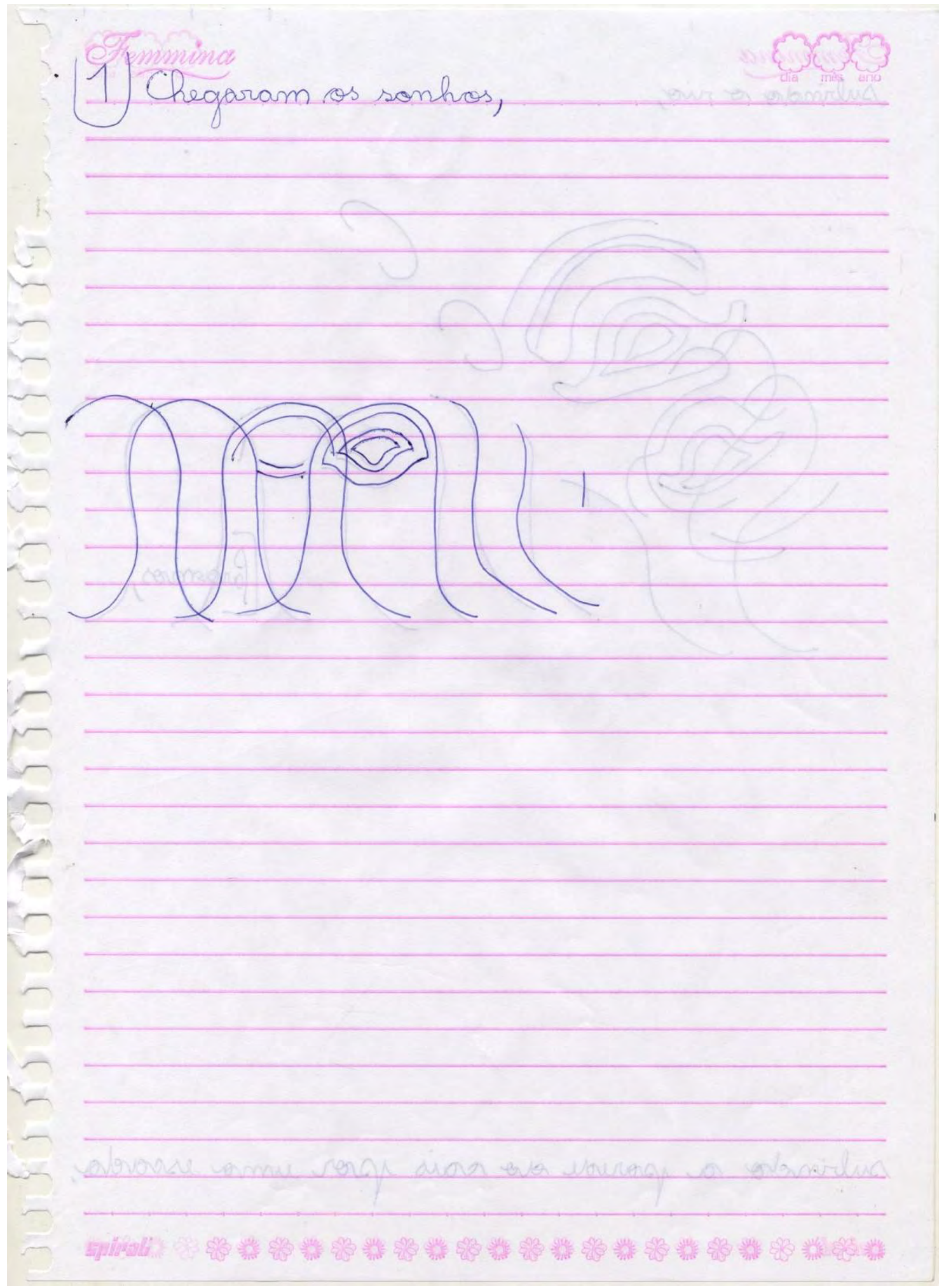


Themminat

- subindo o rio,

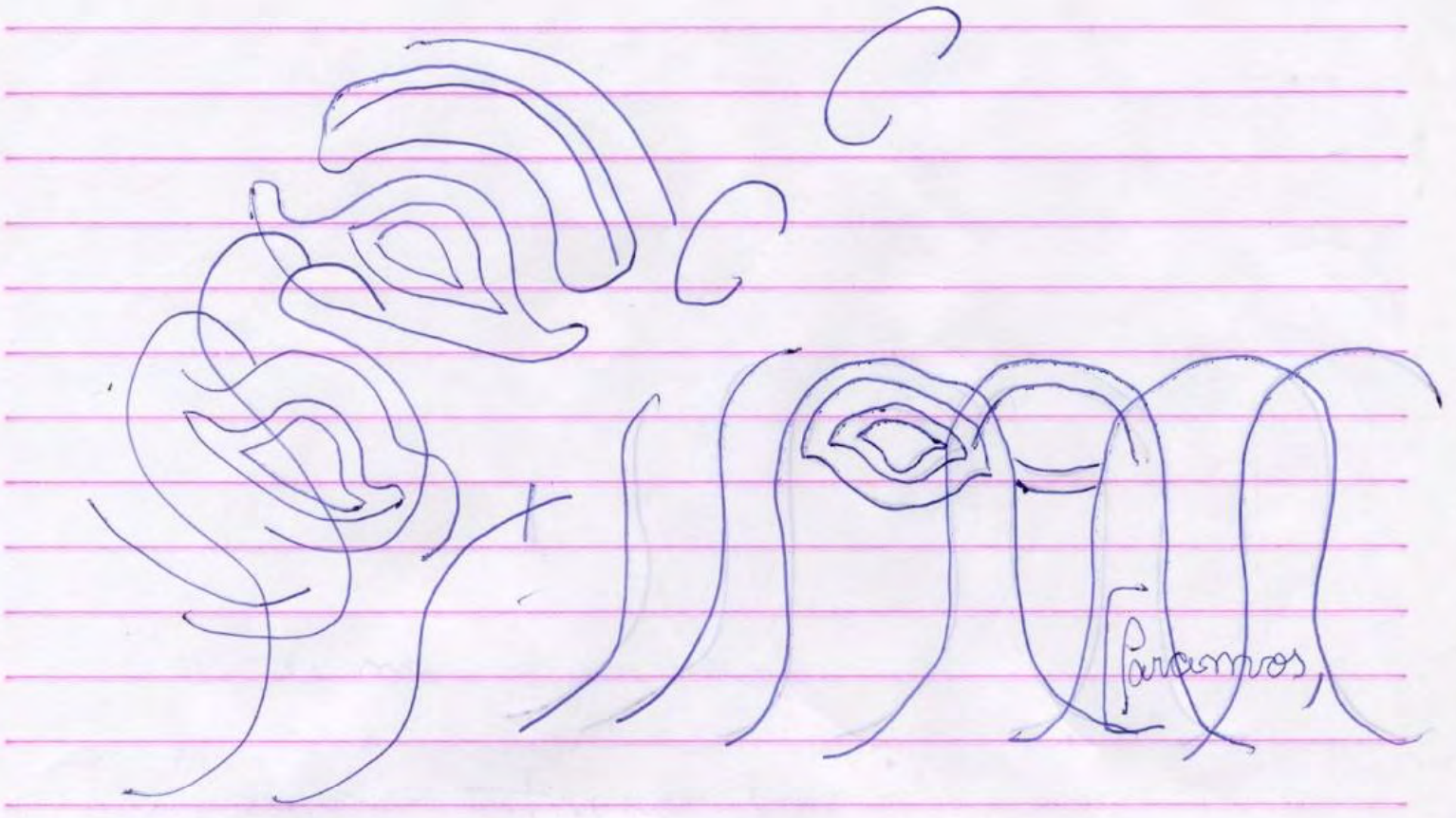

subindo a parvole olo cais par unvo escavela.

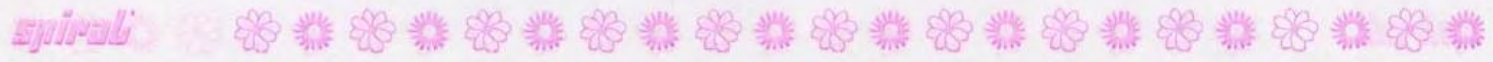




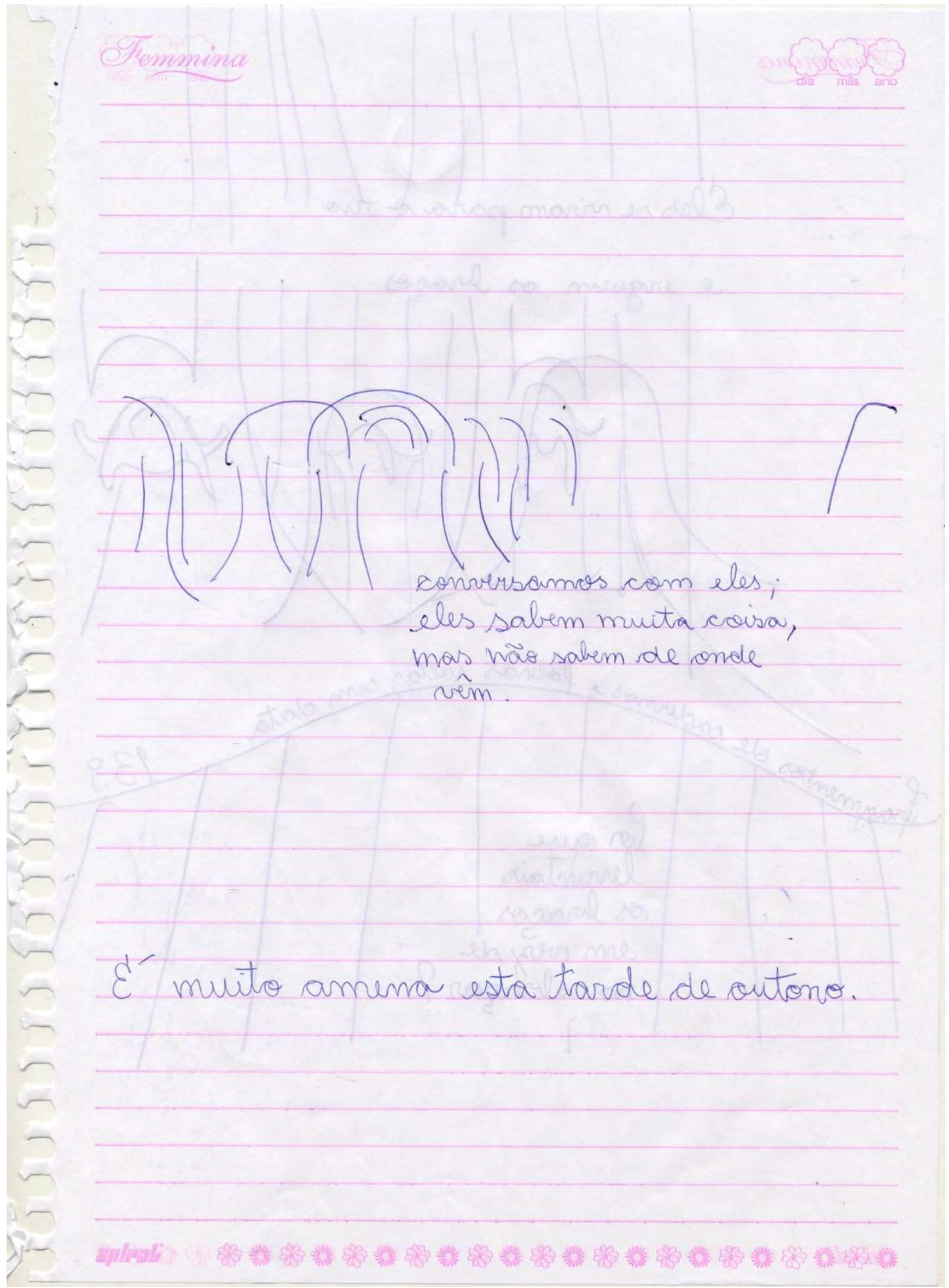




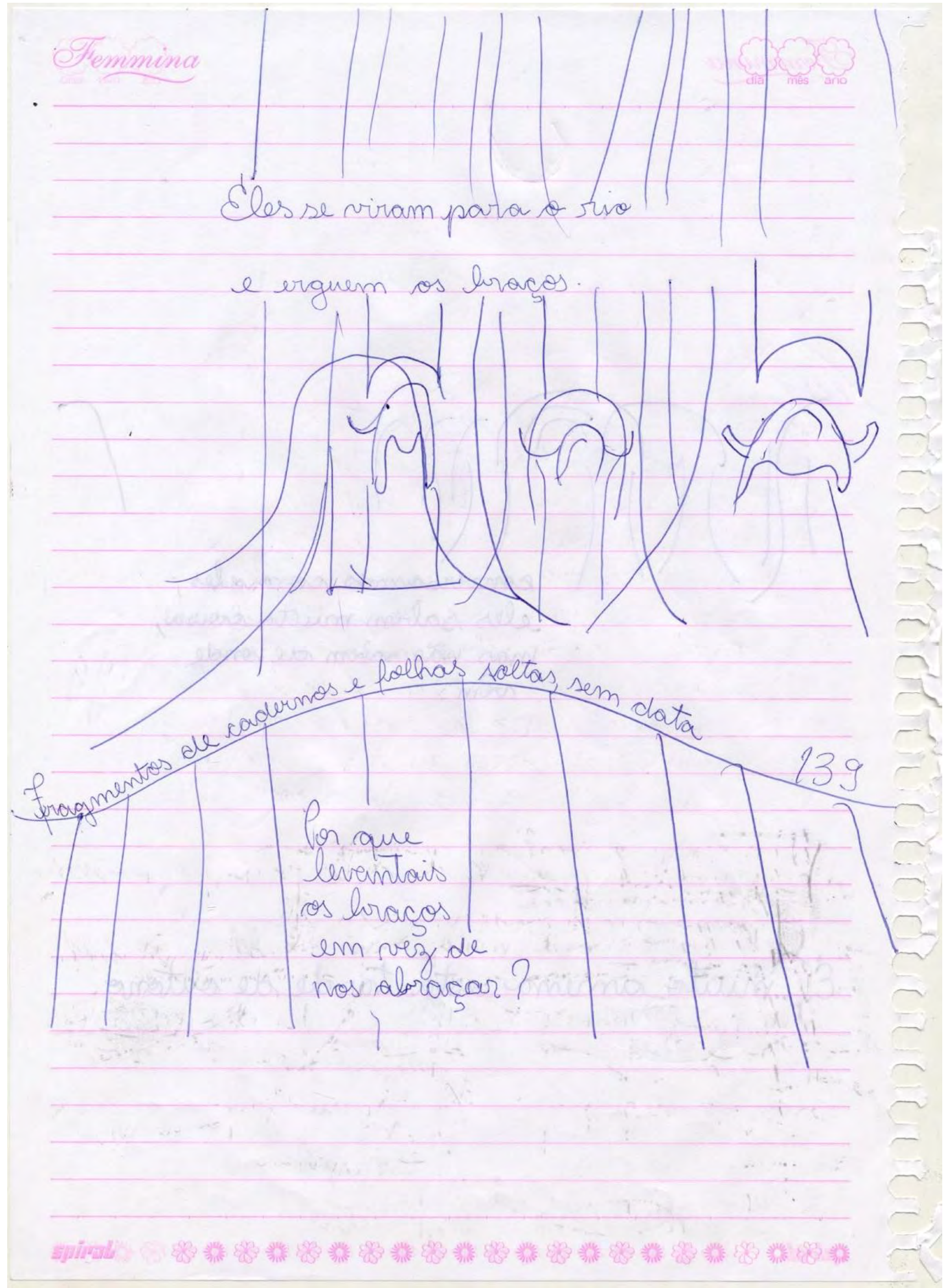




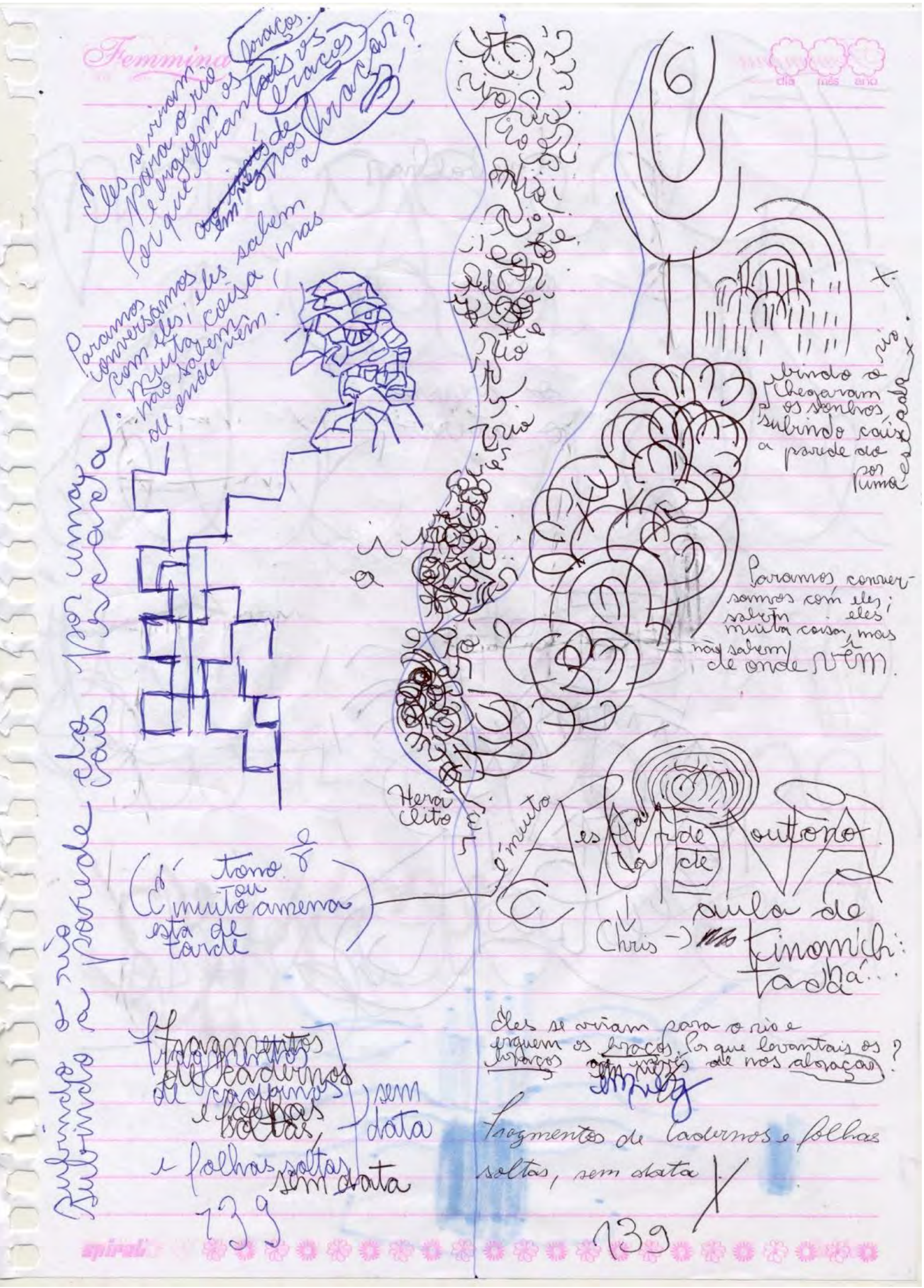




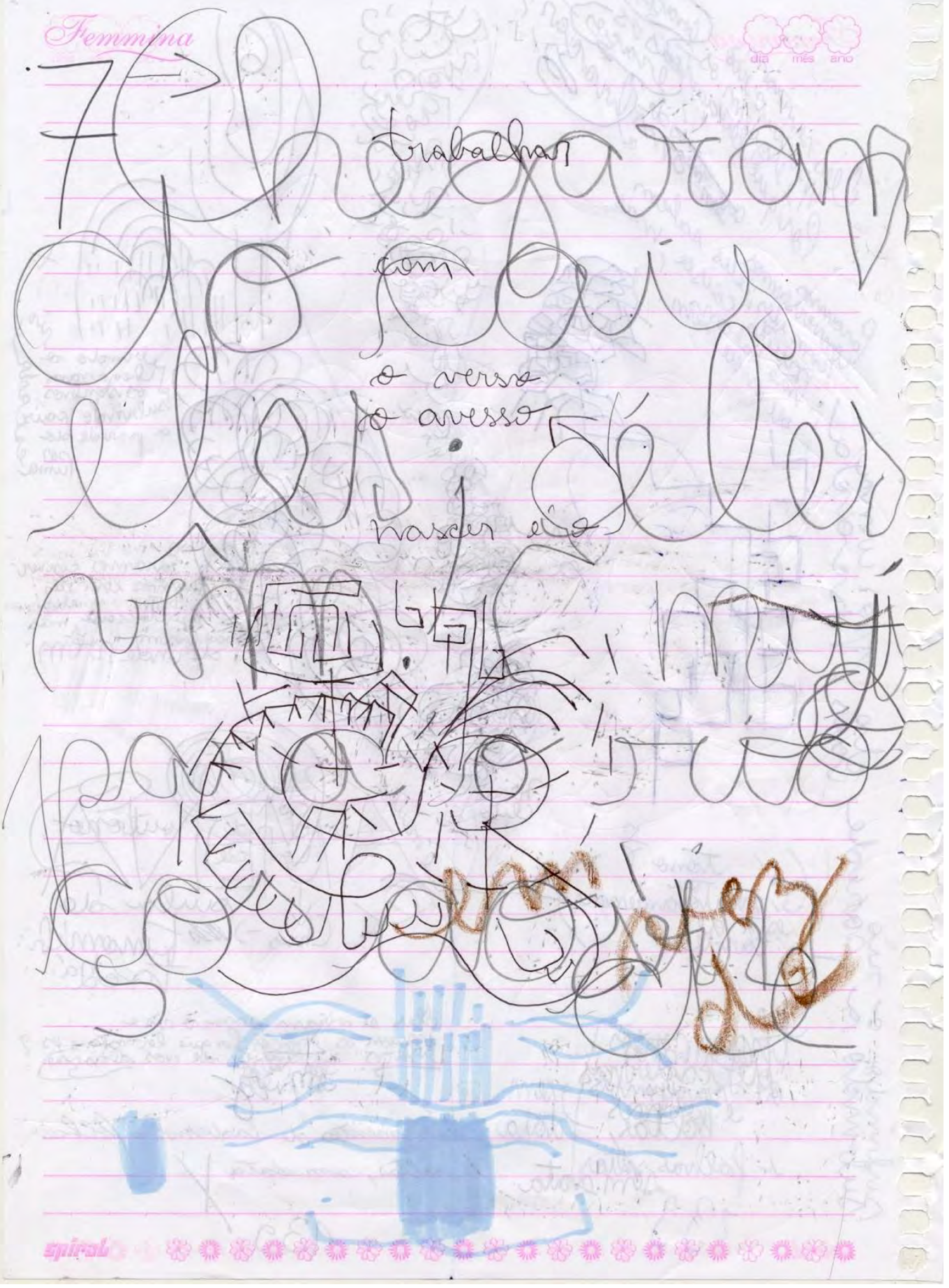


393

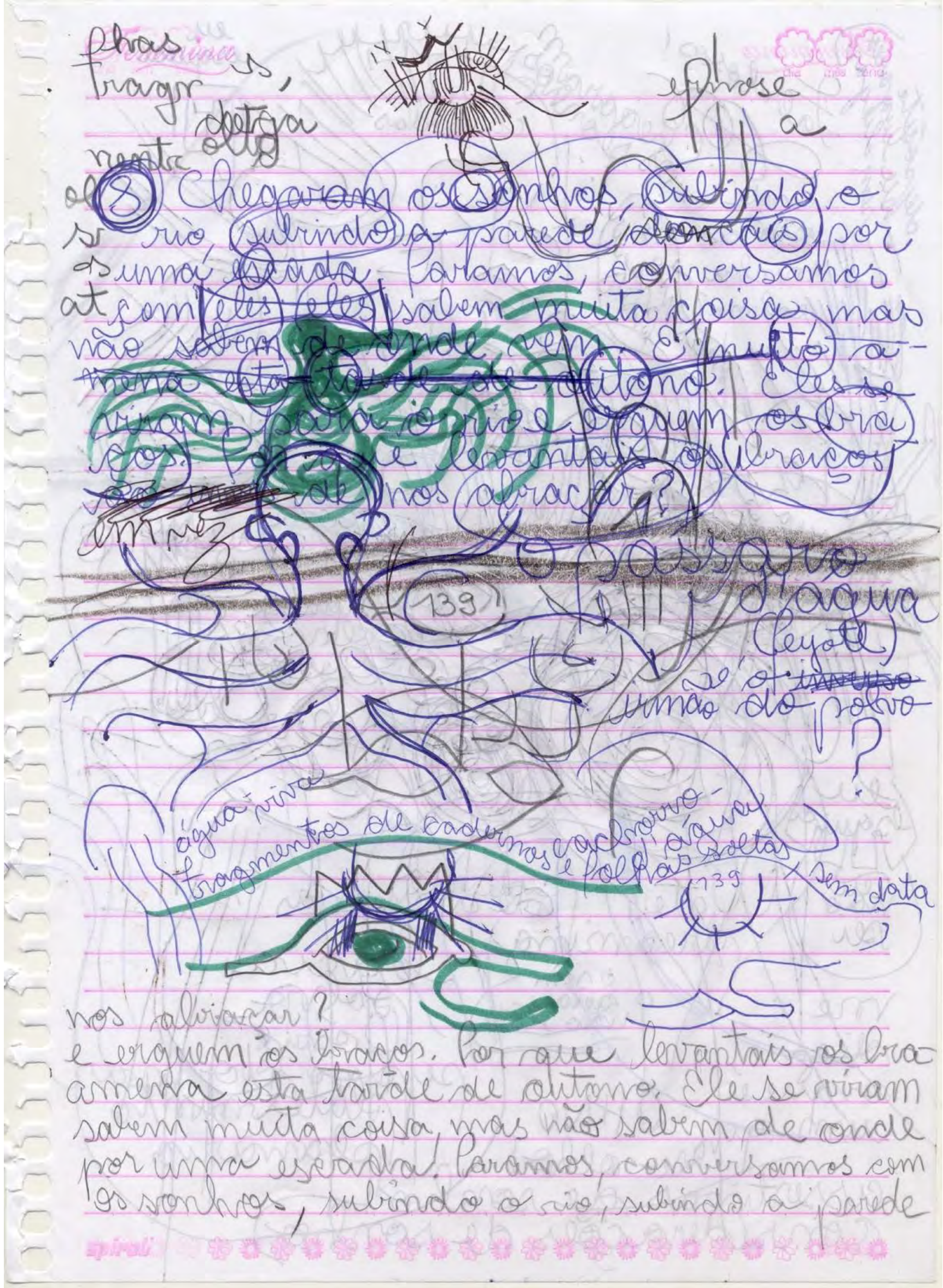




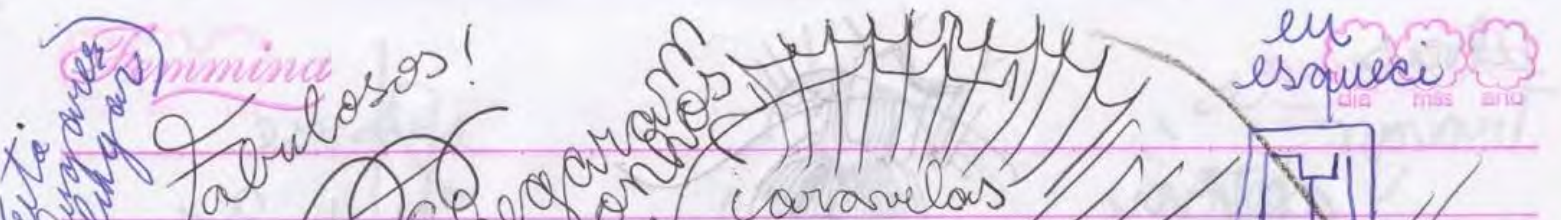

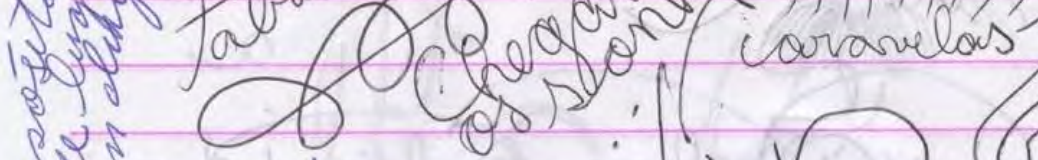

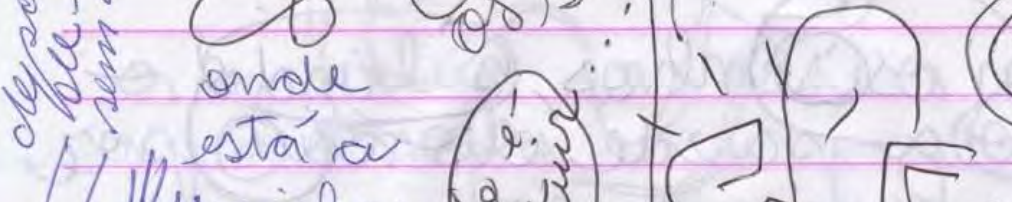

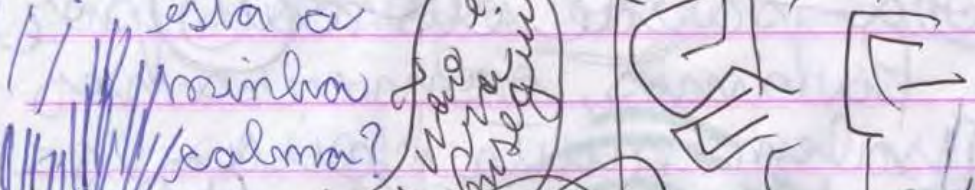
4 (1) $1 / 1 / 1 a^{\circ}$
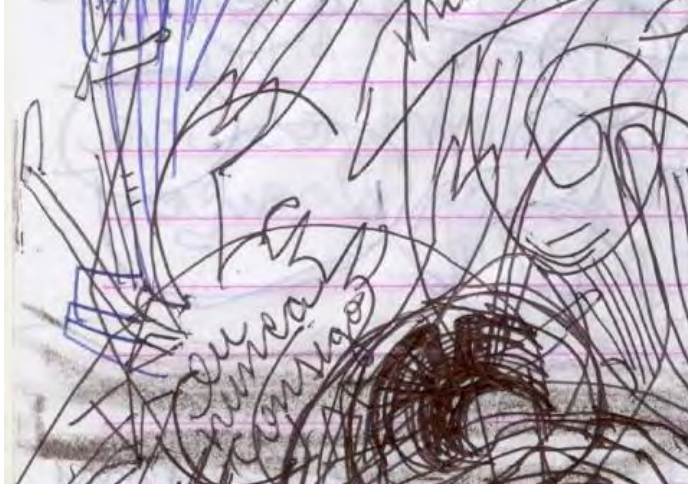

tur

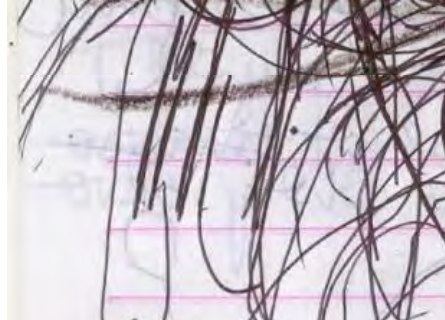

ingurfot

an 1

nais 1 ged

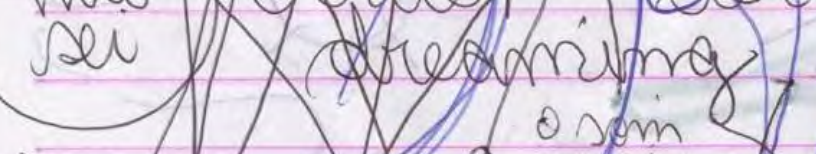

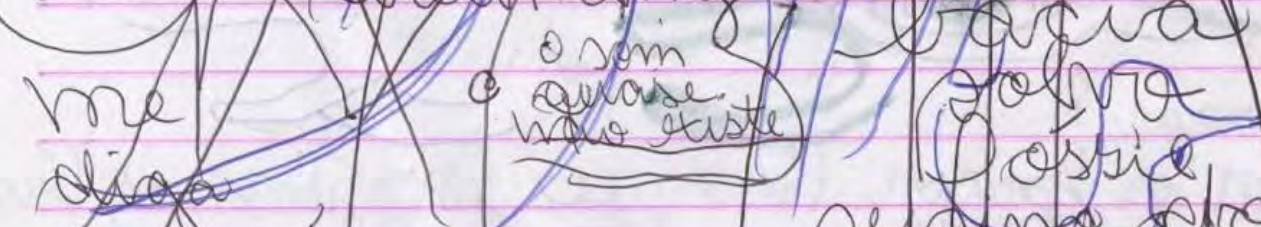

N

o prie

assertinitas olfo sonles consideracaes de sonhos 
395

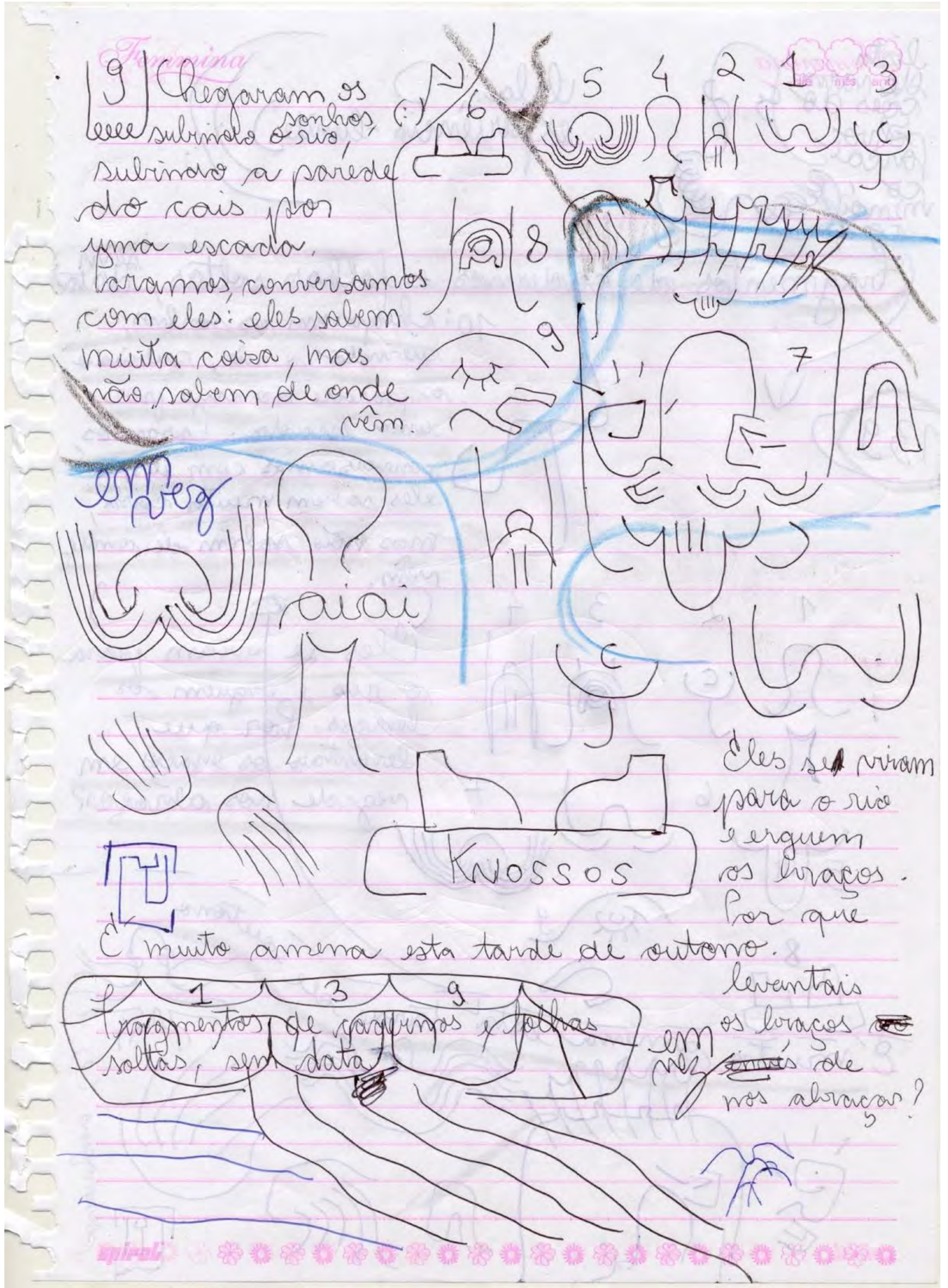


396

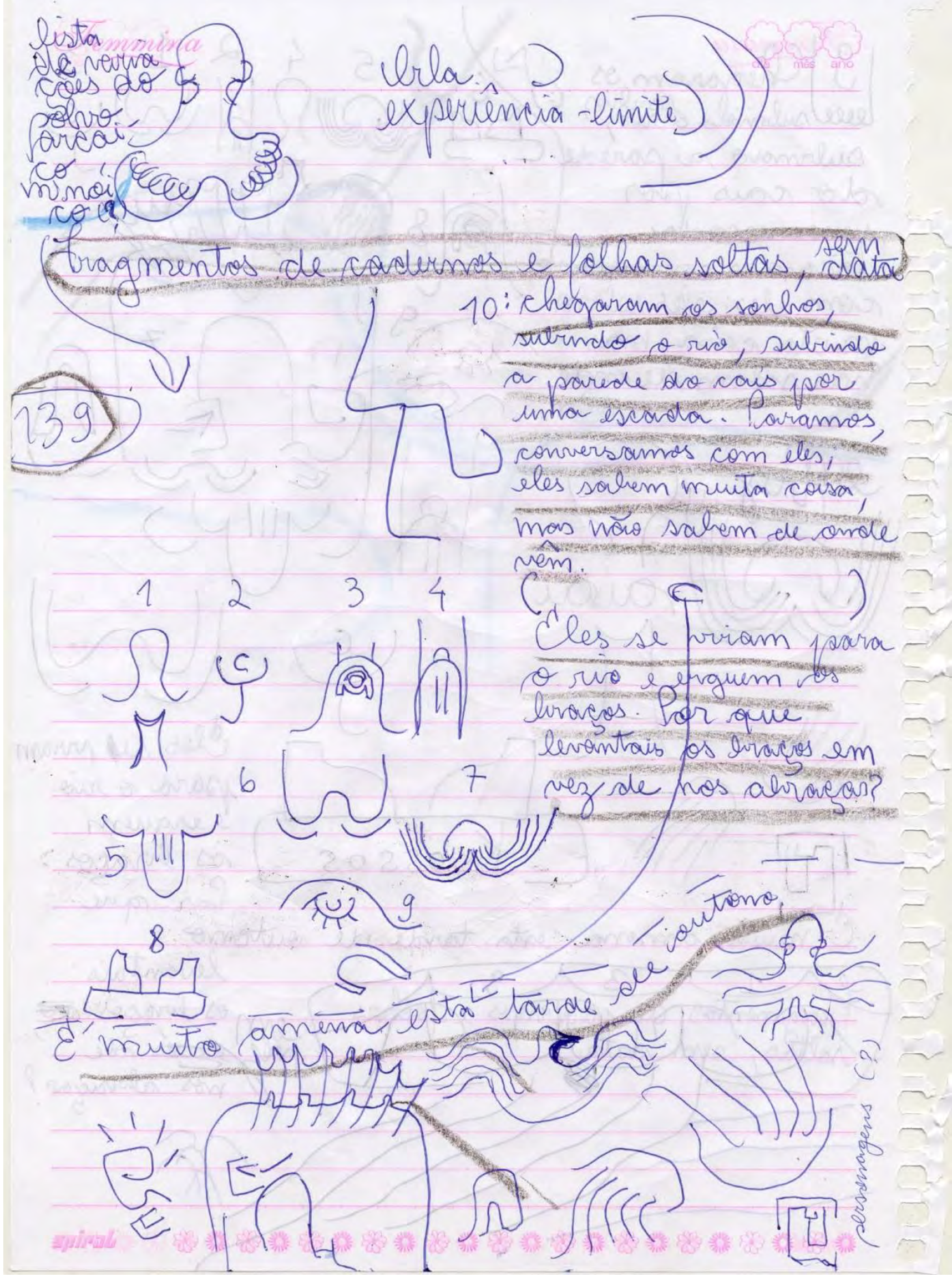


Acho que este é um dos sonhos mais conhecidos do Franz Kafka. Este foi sorteado pela Talita para a transcrição. (sétimo transcrito)

Aqui se estabeleceu uma gramática talvez aquática, talvez atlante ou minoica (digo da referência à entrada do labirinto de Cnossos, ou aos polvos dos vasos cretenses) em relação de habitação da página com diversos outros seres.

0 tipo de espacialidade que se produziu aqui me surpreendeu também. A lembrança dos bonecos Fabulosos da Carolina Vélasquez (não foram desenhados eles mesmo aqui, mas as figuras aparescentes neste último sonho os evocam). Uma espacialidade paralela ao sonho do Auber, do ruído do mar.

Coloquei as folhas do primeiro sonho, que se espalhou, se derramou, se espraiou, se dilatou, enfim pelas páginas, à sua própria vontade, com seu tempo e sua demora.

Os seres se permitiram aqui a uma numeração (últimas páginas). Uma vontade que passou por mim e eu segui. 


\section{0.}

O leitor e leitora já podem ter percebido que o caderno é uma víscera onde estão reunidas, onde se podem produzir muitas coisas.

0 problema da relação do caderno com a performance é aquele do paralelismo. 0 desenho não está subjugado à partitura de ações. De acordo com o pensamento transdutivo que expus na coleta de mitos de Armonia (bloco anterior), trata-se de uma habitação conjunta e produtiva de múltiplos objetos paralelos de experiência, onde os agentes humano-específicos são um elemento dentre tantos outros. Daí a impossibilidade da simetria no trabalho com os cadernos. Aqui há a possibilidade de tracejarmos a companhia de dimensões só captáveis com rumores e corpos estranhos, duvidosos, improváveis. Pareceu-me uma típica atitude transdutiva.

Mas o problema do paralelismo e dos seres insólitos já está evidente. 0 que se passou e que não foi ainda registrado está além dos esboçamentos (as linhas errantes, rastros ou seres insólitos que aparecem, exigem, aconselha, que são isso) e da emergência de 'lugares', nichos, meios associados. Há aquela recapitulação do repertório existencial figurado como os diferentes tipos de tecido, de membrana, de limites do vivente. Isso ficou evidente em um ou outro sonho, contudo esteve gritante durante o processo das Liliths (a série que acompanha o bloco anterior).

As Liliths me contam que havia produção de pele na medida de uma estratégia de vida, de sobrevivência de algo. Há de fato uma topologia de traços, de técnicas locais. Traços paralelos, planos cruzados, traços mais livres como um mar de cabelos etc. eu poderia fazer esta lista.

Esse repertório de fabricação de corpo conta da ativação do pensamento concreto no seu limiar, magnetizado de intuição e do instinto. Da INSTITUIÇÃO para a INSTINTOINTUIÇÃO (INSTINTUIÇÃO).

São traços que surgiram da minha prática de desenho na adolescência, onde eu desenhava compulsivamente, como modo de retirada autista e construção de um 
mundo. Ou ainda uma forma de histeria, de me encaixar repetidamente ao mundo, alimentar-me resfolegadamente sob a sensação de aniquilamento. Ou ainda uma forma obsessiva de ter algo que viesse do meu próprio corpo, confirmando, pelo rastro do objeto liberado, minha própria existência de corpo. Por fim: os adeptos da medicina e da polícia psi poderão calcular qual o traço patológico dominante mais adequado a se nomear. Neste ponto, lembro de uma frase da Amnéris Maroni: 'traços patológicos? Tenho todos. Quanto mais, melhor'. São estratégias da sobrevivência de algo.

[FIM DOS CADERNOS]

[FIM DOS CADERNOS KAFKAS]

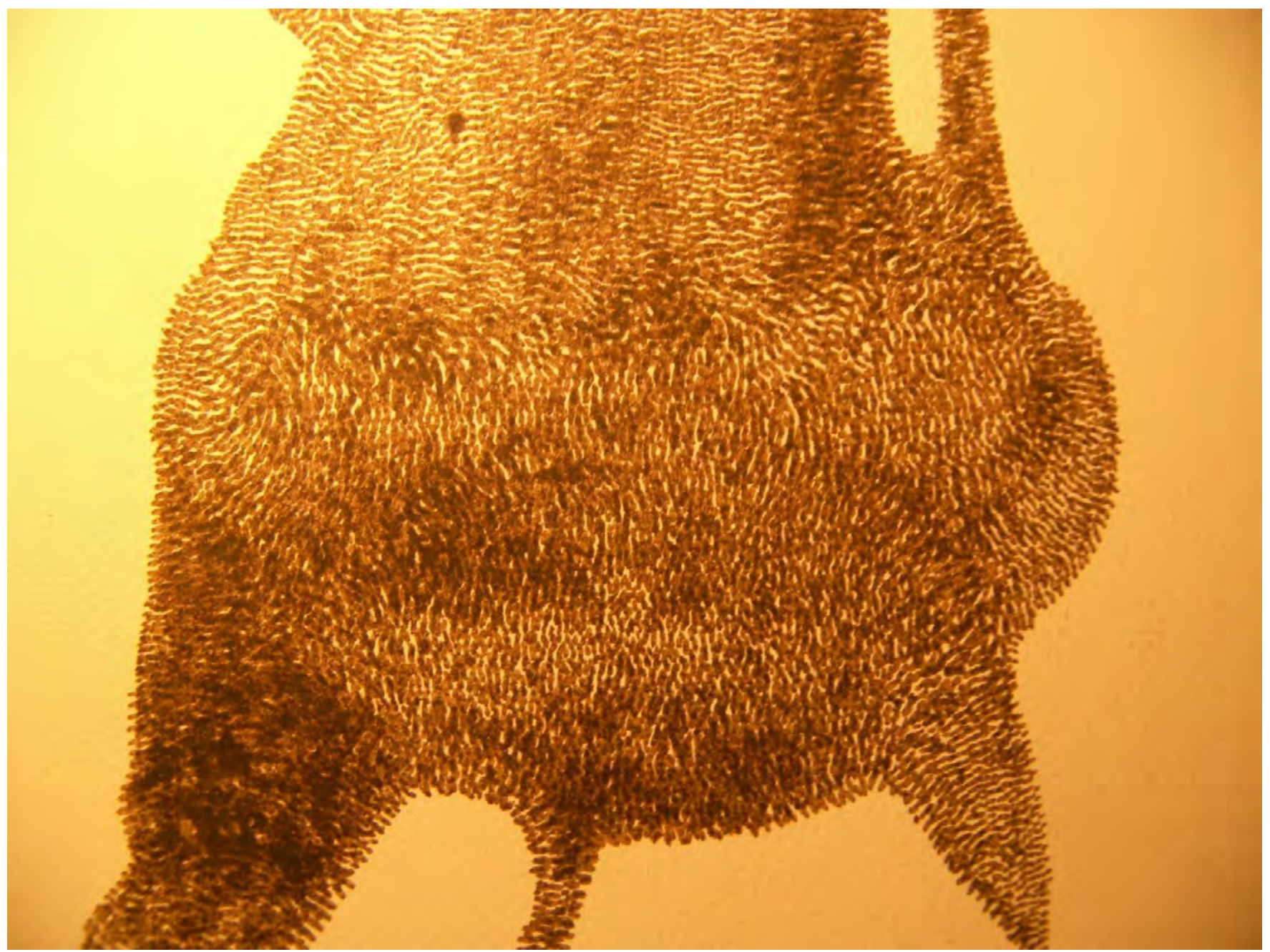

A árvore indestrutível de Lilith logo antes do amanhacer (Lilith 12) (detalhe) 
Não sei exatamente o que se pode definir por instintos de germinação e de cadernos, senão por aquilo que é engendrado, pela individuação conjunta. Lembro do Nijinsky de Uno na medida em que Uno afirma que se trataria da confecção de um platô do pensamento feito de pequenos gestos que testam sua própria capacidade de pensar. Esta engenhosa construção íntima e mundificante dispõe de uma espécie de pontilhismo, de botão ou pontuação acionado no 'sentir', 'sentimento'. Ao mesmo tempo ponteiro de verificação da pressão sanguínea do pensar-sentir, pico de eletricidade que testa a continuidade da corrente, verificação da vida afetiva possível, em seu mínimo ou máximo de intensidade, às vezes pronta a virar do avesso.

Bom, creio que a personagem-Nijinsky ainda tem o que nos ensinar.

A questão de se essencializar o 'caderno', levantada por Kiffer, é um risco a se vigiar. Parece lógico que grande parte dos diários são cadernos.

Para o texto o homem-árvore, carta a Pierre Loeb, também apliquei o procedimento de transcrição cuja genealogia e parte de seu resultado expus. 0 processo está em andamento. Não coletei as páginas aqui, pois a série kafkiana já é extensa e já dá conta da exposição ontogenética dos procedimentos e do campo de trabalho.

Segue um esboçamento-detrito independente das séries, onde eu ecoava o contato com pedaços dos últimos textos artaudianos, em especial dois. 0 homem-árvore, texto que trabalhei e tenho trabalhado neste último período do doutoramento, e aquele que provavelmente foi o último texto escrito por Artaud: os Seres... ${ }^{200}$ : 'Os seres / não saem / para o dia exterior // só têm a força de resplandecer / na noite subterrânea / onde se fazem. // Mas desde eternidades / passam / o seu tempo / e o tempo / a fazer-se / e nem um só chegou / assim / a manifestar-se. [...]

200 Da coletânea eu, Antonin Artaud (2007, p. 163). 
401

$$
(14.10 .2019)
$$

- Conversei

hoje com uma pessoa

de que

nöo se trata de lazer, alescrever de costurvar o proprio corpof, mas
picriour

de, pruncipalmente e e

olvaysa,

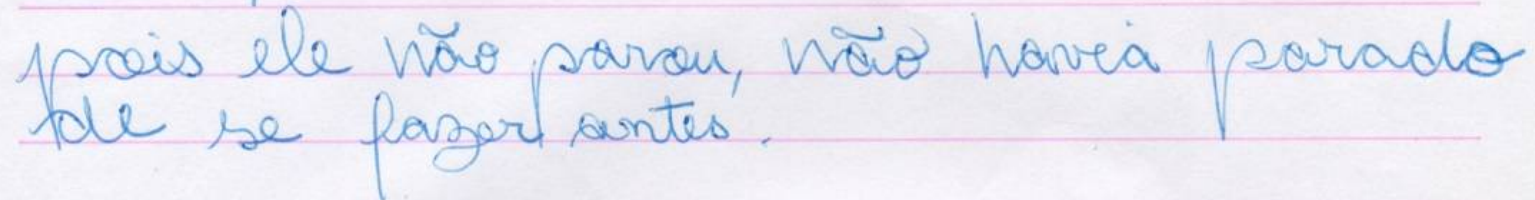

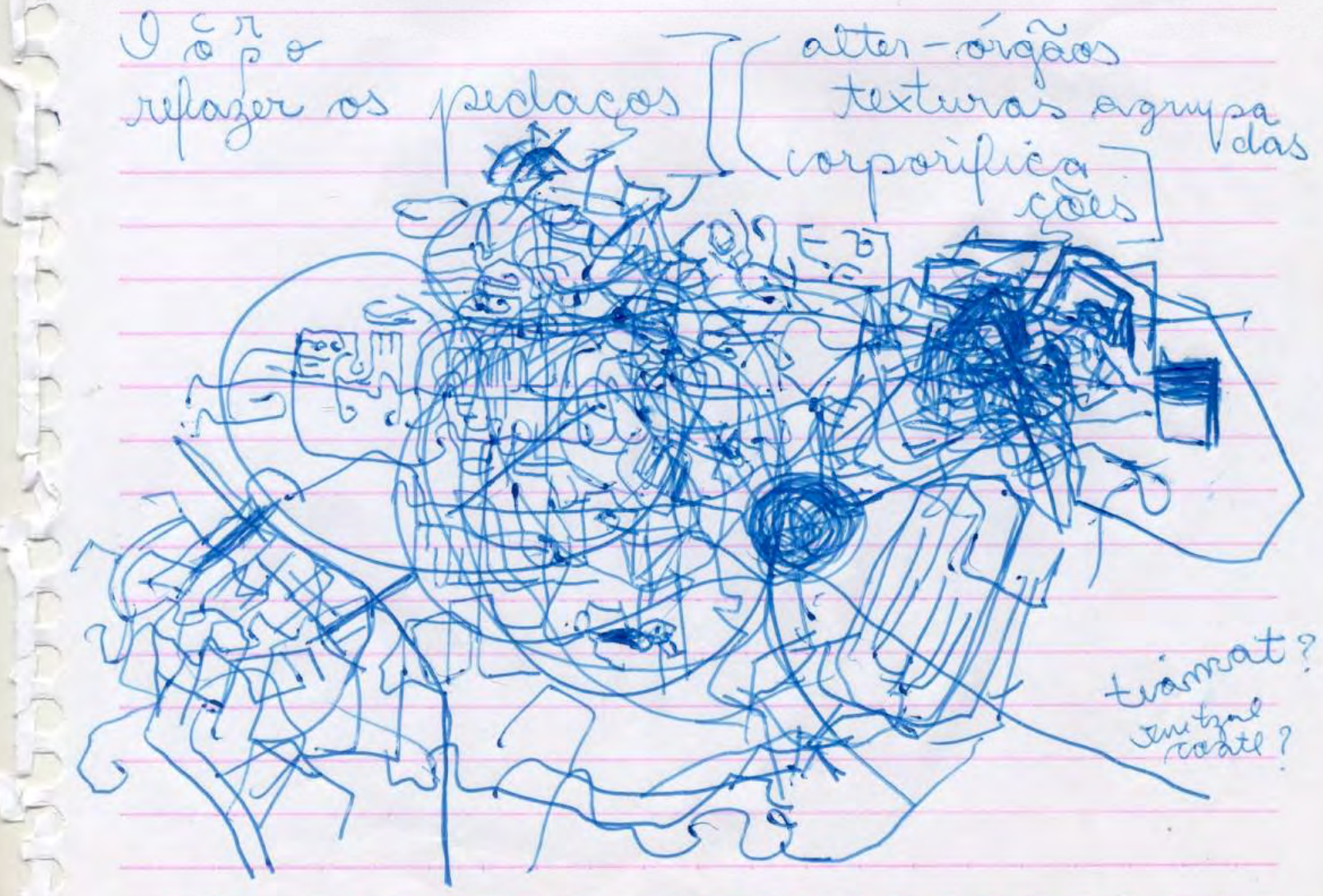




\section{[FINAL DA COLETA DE CADERNOS]}

\section{[PASSAGEM]}

[final do capítulo dois]

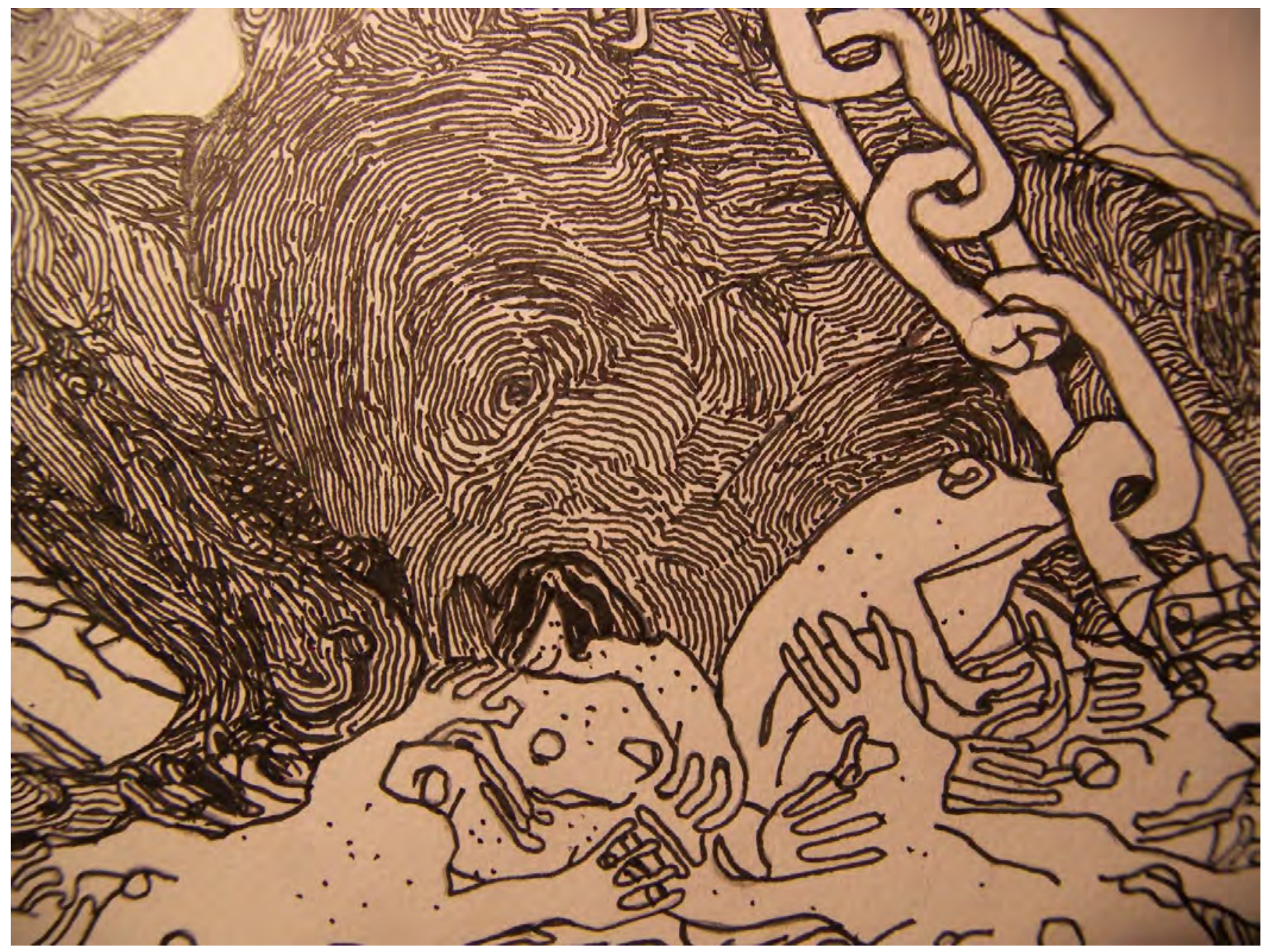

Lilith onze, a partir de visão de Giulia Esteves (Lilith dos sapos) (detalhe) 


$$
\text { [TRÊS] }
$$

[do homem-árvore ao umanimusgo] 
VEMOS DESENHOS INTERCALADOS AO TEXTO E ÀS FOTOS, COMO SE FOSSEM NICHOS OU FENDAS. ISSO À EXCEÇÃO DAS DUAS ANOTAÇÕES-DESENHO DE TRABALHO NO INÍCIO DO CAPÍTULO [[[ZONAS DE HABITAÇÃO, NICHOS SONOROSI]]. DOS DESENHOS, ENTÃO, SÃO AS SÉRIES

ANTECEDENTES DE ESBOÇAM ENTOS (COLAGEM DE NOTAS MAIS ANTIGAS);

ESBOÇAMENTOS PARA LUGARES;

LUGARES. 
406

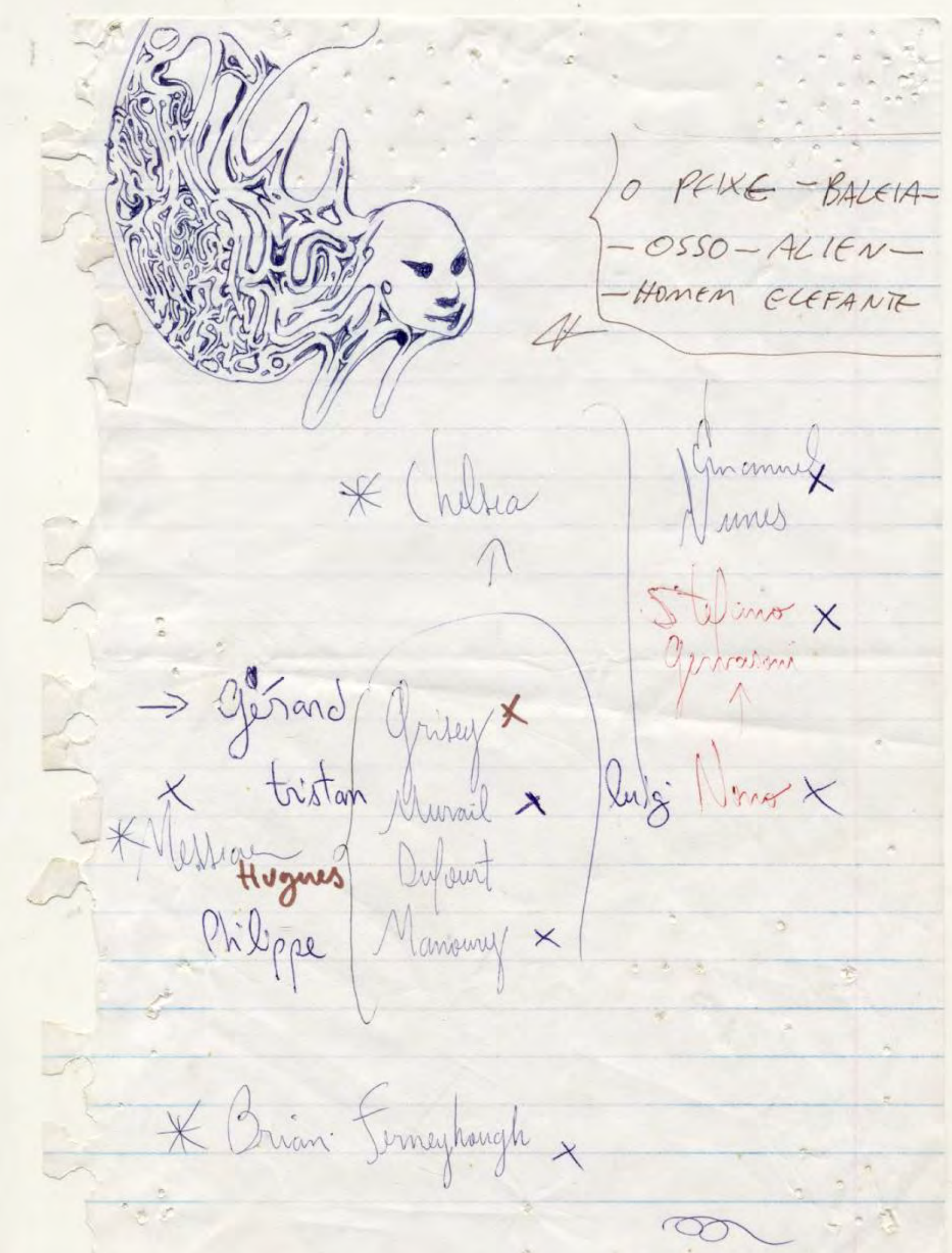




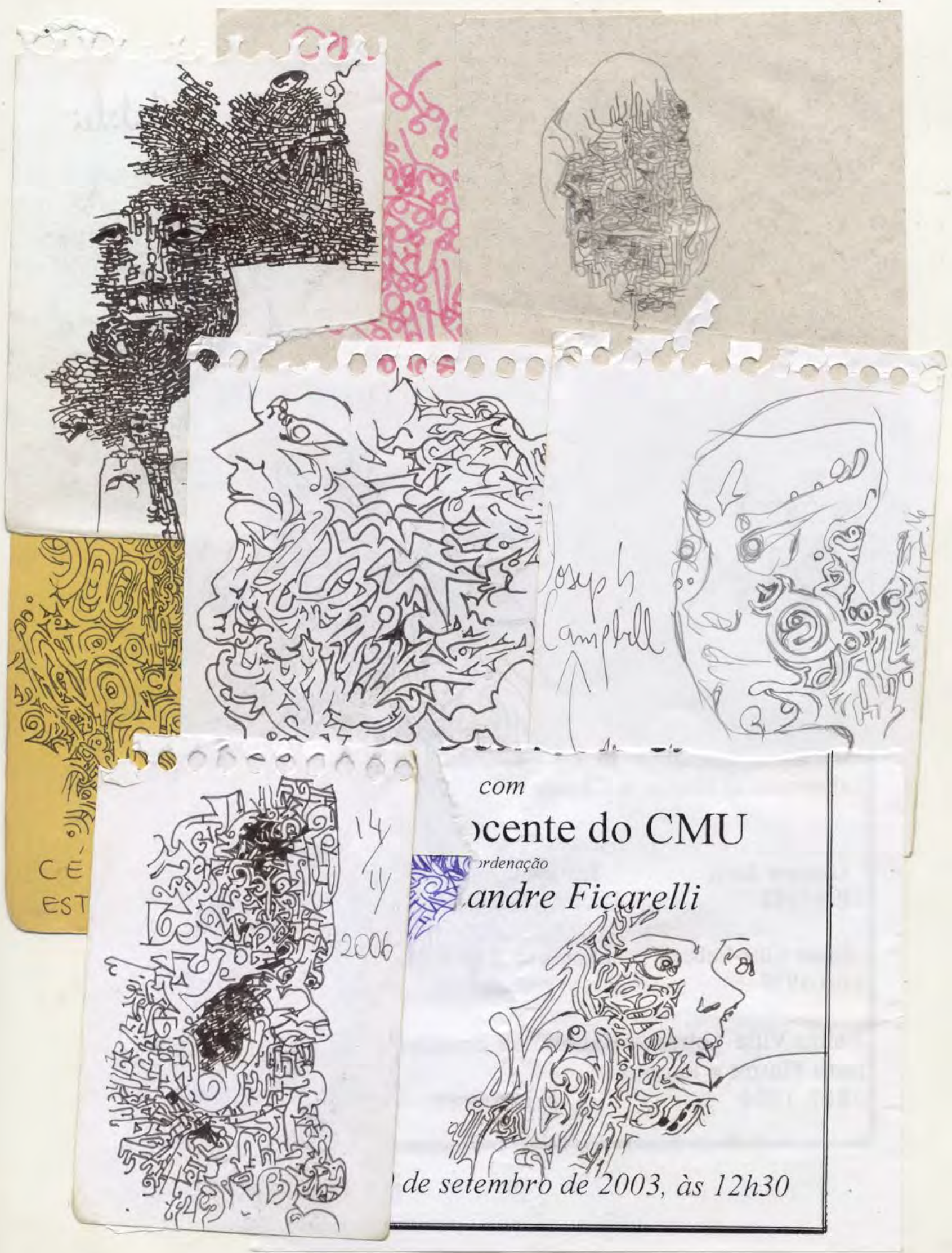




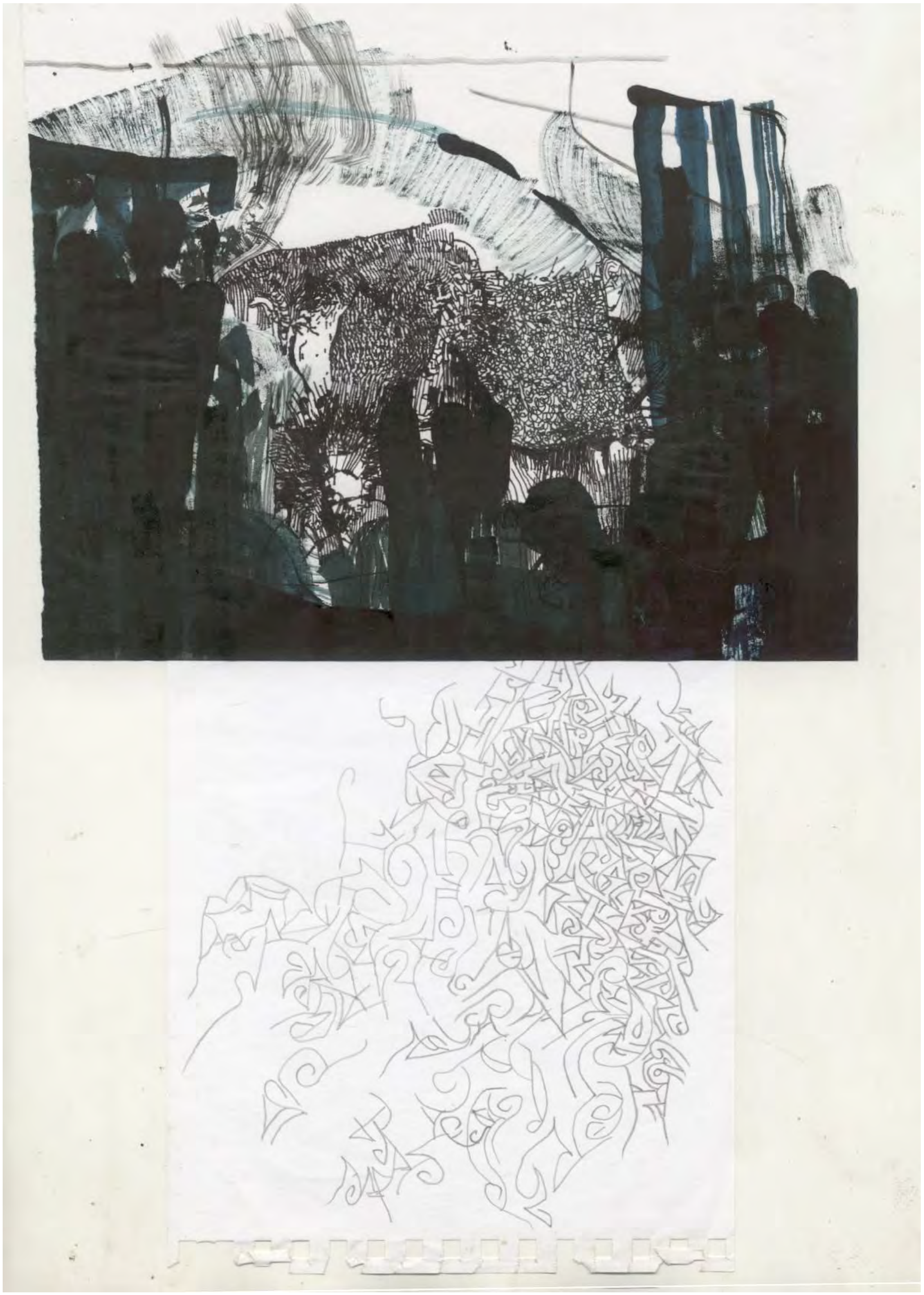


[[[FOTOS - IM PROVISAÇÕES NA CASA DAS CALDEIRAS]]]

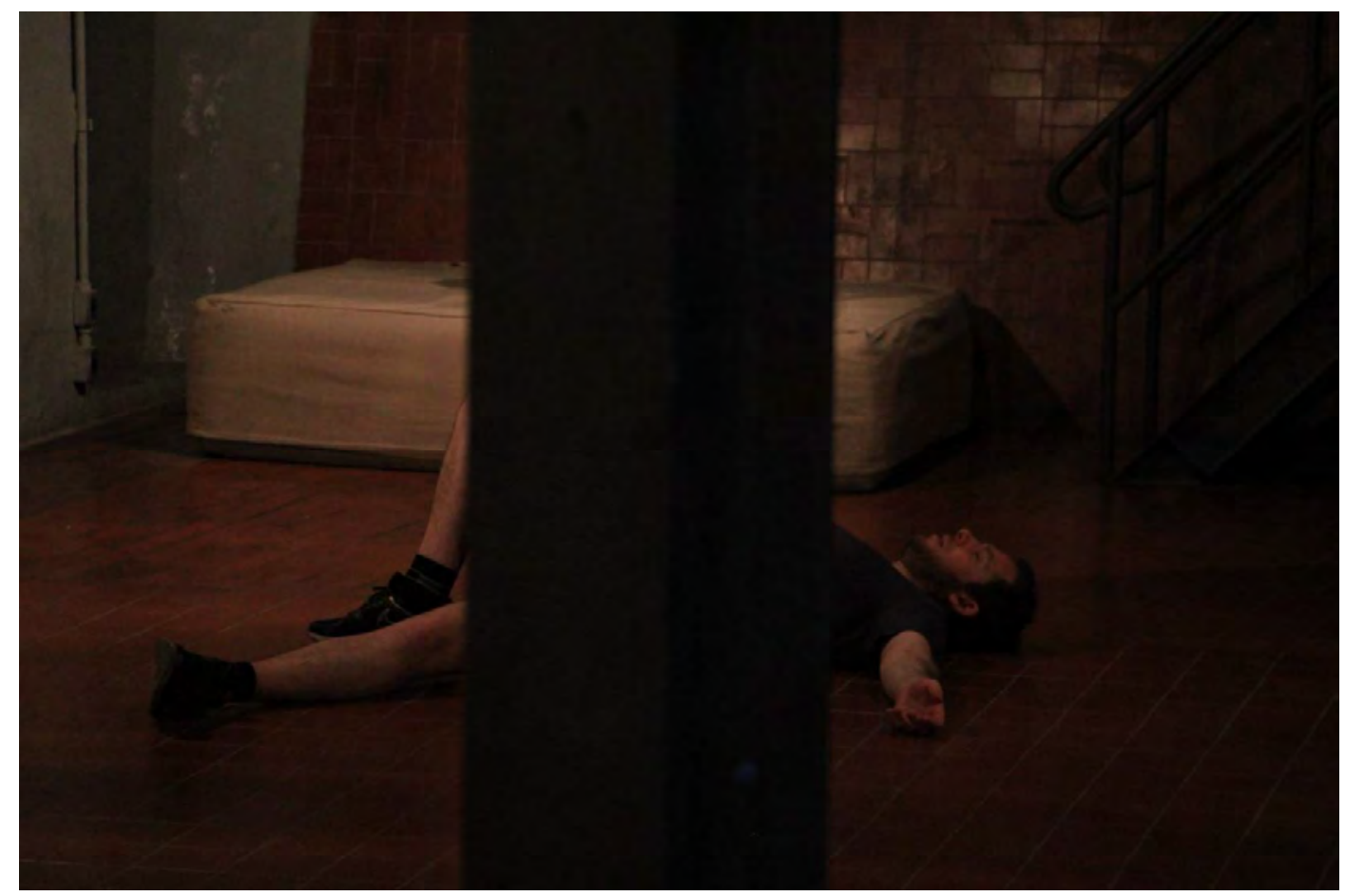

RODRIGO FABBRO. FOTO: TIAGO LUZ 


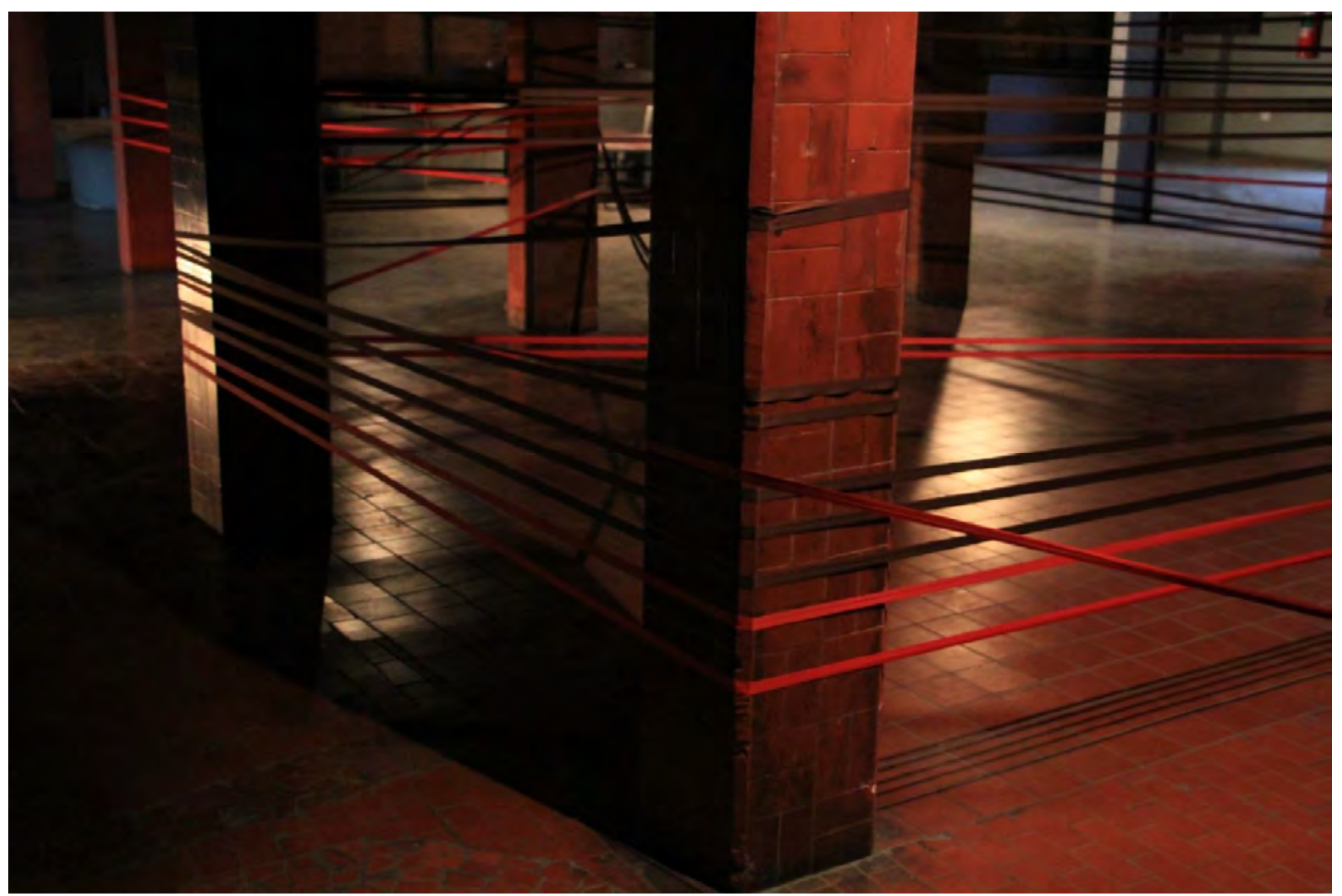

JOGO 'PENETRÁVEIS', DE ALBERTO TEM BO. FOTO: TIAGO LUZ

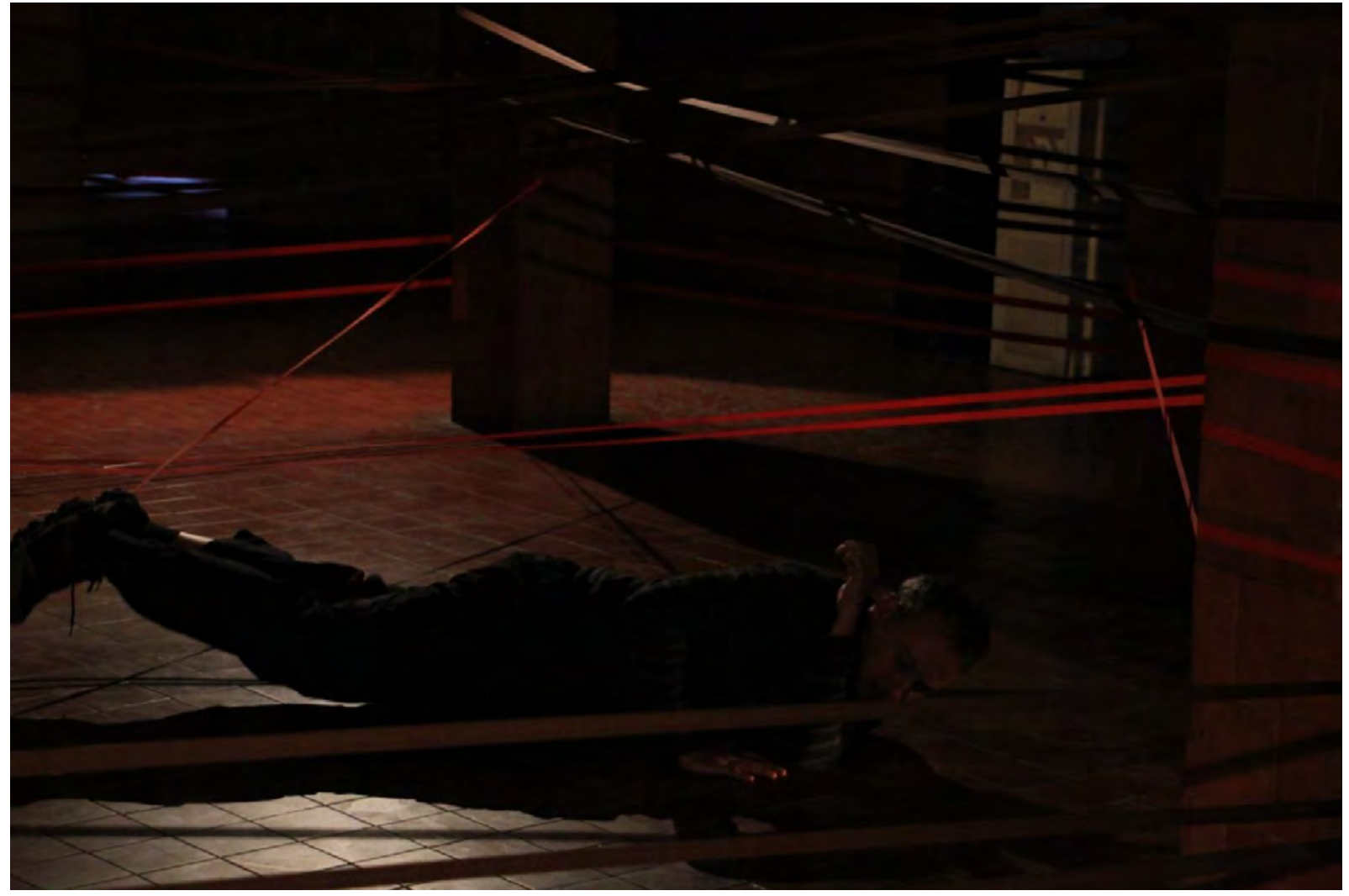

AUBER BERTINEШ, FOTO: TIAGO LUZ 


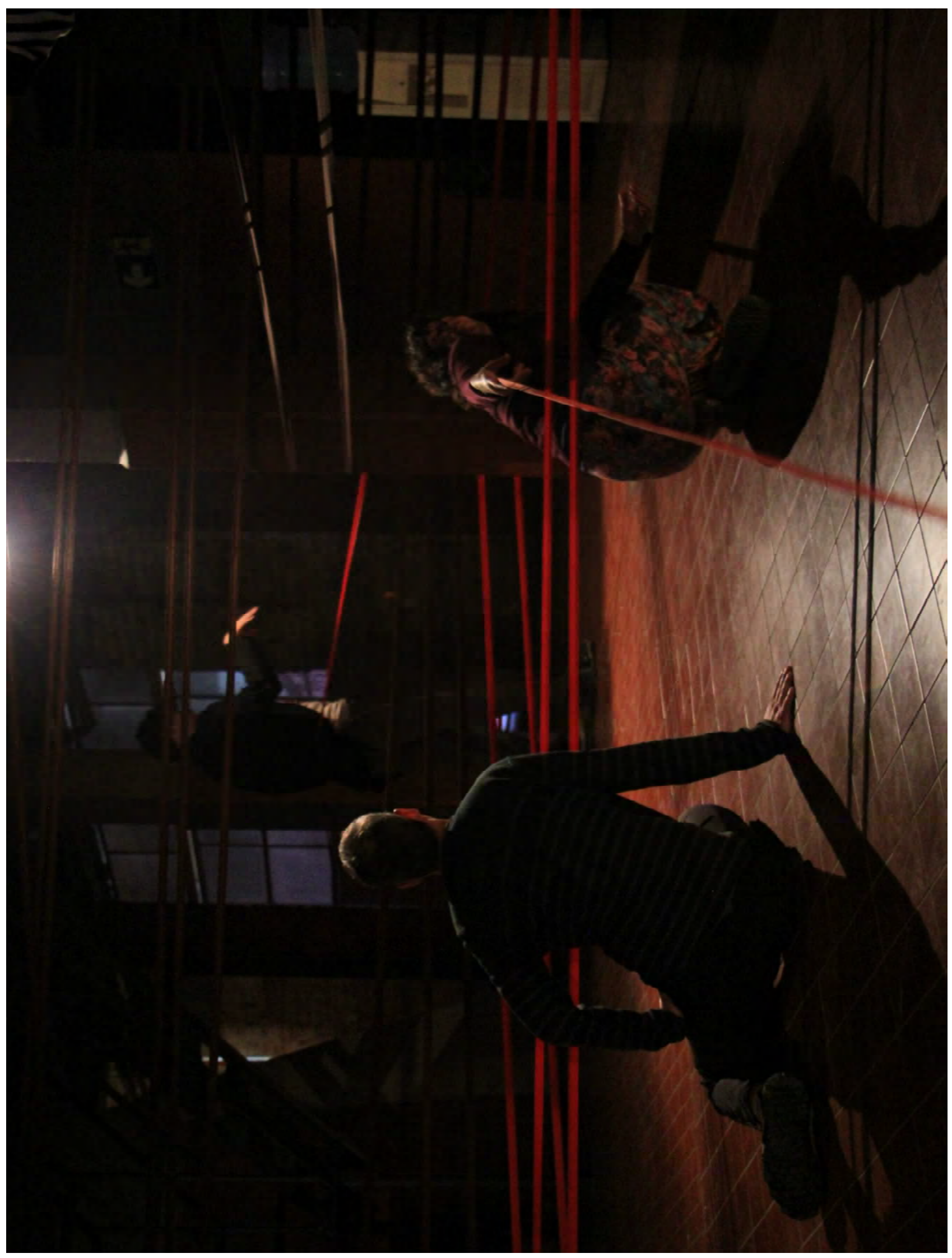




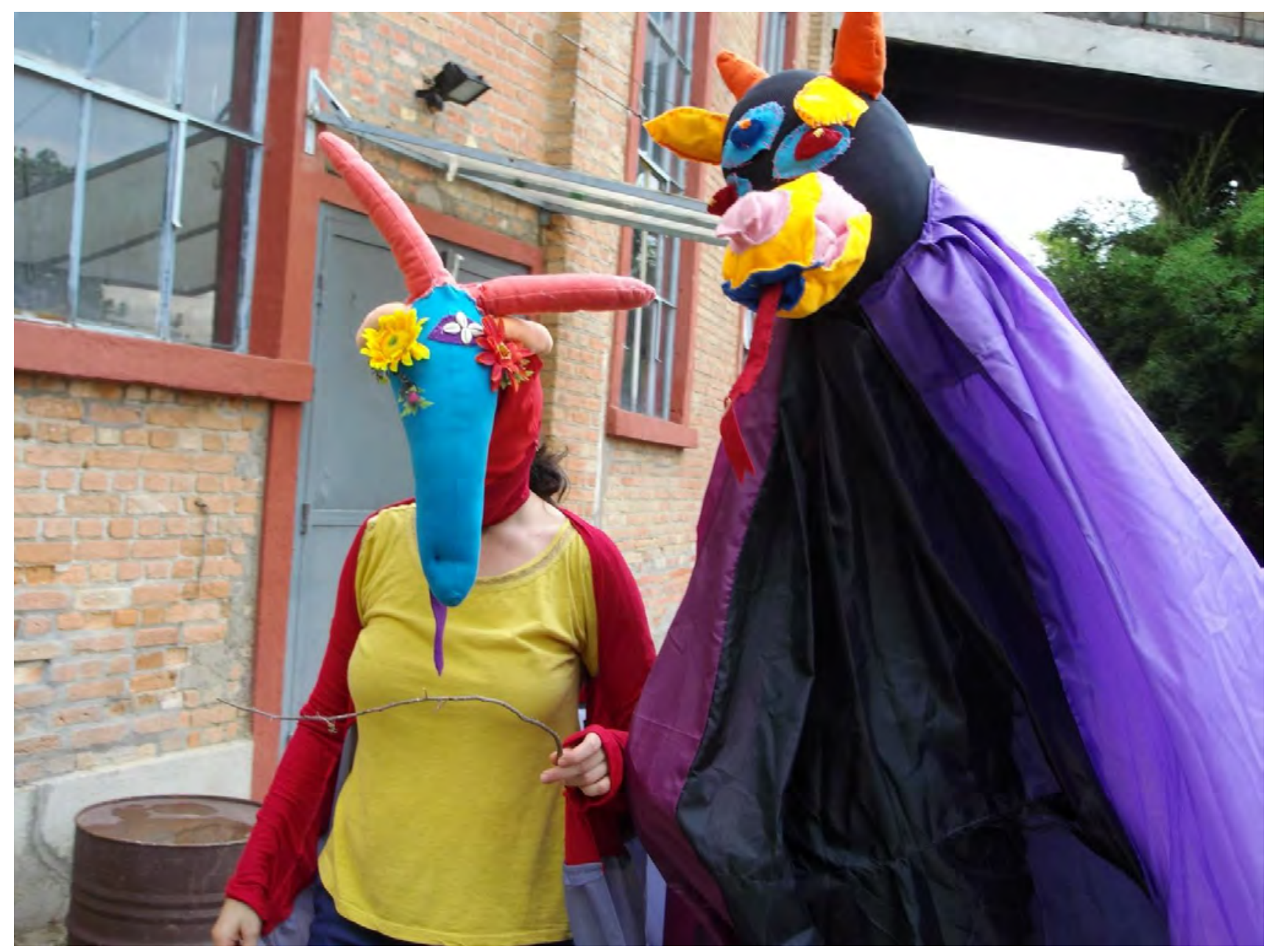

TAUTA E AUBER COM OS FABULOSOS, DE CARO UNA VELÁSQUEZ FOTO: JENNIFER BASTOS

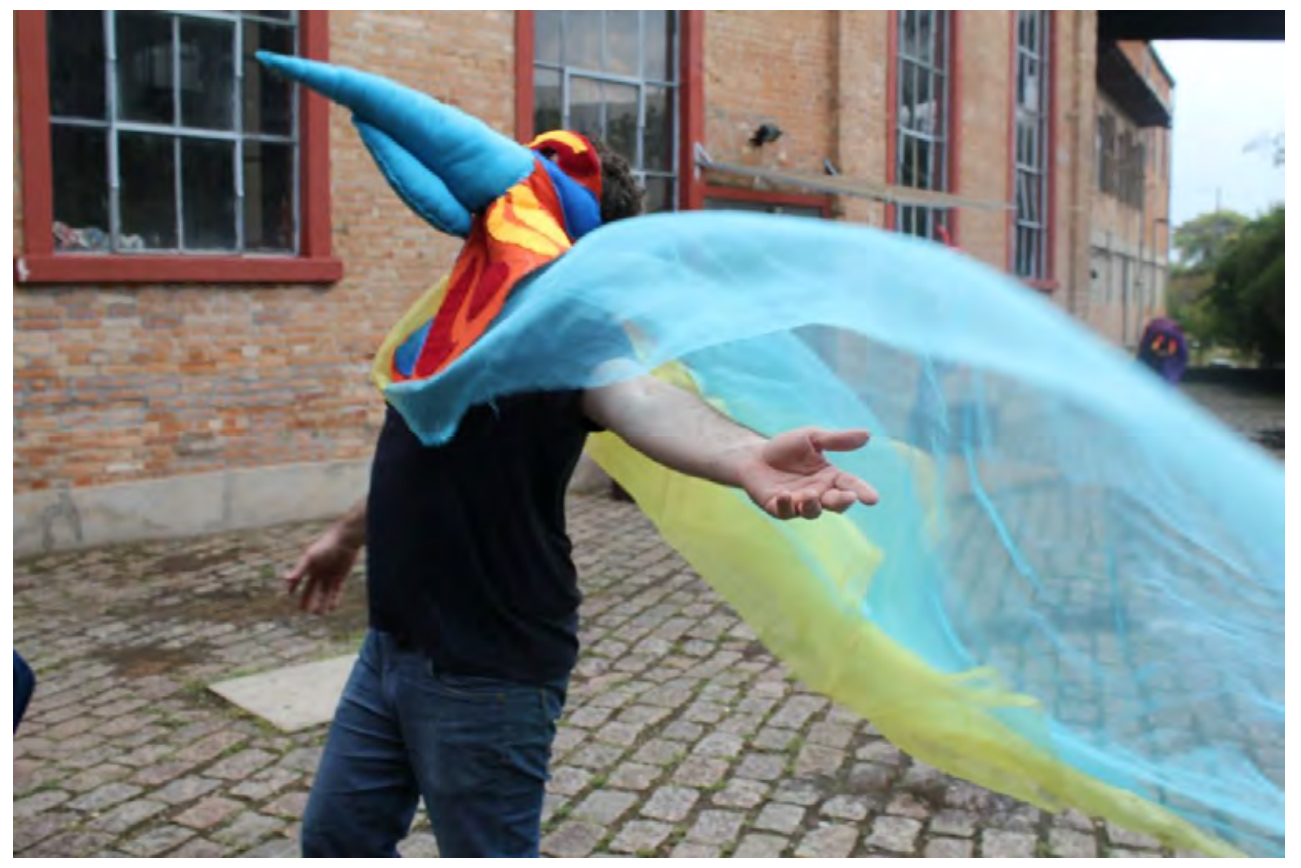

RODRIGO FABBRO E FABU LOSO, FOTO: JENNIFER BASTOS 


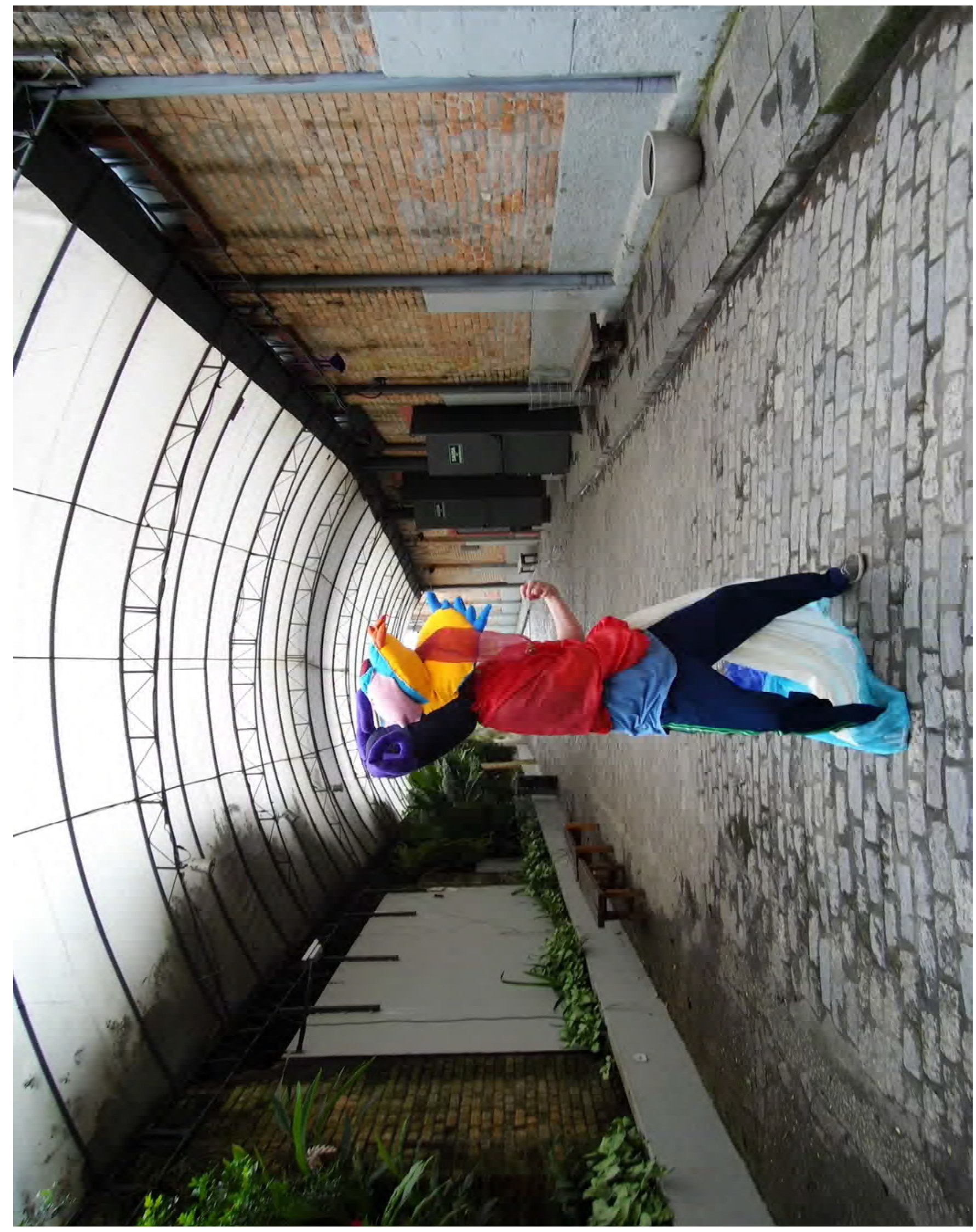


414

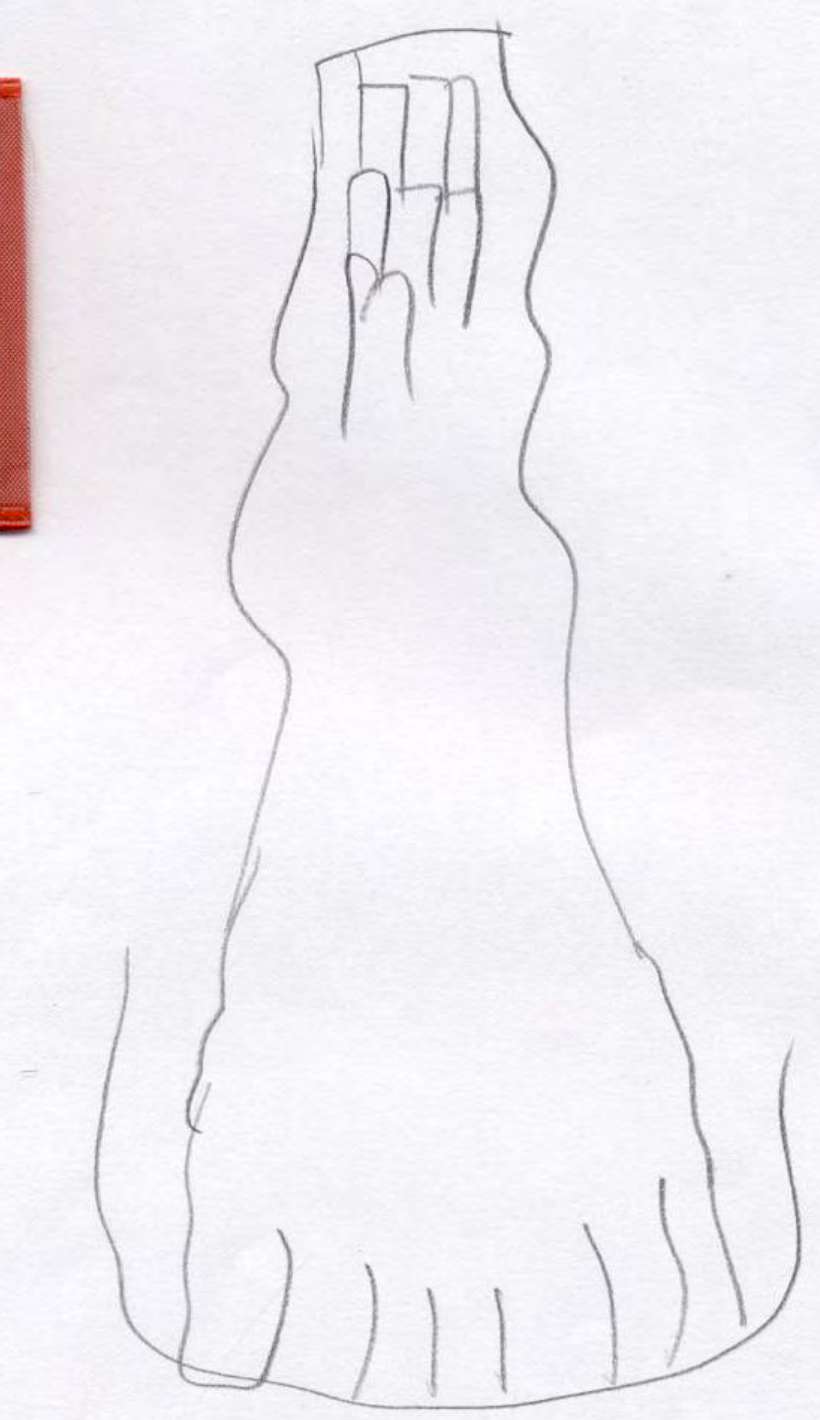




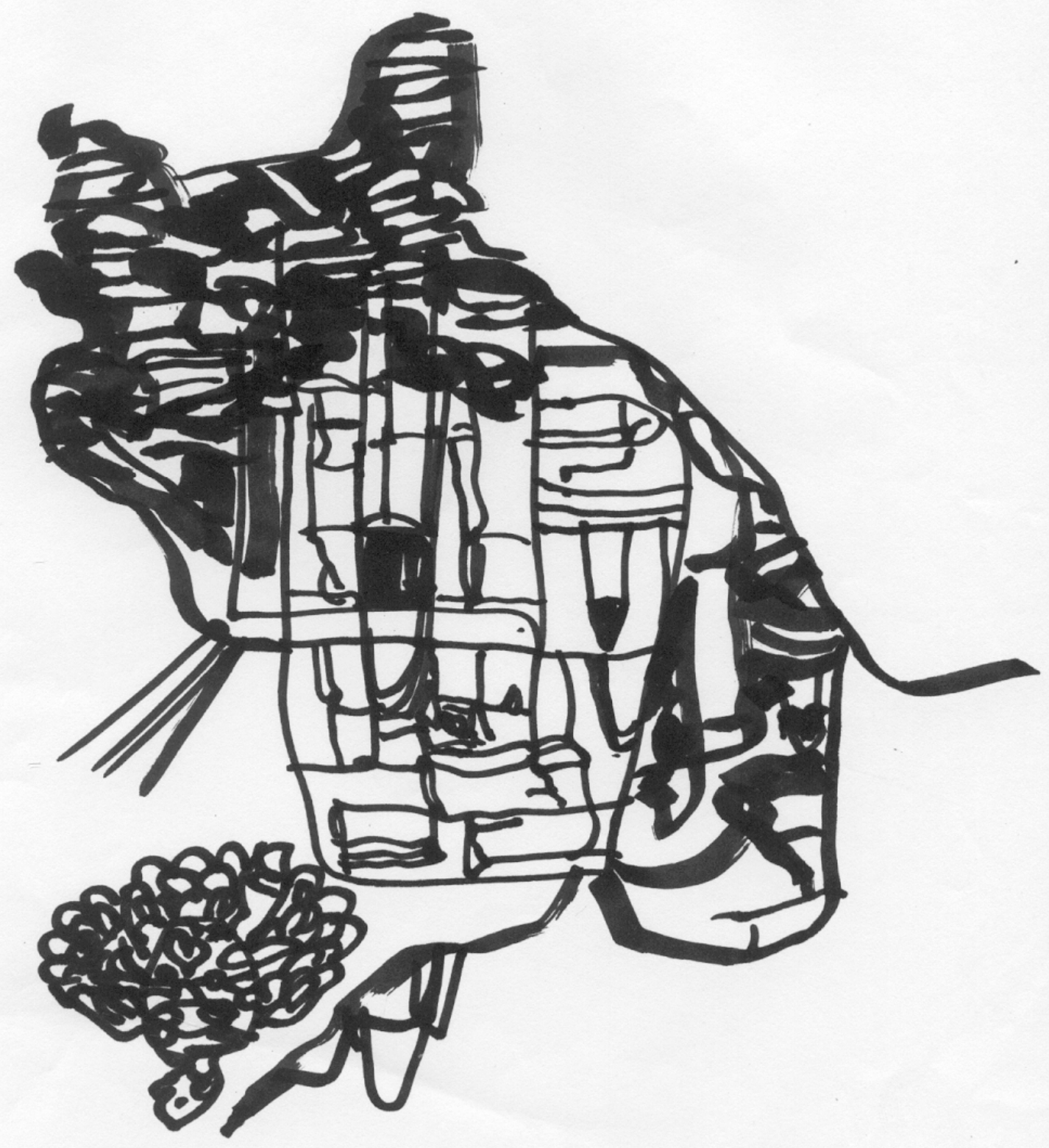




\section{TODAY IS THE DAY BEFORE? $\left.\begin{array}{l}\text { TODAY IS THE DAY } \\ \text { TODAY IS THEDAY AFTER }\end{array}\right\}$}

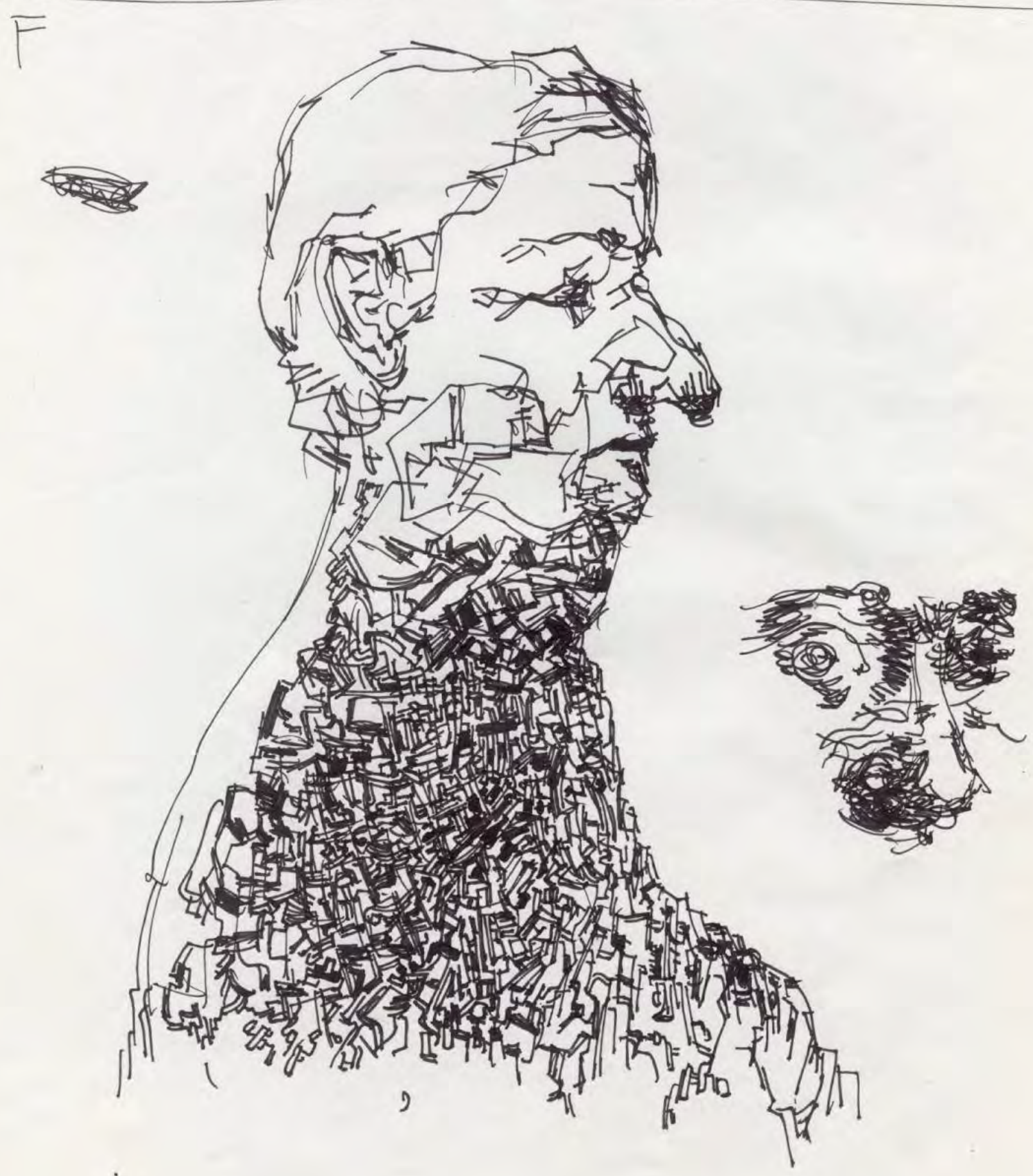


[[[DO HOM EM -ÁRVORE AO UMANIMUSGO]]]

[[[LOCALIZAÇÃO PRECÁRIA]]]

[[[PEDAÇOS DE M APA]]]

[[[ZONAS DE HABITAÇÃO, NICHOS SONOROS]]]
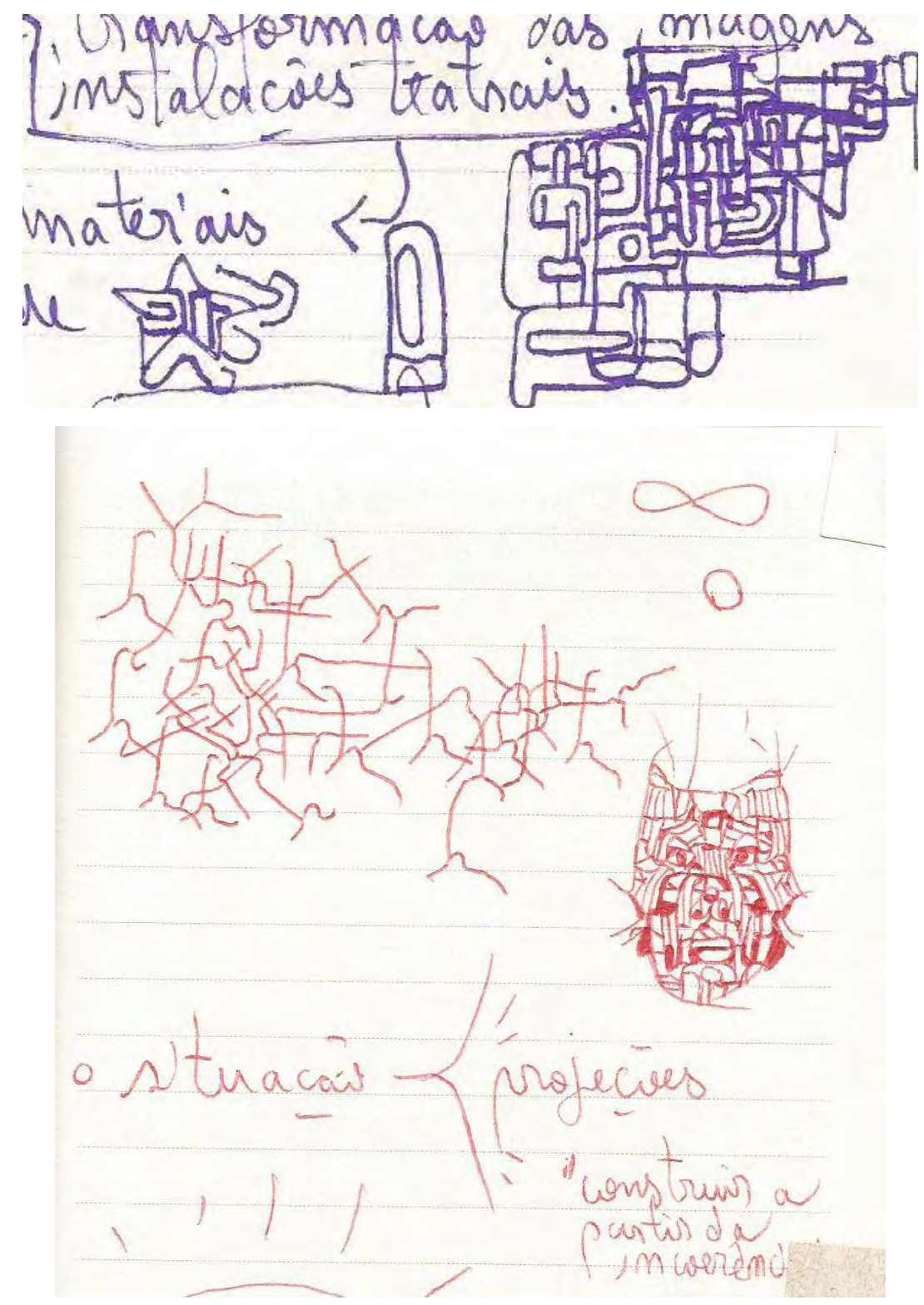

anotações desenhadas em caderno. 2010 (mais acima) e 2008 (logo acima) 


\section{1.}

Perambulação (e meditação como perambulação). A palavra seria mesmo meditação? Uma vez sonhei com um templo simples, com altar não-óbvio, construído em meio à rocha. A palavra corrente no sonho era 'contemplação'. Talvez possamos, depois de praticar perambulação, depois praticar cadernos, conversar um pouco sobre outros nomes? Talvez indagar conjuntamente às próprias palavras?

Tratar-se-ia de refazimento da processualidade do corpo? Construção da receptividade?

De toda maneira, ter atravessado uma reflexão, em tom transdutivo, da coleta de germinações e cadernos, modificou em definitivo o tracejar do discurso: não há mais como escrever da mesma maneira. Os cadernos impuseram uma ética de um discurso experienciado e tracejado que corrói um esquematismo de receituário, de bula, de descrição. Qual será a corporificação possível, neste ponto em que estamos da travessia? Tenho pensado bastante nas pedras...

Voltaremos ainda uma vez ao laboratório corpossom. Penso, por exemplo, quando apresentamos em 2012 na mostra experimentos do Teatro da USP (TUSP) e havia uma frase assim no programa: 'a linguagem de um programa é difícil porque é rasa'. E desde que Silvio Ferraz conheceu nossas práticas em 2011 vem falar que uma das coisas que mais interessaram a ele é esse contato aparentemente informal entre os performers. Há algo aparentemente raso que é a construção de tato para um 'nada' criativo que só será engendrado por alianças informais.

E o posteriori: o que há no avesso da informalidade pode ser entendido como a envergadura das elaborações coletivas.

No segundo semestre de 2016 nós do laboratório conseguimos nos encontrar algumas vezes para conversar sobre 'o que aconteceu, o que estava acontecendo em 2013?' Ao final da nossa temporada na Companhia do Feijão, lá em 2013, Felipe descobriu que ia ser papai, também por lá começava a trabalhar com alguns coreógrafos que Ihe ofereceram, no seu conjunto, uma 'segunda formação'. Miguel ingressaria num período de intensa pesquisa que desembocaria no seu mestrado, que agora, nas portas de 2019, está em reta final. Eu também vivi todo o complexo 
movimento que transbordaria neste estudo, o movimento que incluiu alianças íntimas desfeitas e refeitas, desesperos, abandonos, impasses, descobertas violentas...

É momento de virar pedra e olhar a pedridade das conversas. As pedras estão quase sempre em reunião, em intensa conversa. Elas são uma materialização da conversa.

'Fazer verso conjunto: conversar'. Poesia minha, bem piegas, é verdade, mas bem que possa funcionar. Vamos balancear a atmosfera com um poema sério. 0 poema mais curto do livro a pesar, a pedra de Edith Derdyk (2018), é este:

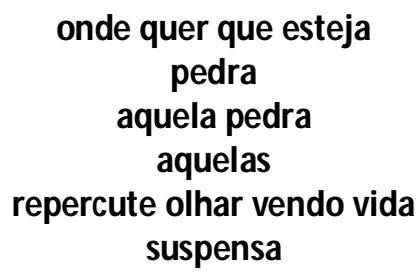

este é um olhar que pensa

Justo o olhar que pensa é o mais curto! Sim, a poeta acertou em cheio. 0 pensamento tem corpo de pedra. Dessas muitas conversas muito ínfimas, compactadas e ativas.

0 que quero dizer é que não podemos fugir dessa conversa paradoxalmente alheia: onde o sujeito é o infinitamente outro. Conversar com pedra. Há dois elementos aqui que pontuarei rapidamente. Um é aquele exposto pela filosofia da diferença ou vitalista, havendo sérias ressonâncias em correntes de antropologia recente, onde temos de realizar um exercício de deslocar o humano-espécie e ir na direção de um humano-relação. Ora, o que seria um humano-relação? 0 próprio Silvio Ferraz, em aula, me dá pistas, quando remete (ele fez isso algumas vezes que me lembre) a uma frase de François Châtelet de uma história da razão. A frase seria mais ou menos assim: 'a razão é tudo em que se introduz uma relação humana'. Se eu distorço a frase é porque já a transformei em algo meu. A constante é 'relação humana'. Vou juntar esta frase com uma vivida em aula com Maria Thais; é possivelmente uma leitura antropológica redescoberta por sua própria prática (sem 
problemas, é isto mesmo o que mais me interessa): 'humano é tudo aquilo que constitui sujeito'. Daí finalmente compreendo a questão: mesmo quando se trata de humano-relação, há uma grave dificuldade de descolamento da referência-espécie. Por razões práticas, que são aquelas de uma ontologia dominante. Sou obrigado a me perguntar da constituição do sujeito humano, e Simondon oferece, na sua filosofia da individuação, uma chave: sujeito201 é aquele outro-que-o-indivíduo, é produção de configurações de defasagem ${ }^{202}$. Minha leitura então seria aquela onde o sujeito, do ponto de vista operativo, é uma configuração assimétrica ${ }^{203}$ : é o infinitamente outro. Vi trechos de uma entrevista com a psicanalista Maria Rita Kehl onde ela dizia assim 'a psicanálise não trabalha com a noção do indivíduo, ela trabalha com a noção de sujeito, que tem muitas partes'. Pois bem, o estranhamento da multiplicidade não basta, de longe, para designar as operações ou contra-operações de uma esfera de sujeito, se tomado na chave simondoniana. Não há como ver acontecer uma multiplicidade e desejar verdadeiramente a recondução do processo dentro e para uma clínica já conhecida. É preciso uma diagnóstica inversa, atenta ao alheio e à pauta inclusive da destruição daquilo que seja clínica. A clínica não pode ter domínio sobre os modos de vida. Se o humano-relação é o sujeito, e o será mais radicalmente se posto em chave simondoniana, o pensamento é também posto em uma chave intrinsecamente estranha.

Então persiste, como a pedra, uma conversa inevitável com 0 alheio, 0 infinitamente outro com que a conversa seja inevitável. A conversa, aqui, é mineral. Uma conversa é sempre uma outra relação.

Penso que noção de diagramas é muito próxima à invenção simondoniana, onde um circuito provisório 'acontece' entre mundos, cujo contato é frágil. As

\footnotetext{
${ }^{201}$ Para Simondon, o sujeito é elemento caracterizador da individuação psíquica.

${ }^{202}$ Além da tese simondoniana, acerca disto indico, além do texto de Peter Pál Pelbart a catástrofe da liberação que já foi visado no capítulo 1, que oferece um certo mapa da questão, a precisa comunicação de pesquisa e ensaio de Muriel Combes uma vida por nascer (2017).

${ }^{203}$ No início de diálogos (DELEUZE; PARNET, 1998 - dialogues, 1977), há isto: uma conversa como uma núpcia (que não é casamento), uma evolução a-paralela dissimétrica (ps. 12-13). 0 problema de se chamar 'paralelismo' ou 'evolução' (como o fazem Deleuze-Parnet) me parece o mesmo: restando o fato de que 0 contato entre conversadores quaisquer muito dificilmente será simétrico, constituindo algo que está entre e fora de ambos: a conversa, um bloco de devir (p.15). Sou movido a deformar a fala de Deleuze ao afirmar que o que aconteceu no primeiro capítulo desta tese, entre o corpossom e o butô, pode ser lido como um paralelismo assimétrico.
} 
coreografias que Helena Bastos no duo M usicanoar ${ }^{204}$, com Raul Rachou: Cães (2001) e Vapor (2006-2007) são ambientes onde o corpo se dilata em conjunção com 0 ambiente, catalisando janelas de metamorfose, quase-mundos que passam. É uma dança do infinitamente outro. Enquanto eu assistia a essas coreografias, sentia meu corpo se acoplar ao espaço e ser destroçado junto a ele.

A conversa inevitável com o infinitamente outro talvez seja então uma marca de um humano-relação. Será isso o que nos diziam Carlos Drummond de Andrade em seu no meio do caminho e João Cabral de Melo Neto em a educação pela pedra, ou ainda Vicente Franz Cecim em desnutrir a pedra? Ou eles ainda querem confirmar a melancolia de um mundo moderno e encerrado? O discurso alheio da pedra não é, contudo, encerrado. Cidade, sertão e mata, suas visões de pedra. Masculinas demais? O bebê de pedra ainda é um bebê. Então: a pedra tem humanidade: por certo, mas uma humanidade não-humana, alheia, duvidosa, incerta ${ }^{205}$.

${ }^{204}$ Fontes de cronologia: enciclopédia digital Itaú Digital: http:// enciclopedia.itaucultural.org.br/pessoa205998/ helena-bastos e a publicação musicanoar - 20 anos (2013).

205 É impressionante o quanto Hesíodo é exato na Teogonia, no trecho do hino a Hécate, ao deflagrar, disparar ali a constituição nunca conclusiva, duvidosa, de uma figura que 'faz o que quer'. Hécate e Lilith são figuras da assimetria, são figuras do infinitamente outro, bem possivelmente como aquelas abordadas em a morte nos olhos, de Jean-Pierre Vernant (1991). 0 infinitamente outro é infinitamente familiar, mas alheio.

Não à toa Lina Prosa utilizou pedras nas suas aulas de dramaturgia (oficina EmpalavradaS, 2017). Ainda sobre pensamento mineral, cabe um adendo sobre um certo corpo:

- A performer Priscila Regina Jorge atua nas conexões entre dança, geografia e geologia. Quando residente em São Paulo, até 2015, atuava com a pele coletiva de criação, com Alice Reis, Maike Rinne, Vitória Cohn e demais colaboradores. A pele coletiva de criação ressoa propostas de Anna Halprin e sua dança de tom vitalista, posta fora do estúdio e do teatro, bem como ressoa uma importante continuadora de Halprin no que concerte ao tom vitalista, a francesa Ivola Demange, docente na universidade Lumière Lyon 2 (http://www.ivolademange.com/ ). Priscila Jorge, já atuante dentro da graduação em dança da UFBA, integra o coletivo da performance-instalação fruta, ação que experimenta um campo entre meditação, cuidado e alimentação. 0 coletivo fruta, assim informalmente nomeado, participa do III ETU (Encontro de Teatro Universitário), realizando uma performanceinstalação no Departamento de Artes Cênicas da USP no dia 30 de março de 2017. Segue a página oficial do coletivo fruta (ainda que não haja atualizações recentes):

http://frutaperformance.wixsite.com/page .

Antes, eu havia conhecido o trabalho de Ivola Demange a partir de uma outra integrante da pele coletiva, Maike Rinne. Participei de um dos dias de oficina que Ivola Demange ofereceu no Tucarena, na PUC, em 2013. Na mesma visita a São Paulo, Ivola apresentou sua performance Peau Pierre (Pele+Pedra $=$ Pálpebra - Peau +Pierre $=$ Paupière) no saguão do Sesc Pinheiros (22 a 30/10/2013). Nesse contexto tomei contato com a pele coletiva. Acompanhei o trajeto do coletivo e depois o deslocamento artístico independente de Maike e, principalmente, de Priscila (a pele coletiva está com página eletrônica bastante desatualizada, mas talvez valha uma busca).

Quando me chega a dimensão de um pensamento vegetal e mineral, sempre tento recompor essa trajetória de encontros, bem como o convívio com a eutonista e performer Débora Oliveira na primeira metade do meu doutoramento. Débora, enquanto residia em São Paulo (hoje mora em 
De volta ao segundo semestre de 2016. Aquele momento do Laboratório corpossom foi importante, dada inclusive a sensação que eu tinha de que o coletivo estava por um fio. Esta sensação teve parte de um gesto inteiramente meu, ocorrido na temporada de 2013. Um gesto de profundo egoísmo. Mas nem tudo podemos falar. Pedra também é o calar.

Então haviam: a reaproximação; o reconhecimento de coordenadas comuns e discrepâncias impulsionadoras.

Falamos sobre a dignidade do fim ou da continuidade; sobre espaço de criação e seus desejos mínimos e persistentes; criação sem promessas; autonomia.

Nem todos os coletivos têm três anos só para decantar e elaborar seus problemas. Mas a vida orquestrou essa distância e escutamos o tempo da decantação. Isto também é estar em grupo: ser pedra - encontro persistente de silêncios.

2.

0 ambiente de trabalho daquele corpossom (laboratório).

Para tocar em algumas perguntas, ao invés de simplesmente entrar na máquina pergunta-resposta ${ }^{206}$, ao final de 2016 eu consultei os colegas que trabalhavam comigo há mais tempo sobre a 'natureza' de nossas práticas - das práticas de um 'corpossom'. Foi em meio a essas conversas que surgiu a ideia de uma relação prática com 0 'detrito'. Esses colegas são, como eu já disse, M iguel Prata e Felipe Stocco - realizamos juntos algumas ações entre 2011 e 2013. Recentemente, em torno dessa tentativa de tocar perguntas de modo prático, retomamos nossos encontros.

O perguntar às vezes é mudo. Mas não é um silenciamento: é um segredar e também uma gramática de silêncios.

Florianópolis), desenvolveu uma série de ações que ela designava, em seu todo, por sp brutalista, onde se relacionava com o concreto da cidade. Nas minhas interlocuções com Débora, nos perguntávamos muito acerca das raízes arbóreas capazes de deslocar os blocos, rachar o cimento. Esta é uma cena mineral-vegetal que testemunhamos na cidade. Creio que ainda voltaremos a ela. Como resultante dessa interlocução nossa, chegamos a organizar um inventário de imagens vegetais para uso da própria conversa e convivência de pesquisas. Segue portfólio de sp brutalista:

http:// deboraoliveirabr.wixsite.com/portfolio/spbrutalista?fbclid=wwAR0cLK7s ntutcqzeBgZBU5teSnFh0LKeG14ygBguifouhlSwYP9J LBT08 .

${ }^{206}$ Percebi a posteriori a afinidade com aquilo que Deleuze-Parnet levantam concernente à conversação na primeira parte de diálogos. 
E as palavras que tateiam. 0 aprendizado da pergunta não é uma prática formalizada por nós. E talvez nem seja formalizável. É algo que diz respeito a um instinto de conhecimento. Tem a ver com uma sensibilidade contextual para o interlocutor, um tato para o instante da pergunta, um trabalho sobre a necessidade que se expressa na pergunta e, por fim, um desarmamento das polaridades ilusórias às quais a máquina pergunta-resposta por vezes pode levar. Antes que pareça uma espécie de conduta moral, eu devo elucidar que essa prática leva a situaç̧ões por vezes desconcertantes e que são realidades por si, dispensando a necessidade apriorística de interpretar.

Há a produção, de atividade, de compositividade do vivo. Máquina criativa. E também as peças prontas: pergunta-resposta.

0 quanto que as minhas interrupções no caminho deste texto são também automáticas, e o quanto que o automatismo pode ser uma face da vida, ficam as questões. Por ora me interessa mais que hajam mais perguntas do que respostas. Então retomemos: meus colegas mais 'antigos', após alguns trânsitos de conversas, colocaram algumas questões importantes, nas quais passamos a trabalhar juntos em seguida, e que vou tentar expor agora dos pontos onde essa reflexão se encontra.

\section{3.}

Primeiras conclusões dessas intensas conversas.

De que não havia nada que definisse de antemão uma única genealogia das práticas, senão essa radicalidade do corpo transformado em som, que, para não ser meramente conceitual, precisaria ocorrer quase como 'acidente'. Daí a importância de práticas que, em si, não são classificáveis nos campos rigorosamente estabelecidos como pertencente às artes cênicas ou da música, ou o que se queira. A intenção desse deslocamento perpétuo é evitar um excesso de caminhos teóricos e fórmulas anteriores à prática cênica. Um exemplo é de quando, no mestrado, organizamos situações análogas ao modelo-vivo, tradição das artes plásticas. Outro caso é o trabalho com algumas abordagens meditativas, de modo a reinventar ou reconhecer as funções vitais como o sono, o impulso ou uma sintonia de uma ação qualquer, uma intenção de vocalização... Dentro desta pesquisa em específico há um lugar de 
investigação que gradualmente se afirmou: aquele das 'baixas frequências', das derivas, dos limbos, dos umbrais da cena, de quando uma coisa ainda não é, mas rumina. Acho que a assunção dos exemplos acima atesta isso (o sono, a compositividade involuntária...). Curiosamente essa assunção de um interesse pelas 'baixas frequências' é posterior ao encerramento do primeiro ciclo criativo, feito em parceria com os colegas 'antigos'. Ou seja, algo aconteceu ali atrás que eu não sabia ainda como tomar, como formular em termos de vontades.

Cabe ainda ressaltar que as pesquisas com as quais tenho entrado em contato, no âmbito do corpo, desde 2014, têm na abordagem dita 'meditativa' um pressuposto não necessariamente fundante, mas fermentador. No que consiste de fato essa abordagem geral, e seus efeitos e relações possíveis, bem como componentes da prática do corpossom que acredito se espelharem nela, explanarei ocasionalmente melhor quando da abordagem de temas específicos do movimento.

4.

Segundo grupo de pequenas e significativas conclusões.

Há um outro polo que acredito haver (artes marciais - jogo - ritmo - ritos de sincretismo), de um grupo de referências da prática, que aparentemente se opõe aos primeiros exemplos. São práticas em si pulsantes, lúdicas, estimulantes. Esse outro grupo tem algumas funções. Romper couraças/resistências mentais, prover confiança (individual e coletiva), resiliência, fazer comporem ativamente as diferentes partes segmentadas do corpo... Esse caráter vibrátil, oscilatório, ondulatório, pendular, tensional, saturável e disparador é praticado, nesta via das 'altas frequências', em separado àquela zona de práticas de 'baixa frequência'. Isto para que, quando imersos naquela primeira zona, possamos ser capturados por um feixe ou uma corrente. Por isso, é importante treinar os exercícios de uma frequência mais 'alta' em separado, para que não haja susto e para que possamos compreender determinados mecanismos de resposta e produção. Isto é apenas estratégico. Quando digo que somos capturados, o que significa? São as transformações de nível qualitativo do corpo: respostas e produções de diferenciais frequenciais, configurando espécies de nomadismos intensivos corporificados e qualitativos. Esses 
transcursos, quando postos em laboratório de escrita ou numa simples prática de anotação, podem produzir seus próprios mapas e é com eles que desenvolvemos as dramaturgias e os roteiros.

Esta distinção entre grupos frequenciais não estava tão clara para mim no período de 2011-13, mas hoje está. Esse proceder com a diferenciação de frequências que se granulam e corporificam em movimento, no caso das investidas dos núcleos de corpossom, talvez seja correspondente ao que aconteceu no ambiente do laboratório do ator. Entenda-se este, mais uma vez, como o ambiente pedagógico proposto por Antonio Januzelli. E o que o Janô fazia conosco talvez fosse em grande parte e medida uma 'extração' de exercícios locais onde houvesse uma zona de diferenciação de frequências, onde se liberassem frequências inéditas e com certe grau, maior ou menor grau de alteridade ao conhecido. É pelo grau de atividade e estranheza que localizamos afetiva e qualitativamente a matéria a se trabalhar. Seria isso uma definição de operatividade da figura cênica para 0 corpossom?

A ciência da atuação é uma ciência radicalmente local, que se nutre da própria pedra e terra: talvez seja essa sua paradoxal e distraída universalidade. E esses exercícios podem estabelecer uma espécie de 'fogo' deste local de trabalho. No espaço entre esses dois pólos, essas duas zonas frequenciais, podemos improvisar e formular exercícios de acordo com a necessidade. Isso sem falar nas mudanças de ambiente, com consequências materiais e acústicas. Isso sem falar o próprio ambiente afetivo que se instaura na conversa. Isso sem falar nos objetos paralelos de experiência são 0 próprio corpo da coletividade. Estaríamos ainda adotando um esquema binário? Não sei, uma vez que, de saída, duas zonas virtuais de frequência produzem, na prática, inumeráveis corpos-práticas. É preciso um sóbrio proceder de perguntar às perguntas prontas, de indagar verdadeiramente às palavras elas próprias.

5.

Seguem as pequenas conclusões, já estendendo a um pensar pedagógico e ao agrupamento corpossom. 
Trata-se de um campo de convivência, de uma habitação do espaço, de um corpo de habitação, por parte de algumas pessoas que se fazem o exercício de se perguntar sobre corpo e som. A partir daí, desse terreno, numa recíproca acidental e numa teoria precária, prosseguir, viver o som de modo duvidoso. Traços incontornáveis.

Com traços metodológicos de algo que possamos chamar 'teatro' em mãos, postos em suspeito reconhecimento, há de se pensar em uma espécie de platô continuamente refeito de onde se poderá rastejar. Lembrei, de súbito, de uma frase da professora Maria Thaís: 'o teatro é algo que se transmite no invisível'. Acoplo esta frase a outra pequena peça de frase, da investigadora lleana Diéguez Caballero: onde a teatralidade tem a ver com 'a instituição ancestral da convivência'.

Para um projeto que já se conhece, abundância e ao mesmo tempo a miserabilidade da simples convivência se torna uma catástrofe. Neste ponto me sinto muito próximo a Deligny.

Daí a importância também de uma preparação que envolva a 'não-técnica', um pouco inspirado no que no que diz o improvisador Phil Minton. Falei sobre ele um pouco no primeiro bloco de perambulação. Diz ele também, a respeito do nome de seu côro nômade 'Feral choir': 'diz respeito a animais que retornam ao ambiente na natureza depois de estarem presos'. A palavra não existe em português: feral. Ainda preciso pensar na aplicação desse termo ao corpossom.

Retomo também a situação descritiva (do mesmo bloco um) daquela situação descrita onde ocorreu o laboratório da nota:

- Situação. Três pessoas (atores?) adentram o espaço. Se posicionam e permanecem de pé. Parece que nada acontece. Aos poucos, começa a soar no espaço uma estrutura pedal vocalizada pelas três pessoas, que parecia soar antes sem você perceber.

Esse é o modo como aquele corpossom trabalha. Aqui talvez possamos dar testemunho a uma descrição e dramaturgia em outro corte.

Estou chamando de estrutura pedal pois cada ator vocaliza sua nota pedal, sua nota longa, mas sem violentar o ciclo da respiração. Considero aqui que nota é uma ação vocal continuada, no empenho de ser o mais simples, direto, concreto possível. Eu dei a indicação de que se deveria tentar a mesma nota não tentando afinar, mas 
escutando e relaxando. Então a única técnica aqui é continuar intentando a vocalização da estrutura pedal, ainda que ela não exista, e sempre relaxar até chegar bem perto da própria escuta. É também um procedimento transdutivo e de captura. Os atores buscam se sensibilizar para uma estrutura harmônica que funciona, uma 'máquina harmônica' com o espaço, com os demais atores que vocalizam. É um harmônico enquanto funcionamento improvável do junto e não de um resultado. Aqui se põe evidente, no meu ver, que é o corpo que vocaliza e não a pessoa, e a 'máquina harmônica', assim concebida, é aquele que provêm da tentativa difícil de deixar 0 corpo cantar.

Na minha vivência, música não é só o som, é aquilo que nos obriga a pensar. Posto que a impossibilidade da música também seja aquilo que nos obriga a pensar. Daí a estreita relação com música e uma improvável filosofia vitalista. Se você não faz anotações vitalistas, está muito certo do que seja o corpo, a música etc. Isso é politicamente comprometedor.

'Máquina harmônica': acontecem uníssonos, oitavas, intervalos consonantes, mas não através de uma estrutura prévia, e sim através de aproximações, relações, um campo de forças. Assim, em relação, eu e meus colegas em conjunto com o espaço somos capazes de construir um som, ao passo em que nos sensibilizamos ao ambiente. Uma afinação que não é só intuitiva, como se poderia fazer crer, mas também instintiva.

Aqui eu já preciso parar. Exercitar minhas quase-metáforas práticas. Eu digo isso porque talvez não sejam metáforas. É possível eu utilizar a voz para escutar? Ou ainda, para escutar, respirar o som? Talvez hajam agora definições tangíveis: refazimento da anatomia afetiva; literalidade contra-metafórica; produção-invenção de corpo...

Convivência como captação e espacialidade sempre refeita me pareceram ser algo que retornou com força nas problemáticas do agrupamento corpossom.

Além da meditação como perambulação, também se dá aqui a habitação de um espaço criativo que não se adapta a imagens prontas de corpo. É uma espécie de habitação, meditação contra-disciplinar, alter-disciplinar. A meditação (com a perambulação) não é apenas recreativa. 


\section{6.}

Seguem espasmos, pedaços de texto totalmente heterogêneos, sobre situações de trabalho. São situações paralelas de experiência, diversamente ao paralelismo que conduziria a uma simetria. É o paralelismo de uma individuação conjunta.

\section{7.}

Esboçamentos para lugares. Uma tentativa incontornável e des-esperançada de localização da própria vida. A grande maioria dos esboçamentos para lugares foram feitos sob crises de pneumonia, e alguns deles sob ressonância direta de acontecimentos políticos do nosso solo comum. Neles se vêem linhas vivas rastejantes, sufocadas pelo próprio muco que é também o traço, no empenho vivo de reconstrução, de reencontro. A passagem desta série para a seguinte, os lugares, é enigmática para mim: é como se houvesse conquistado um senso de assentamento no próprio devir vitalista do desenho. Se alguma correspondência sonora é possível, ela o é na medida de anotação vitalista do avesso do som.

\section{8.}

Vejo que há um paulatino adensamento da relação entre escrita e desenho na direção dos lugares, aqui neste atrito da caligrafia, da escultura e do pensar, operações e corporificações.

\section{9.}

Reafirmo que é preciso demorar-se sobre os desenhos. Eles valem mais do que uma escrita esquemática. Há ensinamentos sobre ser-corpo que brota deles. A cada um havia outra lição a ser praticada no desenho seguinte.

Em noite de insônia, o corpo pedia pra mim: por favor, seja gentil. 


\section{(1) correntes}

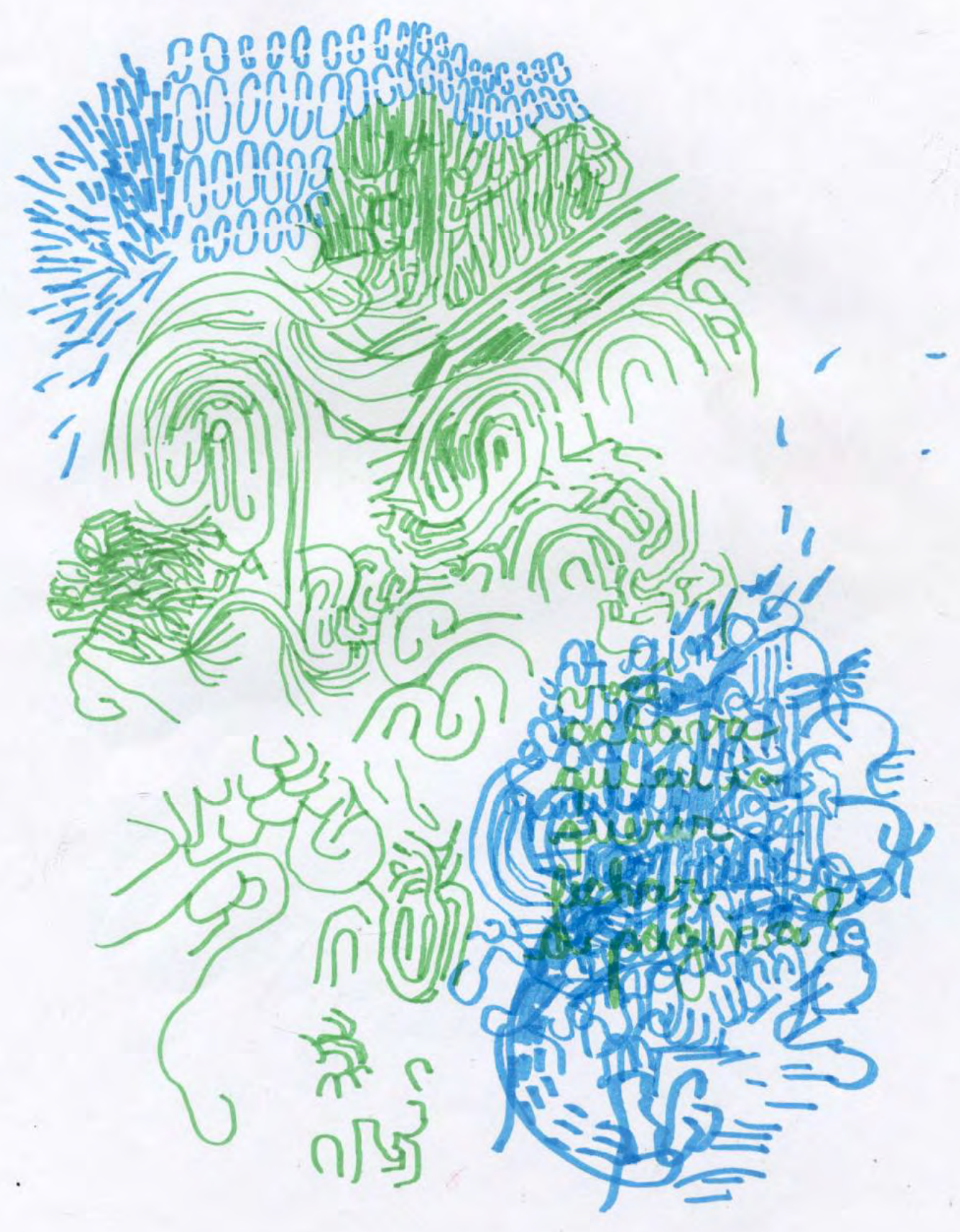




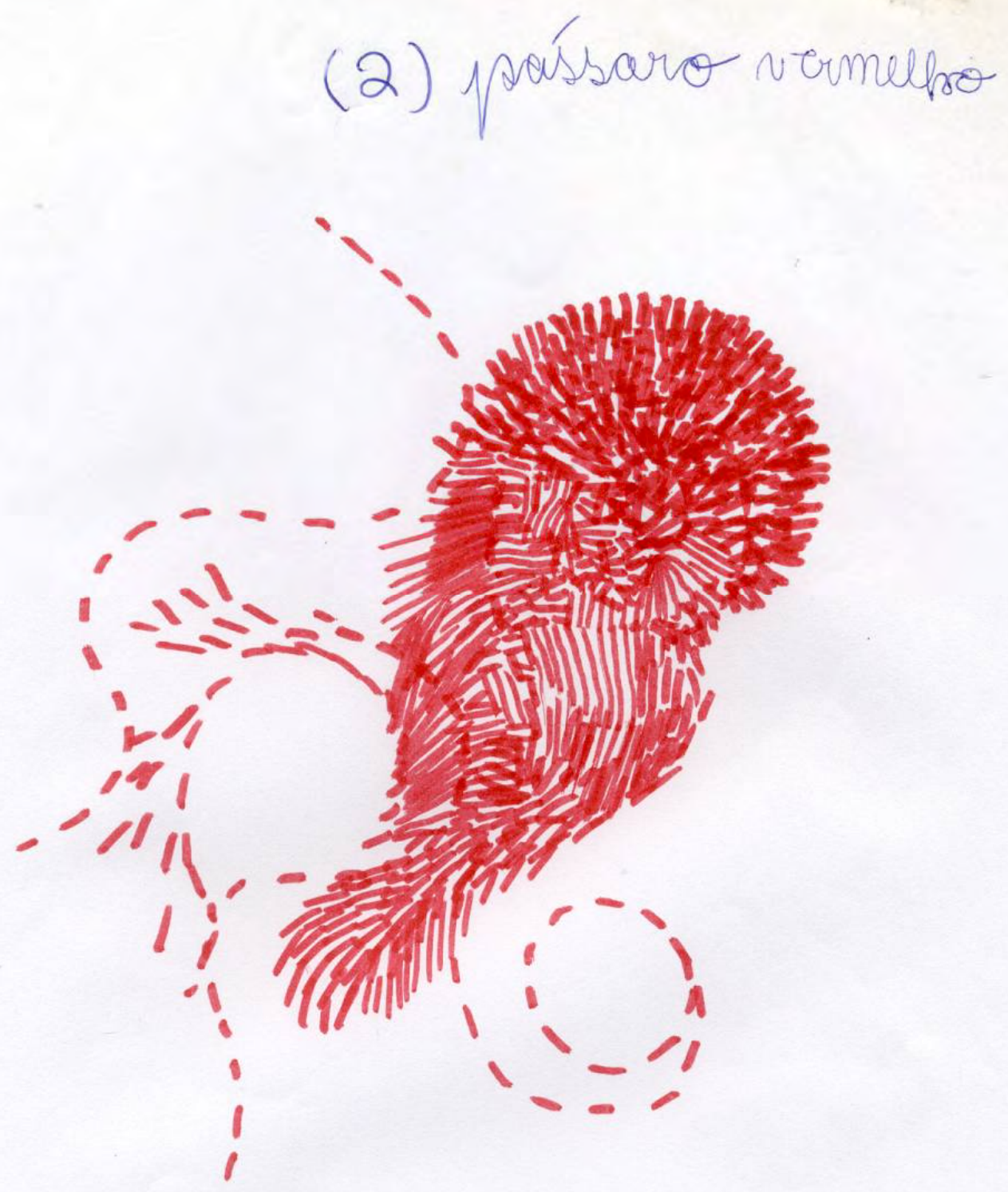




\section{(3)}

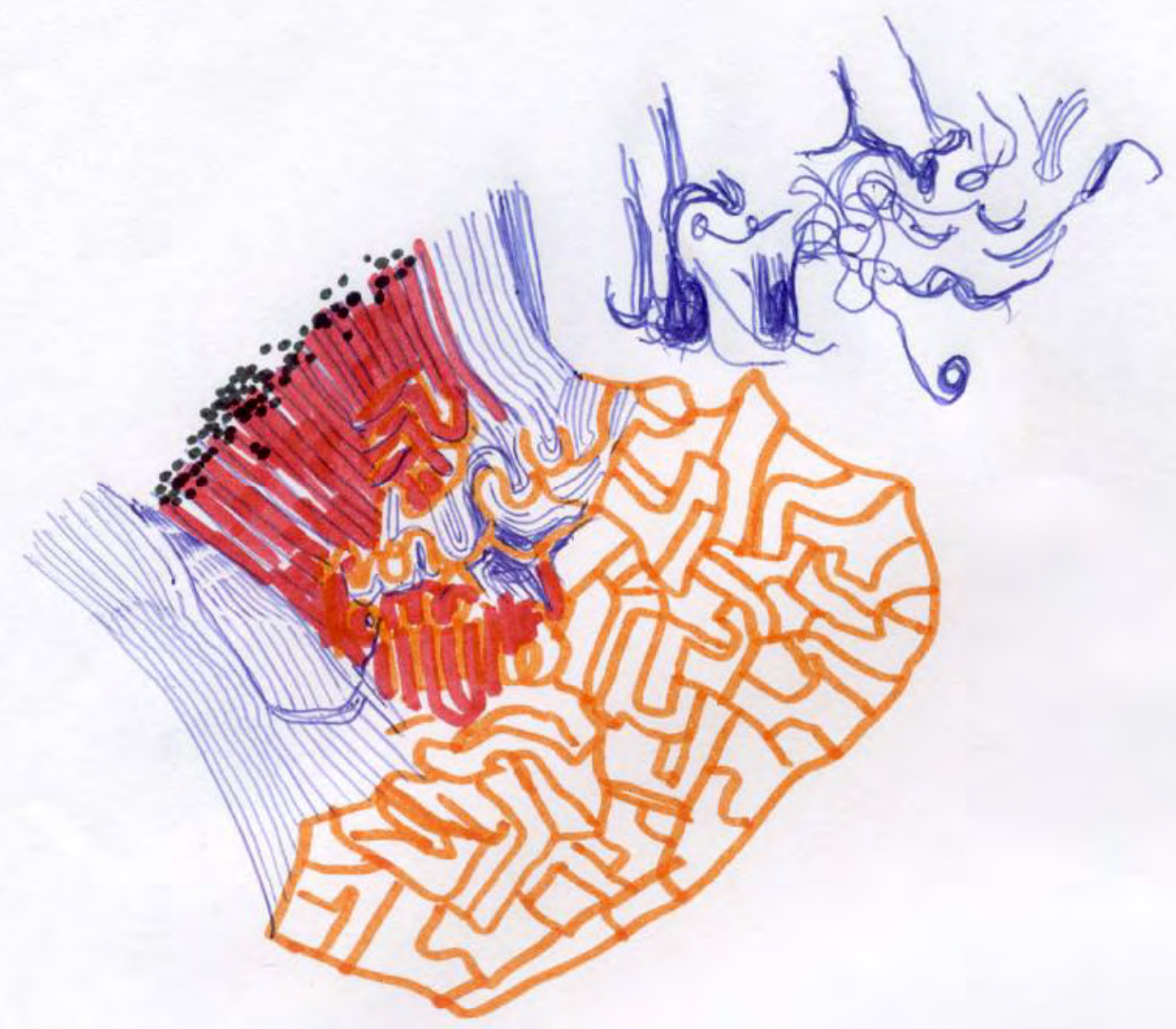




\section{(4)}

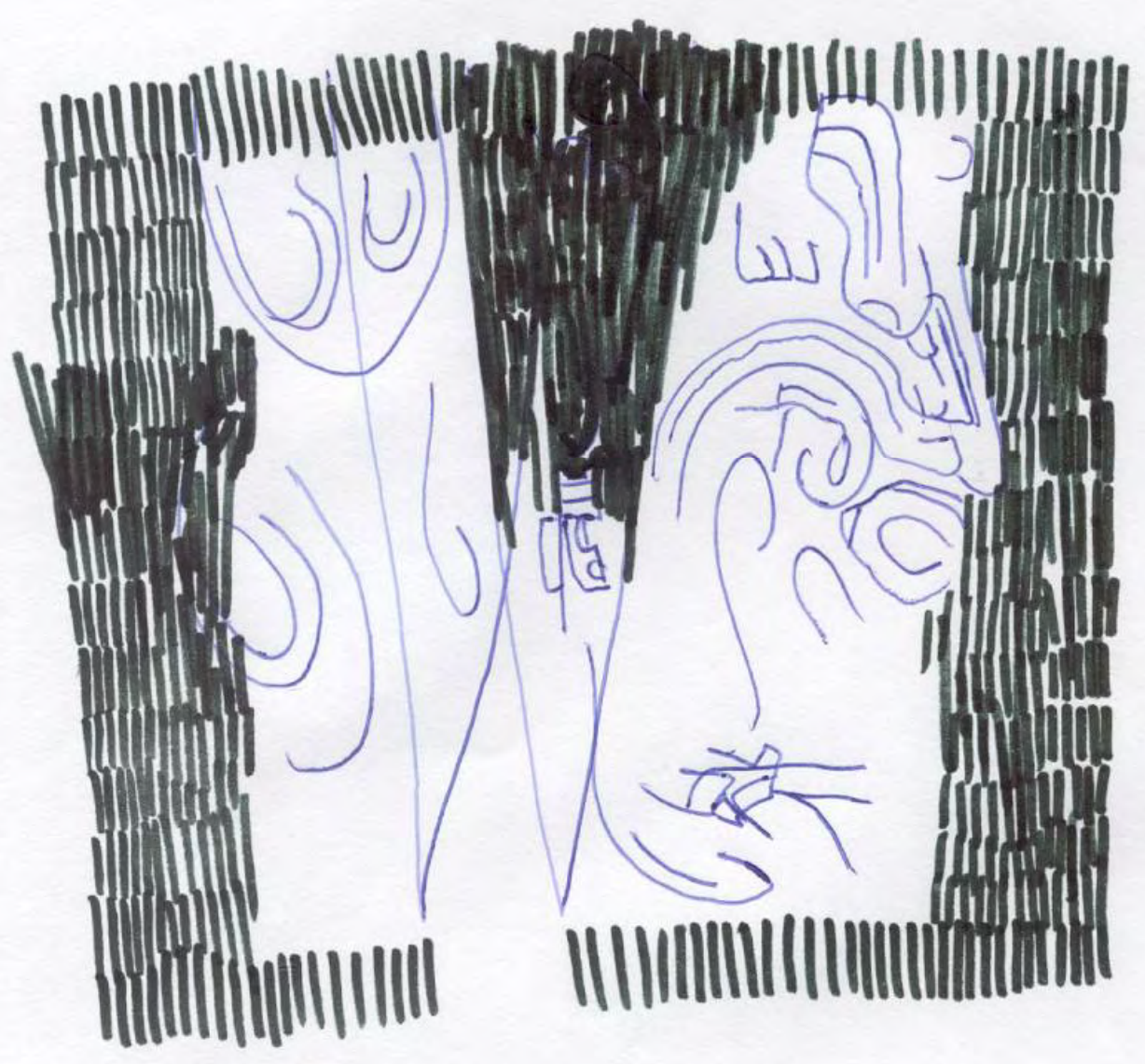




\section{[[[M EDITAÇÃO OU DANÇA DO DRAGÃO]]]}

Nas representações arcaicas ou tradicionais de serpentes, temos algumas possibilidades. Primeiro serpentes que são, de fato, cobras, acentuando o sinônimo entre os dois vocábulos. Temos também serpentes com membros locomotores, bracinhos e perninhas, aproximando-se da figura do lagarto. Às vezes temos literalmente um lagarto que serpenteia.

Como vemos nos mitos arcaicos ou tradicionais, a serpente não é somente um animal em específico, é antes uma função e um sentido: o movimento de serpentear, de fazer a passagem entre domínios, comunicar regiões que se poderiam dizer 'opostas', só por serem diferentes. Opostas significa dizer que essas duas regiões podem, por assim dizer, criar um diagrama, uma circulação de algo, uma polaridade por meio da qual algo circula. E isto por algum tempo, apenas.

Dou um passo adiante: nas representações arcaicas ou tradicionais de dragões, isso é ainda mais complicado. Em primeiro lugar, os dragões também serpenteiam. Isso quer dizer que grande parte dos dragões são também serpentes. Mas, na linha de raciocínio que eu defini, o dragão não é somente um animal, é também uma função e um sentido. Eu me dei conta disso pois, ao passo em que existe o verbo serpentear, existe o verbo dragar, que significa trazer algo do fundo para a superfície. Isso se aplica quando precisamos retirar algo do fundo de um rio ou lago. Temos a draga, um aparelho imenso.

O que é o fundo? É simplesmente o que não se vê, aquilo que está dobrado nas dobras do real, em meio às cores e texturas da paisagem; aquilo que está costurado na granulação do horizonte, cujo grão é o próprio ponto de costura; ou participa da vida de modo desconhecido. Não se trata do fundo de um espaço qualquer, pois estamos aí a falar da superfície do fundo. Aí fundo se mostra. No caso da função empreendida por um dragão, do sentido trabalhado por ele, trata-se mais de um fundo imperceptível, trabalhando dentro da opacidade e da espessura. 0 dragão produz a espessura que sobrevive. Ele traz do fundo o brotamento ou a costura da espessura e da opacidade. Ele 'fecha' a matéria, retendo suas dobras, poros, fendas, cortes, rachaduras. 
Nesse meu estudo sobre visceralidade, resolvi escrever sobre o dragão por dignidade e afinidade de uma ideia arcaica ou tradicional que parece expressar a víscera do mundo. A violência da vida. Uma criatura majestosa, aberrante e ruidosa. Muitos dos deuses primordiais são dragões. 


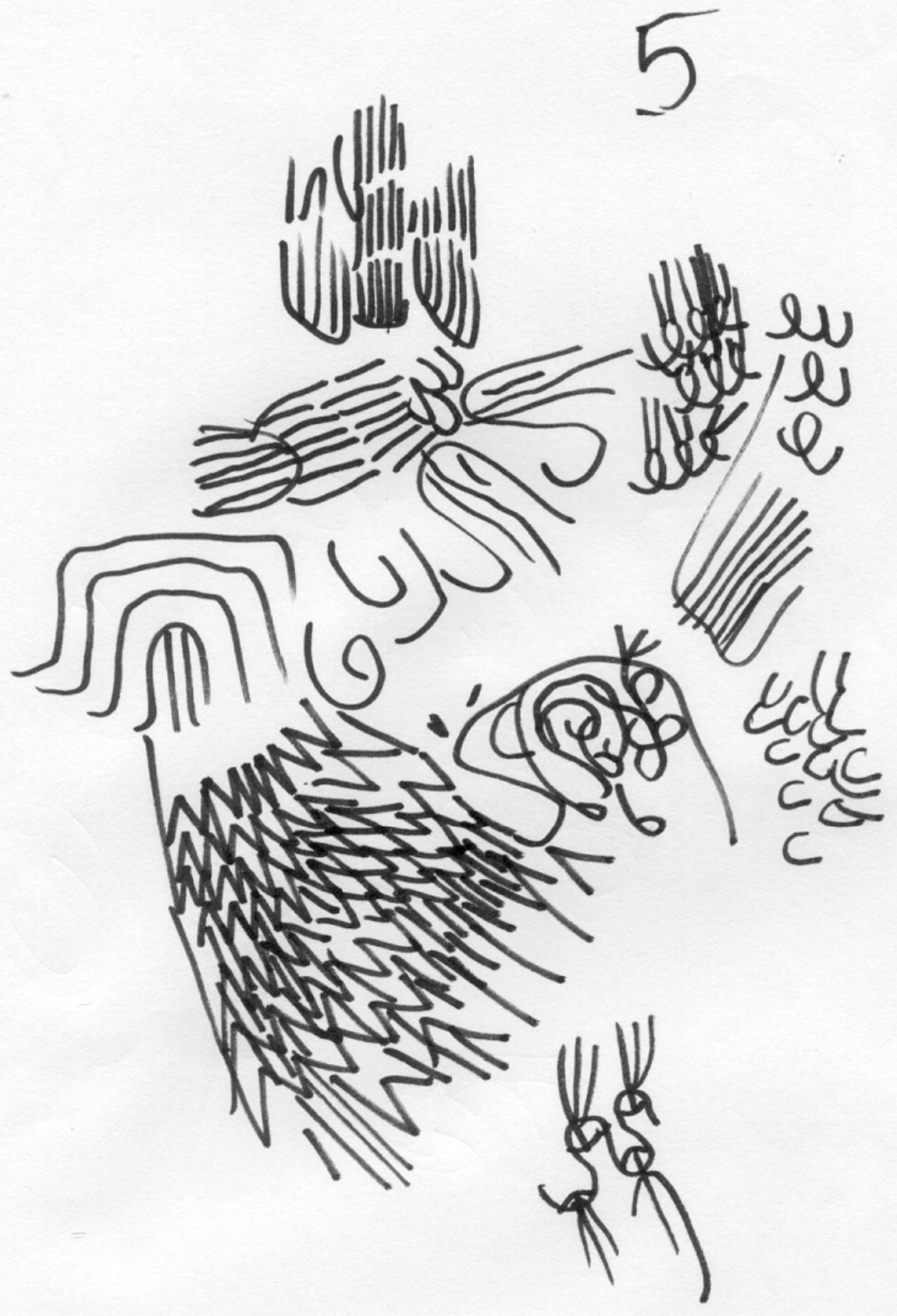




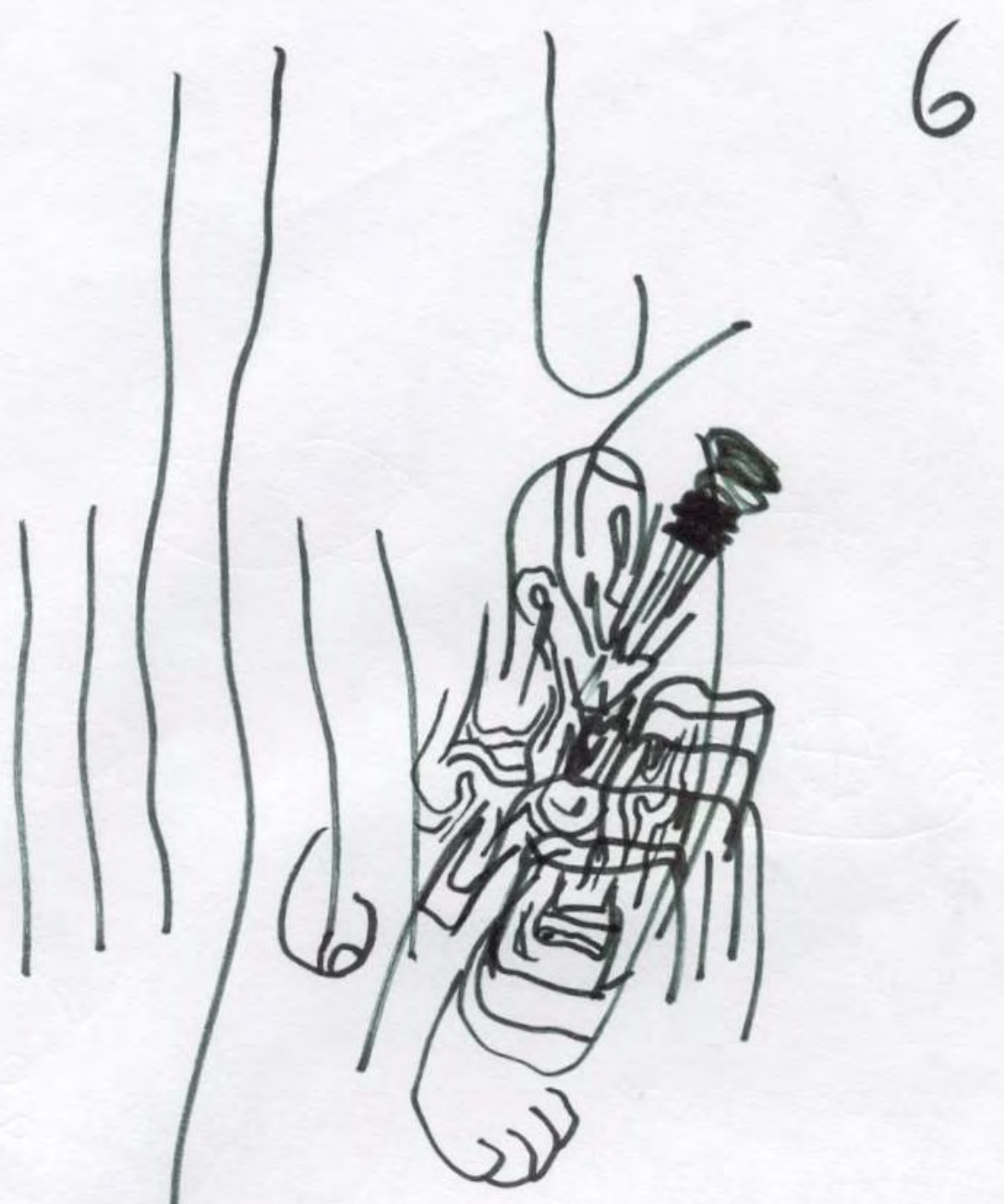




\section{[[[O CHÃO COMO MUNDIFICAÇÃO: A SITUAÇÃO]]]}

Quando eu ia em JAMs de contato-improvisação, na maior das vezes eu era uma daquelas pessoas que ficava muito tempo no chão, perseguindo a produção de peso, sensações. Faço variações mínimas de posição, tudo já muda. Claro que precisaríamos conversar sobre qual o tipo de JAM que era.

Em todo caso, esse chão dançante mínimo aconteceu e eu me apropriei dele, sem dar muitos nomes. Possivelmente há uma presença dos relaxamentos ióguicos na emergência desta prática (parte da minha formação), bem como das poucas aulas de Eutonia que fiz. Naturalmente, venho pensar isto. Já que muitos propositores (prefiro não dizer professores) de contato-improvisação têm um pensamento mais ou menos ligado a uma reinvenção da anatomia ou ao menos a uma anatomia experiencial, a anatomia médica europeia não deveria prevalecer. Assim penso eu. São apenas mapas móveis, e não algo a se perseguir.

Se, de um lado o quase-nada (que é quase tudo) de se habitar o chão vem tomar espaço, em outro aspecto produz inteligências autônomas. É quando o corpo conversa não-mediadamente com 0 chão - isto surge de gestos espontâneos de adaptação, muitas vezes valorados negativamente como ruído do movimento. Porém muito valiosos. Isto é análogo à minha relação com o piano: o corpo é esta produção distraída, duvidosa. Então eu passei a modular, nas conduções que realizo, a noção de 'postura', oriunda do ioga, com aquela de 'situação', onde são permitidos e até desejados ajustes espontâneos. Pequenas frestas que se abrem para algo se passar.

Passei a encaixar o meu corpo com quase tudo, como uma grande Anaconda ou um polvo. Uma cadeira também é chão, uma pia também é chão. Uma parede, etc.

Este é um relato bastante precário de uma imensidão de experiências de produção de chão. Uma mundificação.

Então temos uma 'postura' que é intrinsecamente nômade, corporificada na noção de SITUAÇÃO [1]. Temos também esse chão que se multiplica nos objetos e nas formações, estruturas [2].

A construção da gentileza é uma tarefa árdua, quando tematizamos uma anatomia não só experiencial, mas proto-anárquica, desindividuadora e refazedora dos 
próprios parâmetros. Não se trata de uma utopia. A invasão dos sentidos de Rousseau pelo borbulhar da água é um refazimento da anatomia. Então, este corpo pode ser atravessado por feixes heterogêneos que podem aconselhar complexas lições. Como diz Uno a partir de Hijikata, não é a criança que é livre e vai ao mundo, mas é o mundo que já invadiu o corpo da criança. Então, este é nosso terceiro item nesta discussão $\mathrm{A}$ anatomia refeita é necessariamente multiespecífica, mundificante [3].

Então, sou inevitavelmente invadido por perguntas de toda parte. Uma dessas perguntas converteu-se em axioma: não se sabe o que é o contato [4]. 0 primeiro texto (partes I e II) do livro diálogos (DELEUZE-PARNET), em definitivo não lido como filosofia e tampouco como literatura, poderá dar pistas. Digo isso pois este texto desmistifica o extraordinário do devir e o coloca misturado ao ordinário. DeleuzeParnet, contato-improvisação.

\section{[[[A NECESSÁRIA FICCIONALIZAÇÃO DO CORPO]]]}

Ocorre novamente a necessidade de esquiva, ainda que fadada ao fracasso, da aliança da dança com a medicina da dissecação e do organismo previamente organizado. 0 corpossom - um trabalho de fabricação de escutas e vozes corporificantes - funciona na medida de um narrar insólito que revela a ficcionalidade inerente ao corpo. As conversas com Thais di Marco foram um impulso para se tomar uma distância estratégica geral da educação somática no sentido da docilização e apagamento de narrativas incoerentes com modelos vigentes. M esmo nas sistematizações, havemos de lidar com a produção incessante de narrativas e sua potência subversiva.

Esta formação e formalização corporais não aderentes estão distanciadas à representação, não mascarando o seu uso. Creio que existe uma saída um pouco patética à representação, que problematiza o próprio uso de modelos. 0 tom patético é uma das faces da ficcionalidade crítica. 


\section{[[[APENAS UMA CONVERSA]]]}

Minha última atividade de dentro do período do doutoramento foram trocas de pesquisa e encontros de leitura com a atriz Thais Sodré. Aqui, dou-me conta de que uma proposição aparentemente simples, sem propósito senão o próprio encontro, faz condensarem as forças e se verificarem a cada momento a sobriedade da tarefa. 


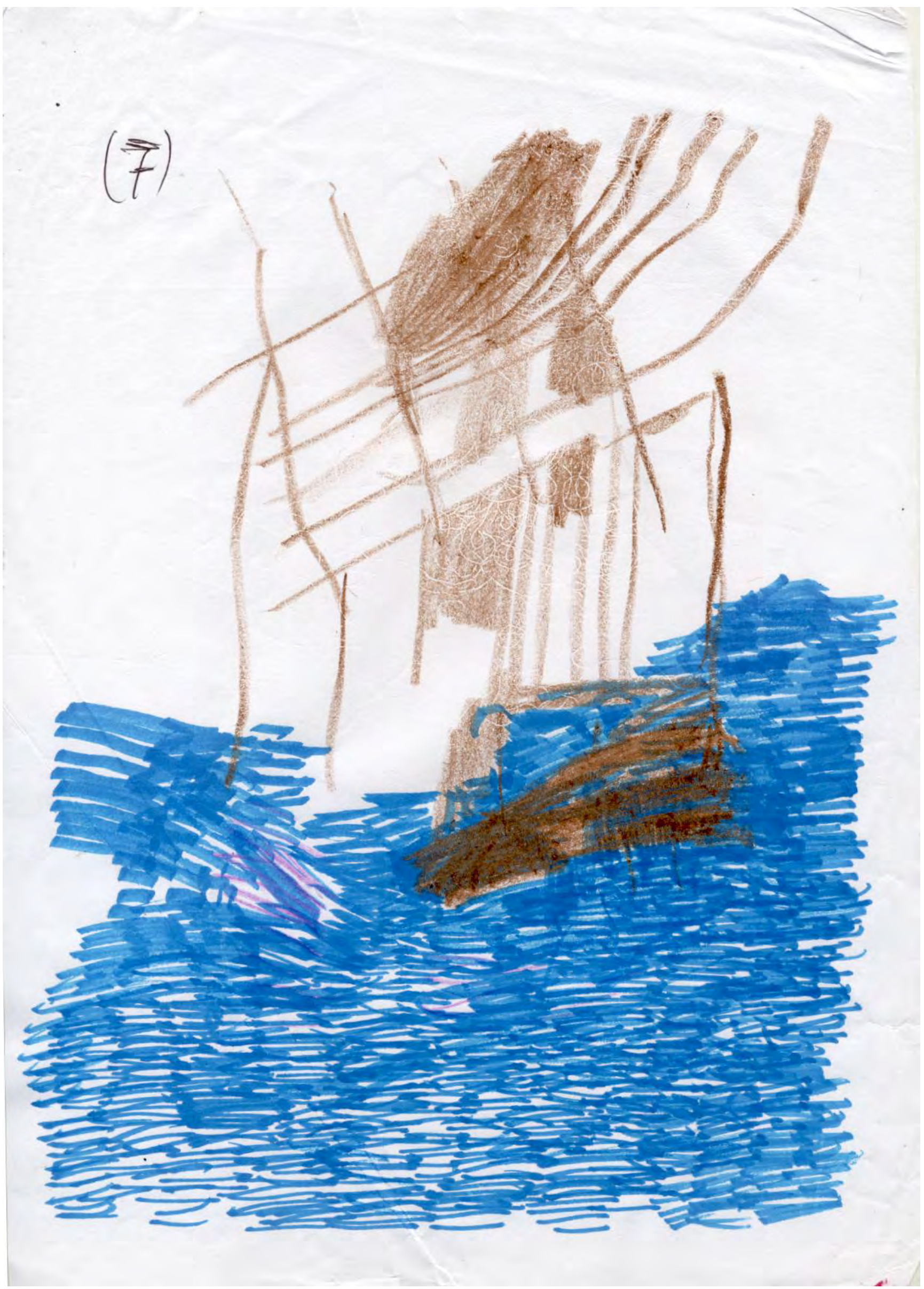


441

(8)
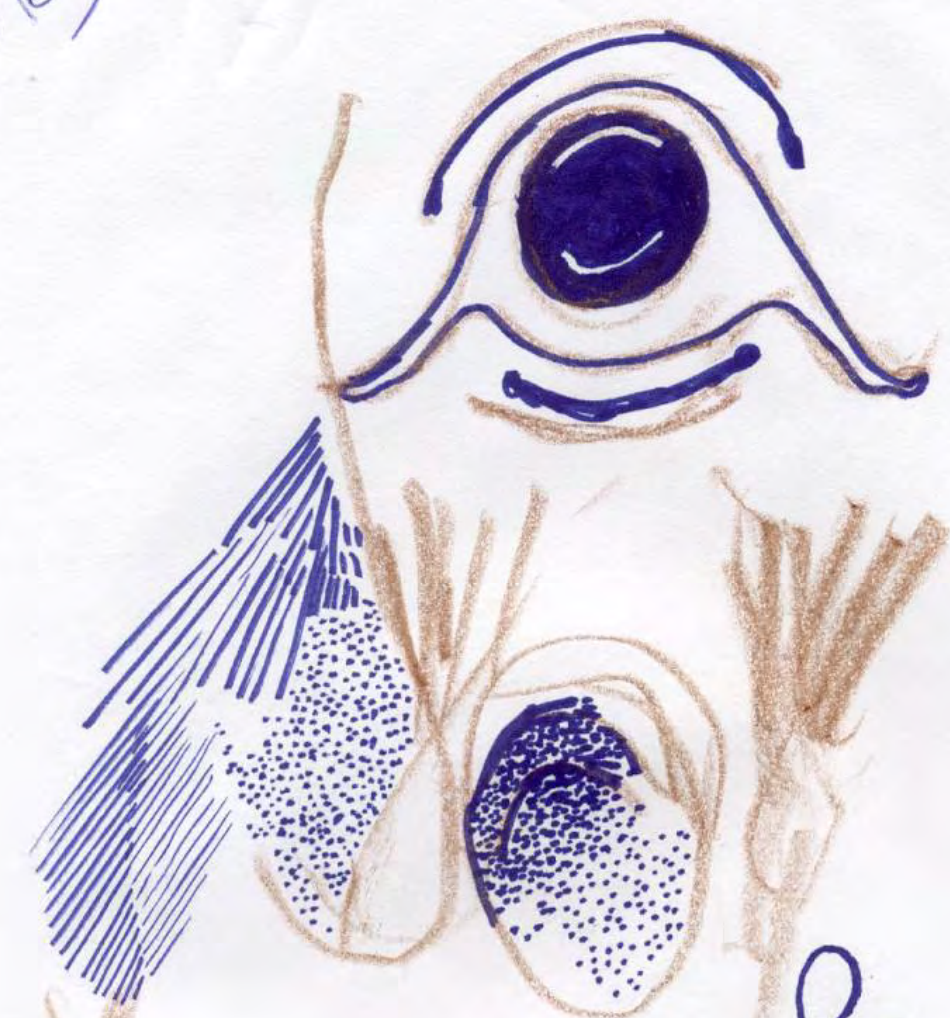

y.
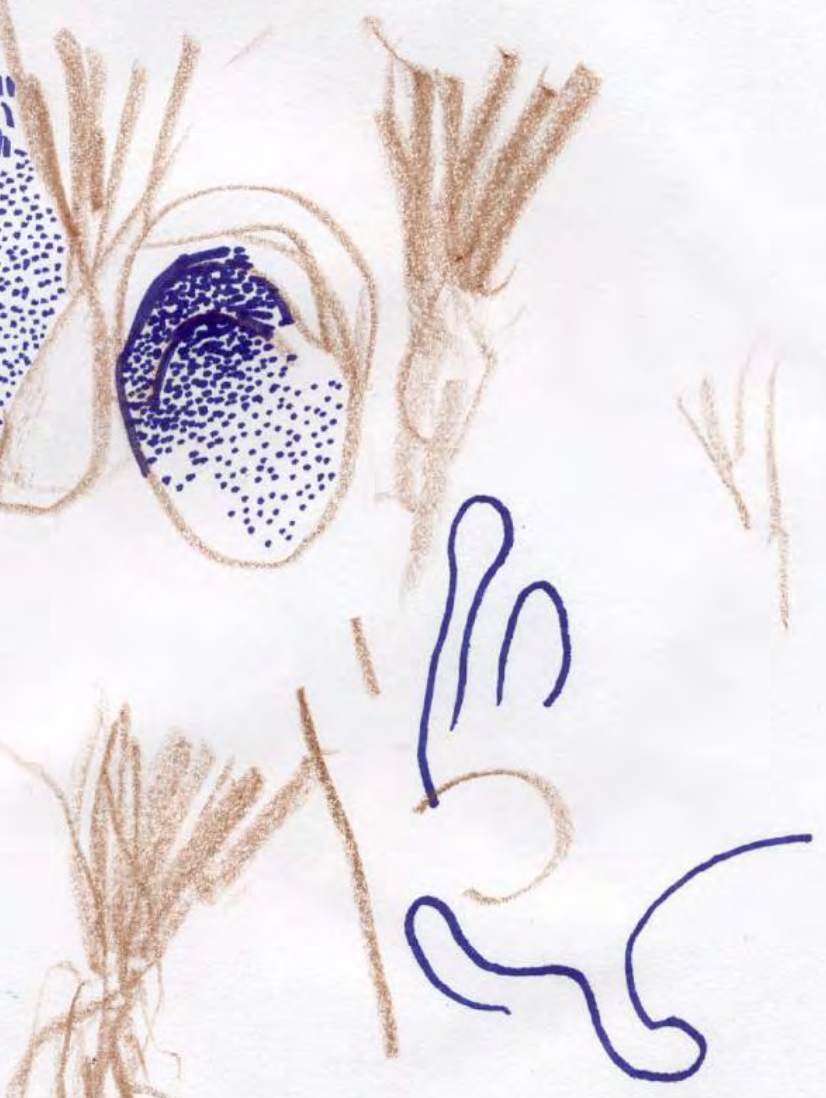


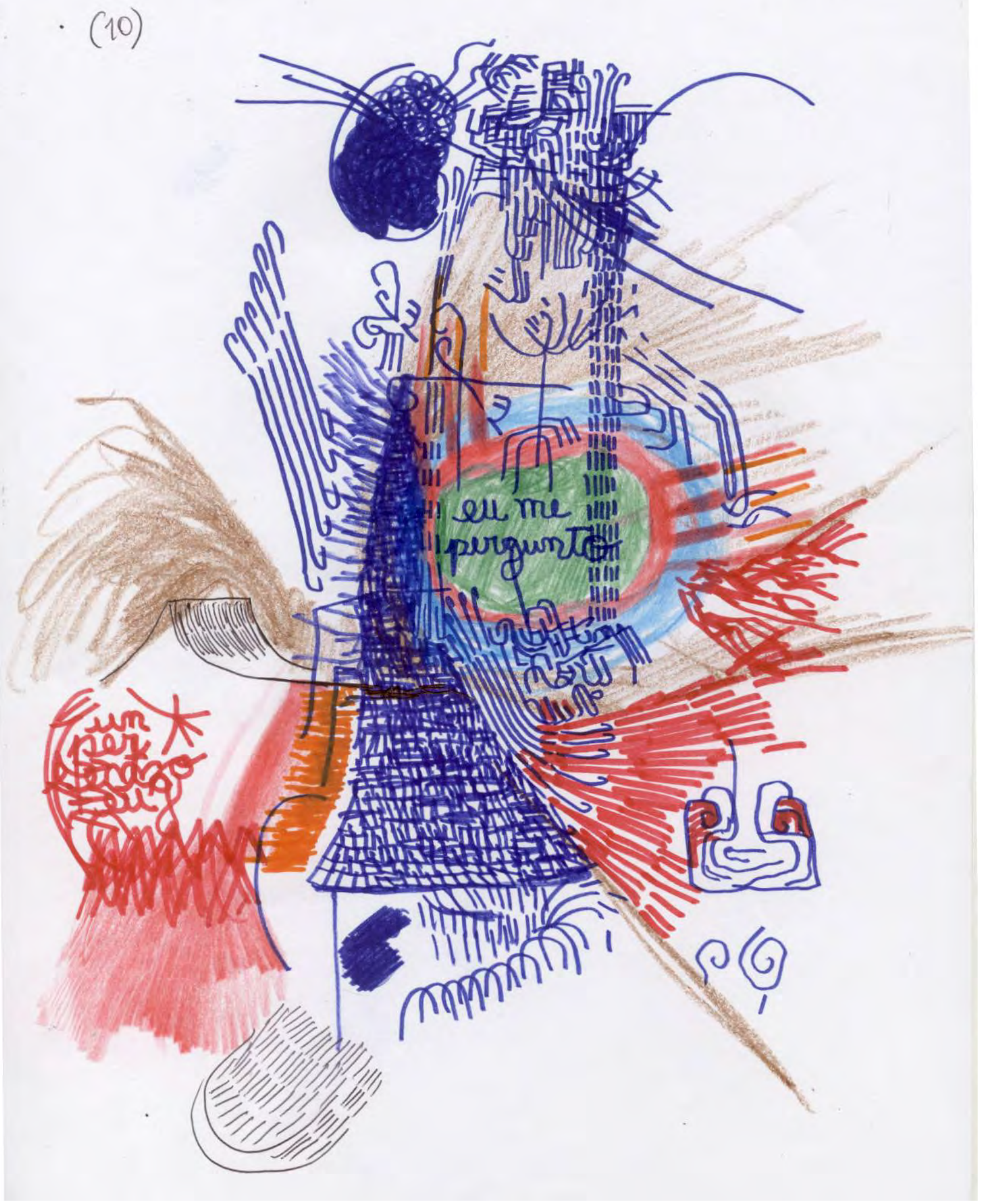




\section{[[[FOTOS DE JÚLLA FÁVERO - PARQUE DA ÁGUA BRANCA]]]}
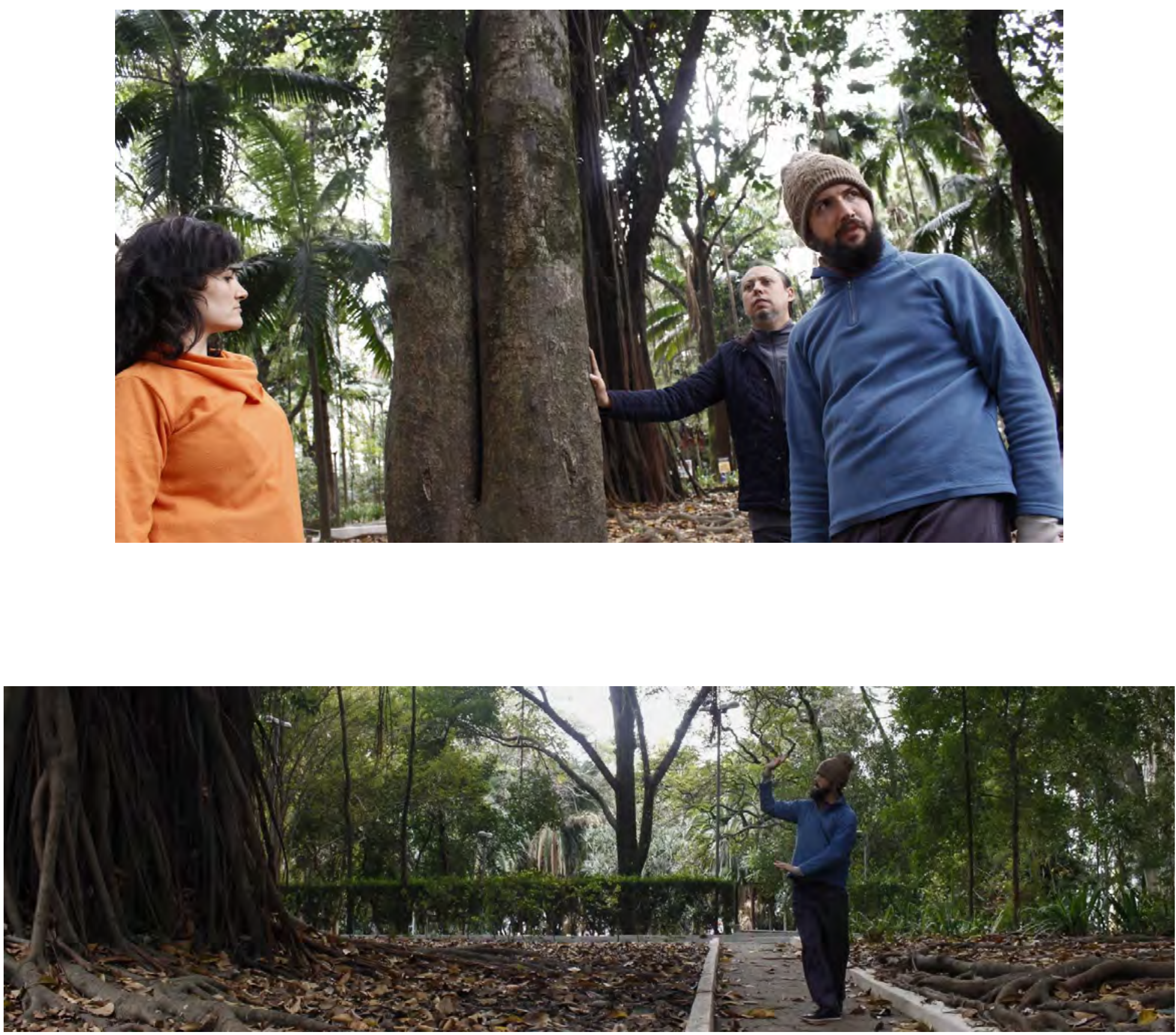

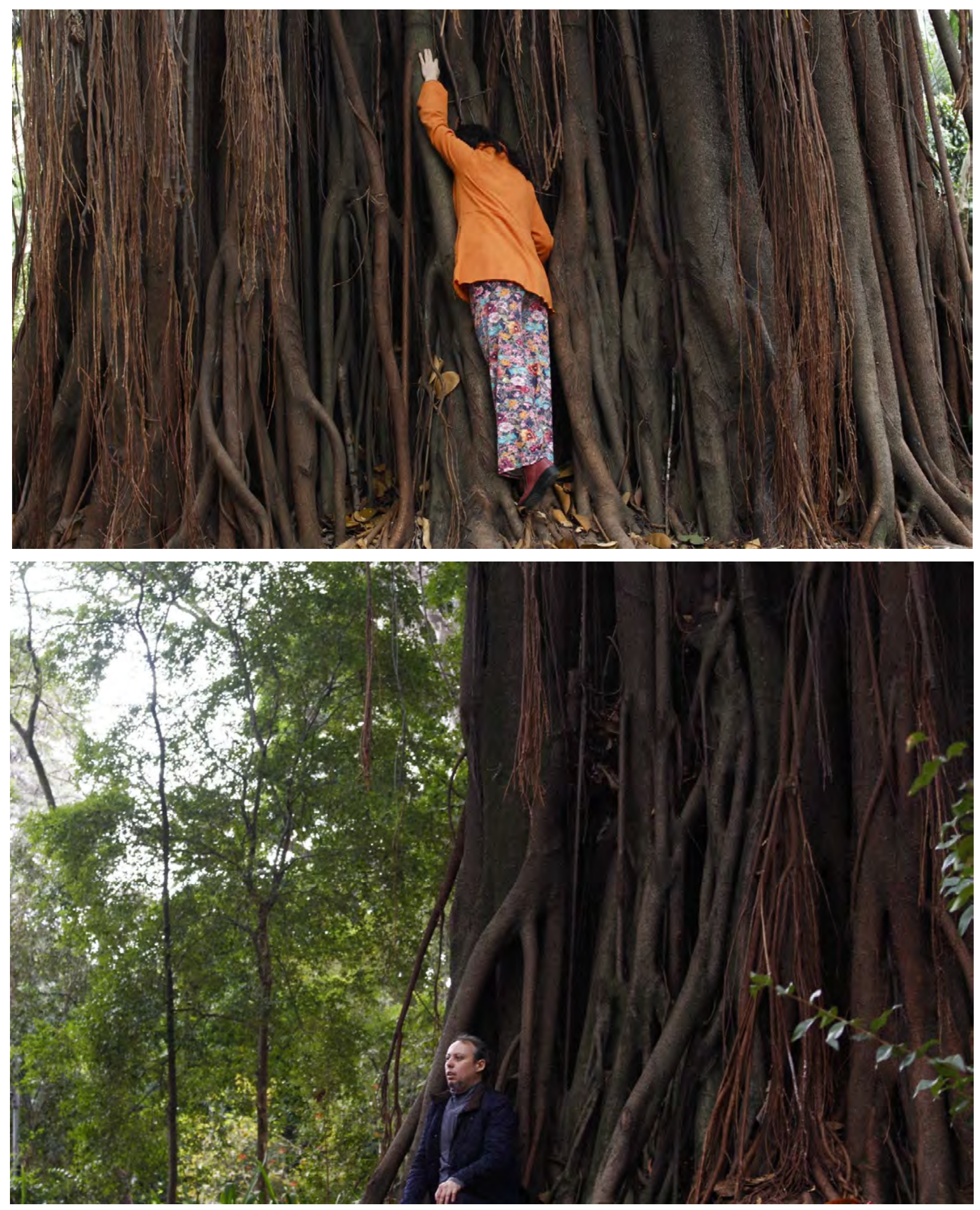
[[[DOS NOMES, MAIS UMA VEZ]]]

\section{Laboratório Corpossom;}

\section{Corpossom Eme-Agá (M ito Harmonia)}

foi o primeiro nome para Agrupamento Corpossom;

\section{Para os experimentos solo}

song of bones;

transfiguração pitagórica;

invocação para cordaria;

I am sorry mister Scelsi;

umanimusgo

utilizo o nome Corpossom em Cisma.

\section{[[[DEZDIAS DE ÁRVORE]]] [[[EM ANEXO]]]}

Dez dias de improvisação numa árvore específica, escolhida dentre tantas na Praça do relógio (USP campus capital). Após cada dia de improvisação, respeitando uma determinada estrutura, eu registrava o meu relato de algo do que havia acontecido, com o gravador de áudio do celular. Segue a transcrição dos áudios. 'Complemento' entre colchetes significa que foi gravado um novo áudio para complementar o registro. As palavras entre colchetes acrescentam algumas informações na ocasião da transcrição.

Esse procedimento foi a vivência-base para o trabalho umanimusgo, que se baseia na carta de Antonin Artaud o homem-árvore. 


\section{[[[POSSÍVEL PROPOSIÇÃO E ESTRUTURA PARA UMANIMUSGO]]]}

\section{Por quê umanimusgo? [proposição]}

O Umanimusgo foi um modo de se traduzir que uma árvore é um nó de muitos mundos, e não um axis mundi, como sugere a cosmologia política do modelo arbóreo. Um umanimusgo é um rizoma e uma simbiose que também depende do suporte e condições de umidade. Um umanimusgo é um bloco de devir vegetal. Há também um incômodo com o modo com que Artaud se utiliza da palavra homem, tendo-se em vista que ele poderia dizer o contrário. Assim, com umanimusgo, viso um corpo descentrado e heterogêneo, alter-orgânico e multi-específico, multi-escalar.

[estrutura] (1) dança da árvore - (2) giros que sabem de si - (3) pseudo-taichi-árvore e variações; serpenteamento - (4) canto da vibração da coluna - (5) possível leitura do texto de Artaud O HOM EM ÁRVORE 


\section{[texto de Artaud: 0 Homem-Árvore (2007, ps. 155-161)]}

\section{[O HOM EM -ÁRVORE]}

(Carta a Pierre Loeb)

Ivry, 23 de Abril de 1947

Caro amigo,

0 tempo em que o homem era uma árvore sem órgãos nem função, mas de de vontade, e árvore de vontade que anda,

voltará.

Existiu, e voltará.

Porque a grande mentira foi fazer do homem um organismo,

$$
\begin{aligned}
& \text { ingestão, } \\
& \text { assimilação, } \\
& \text { incubação, } \\
& \text { excreção, }
\end{aligned}
$$

o que era criar toda uma ordem de funções latentes

e que escapam ao domínio da vontade

$$
\text { decisora; }
$$

a vontade que decide a cada instante de si;

porque assim era esta árvore humana que anda, uma vontade que decide a cada instante de si, sem funções ocultas, subjacentes,

rege.

Na verdade, do que somos e queremos poucas coisas restam, uma poeira ínfima sobrenada, e o resto, Pierre Loeb, o que é? Um organismo de ingurgitar, pesado de carne e que defeca, 
e em cujo campo,

como um irisado, distante,

um arco-íris de reconcilicação com deus,

sobrenadam,

nadam

estes átomos perdidos,

as ideias,

acidentes e acasos no conjunto de todo um corpo.

0 que foi Baudelaire?

0 que foram Edgar Poe, Nietzsche, Gérard de Nerval?

CORPOS

que comeram,

digeriram,

dormiram,

ressonaram uma vez por noite,

cagaram

entre 25 e 30000 vezes,

e que à frente de 30 ou 40 mil refeições,

40 mil sonos,

40 mil roncos,

40 mil bocas acres e azedas ao despertar,

tem, cada um deles, que apresentar cinquenta poemas,

o que não chega, de facto,

e o equilíbrio entre a produção mágica e a produção automática está muito longe de ser mantido,

está abominavelmente desfeito,

mas a realidade humana, Pierre Loeb, não é isto.

Nós somos cinquenta poemas.

O resto não somos nós mas o nada que nos veste,

começa por rir-se de nós,

vive de nós a seguir.

Ora, este nada nada é, 
não é qualquer coisa,

é alguns.

Digo alguns homens.

Animais sem vontade nem pensamento próprios,

quer dizer,

sem dor própria,

sem aceitação em si da vontade de uma dor própria,

e como forma de viver só encontraram isso,

que é falsificar a humanidade.

$\mathrm{E}$ da árvore-corpo

mas vontade pura, que éramos,

fizeram este alambique para merda,

esta barrica de destilação fecal,

causa de peste

e de todas as doenças,

e desse lado de fraqueza híbrida,

de tara congênita,

que caracteriza o homem nascido.

Um dia o homem era virulento,

só era nervos eléctricos,

chamas de um fósforo perpetuamente aceso,

mas isto passou à fábula

porque os animais nasceram-se nela,

os animais,

essas deficiências de um magnetismo inato,

essa cova de oco entre dois foles de força

que não eram,

eram nada

e passaram a qualquer coisa,

e a vida mágica do homem caiu,

o homem caiu do seu rochedo com íman 
e a inspiração, que era o fundo,

passou a ser 0 acaso, 0 acidente,

a raridade,

a excelência,

talvez excelência

mas à frente de um tal acervo de horrores,

que mais valia nunca ter nascido.

Não era o estado edénico,

era 0 estado-manobra,

operário,

o trabalho

sem rebarbas, sem perdas,

numa indescritível raridade.

Mas por que se não manteve este estado?

Pelas razões que vão levar

o organismo de animal, feito para e por animais,

que desde há séculos é seu sucessor,

$$
\text { a explodir. }
$$

Exactamente pelas mesmas razões.

Estas mais fatais do que as outras.

Mais fatal, a explosão do organismo dos animais

que a do trabalho único,

no esforço da vontade única e bastante impossível de ser encontrada.

Porque realmente o homem-árvore,

o homem sem função nem órgãos que Ihe justifiquem a humanidade,

esse homem prosseguiu

sob a capa do ilusório do outro,

a capa ilusória do outro,

prosseguiu na sua vontade

mas oculta,

sem compromisso nem contacto com o outro.

E o que caiu foi o que quis acercar-se dele e imitá-lo, 
e não tardará que revele, com uma grande pancada

de bomba,

a sua inanidade.

Porque deveria criar-se um crivo entre o primeiro dos homens-árvores e os outros, mas aos outros foi preciso o tempo, séculos de tempo para os homens que tinham

começado ganharem o seu corpo, como aquele que não começou e não parou de ganhar o seu corpo, embora no vazio não houvesse ninguém, e não houvesse começo.

\section{E então? \\ Então.}

Então nasceram as deficiências entre o homem e o labor árido e o labor árido de bloquear também o nada.

Será em breve um trabalho concluído.

E a carapaça terá de ceder.

A carapaça do mundo presente.

Construída sobre as mutilações digestivas de um corpo que dez mil guerras despedaçam,

$$
\begin{aligned}
& \text { e a dor, } \\
& \text { e a doença, } \\
& \text { e a miséria, }
\end{aligned}
$$

e a penúria dos gêneros, dos objectos e das substâncias de primeira necessidade.

Os preservadores da ordem do lucro

das instituições sociais e burguesas e burguesas,

que nunca trabalharam

mas grão a grão e desde há biliões de anos amealharam o bem roubado, e o conservam em certas cavernas de forças

defendidas por toda a humanidade, com algumas pequenas excepções,

ver-se-ão obrigados a gastar as suas energias

e por essa causa combater, 
e não poderão deixar de combater

porque a guerra que há-de vir, e esta apocalíptica, tem como final a sua cremação eterna.

Por isso julgo que o conflito entre a América e a Rússia, mesmo com um reforço de bombas atómicas,

Pouca coisa é ao lado e em face do outro conflito

que vai

repentinamente

estalar

entre os preservadores de uma humanidade digestiva,

por um lado,

e pelo outro

o homem de vontade pura e os seus muito raros adeptos e sequazes, mas que têm por si
a inextinguível
força.

Antonin Artaud 


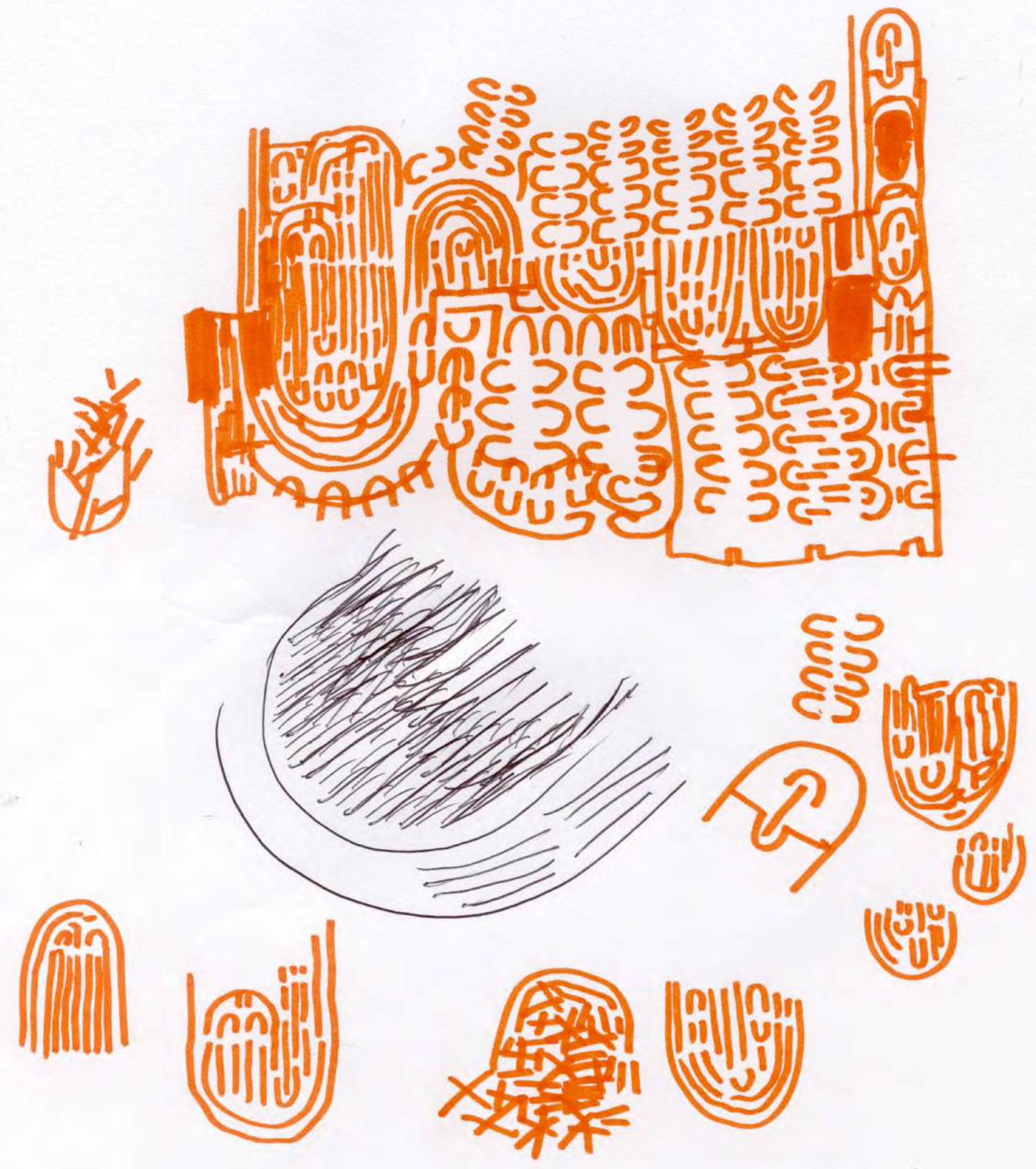




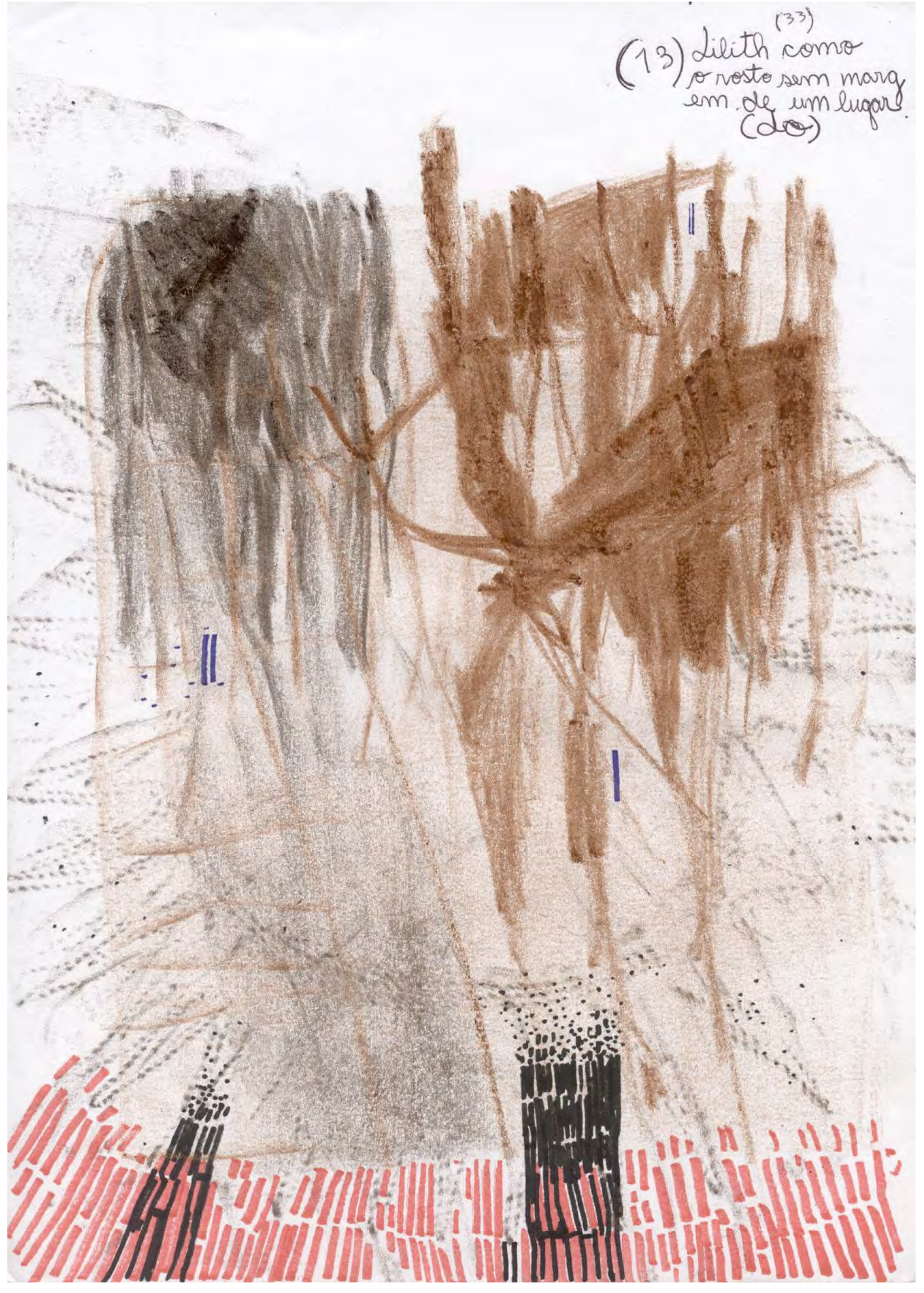




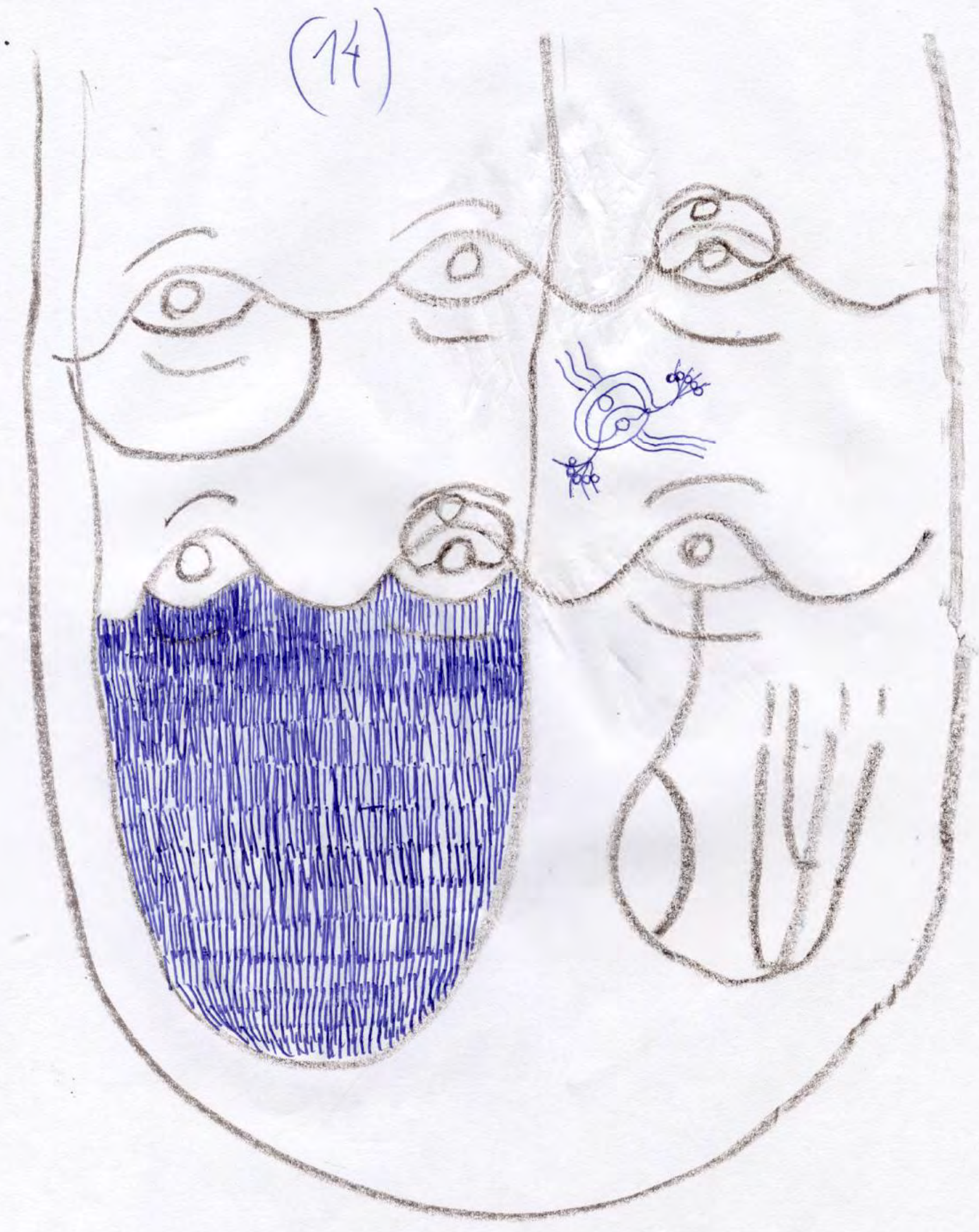




\section{[[[COLAGEM DE BULAS]]] \\ [ESTRUTURA DO UMANIM USGO]}

São as primeiras cinco práticas do roteiro de umanimusgo: as três primeiras aqui descritas são exercícios que, juntos, perfazer continuamente a 'dança da árvore'. Em seguida, descrevo os giros

\section{A. Três modos de habitação arbórea: como se construir uma 'dança da árvore'}

1. Disparar formas. Aqui é preciso brincar e produzir um fluxo de movimentos ou gestos que não necessariamente imitem mas sim acompanhem os desenhos dos galhos, São essas espirais com outras temporalidade.

Quando criança eu gostava de imaginar que as plantas era explosões congeladas, explosões, sim, mas em um tempo ultra-lento. Então o que estávamos a testemunhar ao passar em um jardim, em um matagal, em uma floresta, é uma explosão generalizada.

Então, basta compreender que não se trata de imitar as plantas, apenas de acompanhar o seu movimento - será que o taichi (e outras artes do movimento e do contato) são pensamentos vegetais? Não sei. 0 que ocorre é simplesmente que, por mais que o início que o seu exercício possa parecer imitativo no início, a tarefa consistiria em permitir que as formas se encavalem se disparem.

Este exercício tem alguma base no laboratório 'da ação contínua ao fluxo', exposto no mestrado. Aqui temos a construção de um fluxo de disparos de movimento que acompanham os desenhos vegetais. 0 limiar entre imitação e 0 acompanhar por vezes é tênue e apreendido qualitativamente, a partir do corpo desconhecido que emerge.

2. Configurações e mudanças. Esta etapa se baseia nas conformações vegetais.

Aqui, um exercício de ajuste involuntário, busco me configurar em pé, em qualquer situação mais ou menos sustentável, e espero a forma dinâmica deslizar ou derreter para outra. Aqui o delicado é o tempo que demora àquela forma começar a 'pensar' a forma seguinte. Outra coisa bastante importante é que é preciso deixar a 
respiração livre, é preciso deixar o corpo respirar, pois é como se aquela configuração respirasse.

É uma espécie de tai chi onde a erosão da forma é o tema. Ou uma apropriação da sessão de modelo-vivo, onde o corpo passa a morar uma configuração e se derramar continuamente sobre ela. Ou ainda quando fazemos uma série de ioga repetidas vezes e percebemos aquele poético fluir involuntário de uma posição a outra do corpo...

Esta etapa tem, portanto, uma proposição correspondente ao trabalho chamado 'da ação contínua ao fluxo'. Contudo, o objetivo deste trabalho em específico não é a incandescência, é contínua erosão da formação que ali está: é perceber continuamente a formação. Pois não há como não se ter uma forma. 0 corpo está sempre em formação, ensina-nos Simondon. E, por falar nele e nos seus 'paradigmas físicos', uma imagem, além da erosão, para este exercício, talvez fosse aquela onde vemos um fluido dentro de um corpo de vidro. Esse líquido teria uma viscosidade e uma mistura tais que ele continua a circular lá dentro do copo parado, já que as partículas misturadas continuam a se acoplar, mas a mistura tem uma densidade tal que não permite que isso ocorra. A despeito disto e por causa disto, as formações prosseguem.

Este exercício visa a transformação de uma posição aparentemente fixa em outra. A posição derrete 'por dentro', 'nela mesma', criando devires imperceptíveis. Então, busca-se ficar parado e captar, processualmente, para onde aquela configuração, aquela formação, poderá 'escorrer'.

3. A forma é movimento. Esta etapa é uma conversão sensível onde as formas são captadas como movimentação. No mestrado, eu dizia que 'som é movimento'. Aqui, sem saber ainda se recuei, avancei ou contornei a assertiva, proponho essa suspensão da mimese na direção de uma espécie de bizarra mimese qualitativa das torsões das formas. Uma espécie de divergência da etapa anterior, onde o foco não é apenas 0 movimento mas a própria forma como 'escape', como devir. É isso: a própria forma é um escape, ela é uma forma de escape de si própria. A forma é uma forma de escape.

Assim, não há como negar que estamos dançando com árvores, já que elas estão em intenso em vertiginoso movimento, elas são esse múltiplo movimento de 
parafusar em muitas direções. A cambalhota paradoxal de José Gil, nós a encontramos na forma como forma de escape da própria forma, como subversão cognitiva.

Então, não se trata de acompanhar os desenhos da geografia da planta, ou de erodir as profusas configurações sempre presentes na planta, mas agora de escapar pela forma da planta que é um mover-se.

\section{B. Giros que sabem de si (e decidem por si)}

Esse exercício vem da experimentação da espiral caminhando: um giro ou um círculo se podem armar e, de modo parecido às configurações, o giro ou círculo se esgota e se vai derramar em outro giro ou círculo que já se preparava enquanto o primeiro se punha em vias de saturação. É como se o giro e o círculo fossem o arranjo momentâneo de diversas espirais e circulações que fazem passar algo; esse giro ou espiral criará uma espécie de território ou, por assim dizer, um campo magnético que se esgota.

Aqui, é muito importante, também a processualidade entre um giro e outro, pois há muitas possibilidades. As espirais proliferam.

\section{Pseudo-taichi-árvore}

Pretendeu-se se uma espécie de continuação dos giros continuados e improvisados, que se concentram cada vez mais. Esta proposição veio também de uma percepção que tive durante um treino de taichi, onde eu comecei a prestar atenção nos vegetais à minha volta enquanto treinava, e isto mudou completamente a textura daquilo que se passava. Talvez a própria passagem da atenção fosse uma ação, um derramar de um campo saturado de interesses da criatividade do próprio movimento.

Este exercício produz, ao longo do processo, escalas que percorrem as outras práticas já percorridas, ou ainda percorrem outras formações de movimento, ou ainda, (e o roteiro supõe isso) modos diferenciantes de respiração, vocalização ou vibração. Essa diferenciação e percorrimento pois este pseudo-taichi é também uma 'revisão', das faixas já percorridas, investigação de passagens, verificação de aderências, dobras, contornos, fissuras, escapes... 
(15)

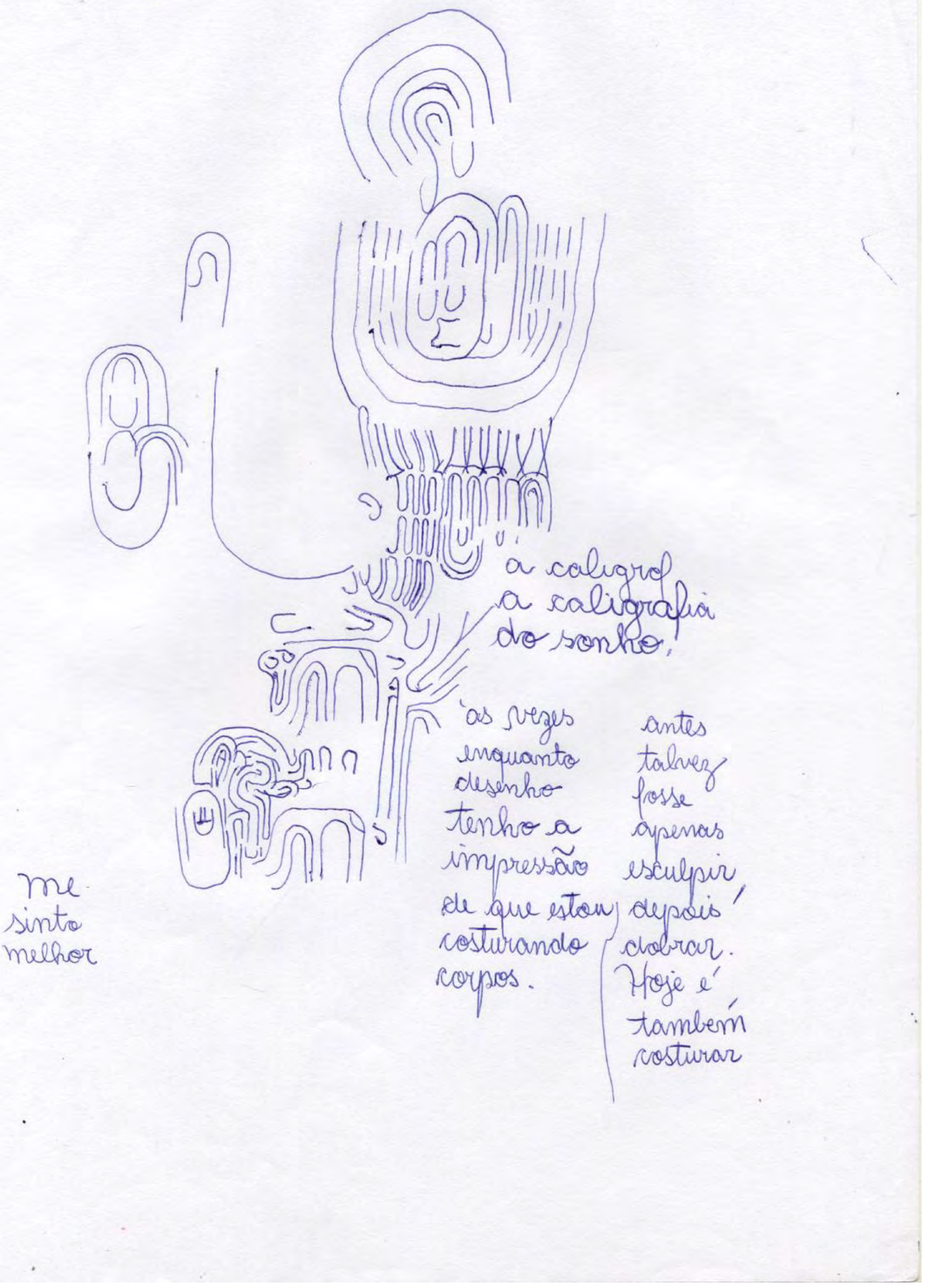




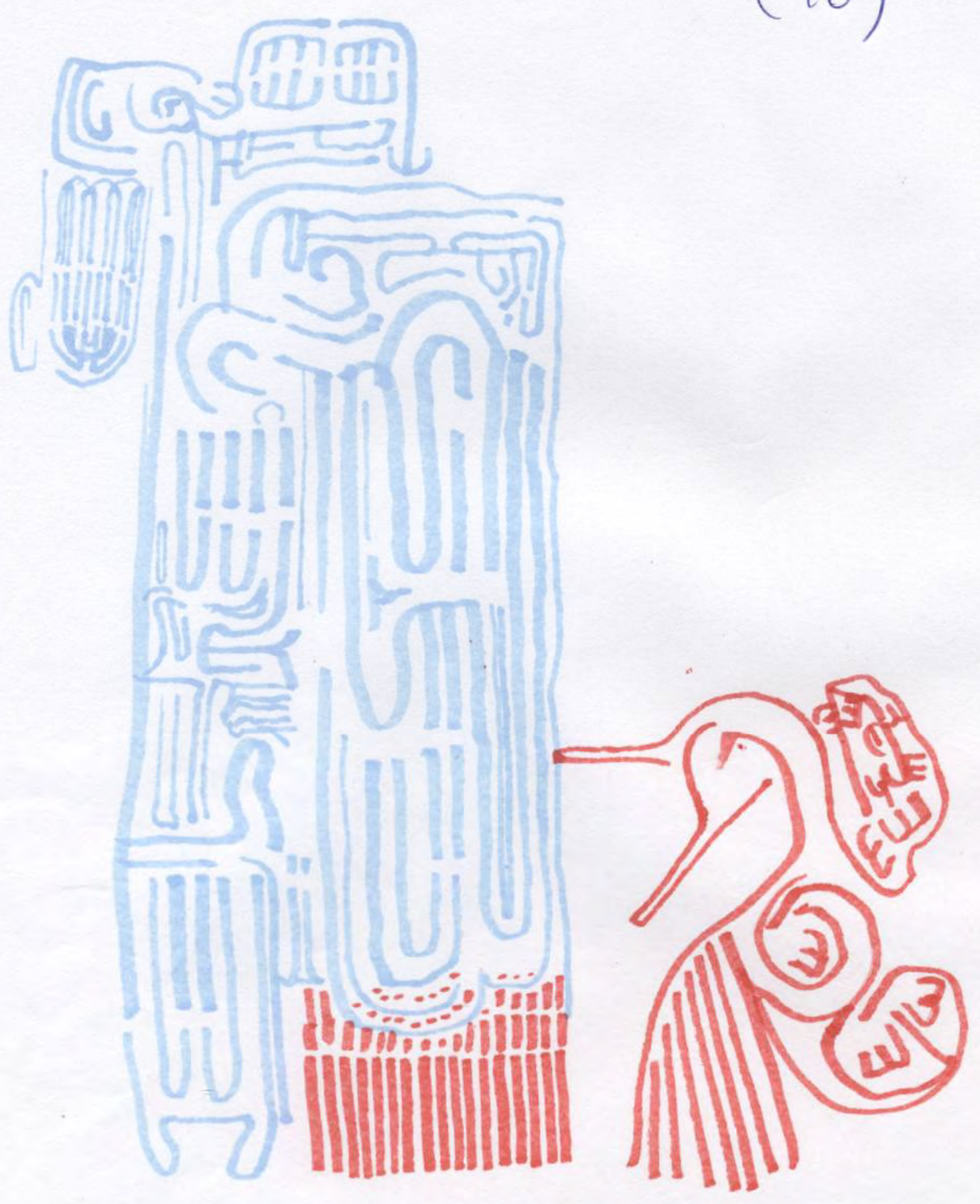

(16) 


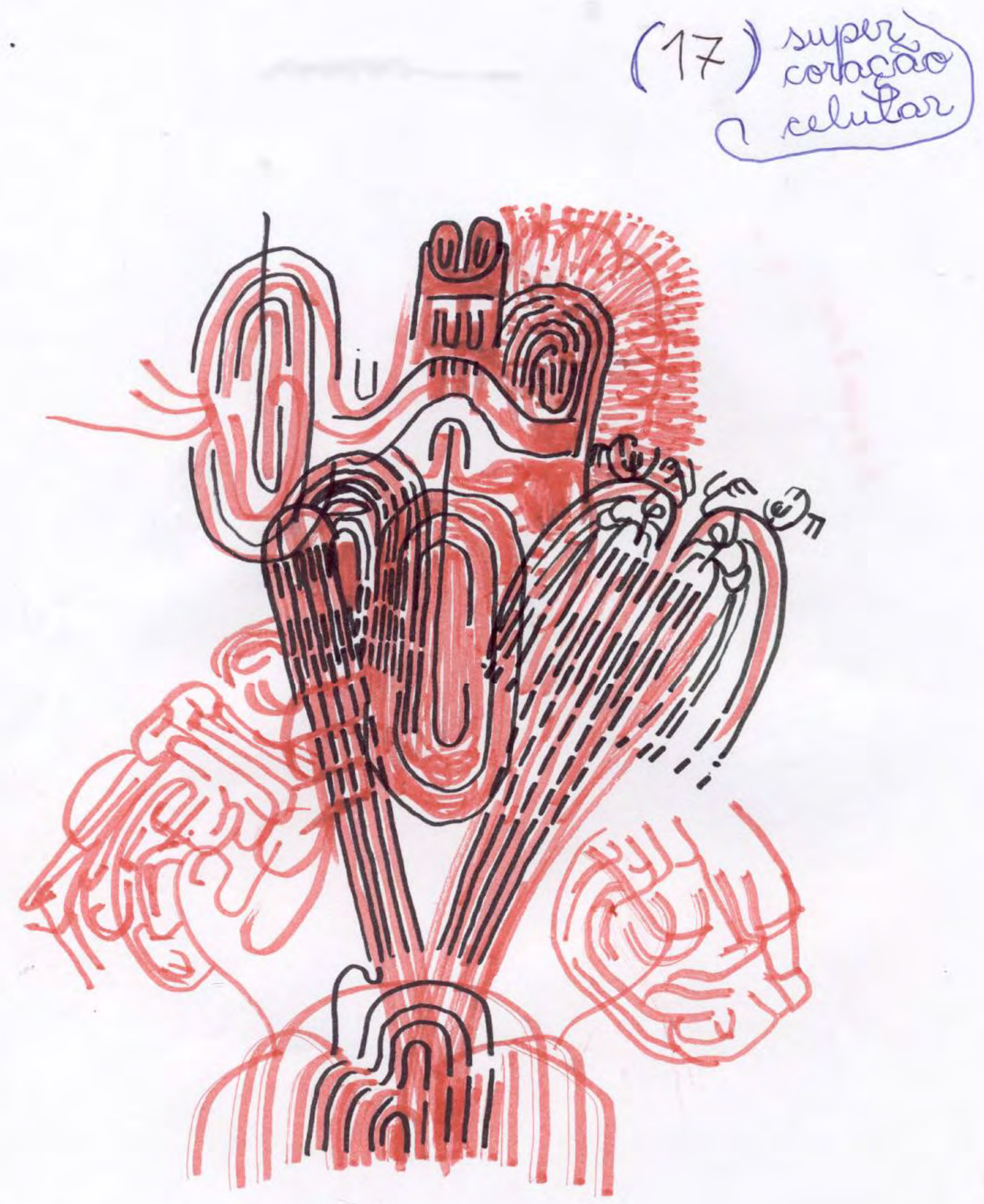




\section{[[[INVENTÁRIO DE PRÁTICAS]]] \\ [[[DESCRIÇÃO DE ALGUM AS PRÁTICAS]]]}

[aqui há a descrição de alguns laboratórios específicos, que podem ser tomados por si ou no contexto desta tese. Essa farmacologia é de responsabilidade sua, é importante deixar o corpo sentir o que ele está sentindo, e saber o momento de se testar algo - a gentileza e a afetividade são prerrogativas. Para melhor compreensão do tom do laboratório no contexto do corpossom, e acesso a um maio número de exercícios, sugiro a leitura da minha dissertação de mestrado preparação do corpossom: atuação e voz concreta (2009)]

\section{Formas de estabilidade viva e trabalhos específicos de chão (modos de se habitar o chão)}

Em cada uma dessas formas, trabalhos ou modos, há a prerrogativa de uma voz em aberto: pode ou não se pode sonorizar, cantar, respirar com tal ou qual textura na passagem do ar, falar (com atenção ao espaço comum) etc. A voz em aberto é uma medida constante contra-disciplinar e alter-disciplinar que deve ser lembrada periodicamente. Em conversa com Tarina Quelho, performer e pedagoga do movimento, ela me ajudou a entender que eu embaralho ações de diversas ordens, tais como padrões e estratégias. Por exemplo: quando eu digo 'vibração', não é apenas um padrão de movimento, mas pode ser uma estratégia de se passar a ler a ação como vibração.

\section{Uma posição confortável ou um alongamento leve. Depois de alguma permanência,} mudamos a outra? Quais tempos são estes? Quais escutas são estas? A permanência viva de uma postura-posição do seu corpo não está necessariamente vinculada apenas com a contenção do movimento e o constante derramar do peso. Por isso eu posso chamar uma postura (por exemplo, uma postura de ioga) de SITUAÇÃO: é uma configuração onde, além dos ajustes espontâneos, há pequenas oscilações e um 
espaço particular de transformação. Então, o primeiro modo de se habitar o chão é onde eu busco posturas-situações quaisquer, que podem ter o foco no alongamento ou apenas no descanso, ou alguma transformação de sensação em especial. 0 alongamento suave me parece um bom paradigma de transformação de sensação. De uma posição-postura-situação a outra, há passagens. Então eu aplico o laboratório 'da ação contínua ao fluxo' descrito em preparação do corpossom: atuação e voz concreta. 0 que isso significa? Significa que eu estudo na prática a passagem de uma posiçãosituação-descanso a outra, até que a própria passagem se torne o tema: posso deixar conduzir o exercício a uma certa incandescência na direção do aquecimento, atrito e friç̧ão, ou deixar que se conduza a um repouso a cada momento mais profundo. Então, além de duas possibilidade de ação (alongamento leve ou posição de descanso), duas possibilidades de condução (fricção ou repouso). Quando o tema é aquele do descanso, eu posso conduzir de modo que se busque a posição mais confortável possível e, em seguida, um gesto de escuta onde perguntamos continuamente ao corpo onde será a nova posição, haverá uma posição ainda mais confortável do que esta?

Dormir sem dormir. Simular um estado de repouso continuado, mas sem se permitir dormir de fato. Este modo pode estar acoplado ao seguinte ('o caminho do osso'), como uma preparação. Esta estratégia visa estados intermediários de sensibilidade.

Exercício da Ivola Demange 'o caminho do 0sso'. Eu dei este nome mas nem sei se ela dá este mesmo nome. 0 mesmo com a condução, que adaptei a partir daquilo que me interessou. Faço pressão de algum local do corpo contra o chão. É um exercício de um perambular da pressão pelo chão; caminho a pressão no chão pela estrutura óssea e pelo apoio: como um escaneamento manual ou uma gravura, busco percorrer o corpo todo, mas sem pular de um ponto a outro. Após um primeiro estágio onde se propõe o movimento suave e contínuo, começo a valorizar as pausas na condução: situações onde me proponho uma contenção da pose. Após trabalhar com a introdução das pausas segue um trabalho com a espacialidade do olhar: experimentar mudar a situação ocular (fechar ou abrir os olhos) quando houver a pausa. Depois posso liberar 
passagens entre as mãos e os pés, apenas, como os únicos pontos onde podem haver 'saltos'. Por último, o caminho livre.

Os balancinhos e o viscoso. As oscilações do centro de gravidade, ou de determinada porção de massa do corpo, em composição com a dinâmica fluída. Ativação de uma autonomia do peso viscoso do corpo. 0 peso viscoso sabe de si. Os rolamentos e espiralamentos do corpo ao chão são uma gramática interessante para aplicar neste modo. Esta é junção de dois procedimentos que em dado momento me apareceram interligados.

Movimento suave e contínuo, mas onde 'não pode haver som'. Este modo é a junção de duas das tarefas descritas em preparação do corpossom.

\section{Formas oscilatórias/pendulares: pêndulos e ondas como movimentos auto-sustentados}

Pés, balanço no plano sagital. É aquele balanço que vai como uma 'cadeira de balanço', transferindo o peso ao longo longitudinalmente ao longo dos pés. É particularmente interessante a transição entre uma fase e outra, a suspensão entre a as direções da transferência do peso. Para os exercícios onde há a transferência lenta do peso, sempre me valho da imagem de dois vasilhames de água, onde eu lentamente 'derramo a água' (o peso) entre um lugar e outro. Este balanço pode ser feito na variação de uma caminhada.

Pequena mola. É como aquele exercício de kundalini, porém a preocupação é divergente, que aqui seria não a estimular e produzir as oscilações, mas apenas 'cair em si'. Quando fazemos com os calcanhares fora do chão é próximo de um exercício que fazemos no taichi que se chama 'para afastar-se das mil doenças'.

Alternância de peso. Como se estivesse caminhando lentamente, só que no mesmo lugar. Transferência de peso entre um e outro pé. 
Elefantinho. É um exercício bem comum de ioga, muito praticado em diversos ambientes práticos. Em verdade, esse exercício vem a ser uma transferência de peso somada a uma torsão ou espiral. Fazemos algumas variações:

variar a direção da torsão (para dentro o para fora, de acordo com a posição do peso); fazer permutações entre direção da torção e posição do peso (por exemplo, permanecer na mesma perna enquanto se torce para um lado e o outro); usar o limite da torsão e energia potencial do peso como impulso para um giro ou para lançar com força os braços relaxados; usar do peso para, a cada mudança, aproximar-se do chão etc.

Pêndulo. Todas as formas pendulares possíveis: com os braços, com as pernas. Este trabalho é usado em muitas áreas, inclusive para liberar o peso dos braços dos instrumentistas que usam muito o peso como componente de acionamento do som (por exemplo: piano).

Tracionar um elástico. É onde acionamos padrões elásticos, tanto como ação contínua como uma tentativa de disparar um movimento em determinada direção (dinâmica 'estilingue'). Nas aulas da Adriana Grechi no espaço Nave ela falava muito da propriedade resiliente dos ligamentos e de como essa propriedade pode ser exercitada por instruções de expansão e condensação.

Eletricidade. Aqui permitimos que um segmento (ou vários) recebam e deixem passar uma corrente elétrica leve que se amplifica em termos de movimento.

Mão trágica. Aqui, as mãos recebem uma descarga oscilatória: pode praticar 0 acionamento desse padrão com a intenção, e não com a força das próprias mãos. 


\section{Formas de contato}

Cinco toques metafóricos. Eles são utilizados como práticas dentre aquelas práticas para produzir sensações. Essas sensações são modos possíveis de vocalização, posto que a vocalização de sensações é também uma produção de sensações. Então é como se, ao vocalizar, sentir e tocar, algo se vai produzir e situar entre essas ações a ponto de operar pequenas metamorfoses no corpo. 0 nome 'metafórico' é só oportuno, pois não é um exercício de abstração, mas de concretização.

Recomendo que essa pequena série de toques metafóricos que recria o corpo seja feita nesta sequência dos cinco toques. Contudo, não fiz tanto as outras combinações a ponto de sugerir outros encadeamentos associados a resultantes específicas. Podese organizar sessões ou etapas de um percurso, com ênfases específicas: (1) cada pessoa consigo mesma; indagar-se, neste contexto, sobre o contato consigo no plano dos corpos desconhecidos, às vezes mínimos ou imensuráveis; (2) onde a respiração é deixada livre como vocalização livre, vocalização que 'pula' das sensações, ou que é um modo da própria sensação, voz em aberto, noção esta fundamental; (3) realizar um paralelo entre postura, posição ou situação do corpo, toque-contato, respiração e voz como variáveis de uma auto-massagem; (4) cada pessoa consigo, porém agora há uma ênfase maior na vocalização - aqui descrevemos uma noção de 'voz' múltipla e compositiva, 'voz' como palavra acoplada desde a sensação ela-mesma atravessada pela atividade da respiração . A noção de 'respiração' também é bastante múltipla e indefinível em toda a sua abrangência, confundindo-se às vezes com a voz aqui abordada. Dizeres involuntários ou que surjam dessa compositividade são admitidos; (5) uma sessão ou região do percurso onde há grupos trocando o toque, isso pode ser feito em diversos arranjos; (6) processos compositivos a partir dessa orquestra de toques, sensações e cantos de metamorfose ínfima.

UM. 0 toque que namora. Aqui, uma forma de contato que surgiu da prática de modelo-vivo, talvez com traços e ecos das JAM s e aulas de contato-improvisação de que participei. Aqui, busca-se 'encaixar' as superfícies entre si, acomodar os tecidos e ficar. As superfícies trocam informações. Elas se 'lêem'. Pode-se propor focalizar a 
sensibilidade no contato, 'na conversa', entre as duas ou mais superfícies. Os contornos da pele se borram e circuitos inesperados se formam. É uma 'mão' de namoro, onde você segura e descansa a mão na mão da outra pessoa, mas em dado momento as mãos se misturam e não se sabe mais de quem é cada mão. É sempre importante refocalizar a respiração espontânea mas não necessariamente passiva. Ela acompanha o brotar e 0 tecer das sensações.

DOIS. 0 toque da pétala de rosa. Aqui, a pétala é uma referência de toque delicado. Mas essa delicadeza é uma difícil construção. Falo do toque que quase não toca, que roça a superfície, dando a ver a amplificação da sensibilidade e das ressonâncias do toque. Nesta condução quase sempre conto de quando eu era bem criança, e passava continuamente uma pétala de rosa naquele espaço logo acima do lábio superior, entre a boca e o nariz. E eu chamava rosa de 'aiosa'. Eu conto esse episódio dado que é evocativo de uma sensibilidade inusitada da criança. É muito importante em todo o itinerário de toques, mas neste talvez em especial, trabalhar ativamente na concessão da respiração ao próprio corpo. 'Deixar o corpo respirar'.

TRÊS. 0 toque da escultura de bronze. Aqui o toque que se modula como se um escultor contornasse com as mãos sua obra uma última vez. Não há uma interferência de modo a modificar o volume-contorno tocado. Há esta modulação, inicialmente da parte que toca, mas que se prolonga à parte tocada. Modulação de intensidade velocidade etc, num regime de modulação (recíproco, portanto) que preserva e verifica a escultura do corpo como ela é.

QUATRO. 0 toque da massa de pão. Aqui é o contrário: tudo tem resiliência, volumecontorno modulável e faculdade de deformação e recombinação

CINCO. 0 toque do fóssil. Aqui o toque é projetado com o olhar, olhar que se demora e mira detalhes. É uma função de desaceleração e de redes novas de captação das texturas-geografias do corpo.

\section{[fim dos toques metafóricos]}


Auto-massagem. Nas conduções que realizo em geral há a proposição um conceito expandido de auto-massagem, entendida como uma variação de pressão em um tecido. Assim compreendida a auto-massagem, o toque e a pressão são automassagens, porém a própria respiração também o é. De acordo com a posição do corpo, a variação de pressão e sua incidência preponderante também mudam, bem como há diferentes organizações onde certos tecidos se dispõem sobre outros. Estas duas últimas noções na minha biografia são oriundas do hatha ioga: respiração e posição do corpo como variação de pressão, auto-massagem. A vocalização pode ser compreendida como um modo sofisticado de auto-massagem.

Fazemos a auto-massagem para produzir sensações e correntes de sensações. Por isso, pode-se fazer sem vocalizar a sensação, vocalizando-a ou deixando essa voz 'em aberto', que tanto compreende as nuances da respiração, quanto pode vir como um som vocal qualquer ou um ruído vocal.

Massagem em parceria. Produção de sensações em dupla. Quem massageia também tem a voz 'em aberto'. 0 toque é livre ou com os 'toques metafóricos' nomeados, ou poderá se guiar por outras narrativa se outras imagens.

O corpo do outro é um instrumento. Um laboratório específico dentro do anterior, é este onde cria-se um vínculo de 'instrumento'. 0 que quero dizer com isso é que se pode criar uma responsividade específica entre os corpos, vinculando acionamentos de pressão e textura do contato a algum sinal sonoro (modo de respiração, ruído, vocalização, fala...).

Automassagem na parede. Aqui há uma espécie de combinação, de arranjo entre forças. Na parede se torna evidente a construção de uma verticalidade através de algo que se passa entre as forças. Aqui acho que se torna mais evidente também a combinação entre auto-massagem e movimento da coluna, ou melhor: 'desejos' que atravessam a coluna.

Cobertor. Aqui podemos fazer algumas estratégias. Mas a estratégia geral é cobrir, com um ou mais corpos, o corpo de alguém deitado, que está trabalhando com a 
vocalização das sensações-pressões desde sempre. 0 grupo deve se dispor a uma pessoa por vez sobre o corpo deitado que recebe os demais corpos. Deve-se dar intervalos entre a chegada dos corpos sobre aquele deitado. Para a saída dos corposcobertores, o mesmo procedimento.

Acoplamentos com objetos, móveis, formações e arquiteturas. É preciso escutar as próprias vísceras para saber se elas querem se pôr sobre algum objeto: uma almofada, uma cadeira, uma mesa, uma pia etc. Existe essa dança com os objetos e as massas. Converte-se em POLVO.

0 toque inescapável da caminhada. Aqui os passos são entendidos como automassagem, o que pode ser abordado em diversas medidas, de acordo com a faixa de ressonância que se quer abordar. Posso estudar na prática a repercussão da massagem entre chão e pés na disposição da coluna, nos membros superiores, nas sensações vocalizadas, etc.

Tocar é ser tocado. Aqui, a aplicação laboratorial daquilo que foi compreendido na experiência pianística. Não se pode querer tocar sem ser tocado. Então: de que modo eu posso tocar para ser tocado? Estranhas modalidades de contato podem aí emergir. 


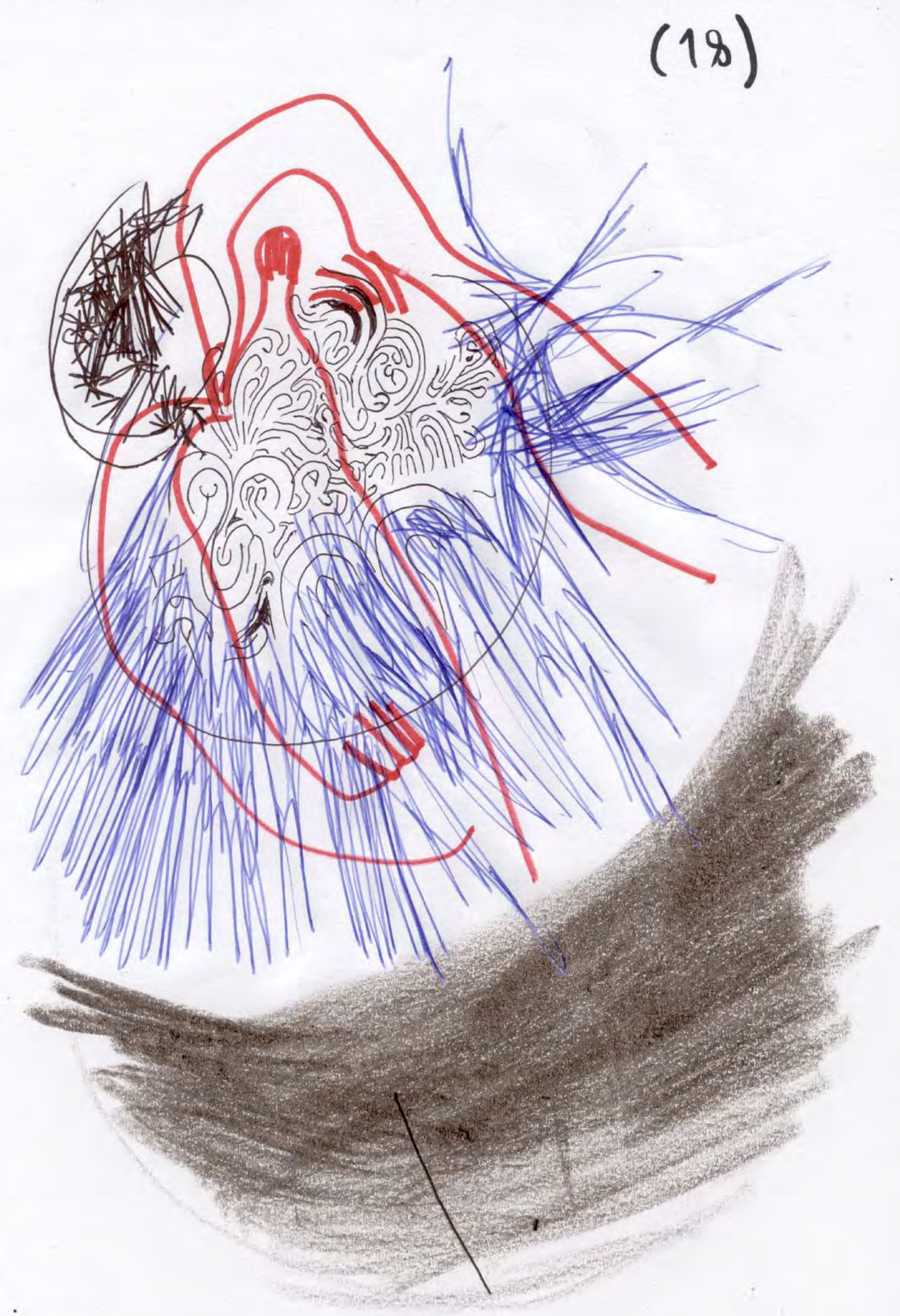


(21)-mar

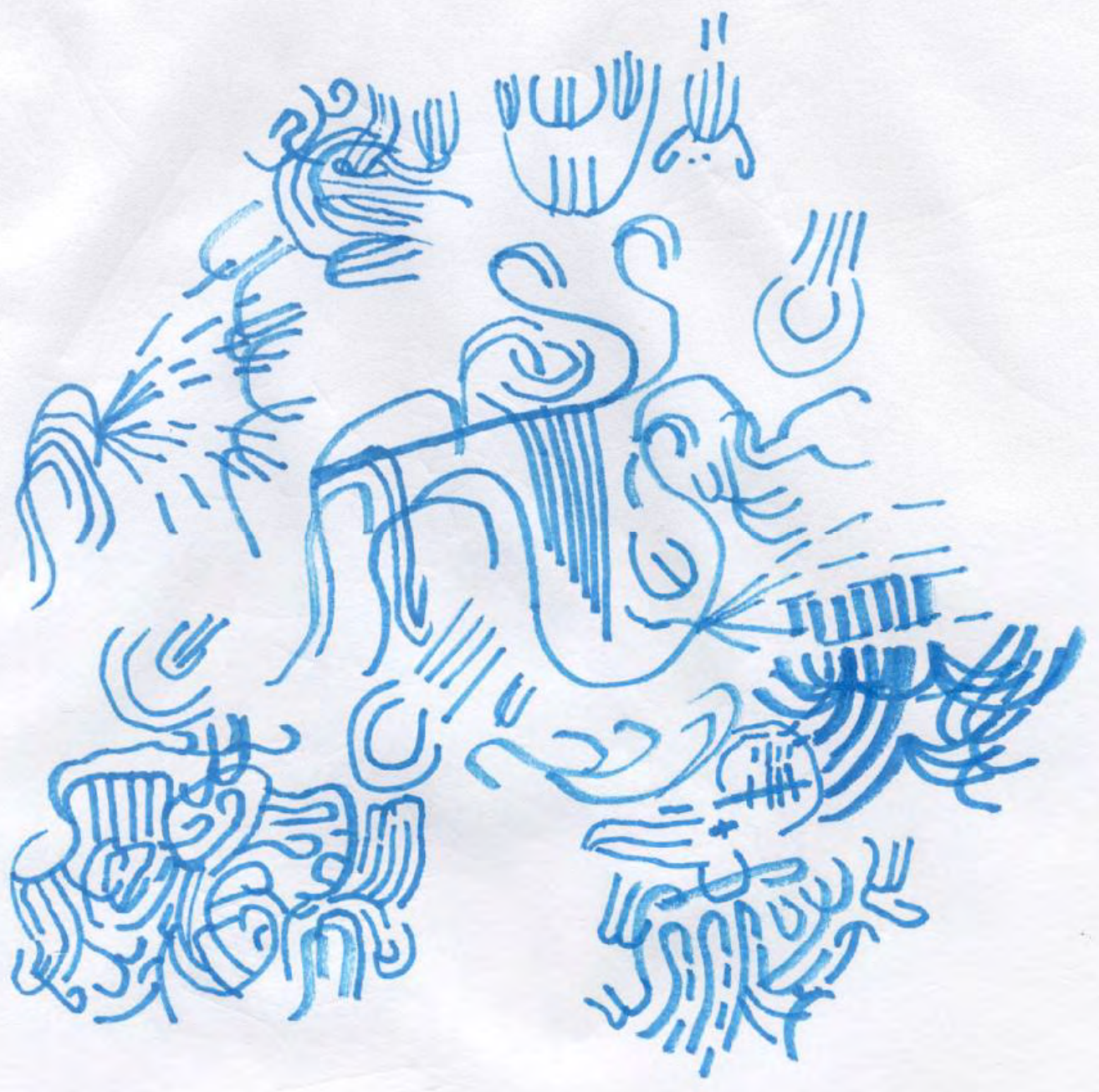


$\cdot(22)$

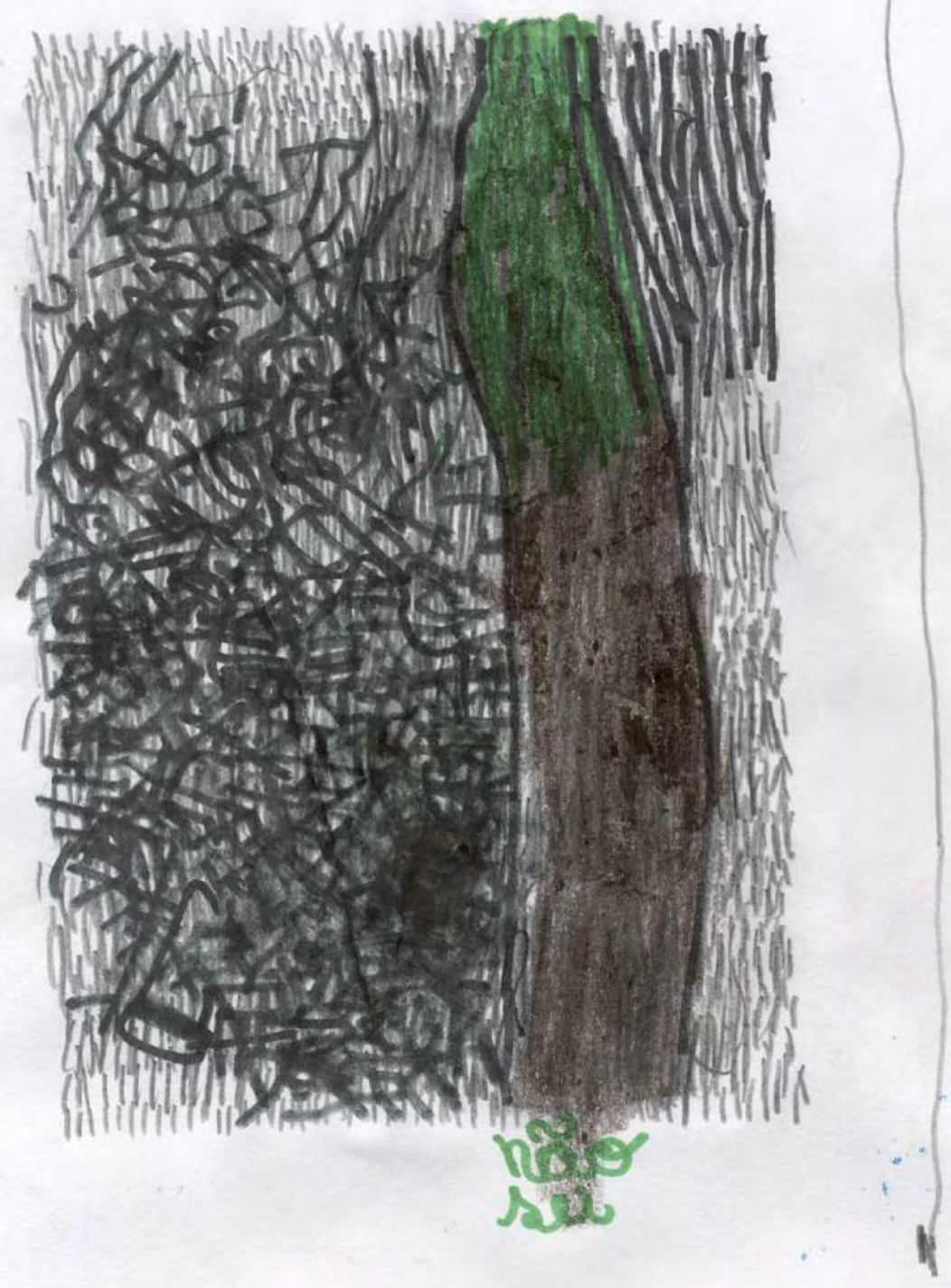


473

(23) 


\section{Formas de emissão}

0 mais relaxado possível. Este procedimento é proporcionar a emissão vocal, por mais estranha que seja, a partir de uma espécie de aprofundamento da sensação de relaxamento, e isso gera pequenas explosões de energia vocal. Uma variação, ou um ponto que se pode dar como exemplo, é o efeito vocal fry.

0 atrito do ar. Consoantes desconhecidas. A partir de exercícios simples de consoantes, buscamos o que chamo de 'consoantes desconhecidas', que estão na passagem entre aquelas conhecidas ou vêm de quaisquer brincadeiras ou acionamentos sem vogais. Este modo de emissão é interessante após aquecimento com consoantes, pois há no senso comum da prática vocal diversos desses exercícios. Pode-se também acoplar este modo de vocalização a trabalhos quaisquer de ar. Quando digo 'trabalhos de ar' me refiro, por exemplo, a trabalhos de condicionamento e organização das musculaturas expressivas. Quando fizemos o projeto do Laboratório Corpossom nas cavernas (2013), fizemos alguns desses exercícios em aulas com a cantora Cida Moreira.

A intenção da vocalização. Este é um trabalho sutil de se deixar configurar qualquer som a partir da força desta intenção.

Camuflagem. Este é um procedimento onde se tenta cantar um som que esteja 'dentro' de algum som ou composição sonora do ambiente. Geralmente este modo de vocalização ocorre no meio de alguma performance, onde uma rede de acontecimentos já foi mobilizada. Este procedimento é também correspondente ao exercício 'do inaudível ao audível', que descrevi no bloco um do primeiro capítulo.

\section{Cantar para escutar.}

\section{Massagear-se com a voz.}

\section{Cantar sem poder cantar.}


A chamada. Aqui, é um modo de chamar algo, como uma pessoa. Mas pode ser literalmente qualquer pessoa-coisa.

\begin{abstract}
A vogal como modalidade de espaço. Vibração vocálica e transição entre vogais. As vogais desconhecidas. As vogais involuntárias. Paralelamente à ideia de que a 'consoantes desconhecida' adquire novos percursos através dos aquecimentos convencionais, o mesmo se dá aqui. Quando vocalizamos as vogais em separado: A, E, É etc, podemos estudar cuidadosamente zonas na passagem entre cada uma dessas configurações. Esta é uma matriz de trabalho que se desdobra em muitas direções, quando permitimos que a formação vocálica se propague.
\end{abstract}

A partir da resiliência e fluidez de 'cair em si'. É a vocalidade que pode emergir do exercício 'pequena mola' (acima).

A caminhada vocal. Uma espécie de caminhada sonora, onde a caminhada mobiliza sensibilizações que podem ser, de alguma maneira, vocalizáveis. Ou transpor a uma caminhada vocal fática.

Vocalizar o crescimento do corpo ou a voz da incandescência. Este exercício parte de uma proposta de incandescência do corpo que se organiza ao redor da sensibilização vocal. Seria a voz como antena ou catalisador de um processo vivido no corpo. Talvez a primeira performance de corpossom, mesmo sem ter esse nome, foi, realizada segundo este modo de ontogênese da voz, em 2007, numa oficina residência com a Taanteatro Companhia. A ação se chamava comentários da nuvem elétrica. Claro que muita coisa mudou desde lá. Mas essa incandescência em torno da voz repetiu-se inumeráveis vezes, sendo constante objeto de debate nas conversas pós-laboratorias com Janô. Acho que aqui é um excelente caso para se pensar em um princípio que Janô sempre pontuava: é preciso inventar novos exercícios a partir dos acontecimentos. Acho que na dissertação preparação do corpossom: atuação e voz concreta, a tarefa chamada 'TÁ' era uma tentativa de retomar uma incandescência do corpo a partir dessa voz-bomba corporificante. 
Relação timbre/ frequência. Primeira construção de espaço escalar.

Relação timbre/frequência/ articulação. Segunda construção de espaço escalar.

\section{Relação timbre/ gestos figurais e segmentos escalares.}

Nota coletiva; afinação; nota comum. Jogos e propostas acerca da nota comum e som comunitário.

Desafios da nota. Presentes em preparação do corpossom: atuação e voz concreta (2011).

Vibração da coluna vertebral. Aqui há um outro exemplo de um exercício ou laboratório formulado a partir de um acontecimento. É importante afirmar que o acontecimento faz o laboratório, e não o contrário. Esta vibração veio de um improviso meu com Miguel Prata que acabou por adentrar o espetáculo-laboratório na foz das cavernas. É uma prática de escape vocal (mais do que vocalização) a partir do choque na coluna. É preciso estar razoavelmente aquecido para realizar este.

Ondulação da coluna vertebral. Com vogais. 0 exercício das vogais desconhecidas se desdobra neste, envolvendo estruturas maiores.

Arquitetura da nota. Como absorver os trabalhos coletivos da nota numa escuta de uma vocalização nômade, errante? Compreender que o mundo está sempre em côro duvidoso. Muito recentemente compreendi que aquilo que chamamos 'personagem' não é uma entidade psicológica, e nem apenas uma modalidade lúdica e criativa singular, mas um tipo de coro. Acho que esta correspondência estranha poderia ajudar a compor figuras vocais em constante mutação, localizando-se no mundo que é essa grande assembleia. 
Voz afetiva. Esta é a prática de uma voz 'em aberto', a partir do primeiro laboratório de relação com o chão ou estabilidade viva, 'o conforto': é um aprofundamento do conforto pela vibração vocal, entendida como um objeto de experiência também aberto. Ou seja: eu não sei o que é a voz nem quando ela vai acontecer. Aqui também se dá algo muito peculiar, análogo ao exercício da voz 'mais relaxada possível'. 0 relaxar persistente dispara, por acidente, vigorosas energias, e isso é algo notável.

\section{Vínculos com a respiração (formas de respiração). A respiração é um tentáculo ou uma serpente que vai buscar algo.}

\section{5. uma sequência pedagógica sensibilizadora para a proliferação de esferas [enquanto movimento, não enquanto forma]}

Sensibilizar as mãos. Reter a atenção ou condensar a atenção à palma de uma mão. Mudar a mão. Testar a alternância de mãos, como se algo fosse transferido à outra mão. Fazemos dessa passagem um circuito. Trabalhamos com as duas mãos. Depois: distância entre as duas mãos. Deixar o espaço de mover: esfera.

\section{Uma pequena condução para espirais}

Pode-se derivar a partir do exercício com esferas, ou se pode trabalhar a partir de posições de uma caminhada, já que ela é um leve espiralar do corpo. Lembremos que as espirais atravessam o corpo em muitas direções. Espirais e esferas se comunicam umas às outras e se proliferam mutuamente em jogo de movimento. 0 taichi é um exemplo dessa proliferação de esferas e espirais. 


\section{7. dinâmicas de movimentação a partir do vegetal, [como uma 'eletricidade gentil']}

Aqui, após a atenta observação conjunta de vegetais. Nós nos colocamos em situação de um espreguiçar leve que conduz a uma 'eletricidade gentil'.

\section{A preguiça}

A preguiça, enquanto matéria de movimento investigada conjuntamente, pode ser campo de propiciação a grandes explosões. Eu me baseio em repetidas instruções que levam, do relaxamento em movimento, a estados paradoxais de muita atividade. A preguiça pode ser pautada como laboratório específico, como estado que se acumula entre outros estados, como produção de movimento preguiçoso, ou apenas como instrução paralela.

\section{Anotar as sensibilizações acontecidas em estados meditativos}

É importante registrar a faculdade que a meditação tem de produzir imagens ou sensações paradoxais. Aqui prolongamos o rastro de uma imaginação do corpo. É um traço metodológico importante para estes ambientes de trabalho que proponho. A meditação não como disciplina, mas como devir. E isto não é apenas o fetiche por imagens bizarras: é uma fabulação, um comunidade de desconhecidos, rumores de mundos que aí estão, que não serão mais do que isto, que não aguardam 0 esclarecimento. Por exemplo: rios que atravessam o corpo... cruzando a membrana... 
lugar 01

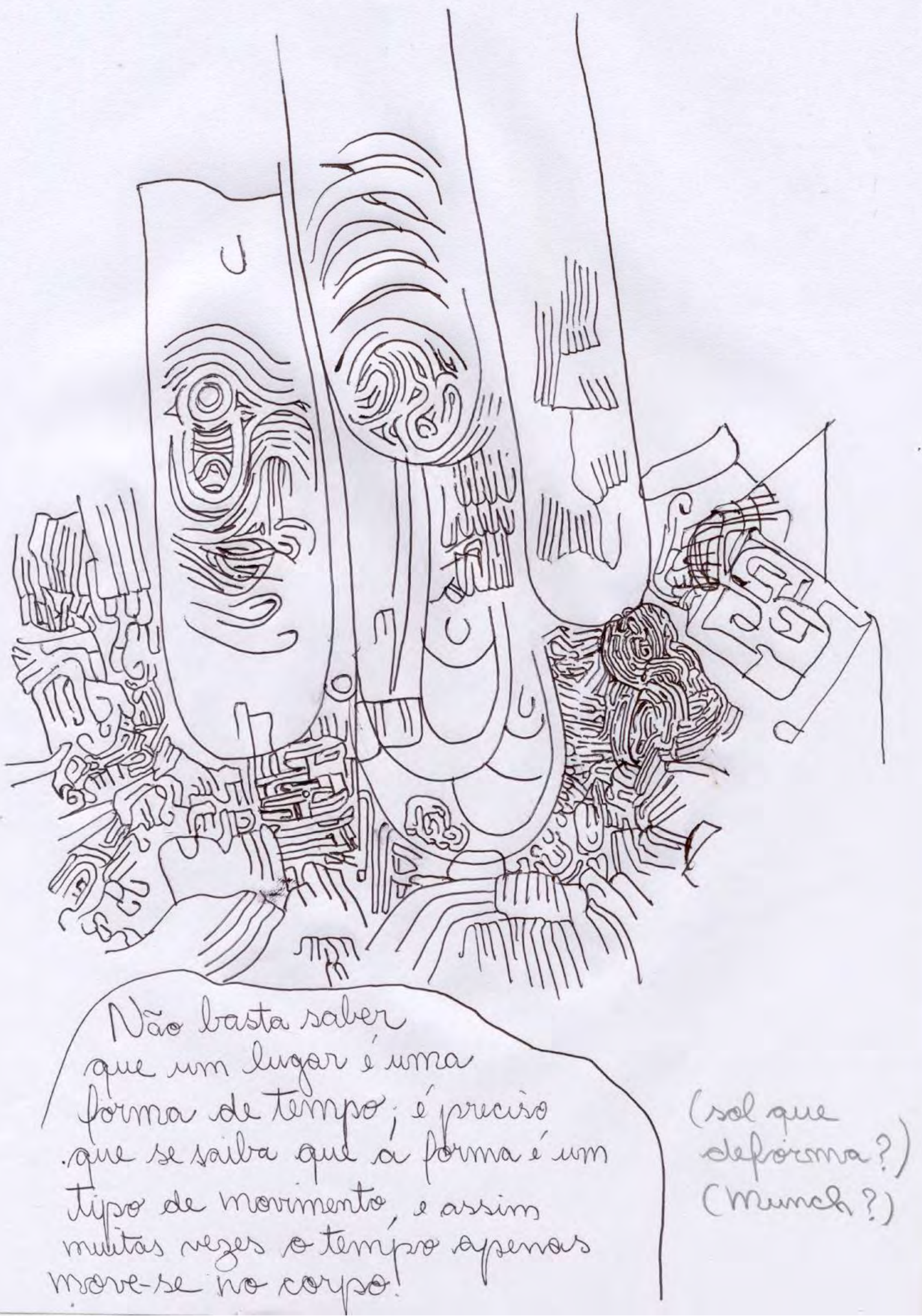




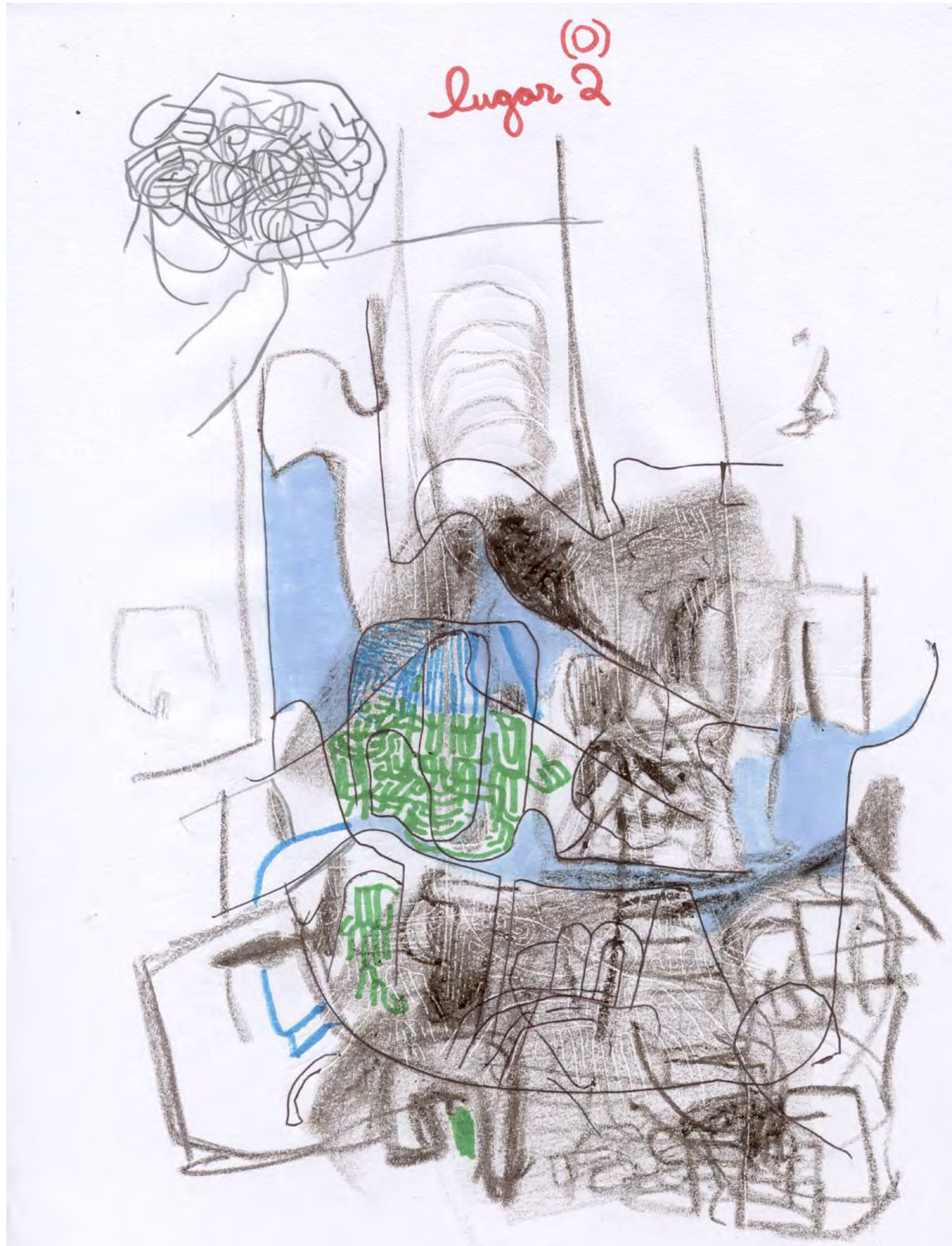




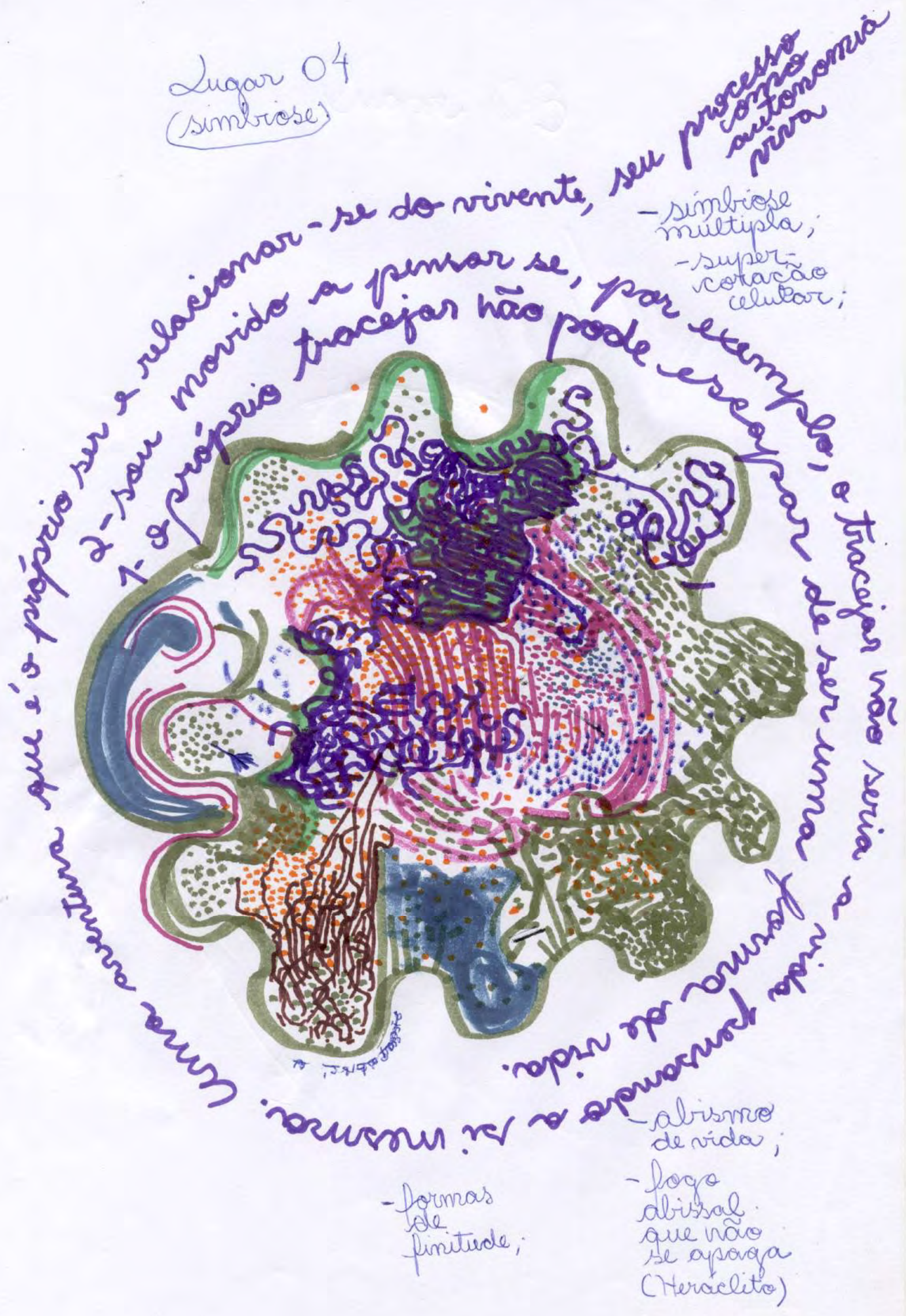




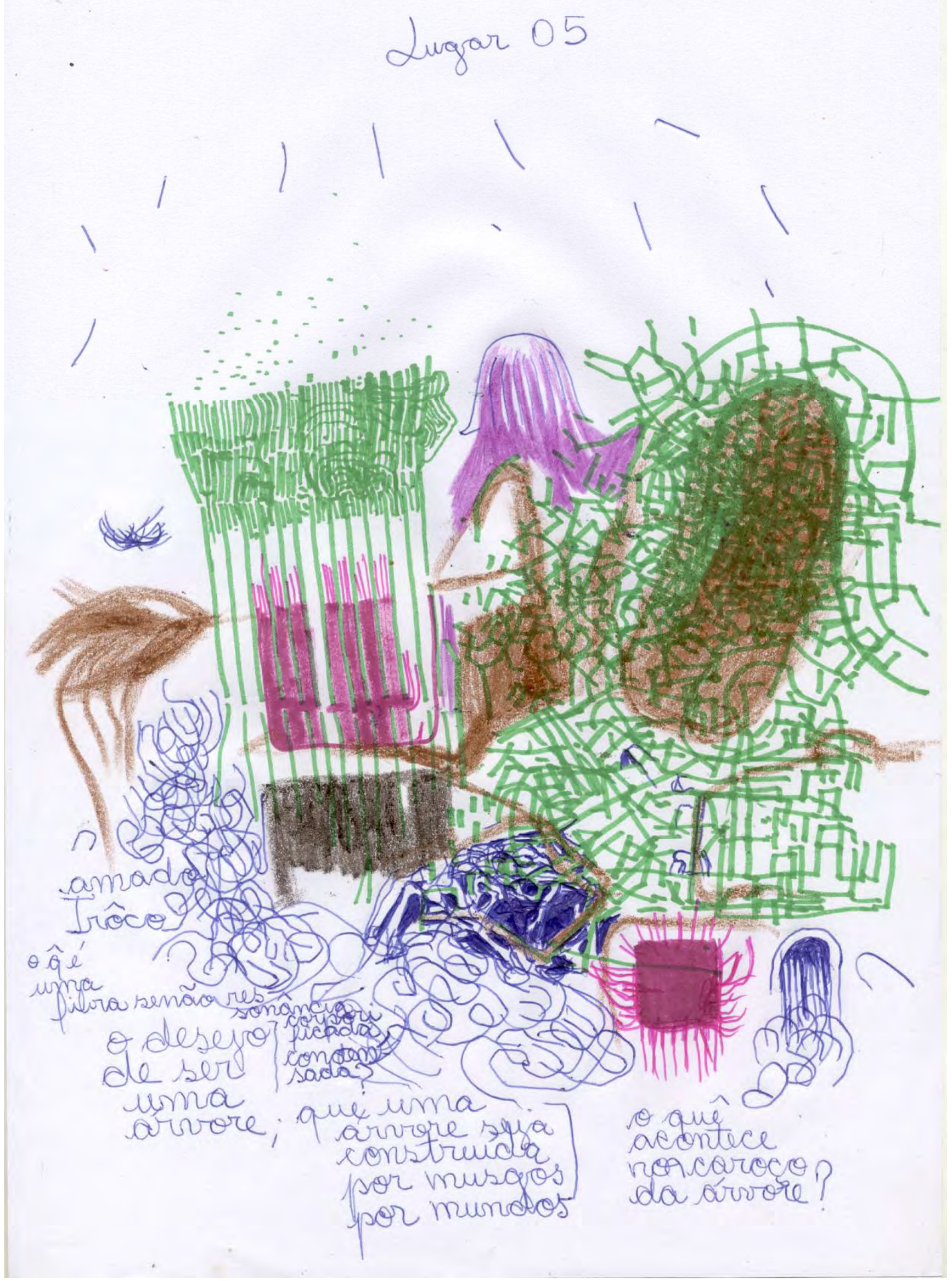


Lugar 07

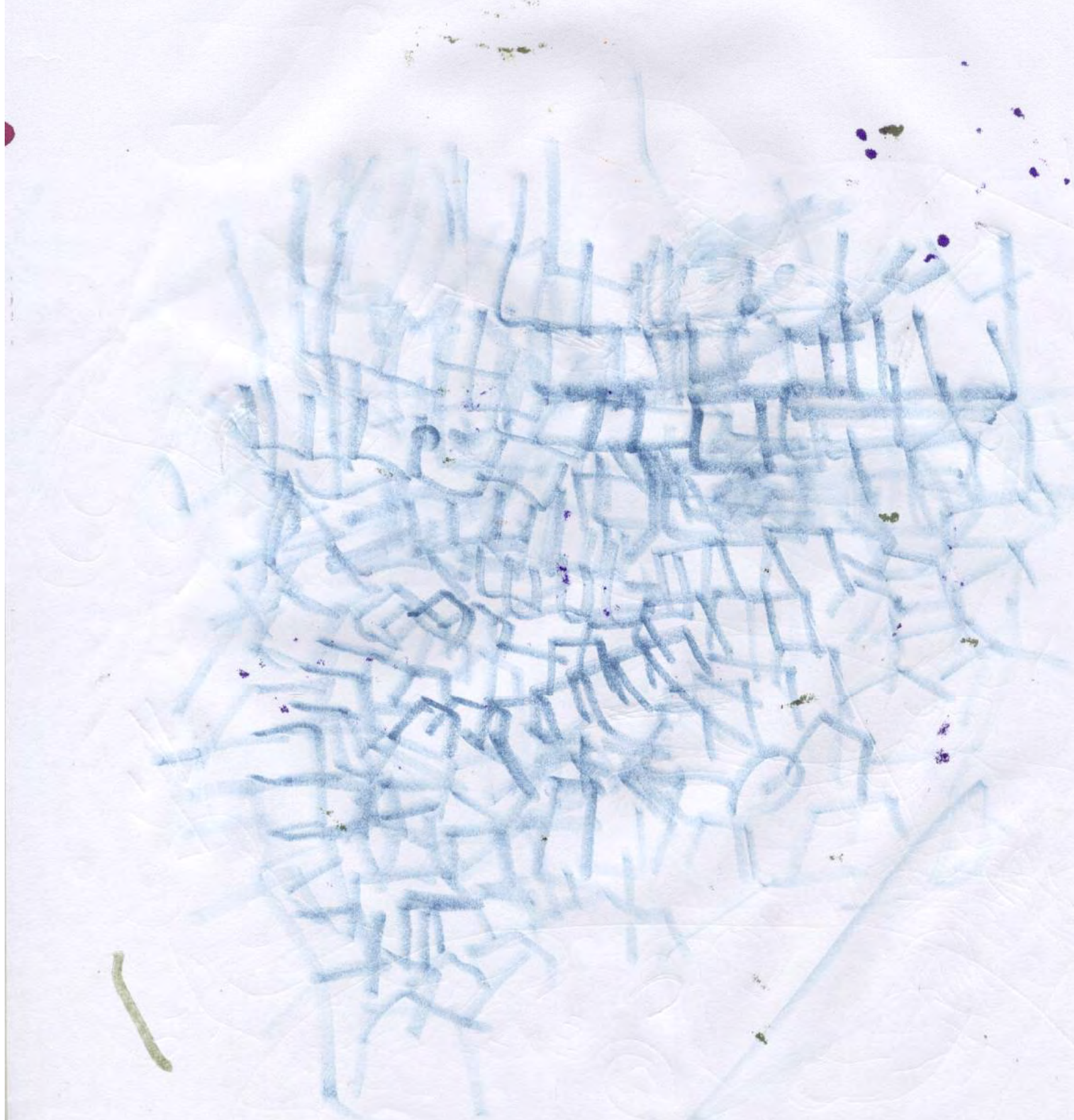




\section{[[[CADEIA DE NOTAS E CONVERSAS}

\section{SOBRE O PROCESSO DE 'CORDARIA' E CORPOCORDA]]]}

Quando deparamos e examinamos um caderno antigo, seguem operações estranhas de conversa e coleta - quem sabe, também de espreita e caça.

Aqui pretendo mais uma vez 'regredir' a escrita para a processualidade de umanimusgo.

Em 2015, na parceria com o compositor Felipe Merker Castellani, propusemos invocação para cordaria pensando nessa acepção de corpocorda, que passava por elaboração paralelamente nas minhas improvisações isoladas, sem a presença de Felipe. Nós trocamos uma pequena série de mensagens por email. 0 primeiro email, onde eu descrevia a minha proposta inicial, teve uma réplica dele e a partir das questões levantadas viemos ao primeiro ensaio com essa rede de perguntas em suspenso. Após alguns encontros chegamos numa estrutura. Realizamos invocação para cordaria em 22 de maio de 2015 no Ibrasotope Música Experimental, no evento [ibr86]: vozes manipuladas. Segue o texto da primeira proposta, já com a réplica do colega, formando os núcleos que desenvolvemos em ensaio:

$(02 / 04 / 2015)$

'evocação da cordaria' [foi o primeiro nome]

A performance ainda não tem nome, mas penso em chama-la 'evocação da cordaria', pois está situada no início da formalização de exercícios que realizarei com grupos de trabalho a partir deste ano. A 'evocação' dita o empenho para trazer diante de si aquilo que se começa. A 'cordaria' se remete aos acordos e negociações, tidos em muitos níveis, formando uma teia de relações, encaixes, distâncias, de armoníai. No vocabulário Pousseriano, seriam os planos de periodicidade, dialética que gera o terceiro, a direcionalidade, a mudança de nível periódico. Estou me apropriando do modelo do Pousseur, e essa correspondência da terceiridade neste caso é por minha conta.

A dramaturgia se organiza em regiões. Cada região tem um grupo próprio de elementos (ações, imagens, objetos) que estão relacionados de modo a formar circuitos que produzem corpo: algo que tenho chamado mais recentemente de aderências - algo próximo 
de lápis que caminha pelo papel, fazendo acumular o pigmento, e assim criando profundidade e densidade.

A região se desagrega conduzindo a ela mesma ou a outra região. Posso começar em qualquer região e acabar em qualquer região. Preciso passar por todas.

Seguem elas, como esboço. Posso ir agregando imagens e outras referências a elas.

\section{REGIÃO I}

- Fotogramas. Lógica próxima de 'modelo vivo'.

- Permutação e aderência de visão e tato.

- Verificar granulações da superfície. Estrutura do espaço. Horizonte. Análise física das distâncias. Perguntas e respostas das peças da estrutura. Verificar densidade do ar. Voz suspensa e livre.

\section{REGIÃO II}

- Entrar nos grãos do espaço. Alternância de seções vocais: glissandi ascendentes, somente, e descendentes, somente, visando localizar o eixo tonal do espaço acústico. Alternância de foco de emissão: da intenção de vibrar à de projetar, visando mapear a passagem de um a outro.

- Como obter disposição positiva a partir do relaxamento total.

- Desdobramento harmônico-melódico.

\section{REGIÃO III}

- Aspectos da respiração: [1] suas oito fases: inspiração, expiração, superexpiração, superinspiração, apinéia positiva, apinéia negativa, despressurização, suspensão. [2] suas variações de regiões e vias aéreas. [3] Suas variações de ciclos, durações e velocidades. [4] Suas variações posturais reconhecidas a partir de [2].

- Aspectos da respiração em relação ao crescimento e diminuição da extensão física do corpo. Expansão e condensação. Permutações.

\section{REGIÃO IV}

- Início: movimento pendular dos membros. Dança da caveira. Voz livre origina um centro de articulação melódico-harmônica. Localizar $o$ centro de gravitação através do movimento e das atrações melódicas.

- Perguntar-se sobre a exaustão e a força.

Isso sem falar nas formas de aquecimento, desaquecimento e deriva. Coisas que iremos conversando.

Vamos lá! 
$(02 / 05 / 2015)$

Comentários, Felipe, 05/02

Algumas perguntas:

- existe uma duração ou espaço temporal para cada região? Por exemplo, alguma forma de direcionalidade: aumento de densidade, rarefação dos comportamentos, que indique que vc deixa uma determinada região?

- Como funciona a passagem de uma região a outra: por cortes, justaposições, ou mudanças graduais?

- existe uma relação das regiões com o espaço cênico (pensando aqui de forma genêrica)

- as decisões de trabalhar uma outra região específica são decidas no momento da performance?

Algumas propostas

- Eu poderia criar a partir de amostras do seus comportamentos vocais minhas regiões, a partir do roteiro. As quais eu poderia difundir em paralelo as suas no momento da performance, promovendo ora encontros, ora desencontros.

- poderíamos experimentar algumas diferentes formas de microfonação: dois microfones de lapela no pulso, por exemplo, assim vc poderia controlar a distância e foco dado a cada comportamento. Eu ainda poderia tratar cada microfone de forma diferente. Ou ainda, um microfone headset e um lapela, trabalhados de forma diferente. 


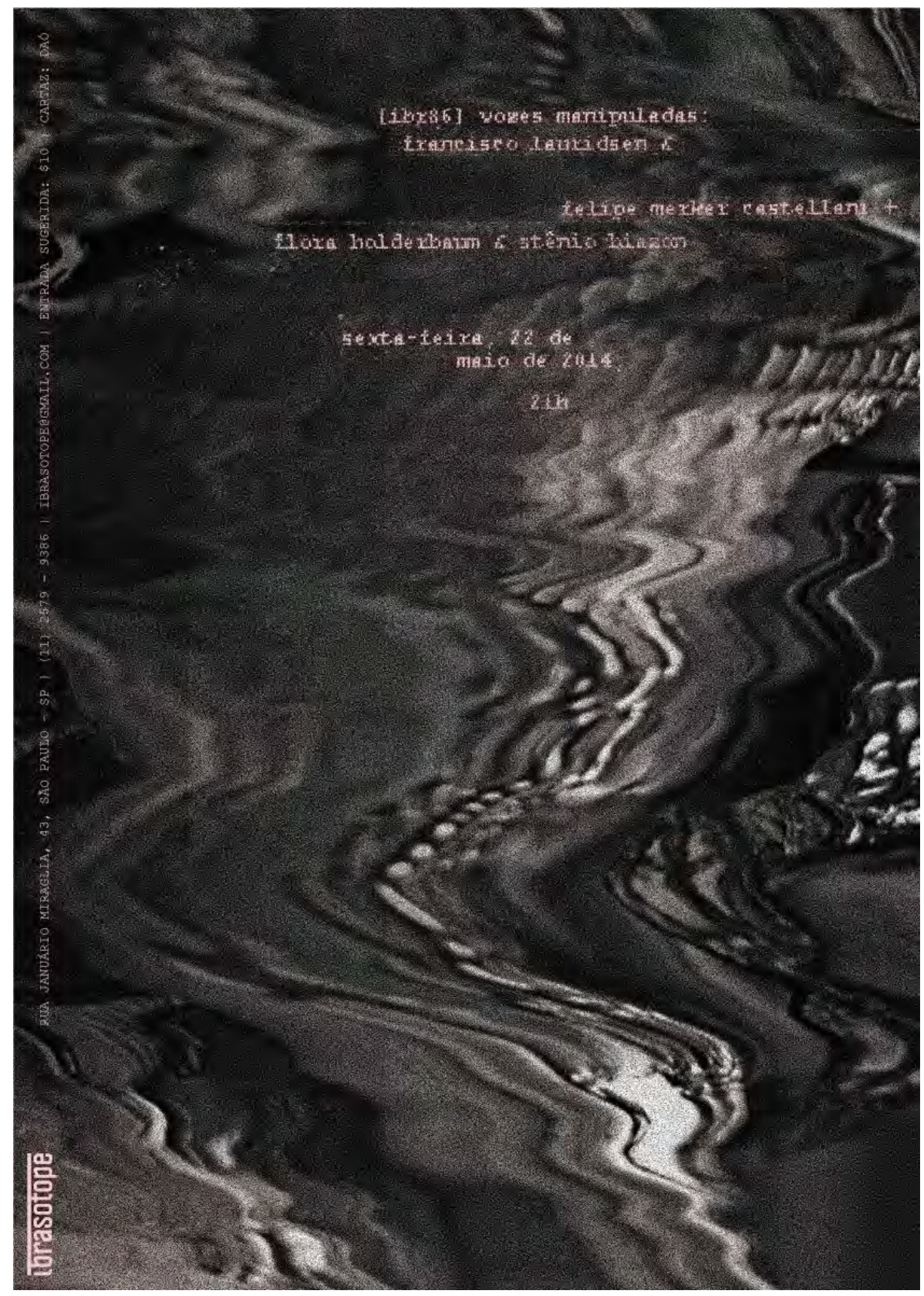

detalhe: 0 ano da performance foi 2015, não 2014. Acho que produziram o cartaz com certa pressa

O corpocorda me parece ser um elemento importante neste momento de doutoramento e das ações que amarram ou tensionam a escritura. Contudo houveram 
dois estágios anteriores à elaboração do invocação. Um deles foi a série de performances song of bones. Esta ação era uma modalidade de ação-habitação-ensaio que possivelmente pesou na concepção correspondente quando ocupamos a Casa das Caldeiras. E em song of bones, de alguma maneira, a árvore se consolidou como alguma sorte de modelo de relação. E eu estava bem longe da filosofia de Simondon, que só fui conhecer em 2017.

E outro estágio ainda foi a performance única transfiguração pitagórica (07/12/2014 no projeto Alberto Seabra 1128). Ambas as ações ocorreram em 2014 e formam uma continuidade de investigação naquilo que eu vejo uma germinação do corpocorda. Acho que esse dois estágios anteriores, bem como a gênese, em paralelo, do exercício de i'm sorry, mister Scelsi, também denotam como a prática de um corpossom se desdobrou no âmbito de um trabalho pessoal de criação.

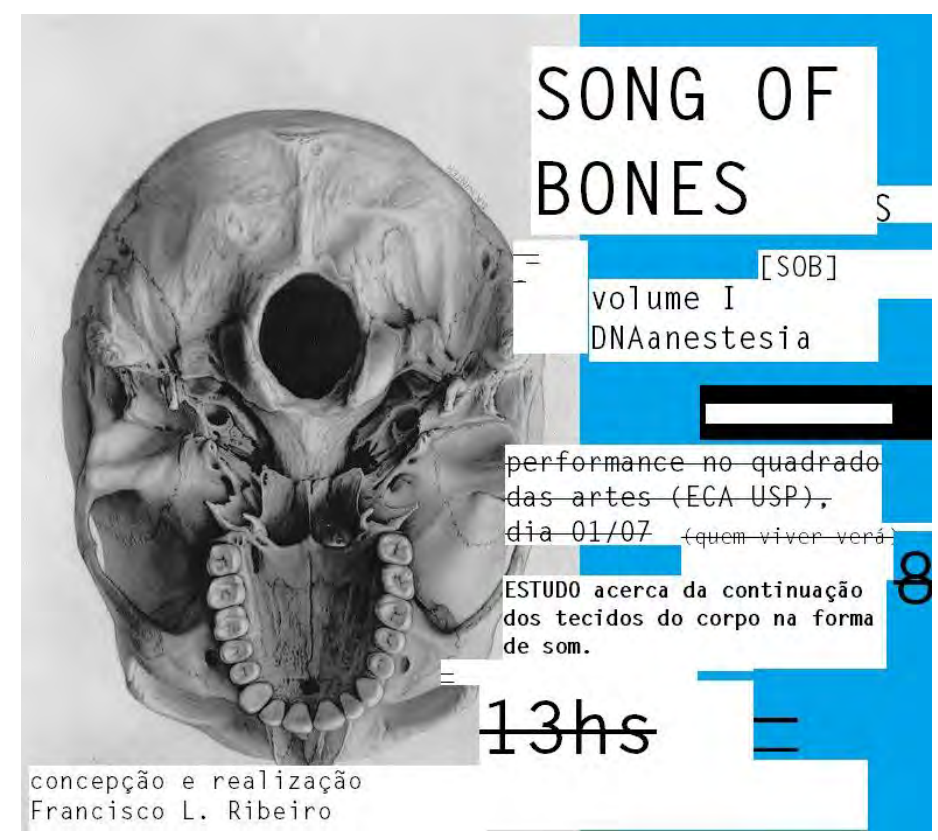

(cartaz para divulgação digital de song of bones)

Todo o problema do corpo, em verdade, começou ao piano. Dali me tornei bailarino. É um espelho que me devolve a própria imagem estilhaçada. Pois o toque 
interferia diretamente com minha carne. Máquina de tocar e ser tocado ${ }^{207}$. É algo que funciona ininterruptamente em mim: inventar reciprocidades involuntárias.

Conforme dizia, do song of bones seguiu-se a transfiguração pitagórica ${ }^{208}$, onde, creio, daquele campo mais livre do aberto, algo se compactou. Foi uma proposta combinada com a José Vieira e Rita M aria, que integravam a equipe do Projeto Alberto Seabra 1128, um coletivo de ações culturais no ambiente de uma casa. As próprias dimensões do espaço favoreceram a formalização da estrutura de transfiguração.

Segue um dos emails de combinação da ação:

Sobre a ação.

'TRANSFIGURAÇÃO PITAGÓRICA (ou 'quatro performances de câmara')

Evocamos aqui o pensamento da afinação entre corpos. Todos ocupam o mesmo lugar. Corpos de extensões e materiais diversos, tais como a anatomia, a pessoa, a cavidade, a distância, a arquitetura, o ar, o tempo. Afinação exata, mas não pré-controlada.

A proposição traz quatro peças: em LUGAR, busca-se um lugar (na casa e fora dela) a partir de vocalizações de diferentes tradições que guardam traços do mesmo princípio vocalizador. A tentativa de se ter um lugar no mundo para fazer o som voar coincide com o ponto de habitar a si mesmo no centro do som. Em VÉRTICEHEFESTO, tentarei afiar a ponta do corpo, o golpe perfeito. Para isso foi elaborada pequena série de exercícios de relaxamento alternados com golpes vocais. PÁSSAROS FICTíCIOS é um estudo sobre não-ser pássaro, onde se tenta atravessar o núcleo não-serpássaro; parto de uma peça musical eletrônica de Henri Pousseur. NOS PRÓPRIOS PÉS consiste numa bula-poema definindo '6 transposições dos sentidos' que almejam enriquecer a produção musical da própria percepção.'

Algumas imagens que podem interessar.... fiquem à vontade para escolher ou sugerir outras.

Na próxima página, o flyer...

${ }^{207}$ Taís Ramirez documentou a última ação de song of bones e fez dois pequenos vídeos-variação em 2015. É o caso deste: https:// www.youtube.com/watch? =IBv1qa-XAG8.

208 'Subi' recentemente a terceira parte da transfiguração: PÁSSAROS FICTíCIOS (estudo sobre não-ser

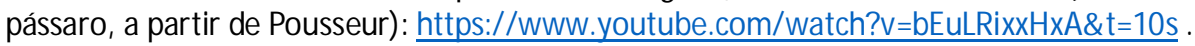



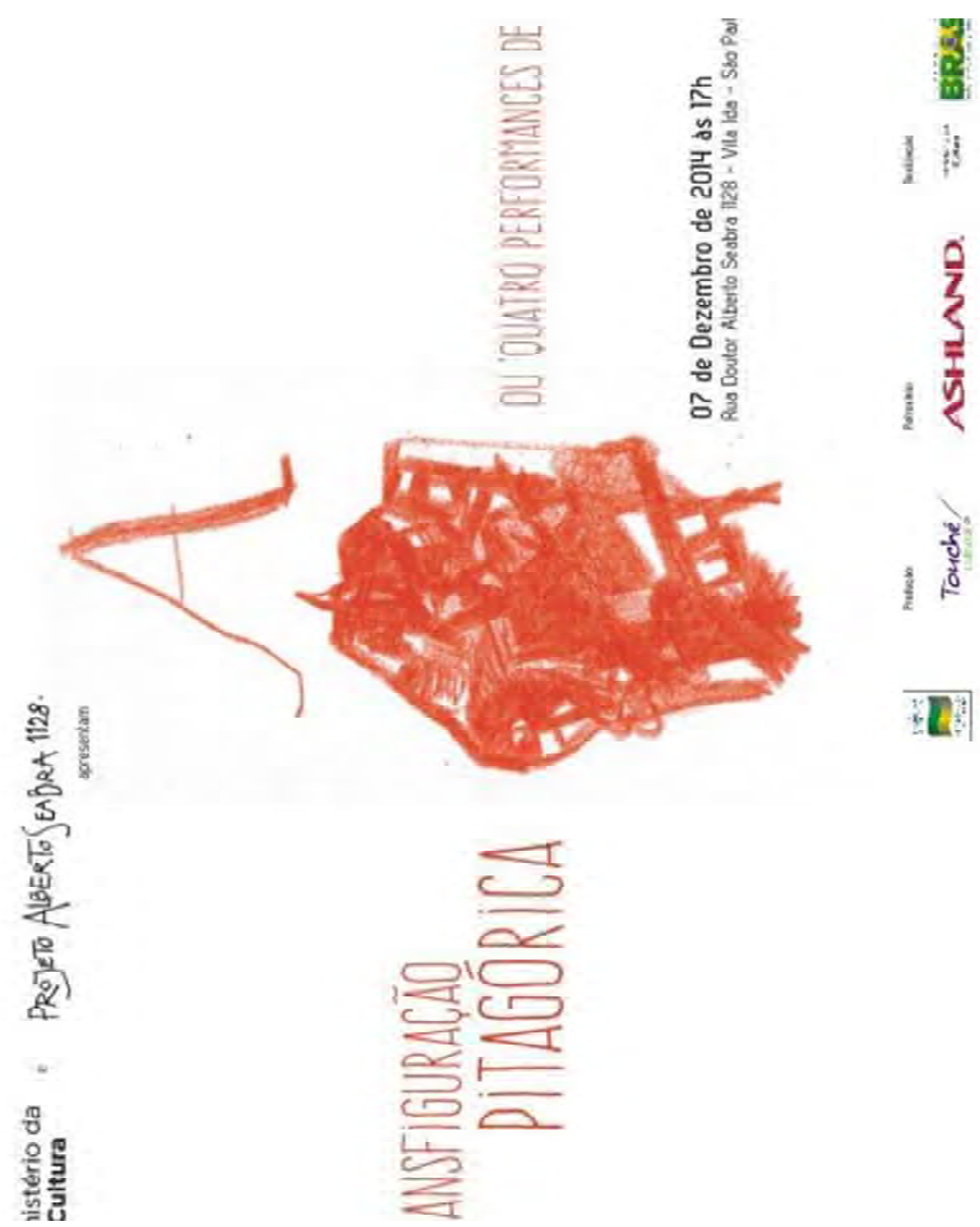

E então, invocação para cordaria. Aí já em 2015, no início do doutoramento... E do após da invocação para cordaria. A tentativa de síntese na elaboração de um corpocorda se deslocou, no meu ver, a pelo menos três terrenos. Primeiro a árvore, como imagem-corte de um dos mitos da Harmonia. Segundo, um tipo de voz afetiva que deu entrada para o tema da visceralidade, que tornou possível pensá-la. Há um experimento à parte que chamei de i'm sorry mister Scelsi. É apenas um conjunto de gemidos que são operados como timbre. Este e outros essa, conformando a coleção de 'exercícios mutantes'. Para enfrentar, assim, uma perspectiva de mutação, parto de um regime de voz afetiva. Pedagogicamente, porém, o grupo chamado 'voz afetiva' 
parte de uma concepção de voz que é corpo ainda desconhecido. Aqui não há técnica vocal anteriormente fixada, apenas ilhas de técnicas inventadas localmente em função de um desejo praticado com muito amor e uma espécie de sobriedade cruel.

Nos terrenos em tensão, há seres interdependentes: a imagem da árvore como nó interelemental-intraelemental e conjunto de escapes, a tradição enigmática e mutante e a voz afetiva. Um exemplo de mutação da tradição pode ser observada em Grotowski, quando ele fala que um ioga possível para o ator de seu teatro seria um 'Yoga dinâmico', e não um Yoga pautado nos pressupostos de controle da atividade vital - tema presente e bastante enfatizado em algumas abordagens de Hatha Yoga. Em transfiguração pitagórica eu tentava causar em mim uma mutação de uma imagem não-consciente de tradição, eu tentava des-individuar a tradição. Ao passo em que na ação anterior, song of bones, era mais uma grande deriva: a espera do imprevisto da mutação.

Talvez invocação para cordaria fosse um campo intermediário, onde houvesse espaço para apreender alguns poucos processos já irrompidos (song of bones), e já condensados e mapeados (transfiguração pitagórica). E eu deixaria para o exercício de i'm sorry mister Scelsi de coletar as marcas resistentes na opacidade do próprio corpo, abrindo uma outra deriva, aquela da sensação vocalizada.

Hoje penso que o corpovoz são os modos de vocalizar a voz do corpo. Isto é muito importante. Por isso é tão difícil definir um único fazer e técnica para o corpossom, pois que independe disso. Eu vejo germinarem as soluções para os problemas.

Um mito pode se dar como uma teoria precária. Mito Armonia, teorias locais, práticas muito inúteis, desativadas de seu utilitarismo.

Segue um amontoado de notas:

Lembrar-se das atividades do ator. $O$ quê ele faz? $O$ ator que é ele mesmo e ao mesmo tempo outra coisa. (2015? 2016? Conversa com Janô) Mecânica (“escrita”) X irradiação (Março de 2010 - anotação do Janô) Campo de escritas sonoras. (sem data... 2010?) Um acampamento de textos. É preciso gerar uma atividade no corpo para perceber o próprio corpo. (2014) Meditação: produção de 
alteridade. (2014) Prometeu: a técnica como impulso titânico - a técnica muda a ordem social. (conversa com Stylianos Tsirakis 2015) Simbolo: para você compreender, você tem que 'colocar junto', ou seja, arriscar sua própria interpretação. (conversa com Stylianos Tsirakis - 2014) Invocação: chamar para dentro de si. Evocação: trazer diante de si. (conversa com Tarsila Doná citando áudio do Ricardo Rizek - conversa 2014) $\boldsymbol{O}$ seio do logos. $O$ seio do ser. $\boldsymbol{O}$ ser é artístico. (conversa com Tarsila Doná citanto áudio do Ricardo Rizek - 2014) You are not the reader. You are (also) the book. (2014)

Possivelmente uma transcrição para transfiguração pitagórica.

Vértice Hefesto. 1. Acuidade/aperfeiçoamento/precisão - uma peça que mostre o processo da precisão; 2. Foco - uma forma de direcionar a energia (no caso do golpe); 3. Transbordamento - o momento antes do derramamento (expressão como pressão para fora) - no mito da expulsão de Ares. (anotação para Vértice Hefesto uma das ações de transfiguração pitagórica - 2014) Som; Deslocamento Densidade Pressão. Sinal. Frente >> fica de olho! (anotação para Vértice Hefesto - 2014)

Por que a resistência de se utilizar o verbo? (2014) Eu percebi, recentemente, que eu não me alimento de palavras. Tenho imensa dificuldade. Percebi, por outro lado, que eu me alimento é de uma espera. Mas não é que eu espere algo. Nem que eu escute algo. É apenas quando habito uma germinação do corpo. (10 de janeiro de 2017)

[Vértice-Hefesto] [...] Estou lidando com os processos corporais da palavra. Com que eu estou falando? É com o 'gigante do espaço'. Da sala prédio espaço campo gramado etc. Song of Bones localização fora da sala. [Vértice Hefesto] Daonde fazer crescer o 
som [?] O som existe; a ação vocal atuação vocal é só uma germinação local, que logo desaparecerá enquanto manifestação, mas fica ecoando no sub-espaço [limiar do nada ou registro da escuta]? Nas impressões e repercussões individuais, nossas conexões mentais coletivas, nas camadas porosas do espaço infinitesimal. (2014)

Aqui há intuições em emergência mas ainda sem um vocabulário compatível. M as já há a intuição do brotamento ou germinação da vibração viva, e a visão de um 'gigante do espaço', ou o MONSTRO COLETOR, este como um parâmetro extra-humano.

Amadorismo X Especialismo (2014) Bio-pseudoespectralidade (2014) 1: Deslocamento qualitativo; 2: Diapason [quando o um é o outro]; 3: Reciprocidade (casamento tenso). (2014) Processualidade, localidade, intermidialidade. (2014) O som como técnica (corporal) (de criança). O som como competência corporal. (2014) Cordaria. Ilíada. Filoctetes Prometeu acorrentado (são obras onde aparece a palavra Armonia, em todos os contextos com sentido diferente). Harmonia - pacto - corda. Como se pode violar o acordo para respeitá-lo. Como respeitar o acordo é violá-lo. (2014) Harmonia acordes - cordas [encordoamento] - cordas [cordaria] - cipó linha. (2014) Cada movimento é um movimento (dentro) do mundo, então ele é um grande movimento, infinito, que influencia todas as partes. Harmonia é o amor de cada movimento - Amor me separa faz distanciar. A guerra me une com o outro. O universo é cada parte unida pela sua alma - Zeus. [...] A música é o assopro do mundo. [...] Processo mundial (pensamento a partir de Taimni e Eliade) [...]. (2014) Estratégias de compressão e descompressão. (2014) Compreender [um nível de] Harmonia: lei do mínimo esforço. Sempre algo que possa ser cantado facilmente. (2014) Forma como fluxo. (defesa de mestrado do Juliano Abramovay 2014) Escuta desconcentrada. (2014, a partir de conversas com Lilian Compesato e Joana Ferraz) Se uma obra musical fala a partir do 
som, é possível também que ela fale sempre, em algum nível, sobre o som. (2014)

\section{$[\ldots]$}

Caderno, anotação, víscera.

Dou-me conta de algo: há um grande número de materiais desta tese que falam sobre vias de transmissão do fazer, onde há esse grande estofo de afirmações contraditórias e cruzadas. A transmissão de algo é feita dessas coisas.

Eu me lembro de que, 1999 eu tinha o hábito de escrever muitas partituras, elas não tinham um sentido exatamente sonoro ou não somente sonoro, eram em grande parte inscrições com perspectiva de acúmulo.

Aqui talvez seja a abertura para refazer, mais uma vez, o percurso desse grupo extenso de inscrições-escritas-desenhos que são os rastros, e que deixam reconhecer um corpossom.

O que pode um umanimusgo contar com sua vocalização quase muda, alheia? 


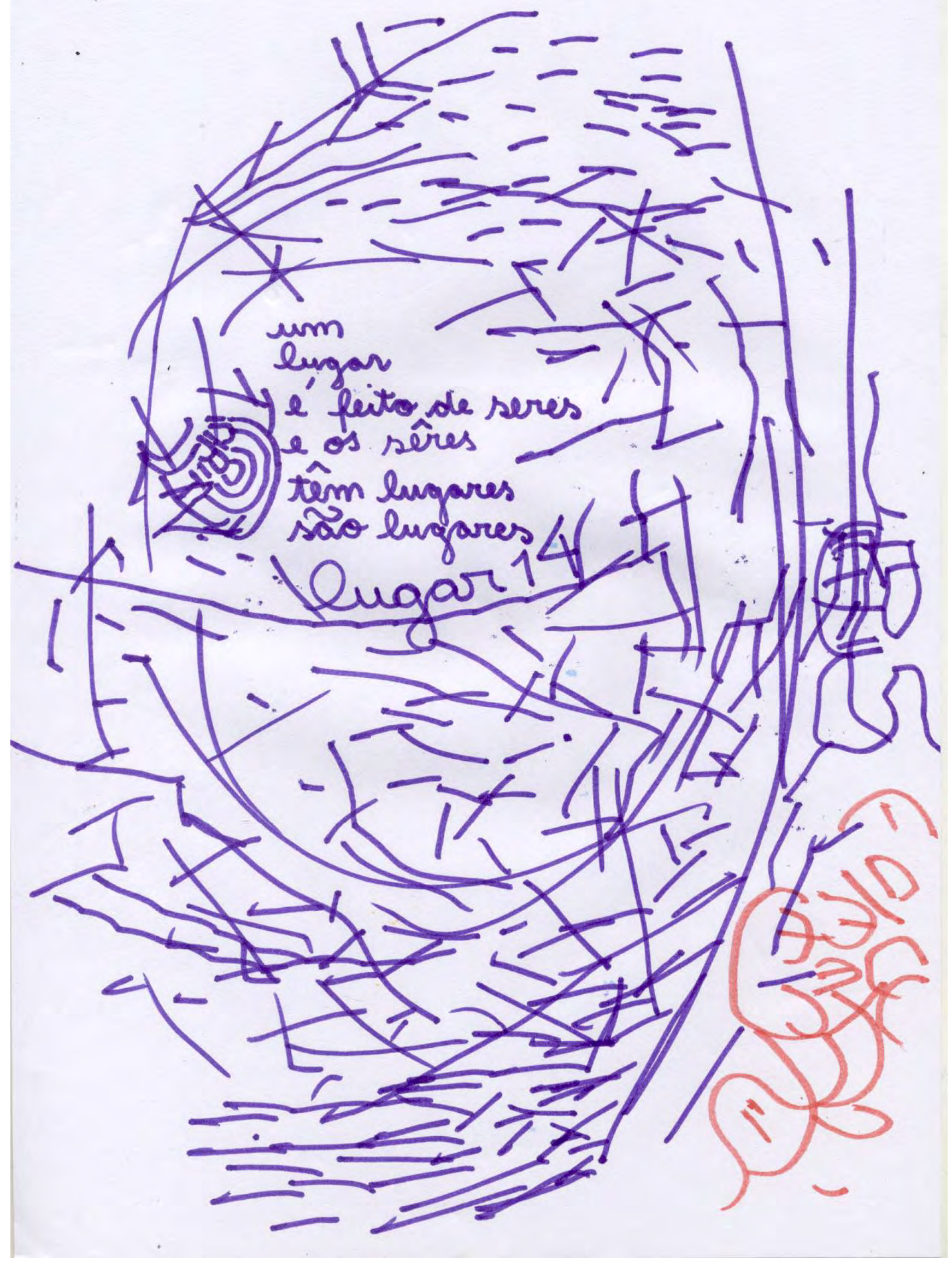


496

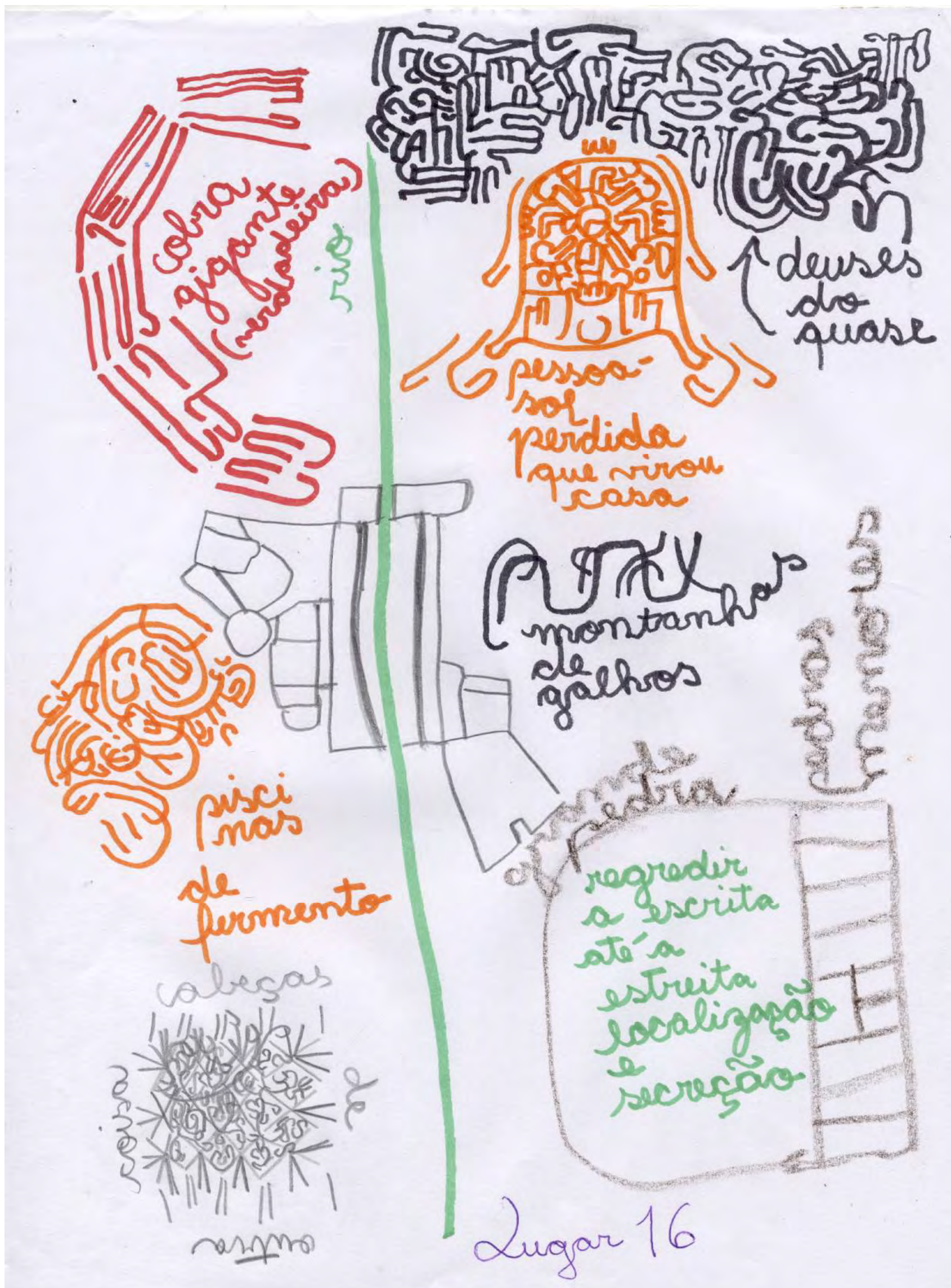




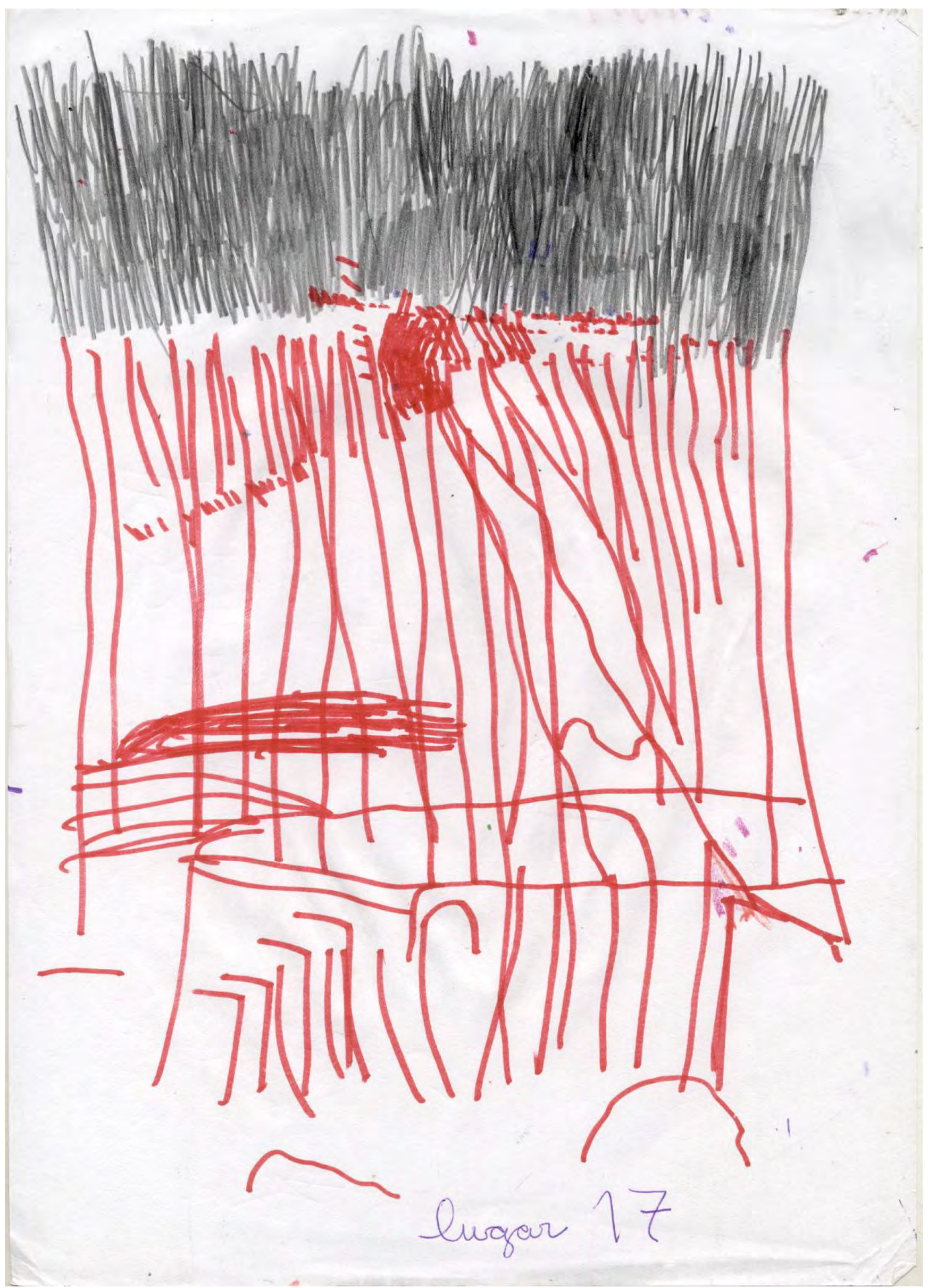




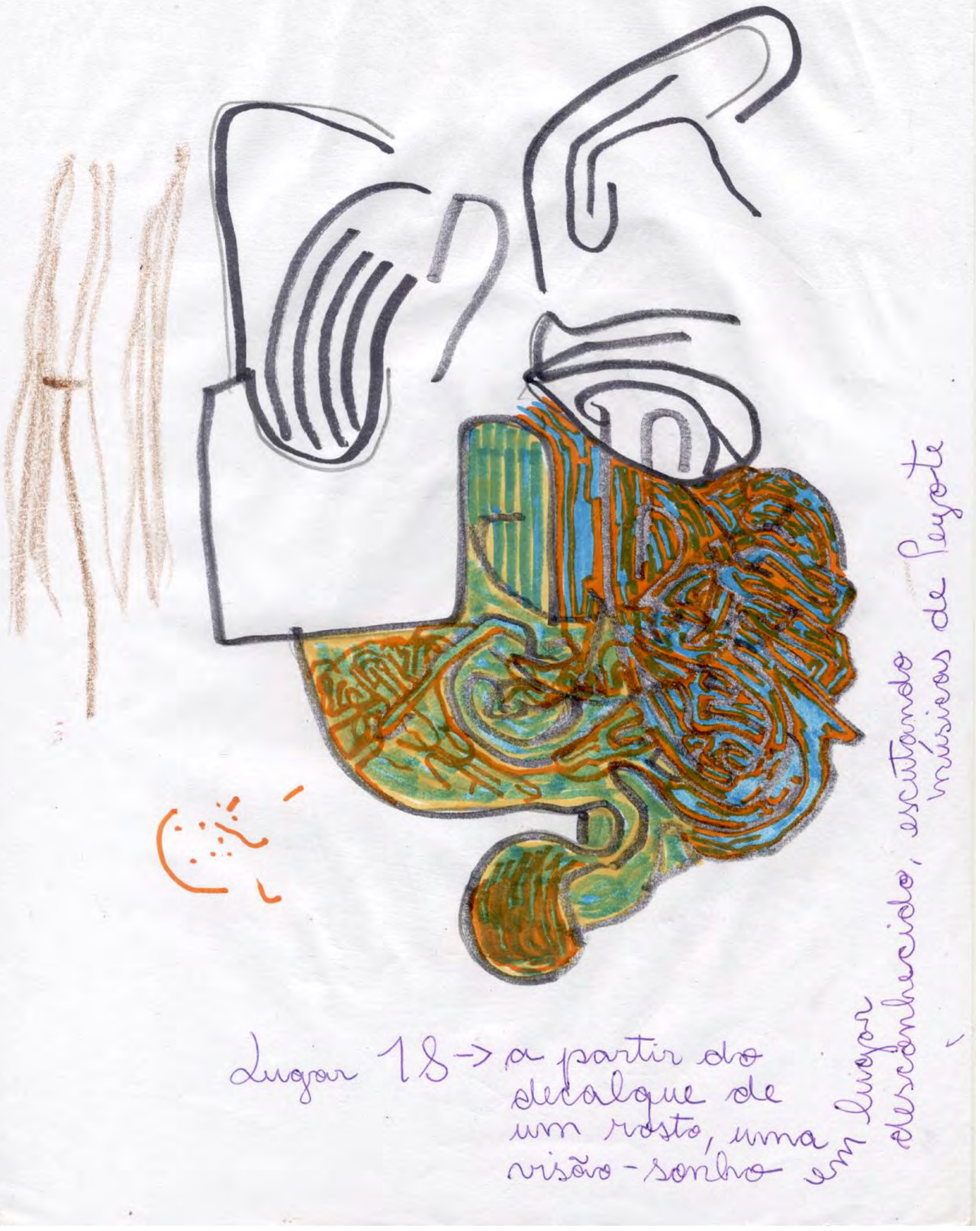




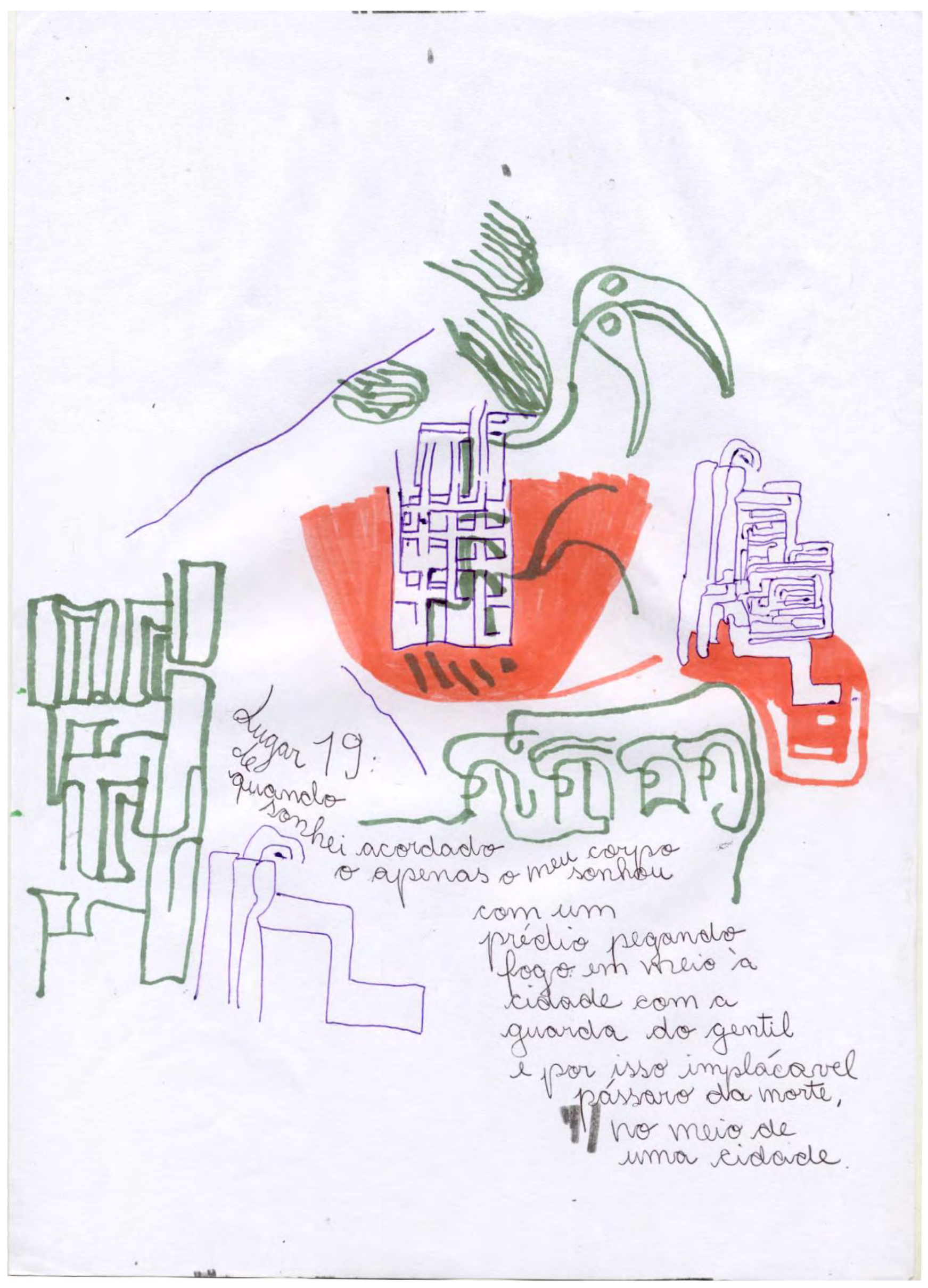


0 fogo há-de queimar-nos a todos, público e actores, ao mesmo tempo L. M. Cintra

\author{
Morreu com o dia \\ o sol fiel que nos aquecia \\ e vejo outro sol \\ depredador
}

Também ele nos deixou

em cena, sós

extintos actores

E vejo outro sol

desfigurado

e outro dia sem cheiro e sem sabor

A fulgurância do supremo actor

um fio de voz a repercute

no coração de quem Ihe escute

anterior às réplicas o tremor.

Luiza Neto Jorge, a lume

\title{
[PEQUENOS APONTAMENTOS CONCLUSIVOS]
}

\section{[GÊNESE DE UM SOM DESCONHECIDO]}

Quando esta tese estiver em impressão, provavelmente vou pensar em muitos detalhes ou ainda em coisas inteiras para se colocar aqui ou para se retirar.

Dentre tantas noite de insônia, nesta última noite de insônia, bem próxima à entrega da tese, escutei uma voz dizer 'chega'. Era a voz do corpo da tese. É o fim. 
Agradeço pela paciência de quem leu.

Estes pequenos apontamentos conclusivos são uma tentativa de pegar alguns fios daqueles tramados no corpo da tese.

ESBOÇAM ENTOS DE CORPOSSOM . A ESCRITA DO CORPO. NA VÍSCERA DO SOM.

Pontos que, por ora, me parecem talismãs.

Detrito. / Compromisso paradoxal. / Máquina de tocar e ser tocado. Ontogênese do contato. / Caminhada-detrito; caminhada-catástrofe; caminhada desconstituinte do som. / Como suportar o prazer? / Voz como salto: galope de excesso de vida, aindanão-morte. / Instintos de germinação. / Voz meteorológica como fermentação, germinação, revoada... / Aprender com o caderno / cosmOVOz (CsO) / Realidade catastrófica do caderno. / Esboçamento é germinação. / 0 que é a construção de uma explosão lenta? / A conversa da pedra.

Há outros.

Auber nos enviou, no grupo da rede digital facebook, um vídeo documental de um pássaro que tem um não-canto: chama-se Urutaú209 (ou Mãe da Lua). Esse é o seu canto. Absolutamente silencioso e atento a tudo o que se passa.

Demorará algum tempo a ressonância deste corpo. Há ainda aquelas dimensões onde a tese já ressoava. Uma ressonância anterior na opacidade do espaço.

Penso que esta junção de matérias abriga o fim de ciclos, alguns extensos, um fim em continuidade, como pensa Donna Haraway. Também início aparente e continuidade suspeita de outros ciclos, de germinações que já começaram. Penso que consegui revisitar, neste estudo, lugares que estavam muito borrados ou ilhados, fazendo comunicarem vínculos inesperados.

\footnotetext{
${ }^{209}$ Encontramos o vídeo em

https:// www .youtube.com/watch?v=Z2NIM3TAolM \&fbclid=IwAR21d9bjfebjNEs4rYFOm3W8 kbw0A3X OlJdbvNInk6lf8boU JePi HaVU.
} 
Como se viu, as práticas germinativas evocadas para cada capítulo se cruzam, se embaralham, se reviram e se encapsulam umas às outras.

Há dois ou três principais pontos que eu gostaria de levantar, ao final.

0 primeiro deles diz respeito ainda à provocação de uma aparente voz sem-técnica como laboratório de fabulação do corpo. Ser, de alguma forma, um performer vocal, mas sem consistente formação técnica dirigida ou autorizada, é algo que ainda me causa constrangimento. Seria o caso de um investimento emocional mais consistente para esquivar esse sentimento meritocrático. Pois neste ponto da tese penso que compreendo o vínculo político das práticas. Foi feito longo caminho de refazimento, retracejamento, elaboração dos percursos nesses quatro anos.

De como a vivência com o instrumento não deixará de fazer parte de mim, por exemplo. De como há, de fato, em jogo, um treinamento e estudo vocais. Trata-se, de fato, de uma técnica. A transfiguração de heranças da atuação, da sonoplastia, de ideias musicais. 0 tempo é aquele de uma lenta metamorfose. 0 elemento que faltava era aquele de que seria necessário o tempo do corpo ser um outro. Um infinitamente outro.

O segundo ponto seria o casulo, sede de metamorfose, colocado ao avesso no mundo.

\section{0 segundo ponto consiste em uma compreensão operacional complexa, a partir da} qual este ambiente de trabalho seria a construção de uma espécie de câmara de ressonância para diversos objetos. Esse pensamento vem do questionamento eventual (e meu próprio) de que o corpossom não teria objeto próprio. É por isso que a filosofia da ontogênese de Gilbert Simondon me foi tão importante. Neste sentido, 0 corpossom pode ser assumido com um modo de deixar que a carne se pense, se cante, desfazendo imagens. Não há nada de metafísico especificamente nesta afirmação: talvez uma pragmática fabular? 
Isso também pois seria abominável uma tese só escrita 'para mim'. Dependerá de qual 'mim' se fala. Um 'si' enquanto ressonância duvidosa, configurada no rumor, um ser e corpo de desconstituição, poderá ser um pensar singular, uma 'peça de pensamento', penso, de alguma valia face os desafios ambientais que se impõem.

O não-objeto, em verdade, não é, mas poderia ser um nó ou conjunto de nós correspondente à experiência das múltiplas ressonâncias. Localização vital.

\section{0 terceiro ponto diz respeito a um outro território desejoso de habitação. DESENHAR} PROCESSOS VITAIS. Retracejá-los. Prolongá-los. Tratou-se de ir mais a fundo nas problemáticas do desenho como produção de corpo, e não como algo submisso à ideia de partitura: isso me convocava. Curiosamente, o procedimento que disparou 0 processo foi, em maior escala, o caderno, principalmente nos retratos práticos de Antonin Artaud por Ana Kiffer e os procedimentos de François Khan. É tudo muito sóbrio e prático.

Da relação dos cadernos com a preparação das ações e os demais campos é que surge a possibilidade de se pensar um paralelismo (assimétrico) de objetos de experiência. Objetos que emergem na ordinariedade das práticas e que são paulatinamente relacionados via transdução, pois a transdução já acontecia, mas precisava ser rastreada no reconhecimento do que ali está ativo, que é uma difícil tarefa. É uma escuta demorada e duvidosa. Nem sempre é figura humana que atua perfurando 0 corpo. A dinâmica insuspeita vem justificar a espera e a ideia de que uma palavra possível seja aquilo que é mais demorado no corpo. Isto é bem importante: talvez a noção-palavra seja o próprio transindividual simondoniano. Algo que é portado demoradamente, cupinzeiro sempre refeito. Agora me ecoa a pergunta de Deleuze em mil platôs 3: não seria a Ética de Spinoza um livro para se fabricar um corpo-semórgãos? 'Finalmente, o grande livro sobre CsO não seria a Ética?' E Deleuze em Spinoza e as três Éticas e nós no meio de Espinosa, quando dessa dimensão vulcânica e contorcida dos escólios: traços de caderno? Não me demorei sobre o problema do corpo-sem-órgãos, apenas sintetizei percursos em pontos aglutinados da minha 
reflexão com os temas do órgão provisório e do alter-órgão multi-específico, lugar de simbiose, produção escalar, invenção...

Então, dois pontos em articulação e um terceiro que corre ao largo: a ontogênese vocal, o próprio ambiente de trabalho ('ateliê voador', nas palavras de Novarina, olhem só) configurado por ressonância. No entanto, seria um ateliê mais à maneira de Francis Bacon, como uma víscera viva do mundo. Um ateliê rastejante...

E o terceiro: produção efetiva de corpo assentada no desenho ou num senso de desenho enquanto corporificação. 0 que quero dizer com senso de desenho? Não é qualquer desenho: é o desenho enquanto sujeito, que aconselha e ensina. Etnografia do invisível. Repito, existe uma autonomia daquilo que emerge na ontogênese.

Creio que se percebeu o quando o discurso da tese mudou quando dos cadernos kafkianos. Estava tudo ali, digamos assim, 'organizado' pelo desenho. Digo, o que havia para ser dito enquanto aprendizagem. Espero também que tenha ficado evidente a transformação que o próprio desenho operou durante as feituras de página. Ali se configurou a noção viva de esboçamento, já emergente em rumor desde as séries de árvores plausíveis e liliths.

Estou conversando com a Artaud-Árvore nos musgos, esse tecido reticulado, miniatura de rizoma multiespecífico, dependurado por um triz nos pedaços de mundo. Me faz também lembrar de seu poema tardio, também exaustivamente lembrado:

\section{Quem sou?}

De onde venho?

Eu sou o Antonin Artaud,

e se 0 disser

como sei dizê-lo,

imediatamente

vereis meu corpo actual

voar em estilhaços

e refazer

com dez mil aspectos 


\section{notórios}

um corpo novo

onde não podereis

nunca mais

esquecer-me.

(2007, p. 65)

Lembro ainda, uma vez, dos ritornelos e dos galopes. 0 percurso com a caminhadacatástrofe (agradeço à paciência de quem leu) vem me deixar suspeitar de que não existiria um ritornelo ou um galope de morte ou de vida, assim, em uma separação tão nítida. São movimentos confusos e heterogêneos que se injetam na máquina abstrata, fazendo girar em falso, fazendo batimentos, fazendo com que dê algo errado. Desejamos isso. De modo que, se quisermos fazer arte, temos de atravessar a possibilidade de destruí-la, e isso é uma medida de sobriedade, e não de vanguarda idealista. É aqui que o enfrentamento uma ontogênese da mitologia Armonia se impõe. Há uma metapoética inevitável nesta específica mitografia, que nos ensina da metapoética geral e da catástrofe da formação de um objeto artístico, modo etnográfico de mundos duvidosos e imanentes. Se é que ainda possamos chamar algo concebido assim por objeto artístico. Dificilmente o será.

Sobre a fantasmagoria não-assumida do terreno das práticas: por exemplo, a fantasia do correto. A não assunção da ficção produtiva é um fantasma. Não sei prosseguir a partir daqui. Teríamos de discutir caso a caso: a prática é sempre local. 0 fantasma é geral. O geral possível são as operações mínimas do corpensamento e os rumores.

Um termo de que eu gostava no meu mestrado era 'o passeio corporal da performance'. Acho que, de lá pra cá, houve uma concretização de intuições, liberação de outras como prática fabular e narrativa, e estabelecimento de um campo estético que lá não existia de forma assumida. 0 que eu dizia lá como a sentença 'do ator ao som', senão afirmar um som desconhecido? 
Tenho muito o que aprender com as estratégias de Nijinsky nos cadernos-caminhadas, e nas estratégias de dança-escrita-devir em conjunção, em Uno. Esse 'devir-qualquercoisa' em conjunção com o 'quase-não-dançar'. Não se trata de um imperativo de contenção nem com a dissolução absoluta, mas de um vínculo de operadores que configuram a estratégia da consistência e da reviravolta nas palavras. Escrever o corpo e a afetividade. Dança germinativa. Fala de pólen. Fala de musgo.

Há consistência no fato de a última prática do doutoramento haver sido aquela de 'apenas encontrar', trocar pesquisas ditas e feitas, ler algo junto. Um eixo mínimo. Um platô em erosão. Aqui, bem como nos testemunhos da palavra 'palavra', se põe em prática a necessidade, reconhecida durante 0 estudo, de se alçar as fontes orais e confrontar esta experiência-palavra de encontro-do-encontro com estudos formalizados, esquemáticos e prescritivos, perfurando-os inevitavelmente, embaralhando as faixas para tentar ser visitado por outros pensares. 0 'valor de prova' evocado por Simondon se torna um valor do contato e da processualidade do contato.

Tive uma vez uma experiência de dilatação semi-alucinógena andando na rua. Apareceu um desenho me atravessando. Um desenho de membrana invadia aquilo que eu entendia como 'interior' do corpo, e esse desenho invadia um espaço diante de mim, por detrás ou em meio à cortina de ar, espaço que eu chamo agora de 'outro espaço'. A sensação conjunta a esse desenho de membrana que apareceu foi aquela que eu traduzo como um semi-autismo. Eu estava lá, caminhando na rua do meu bairro, com coisas a fazer, e ao mesmo tempo eu estava absorvido por essa comunicação que se assemelhava a uma fotografia viva de estágio de mitose celular, onde já há dois corpos, mas eles estão unidos por uma membrana esticada. Eles não iam se separar: tratava-se de uma dilatação. Essa realidade tensionava porém comunicava meu 'interior', com uma região de rumor. Comunicava classes de opacidade. Esse quadro, esta situação: dois espaços em comunicação, dois estados simultâneos. Assim provocou-se em uma dilatação, uma sensação de espaço intermediário nascente e desconhecido. Assim continuei nascendo. Minha realidade é nômade e intermediária. 
Acabaram-se as palavras. 


\section{[REFERÊNCIAS BIBLOGRÁFICAS]}

[PH2]: ESTADO DE TEATRO. Dossiê n ${ }^{\circ}$ : diálogos com o trágico. São Paulo: secretaria da cultura do Município de São Paulo; Cooperativa Paulista de Teatro, 2013.

AGAM BEN, Giorgio. Profanações. São Paulo: Boitempo, 2007.

ALIGHIERI, Dante. A divina comédia: ilustrações de M ichael Mathias Prechtl. São Paulo: Círculo do Livro, publicação germano-brasileira de 1984.

ALUEZ, Éric. (Org.) Gilles Deleuze: uma vida filosófica. São Paulo: Ed. 34, 2000.

AM ORIM, Paloma Franca. Eu preferia ter perdido um olho. São Paulo: Alameda, 2017.

AQUINO, Julio Groppa (org.); IBRI, Bartira (org.); VIEIRA, Elisa (org). M iríade 290: 0 que pode a escrita. São Paulo: Annablume, 2009.

ARTAUD, Antonin. Linguagem e vida. São Paulo: Editora Perspectiva, 1995. . Eu, Antonin Artaud. Lisboa: Hiena Editora, 1988. . Heliogabalo ou o anarquista coroado. Lisboa: Assírio \& Alvim,

1991. . Os Tarahumaras. Lisboa: Relógio D’Água, 2000. . O teatro e seu duplo. São Paulo: Martins Fontes, 2012.

BÂ, Amadou Hampâté. Amkoullel, o menino fula. São Paulo: Palas Athena; Acervo África, 2013.

BACON, Francis; MAUBERT, Franck. Conversas com Francis Bacon: 0 cheiro do sangue humano não desgruda seus olhos de mim. Rio de Janeiro: Jorge Zahar Ed., 2010.

BAIOCCHI, Maura. Butoh: dança veredas d'alma. São Paulo: Palas Athena, 1995.

BARBOZA, Juliana Jardim. Vestígios do dizer de uma escuta (repouso e deriva na palavra) (tese de doutorado). Escola de Comunicações e Artes da Universidade de São Paulo (ECA/USP), 2009.

BASHO, Matsuo. Trilha estreita ao confim. São Paulo: Iluminuras, 1997.

BASTOS, Helena. Corpo sem vontade = cuerpo sin voluntad. São Paulo: ECA/USP; Cooperativa Paulista de Dança, 2017. - (Org.) Musicanoar, 20 anos: deslugares? São Paulo: Cooperativa Paulista de Dança, 2015. 
BENJAMIN, Walter. O narrador: considerações sobre a obra de Nikolai Leskov. In. Magia e técnica, arte e política: ensaios sobre literatura e história da cultura. São Paulo: Brasiliense, 1994, p. 197-221.

BERGSON, Henri. Matéria e memória: ensaio sobre a relação do corpo com o espírito. São Paulo: Editora WM F M artins fontes, 2010.

BLANCHOT, Maurice. A conversa infinita 2: a experiência-limite. São Paulo: Escuta, 2007.

BOLLAS, Christopher. A sombra do objeto: psicanálise do conhecido não pensado. São Paulo: Escuta, 2015. . Hysteria. São Paulo: Escuta, 2000. . Sendo um personagem. Rio de Janeiro: Editora RevinteR, 1998. . The Christopher Bollas Reader. Hove: Routledge, 2011.

BRANDÃO, Junito de Souza. Dicionário mítico-etimológico da mitologia grega. Rio de Janeiro: Vozes 1992. - Mitologia grega. Rio de Janeiro: Vozes, 2013.

CABALIERO, Ileana Diéguez. Cenários liminares: teatralidades, performances e política. Rio de Janeiro: EDFU, 2011.

CALASSO, Roberto. As núpcias de Cadmo e Harmonia: mitos. São Paulo: Companhia das Letras; Editora Schwarcz, 1991.

CASTANEDA, Carlos. 0 presente da Águia. Rio de Janeiro: Editora Record, 1981.

CASTO, Edgardo. Vocabulário de Foucault: um percurso pelos seus temas, conceitos e autores. Belo Horizonte: Autêntica, 2009.

CECIM, Vicente Franz. oÓ: desnutrir a pedra: viagem a Andara, oO livro invisível. Belo Horizonte: Tessitura, 2008.

. Ó Serdespanto: ó ser de espanto, ó ser despanto, ó desdespanto. Rio de Janeiro: Bertrand Brasil, 2006.

CÉSAIRE, Aimé. Cahier d un retour au pays natal: diário de um retorno ao país natal. São Paulo: EDUSP, 2012. . Discurso sobre o colonialismo. Lisboa: Livraria Sá da Costa, 1978.

CINTRA, Fabio Cardozo de Mello. A musicalidade como arcabouço da cena: caminhos para uma educação musical no teatro (tese de doutorado). Universidade de São Paulo (ECA/USP), 2006. 
CHAUÍ, Marilena. Espinosa: uma filosofia da liberdade. São Paulo: Moderna, 1995.

COCCIA, Emanuelle. A virada vegetal (cordel). São Paulo: n-1 ediç̧̃es, 2018.

COHEN, Bonnie Bainbridge. Sensing, feeling, and action: the Experiencial Anatomy of Body-Mind Centering $®$ Northampton: Contact Editions, 2008.

ColLA, Ana Cristina. Caminhante, não há caminho. Só rastros. São Paulo: Perspectiva, 2013.

COMBES, Muriel. Simondon, individu et collecticité: pour une philosophie du transindividuel. Paris: Presses Universitaires de France, 1999.

CORRAZA, Sandra Mara; SILVA, Tomaz Tadeu da. Manifesto por um pensamento da diferença em educação. In. Composições. Belo Horizonte: Autêntica, 2003.

CORRÊA, Paula da Cunha. Harmonia: mito e música na Grécia antiga. São Paulo:

Humanitas FFLCH/USP, 2003.

COSTA, Rogério Luiz Moraes. Música errante: o jogo da improvisação livre. São Paulo:

Perspectiva; FAPESP, 2016.

DA VINCI, Leonardo. Sátiras, fábulas, aforismos e profecias. São Paulo: Hedra, 2008.

DELEUZ, Gilles. A dobra: Leibniz e o barroco. Campinas: Papirus, 2009. . Conversações. São Paulo: Editora 34, 2006. . Crítica e clínica. São Paulo: Ed. 34, 1997. . Diferença e repetição. Rio de Janeiro: Graal, 2006. . Dois regimes de loucos: textos e entrevistas (1975-1995). São Paulo: Editora 34, 2016. . Espinosa: filosofia prática. São Paulo: Escuta, 2002. . Foucault. São Paulo: Brasiliense, 2008. . Francis Bacon: lógica da sensação. Rio de Janeiro: Jorge Zahar Editor, 2007. . Lógica do sentido. São Paulo: Perspectiva, 2015. . Péricles e Verdi: a filosofia de François Châtelet. Porto: Estratégias Criativas, 1997. . Sobre o teatro: um manifesto de menos; 0 esgotado. Rio de Janeiro: Jorge Zahar Ed., 2010.

GUATTARI, Félix. 0 Anti-Édipo: capitalismo e esquizofrenia 1. São Paulo: Editora 34, 2010. 
. Kafka: por uma literatura menor. Rio de

Janeiro: Imago Editora, 1977.

. L'Anti-Erdipe - capitalisme et schizophrénie.

Paris: Les Editions de M inuit, 1972.

_. Mil platôs: capitalismo e esquizofrenia.

Volumes 1-5. São Paulo: Editora 34, 2007.

; PARNET, Claire. Diálogos. São Paulo: Editora Escuta, 1998.

; 0 abecedário de Gilles Deleuze - transcrição integral

do vídeo, para fins exclusivamente didáticos.

DELIGNY, Fernand. 0 Aracniano e outros textos. São Paulo: n-1 edições, 2015.

DERDYK, Edith. A pesar, a pedra. São Paulo: Editora Patuá, 2018.

. Desenhos. São Paulo: Edith Derdyk, 2007.

DESCOLA, Philippe. Outras naturezas, outras culturas. São Paulo: Editora 34, 2016.

DETIENNE, Marcel. A escrita de Orfeu. Rio de Janeiro: Jorge Zahar, 1991.

. M estres da verdade na Grécia arcaica: como abertura: De volta à boca da verdade. São Paulo: Editora WM F M artins Fontes, 2013.

; VERNANT, Jean-Pierre. Métis - as astúcias da inteligência. São Paulo: Odysseus Editora, 2008.

DOSSE, François. Gilles Deleuze e Félix Guattari: biografia cruzada. Porto Alegre: Artmed, 2010.

DUMÉZL, Georges. Do mito ao romance. São Paulo: Martins Fontes, 1992.

DUPONT, Florence. Aristóteles ou o vampiro do teatro ocidental. Florianópolis: Cultura e Barbárie, 2017.

EGYPTO, Joana. Forças em luta para a invenção de uma dança: política cultural e dança contemporânea. Curitiba: Editora Prismas, 2017.

EL HOUU, Janete. Demetrio Stratos: em busca da voz-música. Londrina: PR, 2002.

ELIADE, Mircea. História das crenças e das ideias religiosas. Rio de Janeiro: Jorge Zahar, 2011.

. O sagrado e o profano: a essência das religiões. São Paulo: WMF Martins Fontes, 2010.

. Yoga: imortalidade e liberdade. São Paulo: Palas Athena, 2004. 
ÉSQUILO. Tragédias. Estudo e tradução Jaa Torrano. São Paulo: lluminuras; FAPESP, 2009.

. Oréstia I (Agamêmnon); Oréstia II (Coéforas); Oréstia III (Eumênides). Estudo e tradução Jaa Torrano. São Paulo: lluminuras; FAPESP, 2004.

- Orestéia: Agamêmnon, Coéforas, Eumênides. Tradução do grego, apresentação e notas Mário da Gama Kury. Rio de Janeiro: Jorge Zahar, 2007.

ESPINOSA, Baruch de. Ética. São Paulo: EDUSP, 2018.

EURÍPEDES. M edéia; Hipólito; As troianas. Tradução do grego, apresentação e notas Mário da Gama Kury. Rio de Janeiro: Jorge Zahar, 2007.

FERRAZ, Silvio. Livro das sonoridades [notas dispersas sobre composição] - um livro de música para não-músicos ou de não-música para músicos. Rio de Janeiro: 7Letras, 2005. . Notas do caderno amarelo. . (Org.). Notas. Atos. Gestos. Rio de Janeiro: 7 Letras, 2007.

FERREIRA, Aurélio Buarque de Holanda. Dicionário Aurélio básico da língua portuguesa. Rio de Janeiro: Nova Fronteira, 1988.

FOUCAULT, Michel. A arqueologia do saber. Rio de Janeiro: Forense universitária, 2014.

. Dits et écrits tome I. Paris: Editions Gallimard, 1994. - Introdução a uma vida não fascista. Traduzido por Wanderson Flor do Nascimento. In: Gilles Deleuze e Félix Guattari. Anti-Oedipus: capitalism and schizophrenia. Nova lorque: Viking Press, 1977, pp. XI-XIV. . 0 que é a crítica (27 de maio de 1978) - A cultura de si (12 de abril de 1983). Lisboa: Edições Texto \& Grafia, 2017.

GALÁS, Diamanda. The shit of god. London; New York: High Risk Books; Serpent's Tail, 1996.

GALINDO, Maria. ¡A despatriarcar!: feminismo urgente. Ciudad Autónoma de Buenos Aires: lavaca editora, 2014.

GENET, Jean. 0 ateliê de Giacometti. São Paulo: Cosac \& Naify, 2000.

GIL, José. A imagem-nua e as pequenas percepções - estética e metafenomenologia. Lisboa: Relógio D’Água Editores, 2005. 
. M etamorfoses do corpo. Lisboa: Relógio D’Água, 1997.

. M ovimento total: o corpo e a dança. São Paulo: lluminuras, 2013.

. Caos e ritmo. Lisboa: Relógio D'Água, 1997.

GOGH, Vincent van. Cartas a Theo. Porto Alegre: L\&PM Editores, 2015.

GREINER, Christine. Butô: pensamento em evolução. São Paulo: Escrituras Editora, 2008.

. Fabulações do corpo japonês e seus microativismos. São Paulo: n-

1 edições, 2017.

. Leituras do corpo no Japão e suas diásporas cognitivas. São Paulo:

n-1 edições, 2015.

- O corpo: pistas para estudos indisciplinares. São Paulo:

Annablume, 2005.

; AMORIM, Claudia. (Orgs.) Leituras da morte. São Paulo: Annablume, 2007.

GROTOWSKI, Jerzy; FLASZEN, Ludwik. O Teatro Laboratório de Jerzy Grotowski 19591969. São Paulo: Perspectiva, 2007.

GUATTARI, Félix. Máquina Kafka. São Paulo: n-1 edições, 2011.

GUÉNOUN, Denis. 0 teatro é necessário?. São Paulo: Perspectiva, 2004.

GUINSBURG, J.; KOUDELA, Ingrid Dormien. (Orgs.) Büchner: na pena e na cena. São Paulo: Perspectiva, 2004.

HALLIWELL, Stephen. Between ecstasy and truth: interpretations of greek poetics from Homer to Longinus. New York: Oxford University Press Inc., 2011.

HALPRIN, Anna. Moving toward life: five decades of transformational dance. Middletown: Wesleyan University Press, 1995.

HAUBOLD, Johannes. Greece and Mesopotamia: dialogues in literature. New York: Cambridge University Press, 2013.

HERÁCLITO DE ÉFESO. Heráclito: fragmentos contextualizados. São Paulo: Odysseus Editora, 2012.

HESíODO. Os trabalhos e os dias. Introdução, tradução e comentários M ary de Camargo Neves Lafer. São Paulo: lluminuras, 2006. - Tradução, estudo e notas Luiz Otávio de Figueiredo Mantovaneli. São Paulo: Odysseus Editora, 2011 (coleção kouros). 
. Teogonia: a origem dos deuses. Estudo e tradução Jaa Torrano. São Paulo: lluminuras, 2007.

HOMERO. Ilíada. Tradução de Haroldo de Campos. São Paulo: Arx, 2003.

. Tradução e introdução de Carlos Alberto Nunes. São Paulo: Hedra, 2011.

- Tradução e prefácio de Frederico Lourenço. São Paulo: Penguin Classics Companhia das Letras, 2013.

JANUZELL, Antonio Luis Dias. A aprendizagem do ator. São Paulo: Editora Ática, 2003. - 0 ofício do ator e o estágio das transparências (tese de doutorado). Universidade de São Paulo (ECA/USP), 1992.

JUNG, Carl Gustav. A natureza da psique (obras completas de C. G. Jung, v.8, t.2). Rio de Janeiro: Vozes, 2013. . Freud e a psicanálise (obras completas de C. G. Jung, v.4). Rio de Janeiro: Vozes, 1990.

. 0 Eu e 0 inconsciente (obras completas de C. G. Jung, v.7, t.2). Petrópolis: Vozes, 1985. - Os fundamentos da psicologia analítica (as conferências de Tavistock). Petrópolis: Vozes, 2017.

KAFKA, Franz. 28 desaforismos =28 aphorismen. Florianópolis: Editora da UFSC, 2011. . Sonhos. São Paulo: Editora lluminuras, 2003.

KAHLO, Frida. The diary of Frida Kahlo: na intimate self-portrait. New York: ABRAM S; La Vaca Independiente S.A., 2005.

KAM PER, Dietmar. 0 corpo vivo, o corpo morto. Texto apresentado no Seminário Internacional "Imagem e Violência", promovido pelo CISC - Centro Interdisciplinar de Semiótica da Cultura e da Mídia, no Sesc Vila Mariana, em São Paulo, em março-abril de 2000. Publicado on-line. CISC, SP, 2002.

KANTOR, Tadeusz. 0 teatro da morte: textos organizados e apresentados por Denis Bablet. São Paulo: Perspectiva; Edições SESC SP, 2008.

KAZANTSÁKIS, Nikos. Ascese: os Salvadores de Deus. São Paulo: Editora Ática, 1997.

KERÉNYI, Karl. A mitologia dos gregos: vols. I-II. Petrópolis, RJ: Vozes, 2015. Arquétipos da religião grega. Petrópolis, RJ: Vozes, 2015. . Dioniso. São Paulo: Odysseus, 2002. 
KIFFER, Ana. Antonin Artaud. Rio de Janeiro: EdUERJ, 2016.

. A perda de si: cartas de Antonin Artaud. Rio de Janeiro: Rocco, 2017.

KI-ZERBO, J. (Ed.) História geral da África. I. Metodologia e pré-história da África. Brasília: UNESCO; Secad/M EC; UFSCar, 2010.

KOUDELA, Ingrid D. (Org.) Heiner M üller: o espanto no teatro. São Paulo: Perspectiva, 2003.

KRAUSZ, Luis S. As M usas: poesia e divindade na Grécia arcaica. São Paulo: Editora da Universidade de São Paulo (EDUSP), 2007.

LAOZ. Dao De Jing: Escritura do Caminho e Escritura da Virtude com os comentários do Senhor às Margens do Rio. São Paulo: Editora Unesp, 2016.

LATOUR, Bruno. Jamais fomos modernos: ensaio de antropologia simétrica. São Paulo: Editora 34, 2016.

. Reflexão sobre o culto moderno dos deuses fe(i)tiches. Guarulhos: EDUSC, 2002.

LÉVI-STRAUSS, Claude. Antropologia Estrutural. São Paulo: Cosac Naify, 2008. _. M inhas palavras. São Paulo: Editora Brasiliense S. A., 1991. . 0 cru e o cozido (Mitológicas v. 1). São Paulo: Cosac Naify, 2010. . O homem nu (M itológicas v. 4). São Paulo: Cosac Naify, 2011. . O olhar distanciado. Lisboa: Edições 70, 2010. . O pensamento selvagem. Campinas: Papirus, 1989.

LINARES, Federico Navarrete. Entre a cosmopolítica e a cosmohistória: tempos fabricados e deuses xamãs entre os astecas. São Paulo: Revista de antropologia N 59 (2), ps. 86-108, FFLCH-USP, 2016.

LISPECTOR, Clarice. A paixão segundo G.H. Rio de Janeiro: Rocco, 1998.

MARIA THAIS. (Org.) Balagan: Companhia de teatro. São Paulo, Cia Teatro Balagan, 2014.

_. Na cena do dr. Dapertutto: poética e pedagogia em V. E. Meierhold: 1911 a 1916. São Paulo: Perspectiva: FAPESP: 2009.

MARONI, Amnéris. Eros na passagem (uma leitura de Jung a partir de Bion). Aparecida: Idéias \& Letras, 2008. 
- Fotografando o invisível: ensaios de psicanálise, cinema e literatura. São Paulo: Intermeios, 2017. . Jung, o poeta da alma. São Paulo: Summus, 1998.

MBEM BE, Achille. Crítica da razão negra. São Paulo: n-1 edições, 2018.

MERLEAU-PONTY, Maurice. 0 visível e o invisível. São Paulo: Perspectiva, 2014.

MIGUEL, Luis Felipe. Em torno do conceito de mito político. Dados: on-line version ISSN 1678-4588, Rio de Janeiro: vol. 41 n³, dez. 1997.

MISHIM A, Yukio. Sol e aço. São Paulo: Editora Brasiliense, 1985.

MÜLLER, Heiner. M argem abandonada M edeamaterial paisagem com argonautas. Rio de Janeiro: Paz e Terra, 1993.

NIETZSCHE, Friedrich. A gaia ciência. São Paulo: Companhia das Letras, 2001. . Assim falava Zaratustra. São Paulo: Escala, 2013. . 0 crepúsculo dos ídolos ou como filosofar com o martelo. In. Os pensadores. São Paulo: Editora Nova Cultural. 1996.

NIJINSKI, Vaslav. Cadernos; o sentimento. Rio de Janeiro: Livraria Francisco Alves Editora, 1998.

NOVARINA, Valère. 0 ateliê voador; Vocês que habitam o tempo. Rio de Janeiro: 7Letras, 2009.

NÚCLEO TRÂNSFUGAS. In. RAMOS, Luiz Fernando (coord.) TELESI, Sílvia Fernandes (coord.);. 2. Arte e poder. Sala preta, São Paulo, n7, 2007.

OHNO, Kazuo. Treino e(m) poema. São Paulo: n-1 edições, 2016.

PAZ, Octavio. Conjunções e disjunções. São Paulo: Editora Perspectiva, 1979. . 0 arco e a lira. São Paulo: Cosac Naify, 2012. _. O labirinto da solidão e post scriptum. Rio de Janeiro: Paz e Terra, 1984. - Os filhos do barro: do romantismo à vanguarda. São Paulo: Cosac Naify, 2013.

PELBART, Peter Pál. 0 avesso no nihilismo: cartografias do esgotamento. São Paulo: n1 edições, 2016. . 0 tempo não-reconciliado: imagens de tempo em Deleuze. São Paulo: Perspectiva, 1998.

PERETTA, Éden. 0 soldado nu: raízes da dança butô. São Paulo: Perspectiva, 2015. PÉREZ, Annie. (Dir.) Deleuze, un álbum. Paris: Éditions du centre Pompidou, 2005. 
POUSSEUR, Henri. Apoteose de Rameau e outros ensaios. São Paulo: Editora UNESP, 2009.

PRIGOGINE, Ilya; STENGERS, Isabelle. A nova aliança: metamorfose da ciência. Brasília: Editora Universidade de Brasília, 1984. - La nouvelle aliance: métamorphose de la science. Saint Amand-(Cher): Gallimard, 1990.

RIBEIRO, Francisco Lauridsen. Preparação do corpossom: atuação e voz concreta (dissertação de mestrado). Universidade de São Paulo (ECA-USP), 2011.

RIBEIRO JR., Wilson Alves (ed., org.). Hinos homéricos: tradução, notas e estudo. São Paulo: UNESP, 2010.

RIZEK, Ricardo. A teoria da harmonia em Platão. Um estudo sobre a identidade da música ocidental (dissertação de mestrado). São Paulo: ECA/USP, 2003.

ROLLAND, Romain. L'éclair de Spinoza. Tesserete: Pagine d'Arte, 2010.

ROUSSEAU, Jean-Jacques. Les Rêveries du Promeneur solitaire. Paris: Éditions Gallimard, 2018. . Os devaneios do caminhante solitário. Porto Alegre: L\&PM, 2008.

ROUX, Jacques. (Coord.) Gilbert Simondon: une pensée opérative. Publications de I'Université de Saint-Étienne, 2002.

RULFO, Juan. Pedro Páramo e Chão em Chamas. Rio de Janeiro; São Paulo: Editora Record, 2009. . 100 fotografias de Juan Rulfo. São Paulo: Cosac \& Naify, 2010.

SANDARS, N. K.; OUVEIRA, Carlos Daudt de, (trad.). A epopéia de Gilgamesh. São Paulo: WM F M artins Fontes, 2011.

SCHECHNER, Richard; WOLFORD, Lisa. The Grotowski sourcebook. London: Routledge, 1997.

SCOTT, David. Gilbert Simondon's Psychic and Collective Individuation: a critical introduction and guide. Edinburg University Press Ltd, 2014.

SIMONDON, Gilbert. El modo de existência de los objetos técnicos. Buenos Aires: Prometeo Libros, 2007. . Imagination et invention (1965-1966). Chatou: Les Éditions de La Transparence, 2008. 
- La individuación a la luz de las nociones de forma e de información. Buenos Aires: Cactus, 2015.

- L'individuation à la lumière des notions de forme et d'information. Grenoble: Éditions Jérôme Millon, 2005.

SMITH, Amy. Athenian political art from the fifth and fourth centuries BCE: images of political personifications. In BLACKWEL, C. W., ed.. Dēmos: classical athenian democracy (A. Mahoney and R. Scaife, edd., The Stoa: a consortium for electronic publication in the humanities [www.stoa.org]) edition of January 18 2003. cwb@stoa.org.

SÓFOCLES. Filoctetes. Tradução, introdução e notas Fernando Brandão dos Santos. São Paulo: Odysseus Editora, 2008 (série kouros).

. A trilogia tebana: Édipo Rei, Édipo em Colono, Antígona. Tradução do grego, apresentação e notas Mário da Gama Kury. Rio de Janeiro: Jorge Zahar, 2008.

SOUTO, Alicia. A essência do Hatha Yoga: Hatha Pradipika, Gheranda Samhita, Goraska Shataka. São Paulo: Phorte, 2009.

SUBIRATS, Eduardo. A flor e o cristal: ensaios sobre arte e arquitetura modernas. São Paulo: Livraria Nobel S. A., 1988.

TARDE, Gabriel. Monadologia e sociologia - e outros ensaios. São Paulo: Cosac Naify, 2007.

THOREAU, Henry David. Caminhada. Lisboa: Antígona Editores Refractários, 2013.

TOURNIER, Michel. Sexta-feira; ou, Os limbos do Pacífico. São Paulo: DIFEL, 1985.

UNO, Kuniichi. A gênese de um corpo desconhecido. São Paulo: n-1 edições, 2014. . Hijikata Tatsumi: pensar um corpo esgotado. São Paulo: n-1 edições, 2017.

VARGAS, Eduardo. ANTES TARDE DO QUE NUNCA: Gabriel Tarde e a emergência das ciências sociais. Rio de Janeiro: Contra Capa Livraria, 2000.

VERNANT, Jean-Pierre. A morte nos olhos: figuração do outro na Grécia antiga. Jorge Zahar, 1988. . M ito e religião na Grécia antiga. São Paulo: WM F M artins Fontes, 2006. 
WINNICOTT, D. W.. 0 ambiente e os processos de maturação: estudos sobre a teoria do desenvolvimento emocional. Porto Alegre: Artes M édicas, 1983. . Textos selecionados: da pediatria à psicanálise. Rio de Janeiro: $F$. Alves, 1978.

WOLF, Christa. Cassandra. São Paulo: Estação Liberdade, 2007.

WOSIEN, Bernhard. Dança: um caminho para a totalidade. São Paulo: TRIOM , 2000.

WU, Jyh-Cherng. Tai chi chuan: a alquimia do movimento. Rio de Janeiro: Mauad, 1998.

XAVIER, Jussara (org.); MEYER, Sandra (org.); TORRES, Vera (org.). Tubo de ensaio: composição [intersecções + intervenções]. Florianópolis: Instituto Meyer Filho, 2016.

YOKOYAMA, Ana Cristina. Um fio de memória: um encontro com o Butoh de Kazuo Ohno (Trabalho de Conclusão de Curso). Universidade de São Paulo (ECA/USP), 2006.

ZALTZM AN, Nathalie. A pulsão anarquista. São Paulo: Editora Escuta, 1993.

ZOURABICHVIL, François. Deleuze: uma filosofia do acontecimento. São Paulo: Editora 34, 2016.

ZWEITE, Armin (Ed.); MÜLLER, Maria (colab.). Francis Bacon the violence of the real. London: Thames \& Hudson, 2006. 


\section{[[[DISCOGRAFIA GERMINAL]]]}

SAIM KHO NAM TCHYLAK. Lost rivers. FM P Germany, 1991.

DIAM ANDA GALÁS. Plague mass. Mute (New York), 1991.

GIACINTO SCELSI; MICHIKO HIRAYAM A. Canti del capricorno. Wergo (Alemanha), 2010.

\section{[[[ALGUNS DOS SITES CONSULTADOS]]]}

(não esgotam os citados em tese)

ALMEIDA, Mauro W. Barbosa de Almeida. Caipora e outros conflitos ontológicos.

http://www.rau.ufscar.br/wp-

content/uploads/2015/05/vol5no1 01.M auroAlmeida.pdf

COM BES, M uriel. Uma vida por nascer. [página temporariamente fora do ar]

https://revistas.ufrj.br/index.php/eco pos/article/view/10401

\section{GALÁS, Diamanda.}

http://diamandagalas.com/

(Plague Mass - completo)

https://www.youtube.com/watch?v=w7|ttF6tPZs\&t=1s

Hijikata Tatsumi (Genetic Archive - Keio University)

http://www.art-c.keio.ac.jp/en/archives/list-of-archives/hijikata-tatsumi/

KHAN, François. Reflexões sobre a prática da memória no ofício do ator de teatro.

http://www.revistas.usp.br/salapreta/article/view/57398

KIFFER, Ana. 0 rascunho é a obra: o caso dos cadernos.

http://www.scielo.br/scielo.php?script=sci_abstract\&pid=S2316-

$40182018000300095 \& \operatorname{lng}=e n \& n r m=\dot{s} 0 / \&$ tlng $=p t$ 
MARTY, Emilia. Simondon, um espace à venir.

http://www.multitudes.net/Simondon-un-espace-a-venir/

Simondon du désert (filme).

https://vimeo.com/156520798

STENGERS, Isabelle. A proposição cosmopolítica.

http://www.revistas.usp.br/rieb/article/view/145663

UNO, Kuniichi. Artaud et l'espace de forces.

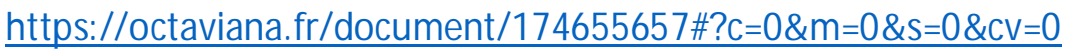

\section{[[[OUTROS]]]}

https://osmilnomesdegaia.eco.br/

https://www.youtube.com/results?search_query=cecil+taylor

http://monoskop.org/Michel Foucault

http://www.theoi.com/

http://www2.univ-paris8.fr/deleuze/

https://www.webdeleuze.com/sommaire

http://www.progettoamazzone.it/ 
[2 anexos] 


\section{[ANEXO UM. $O$ QUE PODE SER UMA VÍSCERA?] [RASTRO DE CAM INHAR PERGUNTANDO]}

1.

A escrita é, primeiramente, uma inscrição. Algo que traz uma violência em si, uma espécie de mutilação. Essa inscrição é pressuposto de toda ação posterior e multiplica a violência de uma sentença que pretenda emitir explicações sobre o mundo.

Além disso, a produção de um texto no computador traz um perigo, já presente nas teses, de uma abstração desta primeira ação violenta de inscrição, e a consequente abstração de corpo. Eu quero concentrar e sobrepor, aglutinar as forças de um corpo. Eu gostaria que esta tese fosse a produção de um corpo de imagens-nuas (para falar um pouco com José Gil de a imagem nua e as pequenas percepções). Assim, propus em daod momento que parte da tese fosse fabricada à mão, com escritadesenho. Por razões de tempo, isso não ocorreu e nem o prazo inteiro de uma tese daria conta.

Além de uma inscrição, um golpe, uma ferida na matéria, a escrita é um acúmulo de matéria. Não necessariamente o acúmulo quantitativo, mas aglutinação e brotamento a partir da ferida da inscrição.

\section{2.}

Cabe definirmos alguns traços da relação da visceralidade com a teatralidade, já que nossa investigação prática se manteve vinculada à prática da atuação, ainda que seja uma víscera do som.

Proponho a visceralidade do som como abordagem da escrita do corpo.

Diz Hijikata Tatsumi que 'a ferida está lá desde o começo do corpo' (UNO, 2018, p. 197). Pois bem. Por que será difícil prosseguir isto em uma escrita? 
Bom, temos um problema de localização: estamos falando sobre um teatro que está em choque sempre com alguma referência europeia dominante de teatro. Então podemos adotar isso, mas apenas em parte, oportunamente, na medida em que essas imagens de teatro com que nos chocamos têm radicais pelo menos em Homero e Hesíodo. Estes últimos nomes carregam em si também imagens do que poderíamos chamar de mito: os nomes os lotes dos deuses pelas bocas das M usas (Hesíodo) ou ainda a realização da finitude dos heróis por desígnio das divindades. Este último, o tema não de uma liturgia (podemos nos poupar deste debate), mas da assimetria entre vida (deuses) e vivente (mortais, incluindo os heróis).

Haveria outra maneira de se produzir míticas, para além de uma escatológica moralista (podemos desde já superar também esta discussão), senão como resultado do fracasso da linguagem e do entendimento?

De outro lado, haveria alguma pressão nomeável capaz de mover o vivente a inventar ou, como propõem os bardos antigos, escutar palavras míticas? Mover o canto para mais uma vez escutar um vozeiraço totalmente improvável que repercute do choque das peças de mundos? Choque terrível de mundificações catastróficas, porém por isso verdadeiras? Seria mesmo mito uma boa palavra, ou apenas poesia não-recreativa?

Uma 'harmonia', essa amarração de partes vivas e massacradas inclui então a violência e a agressividade. Ambas estão no acordo da necessidade (deusa órfica Ananké), que é figura da vida que aperta. Existe um campo mitológico para essas valorações. Károly Kerényi associa a violência e 0 orgulho às figuras dos Titãs, lato sensu, quando se pergunta o quê qualificaria uma ação titânica. Hesíodo canta, na teogonia, a derrocada e o aprisionamento dos titãs no Tártaro, região situada abaixo do mar. 0 Tártaro é uma das variantes para a víscera do mundo.

Todas as informações agora são oriundas da teogonia hesiódica.

Outra variante de víscera da terra, a encontramos no subsolo de Atenas, para onde vão as Erínias, transformadas em Eumênides: narrativa cantada na tragédia Eumênides de Ésquilo. As Erínias são 'originalmente' reequilibradoras dentro do esquema da ordem tribal, motivadoras da reparação (em geral, violenta) para com os assassinatos e violações de gentes dentro da família. Reparadoras de crimes consanguíneos ou entre genealogias. As Erínias (Fúrias), juntamente com as M elíades e 
a maioria dos Gigantes (excetuando os Cíclopes forjadores do Raio), nascem no primeiro crime consanguíneo dentro da teogonia de Hesíodo: a mutilação do Céu (Urano) por Cronos (Saturno), através de sua foice de bronze. Segundo Hesíodo, Zeus evocará as Erínias no momento de vingar a mutilação de seu avô divino e tomar o poder. A mutilação do Céu por Cronos que pode ser lida como a criação do horizonte. 0 horizonte se modifica de acordo com a passagem do tempo. Assim, é revelada a ordem do tempo cronológico, o tempo extenso, demarcado, circular da natureza. Teria nascido aí a respiração do horizonte. Cabe lembrar que a fenda aberta pela mutilação é uma abertura à víscera.

Agora utilizarei falas oriundas da Orestéia de Ésquilo.

As Eumênides, por seu turno, são versões apaziguadas, menos odientas, das Erínias. A conversão acontece quando, sob mando de Atena, concebe-se miticamente 0 direito ateniense. 0 sentimento de ódio envolvido na reparação deve ser apaziguado, e este senso de reparação deve ser colocado a serviço de uma outra ordem, um outro movimento: aquele da supremacia de uma ideia de cidade. Não se trata de elaborar sobre o grau de idealização da cidade. Ocorre que existe, subterraneamente, sobreposto pelo desfecho moral da tragédia, um trajeto geográfico e geológico: durante a gradual conversão de Erínias em Eumênides, esses seres se deslocam para um subterrâneo para a partir dali realizarem sua nova tarefa. 'Descei às profundezas da terra'; 'nas entranhas da terra' (trad. CURY, 2006, p. 193: vs. 1319 e 1338). 'Descei à terra'; ' 'aos lugares ínferos e subterrâneos' (trad. TORRANO, 2004, ps. 145 e 147; vs. 1007 e 1023). Seria a víscera viva da cidade? Seria a própria entrada na terra uma variante da víscera? É válido afirmar a recíproca, que a víscera é uma variante da matéria-terra? Seria o mito a víscera da narrativa?

Essa série de vísceras míticas. 0 tártaro e as profundezas de Atenas. As cavernas (com exemplos na república de Platão, ou filoctetes, tragédia de Sófocles. A própria caverna onde Édipo desaparece em Édipo em Colono). As mutilações, as fendas, as fossas e as descidas que evisceram, que nos permitem ver a víscera viva.

Diz Carlos Nejar em a espuma do fogo: 'nenhuma maior do que a terra dentro de nós. Tão medonha, buliçosa. É perigosa a esperança, se não a adotarmos antes, quando criança.' (NEJAR, 2002, p. 39) 
Este teatro que é um absoluto fracasso do humano vivente face à potência da vida.

\section{3.}

É crucial a produção de corpo. Um corpo é algo que nasce e continua nascendo. Algo se acumula. Uma intenção de acúmulo circula e perdura. Numa escavação em busca do corpo, retira-se massa mas acumula-se matéria.

Durante o mestrado eu propus a analogia da vocalização com o desenho, em razão de um fator convergente: a expressão com uma dimensão linear que acumula e produz corpo. Não modificam só a massa, mas sim qualidades (sensações).

O desenho guarda íntima relação com a máquina viva e com o diagrama de forças animais. $E$ aqui aos poucos proporei que vegetais e minerais também. $E$ a tese se pretende como um novo acúmulo. Uma continuação do nascimento que se inscreve, que martela.

Por vezes penso que a atuação - e o corpo-texto gerado em seu fazer - é muito próxima da escultura nessa intenção que perdura e circula. Desenhar-esculpir. Mais uma vez, um acúmulo, uma sobreposição de gestos, onde se subtrai material e se concentra matéria.

\section{4.}

A escrita do corpo a partir da visceralidade do som. Eu quero me prender um pouco às palavras do título. Eu quero fazer isso pois, em primeiro lugar, as palavras que escolhi para o título são muito utilizadas em contextos diferentes. E essas palavras estão combinadas aqui no título para delimitar um campo específico de estudo em andamento, elas então se individuam conjuntamente. Neste escrito vou focalizar um pouco mais o tema da víscera.

Víscera? Aquilo que é velado, encerrado, ou aquilo que excede, transborda, é empurrado e sobra, resta?

Diz o dicionário Aurélio (1988) de víscera: 'designação comum a qualquer grande órgão alojado na cavidade craniana, na torácica ou na abdominal'. Diz, o 
mesmo dicionário, para visceral: '1. Relativo ou pertencente às vísceras. 2. Fig. Profundo, entranhado'. E para vísceras: '1. Entranhas, intestinos. 2. Fig. A parte mais íntima de qualquer coisa; âmago'. Fiquei curioso acerca da palavra entranha: 'qualquer víscera do abdome ou do tórax'. Para entranhas: '1. 0 ventre materno. 2. Caráter, índole. 3. Sentimento, coração. 4. Profundidade, profundeza'. 0 verbo entranhar e 0 adjetivo entranhado acrescentam um dado de alguém ou algo introduzir-se, entrar, penetrar, avançar, dedicar-se profundamente, concentrar-se, absorver-se, (misturar-se $a_{\text {,) }}$ arraigar-se, inverterar-se etc.

\section{5.}

É um relativo senso comum a acepção de víscera como 'órgão vital'.

\section{6.}

Dentre as definições aqui evocadas para víscera e entranha (e palavras imediatamente próximas), gostaria de reunir algumas delas de acordo com uma leitura das forças aqui explicitadas. Reagrupar algumas definições, e depois tentar suscitar a própria força em questão através da ação da escrita.

\section{7.}

Primeiro, o fato da víscera ser algo concretamente alojado dentro de uma cavidade, ou o próprio ventre materno (entranha). Víscera como a realidade da cavidade. Um pequeno universo, com seus escapes de dissipação para a dimensão do 'fora'. A entranha é ressonância do fora. 0 'fora' faz parte do universo da cavidade e, assim, também participa do universo. A força do fora se dissipa também na indeterminação da víscera.

O termo 'dissipação' eu tomo emprestado da aliança Francis Bacon + Gilles Deleuze. Esse termo aparece quando se diz que a figura pintada se dissipa, através de um furo, como uma boca, um ralo de uma pia ou um guarda-chuva, para uma área maior da pintura ou para o próprio suporte da pintura. Eu posso tomar emprestado 
também outros termos dessa aliança, quando se verifica as categorias de conjuntos de sensações ou vibrações: 'dissipação', 'deformação' e 'acoplamento'. Ou mesmo nas operações dos trípticos (sendo a obra um tríptico ou não), quando se diz em reunião de separações e proliferações. Eu faço esse empréstimo pois reconheci nesse pintor (e no seu acoplamento com Deleuze) elementos de visceralidade. Um desses elementos é a série preparatória para a possibilidade do fato: 'devir-animal', 'força manual', 'instinto', 'diagrama localizado', onde, na minha opinião, o corpo fareja a pintura.

Víscera = cavidade.

\section{8.}

Segundo, o fato de ser a parte mais íntima ou o coração de qualquer coisa.

Pois não se trata aqui do coração do corpo humano. Não se trata aqui de uma dissecação de um cadáver. Não se trata aqui de se chegar ao caroço de uma fruta. Pelo menos é longe de ser só isso. É algo como o caroço do caroço, o coração do coração; 0 caroço ou coração transposto e multiplicado a qualquer instância.

Proponho nesta segunda hipótese que a visceralidade se deixa registrar através de uma intimidade com a matéria.

Algo ocorre aqui diverso da cavidade. Talvez a imagem dominante aqui não seja mais a cavidade que contém algo. Ou sim, talvez seja o mundo como cavidade multiplicada, e aí, como movimento de abismo. Talvez seja o coração da matéria como algo dentro da costura da matéria. Algo proliferado e proliferante, que entra em si e brota-se. 0 coração pode ser o órgão-estalo do nascimento da vida consigo mesma.

O coração proliferado ou intimidade da matéria consigo mesma constitui então uma espécie de acordo, constitui um centro estranho que se efetua no descentramento de forças. Isso significa não somente que essa espécie de acordo, espécie de intimidade, se transforma, desloca e se multiplica. Significa concretamente que o coração proliferado se encontra no interstício da vida. Assim, se abrem fendas vivas. É quando a escuta e o entre são matérias autônomas. Daí que a víscera pode ser lida como interstício infinito em brotamento.

Nos temas da germinação daquilo que prolifera, temos a variante do pontosemente do pintor Klee, na análise de Eduardo Subirats. Perfaz-se assim o 
acoplamento Klee + Subirats. Nos temas do brotamento generalizado, José Gil aborda as pequenas percepções que brotam e a dobradiça ('charneira') infinitamente plástica e proliferante, lugar da imaginação do corpo, paradoxal, 'lugar onde nascem as imagens' (1996, p. 170), lugar de engendramento. Contudo, proponho que haja algo de doloroso e catastrófico nesse brotamento generalizado que ocorre no coração da matéria. Não é apenas o ponto sem peso nem gravidade proposto por José Gil, quando este elabora a dobra ou charneira, espaço objetivo e subjetivo da imaginação do corpo. 0 ponto pensado sem peso tem um avesso comprimido e dilatado, e é ele que me interessa: e ruga fértil é também aquele da ferida aberta, com sua própria série de variações. Variações do combate, a guerra, a incompreensão, a agonia, a mutilação, 0 estilhaçamento, o absurdo do mundo.

0 brotamente não deixa de ser também um enfrentamento de forças. 0 pensamento arcaico me alerta: 'É necessário saber que a guerra é comum e a justiça, discórdia, e que todas as coisas vêm a ser segundo discórdia e necessidade' (Heráclito de Éfeso, fragmento LXXX ou 20 em Costa, 2012, p.133) Discórdia: condição vivente da reunião de alteridades.

Víscera $=0$ ser do entre.

\section{9.}

Terceiro, por consequência: estado ou condição de absorção ou auto-absorção, dedicação profunda, penetração; estado ou condição de arraigamento e autopenetração. Talvez esse seja o regime de trabalho daquilo que eu chamaria ator ou performer que pretenda trabalhar com a visceralidade, com especial atenção para a visceralidade do som. A visceralidade é paradoxalmente sóbria. Imediatamente me recordo do professor Antonio Januzelli (Janô), pedagogo da atuação e meu orientador do mestrado, que mencionava três estágios relacionados à atenção: a concentração, a penetração e a compenetração. 0 que isso significa? 
10.

Quarto: a visão de necessidade que remete ao instinto, ao animal e à natureza. Àquilo que o próprio corpo significa pra si mesmo como natureza.

Por enquanto são estas as quatro forças que registrei. Uma categorização primária.

11.

Quero imaginar que aquilo que chamo 'visceralidade' não é um valor exatamente consciente. São configurações fugazes que eclodem no trabalho de um ator ou atriz que se debruce na conjunção do som com matéria viva. Mas não é o som matéria viva? Se for a penas o que dizem e não o que fazemos, não será. Por isso é preciso ser íntimo da germinação sonora.

Um performer como escutador. A minha hipótese é que a visceralidade é uma fibra de vida e eclode de acordo com uma necessidade estranha. Como podemos segui-la? Não há nada de transcendente nisso. Fazemos parte dela. Ela arranja meios.

Não sei se isso parece óbvio, mas as consequências dessa hipótese talvez não o sejam. A visceralidade, do ponto de vista do humano, pode ser quando um indivíduo se torna apenas corpo e encarna a voz das forças vivas do corpo. Uma espécie de qualqueridade, de voz inorgânica do orgânico? Não sei dizer. Quando o corpo se torna repercussão e não apenas dissipação (vontade hippie de ser vibração), relações fugazes podem ser apreendidas por uma intimidade com a matéria. Então poderia ser: vocalização da intimidade, vocalização das sensações-vibrações de um corpo, um ambiente-membrana. Acho que isso também não tem a ver com as estratégias repressivas da meditação. É um acompanhar da opacidade do corpo ou ambientemembrana.

Eu digo assim categoricamente pois a não-comprovação também faz parte dessa sentença. As relações fugazes podem ser apreendidas em ato ou podem escapar. Fracassar. Atravessar todo o percurso até o retumbante fracasso: contamos com isso. 
12.

A intimidade talvez signifique também a 'penetração'. É a auto-penetração de uma presença que é transformativa.

Eu falo de penetração por causa das aulas práticas de Janô. Falávamos desses três estágios de atenção em sua abordagem. Pareceu-me que o estágio de concentração era o mais imediato, uma atenção para si, para o que estou fazendo. A penetração significava o cuidado e o interesse no detalhe de cada matéria. A respiração, um objeto, um som. A sustentação e continuidade do meu interesse. A compenetração era o estágio mais elaborado onde o foco de interesse se preservava, mas de onde eu podia estabelecer uma rede de relações. É um $360^{\circ}$ de atenção a partir do foco. No doutoramento de Janô, intitulado o ofício do ator e o estágio das transparências, bem como na consequente publicação posterior a aprendizagem do ator, temos descrição de procedimentos para esse e outros esquemas. M as trata-se essencialmente de um saber prático.

Vou utilizar o exemplo da compenetração. Eu cheguei a compreender esse estágio - captar a transformação do ambiente a partir de um ponto. Mas isso se deu num âmbito totalmente prático, e pensamos pouco sobre isso para além da observação e anotação de diário.

Isso leva à segunda razão: à necessidade de uma língua e um modo de inscrição compatíveis com a prática. Não penso que a documentação protocolar e a argumentação sequencial dariam conta de transmitir uma vivência daquilo que é produzido. Talvez seja preciso caminhar por limiares de estilo. Pois trata-se sempre disso: de transmitir uma vivência, e não de ser fiel a uma fórmula.

0 que tem isso a ver com Sonologia? Lembro-me de que esse ambiente de trabalho se pretende uma reflexão prática sobre o som.

Não há fórmulas para uma expressão da visceralidade. Ela pode se dar no mais perfurante silêncio. É importante salientar que a visceralidade não se reduz à representação da visceralidade. É também por conta disso que a anatomia médica européia não me servirá muito, senão algo de anatomia afetiva de Artaud e Nijinsky, senão a anatomia mágica de Goya, senão a anatomia fática de Bacon, senão algo da anatomia planetária de Dante. Mas aqui há ainda algo capcioso, uma aparente 
oposição. Representação e fato não se opõem, se a representação vem como um fato. 0 principal é saber que se trata de um ato de inscrição. A escrita é antes uma inscrição.

E a inscrição é como se fosse uma fenda ou, no limite, uma ferida. Outras coisas brotam, diversamente de um objeto ausente representado. A fenda aberta pela inscrição pode ser uma boca ou um diafragma qualquer que escuta e que diz algo. Um conjunto de fluxos se abre.

13.

Quero associar, num plano de entendimento, a visceralidade a dois denominadores: a necessidade (que difere da utilidade) e o desconhecido. Heráclito nomeia algo como 'discordância e necessidade'.

Uma harmonia da víscera. De um lado, a serpente Ananke que aperta. De outro, o Arco-Lira de Heráclito que estica. De qualquer maneira o rio, mesmo o rio de Heráclito, é serpente. 


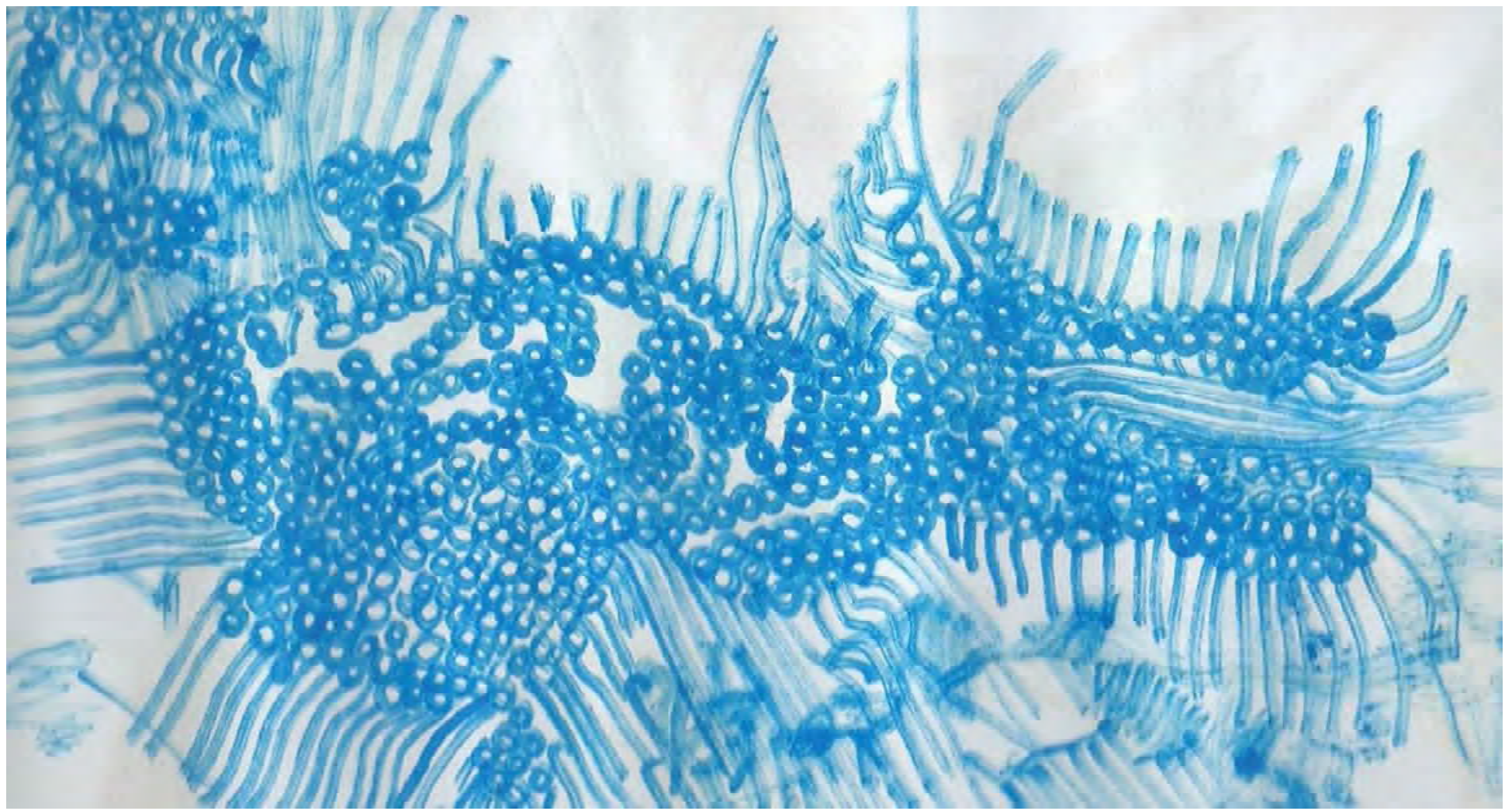

14.

Corporificar o som. 
No livro a lógica da sensação (1981), o filósofo Gilles Deleuze afirma ser desnecessário trabalhar com a separação das artes, e declara que há pintura em todas as artes. Antes disso, porém, ele atesta acerca da música (DELEUZE, 2007, p. 60):

\begin{abstract}
[...] É verdade que a música atravessa profundamente nossos corpos e nos põe uma orelha no ventre, nos pulmões etc. Ela é mestra em onda e nervosidade. Mas ela arrasta nosso corpo, e os corpos, para um outro elemento. Ela livra os corpos de sua inércia, da materialidade de sua presença. Ela desencarna os corpos. De forma que se pode falar com exatidão de corpo sonoro e até de corpo-a-corpo na música como, por exemplo, em um motivo. [...]
\end{abstract}

Este é um trecho do sétimo capítulo do livro citado. 0 nome do capítulo é a histeria. Esse capítulo inicia com uma reflexão sobre o corpo sem órgãos concebido por Artaud: 'é um corpo intenso, intensivo. Ele é percorrido por uma onda que traça no corpo níveis ou limiares segundo as variações de sua amplitude' (p. 51). Temos uma síntese importante aqui: 'A sensação é vibração' (idem). Pois temos a sensação de termos um corpo.

Eu busco uma música que encarna. A música do corpo. Penso na assertiva de Deleuze. ['A música] desencarna os corpos'. Tento desenvolver do meu modo. Um primeiro passo: a música desencarna o corpo dado para reorganizar as imagens de corpo. É possível?

Seria melhor perguntar qual é a tinta do corpo? Qual a pintura do som encarnado?

22.

[...] É notório que Nietzsche e, pouco tempo depois, Artaud se apegaram enormemente à música para a pesquisa do teatro autêntico. Não à música que ilustra ou dramatiza o teatro como acessório ou decoração, mas à música à voz e ao som como aquilo que é invisível. 0 que é irrepresentável deve ser o princípio da criação do teatro ou da tragédia. Não se vê Dionísio, força primitiva que exclui a representação, a imagem, o 
pensamento racional bem articulado. Somente se ouve Dionísio como vibracão direta que trabalha imediatamente a audição, como audível que atravessa e afeta o corpo. Será esse esquema nietzschiano e artaudiano um esquema ultrapassado, fora de moda? [UNO, 2012, p.66. Grifo meu]

Um corpo desconhecido.

Curiosamente, Nietzsche e Artaud foram duas pessoas que pensaram, de certa forma, um fim de Deus. Nietzsche o explicita, através de uma pequena narrativa, no trecho 125 de a gaia ciência (1882 e 1887, expandida). Em o crepúsculo dos ídolos (1888), o autor investiga o componentes que formam as crenças e a culpa. Antonin Artaud, por sua vez, traz em fevereiro de 1948 a obra radiofônica para acabar com 0 julgamento de deus.

\section{4.}

Visceralidade é uma palavra utilizada principalmente no contexto da estética, quando dizemos que sujeito é visceral quando exprimiu uma necessidade vital naquele gesto, ou de um corpo que compreendeu esteticamente uma visão excessiva, barroca, gótica, da vida. Também nos referimos a essa palavra no contexto do sofrimento humano e no contexto mais geral de uma necessidade, de uma urgência, ou de uma emergência. 
25.
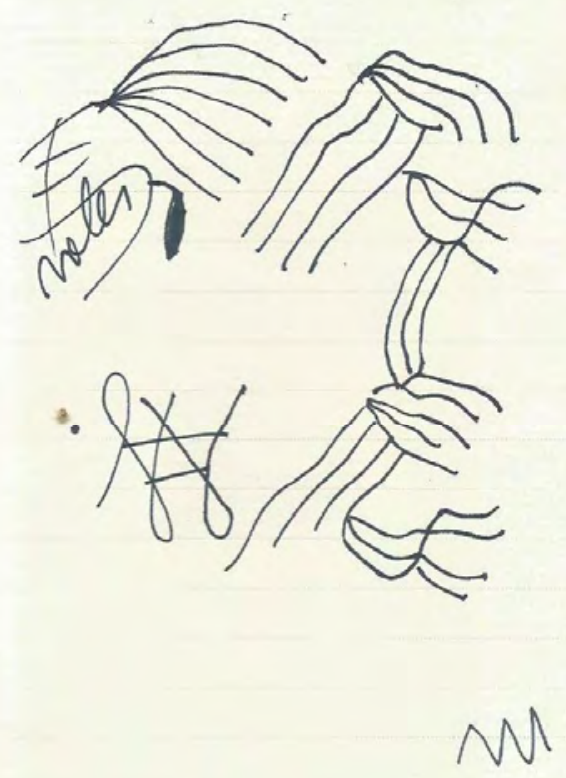

(caderno antigo - 2010?)

Sou repetitivo, algo quase não existe. Sobre a invasão uma outra realidade. A necessidade narra um absurdo.

0 termo visceralidade, hipótese de abordagem, tem validade apenas para articular algumas práticas por algum tempo.

Nascedouro. Nesse sentido a escrita vai no gerúndio mesmo, escapando e buscando fendas para o 'lado de fora' da linguagem, pois o que mais me interessa é, nas palavras de Antonio Januzelli, 'transmitir uma vivência'. Uma vivência de transformação do corpo. Produção de corpo.

As bases da transmissão da vivência, segundo alguns elementos que pude apreender da prática do Janô (Januzelli), têm a ver com desentorpecer e desbloquear as regiões afetivas, vitais, expressivas do humano. Esse humano é trans-humano e habita em tudo o que é vivo. É a vida em mim. Essa é parte da minha apreensão de nossas práticas. Investigamos princípios da expressão humana. Esses princípios têm a ver com o animal-humano. 0 fundamental é o fato de que esse trans-humano e esse 
animal é o que aí está, e não deixará de fazer passagem. De certo modo, é observar o rio de Heráclito, mas é um rio de magma. De forças muito entranhadas e vitais.

\section{6.}

Deleuze-Bacon: Cabeças ao invés de rostos.

Inspiro-me muito nas forças descritas por Deleuze no seu devir-Bacon: forças de acoplamento, dissipação e deformação. Depois: divisão/reunião, diagrama, deviranimal, modulação, força manual involuntária... E outras. Inspiro-me e me transformo nos assuntos corporais dos ensaios de Kuniichi Uno. Devir-Genet: fendas e fissuras. Devir-M in Tanaka: 'o mais importante não é as imagens, mas o que se passa entre as imagens'. O senso de um 'corpo desconhecido'.

Agora mais próximos do nosso campo de estudo: a imagem de um som desconhecido que brota. 0 som da continuação do nascimento que, ao se reconhecer, opera uma corrosão. 0 som opera e resulta desse corpo repleto de geologias.

Seria preciso que aquele que dança e canta interrompa a vocalização durante a dança para deixar ver uma transformação na escuta. Seria preciso desconhecer o som e deixar encarnar uma intenção de som. Seria preciso refazer ou deixar que se refaçam as categorias de propriedades sonoras para dar conta da vocalização de uma nota do nascimento, repleta de prazer e dor, e assim refazer a imagem germinal da Musa.

É uma noção de som encarnado (aqui sutilmente divergente da acepção que Deleuze, quando associa a música a um som desencarnado) que move a prática.

Duas variáveis então: práticas e um certo tempo.

27.

Não se vê Dionísio, força primitiva que exclui a representação, a imagem, o pensamento racional bem articulado. Somente se ouve Dionísio como vibração direta que trabalha imediatamente a audição, como audível que atravessa e afeta o corpo. [UNO, 2012, p.66. Grifo meu] 


\section{8.}

Falar sobre a visceralidade do som, alguma voz vital. Aqui parece que eu tive que recuar o máximo possível para aquilo que pode significar que ainda há vida. Quase não há vida. Mas esse quase é decisivo.

Mas aqui recuar não é exatamente recuar. O rincão da germinação das intenções pode ser aquilo que me arremessa para onde os mundos ruídos se encostam. 0 rumor das ações pode ser aquilo que torna aguda a necessidade de escuta de algo não conhecido e que jamais será conhecido. Eu digo recuar. Recuar no sentido de ter intimidade com a matéria. De apenas ser um fato-corpo. Um pouco repetitivo e autorreferente, mas daqui podemos produzir um nascimento contínuo. Para continuar nascendo. Para continuar a fecundação. Então temos três ou quatro vetores perenes: a cavidade do segredo, o alheio; a intimidade com a matéria, o fatocorpo implicador do devir-animal, e a sintonia com um corpo como um sistema vibrátil deslizante de matéria em transformação.

Visceralidade. A conceituação desse termo que explorarei, penso eu, habita 0 limite da palavra. Aqui, a palavra contempla o seu limite. Lidarei com isso. Assim eu peço licença do leitor de antemão, prevenindo-o de que será um percurso por vezes delicado, por vezes complicado, pela própria consistência do tema. Aqui temos um problema também de discurso: como se deslocar de uma aparência mistificada ('a visceralidade é isso, é aquilo'), de um acúmulo burocrático de pressupostos, para um risco de realidade, algo crucial para o pensamento? Aqui o discurso entra em guerra consigo. Pois, como o afirma em 0 arco e a lira, Octavio Paz declara que as palavras podem ser muitas coisas ao mesmo tempo. Sua remontagem a Heráclito de Éfeso é um corte importante: o pré-socrático anuncia a lei da imanência e o descrédito com as formas devocionais que ele observa. E aqui retomamos o tema da sobreposição e dos fluxos contraditórios que constituem a nossa dança. Espere. É dança ou é música? Não era teatro?

Falar sobre o imprevisível fecundo em um corpo que canta tem também a ver com um projeto de antemão fracassado. Um corpo que canta é um corpo condenado, que fracassa. Aqui reside a assimetria radical entre um corpo civilizado e a vida. 
Assimetria diagnosticada a todo tempo por Artaud e, acredito eu, outros. É necessário fracassar, é necessário reconhecer a consistência da lacuna que tange as incoerências, é necessário dissidir (dissidência). É necessária uma filosofia miserável, uma teoria precária, uma prática sem utilidade, mas como secreção que testemunha brotamento. Assim tento transmitir objetivamente uma vivência (objeto central desta pesquisa). Parece óbvio, mas não é. Para atingir estes fins, estes efeitos, penso que a prática da escrita necessita de uma transfiguração. É o que me envolve. Busquei companhias de artistas e teóricos que me auxiliassem em práticas e recursos para pensar a escrita como transmissão existencial crucial. Aí, repito: a escrita tanto de uma tese quanto a escrita mínima de uma cena de corpo e som.

A calma aqui é política. Uma política vitalista, que acompanha os fluxos contraditórios. 


\section{[ANEXO DOIS. DEZ DIAS DE ÁRVORE]}

A estrutura mínima era pendurar-me em um galho com ambos os braços e entrelaçando os dedos das mãos do outro lado do galho. Três vezes. Depois mais três vezes, entrelaçando os dedos na outra posição. Depois apoiar um dos pés no tronco e permanecer, com a intenção ou de alongar ou de subir, como se fosse um passo. Também três vezes. Depois eu vocalizaria qualquer sensação que pudesse vir, de qualquer maneira.

Essa estrutura produz inúmeras variações. Mas eu sempre tento voltar à célula básica: duas séries de um dependurar-se, cada série com os dedos entrelaçados em uma posição. E o 'pisar' de cada uma das plantas dos pés no tronco, duas séries (direita e esquerda), ou uma (fazer esse apoio e o consequente alongamento alternando-se os lados).

Este trabalho dos dias é o 'recheio', foi o treinamento e é a preparação da performance umanimusgo.

Árvore dia 1 (29/08/2016)

Dia 30 de agosto de 2016 [confundi a data, era 29, pelo registro do áudio]. Primeiro dia nas árvores, retomada. Árvore; contato no estilo cobra ${ }^{210}$ [com a árvore]; e chamada [canto]. Três eixos. Fiz algumas coisas na árvore e em seguida quase como que eu fui

\footnotetext{
${ }^{210}$ Quando eu falo 'estilo cobra' me refiro a algo muito vago em que uma das matrizes atuantes é a pedagogia do Mestre Jo Azer para as artes marciais indianas [Kalaripayattu e Vajra Mushti, sendo a segunda uma arte mais fechada e provavelmente mais antiga do que a primeira], quando este morou no Brasil. Essa pedagogia adaptada foi denominada Kempo Indiano [há um pequeno texto so bre isso alguns itens à frente]. Eu não tive aulas com Jo, mas com um aluno dele, Federico de Aquino, e Federico falava muito que o modo como Jo ensinava, e principalmente a cobra - o que era muito regenerativo, pois a cobra usa muito o chão - era a partir de algum modo de improvisação. No caso da cobra, seria a improvisação a partir do contato da pele com o chão. Então, a cobra se refere a uma matriz de contato que pode se desenvolver nas formas de cobra.
} 
expulso dela. Entre outras coisas lembrei da resiliência. Lembrei do kinomichi211. Lembrei dos três temas vocais que surgiram nessa nova etapa: voz afetiva, uivo, coração da nota. Retomando: ao "ser expulso" da árvore eu me coloquei a uma distância de aproximadamente um metro e meio do tronco, e surgiu uma melodia assim: (canto).

\section{Árvore dia 2 (30/08/2016)}

Dia 2, árvore. Consegui usar mais as pernas, perceber mais, um pouco mais do que que é cobra nas pernas. Surgiram esferas. Eu pude brincar de espirais, esferas, encaixar nas árvores como se o corpo soubesse como encaixar, e existiu alguma outra coisa como se fosse prolongamento, esses tecidos né, a sensação possivelmente da continuidade das cadeias musculares ou dos ligamentos ou das fáscias, possivelmente das fáscias, e ligamentos, que fazem um onda que continua no corpo e o corpo desenvolve uma espécie de radar no movimento, e ele se adequa às curvas da árvore, enfim. Percebi isso, percebi um pouco mais a adaptação dos pés. 0 quanto eu consigo fazer os mesmos alongamentos em vários galhos diferentes. Já são coisas diferentes. Algumas coisas. Cobras. Percebi que em algum momento surgiu necessidade de fazer parada de mão, de duas maneiras, uma é convencional, a outra é aquela com menos impulso possível, usando o impulso das pernas, e eu percebi que existe uma questão de força nas costas, que eu estou percebendo agora com as árvores. E bem que eu tenho percebido que o trabalho com as costas e com o alinhamentos, isso eu já percebi no tai chi, que facilita fazer parada. Mas no tai chi talvez seja por relaxamento 0 alinhamento, energético né. $O$ contato com a estrutura. $E$ aqui é um caso de comunicação das musculaturas também. Talvez tenha mais a ver com as fáscias e os ligamentos do que com os músculos. E os músculos são indiretamente trabalhados. Percebi também essa questão do ioga, que é essa entrega total numa certa, em certas regiões do corpo ao mesmo tempo, essa liberação. Então aconteceram algumas coisas hoje. Liberou o pescoço no final, então talvez seja uma questão da cadeia muscular

\footnotetext{
${ }^{211}$ Kinomichi é uma arte do movimento e do contato criada por Masamichi Noro (1935-2013) em 1979. Eu fiz algumas oficinas desta arte com Christiana Cavalcanti, que estudou com Noro de 1990 a 2002 na França e que leciona na cidade do Rio de Janeiro e esporadicamente vem a São Paulo. O Kinomichi não é uma arte marcial (apesar de guardar resíduos dela), e isto é dito como uma grande contribuição de Noro a partir do Aikido, arte marcial na qual foi educado.
} 
mesmo. E a canção surgiu no final, eu já estava separado da árvore há um tempo e eu fiz assim: (canto). Coisas que descem a garganta e dão uma sensação de que o coração desce a vibração. Dá pra você sentir a base, não sei se é aonde o pulmão divide. Aí eu lembrei de duas coisas nas canções, como se fossem figuras ??? onde o contínuo daquelas canções funciona, o modo de cantar. (trecho inicial de uma canção conhecida - Vale do Jucá - autor: Siba) Aí você posiciona o queixo pra frente. (canto o mesmo trecho, treinando) Aí outra, é como se encostasse o queixo na garganta, se alongasse a coluna. (trecho de outra canção: Cupim de ferro - Lenine e Nação Zumbi - treinando) Ainda há a questão da ligação entre frequência e timbre, ou seja, o timbre(?) como articulação, essa mudança: cada altura é um timbre, isso na voz. Isso é uma coisa. A outra coisa é essa relação da coluna. Da víscera, da entranha: aquilo pra dentro, aquilo que está dentro da estrutura, da cavidade. Essas coisas que surgiram. Estou contente, e aí vamos ver se eu consigo não me dispersar, eleger alguns eixos talvez para amanhã. Sustentar a atenção, aquela coisa da cobra. E etc. Acho que estão coisas por aí. Um abraço.

\section{Árvore dia 3}

Terceiro dia da árvore. Segunda feira, dia 12 [de setembro de 2016]. Foi curto. Fiz uma preparação simples. Espirais. Trabalho com a coluna. Esferas do kinomichi. Exercícios baseados na ideia de pressão interna e Linklater [método de voz para atores], onde você, ao invés do movimento espontâneo você faz todas as variações da variação de pressão, ou seja: você torna a coluna côncava ao inspirar, ao contrário do que esperaria. Mesma coisa inspirando e aumentando o lado direito, voltando expirando. Depois variações na torsão, de acordo com o que o Abieié, o moço faz, o Abieié, esqueci o nome dele. Irineu [Nogueira, bailarino e professor de dança da matriz afrodiaspórica, seu trabalho se chama Abieié dance]. 0 senhor Irineu. Então são algumas coisas que ele falou [acho que] a partir de Graham. [o ioga também tem] Então depois eu fiz um exercício muito simples. Eu talvez pudesse fazer cada em um desses exercícios repetições e desenvolvimento do que acontece entre as repetições.

Por exemplo, esse de se pendurar com os dedos entrelaçados num galho, apoiar os pés no tronco. Isso três vezes entrelaçando os dedos de um modo, e três vezes entrelaçando os dedos de outro. Por último surgiu esse vocalize aqui, ele se 
desenvolveu: (canto). Na verdade ele começava só. (canto se desenvolve) Lembrar de sem tensionar, relaxar internamente. A ideia do som inaudível para o audível. Vontade. 0 ar. Relaxamento. (canto) [...] [complemento] Não precisa de força para inspirar, não precisa de ar para cantar. É preciso considerar que tem um movimento que leva até a voz, até o som, e esse movimento você reconhece na respiração. Por isso é que é preciso trabalhar com a respiração. Mais por causa da sensibilidade do que por causa do preparo, de uma espécie de treinamento, do que uma mecânica. A mecânica ela é a própria sensibilidade que vai reconhecer o caminho. Um beijo [...] [complemento] Existe também uma coisa que aconteceu aqui na árvore, que quando eu fui soltar de uma das repetições, a bola da mão, ela aderiu, como se fosse dar continuidade espontaneamente até a ideia da cobra. Ao longo das repetições, no final da primeira bateria, ou seja, ao final da última vez, ao final de um dos ciclos onde eu entrelaçava os dedos de uma forma, eu percebi que havia uma região mais confortável que era a batata da mão, a almofadinha da mão, e somente na parte do dedinho [no corpo da mão]. Então, mas a partir da segunda bateria, ou seja, os dedos entrelaçados do modo mais fraco... do modo menos usual, não do modo mais fraco: o modo que menos se usa quando se pensa em entrelaçar os dedos das mãos. Eu percebi que se desenvolveu essa segunda informação, de uma aderência dessa região, uma região gostosa de apoiar. Talvez é que seja mais grossa, é a parte que sempre apoia, não sei. Um tipo de sensibilidade que aderiu à casca da árvore. [...]

\section{Árvore dia 4 (14/09/2016)}

(canto) [...] [complemento] Árvore dia 4. M esma sequência do dia 3, só que eu esqueci de fazer a chegada, eu comecei com a primeira repetição da primeira série - a primeira posição - e então eu lembrei que eu precisava fazer a chegada e eu fiz, então foi um pouco mais deslizante na medida em que eu ia lembrando, e afetivamente me (de alguma maneira) sintonizando né, entrando em contato, chegando aos poucos, de alguma maneira habitando por algum tempo aquele lugar, eu fui lembrando do que eu precisava fazer. Foi curto, mas no final uma outra pele, como se de alguma maneira houvesse uma sinestesia, não sei se essa é a palavra, mas. Como se a casca da árvore também fosse a minha pele, e isso gerou uma dança com uma certa consistência e uma certa continuidade. E no padrão de esferas. Por algum tempinho. E a 
continuidade se manteve talvez com maior consistência do que esperado. E aí surgiu essa melodia aí. Hoje foi um dia em que eu carreguei cenário do Pedro Páramo [peça em que fazem parte do cenário 50 pallets de madeira], eu aproveitei então para fazer não só uma sessão curta, mas eu não deixar de treinar, e aproveitar esse estado em contato com a madeira em que eu estava, por causa de que os pallets são de madeira, o cenário são os pallets, então é isso. [...] [complemento] Eu acho que eu tive uma pista desse canto mais fino, que ele vem afinar numa esfera, estou chamando de esfera, ele vem afinar numa região que é frágil aparentemente, tem pouca mobilidade. Existe uma região de passagem que é operar o relaxamento dentro desse lugar [agudo], esse relaxamento que se dá mais nas práticas de um som mais talvez grave. Com essa questão do som agudo ela faz de uma afinação do espaço num outro caminho [uma teia que sustenta o agudo então, através do relaxamento e da sustentação da intenção, o som pode fazer vários caminhos até o agudo]. Eu percebi essa passagem nesse canto. E eu percebi uma coisa, que quando o canto se forma, uma das possibilidade creio que seja acontecer alguma coisa dentro do campo aqui mental, que alguma coisa se formou como se fosse uma impressão dessa árvore mas também um negativo, no sentido gráfico mesmo. Como se fosse, sei lá, um túnel, um cujo diâmetro tem o volume da letra A, com três pernas. Alguma coisa assim. Era um lugar que parece aquele desenho do 'centro de força' que eu fiz há alguns anos atrás naquela série que era 'sobre o que é ter um corpo', então lembrei desse lugar. Mas talvez seja o negativo no sentido gráfico dessa imagem da árvore que eu cantei para ela, então ela apareceu também. Então são duas aparições, a primeira foi dessa sensação da pele, a imagem de quase uma escama, mas na verdade poderia ser

continuação dessa casca, desta árvore, e em segundo lugar, esta imagem que se imprimiu no campo mental, no espaço mental. Tá bom?

\section{Árvore dia 5 (23/ 09)}

(canto) Então. Este acho que é o quarto ou quinto dia da árvore, acho que é o quinto, eu fiz igual ao esquema, começaram a acontecer umas coisas talvez mais acrobáticas. É bom fazer essa proposta simples, porque acontecem variações, uma delas foi descer com o tronco quando eu me pendurava, pra tentar deixar a coluna mais reta, relaxar, seccionar as pernas. A relação com o tronco da árvore foi diferente, e por alguns 
momentos eu me pendurei, como se fosse circo. Depois eu fiz um pouco mais da parada de mão, sem impulso, o mínimo de impulso, o impulso que ele não é descendo mas o impulso que ele já é, ele é só da perna, ele não é do peso, claro que tem um pouco, mas é outro tipo de impulso. E a questão aqui é que apareceu no final, antes de eu testar a acrobacia, eu acho, começou a aparecer aquela dança que é imitando 0 tronco, só que não como acontecia antes [anos antes eu dançava imitando as espirais dos galhos das árvores], que eu fazia muito rápido, como uma produção de coisas, mas não como uma imitação, enfim, mas eu acho que ficou menos superficial a relação com esse, não sei se desenho é a palavra, com o desenho, enfim, acho que dá pra dizer isso. Com esse desenho da árvore. Não desenho, escrita.... não sei se desenho. Ou com, enfim, o corpo dessas árvores. Eu fiz uma dança que era que nem eu fazia, que era imitando os desenhos das árvores, só que agora talvez, pelo corpo estar mais funcionando como um todo, e também pelo fato de que eu agora estou com mais calma e experimentando mais o processo do movimento - engraçado porque a Chris Greiner [Christine Greiner, professora e pesquisadora] falou isso num workshop [anos antes, uma fala de Greiner a partir do trabalho de Toshi Tanaka]. Mas agora estou lembrando. A partir de um outro dado, não meramente da experiência da dança que eu tive, nesse período, mas de ter escutado falar da qualidade da psicologia da terra, de que ela é mais dada ao processo. Então a espera, a sintonia com uma espera que é o processo do movimento. E então, aconteceu isso. Também eu vi espaços de dança com aqueles padrões básicos, de pendurando-se nos galhos, entre as repetições, as vezes em que eu ficava pendurado, aquelas vezes que eu formalizei, então aquela dança, e depois a acrobacia e depois uma canção que é essa que eu cantei agora, com algumas qualidades e com um ponto de chegada. Ok? Então por enquanto é isso. [...] [complemento] (canto) [...] [complemento] Está me ajudando a respirar. E a sensação de tosse que eu tinha no começo do dia melhorou. [...] [complemento] Uma questão que eu tenho sentido muito nos últimos dias, últimas semanas, que agora com árvore ficou claro talvez, essa questão, bom, eu não sei explicar direito. Existe uma relação entre - vou dar os elementos, e eu não sei exatamente se são eles, e qual a relação entre eles - é o espreguiçar (leve), a espiral do kinomichi, a esfera. Quando eu acabo de fazer a árvore fica mais nítido ainda, mas nos últimos dias, nas últimas semanas, mas principalmente nos últimos dias tenho sentido, vinculado a respiração a essa 
esfera que se abre, que é um campo de trabalho mesmo, campo de vida. Não sei. Bom, vamos lá, vamos trabalhando. Acho que vai ficando mais claro isso. Beijo. Aliás, era uma coisa que o Ricardo Neves [bailarino e professor de contato-improvisação] já falava, mas eu não tinha ainda dimensão. Não sei nem se ele tem. Bom, vamos lá. Beijo.

\section{Árvore dia 6 (26/ 09)}

(canto) [...] [complemento] Então. Eu fiz a sequência. De três e três. Primeira coisa. Na chegada eu tive vontade de fazer mais espirais, também porque hoje eu já fiz, mas enfim, eu acho que tem a ver com o que aquilo se desenvolve, tanto no hábito quanto.. no hábito, nos dias né, na sequência de dias mas também no hábito de fazer mais de uma vez no dia. Como algo leve para ser incorporado nas rotinas do cotidiano. A segunda coisa é que, no final, da última repetição da primeira variação, né 3 e 3 né, na terceira ou na quarta, quer dizer, ou na primeira repetição da segunda variação, aconteceu de ficar vontade de ficar pendurado de várias formas, pra complementar os alongamentos, as conexões, e aí ficar pendurado com um braço, o braço de dentro, com o braço de fora, ficar pendurado com os dois, ficar pendurado com um braço totalmente pra trás, com um braço meio pra trás meio lateral, pra sensibilizar e massagear toda o relevo da parte de cima do tórax, alguma coisa de completar a percepção [via massagem] da cintura escapular, não ao redor do pescoço, mas ao redor do ombro. Muito bom. Outra coisa que na primeira repetição da primeira variação, ou nas primeiras três, na primeira variação como um todo, eu senti vontade de trabalhar mais com as pernas. $E$ isso tem a ver com a minha terceira observação que é quando depois de acabar a sequência eu dancei um pouco, fiz um pouco a dança que tinha a ver com a percepção da árvore, com essa percepção desse tipo, que tecido

é esse, e eu fiz um pouco de parada de mão, mas hoje estava um dia fraco para parada de mão, e hoje aconteceu que eu comecei a trabalhar com as pernas, uma das pernas apoiada com a sola dos pés, uma apoiada no chão a outra apoiada [no tronco, com o joelho flexionado. A perna apoiada no chão com o joelho estendido], então fazer como se fosse aquela base baixa, o mergulho do tai chi, mas com o suporte desse galho grosso [segurado com as mãos] e com o suporte, pisando, como se pegasse um plano do chão e inclinasse ele, fizesse ele a oitenta graus, alguma coisa assim. E com 0 
suporte do galho. Então eu consegui alongar, e teve variações também, me ocorreu aquela postagem da moça sobre miofascial, ioga miofascial, só que eu não sei se tem a ver com isso, mas comecei a sentir a espiral das pernas também a partir daí. Na primeira variação, que era a perna de cima flexionada, eu senti mais o assoalho pélvico, assim, a parte posterior da coxa [da perna flexionada] trabalhar bem, depois estender [a perna apoiada no tronco da árvore] e perceber mais a espiral que leva da perna de baixo até a perna de cima: duas espirais. Muito bom. Então a primeira observação era do aquecimento, a segunda era dos alongamentos, a terceira tem a ver com as pernas. E aquela foi a canção que eu fiz. Eu acho que era isso que eu tinha pra observar hoje. Eu fiquei um pouco desastrado no começo, acho que a minha energia está meio forte, e também hoje é segunda-feira, então o dia da Lua, então eu acho que a energia está um pouco mais, talvez, recolhida, não sei. Mas eu acho que tem a ver com a mudança de energia daquela prática da Tarina [Quelho, bailarina, diretora e professora], que tem a ver com o Rize [movimento 'krumping', documentado no filme rize, dirigido por David LaChapelle], que é um chicotear, não é exatamente um chicotear [é mais uma onda], mas um impulso que parte, ela diz, mais ou menos do centro, só que, na minha percepção, o centro ele comenda mas a energia vem do chão. Não pode nunca perder. E aquela imagem da 'Torre Eiffel' de novo veio à mente. Pode ser uma imagem de árvore também. Então, talvez o centro possa ser o centro da cruz. Não sei. Que é onde a árvore se, né, o começo do tronco, o final das raízes e o começo do tronco. Não sei. Então tem uma energia está muito, eu estou com uma energia bem pra fora. Não pra fora. O corpo talvez esteja, não entendi. Mas eu estou com uma energia um pouco mais intensa e um pouco mais densa por causa talvez dessa prática e do que está mudando no meu corpo. Acho que pode ser isso. Agradeço aí. Abraço. [...] [complemento] Duas coisas: primeiro, necessidade de liberação emocional muito forte, que agora eu fiz algumas paradas de mão, mais como um exercício de pêndulo do que como um exercício de estabilidade da própria parada. Então aí eu desci, respirei, e aí eu melhorei. A segunda coisa é que depois de fazer 0 exercício das pernas eu subi um pouco [na árvore], modo livre, não surtiu muito efeito, mas, necessidade de ter aderência, é, talvez seja o quarto comentário de hoje. Ao final uma necessidade muito grande de aderência, assim, só que sem saber muito como, com um pouco de insegurança e numa outra energia, que retraía, como se não tivesse 
meios ainda pra realizar isso, como se tivesse desenvolvendo um outro trabalho. Outro comentário é que ao final da terceira repetição da primeira variação eu tentei ficar de algumas variações com as pernas suspensas, uma onde a perna estendida pressionava o tronco [da árvore] e outra ??? abrindo o fêmur pra fora da outra perna, com o joelho flexionado. Fiz os dois lados, como se fosse uma voadora [golpe marcial: salto com chute geralmente lateral] né, só que congelada. Enfim, aí tentei pendurar, na última variação, uma das repetições eu tentei pendurar e não deu certo. É mais fraco. Os dedos estão mais fracos, engraçado. Bom, essas coisas. Até.

\section{Árvore dia 7 (29/09)}

(canto) [...] [complemento] Oi, hoje foi o contrário do dia 6 no sentido de que eu cheguei já fazendo as sequências, e entre a primeira [e a segunda] série de repetições, ou seja, entre a primeira variação e a segunda variação, eu tive vontade de fazer todas os alongamentos de braço né, pendurando, torcendo, pensando no pé, pendurando com o braço pra trás, com o braço mais ou menos pra trás, com os dois, pendurando, verificando se era mesmo aquilo, depois eu fiz a segunda variação, as três repetições, depois um pouco de perna, e, assim, entre as repetições aconteceu uma coisa da 'dança das árvores' [que] foi se desenvolvendo, e acho que aos poucos eu vou percebendo como o tai chi tem a ver com as árvores, ou as árvores têm a ver com o tai chi, ou eu reuni as duas coisas, ou, sei lá, a partir do tai chi eu cheguei nas árvores. Talvez fosse o caso de eu registrar algumas configurações e treinar elas, assim, registrar elas... uma que tem... é, tem algumas né. Registrar algumas configurações que pareçam árvores. Aconteceram mais giros, então eu acho mais tranquilo fazendo a dança, aproveitando mais estados específicos, configurações específicas, acho que é mais ou menos isso. Aí depois surgiu esse canto aí... talvez seja o começo de uma coreografia, assim, apontamentos primeiros né. Que tem o tai chi, e tem esses giros, tem essas configurações provisórias que são árvores, tudo a partir delas, e as árvores elas são muito vivas, acho que elas continuam girando. Acho que veio uma intuição agora: as árvores estão sempre girando. Então, umas duas vezes vieram padrões de

giro a partir do padrão de árvore, isso foi interessante. Além das configurações né, de tai chi, que eu acho que são do tai chi. Que mais? Não, acho que foi isso, mais ou menos. [...] [complemento] Hoje a esfera está bem pronunciada, mas talvez esteja com 
outra consistência, mais fácil de fazer, talvez. Não sei se é porque no ensaio que eu tive de manhã com a Thaís Sodré e o pessoal do Hamlet [projeto teatral com o qual fui colaborador como ator e sonoplasta] eu dei uma dançada, a gente fez aquilo a primeira vez, aquele exercício do fone [de ouvido; escutar uma música enquanto lê um texto, para aprimorar a musicalidade do texto], eu usei aquela música grega do [Christodoulos] Halaris, a 'minha montanha', vouno mou, e aí eu também fiquei trabalhando o texto da Ofélia com o le premier bonheur du jour [canção de Françoise Hardy, para a qual o grupo os Mutantes fez uma versão no seu álbum de estréia em 1968] , então a música pode ser que tenha a ver com a consistência de uma esfera no corpo, eu já verifiquei isso algumas vezes, na relação da música com o tai chi, tocando e ouvindo, tocando e fazendo tai chi, ouvindo e fazendo tai chi, enfim, nas relações da música com o tai chi. Modifica a vibração, não sei [fica diferente]. Desloca a vibração, transfigura, transforma a vibração do corpo. Bom, isso. 0 pensamento ele é um acontecimento, então esses deslocamentos que são da narrativa, estão presentes na música, por mais que você não conheça isso, como é que isso se processa na música, mas você passa por um, você tem uma passagem, você vive um deslocamento escutando aquela música, não importa se você está achando aquilo chato ou não. Isso é uma coisa. E aí eu pensei nisso aí. As esferas tomam (?) uma diferença, eu consigo sustentar o braço, talvez tenha a ver também com ???? [posturas fixas com respiração cadenciada?], aquilo que eu tenho praticado de ficar, de sustentar, talvez tenha a ver com a questão do centro que tenho praticado lá nas ondulações da Tarina [krumping]... Daonde vem a sustentação. Eu sinto 'a mão sente o pé', alguma coisa assim. Senti uma conversa. Bom, não sei, estou pensando essas coisas. 0 que que pode ser essa sustentação. Acho que vem um pouco do trabalho de hoje, do trabalho que eu tenho feito, o trabalho inclusive das árvores. Sei lá. ??? Talvez essa parte eu suprima, porque ninguém vai entender 0 que estou falando. 0 que mais eu posso falar? Talvez tenha a ver com a árvore sim, por causa da sustentação, eu estou também achando. Tem a ver com tudo. Vai demorar um pouco pra eu discriminar. Beijo

\section{Árvore dia 8 (30/ 09)}

Hoje eu tenho muita coisa pra falar. Não sei se eu consigo falar de tudo. Eu tive uma conversa com Agmar [Beirigo], Camila [Florio], Bianca [Nuche] e Thais [Sodré] (amigos 
e colegas de teatro), e no final eu chutei uma garrafa e eu desloquei o joelho. Então eu vim meio com esse incômodo do joelho deslocado. Aí eu resolvi vir direto pras repetições, no final da primeira eu já tive vontade de fazer tai chi, acho que depois da segunda [variação] eu fiz a dança dos giros que surgiu hoje no ensaio do Hamlet, talvez seja uma das possibilidades, para concatenar as configurações de árvore, e aí surgiram uns giros que eram giros tanto em torno de si como em torno em torno de um centro fora [a improvisação do giro surgiu já algumas vezes ao longo dos anos, mas nunca tão concatenado e encadeado], então surgiu uma pequena, talvez um pequeno tema ou núcleo. Que que aconteceu? Isso talvez seja bem importante hoje. Eu estou brincando com as pessoas de falar que eu estou saindo da instituição e indo pra instinto-intuição. INS TIN, INS TIN TUIÇÃO. Instintuição. E o que acontece? Aconteceu uma posição muito estranha, que era metade de um mergulho [com o tronco] torcido, que nem 0 segundo movimento do pa kua [ba gua zhang - arte marcial taoísta], ele torce, mergulha... só que pela metade, e aí ficou um tempo ali, e voltou pro lugar naquela posição [o joelho]. Então, como se fosse a espiral, que eu acho que também tem a ver com essa árvore que é uma figura em movimento, eu estou tentando capturar isso a partir de ontem, a árvore como algo que está sempre em movimento, mas é um movimento espiralado. E eu posso na verdade sintonizar. Algum padrão que ele é muito vivo, não sei se tem a ver com o que a Tica Lemos [bailarina, coreógrafa e pedagoga da dança, praticante e professora de aikido e kinomichi] falou, da excelência da espiral, mas eu acho que tem alguma coisa a ver com regeneração, que o M estre Noro [criador do kinomichi, criou esse sistema a partir do aikido, mas também para se regenerar de um sério acidente] intuiu também, talvez com mais força no kinomichi, e então o que aconteceu: o joelho voltou para o lugar, aquele alívio, então tem uma inteligência intrínseca da espiral, mas essa espiral talvez da árvore, ou talvez a espiral seja uma árvore já. A outra coisa que eu ia falar é que depois disso eu voltei pras repetições, a última da primeira variação, aí relaxou muito depois daí, e eu fiz duas repetições da segunda variação e depois eu já comecei a fazer pernas, fiz as duas variações pernas, depois fiz a última vez pendurado, fiz as variações, eu não tive vontade de fazer os alongamentos do braço, todos, mas porque hoje acho que 0 trabalho era outro. Ao final eu fiz as espirais do kinomichi, aquilo que deveria ser a preparação né: um pouco as esferas do kokyu-ho [práticas de respiração vinculadas a 
formas de energia esféricas e espiraladas ${ }^{212}$ ] e depois as variações nessa pressão e descompressão, essa focalização... essa focalização da variação de pressão do ioga, que é do tipo pegar o espontâneo, que é: quando você inspira, a amplitude da parte anterior aumenta [parte da frente do corpo], fiz o contrário, que é quando inspira a amplitude [da parte posterior aumenta, tornando as costas côncavas na inspiração] ... onde é que se dá a variação de amplitude né, quando você inspira, aí eu faço na frente, atrás, de um lado, de outro, quando torce expira, quando volta a torsão também expirando, de um lado e de outro, e depois quando torce inspira [torce quando inspira seria melhor], permanece no limite confortável da torsão, expirando, e então são duas variações dentro da torsão. Depois eu cantei. Mas essa ideia de uma rede, talvez, acho que a espiral é muito mais do que o padrão. Talvez seja um desses arkhé, não sei. Eu

${ }^{212}$ Kokyu ho designado como respiração pela sola dos pés é também uma arte do movimento, mais vinculada à respiração. ' $O$ movimento vem da respiração', diria o Mestre Ono, com quem fiz aulas durante alguns meses. Outra frase que Ono sentenciou em aula algumas vezes é 'kokyu ho é a base do Aikido' - não sei exatamente o que ele queria dizer com isso, mas acho que tem a ver com [1] um campo receptivo que a respiração-movimento produz, pois o aikido (e o taichi também) trabalham com 0 movimento do outro; [2] as formas-movimentos que são de fato o acompanhar de outros movimentos, visíveis e invisíveis, e também redistribuições de forças, como esferas em movimento e espirais, rodamoinhos etc; [3] uma dimensão criativa do mundo que atravessa o corpo do praticante, comunicando-se a todo momento com as forças da terra e do ar. A respiração aqui, bem como em outras tradições com que tive contato, não se resume apenas às trocas gasosas, mas aos circuitos vitais. Para mais informações recomendo a Associação Paulista de Aikido (APA)

https://aikidopesquisa.wordpress.com/ono-sensei// e o bem-cuidado blog https:// osprimeirosdiasdalei.wordpress.com/2014/08/02/a-primeira-parte-do-kokyu-ho/ .

Uma pequena observação: kokuy-ho tem certa comunicação com o kundalini yoga. 0 próprio Ono usava inumeradas vezes a palavra kundalini, que me parece ser um conceito que nomadizou pela Ásia adquirindo diversas variantes, preservando contudo um certo tom com algo dizendo respeito às linhas do corpo (não importa que corpo) que circulam ou são correntes de mobilidade, vitalidade, libido, potência, alegria (seu estágio mais refinado).

Uma segunda observação: o kokyu ho, o kinomichi e o taiji quan permite sabermos que 0 contato é da vida com a vida, ou seja: dançamos com o mundo. Ser corpo é dançar. Caminhas, habitar.

Há algo a se pontuar, que um dos fatores que fez com que eu interrompesse as aulas de Ono Sensei (Kenji Ono, chamado por Keizen Ono Sensei), era que o meu corpo me contava que ele havia absorvido tudo o que ele precisava. Não sou um praticante de kokyu ho e o que ocorreu foi que alguns gestos e recursos passaram a habitar o meu corpo, compondo-se com outros elementos, outras matrizes. Não tenho a pretensão de falar das formas justas dessa arte, mas posso falar a partir de acontecimentos e sensações, o que não é pouco.

Ainda sobre respiração, há uma frase que foi uma espécie de escultura mágica transmitida por Isabel Tica Lemos, que é uma das suas 'historinhas sobre a respiração' que ela contou em uma oficina em 2015 (Projeto Juanita, última oficina - eu fiz uma oficina ao final de 2014 e esta). Tica é improvisadora do movimento e sensei de Aikibo. Então ela pôde experimentar de maneiras inteiramente distintas os elementos da respiração de Ono. Contudo, ela fez algo mais: ela repensou 0 próprio sentido da respiração. É apenas uma frase que ela examina: 'RESPIRAÇÃO - o reflexo no espaço da ação do espírito'. 
vou começar a pensar nisso também. São essas coisas. Se eu esquecer de mais alguma coisa eu falo jajá. Ah registrar também, que na vinda pra cá eu fiquei pensando no arkhé, e o arkhé... tentar pegar o arkhé do Rizek [professor Ricardo Rizek, com seu estudo sobre teoria da harmonia] e ligar a uma ideia de contemporâneo [o arkhé é um princípio ativo e vivo]. Começar do texto do Groppa com a Ju Jardim [entrevista em dupla com Julio Groppa Aquino e Juliana Jardim: o trágico como experiência radical do corpo], da ideia do, não só o que pode um corpo, mas o corpo do resto, tentar ligar depois talvez com essa ideia de menos [teatro de menos], Deleuze, mas aí pegar imediatamente duas questões: a do corpo desconhecido, e pegar desse arcaico que é na verdade ele é o contemporâneo, ele é o resto. Como uma categoria ontológica talvez, pensando paralelamente ao transpessoal, só que eu não sei se consigo fazer isso... talvez perguntar pra Camila [astróloga, filósofa e poeta] Jabur, se eu consigo trazer isso, onde é que o corpo pega. Talvez pensar que tudo é natureza, enfim. Talvez pelo ???? só o Simondon me responda isso [pelo conceito de trans-individualidade]. Eu acho que é mais ou menos por aí. Depois eu fiquei olhando as árvores, eu tive vontade de cantar para outra árvore hoje, e o final do canto, ele, eu tive o contato, eu lembrei das tentativas da transfiguração pitagórica né, que elas deram, talvez surgiu como um embrião ali, no song of bones, e depois no transfiguração aquilo não deu muito certo e depois pro invocação de cordaria [esses três nomes são grupos de performances que eu desenvolvi] sumiu porque meio que virou, ficou no plano do som, no plano talvez mais. o plano ético deslocou pro som e o plano estético da proposta com a natureza deu uma diluída, não sei explicar direito. Não sei se é isso, mas enfim. Eu acho que foi um caminho. E eu lembrei daquela proposta de inversão dos sentidos [presente em song of bones e em transfiguração pitagórica], e no meio do canto, quando eu coloquei a mão na árvore, o canto, não sei, foi um pouco depois disso, o canto ganhou um padrão, essa coisa do contato que me devolve um contato. Então de novo essa ideia da natureza conversando com ela mesma. Não sei. 0 som ??? só uma camada a mais da sobreposição que é a natureza. Não sei, estou pensando. Bom, mais ou menos essas coisas. Se faltar alguma coisa eu complemento. Ah acabei de ver um galho cair, talvez tenha a ver também com essa coisa de cair e de coisas que morrem também. Pedaços que morrem. Uma ideia plutoniana. Nesse caminho de transformação coisas morrem, parecem morrer né. Coisas se despregam do corpo vivo, e caem numa ideia 
maior de corpo, isso é uma coisa. Mas a coisa principal, por onde eu tinha começado, essa ideia do joelho, tendo voltado pro lugar na prática e isso na verdade não tem 'sentido anatômico' nenhum, sentido clínico, sei lá, na medicina europeia, MAS é uma relação de instinto-intuição, quer dizer, é um contato com a matéria que foi me fazendo um caminho até lá, e é um caminho [que é corpo], é deixar o caminho fazer, deixar o corpo fazer aquele caminho até aquele local. Essa disponibilidade talvez transindividual. Estou pensando nisso. Aí a coisa que eu ia falar do joelho é: veio na minha cabeça assim como a verdade da violência se revelou, quer dizer, a violência, quando ela vem pelo medo, ela é.. medo no sentido de evitar, de reprimir, o medo como repressão, então, como um mecanismo, alguma coisa nesse lugar, a violência nesse lugar - tanto que eu lembro quando eu chutei a garrafa, foi lá que deslocou [destroncou?], eu percebi que era uma violência aquilo, eu poderia ter chutado a garrafa de muitas formas, só que eu chutei a garrafa de um modo que eu não pensei na garrafa, pensei só no chute. Talvez eu tenha, e talvez essa coisa externa né, de eu chutar pensando em como eu vou ser visto pelos outros, uma coisa de ansiedade, Mas eu acho que essa coisa de não pensar naquele lugar que não sou [só] eu, lembrei do que a Dandan Liang [performer chinesa] da harmonia como uma conexão com [com! Conjuntamente] tudo aquilo que não sou eu, isso é muito interessante. E não é à toa que virou cortejo do Amor [Afrodite], o amor como uma força [de coesão através da] de alteridade [em Atenas Harmonia passou a ser parte do cortejo de Afrodite]. A verdade da violência no sentido de, existe uma violência da vida e existe uma violência necessária para que eu exista. Só que a violência necessária para que eu exista ela vem da vida, ela não pode servir para reprimir a vida. Estou falando nesse sentido que é da ação possível e uma vida possível. E o que que é a vida né? Pode ser que a vida seja tudo aquilo que acontece. Não sei se a palavra da repressão, não sei ao que que estou opondo ela, mas a repressão seja uma redução sem alteridade, uma redução a priori. Sem alteridade, eu não sei explicar isso, mas tem a ver com essa coisa do medo. M edo no sentido de repressão, que é mecânico. Essa regressão, não sei explicar. Mas a verdade da violência nesse lugar, não sei se alguma coisa realmente abriu aí, mas a percepção foi essa. Porque quando soltou [o joelho voltou ao lugar] veio uma sensação muito prazerosa, e ao mesmo tempo eu sei que padrão que é, e eu lembro que das outras vezes que destroncou o joelho era uma coisa de falta de atenção, e quando 
deslocava era em função de uma contração fora da hora, ou fora da posição mais consciente. Então a violência que tem esse amor da alteridade. Talvez eu esteja chegando em algum lugar com isso, não tenho certeza ainda, mas. A verdade da violência [tem a ver com as afirmativas de Francis Bacon, mas não sei se pensava nisso quando falei]. Estou pensando também no Urano em Escorpião... [elementos de mapa astral] Fundo do Céu... qual é a verdade da violência? Bom, vamos ficar com isso. Beijo. [...] [complemento] Lembrei do que minha mãe diz, 'juízo filho', aí eu estou identificando agora um pouco esse lugar do juízo, não o que ela quer me dizer, mas [num outro lugar totalmente diferente] sentindo um pouco esse pedido como não recorrer à violência do medo. Você pode ter medo, a gente tem medo, só que esse medo que tem a repressão, o medo que é se isentar, não se responsabilizar, não querer ver. É a violência da mentira. A violência da mentira. Não sei explicar. Violência... violência... é. Não recorrer à violência da repressão. Que que eu quero dizer com repressão? Violência que nega a alteridade enquanto transformação, enquanto deslocamento. Eu acho que a alteridade pode estar aí. Enquanto desconhecido vivo, mas enquanto possibilidade de deslocamento. Eu não sei qual a palavra, porque não é mentira, não é ilusão, é a violência da repressão da realidade. Não recorrer à violência da repressão da realidade. Pegando bem o Bacon, acho que 0 Bacon inspira muito aí. Então a mãe fala 'juízo' eu tô tentando ligar.. a sensação já é clara, depois de tudo o que aconteceu hoje. Mas as palavras ainda não estão com. Mas acho que talvez nunca estejam. Bom, é isso. [...] [complemento] Então, muita coisa agora aconteceu no caminho, primeiro eu estava pensando nessa ideia do Sérgio [de Carvalho, crítico, dramaturgo, diretor, professor de dramaturgia e crítica], preciso perguntar pra ele, dessa dupla ontologia. Como é que começou essa ideia? Não lembro exatamente. Dupla ontologia... e aí eu pensava nas falsas oposições. Ah então, pensava no Heráclito [de Éfeso] lá do livro do Octavio Paz [o arco e a lira], a maneira que ele se aproximava do Heráclito, como exemplo dessa dupla ontologia possível. Não ser somente a ontologia identitátia. Eu pensei nisso, eu não sei como é que eu fui parar aí, mas logo em seguida eu pensei no Heráclito, e eu pensei aí na questão de uma falsa oposição talvez pra ser combatida, que é a oposição subjetiva e objetiva, e aí talvez pegar o Foucault [?? Michel Foucault], pra pegar que a subjetividade ela é uma produção objetiva, porque passa pela educação, enfim, e aí porque eu estava tentando 
dar uma versão minha da tradição, explicar que, por exemplo, eu posso nomear tai chi chuan como 'o punho da grande polaridade', mas o que que é o punho né, a ideia da guerra, o que que é a guerra? Aí a minha versão talvez seja por causa do meu mapa astral, mas enfim, isso não vem ao caso, de que.. uma tarefa. Aliás é uma acepção que é possível que esteja presente no ioga também: uma tarefa. Que acontece. Que você realiza mas que principalmente acontece através de você. Na tarefa que está acontecendo [a tarefa de estar vivo], e você participa dela. Então: a tarefa da grande polaridade. E ai, se não existia essas falsas oposições, se eu quiser desarmar as falsas oposições, eu fico me perguntando imediatamente o que que está tensionando, quando eu penso que é oposição. Aí a resposta veio: tudo. Tudo com tudo. Por causa desse mundo que é um encontro de alteridades, é um choque de alteridades. Então é isso. A ideia, está mais próxima a ideia da narrativa, do deslocamento, do nomadismo. Engraçado, porque eu lembrei de tudo o que eu queria gravar, só que eu não lembrei de como começou, começou com a ideia da dupla ontologia, mas por que eu estava pensando em dupla ontologia? Não lembro. Jajá eu lembro. Ah, de que se é muitas coisas, é, uma possibilidade, às vezes eu penso nisso. Acho que eu não lembrar de onde é que eu cheguei na dupla ontologia. Mas eu acho que tem a ver com a gente poder ser muita coisa. Eu e outro, eu e.. tem a ver com esse deslocamento. É uma leitura possível. Beijo. [...] [complemento] Acho que tem a ver com essa ideia de eu e outro, alteridade, e o deslocamento. E é o movimento da vida. Então, sempre eu e outro. Sempre eu desconhecido, e o outro como movimento da vida. Vamos ver. Pensando no Octavio Paz quando ele fala da pedra e da pluma [em o arco e a lira], e aí essa ideia de que a gente pode ser perguntado 'mas uma pedra tem movimento?' Tem. Tem muito movimento em torno da pedra. E a pluma, ela é algo né. Você reconhece uma pluma também. Algo diferente. $M$ as ela não para. Mas a questão da pedra é assim: a sua percepção muda o tempo todo. A ideia do Octavio Paz né. Que tudo pode ser alteridade. Bom, enfim. Beijo. [...] [complemento] Cheguei na dupla alteridade não só por causa da questão que eu cheguei depois, que é objetivo e subjetivo, mas também a falsa oposição realidade-fiç̧ão, aí lembrando das discussões da aula da Silvinha [Sílvia Fernandes Telesi, professora de teoria e uma parceria constante], de que as coisas, pegando a linha lacaniana, elas têm uma, tudo que é comunicado tem uma instância de representação, mas tem uma espécie de uma outra, 
existe uma, não é a palavra que se usa, mas existe um estatuto ou uma qualidade que ela é, do real também, sobreposta. Então eu pensei por causa do Francis Bacon né, quando ele fala de realidade, que no caso dele é o impacto da sensação, é a sensação,

que pode ser interpretada como algo não válido, algo que não tenha valor de conhecimento. Então essa talvez seja a segunda.. talvez lembrando de que isso originou, talvez seja, não uma primeira, mas uma outra falsa oposição. Beijo. Lembrei. [...] [complemento] Eu acho que a ideia de realidade pode se haver com aquilo que, é uma visão possível, aquilo que é válido, útil, ou apreensível, ou está no sistema de códigos de uma determinada sociedade, lembrando de, sei lá, mitos cosmogônicos. Acho que tem um pouco disso. [a ideia do utilitário como a camada mais simplória de real, que pode reduzir seu campo de ação; no caso de Francis Bacon, a realidade, fato ou verdade da sensação, sendo sensação também, empreendem outras tarefas]

\section{Árvore dia $9(08 / 10)$}

Oi. Eu cheguei aqui, é uma sábado à tarde, eu fiz as duas séries de três repetições, das três (duas) variações de pendurar o braço. Não fiz a chegada e nem fiz os alongamentos intermediários, senão antes da última repetição da última variação do braço. Fiz alguns alongamentos que eu nunca tinha feito antes. Um, pelo menos. E eu fiquei fazendo que nem um pássaro; é como se o tai chi tivesse passando pelo meu corpo, mas com uma densidade diferente. Mais talvez misturado àquela coisa do Rize (krumping), misturado com a densidade da árvore, a coluna bem acordada, fiz as duas posturas de perna né, um lado e outro, aí depois eu fiz as coisas que funcionaram: consegui andar um passo de parada de mão, isso é interessante, talvez eu consiga experimentar mais em movimento do que ficar parado. Isso é uma coisa. A outra coisa é eu vi depois fiz a dança da árvore, aquela dança que são umas qualidades da árvore, como se fosse um ser que é aparentemente parado, mas está eternamente girando, torcendo, espiralando. Eu não sei se isso... eternamente em movimento, só que é um movimento que ele é qualitativo, ele não é aquilo que eu vejo necessariamente, aquilo que eu meço, não sei explicar. Aquilo que eu já falei antes. E depois eu fiz aquela dança dos eixos, dos giros. Fiz as duas, as paradas, e aí interessante no cato foi que surgiu um padrão escalar, e talvez eu possa utilizar isso que aconteceu hoje como um modelo de embate com a relação da tradição. Porque eu fiz um padrão escalar né, que tem o seu 
comportamento, só que ele começou a ser gerado a partir da coluna, e com um estado muito especial, e muito específico. E a coluna chacoalhando, assim. Então essa última escala eu queria repetir ela, me deu vontade de repetir, porque ela corresponde a um corpo, por mais que ela tenha esse corte do código musical né, você conseguiria escrever, e talvez tivesse que escrever uma bula. Eu lembro um pouco do estado. (canto com vibração da coluna) É uma espécie duma vibração do diafragma, não sei, que faz o tórax oscilar, não sei. E às vezes parece que vem da coluna. (canto com vibração da coluna) alguma coisa assim. Espero conseguir descer essa energia até o ventre para depois subir até também aquele ponto que também é o centro do músculo, o centro do diafragma. Então acho que é mais ou menos isso. Eu quis que fosse mais breve, porque estão surgindo umas dramaturgias já, tanto a dança da árvore quanto os giros já é uma dramaturgia, e esse canto é o começo de uma dramaturgia desse trabalho pro canto, pra voz. Gostei muito. Se eu lembrar de mais alguma coisa eu complemento. Até. [...] [complemento] queria complementar falando que aquele padrão de aderência que surgiu na batata da mão, ou seja, a almofada da mão, mas a do dedinho que a do dedão, talvez seja por onde apoia mais, geralmente vai sensibilizando aos poucos e aí na segunda variação do alongamento do braço que rola, assim, como uma coceira, uma vontade gostosa de aderir à casca da árvore, que essa casca específica é suave. Tem uma textura suave. 0 que me fez lembrar da prática de ontem do corpossom (EME-AGÁ) [EM E-AGÁ foi o primeiro nome para agrupamento corpossom onde a gente fez as quatro variações do toque: a mão do namorado (namoro), a pétala de rosa, a estátua d bronze e a massa do pão, e essa necessidade de encostar nas coisas né, pegar nas coisas. Pensando nisso. Tá bom? Como é que esse toque da cobra pode se desenvolver, talvez isso possa ser o próximo... ou, que radar é esse, que eu identifiquei lá desde o song of bones, é o olho e é o tato, eu não sei se ele tem relação com essa sensibilidade pra isso que eu estou chamando de 'padrãoárvore' de movimento, que gerou essa pré-dança, esse padrão pré-arbóreo, qualidade arbórea que inclusive o tai chi me conectou com ela, e aparece tai chi também um pouco nessa dança da árvore, não sei se tem a ver, deve ter um pouco a ver mas ainda não surgiu a conexão. Vamos estudar isso aí. Talvez eu consiga focar isso no próximo. Beijo. [...] [complemento] eu não sei se eu já tinha falado, mas o padrão do Rize: era quatro coisas, né. 0 padrão do Rize e o contato-improvisação, depois as espirais, 0 
Arqueiro (étude biomecânico de Meyerhold 'disparando o arco') do Meyerhold e os bichos. Não sei qual desses componentes em específico, talvez alguns em especial, ou todos em alguma camada, depende de quando eu recebi essas informações no corpo, participam desse elemento que é a COBRA, assim. Ainda preciso... ou ela já está presente, e ela ainda não se mostrou, os pontos não se ligaram. Então, só pra mencionar esses elementos que eu tava treinando também. Tá bom? Esse alongamento mais firme da coluna, deonde que ele veio? Ele é, por exemplo quando faço no banheiro apoiado lá, os ísquios pra outra parede, vem da Maria Thais, só que eu preciso lembrar que tem algum momento onde isso entrou de vez, eu incorporei isso aí. Talvez em contato com a Maria Thais, possivelmente. O Ivengar [yoga] né. Lembrar de fazer o alongamento lá que eu vi o Antônio fazendo na casa da Thais a última vez, que é os polegares presos um no outro, eleva os braços frontalmente também. Preciso testar esse. Esses dois também. E tentar na sequência da árvore também fazer alguns, testar talvez alguns que já estão começando a acontecer. Fazer a ponte. Talvez eu tenha que fazer algumas pontes também. Até.

[dia 10/10 - dia em que fiz um ensaio produtivo da energia dos animais, em articulação com vocalização - registrei esse dia em 'comentários pré cobracomeçou', que não está transcrito ainda]

[dia 19/10 - dia em que chorei demoradamente sob a mesma árvore, após uma discussão de trabalho]

\section{Árvore dia 10. (01/11)}

Oi. Então, eu fiz as duas variações, alongamento pendurando com o braço, duas variações três repetições, depois fiz perna um, perna dois (variações). Depois fiz três variações uma duas três empurrando até a escápula, sentir ela perto do rim, e quatro.. pendurando com o eixo alinhado com as pernas, como se fosse cristo né. Então quatro variações de braço depois as pernas, depois fiz: dança da árvore, depois fiz dança dos giros, depois fiz parada de mão, um ???? da coluna, depois fiz o que seria 0 aquecimento, as espirais, depois os mosubi [procedimento do kokyu-ho, de juntar energia como em uma bola à frente da barriga], depois as regiões por onde se pode 
perceber a inspiração e a expiração, algumas variações. Depois a gente pode explorar variações de como essa inspiração-expiração é explorada no movimento da coluna na torsão. Eu cheguei em algumas variações e estou no último eu resumi isso. E o canto. O canto teve duas coisas, dois eventos importantes, o primeiro foi essa coisa da construção da nota como um lugar complexo, que tem a ver com vibração, que se confunde com vibrato mas aí já é vibração a construção desse contínuo, que é uma coisa que eu esquecia às vezes. A segunda coisa que foi um acontecimento, foi quando a coluna começou a vibrar. Num dado momento aqui. Foi uma coisa do, não sei se do último ou do penúltimo encontro. Então é uma reincidência de materiais, hoje eu fui bem sucinto, tentando recapitular, mas o estado não se perdeu muito. Achei legal. Senti um pouco tenso na dança da árvore, talvez pelo pouco tempo, talvez porque a dança da árvore precise de uma calma, uma atividade na calma, assim. Não sei. Tá bom? Beijo. [...] [complemento] Oie, Então, o quê que é a dramaturgia desse experimento? O que que precisa acontecer? Eu acho que precisa acontecer uma sequência à lá Janô (Antônio Januzelli): chegada, aquecimento, brincar. 0 brincar ele ter alguma maneira um ponto de culminância que talvez possa ser o canto, talvez possa ser as danças. Não sei: que dramaturgia é necessária. O que eu acho que aconteceu, que um acontecimento possível é essa vibração da coluna ser a nota, e isso gerar os grupos de notas, as constelações, gerar os conjuntos de notas específicos [ou específicas] que podem ser segmentos escalares, podem ser gestos, podem ser motivos, podem ser. Estou pensando nisso. Beijo. 
562

( ) belê de pedra (uma danféa)

(Duem é a mãe da dua t tem muitas mäes, $l$ isito poraue sato muitas as Luas Mas una mesma lua aind tem muitas maes.

Una rolas mães pucorre quase todos os lugares durante o anoitecer Uma outro í a quietude de seu próprio bebé de pedra. O belế de pedra estáem pesta, ele é uma incontável metramorfose. Cle é a pedra, umra pedra.

(D) escurvo que é sua mäle é exatramente o visivel. Comple. tamente fora da terra, dentro ala terra.

Só que disso nadra saberros. 


\section{glândula-caderno}

quase

umanimusgo

Francisco Lauridsen Ribeiro

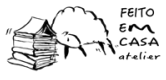




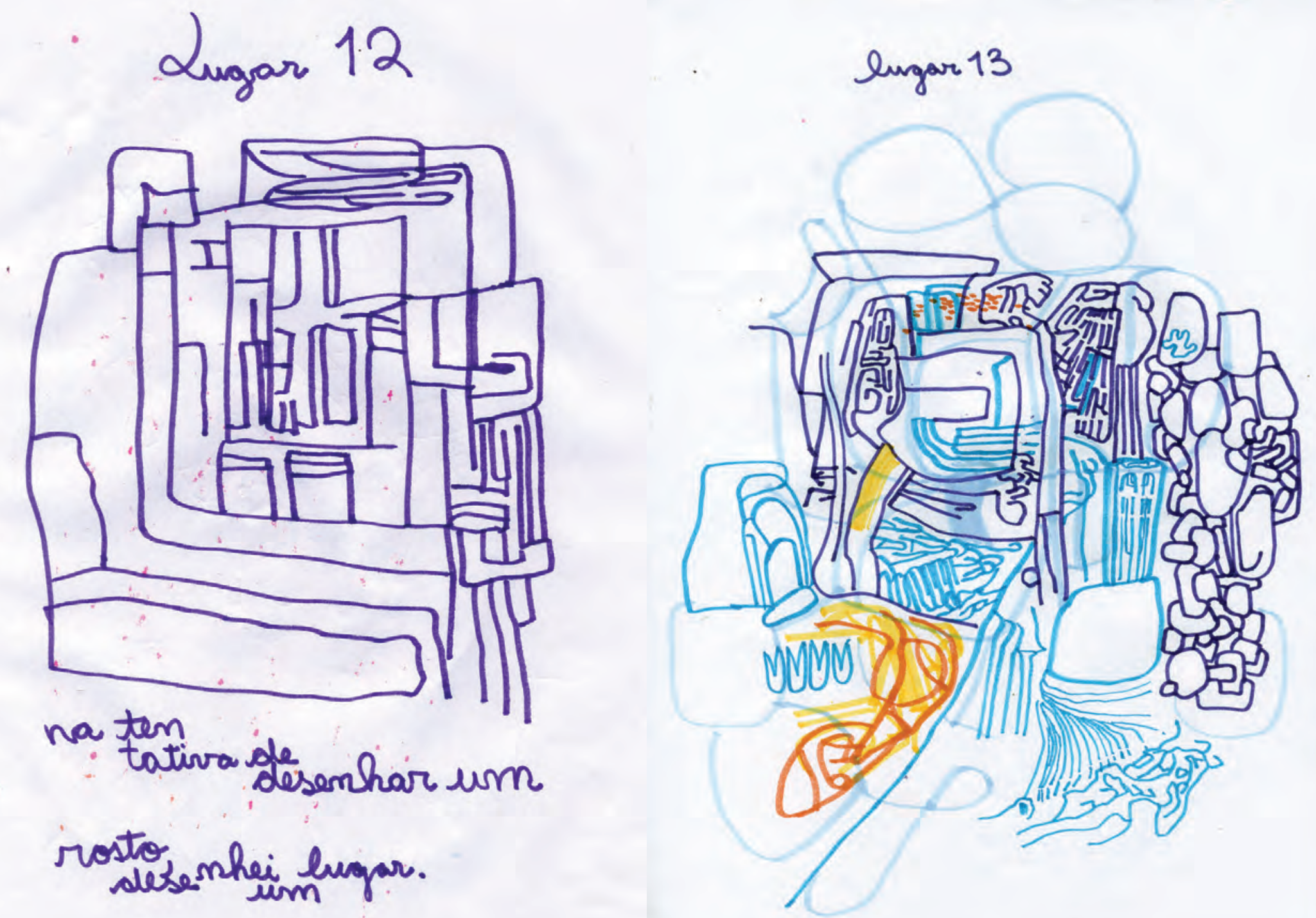




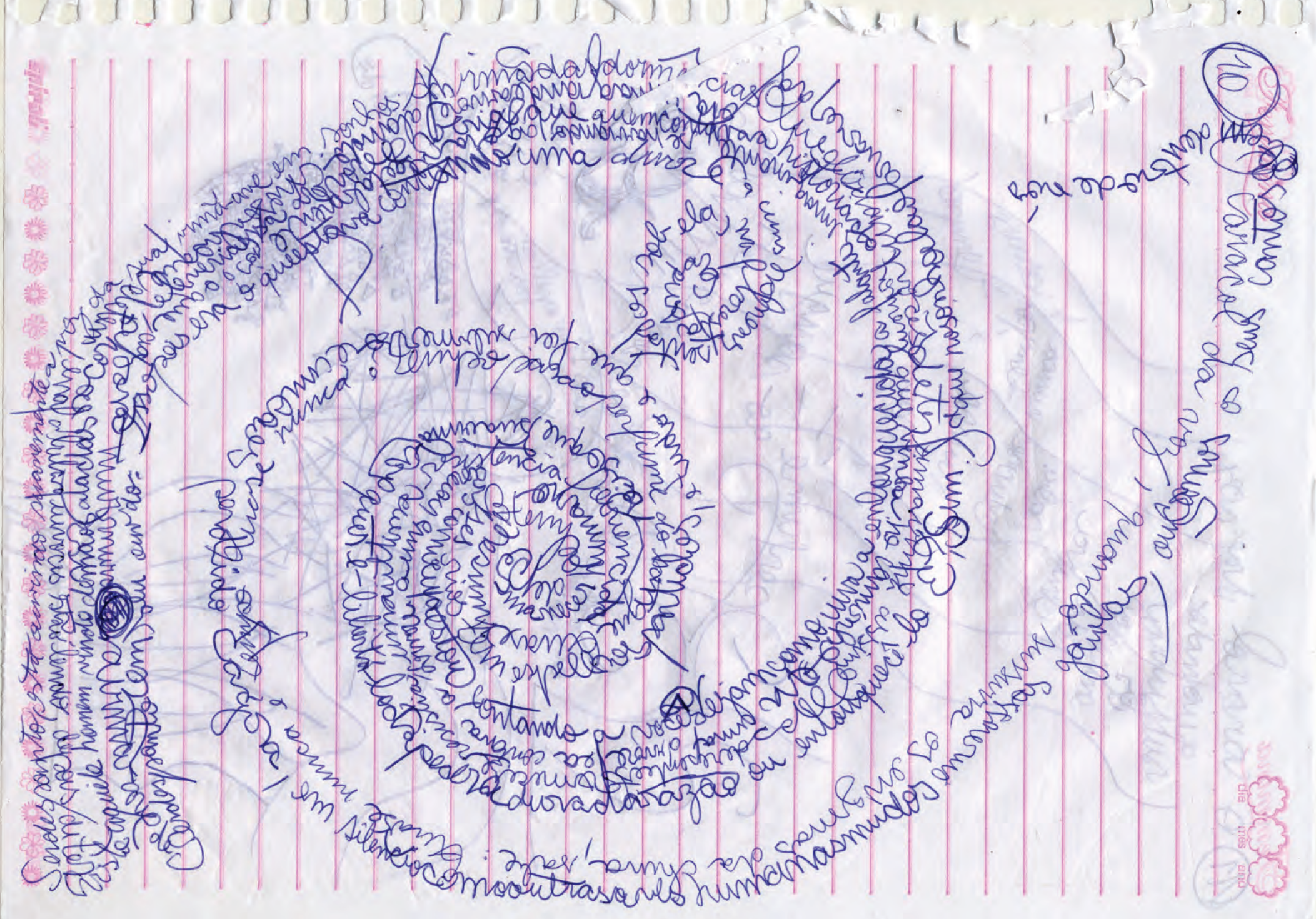




\title{
poema-talismã ou partitura quase mundana em resposta ao vento noturno
}

\author{
para Helena Bastos e Silvio Ferraz
}

- Tocar / Revirar o vento / vento, reviravolta / pedaços de toque / som de grâo ou cascas, cacos, quandos, acúmulo quase-nadas, matéria de mundo / esculpir uma dificil sensação pela escultura / tentei começar do começo mas não consegui // - Toque reviravolta / uma dor é comunidade de coisas, fervura fria, furos caminhos, relevo de algo-menos-que-pedra. Venta muito dentro da pedra, e o vento também é pedra e bomba invertida cozida pelo fogo das plantas. / Deslize e ressonância săo imprevistas dobraduras. Mudo de assunto: personagem furos / ficou ali. Não percebi. / rios cruzam corpo feito de rio / A espera pode ter rios, além daquelas bombas de vazio. // - Revira o concreto / Caminho se cava no vento da noite, que nunca vi nem ouvi / muitas infinitas gotas com casca, atmosfera pessoa levanta levantada, tudo deitado, espalhado / na tempestade perpétua / que gira em muitas direçôes / cria direçóes / corpo guardado na noite das coisas // - céu profundo é carne / há um calor escondido e demora / perpétuo fim de mundo inesperado / silêncio com canto pavoroso, desejado, rosto insuportável // - Revirar, revirar quandos / é preciso apenas perguntar / luz é quando eu não vejo? / quando o mundo fermenta sonâmbulo / é olhado por um mato e folhas / mas mira com olho artrópode / ele está acabamento de mundo / tão próximo tão próximo estranho habitante / o som é dele / toque refeito rastejante revirado / movimento perpétuo, concentrado e disperso / um grande esforço duplica o ar / fervura apocalíptica e fria desde sempre / poesia por um fio, afogada pelo ar / quando nos descobrimos submersos, nāo há o drama da asfixia, há coisa, há algo / quando algo se guarda de impossível / assim começo, assusto de pavor, assim que começo a escrever e assim pareceu.) 


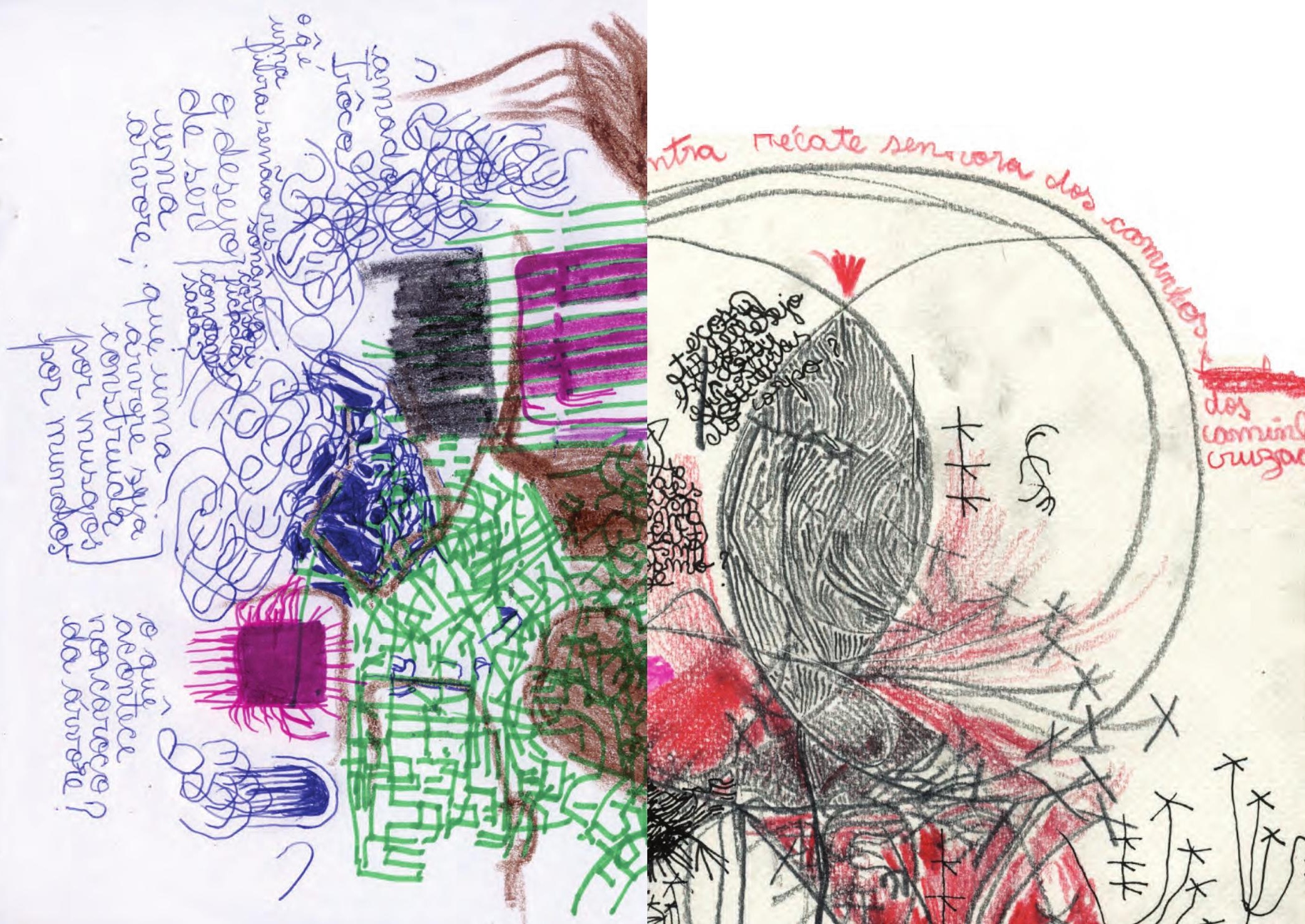




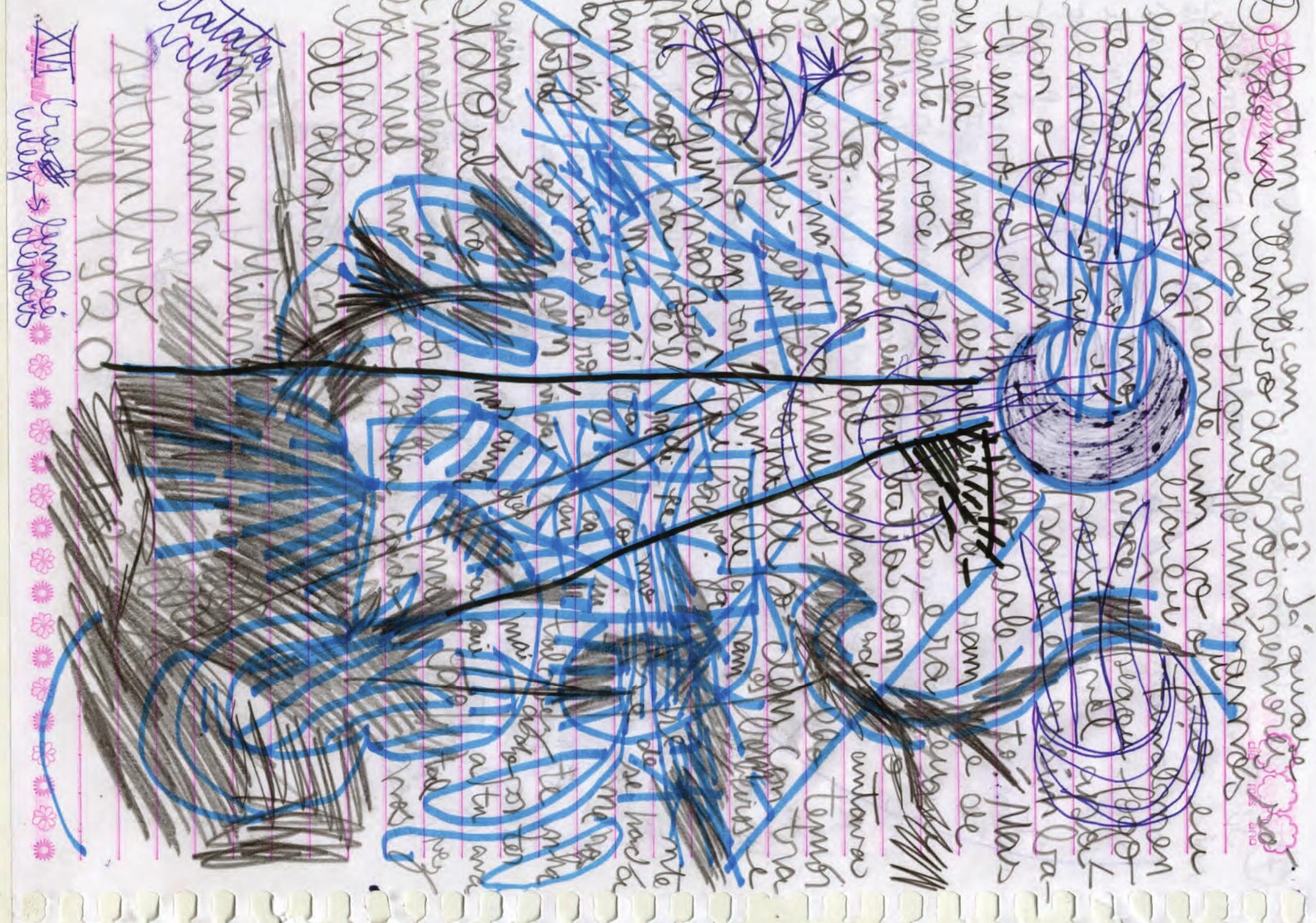


Lielth 3.

模

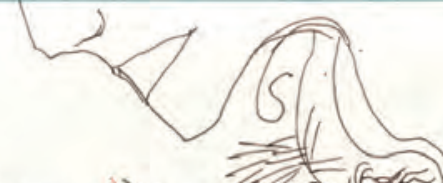

Ty

(1)

त)

$\sqrt[3]{351}$

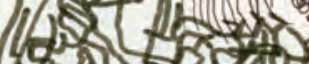

is tort

I

一

(2)

- 15 (5) (5)

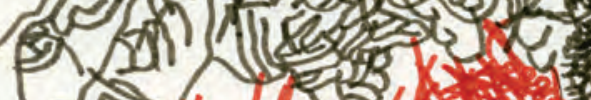

(1)

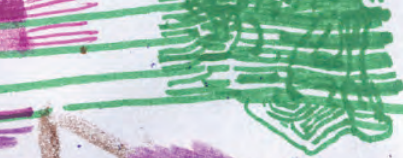

(1.)

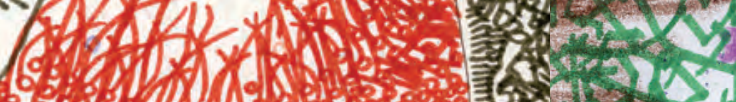

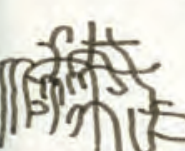

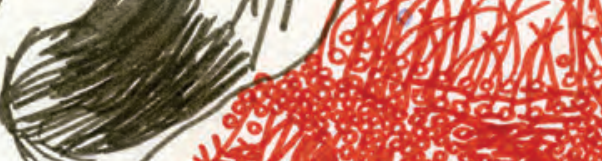

5. 2 in

aid $-5=1$

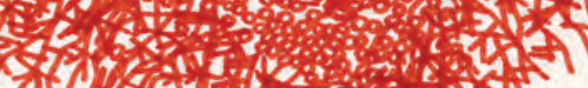

f

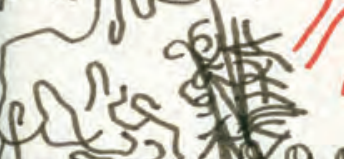

ge

$v^{\prime}+t^{*}$

in:

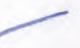


3. nem tudo säo imagens internas. Algumas imogens conhe c' das "servem", estao al " para constelar unma outra imagem, descomhecida. (O) de una imagem dercomhecida ou mesmo unn conpo laldicante de J'magens ou mesmo. un conpo sem imagem? 
-1) Chegaram os sonhos,
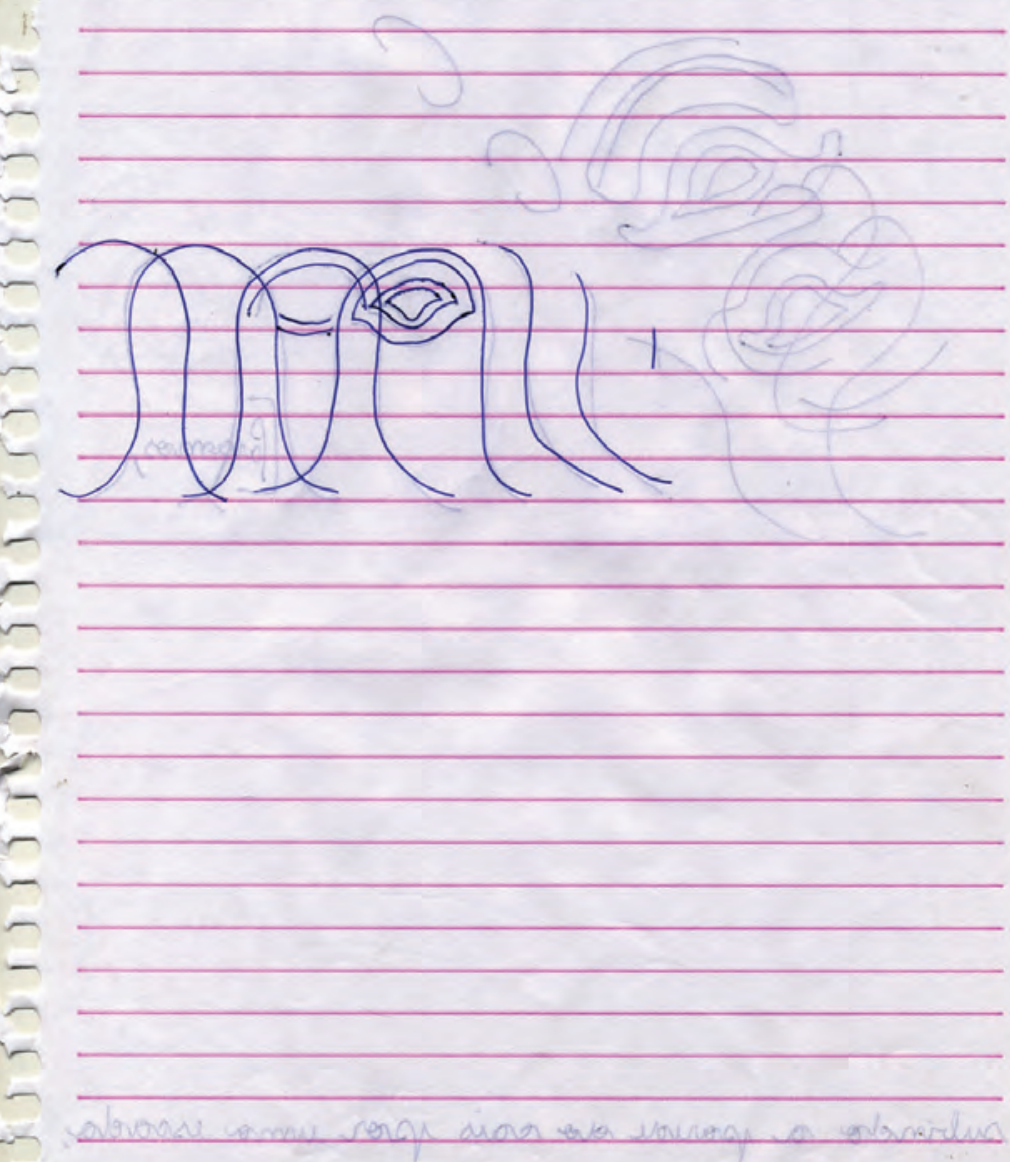
spivali (
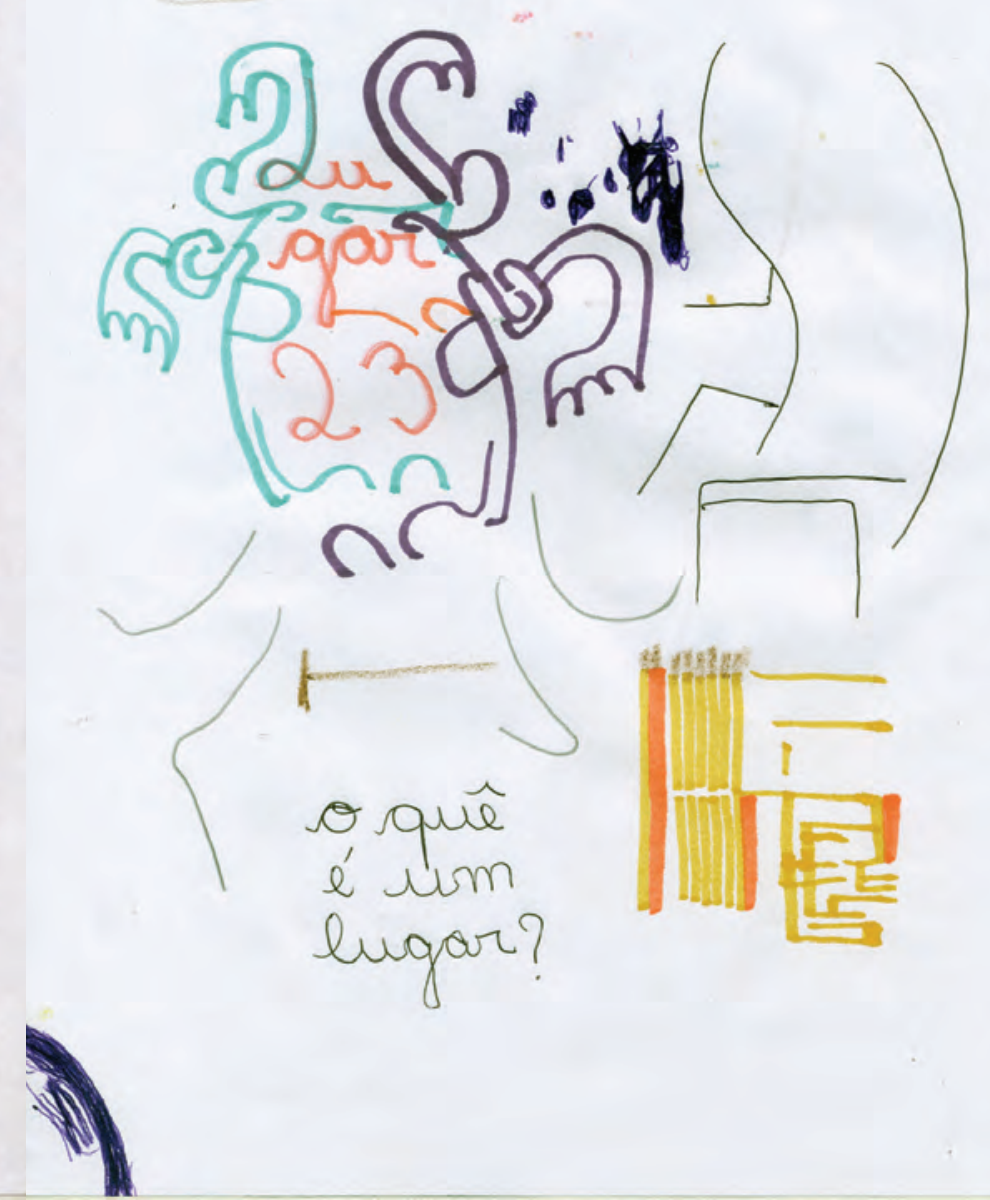
Quando vemos o inverso do corpo, o que vemos? Além da carne, somos ossos, veias, buracos, cavidades, fissuras, desejos e afectos, um corpo conjunto e desconjuntado. Ao me deparar com o trabalho do Francisco Lauridsen Ribeiro, vejo o verso/reverso do corpo, o inverso do corpo, onde é possível tocar o invisível através das imagens que cria sem o propósito de serem um resultado e sim, um processo. 
Este livrinho-zine é um alter-órgão, um pedaço de corpo anexado à tese esboçamentos de corpossom: a escrita do corpo na víscera do som de Francisco Lauridsen Ribeiro.

Contudo, pode circular sozinho também.

Se chegou na sua mão, cuide bem dele!

O zine foi editado e impresso em papel pólen $90 \mathrm{~g} / \mathrm{m}$

pelo Atelier Feito em Casa em janeiro/2019. 


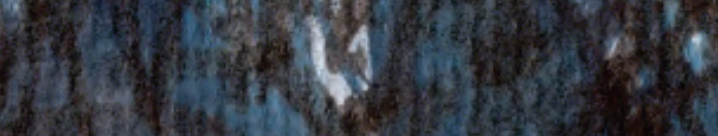

1.9 (1)

in

$$
\text { 1) }
$$
2. (2)

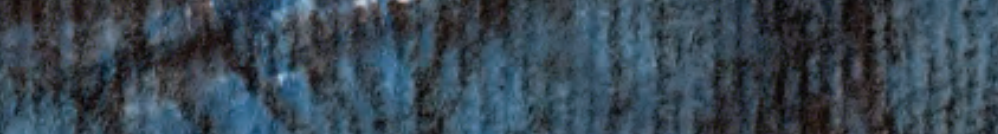

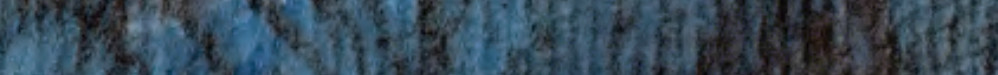

axis 15

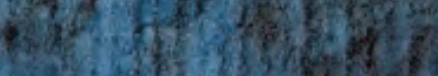
4. 100 is

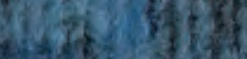
(1)

aris

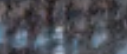

